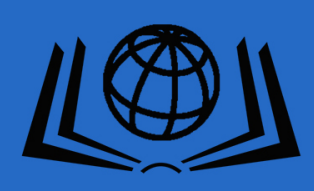

International Science Group

ISG-KONF.COM

\title{
CONCEPTUAL AND MODEL SUPPORT FOR THE DEVELOPMENT OF AN INNOVATIVE-ACTIVE UNIVERSITY
}

\author{
edited by Ponomarenko V., \\ Rayevnyeva O., Yermachenko V.
}

Monograph 
UDC 378.095

Reviewers:

Opirskyy Ivan - Professor, Doctor Of Technical Science, Lviv Polytechnic National University (Ukraine)

Ryabova Zoya - Professor, Doctor Of Pedagogical Sciences, State Institution of Higher Education University of Educational Management National Academy of Educational Sciences of Ukraine(Ukraine)

Yelnykova Halyna - Professor, Doctor Of Pedagogical Sciences, Ukrainian Engineering Pedagogics Academy(Ukraine)

Conceptual and model support for the development of an innovative-active university: monograph / edited by Prof., D.Sc. (Economics) Ponomarenko V., Prof., D.Sc. (Economics), Rayevnyeva O., Prof., Assoc. prof. (Economics) Yermachenko V. - Primedia eLaunch, Boston, USA $-377 \mathrm{p}$.

Library of Congress Cataloging-in-Publication Data

ISBN - 978-1-68564-524-3

DOI: 10.46299/978-1-68564-524-3

The monograph is devoted to the development of theoretical-methodical and modelinformation basis for the construction of innovative- active HEI on the basis of autonomy of its activities, quality of education, anti-corruption. Trends in the modernization of the world system of higher education have been identified, a study of the phenomenon of "autonomous, innovative- active university" has been conducted, and a list of factors influencing the increase in the competitiveness of individual HEIs has been formed. Based on the analysis of the legislative basis and state initiatives, the opportunities for the development of an innovative-active university (IAU) have been identified. The stratification of HEI of Ukraine according to the level of their educational, scientific and technical, innovative and international activities was carried out. Conceptual and methodological bases of IAU construction are developed, the mechanism of its functioning is formed and conceptual bases of formation of system of corporate management of rendering of HEI educational services on the principles of counteraction of corruption are offered.

Recommended for researchers, professionals in education, economics, information management and protection, teachers, graduate students and students of higher education institutions.

ISBN -978-1-68564-524-3

UDC 378.095

(C) Ponomarenko V.,Rayevnyeva O., Yermachenko V., 2021 


\section{CONTENT}

Introduction $\quad 5$

Chapter 1. Challenges and limitations of the current stage of higher 8 education system development

1.1. Current trends in the development of higher education

1.2. The impact of force majeure of COVID-19 pandemic on the higher 20 education system

1.3. The phenomenon of innovative university: understanding the essence 30 and characteristics

1.4. Factors of university competitiveness: world experience

Chapter 2. Formation of innovative-active university: experience of 59 integration of state and HEI

2.1. Analysis of the legislative basis and state initiatives to build an 59 innovative university

2.2. Innovations in education: essence, types, stages of implementation

2.3. Concepts and strategies of innovative development of the leading

Ukrainian HEI: experience of realization and methodical maintenance of construction

2.4. Factors of university competitiveness: national experience

Chapter 3. Formation of the monitoring system and stratification of the higher education system of Ukraine and its subjects

3.1. University monitoring and stratification system: methodological basis for construction

3.2. Development of methodological support for determining the attractiveness of the national higher education system in the European educational space

3.3. Development of methodological support for the assessment and stratification of national HEI according to the level of innovation activity

3.4. Educational migration: challenges and threats to the higher education system and the activities of innovative-active HEI

Chapter 4. Conceptual-methodological basis of construction of an innovative-active university 
4.1. Modern paradigm of higher education system development and formation of theoretical basis for building an innovative-active university

4.2. Development of the concept of formation of innovative-active university

4.3. The mechanism of functioning of innovative-active university: conceptual and methodological support

Chapter 5. Managing the development of the educational environment of an innovative higher education institution on the basis of quality assurance

5.1. Global changes and transformation of universities

5.2. Ensuring the quality of education as a factor in the development of the educational environment of an innovative type of higher education institution

5.3. The essence and technology of managing the development of the educational environment of higher education institutions of innovative type on the basis of ensuring the quality of education

Chapter 6. Development of the concept of security and anti-corruption in the corporate governance system in the provision of educational services in higher education institutions

6.1. Development of a conceptual framework for building a corporate governance system in the provision of educational services at a university based on anti-corruption

6.2. Development of a model for ensuring anti corruption and simulation modeling

6.3. Synergetic model of threats to the security components of cybersystems

6.4. Development of methodological principles for building and managing CIES in the fight against corruption

6.5.Technology of building a modified electronic document management system at the university

References

Annex 


\section{INTRODUCTION}

The current state of development of the education market and the market of consumer preferences for higher education requires universities to promptly take into account changes and new trends in the labor market, which largely depends on the ability and ability of HEI to make decisions in a changing environment. With HEI completely dependent on state regulatory action, it is impossible to use the opportunities associated with market mechanisms, it is impossible to be flexible and adaptable to changes in the educational environment. In this regard, in recent years, the problem of finding the optimal ratio of government regulation and market mechanisms in the practice of higher education institutions has become acute.

On the one hand, market mechanisms help to increase the competitiveness of higher education institutions and strengthen their relationships with employers (in funding, joint programs, curriculum adjustments, student internships, internships, joint research, innovation), development of regional clusters, etc. On the other hand, reducing the level of state influence in such a strategically important area as education can have irreversible consequences for the country as a whole: an imbalance between the markets of educational services and labor, shifting the focus from basic to applied research, reducing the quality of educational services.

In addition, in the context of globalization, consumers of educational services have long ceased to be limited to the national higher education system. Today, they strive to enter the best educational institutions in the world, not limited to their country, focusing only on the quality of education. In this regard, Ukrainian HEIs must be competitive not only in the national market of educational services, but also offer a quality, attractive to foreign consumers educational and scientific product.

The competitiveness of HEI, first of all, requires a significant improvement in the quality of education based on an innovative search for effective ways, modern tools, instruments and forms of learning. Modernization requires not only the training process, but also the management system of HEI, the system of financing its educational and research activities, forms of interaction with employers and international partners. In turn, the above forms the basis for the emergence of an innovative university on the basis of quality education and anti-corruption, which operates in the new realities of the information society - cyber threats and attacks on educational corporate systems. 
The need to transform a traditional university into an innovative-active (entrepreneurial) one arose due to the emergence of the XX century. global trend of reducing funding for universities from public sources, increasing competition in the international educational space and changing the global paradigm to the place of education in the social and economic development of society and civilization. Modern universities, in order to meet the requirements of the time, must perform not only the classical functions (education, research, education), but also acquire new features innovation and entrepreneurship. Innovative development is an integral part of meeting a wide range of national interests of the state.

Today in Ukraine there is a radical modernization of the higher education system, which affects not only the quantitative characteristics of the presence of HEI in its structure, but also covers qualitative transformations. That is, an environment is gradually being formed for the transformation of traditional universities into innovative-active ones. The latter, along with training and research, acquire a third function - entrepreneurial, associated with the commercialization of research results. It is the innovative-active (entrepreneurial) nature of the university's activity that allows to create a new balance between science, education and innovative technologies in business and society.

Ukraine is on the initial path of forming innovative universities. To implement the concept of innovative-active university in the country is widely used foreign experience in the creation and development of universities of this type, approaches and means of their adaptation in higher education and society. Thus, the dominants of the innovative-active university, aimed at the current and long-term perspective are:

science as a tool for generating new knowledge on the basis of integration with the external environment, primarily with high-tech enterprises;

education as a way to bring knowledge to people, the formation of the intellectual potential of society;

interaction with industry, government, society as a means of concerted efforts to ensure the stable development of the nation and civilization.

Thus, the innovative-active university in modern society is one of the main market participants, which teaches, conducts research, patents and sells its intellectual property.

The novelty of the idea and working hypotheses of the study is contained in the author's understanding of innovative-active university as a rational symbiosis of efforts 
of the state and the individual university on the basis of autonomy of its activities in the scientific and educational space. An innovative type of university is not only an educational institution, but also a center of research and expert activity, capable of creating new knowledge and implementing it in the economic and social environment. Based on this, the definition of external and internal factors influencing the quality of HEI, development on this basis of conceptual foundations, structural and functional model, organizational and methodological, information and analytical management of innovative HEI development, ensuring timely response to cyber threats, effective operation of subsystems corporate research and education system and the creation of an information basis for combating corruption schemes are priority areas for the development of each HEI.

Author's composition: Ponomarenko V. (edition, 1.1, 1.2, 4.1), Rayevnyeva O. (edition, introduction, 1.3, 4.2, 4.3), Yermachenko V. (edition, 2.3, 2,4), Yevseiev S. (6.1, 6.2), Poliakova H. (Chapter 5), Milov O. (1.4, 6.4), Labunska S. (2.1., 2.2), Aksonova I. (3.1, 3.2), Brovko O. (3.3, 3.4.), Shmatko O. (6.4, 6.5).

The author's team expresses deep gratitude to the reviewers of the work, Opirskyy Ivan, Professor, Doctor of Technical Science, Lviv Polytechnic National University (Ukraine), Ryabova Zoya, Professor, Doctor Of Pedagogical Sciences, State Institution of Higher Education University of Educational Management National Academy of Educational Sciences of Ukraine (Ukraine), Yelnykova Halyna, Professor, Doctor Of Pedagogical Sciences, Ukrainian Engineering Pedagogics Academy (Ukraine). 


\section{CHAPTER 1. CHALLENGES AND LIMITATIONS OF THE CURRENT STAGE OF HIGHER EDUCATION SYSTEM DEVELOPMENT}

\subsection{Current trends in the development of higher education}

The sphere of education is the most dynamic component which is, due to the growing interest of the population in higher education, increasing its prestige, and the growing demand for highly qualified specialists due to the development of market relations. From a translator of knowledge and a generator of specific skills and abilities, it becomes a direct producer of knowledge and an active participant in the process of their transformation into new products, technologies and services. The state policy of the country has a significant impact on the intensification of the acquisition of fundamentally personal knowledge.

In Ukraine, there was formed the legal support of the functioning of education system, all its levels and subsystems, the activities of educational institutions of different types and forms of ownership, the organization of various forms of education. Legal aspects of higher education are based on the Constitution of Ukraine, taking into account the Joint Declaration of the European Ministers of Education "European Higher Education Area" and embodied in the National Doctrine of Education Development, the Law of Ukraine "On Higher Education", the National Strategy for the Development of Education in Ukraine until 2021, the Order of the Cabinet of Ministers "On approval of the action plan for the development of higher education for the period up to 2015."

In most countries of the world, the modernization of education is a priority that ensures the socio-economic, political and scientific development of society. Modernization of the education system is a tool for forming a personality that can quickly adapt to today's dynamic environment and be competitive in the labour market. Current trends have led to the further choice of the vector of development of domestic higher education in the direction of building its content in accordance with the world and European standards and affect the quality and process of university education and require to begin the process of restructuring the entire education system. The following main trends in the development of higher education can be identified [52, 278, 41] (Table 1.1). 
Table 1.1

\section{Current trends in higher education}

\begin{tabular}{|c|c|}
\hline Trend & Characteristic \\
\hline 1 & 2 \\
\hline $\begin{array}{l}\text { The transition } \\
\text { from mass to } \\
\text { universalization }\end{array}$ & $\begin{array}{l}\text { Universalization involves the adaptation of the entire population to rapid social } \\
\text { and technological change. Higher education that meets the requirements of the } \\
\text { time should not only prepare the individual for the future profession, but also } \\
\text { teach basic analytical skills and critical thinking, develop self-learning skills, } \\
\text { the ability to find and filter the necessary information, resist stereotypes and } \\
\text { ideological constructs. In most OECD countries, the percentage of the adult } \\
\text { population with higher education has long exceeded 50\%, indicating a transition } \\
\text { from the mass to the universal stage (the average for OECD countries is 70\%). } \\
\text { However, educational policies, which is aimed at restricting rather than } \\
\text { expanding access to higher education, can quickly change the situation }\end{array}$ \\
\hline $\begin{array}{l}\text { Development of } \\
\text { open online } \\
\text { courses and } \\
\text { MOOC- } \\
\text { platforms }\end{array}$ & $\begin{array}{l}\text { Since 2012, the number of online platforms (MOOC - massive open online } \\
\text { lines) and the number of their users has been steadily growing. The world's most } \\
\text { famous platforms are Coursera, edX and Udacity. According to the NMC } \\
\text { report, today one in ten US students study exclusively through online courses } \\
\text { and the demand for such available teaching methods is growing [150]. A } \\
\text { separate trend is the desire of universities to establish a relationship between } \\
\text { full-time and online learning, i.e. to teach students in a mixed form. MOOC } \\
\text { implementations provide high quality, which is achieved through technology, } \\
\text { design and the level of teachers of online courses. MOOC has many advantages } \\
\text { over standard teaching: accessibility from anywhere in the world, } \\
\text { communication with teachers and other students in forums, the development of } \\
\text { self-organization, independent choice of study time, free training, etc. The } \\
\text { presence of MOOC enhances the image of the educational institution and has } \\
\text { great potential in updating traditional methods, tools and forms of organization } \\
\text { of the educational process. }\end{array}$ \\
\hline $\begin{array}{l}\text { Autonomy of } \\
\text { universities }\end{array}$ & $\begin{array}{l}\text { Autonomy is one of the three basic principles of the European universities, } \\
\text { enshrined in the Grand Charter of Universities. According to the decision of the } \\
\text { Lisbon Declaration of 2007, there are four components of institutional } \\
\text { autonomy: academic (addressing the formation of curricula and teaching } \\
\text { methods, areas, scales and methods of research, the number of students in } \\
\text { certain specialties, etc.); financial (solving issues related to the receipt and } \\
\text { distribution of budget funding, determining the amount of tuition fees, use of } \\
\text { profits, etc.); organizational and personnel (determination of issues related to } \\
\text { recruitment, remuneration and career growth of staff). The analysis of the } \\
\text { European and world experience in the formation of autonomy in higher } \\
\text { education in developed countries showed that it was identified by two main } \\
\text { trends: centralization of management and diversification of types of HEI and } \\
\text { their curricula, accompanied by decentralization of management at regional and } \\
\text { municipal levels }\end{array}$ \\
\hline $\begin{array}{l}\text { Sources of } \\
\text { funding for } \\
\text { higher education }\end{array}$ & $\begin{array}{l}\text { Funding for higher education has been provided in various countries around the } \\
\text { world. In some countries, public funding has historically predominated } \\
\text { (particularly in the EU), while in others, such as the United States and South } \\
\text { Korea, private and corporate funding has been more prevalent. The ratio of } \\
\text { expenditures on education is due to the peculiarities of the socio-economic } \\
\text { situation in the country. In the last } 10 \text { years, there has been a tendency to } \\
\text { diversify sources of education funding and the position of top universities on } \\
\text { independence from public funding. However, in the context of Covid-19, the } \\
\text { need for government support has deepened. }\end{array}$ \\
\hline
\end{tabular}


Continued of the table 1.1

\begin{tabular}{|c|c|}
\hline 1 & 2 \\
\hline $\begin{array}{l}\text { Continuous } \\
\text { learning }\end{array}$ & $\begin{array}{l}\text { With the automation of production and robotics, working places disappear, } \\
\text { which will lead to the release of specialists. This creates new challenges for the } \\
\text { retraining system. The result is the concept of lifelong learning for adults } \\
\text { ("lifelong learning"). According to this concept, every person who is interested } \\
\text { in maintaining their level of professional competence in the labour market } \\
\text { should constantly improve their professional skills, or undergo professional } \\
\text { retraining. The development of a knowledge-intensive society and ensuring a } \\
\text { competitive economy requires constant updating of knowledge, training, } \\
\text { expanding opportunities for professional development }\end{array}$ \\
\hline $\begin{array}{lr}\text { An } & \text { effective } \\
\text { balance between } \\
\text { niche } & \text { learning } \\
\text { and } & \text { micro- } \\
\text { credentialism }\end{array}$ & $\begin{array}{l}\text { Employers value more specialized knowledge and skills certified by various } \\
\text { professional standards (e.g., CFA, CIMA, ACCA, etc.) than a diploma in a } \\
\text { particular field of knowledge. Maintaining a balance between the possibility of } \\
\text { obtaining a traditional academic degree, which requires research in a number of } \\
\text { different subjects, and micro-credentialism to create an environment that } \\
\text { focuses on performing specific functions in specific fields. This provides } \\
\text { specialized skills with a broad outlook. }\end{array}$ \\
\hline $\begin{array}{l}\text { Individualizatio } \\
\mathrm{n} \text { of learning }\end{array}$ & $\begin{array}{l}\text { Creating new criteria for assessing students and focusing on the individuality of } \\
\text { each student provides an opportunity to see a clearer picture of what students } \\
\text { need to know to gain skills and competencies. For this purpose, adaptive } \\
\text { learning technologies are used - educational programs and platforms that take } \\
\text { into account the individual needs of students [133]. } \\
\text { The most popular skills of the future will be vocational and technical skills, } \\
\text { creative skills and critical thinking skills of students. Developing criteria for } \\
\text { assessing such skills is a priority for universities. This approach aims to } \\
\text { motivate students to continuous self-study not only during university studies, } \\
\text { but also throughout life. }\end{array}$ \\
\hline $\begin{array}{l}\text { Priority of } \\
\text { training and case } \\
\text { studies }\end{array}$ & $\begin{array}{l}\text { Teachers should use a variety of teaching methods and approaches that allow } \\
\text { students to be active participants with strong motivation and involvement in } \\
\text { their own learning. Information and computer technologies (ICT) create } \\
\text { preconditions for the use of new approaches and methods for the } \\
\text { implementation of active learning with the use of trainings, cases, simulation in } \\
\text { learning, which will provide the opportunity to acquire the necessary skills and } \\
\text { use them most effectively in professional work. }\end{array}$ \\
\hline $\begin{array}{l}\text { Mentoring } \\
\text { (mentoring) }\end{array}$ & $\begin{array}{l}\text { The main tasks for teachers will be to find an individual approach to each student, } \\
\text { motivation for further development and success. Teachers must become trained } \\
\text { mentors, coaches, and leaders in both teaching and student support. } \\
\text { To do this, teachers will need to develop their own skills: interpersonal } \\
\text { communication, conflict management, stress and time management, as well as } \\
\text { continuous professional development - daily viewing of specialized publications, } \\
\text { regular online courses, participation in training programs. It is necessary to move } \\
\text { from standard lectures, memorization of material, examinations, but to pay } \\
\text { attention to the acquisition of valuable skills and adapt to current market } \\
\text { conditions and requirements of student clients [207] }\end{array}$ \\
\hline $\begin{array}{l}\text { Practice- } \\
\text { oriented, dual } \\
\text { learning }\end{array}$ & $\begin{array}{l}\text { This method of teaching and learning allows students to combine higher education } \\
\text { with practical work. Students are provided with real working conditions in which } \\
\text { they can gain the practical and social skills necessary for successful work. } \\
\text { The main features of practice-oriented professional training are the creation of an } \\
\text { environment that stimulates the formation of students' motivated need to acquire } \\
\text { professional competencies; introduction of practice-oriented }\end{array}$ \\
\hline
\end{tabular}


The end of the table 1.1

\begin{tabular}{|l|l|}
\hline 1 & \multicolumn{1}{|c|}{2} \\
\hline & $\begin{array}{l}\text { technology of professional training, which provides the formation of personal } \\
\text { qualities, as well as experience in performing professional duties; organization } \\
\text { of practical training of students; development and implementation of innovative } \\
\text { forms of student employment in order to solve real professional, scientific- } \\
\text { practical and research-production works }\end{array}$ \\
\hline $\begin{array}{l}\text { Academic } \\
\text { mobility and } \\
\text { internationalizati } \\
\text { on }\end{array}$ & $\begin{array}{l}\text { The internationalization of higher education means measures to strengthen and } \\
\text { promote the creation of an international academic community that will prepare } \\
\text { students for life in a globalized environment [150]. Internationalization in the } \\
\text { field of higher education includes the following forms of mutual cooperation: } \\
\text { individual mobility, mobility of students or faculty for educational purposes; } \\
\text { mobility of educational programs and institutional mobility; formation of new } \\
\text { international standards of educational programs; integration into curricula of } \\
\text { international dimension and educational standards; institutional partnership; } \\
\text { creation of strategic educational alliances [248] }\end{array}$ \\
\hline
\end{tabular}

The strategic task of higher education in Ukraine is the need to significantly update the content of education, teaching quality, search and application of the latest, innovative forms and methods of teaching in order to ensure high quality competencies of modern specialists. However, the process of integration should take into account the peculiarities of national educational and cultural identity and should not be accompanied by the leveling of its own national educational system, which has accumulated significant achievements of domestic and world science.

High competition for resources between higher education institutions, including human ones, has led to the need to develop appropriate comparison tools. Ratings have become one of such tools. Updating the world rankings of national education systems and individual educational institutions is associated with the processes of globalization and increasing competition in the field of education in the world. If the national education system or educational institution falls into the world ranking of leading places, it significantly increases its attractiveness not only for applicants but also for employers, investors, and provides additional government subsidies.

The existence of a single world educational space, increasing competition between higher education systems and individual universities, due to the processes of progressive globalization, justify the need for international comparisons based on the ratings of national education systems and individual educational institutions. Obtaining by the latter a high position in the world rankings significantly increases the attractiveness of higher education system or a specific HEI not only for international and national applicants, employers, investors, but also provides additional state 
subsidies.

Today, there are more than 50 national and more than 10 international ratings to assess the activity of HEI. The purpose of the ratings is to determine the best HEI in the world and evaluate their activities, but each rating involves the use of certain indicators to determine the competitive potential of HEI. Among the ratings recognized in the world educational space, influential international rankings include ARWU (Academic Ranking of World Universities), QS World University Rankings and THE Times (Times Higher Education World University Rankings).

It should also be noted the effectiveness and significance of the existence of such international ratings as: webometrics ranking "Webometrics" (Webometrics Ranking of World Universities), webometric ranking of the world universities "4ICU" (4 International Colleges \& Universities), ranking of universities by academic indicators "URAP" (University Ranking by Academic Performance), CWUR (Centre for World Universities Rankings), U-Multirank, Europe's best Scimago Institutions (Scimago Institutions Rankings), Clarivate Analytics, Europe's most innovative university etc.

Historically, Ukraine has had high ranking positions in the field of education, but, unfortunately, in recent years there has been a negative trend towards their loss. For example, as of 2018, in the Global Competitiveness Rating (GCI) [253], Ukraine ranked 85th among 141 countries and 44th in terms of Skills. For comparison, Ukraine is in the top twenty of the GCI ranking in the sub-index of higher and secondary education, but since 2018 this indicator is excluded from the ranking and focuses on quality indicators of education. Table 1.2 shows the ranking positions of Ukraine by educational components.

According to the analysis of individual indicators, Ukraine ranks above average. According to the indicator "Quality of education" for the last 10 years Ukraine ranked from 54 to 72 places, as of 2019 Ukraine took the 65th place among 140 countries. A significant decline in rate occurred in 2014, although some ranks had a slight increase. Thus, the indicator "On-the-job training / Volume of staff training" has increased over the last 5 years from 94 to 65 places. All this indicates the development and strengthening of scientific and educational potential of the country, and the national education system is aimed at stimulating the quality of higher education, ensuring its competitiveness in the market of educational services and the labour market. 
Table 1.2

Ukraine's position in the GCI ranking by educational components

\begin{tabular}{|c|c|c|c|c|c|c|c|c|c|c|c|c|c|c|}
\hline \multirow{2}{*}{ Indicator } & \multicolumn{2}{|c|}{$\begin{array}{c}2009 \\
\text { (of } 133 \\
\text { countries) }\end{array}$} & \multicolumn{2}{|c|}{$\begin{array}{c}2014 \\
\text { (of } 148 \\
\text { countries) }\end{array}$} & \multicolumn{2}{|c|}{$\begin{array}{c}2015 \\
\text { (of } 140 \\
\text { countries) }\end{array}$} & \multicolumn{2}{|c|}{$\begin{array}{c}2016 \\
\text { (of } 138 \\
\text { countries) }\end{array}$} & \multicolumn{2}{|c|}{$\begin{array}{c}2017 \\
\text { (of } 137 \\
\text { countries) }\end{array}$} & \multicolumn{2}{|c|}{$\begin{array}{c}2018 \\
\text { (of } 140 \\
\text { countries) }\end{array}$} & \multicolumn{2}{|c|}{$\begin{array}{c}2019 \\
\text { (of } 141 \\
\text { countries) }\end{array}$} \\
\hline & 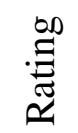 & 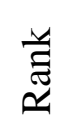 & : & 崖 & : & 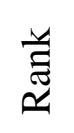 & 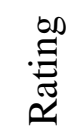 & 峁 & : & 駡 & : & 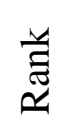 & 蔦 & 䒕 \\
\hline $\begin{array}{l}\text { Higher education } \\
\text { and professional } \\
\text { preparation } \\
\text { / Skills of the } \\
\text { current workforce }\end{array}$ & 46 & 4.4 & 40 & 4.9 & 34 & 5.0 & 33 & 5.1 & 35 & 5.1 & 46 & - & 53 & - \\
\hline $\begin{array}{c}\text { Coverage of } \\
\text { education }\end{array}$ & 9 & 76 & 13 & 79 & 14 & 79 & 11 & 82 & 16 & 82 & - & - & - & - \\
\hline $\begin{array}{l}\text { Quality of } \\
\text { education }\end{array}$ & 61 & 3.9 & 72 & 3.7 & 54 & 4.0 & 56 & 4.0 & 56 & 3.9 & 63 & 4.1 & 65 & 4.2 \\
\hline $\begin{array}{l}\text { On-the-job } \\
\text { training (Volume } \\
\text { of staff training) }\end{array}$ & 89 & 3.6 & 92 & 3.8 & 74 & 3.9 & 94 & 3.7 & 88 & 3.7 & 74 & 3.8 & 65 & 4 \\
\hline
\end{tabular}

According to the QS SAFE National System Strength (rating of national higher education systems) rankings [182], Universitas 21: Rankings of National Higher Education Systems [270] (rating of national higher education systems) and other world rankings, where the level of education is represented by individual components, Ukraine occupies a middle position and has a positive trend in contrast to other socioeconomic components of these ratings, such as innovation, ICT, labour market, etc. (Table 1.3).

Table 1.3

Positioning of the Ukrainian higher education system in global rankings at the international level

\begin{tabular}{|c|c|c|c|c|c|}
\hline \multirow{2}{*}{ Rating } & $\begin{array}{c}\text { QS SAFE } \\
\text { National } \\
\text { System } \\
\text { Strength } \\
2018-2019\end{array}$ & $\begin{array}{c}\text { U21 Rankings } \\
\text { of National } \\
\text { Higher } \\
\text { Education } \\
\text { Systems } \\
2020\end{array}$ & $\begin{array}{c}\text { Education } \\
\text { Index } \\
\text { (Human } \\
\text { Development } \\
\text { Index) } \\
2019\end{array}$ & $\begin{array}{c}\text { Bloomberg } \\
\text { Innovation } \\
\text { Index } \\
2020\end{array}$ & $\begin{array}{c}\text { Education } \\
\text { (Global } \\
\text { Innovation } \\
\text { Index) } \\
2020\end{array}$ \\
\hline $\begin{array}{c}\text { Position / } \\
\text { number of } \\
\text { countries }\end{array}$ & $38 / 50$ & $36 / 50$ & $46 / 189$ & $56 / 60$ & $23 / 121$ \\
\hline
\end{tabular}

Analyzing the above data, we can conclude that our country is gradually losing leadership in education, its current place in almost all rankings is the average that once again emphasizes the relevance of further development of higher education, in particular, 
to transform the traditional university into innovaion--active, business educational institution.

The main problem in the development of higher education is the inconsistency of the state of higher education in Ukraine with the needs of society in the XXI century. The prerequisites for this problem are the gradual deterioration of the quality of higher education, as well as the attitude of the subjects to this process.

On the way to reforming higher education there is a significant number of limiting factors which can be divided into three areas: funding and scientific-technical support; organizational support; staffing (Fig. 1.1).

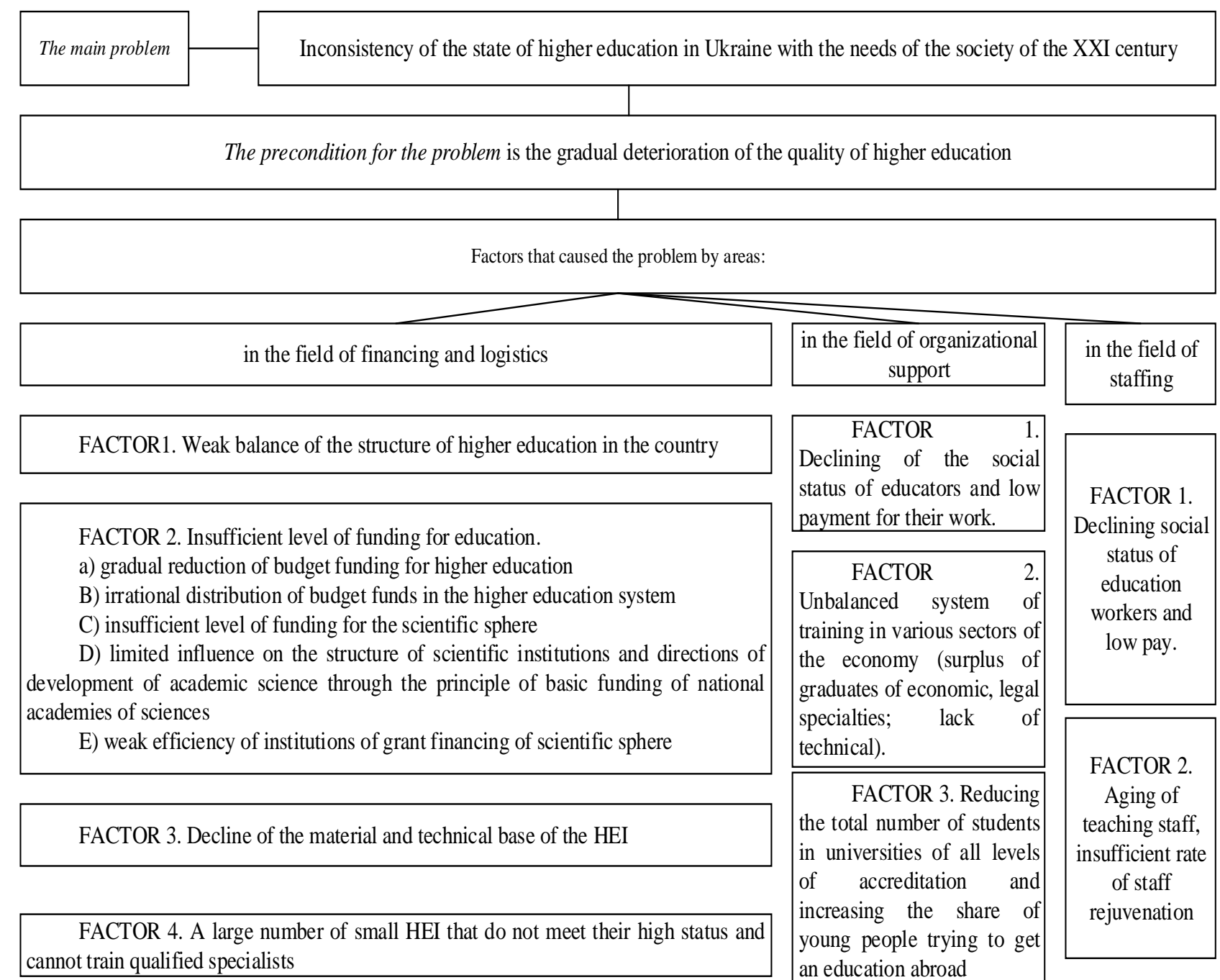

Fig. 1.1. Factors limiting the development in higher education

\section{Sphere of funding and scientific-technical support:}

Factor 1. Weak balance of the structure of higher education in the country. Considering the clearly defined course of Ukraine to enter the European educational space, it is necessary to modernize educational activities in the context of the European 
requirements. Its first step is to reduce the number of state and municipal higher education institutions. Such a process has already been begun in Ukraine. Thus, for the period 2000-2019 the number of HEI decreased by 11\% (in 2000 - 315 HEI, in 2019 $282 \mathrm{HEI})$. Also, it should be noted the tendency to decrease, after the academic year $2007 / 2008$, the number of higher education institutions of private ownership, which is associated with government policy and increasing requirements for them. This process should continue in accordance with the strategy of improving the quality of higher education in Ukraine and the start of work of the National Agency for Quality Assurance in Higher Education in 2019.

Factor 2. Insufficient level of funding for education.

a) falling budget funding for higher education

The process of educating the population, which precedes the materialization and commercialization of knowledge, requires some financial support from the state and non-governmental (private) organizations. Insufficient level of such support and irrational use in terms of society's needs for the EU development hampers the development of education. It is thanks to the education system and science-intensive industries based on it that countries of the world receive up to $40 \%$ of the gross national product. The countries of the Organization for Economic Co-operation and Development (OECD) spend on average $4.6 \%$ of GDP on education, countries of the European Union (EU-27) - 5.07\%, the EU-15 - 4.97\%. The amount of expenditures on education in Ukraine is legally enshrined in the Law "On Education" in the amount of $10 \%$ of GDP. However, in recent years, only $5-7 \%$ of GDP has been allocated from education to state and local budgets. Due to the small size of GDP, Ukraine lags significantly behind other countries not only in terms of absolute funding, but also in terms of education expenditure per pupil / student.

B) irrational distribution of budget funds in the higher education system. However, the effectiveness of budget allocation remains questionable and, above all, this applies to higher education. Most of the funds allocated from the budget for education are spent on the following items: wages and utilities, food, administrative services, inventory and uniforms, as well as textbooks and stationery. Investing in the improvement of material-technical base and innovation is based on the final principle. It should be noted that in developed countries (the USA, England, Canada, France) preference in the structure of education is given to its highest degree, i.e. training the necessary personnel for the development of science and the creation of new knowledge. 
In Ukraine, on the contrary, judging by the above data, preference is given to general secondary education, i.e. it is a question of mass. In absolute terms, the amount of expenditure on education continues to increase, but at a much slower pace than GDP. In other words, the growth of education expenditures is proportional to the growth (or decline) of the Ukrainian economy as a whole.

A positive point is the increase in the share of expenditures on preschool education (1.6\% of total expenditures in 2000 compared to $15 \%$ in 2019). This is due to the increase in the birth rate in Ukraine and the need to expand funding for preschool education. Expenditures on vocational education are also rising, which can be explained by the need to increase the workforce in production.

Secondary and higher education reflect the same trend as the general level of funding. Over the past 13 years, the state has tended to increase spending. However, these funds are too small to form a quality education system in Ukraine. Since 2009, there has been a slight decrease in expenditures on higher education. This is due to the decrease in the number of students and entrants as a result of the reform of the education system since 2000. This level of funding for the education sector is fully justified and related to the natural demographic phenomena in the country. However, this does not meet the European standards for the quality of education systems and training.

C) insufficient level of funding for the scientific sphere

The scientific sphere of Ukraine needs significant reform, because as of today domestic science has lost its influence on the socio-economic development of the state, the indicator of domestic scientific and technical potential has decreased to a critical level, which has become a threat to the national security of Ukraine. The basis of the domestic economy are raw materials and low-tech industries, which significantly reduces the potential for development of Ukraine as a competitive state in the long run. The results of scientific research and scientific-technical developments have only a small effect on Ukraine's GDP growth.

The level of interest of scientific institutions in the practical application and implementation of their own results of research and development is extremely low, the interaction between the subjects of scientific and scientific-technical activities and the executive authorities in this area is virtually absent.

Budget financing of scientific and scientific-technical activities at the expense of budget funds in 2019 amounted to $0.47 \%$ of Ukraine's GDP. About $90 \%$ of which 
is aimed at ensuring the activities of state research institutions on the principle of basic funding.

The reasons for the decline in science-intensive GDP (in 2019 this figure is not more than $0.17 \%$ ), as well as reducing the role of science and its impact on scientifictechnological and innovative development of the country are not only a lack of funds, outdated material and technical base of science, human scientific potential, inefficient use of available resources, but also inefficient system of public administration in the field of science, lack of coordination of efforts, which does not allow to focus on specific tasks of national economy and defense capabilities.

Extremely low level of funding for science and outdated material-technical base have led to a serious decline in the social prestige of scientific work and a mass exodus of quality scientific personnel abroad or in other fields.

D) limited influence on the structure of scientific institutions and directions of development of academic science through the principle of basic funding of national academies of sciences.

The lack of an effective system of coordination of science development in the country is due to the conservatism of the system of national academies of sciences formed mainly in Soviet times, which remain the main recipients of state financial support for research and development. Therefore, public authorities have a rather limited influence on the structure of scientific institutions and directions of development of academic science, which is financed mainly by the principle of basic funding. Scientific topics that receive financial support from the state budget reflect the long-established structure of state research institutions, whose scientific priorities have often become outdated and unpromising, and their change in accordance with changes in the needs of the economy or development of the scientific society is rather slow.

Today, the main managers of budget funds for scientific and scientific-technical activities are almost 30 executive bodies and other state institutions. However, a single approach to assessing the effectiveness of their use of budget funds has not been introduced, nor are there institutions that would have the authority to coordinate the activities of the public sector of research and development and harmonize the vector of its development with the national vector of economic development.

E) lack of appropriate funding institutions for grant funding of science

At the same time, grant funding, as a tool, has a very limited application due to 
the lack of appropriate funding institutions. The practice of technologically developed countries shows the need to establish funds to support scientific activities as additional alternative sources that provide independent grant support for research projects, but within the state priorities set by the relevant institutions of state power.

Factor 3. Decline of material-technical base. Lack of sufficient state funding for HEI and crisis conditions for enterprises and organizations of real sectors of the economy reduces the sources of replenishment of the special fund of HEI by reducing economic contract topics and makes it impossible to update the material-technical base. This has a negative impact on the training of modern professionals.

Factor 4. A large number of small HEI that do not correspond to the status and cannot train qualified specialists.

The current network of higher education institutions far exceeds the needs of Ukraine. Such a dispersion of managerial, financial-material, human resources of the educational sphere through a large network of educational institutions, which in absolute and relative terms is almost ahead of the rest of the world, including The United States and the EU do not correspond to the globalization and integration processes to which our country has joined.

\section{2) sphere of organizational support:}

Factor 1. Weak connection of higher education with the needs of the labour market.

The discrepancy between the demand and supply of knowledge and skills in Ukraine is due to the fact that in the labour market there is a shortage of specialists in certain professions and a relative surplus of others. This is evidenced by the difficulties that arise for employers in hiring professionals with appropriate qualifications, on the one hand, and graduates of HEI with job search, on the other. This was due to the fact that in the country due to the structural crisis, the collapse of mechanical engineering, military-industrial complex, bankruptcy of many enterprises of light and other types of processing industry, the effective system of basic (for educational institutions) enterprises and cooperatives was destroyed.

Factor 2. Unbalanced system of training in various sectors of the economy (surplus of graduates of economic, legal specialties; lack of technical).

In addition, certain professions are aging in Ukraine. These are areas that are characterized by low wages due to the lack of a full-fledged competitive labour market, as well as fairly specific working conditions and qualification requirements. Young 
people do not want to work in these areas. There is a shortage of qualified personnel in the fields of material production. The issues of mobility, competitiveness and the level of qualification of employees become especially relevant. Thus, in Ukraine there is a problem of retraining and orientation of educational institutions to train professionals capable of implementing and maintaining the latest technological processes.

Factor 3. Reducing the total number of students in HEI at all levels of accreditation and increasing the share of young people trying to study abroad.

One of the reasons for this trend is the new requirements for admission to HEI (introduced in 2008) based on the results of external independent testing, HEI economic education, as the passing score increases every year. In addition, the sharp decline in the birth rate in Ukraine in the first years of independence was reflected in 2007-2011 by a reduction in the number of graduates of secondary schools and, accordingly, a decrease in the number of HEI entrants. The structure of higher education in Ukraine is quite diverse and is constantly in a changing state under the influence of dynamic changes in the external and internal environment. Among the total number of freelance students, the greatest burden falls on the funds of individuals.

\section{3) sphere of staffing:}

Factor 1. Declining of the social status of educators and low payment for their work. Part-time teachers are widespread. In case of insufficient workload, teachers often undertake to teach the maximum number of disciplines, which, of course, has a negative impact on the quality of training.

Factor 2. Aging of teaching staff, insufficient rate of staff rejuvenation

Thus, without quality training of skilled workers, adapted to the requirements of technological development of industries, which have a high level of theoretical training and professional competence, have multifunctional skills, capable of self-organization, self-realization in professional activities, prepared to solve production problems and socio-economic problems, it is impossible to develop high-tech production, those are areas that determine the pace of economic development of the country, ensure the quality and competitiveness of products. This reaffirms the urgent need to improve the education system to create conditions for the growth of the intellectual component of human capital, the formation of a competitive personality, so that Ukraine can emerge in the world community as a generator of new knowledge and innovation.

Based on the analysis of the above reasons for the main problem of the higher education system of Ukraine, it can be concluded that the HEI of Ukraine is not able 
to create a certain level of competitiveness of national education at the global level. This leads to a deterioration of Ukraine's performance in international studies of competitiveness and innovation attractiveness, which affect the economic development of Ukraine. In these rankings, the Ukrainian universities occupy low positions or are completely absent from the lists.

In order to solve these problems, Ukraine is purposefully in the process of improving the legal framework for the functioning of the education system, all its levels and subsystems, the activities of educational institutions of different types and forms of ownership, the organization of various forms of education. Legal aspects of higher education are based on the Constitution of Ukraine, taking into account the Joint Declaration of the European Ministers of Education "European Space in Higher Education" and embodied in the Laws of Ukraine "On Education", "On Higher Education", "On Scientific and Technical Activities", "On state forecasting and development of programs of economic and social development of Ukraine", Strategy for development of higher education in Ukraine for 2021-2031, Resolution of the Cabinet of Ministers "On development of forecast and program documents of economic and social development and drafting of the Budget Declaration and State Budget", Regulations on the Ministry of Education and Science of Ukraine, the National Doctrine of Education Development, the Decree of the President of Ukraine "On the Sustainable Development Goals of Ukraine until 2030".

\subsection{The impact of force majeure of COVID-19 pandemic on the higher education system}

In 2019, the UN General Assembly recognized education for sustainable development (SDR) as a model for rethinking learning to achieve the goals of sustainable development [112]. The SRF overestimates what we learn, where we learn and how we learn, and develops knowledge, skills, values, and attitudes that enable students to make informed decisions and actions about global issues such as the climate crisis. This enables students of all ages to change their way of thinking and work towards a sustainable future. The SRF addresses the content of education in such a way that curricula include the study of environmental integrity, economic viability and how to work towards a just society. But it also reevaluates teaching methods and outcomes to form critical, responsive students who can work together to solve problems and act in 
local and global emergencies.

SRF is a key factor contributing to all 17 sustainable development goals, but can also be a key to preparing the world for future crises, such as COVID-19. The pandemic has shown us the importance for people and society of being able to respond quickly to unexpected risks. This involves the ability to understand complexity, anticipate different scenarios, negotiate trade-offs, be prepared to act quickly on the basis of limited information, and work together to find the best solutions.

A recent UNESCO study found that countries place strong emphasis on cognitive learning over socio-emotional and behavioral learning, which are the key tools for student empowerment and change. It is important to ensure that education provides students with the tools to address the present and the future, tackle the climate crisis and transform society.

The COVID-19 pandemic has caused various changes in life. One of the most affected sectors is higher education, and more specifically - student exchange. COVID19 has unprecedentedly disrupted education around the world. Millions of students have been unable to continue their education in schools, universities, vocational schools and adult education programs. Many governments have responded to the urgent need to provide students with online and distance learning opportunities. Virtual lessons were accepted, homework materials were distributed, and education was provided through television and radio or in the open. These efforts have been significant and undoubtedly very challenging for many governments, faculty and students, as they have required a reshuffle not only of service delivery mechanisms but also of roles and responsibilities.

According to UNESCO, on April 1, 2020, schools and institutions of higher education (HEIs) were closed in 185 countries, affecting 1,542,412,000 students, which is $89.4 \%$ of the total number of enrolled students. On May 7, schools and HEIs were still closed in 177 countries, covering 1,268,164,088 students, representing $72.4 \%$ of the total number of students enrolled.

Various organizations, such as the International Institute of Education (IIE) in the United States or the European Association for International Education (EAIE), the International Association of Universities (IAU) and the Erasmus Student Network (ESN), have participated in separate studies to understand the impact of COVID-19 on communities which they directly support. According to these surveys, the following issues were addressed:

impact on student exchange. When asked about the impact of COVID-19 on the 
international level, $53 \%$ of higher education institutions answered that foreign students are based in their educational institutions and $43 \%$ of their students find themselves in foreign institutions;

canceled mobility. 30\% of HEI answered that all their mobility was canceled and $47 \%$ of freelancers answered that student exchanges were canceled with some countries, while $25 \%$ of students claimed that their mobility was canceled;

connection between higher education institutions and students. They were asked whether the HEIs had the appropriate infrastructure to communicate with students, and 97\% of higher education officials confirmed that they had done so. However, the fact that there is an appropriate infrastructure does not say anything about the effectiveness of communication. There was analyzed more detailed information on the availability of information on health measures, availability of information in English, and availability of travel restriction information. These results mean that HEIs are really trying to communicate effectively with their students, and that in most cases the flow of information is good. However, there is a small percentage of HEIs where these efforts are not effective. In these HEI there is a need to reconsider the method of information delivery both in terms of content, language, and technical platforms used;

the need to adapt teaching methodologies due to the impossibility of conducting presentation classes. Therefore, online teaching and learning has played an important role in higher education in recent months. Eighty-five percent of international students who responded to the survey said that presentation classes had been completely or partially replaced by online methodologies. In addition, $12 \%$ of the respondents, who completely dropped out of training, developed solutions for teaching and learning, for example, by using online methodologies and self-learning tools;

the need to support students more holistically not only at the academic level. $42 \%$ of HEI stated that contingency plans had been developed in partner institutions abroad, $34 \%$ - in domestic universities and $23 \%$ had no contingency plans in their institutions or in partner institutions abroad. Although most higher education institutions have responded positively to the support they provide to students, the lack of action plans in almost a quarter of HEIs can have a negative impact on students' experiences. It is very important that educational institutions do not allow students to feel abandoned without the support of institutions;

finding the right balance between face-to-face and online learning, between physical mobility and "virtual exchange". It is necessary to provide a safe environment 
on campus for all students (including international students), which will require more effort on the part of both HEI and students. International mobility will require more and possibly different support from higher education institutions. Therefore, as never before, it is necessary for HEIs and students to work closely together to find solutions to provide the current and next generation of students with the same, if not better, learning opportunities than the previous generations of students [59].

This leads to the conclusion that, despite difficulties in adapting to a completely different methodology for teaching, the higher education sector has demonstrated a reactivity to find solutions to challenge the pandemic and to continue teaching and learning. It remains to be seen how the quality of education is affected by the transition from personal to online teaching, especially when the situation changes from crisis management to a new normal one for the new school year. It will be important to study this change in more detail both from universities and from the students' point of view.

Higher education must now move from a crisis management situation to longerterm planning for the new school year. Many of the solutions implemented during the crisis have proven useful and probably worth pursuing, but in order to continue to offer quality education in the new school year, careful planning is needed as new challenges arise.

In order to better understand the disruptions caused by COVID-19 in higher education and to explore the first steps taken by higher education institutions in the world to respond to the crisis, the International University Association (IAU) has decided to create an IAU Global Survey on the Impact of COVID-19 on Higher Education the world. The analysis of the survey is based on 424 complete responses from unique HEIs in 109 countries and two special administrative regions of China (Hong Kong and Macao) (Table 1.4) [112].

It is important to make the forced transition to distance learning and learning opportunities to offer more flexible learning opportunities, explore blended or hybrid learning, and combine synchronous learning with asynchronous learning. The type of influence is various and varies from institution to institution, but everywhere it was negative. Most HEIs have contingency plans to mitigate this impact. Most educational institutions around the world have canceled their studies and switched to distance learning, trying to curb the spread of COVID-19 (Table 1.5). Part (or all) of the formal education system will not open this school year in some countries, while others (parts) of the formal education system are gradually reopening. 
Table 1.4

\section{Results of the IAU Global Survey on the Impact of COVID-19 on Higher Education Worldwide}

\begin{tabular}{|c|c|c|}
\hline Question & $\%$ & Features \\
\hline $\begin{array}{l}\text { affected by COVID-19: all activities at the university ceased and the } \\
\text { institution became completely closed }\end{array}$ & 59 & in Africa it reaches $77 \%$ \\
\hline $\begin{array}{l}\text { have the infrastructure to communicate with their students and staff for the } \\
\text { COVID-19 period }\end{array}$ & 91 & - \\
\hline $\begin{array}{l}\text { COVID-19 will have an impact on the admission campaign for the new } \\
\text { school year }\end{array}$ & 80 & $\begin{array}{l}46 \% \text { believe that the impact will affect both international and local students. } \\
\text { Some HEI, especially private ones, reported that this impact would have } \\
\text { negative financial consequences }\end{array}$ \\
\hline $\begin{array}{l}\text { senior management and faculty were consulted by the government or civil } \\
\text { servants in the context of COVID-19 public policy development }\end{array}$ & 67 & \\
\hline $\begin{array}{l}\text { the government / ministry of education will support their institution in } \\
\text { overcoming the obstacles posed by COVID-19 }\end{array}$ & 48 & The most common support is help at the end of the school year \\
\hline COVID-19 will have a variety of effects & 64 & $\begin{array}{l}\text { Half of the HEIs reported that COVID- } 19 \text { weakened partnerships, while only } \\
18 \% \text { reported that it strengthened them. However, for } 31 \% \text { of respondents, the } \\
\text { COVID- } 19 \text { pandemic created new opportunities with partner institutions }\end{array}$ \\
\hline teaching in the classroom was replaced by distance learning & 67 & $\begin{array}{l}\text { The transition from personal to distance learning has not been without } \\
\text { problems, the main of which are access to technical infrastructure, competence } \\
\text { and pedagogy of distance learning and the requirements of specific areas of } \\
\text { study }\end{array}$ \\
\hline $\begin{array}{l}\text { COVID-19 Increased Virtual Mobility and / or Collaborative Online } \\
\text { Learning as an Alternative to Student Physical Mobility }\end{array}$ & 60 & This can to some extent protect internationalization \\
\hline $\begin{array}{l}\text { HEI plan to take exams during the semester as planned, although most of } \\
\text { them are carried out through new activities }\end{array}$ & 51 & $\begin{array}{l}\text { However, there are significant regional differences when } 80 \% \text { of HEI in } \\
\text { Europe plan to take exams, while exams risk postponing or canceling } 61 \% \text { of } \\
\text { HEI in Africa. }\end{array}$ \\
\hline $\begin{array}{l}\text { Conducted research on the negative effects of the COVID-19 pandemic in } \\
\text { their institutions }\end{array}$ & 80 & $\begin{array}{l}\text { The most common effects of COVID-19: } \\
\text { cancellation of international travel (by } 83 \% \text { of } \mathrm{HEI}) \text {; } \\
\text { cancellation or postponement of scientific conferences }(81 \%) \\
\text { research projects risk not being completed }(52 \%)\end{array}$ \\
\hline participate in COVID-19 studies & 41 & $\begin{array}{l}\text { In almost all of them, researchers contribute to the modern development of } \\
\text { public policy. Three-quarters of institutions contribute to public policy either } \\
\text { through their institutions or through their researchers. A quarter of the HEIs } \\
\text { consider it important to involve stakeholders in the development of public } \\
\text { policy by their governments as institutions, as such that should be consulted } \\
\text { and take into account their experience in the study. }\end{array}$ \\
\hline
\end{tabular}


Table 1.5

\section{Features of the educational process in some countries and regions}

\begin{tabular}{|c|c|}
\hline Country / Region & Features \\
\hline $\begin{array}{l}\text { in Quebec, } \\
\text { Canada }\end{array}$ & $\begin{array}{l}\text { Schools are required to provide computers for teachers who are not at home, } \\
\text { but reimbursement of other fees, such as Internet access and telephone } \\
\text { communications, is determined by the local school administration. } \\
\text { Although some schools, HEIs and the Ministry of Education have introduced } \\
\text { emergency courses on online content delivery, virtual classroom management } \\
\text { and the use of technology, and facilitated the transfer of learning resources } \\
\text { and learning materials to online platforms. } \\
\text { Collective agreements with teachers and educational staff have been } \\
\text { suspended to allow for changes in tasks, schedules and jobs to take account of } \\
\text { emergencies. }\end{array}$ \\
\hline $\begin{array}{l}\text { The Ministry of } \\
\text { Education of the } \\
\text { United Arab } \\
\text { Emirates and } \\
\text { Hamdan Bin } \\
\text { Mohammed } \\
\text { Smart University }\end{array}$ & $\begin{array}{l}\text { conducted an e-learning course for more than } 42,000 \text { teachers and researchers } \\
\text { on online classroom management and technology use. With } 22,000 \\
\text { certificates already issued, the course states that it can provide training for } 24 \\
\text { hours. Although such activities are aimed at immediate need, training should } \\
\text { meet professional standards, should not undermine the quality of education } \\
\text { and should be carefully designed to complement virtual teaching in long term. }\end{array}$ \\
\hline $\begin{array}{l}\text { in some states of } \\
\text { Australia }\end{array}$ & $\begin{array}{l}\text { schools remain open to ensure that childcare responsibilities do not prevent } \\
\text { advanced health professionals and first responders from reporting on work. } \\
\text { On the other hand, teachers call for the closure of schools, along with all other } \\
\text { unimportant services, to protect not only their own safety and health, but also } \\
\text { the safety of their students and the general public, with many of them citing } \\
\text { the stress of continuing personal learning. }\end{array}$ \\
\hline in Belgium & $\begin{array}{l}\text { kindergartens continue to operate for children of parents working in critical } \\
\text { sectors. Even in situations where their services are deemed necessary, teachers } \\
\text { should be consulted on the potential risks to health and safety at work and } \\
\text { involved in the development of appropriate strategies to ensure healthy and } \\
\text { safe workplaces, including access to hygiene and prevention training. }\end{array}$ \\
\hline $\begin{array}{l}\text { In some parts of } \\
\text { the United States } \\
\text { (In Los Angeles) }\end{array}$ & $\begin{array}{l}\text { teachers report that they must make their own payments for the purchase of } \\
\text { cleaning supplies for their classrooms. } \\
\text { The United Teachers of Los Angeles has agreed with the Los Angeles Unified } \\
\text { School District to set conditions for teachers on online teaching and learning } \\
\text { during a pandemic, including flexibility in scheduling their work, reasoning } \\
\text { about teaching methods, and protection against loss of pay or benefits during } \\
\text { school closure. The agreement is expected to be a model for other areas } \\
\text { currently being negotiated. }\end{array}$ \\
\hline In Argentina & $\begin{array}{l}\text { The Ministry of Education set up a commission, which consists of } \\
\text { representatives of six teachers' associations, to plan distance learning. }\end{array}$ \\
\hline In Kenya & $\begin{array}{l}\text { Job losses are reported when teachers, who work in some low-cost private } \\
\text { schools, are temporarily laid off without pay during school closures. During } \\
\text { compulsory leave, staff will receive } 10 \text { percent of their salaries and health } \\
\text { benefits. }\end{array}$ \\
\hline $\begin{array}{l}\text { in private schools } \\
\text { in Pakistan }\end{array}$ & $\begin{array}{l}\text { Teachers expressed concern about job losses and income. The Punjab } \\
\text { government recently asked private schools to voluntarily reduce their monthly } \\
\text { tuition fees by } 20 \text { percent to ensure the safety of teachers. }\end{array}$ \\
\hline In Finland & $\begin{array}{l}\text { They consulted with the Finnish Education Trade Union (OAJ) on emergency } \\
\text { measures in education which it had supported. }\end{array}$ \\
\hline In many countr & Is have an inte \\
\hline
\end{tabular}




\begin{tabular}{|l|l|}
\hline $\begin{array}{l}\text { in south-west } \\
\text { Asia and sub- } \\
\text { Saharan Africa }\end{array}$ & $\begin{array}{l}\text { have personal computers. } \\
\text { In Peru, 35 percent of teachers have access to a computer and the Internet. } \\
\text { Therefore, the Peruvian government uses television and radio channels to } \\
\text { provide classes and content to students, as well as online platforms such as } \\
\text { Aprendo en casa (I study at home). It is estimated that in Cameroon, 20-25 } \\
\text { percent of teachers have access to the Internet and that most teachers do not } \\
\text { have ICT skills. A national government working group has been set up to } \\
\text { establish a Protective Curriculum that allows teachers and students to access } \\
\text { education through familiar platforms such as radio and television. In Uganda, } \\
\text { educational institutions have been set up to conduct capacity-building } \\
\text { workshops for teachers who do not have ICT information }\end{array}$ \\
\hline $\begin{array}{l}\text { Pakistan and } \\
\text { Somalia }\end{array}$ & $\begin{array}{l}\text { With regard to wages, in countries where private schools are widespread, } \\
\text { there are reports of teacher redundancies due to the lack of demand, while in } \\
\text { public schools, governments are making efforts to maintain teachers' salaries. }\end{array}$ \\
\hline In the Philippines & $\begin{array}{l}\text { The government sought to pay teachers' salaries ahead of schedule for March } \\
\text { and April, and the teacher performance checks were suspended during the } \\
\text { state of emergency. Teachers and educators who are still in school will be } \\
\text { rewarded for danger and help with clothing. It is unclear whether such } \\
\text { measures have been taken, as trade unions have expressed concern about the } \\
\text { financial situation of teachers in the crisis }\end{array}$ \\
\hline In Uganda & $\begin{array}{l}\text { The Ministry of Education and Sports announced the timely payment of } \\
\text { salaries so that teachers could stock up and focus on their mission. }\end{array}$ \\
\hline
\end{tabular}

Renew education to support those who change the situation, ready for global challenges. The closure of schools in more than 180 countries has revealed inequalities in education, the disadvantages of distance learning, the cost of the digital divide, and the important role that schools play in the health and well-being of students. Following this crisis, governments around the world will have to review the assessment of education systems to meet these challenges. This is an opportunity for generations to improve education, along with the economy, to combat the climate crisis. It is time for the heads of educational institutions to use this period to make sure that what people learn is really about their lives and the survival of the planet (Table 1.6).

Table 1.6

\section{Areas of support and recommendations of world organizations during the} pandemic

\begin{tabular}{|c|c|}
\hline Organization & Recommendations / areas of support \\
\hline 1 & 2 \\
\hline $\begin{array}{l}\text { According to the } \\
\text { International } \\
\text { Monetary Fund } \\
\text { (IMF) }\end{array}$ & $\begin{array}{l}\text { Almost all governments have increased spending on education. Much of this } \\
\text { funding has been used to implement online and distance learning technologies, } \\
\text { and there is little evidence that the funding went to pay teachers or teach the use } \\
\text { of Internet technology. } \\
\text { Converting teaching materials to digital format has become a problem in a short } \\
\text { time, as few teachers have strong digital and ICT skills. }\end{array}$ \\
\hline $\begin{array}{l}\text { At the } \\
\text { international } \\
\text { level, the United } \\
\text { Nations }\end{array}$ & $\begin{array}{l}\text { founded the Global Education Coalition, of which the ILO is a member, which } \\
\text { seeks to unite international organizations, non-governmental organizations and } \\
\text { the private sector to support COVID-19 responses in education. The } \\
\text { International Working Group on Teachers in Education by 2030, of which the }\end{array}$ \\
\hline
\end{tabular}


The end of the table 1.6

\begin{tabular}{|c|c|}
\hline 1 & 2 \\
\hline $\begin{array}{l}\text { Economic, } \\
\text { Scientific and } \\
\text { Cultural } \\
\text { Organization } \\
\text { (UNESCO) }\end{array}$ & $\begin{array}{l}\text { ILO is also a member, has published a Call to Action for Teachers, calling on } \\
\text { governments, providers and financiers - public and private - and all relevant } \\
\text { partners to maintain teacher employment and wages; prioritize health, safety } \\
\text { and well-being of teachers and students; involve teachers in the development } \\
\text { of educational responses to COVID-19; provide appropriate professional } \\
\text { support and training; put justice at the centre of reactions to education; and } \\
\text { involve teachers in responding to assistance. }\end{array}$ \\
\hline $\begin{array}{l}\text { Many other } \\
\text { international } \\
\text { organizations }\end{array}$ & $\begin{array}{l}\text { developed tools to support education during school closures, including } \\
\text { recommendations from the United Nations Children's Fund (UNICEF) on how } \\
\text { teachers should talk to children about COVID-19. } \\
\text { Companies and foundations have responded by releasing several tools to } \\
\text { promote distance learning management systems, mobile learning systems, mass } \\
\text { open online courses, self-directed learning content, collaborative platforms that } \\
\text { support real-time video, tools, which can be downloaded for offline learning, } \\
\text { and tools for teachers to create digital learning content. The widespread use of } \\
\text { digital technologies, many of which are offered free of charge, has been praised } \\
\text { by governments, many of which use them as part of distance learning } \\
\text { strategies. At the same time, this rapid spread of technology in education has } \\
\text { raised concerns without undergoing quality control procedures and public } \\
\text { procurement. }\end{array}$ \\
\hline $\begin{array}{l}\text { Global } \\
\text { Federation of } \\
\text { Trade Unions } \\
\text { Education } \\
\text { International }\end{array}$ & $\begin{array}{l}\text { issued the COVID-19 Pandemic Guidelines which include the principles of } \\
\text { teacher protection, social dialogue and the promotion of equity in distance } \\
\text { learning }\end{array}$ \\
\hline teachers' unions & $\begin{array}{l}\text { raised concerns about school safety and the need to protect teachers and school } \\
\text { staff from infection, as social distance between students and staff is difficult to } \\
\text { achieve in many school settings. Some unions have made specific proposals for } \\
\text { safe returns. For example, the German Teachers' Association offers a two-week } \\
\text { model of variable change. Trade unions have also expressed concern about the } \\
\text { growing inequality exacerbated by the pandemic and called for social dialogue } \\
\text { in the development of a return to school policy. Union Education International } \\
\text { has issued a Guide to Restoring Schools and Institutions which emphasizes } \\
\text { social and political dialogue with teachers and their representative unions and } \\
\text { organizations to assess the needs and harmonize occupational safety measures } \\
\text { for students and staff, and the framework and resources for transition return to } \\
\text { teaching and learning in the field. }\end{array}$ \\
\hline $\begin{array}{l}\text { ILO and } \\
\text { UNESCO } \\
\text { together with the } \\
\text { International } \\
\text { Working Group } \\
\text { on Teachers for } \\
\text { Education by } \\
2030\end{array}$ & $\begin{array}{l}\text { issued Guidelines to support national authorities in their efforts aimed at social } \\
\text { dialogue, safety and health of school staff, mental health, teacher training and } \\
\text { education, labour rights and conditions, education: monitoring and evaluation. }\end{array}$ \\
\hline
\end{tabular}

Quarantine and forced use of distance learning have only exacerbated a number of problems that were previously known to educators and managers in most cases. The 
forced transition to distance learning revealed serious organizational, educational, psycho-emotional, technical problems with ensuring the right to quality education (Fig. 1.2).

The increased disparity in cognitive abilities that may occur during the COVID19 pandemic will have consequences not only in the short term but also in the long term. Numerous studies $[59,112,117]$ show that the cognitive and socio-emotional level of learning is a good predictor of further results.

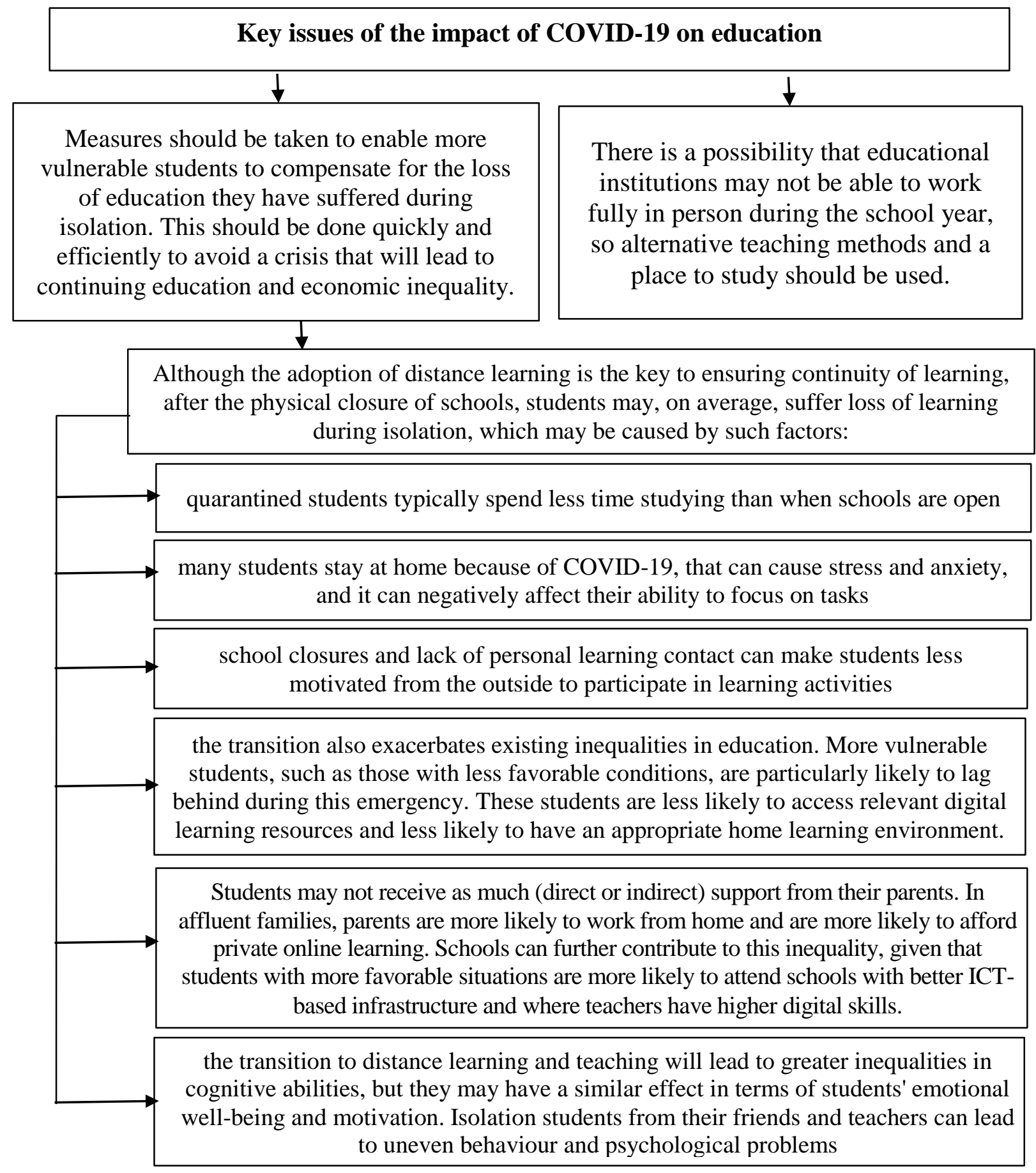

Fig. 1.2. Key learning challenges caused by COVID-19 
prospects for both employment and pay. Thus, there is a risk that, in the absence of appropriate policy measures, short-term educational inequalities caused by COVID-19 may persist or even increase over time, that will lead to a greater economic inequality in the future. The learning difficulties experienced by students during COVID-19 will lead to a reduction in human capital, which will have a negative impact on productivity growth, innovation and employment, including future lower earnings for student cohorts directly affected by isolation.

Blended / rotary learning system (with offline and online elements) has the following features:

1) requires a change in both quantitative and qualitative learning abilities,

2) requires a review of the curriculum,

3) there may be problems with adaptation to this model, especially regarding the use of ICT,

4) the structure of many existing buildings of educational institutions may not meet the requirements for maintaining physical distance.

The following elements should be part of a successful online and offline learning strategy:

ensure access to the Internet and ensure the availability of computers, laptops or tablets: access to the Internet at the appropriate speed and to the appropriate means of ICT is a prerequisite for any online teaching and learning strategy;

adopt appropriate virtual learning environments (VLEs): VLEs can provide students with access to educational resources, connect students with teachers, and promote distance learning;

rethink the role of radio education: educational broadcasting can be such a useful addition to online programs, as it provides education to those who do not have access to the Internet and equate teaching methods and materials in different schools in the country or region;

improve access to learning technologies for students with special needs and / or disabilities (SEND): digital technologies can provide useful support to students, especially if they are a part of a coherent and inclusive process.

teacher support: teachers must learn to adapt their role to the situation in Ukraine, with which they can communicate only on the Internet and in which, as a rule, even students may lose motivation when moving to study on the Internet. This is crucial for improving the digital competences of teachers at any age, as well as for providing pedagogical approaches that are best suited to the Internet. 
By analyzing secondary information from university and government sources in 20 countries [125], we can summarize the challenges and consequences that the COVID-19 pandemic has caused for the global higher education community:

research and the world's leading universities are faster than others to overcome the crisis and will retain a leading role in higher education, will remain and perhaps will even intensify. Private institutions, which are largely dependent on tuition fees, are more prone to crisis;

research will mainly focus on overcoming the crisis, as well as supporting society in relevant important projects. Leading research institutions specializing in life sciences will receive more attention and funding;

opportunities for access to relevant ICTs have become significant challenges, increasing inequality among higher education students. At the same time, teachers' skills are being improved and learning platforms and distance learning programs are being improved;

studying abroad can be problematic, as the infrastructure of higher education will be sharply reduced and there will be a need to adapt to new models. The practice of hiring and studying will change: there will be flexible application deadlines and qualification requirements for students will change. Long-distance travel will partially replace teleconferencing.

\subsection{The phenomenon of innovative university: understanding the essence and characteristics}

Much attention at the present stage of development of higher education is paid to the problem of translating it to an innovative basis, i.e. taking into account in the process of training such innovative elements that would ensure an appropriate level of competitiveness of domestic education in the globalization space [115]. Modern universities, in order to meet the requirements of the time, must perform not only the classical functions (education, research, education), but also acquire new features innovation and entrepreneurship.

Innovative development is an integral part of meeting a wide range of national interests of the state. The importance of innovative development of society in Ukraine is confirmed by a number of laws and regulations, namely the Law of Ukraine (LA) "On Innovation", the Law "On Priority Areas of Innovation in Ukraine", the Concept 
of Scientific, Technical and Innovative Development of Ukraine, Innovation Development Strategy Ukraine for 2010-2020 in the context of globalization challenges ", the National Doctrine of Education Development of Ukraine in the XXI century. Regulatory and legal support determines the essence, conditions and main mechanisms of innovation, the purpose of innovation policy of Ukraine. According to the law, innovative development is a process of structural improvement of the national economy, which is achieved mainly through the practical use of new knowledge to increase social production, improve social product quality, strengthen national competitiveness and accelerate social progress in society [289], and education is a strategic resource for improving the welfare of people, ensuring national interests, strengthening the authority and competitiveness of the Ukrainian state in the international arena, and the quality of education is a priority of public policy in education and is a prerequisite for national security [2].

Increasing competition in the market of educational services, reduction of direct funding from the state budget exacerbate the problem of adaptation to new conditions of development for modern higher education institutions. The best experience of the world's leading universities shows that the key factor in their successful development is innovation and entrepreneurship, which provides an adequate response to changes in the environment while meeting the social needs of society and market needs. In this regard, it is especially important to define the essence of innovative-active university as a form of integration of education, science and business within the national innovation system [145].

The need to transform a traditional university into an innovative, entrepreneurial one arose due to the emergence in the XX century of a global trend of reducing university funding from public sources, increasing competition in the international educational space and changing the global paradigm to education in social and economic development of society and civilization [196]. The foundations of the innovatve-active (entrepreneurial) university were laid in the works of such foreign scientists as B. Clark, M. Gibbons, D. Kennedy, S. Kerr, G. Itzkowitz, L. Leidesdorf, and others [58, 127, 90, 126, 129, 115, 111, 149]. The concept of "entrepreneurial university" was developed in the mid-90s of the XIX century in the works of the German scientist G. Itzkowitz (Triple Helix model, which describes the interaction between universities, industry and the state) and the American scientist B. Clark who based on an analysis of ten years of experience in the transformation of five European universities proved that the University of Entrepreneurship strives for innovation in its 
work. Its important feature is the acceptance of risks in the development of new practices, permanent search for new, non-traditional methods, approaches and tools of educational and scientific activities to form current and future competitive advantages to enhance its attractiveness to key stakeholders - applicants, society, economy.

G. Itzkowitz's triple helix model reveals the potential for innovation and economic development of society. Under this model, universities acquire certain features of enterprises and government agencies and become the basis for innovation, scientific-practical development and entrepreneurial projects. [266, 149, 111]. The model of innovation with a triple helix, theoretically developed by G. Itzkowitz and L. Leidesdorf, is based on the interaction between three elements: universities engaged in basic research; industries that make commercial goods; a state that regulates markets. It shows the inclusion in the interaction of certain elements at each stage of creating an innovative product. At the initial stage of knowledge generation, the state and the university interact, then during the technology transfer the university cooperates with business (industry), and the result is brought to market by the government and business $[111,266]$. New knowledge and technologies become the main factor of state competitiveness. In this situation, universities that conduct research and development become the most important resource for science-intensive production.

According to the concept of B. Clark, the advantages of innovative universities are $[58,127]$ :

strong governance mechanism - universities cannot depend on traditional (weak) control or governance. They need to become faster, more flexible, more focused in responding to environmental demands;

periphery of development - universities must have mechanisms of interaction with the external environment, for which it is advisable to create special organizational units;

diversified funding base - universities need financial resources, for which it is necessary to expand their financial base (and become less dependent on the government);

strong academic support - universities need basic academic units that adopt an entrepreneurial culture. These core units should be encouraged to respond positively to change;

integrated business culture - universities need a culture that encompasses change, work ethic and a set of beliefs that are university-wide and that become the very basis of the institution's identity [121]. 
Considering the importance of innovative development of society in Ukraine, several important laws have been adopted: "On Innovation", "On Priority Areas of Innovation in Ukraine", the Concept of Scientific, Technical and Innovative Development of Ukraine. These documents set out the essence, conditions and basic mechanisms of innovation, formulate the purpose of innovation policy of modern Ukraine. Innovative development is an integral part of meeting a wide range of national interests of the state. In the Law of Ukraine "On Innovation" it is seen as a process of structural improvement of the national economy, which is achieved mainly through the practical use of new knowledge to increase social production, improve social product quality, strengthen national competitiveness and accelerate social progress in society [111]. In pursuance of the Resolution of the Verkhovna Rada of Ukraine of February 17, 2009 № 965-VI "On Holding Parliamentary Hearings“" Strategy of Innovative Development of Ukraine for 2010-2020 in the Context of Globalization Challenges "by the Verkhovna Rada Committee on Science and Education, Centre for Scientific and Technical Research potential and history of science named after H. M. Dobrova of the NAS of Ukraine with the participation of other scientific institutions of the NAS of Ukraine, as well as central and local authorities taking into account the key provisions laid down in the draft the Strategy of Innovative Development of Ukraine for 20092018 and for the period up to 2039, the Strategy of innovative development of Ukraine for 2010-2020 in the conditions of globalization challenges is developed (hereinafter the Strategy) [232]. The National Doctrine of Education Development of Ukraine in the XXI century states that "education is a strategic resource for improving the welfare of people, ensuring national interests, strengthening the authority and competitiveness of the Ukrainian state in the international arena, and the quality of education is a prerequisite for national security"[232].

Modern universities, in order to meet the requirements of the time, must perform not only the classical functions (education, research, upbringing), but also acquire new features - innovation and entrepreneurship prerequisite for the competitiveness of the university is its ability to innovate and independently produce innovations.

Based on the definition of "innovation" according to the Law of Ukraine "On Innovation" [111], innovations in education or educational innovations can be interpreted as newly created (applied) and (or) improved competitive technologies, products or services, as well as organizational and technical decisions of production, administrative, commercial or other nature that significantly increase the quality, efficiency and effectiveness of the educational process. In this case, the main elements 
of "educational innovation" are:

a carrier (creative personality) who has a certain innovative idea (the core of innovation) and conducts an innovative experiment (source of innovation);

consumer of innovation - a student or group of students, listeners (who acquire knowledge in a particular area);

institutions that ensure the introduction of innovations in the educational process (educational institutions; scientific, methodological, scientific-methodological institutions; research and production enterprises; state and local education authorities and self-government in the field of education). The types of university innovations are given in table 1.7 [2].

Table 1.7

\section{Types of university innovations}

\begin{tabular}{|c|c|c|c|}
\hline Type & Essence & Sphere & Result \\
\hline 1 type & economic & $\begin{array}{l}\text { products and } \\
\text { services }\end{array}$ & $\begin{array}{l}\text { concepts, theories, systems, models, methods, } \\
\text { technologies, techniques, forms and more, both in } \\
\text { educational activities and in ensuring the educational } \\
\text { process }\end{array}$ \\
\hline 2 type & technological & $\begin{array}{l}\text { production } \\
\text { and } \\
\text { maintenance }\end{array}$ & $\begin{array}{l}\text { development, implementation and use of innovative } \\
\text { products and services in their educational activities, } \\
\text { namely the introduction of methodological support of } \\
\text { the educational process (creation of methodological } \\
\text { literature, publication of electronic textbooks, etc.), } \\
\text { innovation of process technology, distance learning, } \\
\text { training in online classrooms, internships with } \\
\text { inventors innovative technologies, etc.), provision of } \\
\text { innovative educational services, etc. }\end{array}$ \\
\hline 3 type & organizational & $\begin{array}{l}\text { associated } \\
\text { with changes } \\
\text { in the overall } \\
\text { organizational } \\
\text { structure of } \\
\text { the university } \\
\text { and their } \\
\text { departments }\end{array}$ & $\begin{array}{l}\text { implementation of joint activities to create innovations } \\
\text { with innovative organizations (research, project } \\
\text { expertise, consulting services) in the structure of } \\
\text { integrated organizations, which are formed on the basis } \\
\text { of the national innovation system and combine in } \\
\text { various organizational forms science, technique, } \\
\text { technology and education with a focus on the world } \\
\text { market of knowledge-intensive products and high } \\
\text { technologies }\end{array}$ \\
\hline 4 type & managerial & $\begin{array}{l}\text { relate to the } \\
\text { field of } \\
\text { psychology } \\
\text { and behaviour } \\
\text { of teachers } \\
\text { and support } \\
\text { staff }\end{array}$ & $\begin{array}{l}\text { acquisition of skills in research activities of teaching } \\
\text { staff and researchers, training and interdisciplinary } \\
\text { training }\end{array}$ \\
\hline
\end{tabular}

The Law of Ukraine "On Higher Education" (2014) provides the following definitions of a higher education institution and a university: 
a higher education institution - a separate type of institution, which is a legal entity of private or public law, operates in accordance with the issued license to conduct educational activities at certain levels of higher education, conducts scientific, scientific-technical, innovative and/or methodological activities, provides educational process and the acquisition of higher education, postgraduate education, taking into account their vocations, interests and abilities [92, 28];

one of the types of higher education institutions is a university - a multidisciplinary or branch institution of higher education, which conducts innovative educational activities at various levels of higher education, conducts basic and/or applied research, is a leading scientific and methodological centre, has a developed infrastructure of educational, scientific, research and production units, promotes the dissemination of scientific knowledge and conducts cultural and educational activities.

That is, higher education institutions have a legal basis for the introduction and strengthening of their innovative activities.

Much attention at the present stage of development of higher education is paid to the problem of translating it to an innovative basis, i.e. taking into account in the process of training such innovative elements that would ensure the appropriate level of competitiveness of domestic education in the globalization space [276]. Modern universities, in order to meet the requirements of the time, must perform not only the classical functions (education, research, upbringing), but also acquire new features innovation and entrepreneurship.

Scholars distinguish between the types of universities according to the criteria of participation in the innovative development of the economy. Thus, according to the criterion of innovation, universities can be traditional (classical) and innovative (entrepreneurial) (Fig. 1.3).

An example of an open university is the Open University of Great Britain [265] as an independent educational institution to provide a "second" opportunity to obtain or continue their education to working adults. The educational process is mainly based on the use of printed materials and the use of audio, video, etc.; students have the opportunity to receive consultations in 250 training centres located in many cities of the country and the world.

The most influential innovations are: mass open social learning (including mass open online courses - IOC), the use of data collection and analysis to develop pedagogical methods, inverted learning, meta-learning, BYOD principle, dynamic assessment, education through events, storytelling in education, the concept of 
thresholds, bricolage [120].

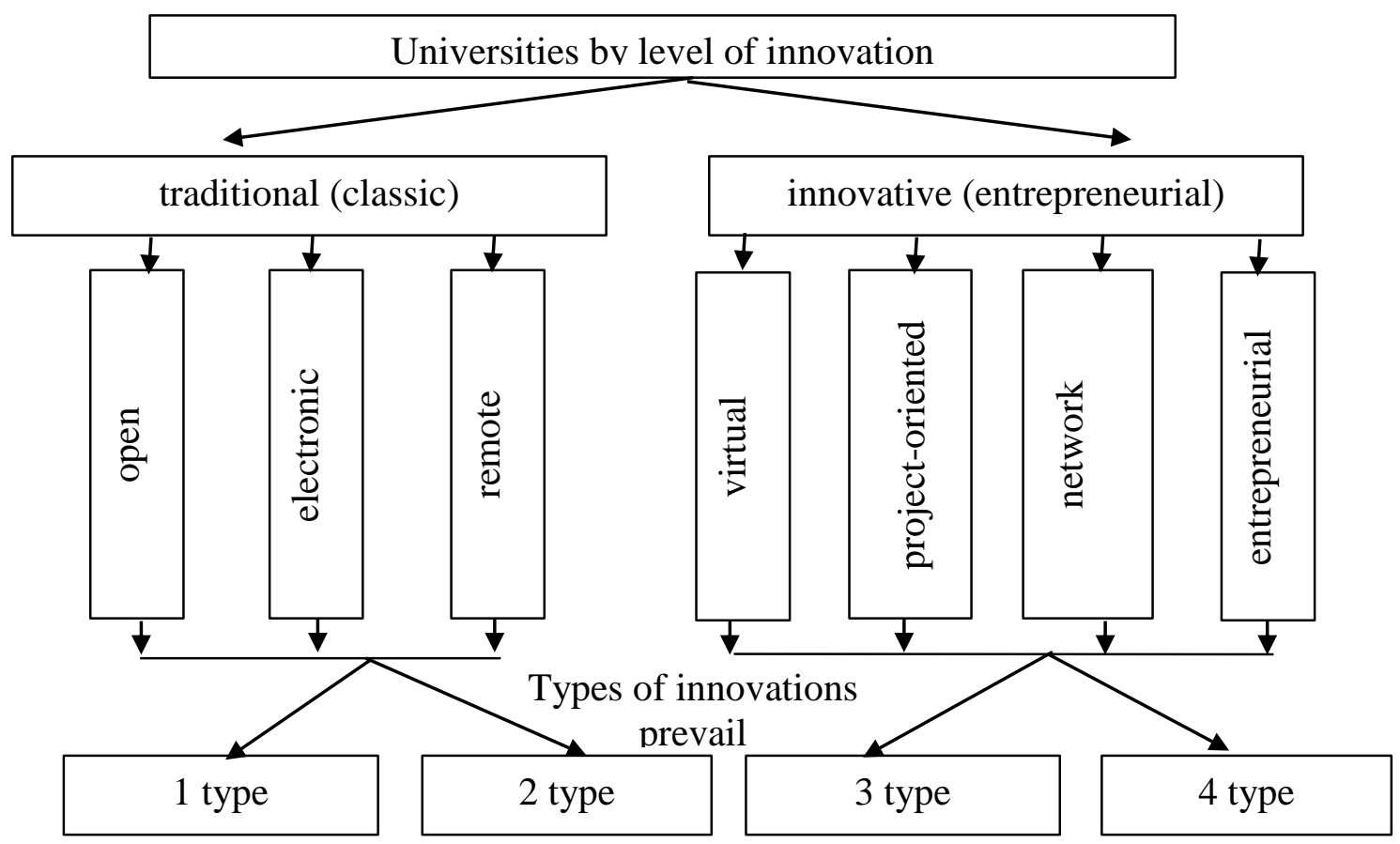

Fig. 1.3. Classification of universities by the level of innovation

The analysis of the proposed list of innovations leads to the conclusion that if the first two innovations - mass open social learning and data collection and its use in education - can be called qualitatively new or updated principles of existence and functioning of education in society, the last eight are relatively new approaches and methods in pedagogy, which, however, will have a significant impact on the educational space in the near future.

The concept of open knowledge, embodied in MOOC projects (English MOOC - Massive open online courses), is becoming increasingly important in modern conditions, because there is a growing understanding that knowledge is becoming a necessary key to the development of both the individual and society as a whole. The examples of IOC portals are Coursera online courses. These online courses have already partnered with 83 universities around the world.

Various approaches to building the concept of e-university are due to the level of development of information technology, the willingness of staff and recipients of eservices to their active use. Modern information society in combination with the concept of lifelong learning requires a comprehensive approach to understanding and implementing an e-university.

An e-university is often understood as having a dynamic website and electronic document management. The merging of traditional and electronic services, traditional 
and electronic educational, research, scientific-methodological and administrative processes into a single integrated management system is the basis of the concept of electronic university higher education institution [130].

The National University of Distance Education in Spain [264] was established to provide higher education to all those who, for various reasons, can not study in traditional university programs. Specially prepared printed publications are used as educational material, which are supplemented by audio and video cassettes, computer learning technology, television lectures and teletext. To maintain a constant dialogue with students, in 50 training centres they use telephone interviews and face-to-face meetings to discuss educational material. Currently, one of the most authoritative in the field of distance education is considered to be the University of Pennsylvania (Penn State University), whose experience was used by UNESCO in developing the concept of a virtual university.

In the late 90's of the twentieth century on the basis of distance education in the European educational environment, a new organizational form of modern education has emerged - a virtual university, the essence of which is not only distance learning, but also its independence from any institution. The experience of the Western countries shows that the modern university is not tied to the area, the concept of cyclical learning disappears because you can start studying in some higher education institutions at any time. There are no faculties in such universities, but there is a list of courses required for qualification. In addition, a virtual university is defined as a higher education institution based on the collaboration of administrators, course developers, teachers, technologists, and learners who are separated by long distances often across national borders but who work together using modern telematics technology. The concept of a virtual university involves a systematic analysis of all key processes occurring in the university, the formation on its basis of an updated vision, reengineering and improvement of these processes in the online environment [151].

According to UNESCO experts, the creation of national virtual universities allows governments to: concentrate high-quality technical and human resources; focus the efforts of the virtual university on the urgent needs of the national labour market or education system; use and develop the existing infrastructure of Internet technologies; to support the development of e-learning in traditional educational organizations; to ensure the advantages of national e-learning programs over foreign ones; to export elearning programs to other countries in national languages, which may reimburse part of the cost of creating these programs [65, 69]. The most important factors are the 
increase in the requirements for the level of qualification of employees through the constant technological improvement of the modern labour market; prolonged replacement of production models, which requires prompt retraining and advanced training of specialists; public awareness of the value of quality education.

Project-oriented learning has been gradually introduced in the field of higher education since the 1970s. One of the first practical implementations of projectoriented approaches in education was the founding of Aalborg University, which is now the fifth largest higher education institution in the country. The training of students at the University of Aalborg necessarily includes the implementation of research in the educational process with the provision of flexible interaction between theory and practice [28]. The experimental curriculum is based on interdisciplinary basic courses with further specialization. Project-oriented learning can be implemented in different scenarios. Projects can be designed for one performer or a group of participants, be the basis of an entire training course or the entire training cycle. Although the concept of project-oriented learning is actively developing, there are a number of issues that remain open, namely the establishment of the optimal combination of the problem to be solved, project activities, teamwork, existing technological aspects and requirements for student development [148].

The Ministry of Education and Science of Ukraine by its order "On approval of the Regulations on the institutional form of general secondary education" [13] officially introduced a new form of education for students - online. The Law of Ukraine "On Amendments to Certain Laws of Ukraine on Improving Educational Activities in the Sphere of Higher Education" [8] also recognizes network as one of the forms of obtaining higher education. The online form of education is a way of organizing the education of students, through which the mastery of the educational program takes place with the participation of various subjects of educational activities, interacting with each other on a contractual basis. The purpose of the organization of network interaction between the subjects of educational activity is to attract and use additional resources (personnel, material-technical, educational-methodical, information and others) necessary to ensure the quality of education.

This format of education is designed to solve the following problems: humanization of education; defining the paradigm and strategy of education; solving the crisis of education (which is as follows: lack of education strategy; the state of funding for education; staff quality; the role of ICT in education; bilingualism, "knowledge consolidation", etc.); monitoring and differentiation of education; the 
problem of teaching gifted children; profile, personality-oriented, continuous education; resolution of the information crisis (the amount of existing information is so large that high-quality and reliable information is almost impossible to find in the "ocean of information"); the influence of the Internet on the formation of values and ideals of a modern man; scientific creativity of the teacher, etc.

The features of the current stage of development of higher education, as evidenced by the practice of the world's leading universities, are their partnership with the business sector, increasing funding for international organizations in the form of grants and income to university endowment funds [275]. Entrepreneurship students are not only the next generation of professionals, but are also preparing to become entrepreneurs and company founders, using a variety of entrepreneurship and incubation programs, new educational modules, among which are interdisciplinary centres, science parks, academic start-ups, incubators and venture companies. The University of Entrepreneurship is one of the entities that creates new technologies and their transfer, transforming from one of the sources of new ideas for existing firms to a source of new firms, especially in the areas such as science and innovation [116].

On the one hand, it is understood as a set of efforts of universities aimed at promoting the commercialization of the results of scientific (applied and fundamental) research and other forms of knowledge on the university campus and surrounding regions. On the other hand, academic entrepreneurship can be considered as investing the efforts, time and capital of the members of academic community both in the domestic academic environment and in the region, country or international space in order to obtain business benefits or socio-economic effect.

Despite the significant advantages of an entrepreneurial university, some scholars have a negative attitude towards the process of transition from a traditional university to an entrepreneurial one $[145,238]$. The opponents of this direction of modernization of the university, as the main one, predict the following consequences:

1) for an entrepreneurial institution of higher education - the focus of its activity may be not educational, but business activity, which will significantly change the purpose of the university as an institution of knowledge production for society;

2) supporting the development of entrepreneurial skills of teacher,s as the main resource of the university, can provoke their desire using the resources of the university to pay more attention to the implementation of their own business projects, while neglecting their direct responsibilities. In fact, there is a contradiction between the traditional values of teaching and the need to form in teachers the skills of 
entrepreneurship in order to earn extra money for the university.

The innovative type of the development of society is characterized by the transfer of emphasis on the use of fundamentally new advanced technologies, the transition to the production of high-tech products, progressive organizational and managerial decisions in innovation. Fig. 1.4 shows the contours of the management of educational innovations of the university.

The management of educational innovations of the university covers strategic, operational aspects and infrastructural support, which should be aimed at creating and attracting innovations, systematic and purposeful activities to improve existing technologies, techniques and methods of implementation.

Strategic management of educational innovations at the university is aimed at implementing global challenges in the field of education and identifies the main activities in the organizational, educational, methodological areas. To implement these tasks, regulatory and legal support has been developed in accordance with state policy. Plans and programs are based on the analysis of the external environment, economic, scientific-technological, demographic, environmental, and other factors. At the same time, the educational and scientific potential of the university is assessed, as well as opportunities for financial support for the implementation of plans and programs.

Operational management of educational innovations of the university consists in drawing up plans-schedules of performance of works and control of their performance; analysis of economic, organizational and managerial, socio-psychological factors that affect the ability to implement strategic objectives; development of effective forms of organization of educational and innovative activities of the university. It provides for the development of an incentive system to encourage initiative, participation in innovative changes, discussion of problems arising in the process of implementing educational innovations, etc.

Management and infrastructure innovations are a subsystem that provides an opportunity and support in the implementation of the educational and innovation process. The content of the infrastructure is revealed by its functions, namely: organizational and legal design; providing information to participants; ensuring an organic combination of all elements and subjects of management of educational innovations; promoting the process of regulating the implementation of educational innovations. 


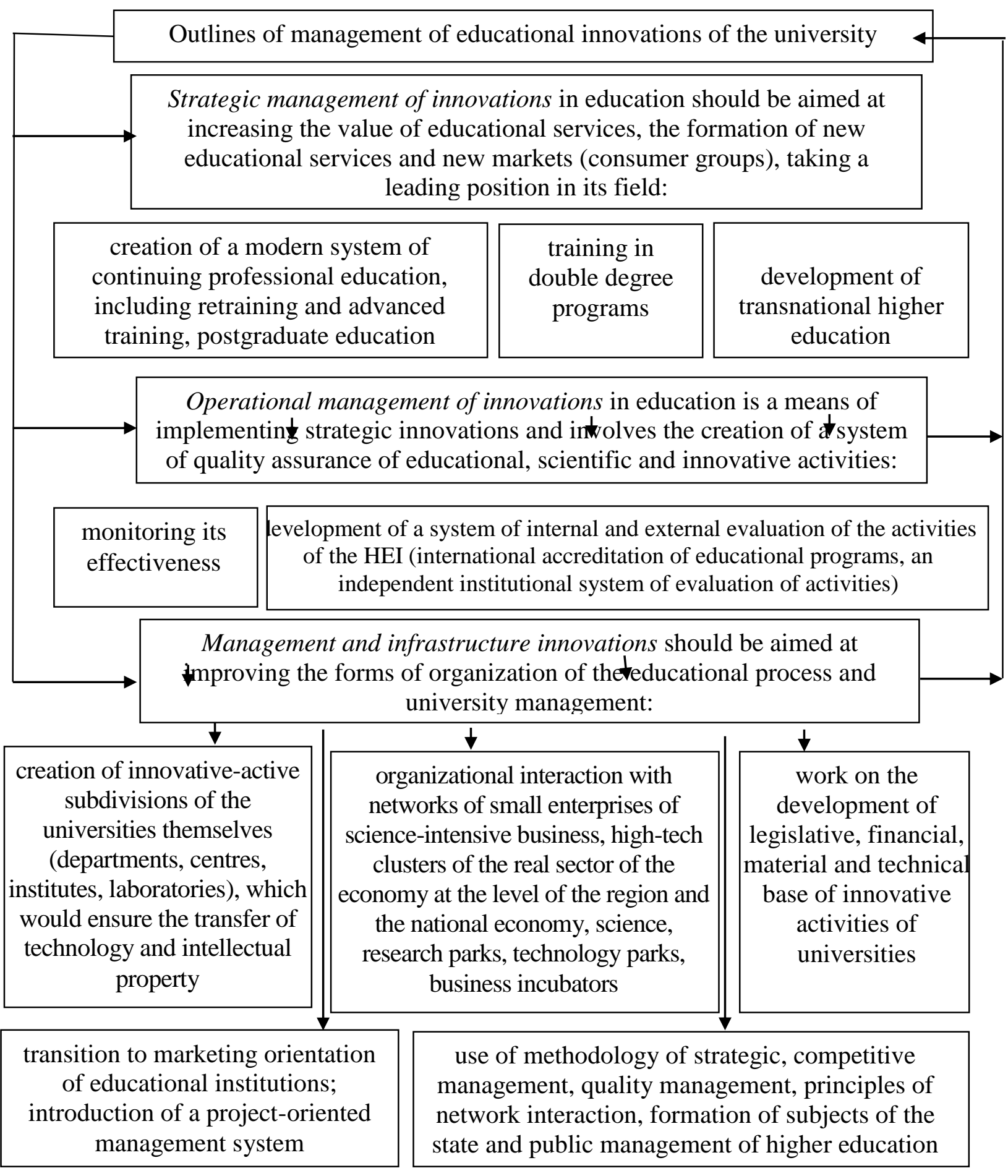

Fig. 1.4. Outlines of management of educational innovations of the university (author's development)

The contours of management of educational innovations fundamentally delimit the composition, structure and content of management, the priority of methods of analysis and forecasting and methods of implementing the educational and innovation process. Implementation and management of educational innovations requires changes in organizational structures and a combination of disparate factors to a new system of organizational interaction, staff transformation, readjustment of the communication 
system, a system of innovative measures for the material and resource management base, and so on.

Growing competition in the market of educational services, reduction of direct funding from the state budget exacerbate the problem of adaptation to new conditions of development for modern higher education institutions. The best experience of the world's leading universities shows that the key factor in their successful development is innovation and entrepreneurship, which provides an adequate response to changes in the environment, while meeting the social needs of society and market needs. In this regard, the definition of the essence of an innovative university as a form of integration of education, science and business within the national innovation system is of particular importance [52].

It should be noted that the Law of Ukraine "On Higher Education" (2014) provides the following definitions of higher education institution and university:

A higher education institution - a separate type of institution, which is a legal entity of private or public law, operates in accordance with the issued license to conduct educational activities at certain levels of higher education, conducts scientific, scientifictechnical, innovative and/or methodological activities, provides educational process and the acquisition of higher education, postgraduate education, taking into account their vocations, interests and abilities [29, 2];

one of the types of higher education institutions is a university - a multidisciplinary or branch institution of higher education, which conducts innovative educational activities at various levels of higher education, conducts basic and/or applied research, is a leading scientific and methodological centre, has a developed infrastructure of educational, scientific and research and production units, promotes the dissemination of scientific knowledge and conducts cultural and educational activities [2].

That is, we must conclude that higher education institutions have a legal basis for the introduction and strengthening of their innovative activities.

Thus, we see that the legislation of Ukraine enshrines the implementation of innovative activities by the university (institution of higher education), in particular innovative educational activities. This determines the relevance of the study of innovative-active university. It should also be noted that the study and analysis of the works of both Ukrainian and foreign scientists [115, 114, 271, 217, 52, 276, 284, 127, $58,90,126,129,238,111]$ allows us to conclude that there are some differences in defining the essence of an innovative university. In particular, the semantic load of the 
concept of innovative university differs significantly. Thus, the study of innovation in educational activities are devoted to the work of such scientists: S. Belyakov, N. Kovaleva, N. Komkov, Y. Krasnov, G. Kulakin, V. Mamayev, E. Nechaeva, N. Savchenko, A. Khutorsky, etc. The main issues of innovation management are covered in the works of A. Galchinsky, V. Geets, A. Dagaev, G. Kovalev, V. Kolokolov, V. Samoilenko, O. Solovyov. The foundations of the innovative (entrepreneurial) university are covered in the works of such foreign scientists as B. Clark, M. Gibbons, D. Kennedy, S. Kerr, G. Itzkowitz, and others. Despite the significant contribution of scientists to the study of innovative and (entrepreneurial) university, today these issues need further development in both theoretical and organizational-practical aspects, as the nature of universities in today's market competition has changed fundamentally.

The analysis of the definitions of the essence of "innovative university" by different scientists makes it possible to consider this concept in terms of functional approach (Table 1.8).

Table 1.8

\section{Defining the essence of the concept of "innovative university"}

\begin{tabular}{|c|c|}
\hline Scientists & $\begin{array}{l}\text { Defining the essence of the concept } \\
\text { "Innovative university" }\end{array}$ \\
\hline 1 & 2 \\
\hline $\begin{array}{l}\text { I.V. Artyomov } \\
\text { [114] }\end{array}$ & $\begin{array}{l}\text { The main task of scientific and innovative activities of the university is the } \\
\text { acquisition of scientific knowledge through research and development and } \\
\text { their focus on the creation and implementation of new competitive } \\
\text { technologies, ensuring the innovative development of society and training of } \\
\text { specialists of innovative type }\end{array}$ \\
\hline $\begin{array}{l}\text { L.S. Shevchenko } \\
\text { [217] }\end{array}$ & $\begin{array}{l}\text { The innovative activity of the university is aimed at creating and mastering } \\
\text { innovations, i.e. updating educational products and services, forms and } \\
\text { technologies of education at different stages of the innovation process (from } \\
\text { the idea or new technology to its market realization) in educational and } \\
\text { scientific spheres, as well as postgraduate professional education, which } \\
\text { provides the necessary economic and (or) social benefits }\end{array}$ \\
\hline $\begin{array}{l}\text { A.V. Vostroilov, } \\
\text { V.I. Belousov, } \\
\text { V.E. Shevchenko } \\
{[121]}\end{array}$ & $\begin{array}{l}\text { Innovative University is a business-type higher education institution. Its main } \\
\text { activities are scientific and educational on the basis of innovative approaches } \\
\text { and management methods }\end{array}$ \\
\hline $\begin{array}{l}\text { I.V. Artyomov, } \\
\text { I.P. Studenyak, } \\
\text { S.I. Ustich } \\
{[115]}\end{array}$ & $\begin{array}{l}\text { An innovative or entrepreneurial university is, first of all, not an economic or } \\
\text { managerial educational institution that graduates certified entrepreneurs or } \\
\text { managers but, above all, a university of natural sciences and engineering- } \\
\text { technological profile, teachers, students and postgraduates of which are able to } \\
\text { implement their innovative developments and the results of their research and } \\
\text { development in the economy by creating new enterprises }\end{array}$ \\
\hline $\begin{array}{l}\text { Frans Van Vucht } \\
\text { [85] }\end{array}$ & These are universities that seek to adapt to changing environmental conditions \\
\hline B. Clark $[58,127]$ & $\begin{array}{l}\text { It is a university that combines the following elements: a reinforced guiding } \\
\text { core; expanded periphery of development; diversified funding base; stimulated } \\
\text { academic stronghold; integrated business culture. }\end{array}$ \\
\hline
\end{tabular}


The end of the table 1.8

\begin{tabular}{|c|c|}
\hline 1 & 2 \\
\hline $\begin{array}{l}\text { M. Gibbons [90] } \\
\text { G. Itzkowitz [266, } \\
\text { 111] }\end{array}$ & $\begin{array}{l}\text { It is characterized by a socially distributed system of knowledge production, } \\
\text { described by the concept of the triple helix, which explains the innovative } \\
\text { activities of universities and the processes of knowledge transfer in network } \\
\text { interaction. } \\
\text { The central concept of the triple helix is an innovative (entrepreneurial) } \\
\text { university, which, along with the implementation of traditional missions of } \\
\text { teaching and research, plays an active role in socio-economic development as } \\
\text { one of the main agents of knowledge production. Such a university not only } \\
\text { gives the student new ideas and skills, but also develops entrepreneurial talent } \\
\text { for a science-oriented business. }\end{array}$ \\
\hline $\begin{array}{l}\text { M. Curley, } \\
\text { P.Formica [63] }\end{array}$ & $\begin{array}{l}\text { The University of Entrepreneurship (Innovation) promotes a harmonious } \\
\text { relationship between research and academic entrepreneurship, and its ecosystem } \\
\text { is able to increase the resources of scientific discovery with commercial } \\
\text { potential so that it becomes a viable business. }\end{array}$ \\
\hline $\begin{array}{l}\text { A.O. Karpov } \\
{[122]}\end{array}$ & $\begin{array}{l}\text { distinguishes between basic and metalevel in the structure of the University of } \\
\text { Innovation and Entrepreneurship. The basic level includes: venture projects, } \\
\text { small innovative enterprises (startup companies), business incubators, } \\
\text { investment platforms, knowledge dissemination offices, technology transfer } \\
\text { centres, innovation and technology centrrs. The meta-level agents include: } \\
\text { technology consortia, which unite innovative divisions of educational } \\
\text { institutions and high-tech business; generalized knowledge funds that integrate } \\
\text { research environments of universities and research organizations; science parks } \\
\text { create a common creative space for knowledge-intensive firms and research } \\
\text { teams; technology parks provide an infrastructure component for innovation and } \\
\text { a complete engineering and technological cycle of materialization of scientific } \\
\text { innovations }\end{array}$ \\
\hline $\begin{array}{l}\text { G.N. } \\
\text { Konstantinov } \\
{[133]}\end{array}$ & $\begin{array}{l}\text { It is a higher education institution that systematically strives to overcome } \\
\text { limitations in three areas - knowledge generation, teaching and putting } \\
\text { knowledge into practice - by initiating new activities, transforming the internal } \\
\text { environment and modifying interaction with the external environment. }\end{array}$ \\
\hline $\begin{array}{l}\text { A.O. Grudzinsky } \\
\text { [274] }\end{array}$ & $\begin{array}{l}\text { Considers the Entrepreneurship (Innovation) University as: " } \\
\text { 1) an organization based in its activities on targeted innovations, able to work in } \\
\text { conditions of risk and dynamic demand; } \\
\text { 2) a cost-effective organization engaged in profitable activities and relies } \\
\text { primarily on their own capabilities; } \\
\text { 3) a liberal organization with a flexible network structure; } \\
\text { 4) an organization in which the key factors are people, groups and their } \\
\text { competence, where people's work is based on a balance of benefits and risks; } \\
\text { 5) an organization whose management in the first place is not planning and } \\
\text { control of actions of employees, but their comprehensive support in the } \\
\text { activities within the strategy of the organization, for which the management } \\
\text { delegates the rights and responsibilities of performers; } \\
\text { 6) an organization that faces the consumer and allows timely and flexible } \\
\text { response to changes in its requirements " }\end{array}$ \\
\hline $\begin{array}{l}\text { A.A. Sidorova, } \\
\text { N.A. Rumyantsev } \\
\text { [195] }\end{array}$ & $\begin{array}{l}\text { Entrepreneurship (Innovation) University is a kind of research centre in which, } \\
\text { in addition to the traditional functions of education and science, there is a } \\
\text { transfer of knowledge to practical areas of economics and society as a whole, } \\
\text { the implementation of knowledge into a product or service }\end{array}$ \\
\hline $\begin{array}{l}\text { S.V. Golubev } \\
\text { [50] }\end{array}$ & $\begin{array}{l}\text { Socio-entrepreneurial university is a university whose main task is to create and } \\
\text { maintain an entrepreneurial environment in the territory of its presence, due to } \\
\text { the widespread use in its activities of innovative educational programs and the } \\
\text { results of applied research. }\end{array}$ \\
\hline
\end{tabular}

* author's development 
The analysis of the given interpretations of the category "innovative university" allows to draw the following conclusions:

- all scientists state that an innovative university should innovate in all areas of its activities;

- such a university must produce new knowledge to implement it in the practice of organizations of various spheres of society;

- it must look for new ways and forms of interaction with external stakeholders;

- Innovative University strengthens the link between research and academic entrepreneurship.

But, considering the similarities in the understanding of an innovative university, it must be acknowledged that a single, common interpretation does not exist today.

Therefore, for a deeper understanding of the meaning of this concept with the help of morphological analysis, we will decompose the definitions given in table 4 into the main components on the following grounds of comparison: the essential component of the concept; orientation of the innovative university; appointment of an innovative university. The results of the decomposition are given in table 1.9.

Table 1.9

\section{Morphological decomposition of defining the essence of an innovative} university

\begin{tabular}{|c|c|}
\hline $\begin{array}{l}\text { A sign of } \\
\text { comparison }\end{array}$ & Structural composition with indication of sources \\
\hline 1 & 2 \\
\hline 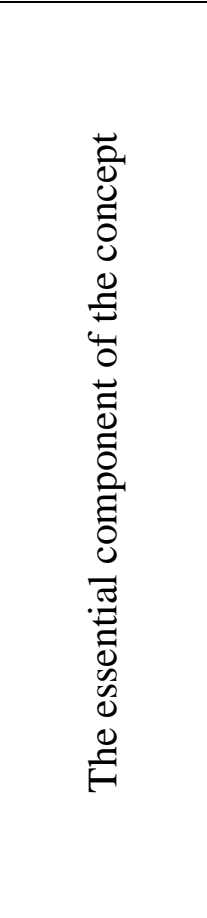 & $\begin{array}{l}\text { acquisition of scientific knowledge through research and development [114]; } \\
\text { creation and development of innovations, i.e. updating of educational products and } \\
\text { services, forms and technologies of training at different stages of innovation process } \\
\text { (from emergence of idea or new technology to its market realization) in educational } \\
\text { and scientific spheres, and also postgraduate professional education [217]; } \\
\text { scientific and educational activities based on innovative approaches and management } \\
\text { methods [276]; } \\
\text { universities of natural sciences and engineering and technological profile, teachers, } \\
\text { students and graduate students [115]; } \\
\text { universities that seek to adapt to changing environmental conditions [85]; } \\
\text { a university that combines the following elements: a reinforced guiding core; expanded } \\
\text { periphery of development; diversified funding base; stimulated academic stronghold; } \\
\text { integrated business culture [58, 127]; } \\
\text { performs the traditional mission of teaching and research, plays an active role in socio- } \\
\text { economic development as one of the main agents of knowledge production [90, 266, } \\
\text { 111]; } \\
\text { a higher education institution that systematically strives to overcome limitations [133]; } \\
\text { an organization based in its activities on targeted innovations, in the management of } \\
\text { which in the first place is not planning and control of actions of employees, but their } \\
\text { comprehensive support in the activities within the strategy of the organization [101]; }\end{array}$ \\
\hline
\end{tabular}


The end of the table 1.9

\begin{tabular}{|l|l|}
\hline 1 & \multicolumn{1}{|c|}{2} \\
\hline & $\begin{array}{l}\text { to create and implement new competitive technologies [114]; } \\
\text { provides the necessary economic and (or) social benefits [217]; } \\
\text { implementation of innovative developments, implementation in the economy of the } \\
\text { results of their research and development [39]; } \\
\text { gives the student new ideas and skills [90, 266, 278]; } \\
\text { promotes the development of a harmonious relationship between research and } \\
\text { academic entrepreneurship [63]; } \\
\text { knowledge generation, teaching and transformation of knowledge into practice } \\
\text { [133]; } \\
\text { the transfer of knowledge to practical areas of the economy and society as a whole, } \\
\text { the embodiment of knowledge into a product or service [238]; } \\
\text { creation and maintenance of the business environment in the territory of the } \\
\text { presence, at the expense of wide use in the activity of innovative educational } \\
\text { programs and results of applied researches [93] }\end{array}$ \\
& $\begin{array}{l}\text { ensuring the innovative development of society and training of specialists of } \\
\text { innovative type [114]; } \\
\text { creation of new enterprises [115]; } \\
\text { develops entrepreneurial talent for science-oriented business [90, 266, 111]; } \\
\text { its ecosystem is able to increase the resources of scientific discovery with } \\
\text { commercial potential so that it becomes a viable business [63]; } \\
\text { initiating new activities, transforming the internal environment and modifying the } \\
\text { interaction with the external environment [133] }\end{array}$ \\
& \\
&
\end{tabular}

* author's development

Summarizing the above definitions and summarizing the analysis, it is proposed to understand an innovative-active university as an educational and entrepreneurial organization that has the resource readiness to promote accelerated socio-economic development of society through intensive transfer of knowledge and technology generated at the university through partnership with stakeholders. At the same time, the latter include labour market actors, governmental and non-governmental organizations [137].

Thus, a comparative analysis of the works of both Ukrainian and foreign scientists allows us to draw a conclusion about the debatable nature of this issue, which indicates its relevance in the global and national educational markets. Despite the significant contribution of scientists to the study of innovative and (entrepreneurial) university, today these issues need further development in both theoretical and organizational and practical aspects, as the nature of universities in today's market competition has changed fundamentally.

According to Burton R. Clark, successful innovative (entrepreneurial) universities have five main characteristics [115, 114]:

- Strong steering: universities that want to change cannot depend on traditional (weak) control or governance. They need to become faster, more flexible, more focused 
in responding to environmental demands;

- the periphery of development: universities that want to change must have mechanisms to interact with the outside world. They must reach their traditional limits. To do this, they need to create special organizational units;

- diversified funding base: universities that want to change need resources to do so. They especially need discretionary means. Therefore, they need to expand their financial base (and become less dependent on the government);

- strong academic heart: universities that want to change need basic academic units that embrace an entrepreneurial culture. These core units should be encouraged to respond positively to change;

- integrated business culture: universities that want to change need a culture that embraces change; work ethic and a set of beliefs that are university-wide and that become the very basis of the institution's identity.

For today, there are two models of innovative university [115]: by the result teachers and graduates create innovative companies; by the type of action of the management team (university-entrepreneur).

The first model provides for the creation of favorable conditions for students, teachers and graduates for the formation of high-tech start-ups and spin-off companies.

The second model involves the creation of a powerful research centre that produces and markets new scientific and technical products, thereby attracting financial resources and increasing its independence from public resources.

Despite the choice of the model of business university, its distinguishing feature is: - intensification of resource use and search for additional sources:

- development of infrastructure and network of branches and representative offices; - economic interest in combination with the satisfaction of public interests [276].

The analysis of the authors' opinions allowed to identify the structural components of the innovative university (Table 1.10).

Table 1.10

\section{Structural components of an innovative university}

\begin{tabular}{|l|l|}
\hline \multicolumn{1}{|c|}{ Author / source } & \multicolumn{1}{|c|}{ Characteristic } \\
\hline \multicolumn{1}{|c|}{1} & \multicolumn{1}{|c|}{2} \\
\hline $\begin{array}{l}\text { Shah Ali and } \\
\text { others [177] }\end{array}$ & $\begin{array}{l}\text { education and research with components (assessment of training needs, creation } \\
\text { of research and research centres that hold conferences and scientific meetings } \\
\text { at the national and international levels), and structure with components } \\
\text { (flexibility in infrastructure, communication networks and centralized } \\
\text { structure), and in strategic measuring components (goals and prospects, } \\
\text { strategic decisions) }\end{array}$ \\
\hline
\end{tabular}


The end of the table 1.10

\begin{tabular}{|l|l|}
\hline \multicolumn{1}{|c|}{1} & \multicolumn{1}{c|}{2} \\
\hline $\begin{array}{l}\text { Dehgan, Talebi } \\
\text { and Arabian } \\
\text { [32] }\end{array}$ & $\begin{array}{l}\text { structural measurement of components (structure and evaluation of efficiency) } \\
\text { and environmental aspect of the component (extragroup capital). } \\
\text { There is also a structure that corresponds to the components (appropriate } \\
\text { education system, organizational structure, human resource management and } \\
\text { organization of culture) }\end{array}$ \\
\hline $\begin{array}{l}\text { Skirbants and } \\
\text { others [181] }\end{array}$ & $\begin{array}{l}\text { structural measurement of components (structure and evaluation of efficiency) } \\
\text { and environmental aspect of the component (extragroup capital). } \\
\text { There is also a structure that corresponds to the components (appropriate } \\
\text { education system, organizational structure, human resource management and } \\
\text { organization of culture) }\end{array}$ \\
\hline
\end{tabular}

* author's development

The system of activity of the innovatve-active university can be presented as a combination of components of the internal and external environment (Fig. 1.5).

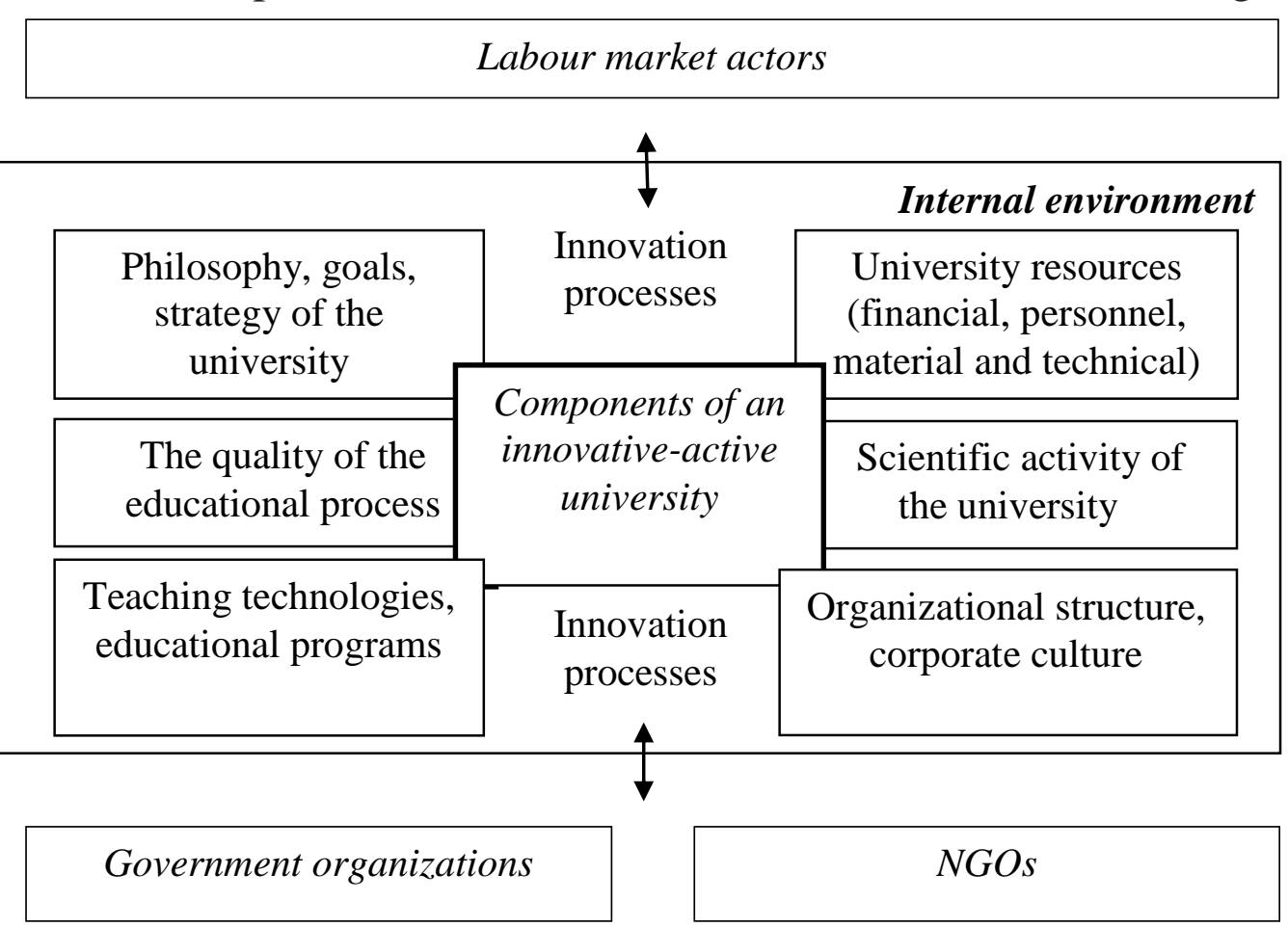

\section{Environment}

\section{Fig. 1.5. Interaction of components of internal and external environment of innovative-active university (author's development)}

Thus, the innovative-active university (IAU) is aimed at the development of society in the current and long term, and the dominants of its activities are:

science as a tool for generating new knowledge on the basis of integration with the external environment, primarily with high-tech enterprises;

education as a way to bring knowledge to people, the formation of the 
intellectual potential of society;

interaction with industry, government, society as a means of concerted efforts to ensure the stable development of the nation and civilization.

Under these conditions, IAU should implement innovations in eight key dimensions (Table 1.11).

Table 1.11

\section{Key dimensions of an innovative-active university}

\begin{tabular}{|c|c|}
\hline Measurement & Characteristic \\
\hline $\begin{array}{l}\text { Leadership and } \\
\text { management }\end{array}$ & $\begin{array}{l}\text { are the two most important and complex factors in the development of } \\
\text { entrepreneurial and innovative higher education institutions. Positive and } \\
\text { responsive leadership is what supports a dynamic and successful organization, } \\
\text { especially in times of uncertainty, unpredictability and complexity. Leadership } \\
\text { and management can stimulate all kinds of innovations in an organization that } \\
\text { combines a shared vision and culture, not overloaded with management } \\
\text { systems, constantly striving for their autonomy through entrepreneurial } \\
\text { management of various interdependencies with stakeholders }\end{array}$ \\
\hline $\begin{array}{l}\text { Organizational } \\
\text { capacity }\end{array}$ & $\begin{array}{l}\text { constant focus on the development of their organizational capabilities. To this } \\
\text { end, there are incentives and rewards for employees, students, and } \\
\text { stakeholders who promote the entrepreneurial program and remove barriers } \\
\text { and constraints in the organization. The goal is to empower organizations on } \\
\text { their own initiatives, engage in innovation, and build personal relationships } \\
\text { between stakeholders based on trust across external and internal borders. }\end{array}$ \\
\hline $\begin{array}{l}\text { Independence and } \\
\text { responsibility }\end{array}$ & $\begin{array}{l}\text { learning requires something other than standard textbooks and regular } \\
\text { classrooms, seeks to enhance the entrepreneurial abilities and capabilities of } \\
\text { students, giving them greater independence and responsibility in the learning } \\
\text { process through experimental, collaborative and reflective learning }\end{array}$ \\
\hline $\begin{array}{l}\text { Training and } \\
\text { support of } \\
\text { entrepreneurs }\end{array}$ & $\begin{array}{l}\text { provides teaching strategies and learning environments that offer targeted } \\
\text { support for students and staff aimed at creating a business provided directly } \\
\text { by educational institutions or directing potential entrepreneurs to specialized } \\
\text { support services for beginners within the (local) business ecosystem }\end{array}$ \\
\hline $\begin{array}{l}\text { Digital } \\
\text { transformation } \\
\text { and opportunities }\end{array}$ & $\begin{array}{l}\text { use of the opportunities provided by digital technologies, which are a key } \\
\text { factor in promoting innovation and entrepreneurship, including the } \\
\text { development of a positive digital culture, development and maintenance of } \\
\text { appropriate and modern digital infrastructure and development of digital } \\
\text { competence among staff and students to take full advantage of digital } \\
\text { technologies and tools }\end{array}$ \\
\hline $\begin{array}{l}\text { Knowledge } \\
\text { exchange and } \\
\text { cooperation }\end{array}$ & $\begin{array}{l}\text { Negative attitudes towards entrepreneurship, entrepreneurs and business in } \\
\text { higher education can limit and hinder the formation of a network and } \\
\text { cooperation with business partners. Communication, which ensures that both } \\
\text { sides of the knowledge sharing network clearly understand the relevant } \\
\text { expectations, constraints and requirements, is a key element of the University } \\
\text { of Entrepreneurship and Innovation. }\end{array}$ \\
\hline $\begin{array}{l}\text { Internationalized } \\
\text { institution }\end{array}$ & $\begin{array}{l}\text { Internationalization is an important indicator of the quality of higher } \\
\text { education, a means to continuous change and advancement through its } \\
\text { teaching, research and knowledge sharing activities, as well as through its staff } \\
\text { and students. }\end{array}$ \\
\hline
\end{tabular}

According to the selected measurements, the main types of innovation activities are distinguished, which are sometimes interpreted as functions of the IAU (Table 1.12). 
Table 1.12

\section{Types of innovative activities of the university}

\begin{tabular}{|c|c|c|}
\hline Author & Type / function & Characteristic \\
\hline \multirow{3}{*}{ 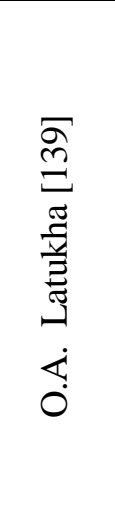 } & innovation activities & $\begin{array}{l}\text { implementation of basic and applied research, development of own } \\
\text { infrastructure of innovations, bringing to market of results of own research } \\
\text { activity, development and realization of complex projects and programs } \\
\text { of innovative development }\end{array}$ \\
\hline & $\begin{array}{l}\text { teaching innovative } \\
\text { activities of teachers, } \\
\text { researchers, graduate } \\
\text { students, doctoral students, } \\
\text { applicants, students }\end{array}$ & $\begin{array}{l}\text { reproduction of innovative personnel, which is important in the formation } \\
\text { of the knowledge economy }\end{array}$ \\
\hline & $\begin{array}{l}\text { actually educational } \\
\text { activities }\end{array}$ & $\begin{array}{l}\text { the traditional direction of the university, supplemented in a market } \\
\text { economy by the creation of various training courses, seminars, trainings, } \\
\text { "round tables" on the development of the industry, etc. }\end{array}$ \\
\hline \multirow{3}{*}{ 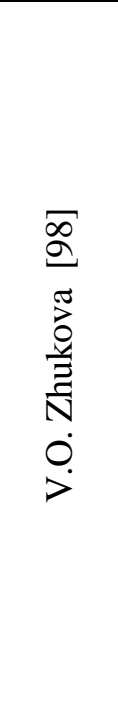 } & pedagogical innovations & $\begin{array}{l}\text { change of style of pedagogical activity and organization of educational } \\
\text { and cognitive process; introduction of innovative learning models. The } \\
\text { latter transform the nature of education in relation to its essentially and } \\
\text { instrumentally important characteristics, such as the target organization; } \\
\text { the nature of the teacher's interaction with students and their position } \\
\text { during the learning process; effective organization of the educational } \\
\text { process, in particular, with the use of modern information and } \\
\text { telecommunication technologies, etc. }\end{array}$ \\
\hline & $\begin{array}{l}\text { scientific and } \\
\text { methodological } \\
\text { innovations }\end{array}$ & $\begin{array}{l}\text { updating the content of educational programs in accordance with the best } \\
\text { domestic and foreign counterparts; introduction of innovative courses; } \\
\text { creation of modern content of educational and methodical materials (new } \\
\text { textbooks and manuals, scientific-methodical and software) }\end{array}$ \\
\hline & $\begin{array}{l}\text { educational and } \\
\text { technological } \\
\text { innovations }\end{array}$ & $\begin{array}{l}\text { use of new or improved learning technologies (for example, distance } \\
\text { learning, Internet technologies, project-organized technologies, etc.); } \\
\text { providing students and teachers with access to electronic libraries; } \\
\text { creation of corporate information management systems of the university. }\end{array}$ \\
\hline
\end{tabular}

Thus, innovative-active universities differ from traditional ones by their emphasis on the academic values of science and innovation. The problems that arise in their environment are forcing innovative universities to find new management systems and processes.

The analysis of research on the nature and specifics of the functioning of innovative universities has led to the conclusion that the educational component is essential in its relationship with major stakeholders. It is this component that provides the formation of a specialist needed by the labour market today and in the future, it directly affects the educational potential of society, influences the development and implementation of innovations in the real sector of the economy. Therefore, the effectiveness of innovation management in the educational process transitively affects all the activities of IAU. 


\subsection{Factors of university competitiveness: world experience}

Innovative University aims to ensure efficient operation in order to create opportunities for its competitiveness and attractiveness in the market in the long run [160].

To establish the factors of competitiveness of universities around the world, we will analyze global models of education (Anglo-Saxon, German-French-Russian, Scandinavian, American, Asian models) and evaluate these models according to the following criteria: autonomy, underlying concept, strategic orientation of the educational process, qualitative component, targets, centralization, availability of higher education, degree of selectivity (Appendix A, B). Thus, the uniqueness of the current situation of educational paradigms is that if the shortcomings of the AngloSaxon model of education, expressed in the narrow pragmatic focus of actors in the educational process to address specific applications, are eliminated by humanizing education and expanding ideas about the experience of others. German-Russian model of education, on the contrary, is a departure from the principle of fundamentality to pragmatic orientation. The signing of the Bologna Declaration became a catalyst for this process in this context. For many universities based on the Prussian (Austrian) education system, the desire to become an equal participant in the international educational space is not just a revision of existing requirements for the education system within the country but, in fact, a change in the model of education, changing relationships between actors.

According to researches of L.L. Antonyuk and V.I. Satsyk [27], today the following general trends in the development of universities have been formed:

1. Global scale of activity and significant impact on social development.

2. Systematic integration of research and educational activities.

3. Deepening regional and international cooperation.

4. Selectivity in the selection of students and faculty. High levels of scientific productivity of teachers.

5. Implementation of interdisciplinary research and training of doctors of sciences.

6. Diversification of funding sources.

7. Joint coordination of actions with business representatives in the training of specialists.

8. Formation of modern infrastructure of scientific and innovative activity. 
9. Ensuring the highest quality of scientific and educational activities.

10. Increasing the volume of consulting services provided by teachers.

Summarizing the views of scientists $[85,115,155,32,161,39,34,107,207$, $123,45,202]$ we define the essence of the factors of competitiveness of universities. Thus, the factors of university competitiveness are elements, processes and phenomena that affect the indicators of educational, scientific, innovative activities of the university and lead to an increase (decrease) in the attractiveness and competitiveness of the university.

The analysis of scientific research by such scientists as J. Lombardi [155], F. Altbach [32], S. Marginson [161], A. Take, L. Armstrong [39], A. Strambu-Dima, K. Veges [34], J. Salmi [207], Antonyuk LL. and Satsyk VI [27, 211], F. Van Vucht [85], A. Hobbes [115], H. Horta [107] and others allowed to draw the following conclusions about the factors of competitiveness of the world universities (Table 1.13).

Table 1.13

Factors of competitiveness of the world universities

\begin{tabular}{|c|c|c|c|c|c|c|c|c|c|c|c|c|}
\hline № & Scientists & 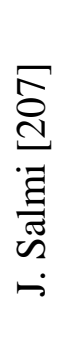 & 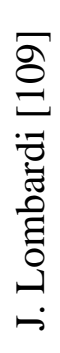 & 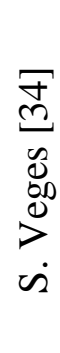 & 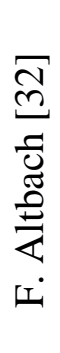 & 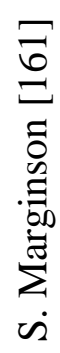 & 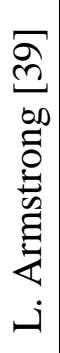 & 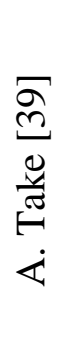 & 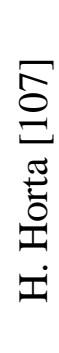 & 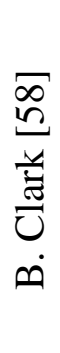 & 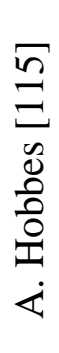 & 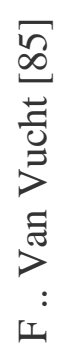 \\
\hline 1 & 2 & 3 & 4 & 5 & 6 & 7 & 8 & 9 & 10 & 11 & 12 & 13 \\
\hline 1 & $\begin{array}{l}\text { Talented researchers, teachers and } \\
\text { students }\end{array}$ & + & + & + & + & + & + & + & + & + & + & + \\
\hline 2 & $\begin{array}{l}\text { Sufficient material and financial } \\
\text { resources, developed infrastructure of } \\
\text { the university }\end{array}$ & + & + & + & + & + & + & + & + & + & + & + \\
\hline 3 & $\begin{array}{l}\text { Transparent and effective system of } \\
\text { leadership, management }\end{array}$ & + & + & + & + & + & + & + & + & + & + & + \\
\hline 4 & $\begin{array}{l}\text { Conducting (breakthrough) research } \\
\text { in priority areas of knowledge }\end{array}$ & + & & & + & + & + & + & + & + & + & + \\
\hline 5 & $\begin{array}{l}\text { Qualitative and innovative } \\
\text { educational process, integration of } \\
\text { research into students' educational } \\
\text { activities }\end{array}$ & + & & & + & + & + & + & & & + & + \\
\hline 6 & $\begin{array}{l}\text { Academic freedom and autonomy of } \\
\text { universities }\end{array}$ & + & + & + & + & + & + & & & & & + \\
\hline 7 & State financial support & + & & & & & & + & + & & & + \\
\hline
\end{tabular}


The end of the table 1.13

\begin{tabular}{|c|c|c|c|c|c|c|c|c|c|c|c|c|}
\hline 1 & 2 & 3 & 4 & 5 & 6 & 7 & 8 & 9 & 10 & 11 & 12 & 13 \\
\hline 8 & $\begin{array}{l}\text { International reputation and } \\
\text { successful experience of } \\
\text { internationalization }\end{array}$ & + & & & & + & & & + & & & + \\
\hline 9 & $\begin{array}{l}\text { Productive cooperation with business, } \\
\text { other organizations, graduates }\end{array}$ & + & & & & & & & & + & & + \\
\hline 10 & $\begin{array}{l}\text { Developed business culture (sphere) } \\
\text { of the university }\end{array}$ & + & + & & & & & & & + & & \\
\hline 11 & $\begin{array}{l}\text { Extensive diversification of research } \\
\text { and education, social and cultural life } \\
\text { of the university }\end{array}$ & + & & & & & & & & + & + & + \\
\hline 12 & $\begin{array}{l}\text { Belonging of the university to the } \\
\text { countries with the developed system } \\
\text { of education and researches }\end{array}$ & & & & & & & & + & & & \\
\hline 13 & $\begin{array}{l}\text { State funding of research and } \\
\text { investment in the development of } \\
\text { university infrastructure }\end{array}$ & & & & & & & + & + & & & \\
\hline
\end{tabular}

For further analysis, we construct a polygon of the distribution of factors of competitiveness of universities by the total number (Fig. 1.6).

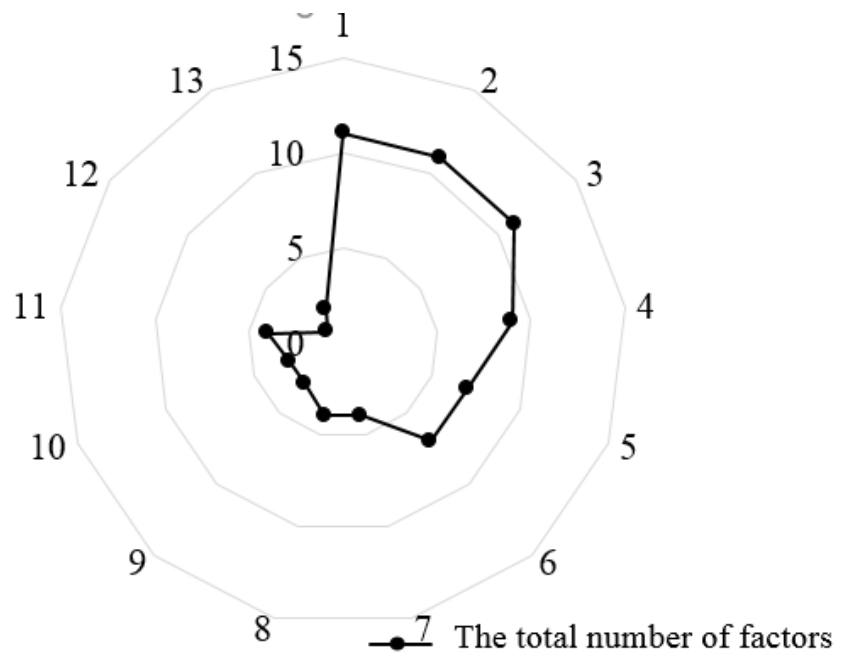

Fig. 1.6. Polygon of the distribution of scientists' opinions on the factors of competitiveness

Summarizing the views of the scientists on the factors of competitiveness of universities, we can conclude that scientists believe that the greatest influence on the competitiveness of the university have factors number 1, 2 and 3, namely: staff (researchers, teachers, leaders) of the university, student learning outcomes (quality of the educational process), material and financial resources, developed university infrastructure, transparent and effective system of leadership and management. 
It should also be noted that all factors of competitiveness are classified into external and internal. External factors mean everything that sets the formal rules of the university in the market of higher education services, which are not influenced by the university:

state regulation of the education system;

political factors;

regulatory and legal support;

regional factors;

scientific-technological and innovative factors;

the level of economic and scientific-technical development of the country;

socio-demographic factors;

natural and geographical factors, etc. [123, 45]

Internal factors are the university's ability to ensure its own competitiveness: the creation of certain competitive advantages of the university from the standpoint of the choice of the university by applicants and their parents, employees [202].

The nature of the influence of factors is different. The competitiveness of the university can be directly or indirectly affected. As a rule, indirect influence is felt by external factors. Thus, one of the most important components of the competitiveness of the university is the ability of the institution to compete under the influence of external and internal factors, the main of which are systematized and presented in Fig. 1.7.

The above system of factors influencing competitiveness (Fig. 1.7) is quite generalized, as not all of these factors necessarily affect each university at the same time. In addition, with the development of educational activities, there may be changes not only in the number and structure of factors, but also may change the level of influence of each of them.

The ability to withstand the influence of the environment, to adjust their own activities in accordance with the actual market conditions, the ability to effectively manage within the university are important conditions for creating an attractive and competitive university.

If we compare the above external factors that affect the competitiveness of the university with the situation in the country, we can conclude that the situation with COVID-19, foreign economic relations, the state of the financial market directly affect the activities of universities, undermining their competitiveness. 
The internal influences operating within the university are mostly manageable and management can adjust the endogenous situation if necessary. Management of each factor is carried out systematically depending on tactics and strategy of university.

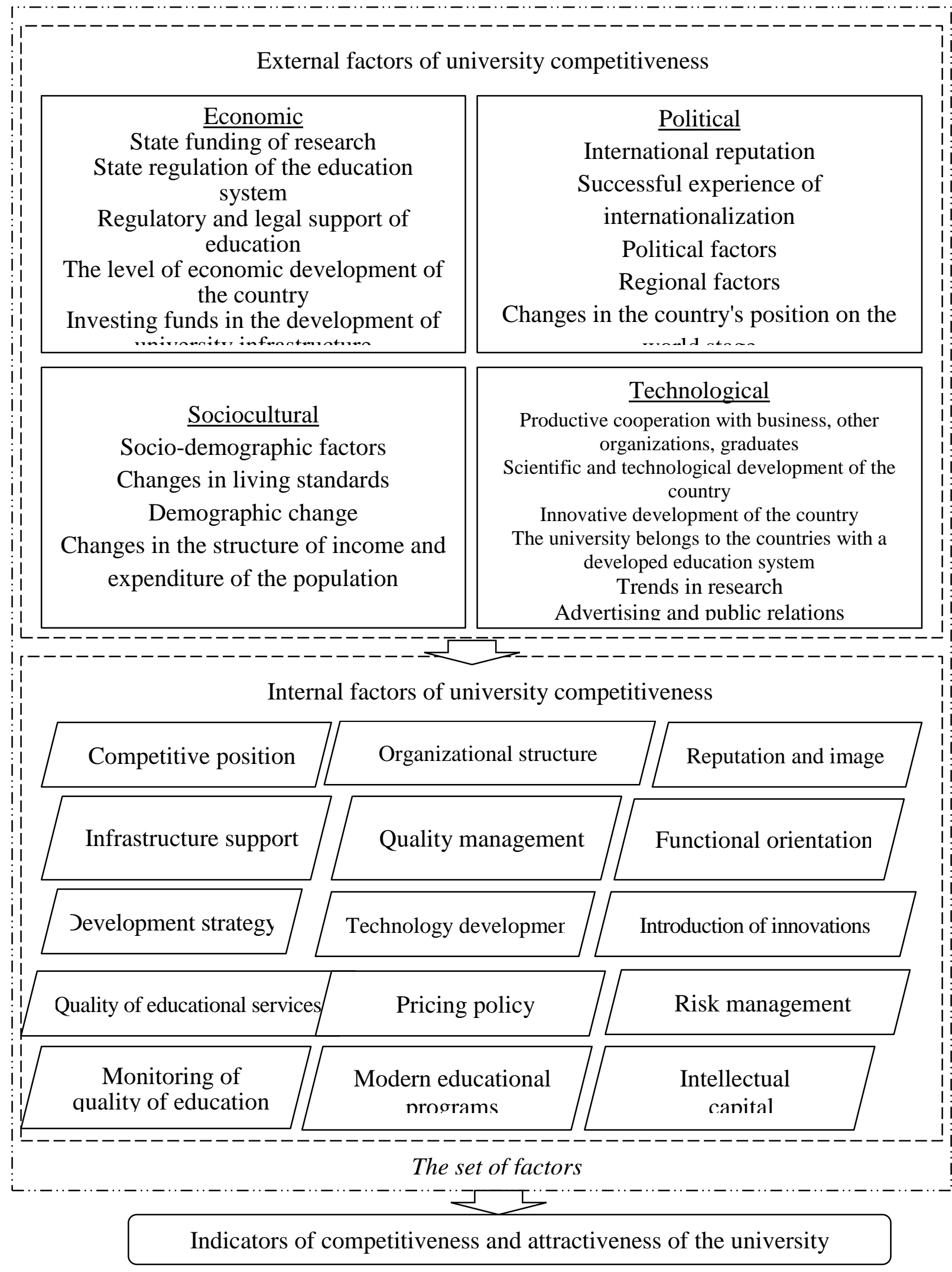

Fig. 1.7. Composition and interrelations of factors of competitiveness of university 
Ensuring competitiveness is one of the priority strategic objectives of each subject of economic relations, so universities are no exception. Today, competitiveness in the education sector directly depends on the attractiveness and trust of applicants. The higher the level of trust, the greater the attractiveness of the university is and, as a result, the higher is its competitivenessOf particular note is the definition of strategies for the formation of competitive universities in the world, made by a well-known Australian expert in higher education S. Marginson [161]. The researcher argues that in the current context of globalization in different countries they practice three main models of world-class university development strategies: breadth strategy, depth strategy, combined strategy of breadth and depth (breadth depth strategy).

Breadth strategy - there is a transition from high-quality mass higher education to the creation of a world-class university, the country's achievement of the highest standards of higher education in teaching and learning, expanding public access to high quality educational services, increasing potential of universities, the gradual evolutionary allocation of university institutions capable of competing in the global market. This strategy is used mainly in the Western Europe (e.g., University of Vienna, University of Manchester) [161, 211].

Depth strategy - there is a transition from scientific, innovative research in breakthrough areas of knowledge to the creation of a world-class university, involves active participation and financial support of universities by the state, the creation of a world-class university based on a small number of existing universities which are capable of carrying out serious research. This strategy was used by East Asian countries during the second half of the XX century (Peking University and Qinhua University, Tokyo University, Taiwan National University, Seoul University, etc.). Currently, this model is being used in Saudi Arabia, Brazil [161, 211].

The combined breadth depth strategy is a combination of the two previous strategies and is currently used in the United States and China and is gaining ground in some Western European countries [161,211].

The university development strategy is determined by a set of factors, priorities, resources available to the university. Depending on the specific conditions and tasks of development, the university forms a new strategy or adjusts the existing one, which gives it the opportunity to maintain or improve its own competitive position.

To ensure the desired level of functioning in a competitive environment, universities need to maintain high performance. This position requires management to 
implement a sound effective strategy that serves as a guarantee of competitive activity.

Also, it should be noted that the formula for high competitiveness of the university is the ratio of such components as analysis, strategy and attractiveness of the university (Fig. 1.8).

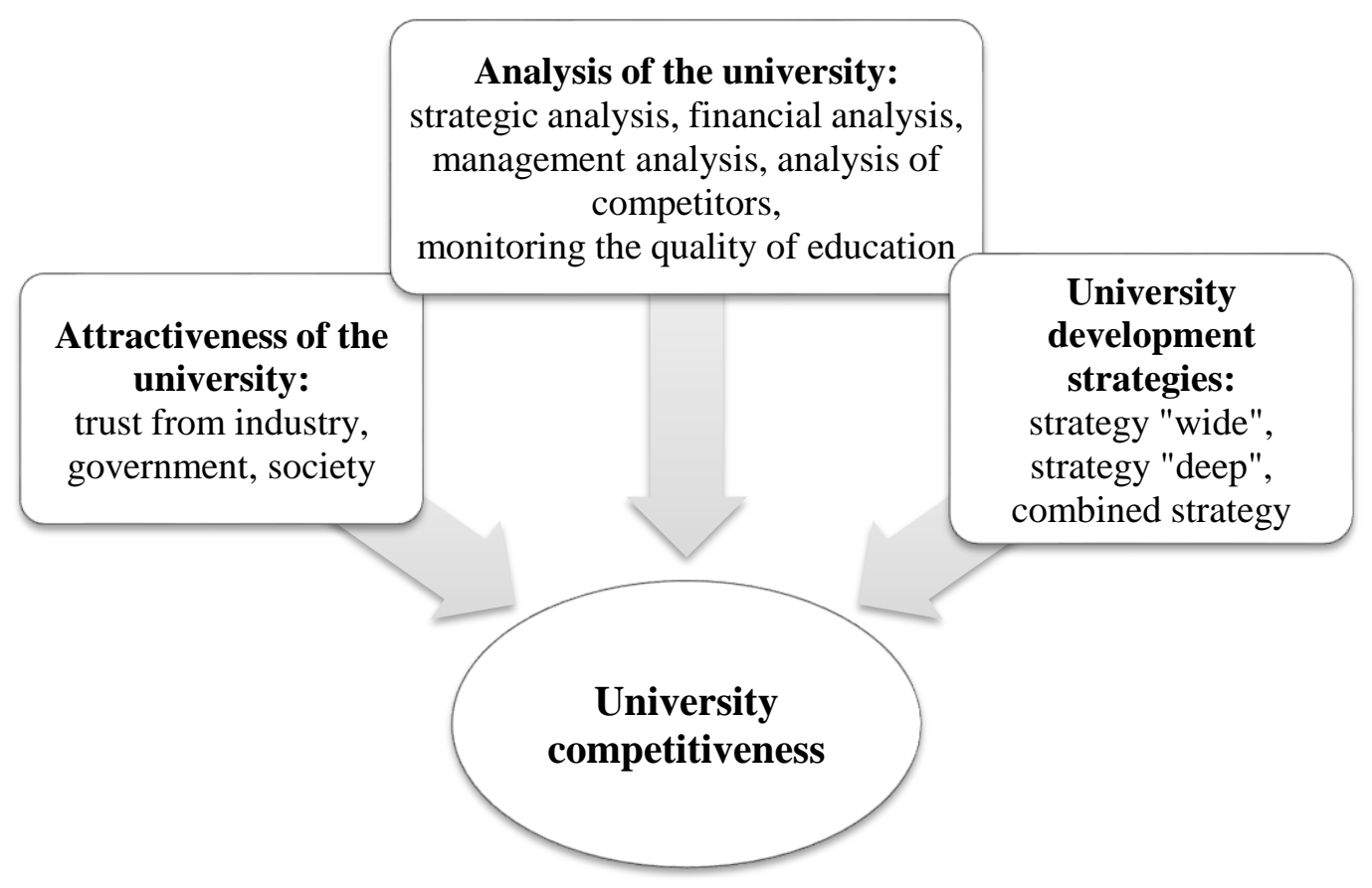

Fig. 1.8. Factors of formation of high competitiveness of the university

To determine the most important factors in the competitiveness of the world's universities, we use the ranking of the best universities in the world according to the British consulting company Quacquarelli Symonds (QS World University Rankings). The ranking evaluates universities on the following indicators: activity and quality of research, opinion of employers and career potential, teaching and internationalization. These indicators cover the key strategic missions of universities of global importance, for which they are accountable to the participants in the process: academic community, employers, students and their parents. The study evaluates more than 2,500 higher education institutions worldwide each year. According to its results, there is a ranking of the best 500 universities in the world, as well as rankings of universities in certain disciplines [191, 186]. The weight of each indicator is shown in Fig. 1.9.

From Fig. 1.9 we see that the most important factors in the competitiveness of the world's universities (according to the QS rating) are internal factors, namely the academic reputation of the university and citations of scientific papers of university teachers. It should be noted that the leaders in this ranking are the Massachusetts Institute of Technology (USA), Stanford University (USA), Harvard University 
(USA), Oxford University (Great Britain), California Institute of Technology (USA).

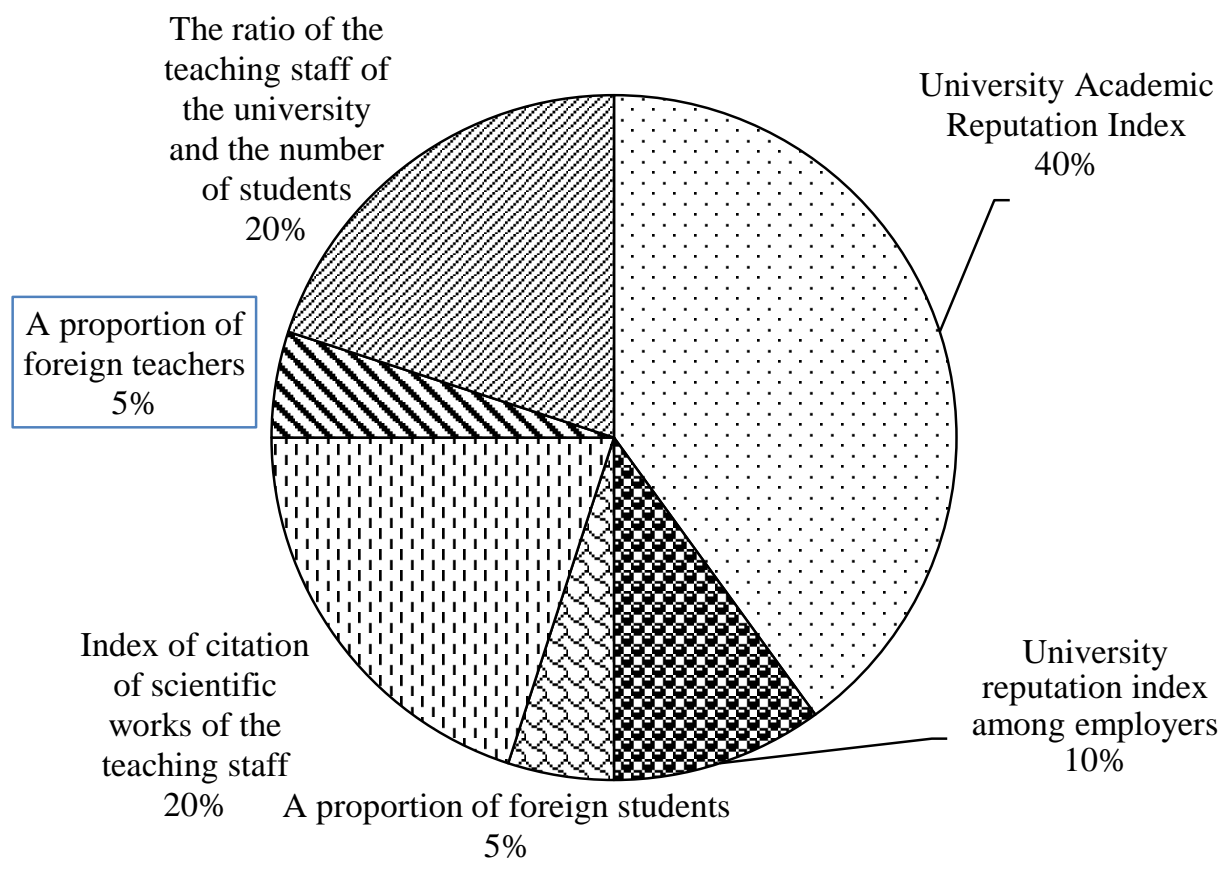

Fig. 1.9. The share of university performance indicators for which the QS rating is calculated

Thus, based on the results of the analysis, we can conclude that a university allows to achieve and maintain a high level of competitiveness through:

quality development strategy;

introduction of innovations in the educational process;

international cooperation;

developed infrastructure that attracts the best applicants with high learning potential;

intellectual capital;

in-demand graduates;

modernization of educational programs, taking into account current and future needs of society;

financial opportunities, by developing its core business under the influence of academic entrepreneurship, the university will achieve high positions in the world rankings of education.

With this in mind, it can be stated that in order to achieve and maintain high competitiveness of the university, the nature of the competitive advantages that it develops is important. Intellectual capital, innovation, international cooperation and financial opportunities are important factors in the attractiveness and competitiveness of universities in the economic competition for leadership in the world markets. 


\section{CHAPTER 2. FORMATION OF INNOVATIVE-ACTIVE UNIVERSITY: EXPERIENCE OF INTEGRATION OF STATE AND HEI}

\subsection{Analysis of the legislative basis and state initiatives to build an innovative university}

The current stage of evolution of the world economy is characterized by radical socio-economic transformations and the transition of countries - key innovators to the knowledge economy. Its main attributes are the internationalization of educational and scientific activities, technological advances in education and science, diversification of funding mechanisms for research carried out by universities, the intensification of competition between them.

The formation of a modern Europeanized system of higher education in Ukraine began after the declaration of independence in 1991. The activity of the HEI of Ukraine is regulated by legislative and regulatory acts, on which both the functioning and the possibilities and direction of development of the sphere of higher education completely depend. During the years of Ukraine's independence, significant changes and transformations have taken place in the activities of the HEI, which were caused by changes in the legislative field and globalization processes and were aimed at achieving world educational standards. The priority task of forming a new independent educational policy of the Ukrainian universities was to create a national education system as a basis for reproducing the intellectual potential of the population, the emergence of domestic science, technology and culture at the world level, national revival, statehood and democratization in Ukraine.

Critical analysis of the legal framework of the process of functioning of domestic HEIs and their transformational development allowed to identify 4 main stages of modification of the legislation of Ukraine in the field of higher education. The evolutionary vector of transformational reformations is shown in Fig. 2.1.

Let us consider in more detail the content of each of the stages on the tuple model "basic regulations - transformations of the higher education system - changes caused by legislation."

\section{Stage 1. (1991-2002).}

This stage is the beginning of the development of the higher education system of Ukraine in general as an independent unit, independent of the post-Soviet educational 
space, and the beginning of transformation processes in the order of training specialists in the higher education system.
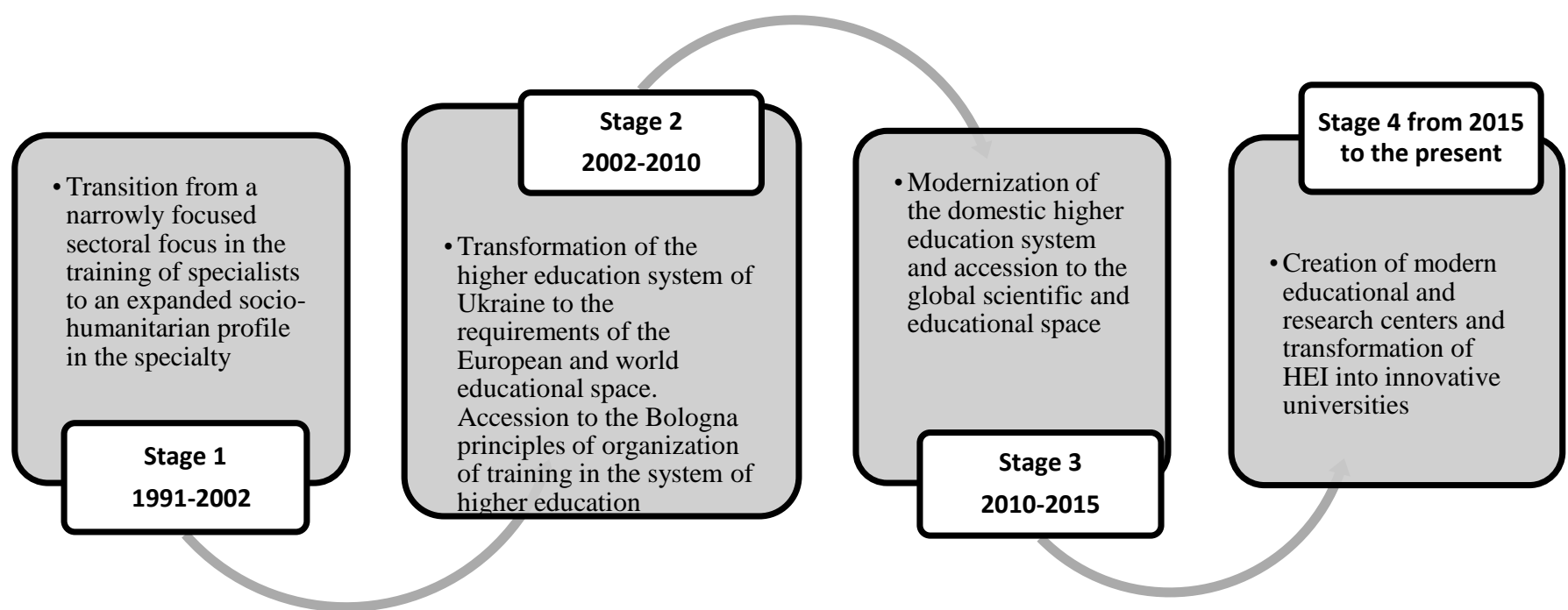

Fig. 2.1. Evolutionary vector of transformation of the higher education system of Ukraine (developed by the authors)

This stage of development of the legal framework is both self-identifying and strategic, as Ukraine has been separated from the post-Soviet educational space and the national legal framework for the development of higher education has been created. In addition, the foundations were laid for the development of higher education in the field of innovation. The key normative acts, which determined the creation of the regulatory framework of the higher education system of Ukraine and its vector of development in the innovative direction at this stage, were the Laws of Ukraine "On Education", "On Higher Education", "On Scientific and Scientific-Technical Activity", program "Education: Ukraine of the XXI century".

The Laws of Ukraine "On Education" [23] and "On Higher Education" [7] created a fundamental basis for the development of higher education in Ukraine and initiated the direction of its reform. These normative acts form the structure, types of HEIs, principles of their management and financing and determine the main types of their activity educational, scientific and scientific-technical. This stage focused only on establishing a national system of higher education. The provisions of the laws concerning international educational and scientific cooperation were only declarative in nature, without concrete actions in the direction of integration into the global and European educational space.

As for the qualitative improvement of the work of HEI, it is at this stage that the procedures for licensing and accreditation of areas and specialties and institutions of higher education have been introduced and detailed.

In order to support the development of education as one of the main factors in the development of the Ukrainian state, a strategic plan for the development of education was 
developed in the form of the State National Program "Education" ("Ukraine of the XXI century"). This document emphasized the inconsistency of the current education system in Ukraine with social needs and global trends, the need to reform education in order to bring domestic science, technology and culture to the world level, national revival, statehood and democratization of society in Ukraine "[66].

The results of this stage were the formation of the legislative framework of education as a system of framework provisions. Thus, the activities of the HEI focused on the educational process, but there were no provisions for strengthening and developing innovation and international activities. Thus, we can identify the main characteristics of the development and modernization of higher education at this stage:

- development of the system of public administration of higher education in Ukraine;

- establishment of legal, organizational and financial bases of functioning of the system of higher education of Ukraine;

- legislation in the field of higher education was in a state of development, refinement and improvement;

- laid the foundations for further development, reform and modernization of the national education system, including the higher one;

- introduction of procedures for licensing, accreditation and certification of HEI in order to improve the quality of their services.

The analysis of the provisions of regulations at this stage are presented in table 2.1.

Table 2.1

\section{Analysis of the provisions of regulations of the first stage of development of higher}

\section{education in Ukraine}

\begin{tabular}{|l|l|}
\hline \multicolumn{1}{|c|}{ Basic legislation } & \multicolumn{1}{|c|}{ Substantive provisions } \\
\hline \multicolumn{1}{|c|}{ 1 } & \multicolumn{1}{|c|}{ 2 } \\
\hline $\begin{array}{l}\text { Law of the Ukrainian SSR "On } \\
\text { 23.05.1991 [7] №1060-XII of }\end{array}$ & $\begin{array}{l}\text { - the basis for the development of the national education system and its } \\
\text { reform has been established. } \\
\text { - among the types of activity of the higher educational institution the } \\
\text { training of specialists of different levels of qualification is indicated; } \\
\text { research work; implementation of external relations. } \\
\text { - the priority is given to basic research in the field of national education and } \\
\text { culture } \\
\text {-limited autonomy of the HEI }\end{array}$ \\
\hline $\begin{array}{l}\text { Law of Ukraine "On Scientific and } \\
\text { Scientific-Technical Activity" № } \\
\text { 1977-XII of 13.12.1991 [19] }\end{array}$ & $\begin{array}{l}\text { - Higher educational institutions of III-IV levels of accreditation are referred } \\
\text { to the subjects of scientific and scientific-technical activity; } \\
\text { - Scientific and scientific-technical activity is recognized as an integral part } \\
\text { of the educational process of the university }\end{array}$ \\
\hline
\end{tabular}


The end of the table 2.1

\begin{tabular}{|c|c|}
\hline 1 & 2 \\
\hline $\begin{array}{l}\text { National Program "Education } \\
\text { (Ukraine of the XXI Century)", } \\
\text { 1993, approved by the resolution } \\
\text { of the Cabinet of Ministers of } \\
\text { Ukraine dated 03.11.1993 № } 896 \\
\text { [66] }\end{array}$ & $\begin{array}{l}\text { The main strategic objectives of higher education reform: } \\
\text { - transition to a step-by-step system of training; } \\
\text { - formation of a network of universities, which by educational and } \\
\text { qualification levels, types of institutions, forms and terms of study, sources } \\
\text { of funding would satisfy the interests of the individual, the region and the } \\
\text { state; } \\
\text { - raising the higher education of Ukraine to the level of developed countries } \\
\text { of the world and its integration into the international scientific and } \\
\text { educational community. } \\
\text { The document approves the need for accreditation of universities of all } \\
\text { levels and forms of ownership. }\end{array}$ \\
\hline $\begin{array}{l}\text { Resolutions of the Cabinet of } \\
\text { Ministers "On accreditation of } \\
\text { higher educational institutions" № } \\
303 \text { of 01.06.1992 [5], "On } \\
\text { licensing, certification and } \\
\text { accreditation of educational } \\
\text { institutions" № } 200 \text { of 12.02.1996 } \\
\text { [18] }\end{array}$ & $\begin{array}{l}\text { came into effect: Regulations on the State Accreditation Commission and } \\
\text { its personnel; Regulations on licensing of educational institutions; } \\
\text { Regulations on accreditation of higher educational institutions; Regulations } \\
\text { on certification of vocational schools. } \\
\text { established the basic principles of accreditation, accreditation criteria, the } \\
\text { level of autonomy of the educational institution in a particular economic } \\
\text { activity }\end{array}$ \\
\hline $\begin{array}{l}\text { Resolution of the Cabinet of Ministers } \\
\text { of Ukraine "On the list of areas and } \\
\text { specialties for which specialists are } \\
\text { trained in higher educational } \\
\text { institutions at the appropriate } \\
\text { educational and qualification levels" } \\
\text { of 24.05.1997 №507 [25] }\end{array}$ & $\begin{array}{l}\text { The list of areas and specialties for which specialists are trained in higher } \\
\text { educational institutions has been approved }\end{array}$ \\
\hline $\begin{array}{l}\text { Resolution of the Cabinet of } \\
\text { Ministers of Ukraine "On approval } \\
\text { of the Regulations on the state } \\
\text { higher educational institution" } \\
\text { dated } 05.09 .1996 \text { № } 1074 \text { [3] }\end{array}$ & $\begin{array}{l}\text { The main tasks of the higher education institution are: } \\
\text { - conducting educational activities and ensuring the acquisition of } \\
\text { knowledge by students in a particular field; } \\
\text { - conducting research as a basis for training future professionals and } \\
\text { scientific, technical and cultural development of the state; } \\
\text { There are no provisions on international activities }\end{array}$ \\
\hline $\begin{array}{l}\text { Law of Ukraine "On Higher } \\
\text { Education" of January 17, 2002 [7] }\end{array}$ & $\begin{array}{l}\text {-established legal, organizational, financial and other principles of } \\
\text { functioning of the higher education system; } \\
\text { - the principles of state policy in the field of higher education include the } \\
\text { integration of the higher education system of Ukraine into the world system } \\
\text { of higher education; } \\
\text { - the tasks of the HEI, scientific and scientific-technical activities; } \\
\text { - } 3 \text { educational and } 4 \text { educational-qualification levels are determined; } \\
\text { - the need to implement state and industry standards of higher education, } \\
\text { which are designed to assess the quality of educational activities and } \\
\text { training in higher education; } \\
\text { - the system of higher education standards was approved; } \\
\text { - the forms of conducting scientific and scientific-technical activity of the } \\
\text { university are determined, which include: } \\
\text { fundamental, applied research for the creation and implementation of } \\
\text { competitive equipment, technologies and materials; } \\
\text { development of various forms of scientific cooperation (including } \\
\text { international); } \\
\text { participation in research and development work carried out in universities; } \\
\text { organization of seminars, conferences, Olympiads, competitions, course, } \\
\text { diploma and other works of the participants of educational process. }\end{array}$ \\
\hline
\end{tabular}


Stage 2 (2002-2010). Transformation of the system of domestic higher education to the requirements of the European and world educational space and the basis of joining the Bologna process of training.

At the beginning of the XXI century there was a formation of the world knowledge economy and the transition from the use of industrial to scientific and information technologies. In such conditions, higher education gained the role of one of the main factors of economic development, which required a change in approaches to the management of the education system and the development of strategic plans for its development. To this end, the Decree of the President of Ukraine of April 17, 2002 approved the National Doctrine of Education Development, the provisions of which gave education the role of "strategic resource for improving the welfare of people, ensuring national interests, strengthening the authority and competitiveness of the state in the international arena" [2].

Among the priorities of state policy in the development of education was the integration of education and science; introduction of educational innovations and information technologies; establishment of the market of educational services and development of its scientific and methodological support; accession of domestic education to the European and world educational space, i.e. the foundations of integration processes and innovative changes in the HEI of Ukraine have been laid.

At this stage, the lag of the development of education and science in Ukraine from the leading countries of the world and their inconsistency with global trends and world practice was observed. Therefore, during this period, the development of the regulatory framework and public policy in the field of higher education was characterized by the beginning of transformational processes of integration into the European and world educational space on the basis of research and innovation of human development.

Ukraine's integration into the global educational space began with the accession to the Bologna Process in 2005, which aimed to create a single higher education space with Europe. However, even before joining the Bologna Process in Ukraine, regulations were adopted to amend the higher education system in order to comply with the European standards and prepare for the Bologna innovations: orders of the Ministry of Education and Science "On the implementation of credit-module system of education" № 812 dated 20.10.2004 [14], "On approval of the action program for the implementation of the provisions of the Bologna Declaration in the system of higher education and science of Ukraine for 2004-2005" [38] of 23.01.2004 [15] (Table 2.2). 


\section{The main regulations of the second stage of development of higher education in}

\section{Ukraine}

\begin{tabular}{|c|c|}
\hline Basic legislation & Substantive provisions \\
\hline $\begin{array}{l}\text { Decree of the President of Ukraine "On the } \\
\text { National Doctrine of Education Development" } \\
7347 / 2002 \text { of } 17.04 .2002[2]\end{array}$ & $\begin{array}{l}\text { - Education is recognized as a determining factor, a } \\
\text { strategic resource for improving the well-being of } \\
\text { people, ensuring national interests, strengthening the } \\
\text { authority and competitiveness of the state in the } \\
\text { international arena. } \\
\text { - the priorities for the development of state policy in the } \\
\text { field of education include: the creation of a market for } \\
\text { educational services and its scientific and } \\
\text { methodological support; integration of domestic } \\
\text { education into the European and world educational } \\
\text { space; financing of the state order according to the } \\
\text { established standards taking into account the quality of } \\
\text { education }\end{array}$ \\
\hline $\begin{array}{l}\text { Orders of the Ministry of Education and Science } \\
\text { № } 49 \text { of } 23.01 .2004 \text { "On approval of the } \\
\text { Program of Action for the implementation of the } \\
\text { provisions of the Bologna Declaration in the } \\
\text { system of higher education and science of } \\
\text { Ukraine for 2004-2005" [14]; } \\
\text { "On the peculiarities of the introduction of } \\
\text { credit-modular system of organization of the } \\
\text { educational process" №812 of } 20.10 .2004 \text {. [24] }\end{array}$ & $\begin{array}{l}\text { The goal is to take measures for the entry of the national } \\
\text { system of education and science into the European space. } \\
\text { The main tasks that need to be addressed for the } \\
\text { implementation of the Bologna Process in Ukraine are } \\
\text { identified: } \\
\text { - take into account the European practice of organization } \\
\text { of accreditation and quality control of education; } \\
\text { - to ensure further development of autonomy and self- } \\
\text { government in higher education. }\end{array}$ \\
\hline $\begin{array}{l}\text { Decrees of the President of Ukraine: "On } \\
\text { measures to improve the system of higher } \\
\text { education in Ukraine" 99199/2004 of 17.02.2004 } \\
\text { [15], "On urgent measures to ensure the } \\
\text { functioning and development of education in } \\
\text { Ukraine" №1013 / 2005 of } 04.07 .2005 \text {. [22], } \\
\text { "On ensuring the further development of higher } \\
\text { education in Ukraine" №857 / 2008 of } \\
\text { 25.09.2008 [10] }\end{array}$ & $\begin{array}{l}\text { The system of measures on improvement and } \\
\text { development of education of the system of higher } \\
\text { education of Ukraine, its integration into the European } \\
\text { educational space is approved }\end{array}$ \\
\hline $\begin{array}{l}\text { Orders of the Ministry of Education and Science } \\
\text { № } 774 \text { of } 30.12 .2005 \text { "On the introduction of } \\
\text { credit-modular system of organization of the } \\
\text { educational process" [9], № } 612 \text { of } 13.07 .2007 \\
\text { "On approval of the Action Plan for quality } \\
\text { assurance of higher education in Ukraine and its } \\
\text { integration into the European and world } \\
\text { educational community for the period up to } 2010 \\
\text { " [12] }\end{array}$ & $\begin{array}{l}\text { Ensuring the quality of higher education and integration } \\
\text { of higher education in Ukraine into the international } \\
\text { educational space }\end{array}$ \\
\hline $\begin{array}{l}\text { Resolutions of the Cabinet of Ministers of } \\
\text { Ukraine "On licensing of educational services" } \\
\text { № } 1380 \text { of } 29.08 .2003 \text {, "On licensing of } \\
\text { activities for the provision of educational } \\
\text { services" № } 1019 \text { of } 08.08 .2007 \text {; } \\
\text { Order of the Ministry of Education and Science } \\
\text { № } 847 \text { of } 24.12 .2003 \text { "Licensing conditions for } \\
\text { the provision of educational services in the field } \\
\text { of higher education" }[1,17,18]\end{array}$ & $\begin{array}{l}\text { the Procedure for licensing educational services was } \\
\text { approved; the minimum standards for providing } \\
\text { educational institutions with scientific-pedagogical and } \\
\text { pedagogical staff, material-technical, educational- } \\
\text { methodological and information base have been } \\
\text { established. }\end{array}$ \\
\hline
\end{tabular}


In fact, such accession was formal, as the implementation of the main instruments of the Bologna Process (cyclical organization of higher education, the European Credit Transfer and Accumulation System, national qualifications framework, Standards and Recommendations for Quality Assurance in Higher Education) took place much later.

Thus, the main characteristics of the development and modernization of higher education at this stage were as follows:

approval of the strategy for the development of higher education;

the beginning of integration into the European educational and scientific space after Ukraine's accession to the Bologna process;

the beginning of structural and functional changes in the activities of the HEI, aimed at ensuring the highest quality of higher education and ensuring its innovative development;

continuation of the development of licensing and accreditation procedures for HEI of Ukraine;

state and branch standards of higher education are introduced.

\section{Stage 3 (2010-2015).}

Modernization of the higher education system in Ukraine and real accession to the global scientific and educational space.

The content of the third stage of modernization of the HEI of Ukraine was characterized by the transition from declarativeness to the actual implementation of the world and European values and practices of the educational process.

The first steps towards overcoming the inconsistency of domestic legislation in the field of higher education with international standards was the development and approval of the National Qualifications Framework in 2011 as the national classifier of Ukraine. This document approves five levels of higher education: junior bachelor, bachelor, master, doctor of philosophy and doctor of sciences [11].

In order to recognize the need for the development of HEI in the field of innovation and create conditions for stimulating these processes in 2010 there was introduced the concept of "research university", the main characteristics of which are scientific achievements, research and innovation, implementation of international projects and integration of education and science with industry [4]. The status of a research university was granted to 14 HEI of Ukraine by the acts of the Cabinet of Ministers of Ukraine .

However, the state of development of the higher education in Ukraine, despite the measures taken, still did not correspond to the European level. In conditions of the need for significant changes to improve the level of quality, increase the competitiveness of 
domestic HEI, as well as continue the process of integration into the global educational space, in 2013 the National Strategy for Education Development in Ukraine until 2021 was approved. The main directions of the Strategy implementation were identified [21]:

- revision, modernization and adoption of new legislation in the field of education, including higher education (especially the new versions of the Laws of Ukraine "On Education", "On Higher Education");

- improving the structure of the Ukrainian education system;

- modernization of the content of education,

- informatization of education,

- support of scientific and innovative activity and other.

In pursuance of the Strategy, measures have been taken to comprehensively modernize the educational and scientific sphere by adopting a new version of the Law of Ukraine “On Higher Education” (2014).

The main purpose of the Law of Ukraine "On Higher Education" was the qualitative transformation of higher education, strengthening cooperation between the government agencies and businesses with higher education institutions, preparation of competitive human capital for high-tech and innovative development, further introduction of Bologna instruments and integration with the European Research Area.

That is, the main characteristics of the development and modernization of higher education at this stage are as follows:

- granting the status of a research university;

- innovation in the development of education;

- improving the availability and quality of education;

- continuation of the process of the European integration of higher education;

- adaptation of legislation in the field of higher education to the European requirements and bringing the regulatory framework of higher education to modern needs of the economy and its innovative development;

- the strategic plan of development of the educational branch is approved.

Table 2.3 shows the analysis of regulations adopted in the period 2010-2015.

\section{Stage 4 (from 2015 to the present).}

Creation of modern educational and research centres and transformation of HEI into innovative and active universities of entrepreneurial type. Since 2015 a new stage of modernization of the higher education system of Ukraine has begun, in which the regulations were prepared that continued to modernize the legislative framework of the 
national higher education, and new strategic directions of development were adopted.

Table 2.3

\section{The main regulations of the third stage of development of higher education in}

\section{Ukraine}

\begin{tabular}{|c|c|}
\hline Basic legislation & $\begin{array}{ll}\text { Substantive provisions } \\
\end{array}$ \\
\hline $\begin{array}{l}\text { Resolution of the Cabinet of } \\
\text { Ministers of Ukraine of } \\
\text { February 17, 2010 № } 163 \\
\text { "Regulations on the } \\
\text { Research University" [4] }\end{array}$ & $\begin{array}{l}\text { - approval of the concept of "research university", } \\
\text { - main activities: educational, scientific and innovative, international; } \\
\text { - approved the criteria of the university, which gives the status of research; } \\
\text { - the main tasks of the research university are defined, among which: } \\
\text { realization of innovative programs of preparation of scientific and scientific- } \\
\text { pedagogical staff; implementation of basic and applied research; realisation } \\
\text { of innovative projects for the development, implementation and production } \\
\text { of new high-tech products; integration of education and science with } \\
\text { production through the creation of educational-research-production } \\
\text { associations, basic departments, laboratories; participation in the } \\
\text { implementation of international projects and programs, in scientific and } \\
\text { practical conferences, seminars and exhibitions. }\end{array}$ \\
\hline $\begin{array}{l}\text { Resolution of the Cabinet of } \\
\text { Ministers of 23.11.2011 № } \\
1341 \text { "On approval of the } \\
\text { National Qualifications } \\
\text { Framework" [11] }\end{array}$ & $\begin{array}{l}8 \text { qualification levels have been approved, including } 5 \text { levels of higher } \\
\text { education, and their description on the basis of the European and national } \\
\text { standards of quality assurance of education, which takes into account the } \\
\text { requirements of the labour market to the competencies of employees and is } \\
\text { introduced to harmonize legislation in education and social relations, } \\
\text { promote national and international recognition of qualifications in Ukraine }\end{array}$ \\
\hline $\begin{array}{l}\text { Presidential Decree "On the } \\
\text { National Strategy for the } \\
\text { Development of Education in } \\
\text { Ukraine until 2021" № } \\
\text { 344/2013 of 25.06.2013 [21] }\end{array}$ & $\begin{array}{l}\text { The strategic tasks of the development of the sphere of higher education are } \\
\text { determined, from which the main ones are: } \\
\text { - creation of research universities, expansion of university autonomy; } \\
\text { - reforming and optimizing the network of higher education institutions; } \\
\text { - bringing the management system of higher education in line with the needs } \\
\text { of the national economy and the demands of the labour market; } \\
\text { - development of the standards of higher education focused on the } \\
\text { competence approach; } \\
\text { - expanding the interaction of higher education with employers; }\end{array}$ \\
\hline $\begin{array}{l}\text { Law of Ukraine "On Higher } \\
\text { Education" of 01.07.2014 [6] }\end{array}$ & $\begin{array}{l}\text { - among the tasks of the higher educational institution is the conduct of } \\
\text { educational and scientific activities; ensuring a combination of educational, } \\
\text { scientific and innovative activities; establishing international relations; } \\
\text { - structural changes in the management system of higher education are } \\
\text { envisaged; } \\
\text { - development of university autonomy; } \\
\text { - creation of new standards of higher education; } \\
\text { - increasing the mobility of students and teachers; } \\
\text { - higher education institutions have been given the authority to develop } \\
\text { educational programs; } \\
\text {-opportunity to issue their own diplomas; state diplomas can be issued only } \\
\text { for accredited programs; } \\
\text { - the system of quality assurance of higher education was introduced and the } \\
\text { status of the National Agency for Quality Assurance of Higher Education } \\
\text { was determined. }\end{array}$ \\
\hline
\end{tabular}

This period is also characterized by a significant intensification of international cooperation in education and science, the continuation of the European vector of 
development.

In pursuance of the requirements of the Law of Ukraine "On Higher Education" of July 1, 2014, the National Agency for Quality Assurance in Higher Education was established to be responsible for the accreditation process.

In the conditions of the shift of a vector of development and principles of functioning of HEI from educational to educational-scientific activity there was a need for development of the norms regulating the sphere of scientific activity. In 2015, the Law of Ukraine "On Scientific and Scientific-Technical Activities" was adopted to manage relations regarding the implementation of scientific and scientific-technical activities in Ukraine and to perform the National Strategy implementations; accoring to the Law, universities are classified as subjects of scientific and scientific-technical activity (Table 2.4).

Table 2.4

\section{The main regulations of the third stage of development of higher education in}

\section{Ukraine}

\begin{tabular}{|c|c|}
\hline Basic legislation & Substantive provision \\
\hline 1 & 2 \\
\hline $\begin{array}{l}\text { Resolution of the Cabinet } \\
\text { of Ministers of } \\
\text { 15.04.2015 № 244 "On } \\
\text { the establishment of the } \\
\text { National Agency for } \\
\text { Quality Assurance in } \\
\text { Higher Education" [26] }\end{array}$ & $\begin{array}{l}\text { the National Agency for Quality Assurance in Higher Education was } \\
\text { established as a permanent collegial body for the implementation of state } \\
\text { policy in the field of quality assurance in higher education and its } \\
\text { regulations were approved }\end{array}$ \\
\hline $\begin{array}{l}\text { Law of Ukraine "On } \\
\text { scientific and scientific- } \\
\text { technical activities" of } \\
11 / 26 / 2015[20]\end{array}$ & $\begin{array}{l}\text { Scientific and scientific-technical activity in higher educational } \\
\text { institutions is an integral part of educational activity and is carried out } \\
\text { in order to integrate scientific, educational and industrial activities in the } \\
\text { system of higher education. }\end{array}$ \\
\hline $\begin{array}{l}\text { Strategy for the } \\
\text { development of higher } \\
\text { education in Ukraine for } \\
\text { 2021-2031 [235] }\end{array}$ & $\begin{array}{l}\text { Priority principles of the higher education development in Ukraine: } \\
\text { - autonomy of the HEI of Ukraine; } \\
\text { - implementation of the principles of academic integrity, academic } \\
\text { freedom and professionalism; } \\
\text { - ensuring high scientific achievements; } \\
\text { - achieving quality standards of higher education and its continuous } \\
\text { improvement; } \\
\text { - focus on current and future priorities of society and the national } \\
\text { economy; } \\
\text { - research universities are the core of higher education; } \\
\text { - research universities are leaders in creating new knowledge, their own } \\
\text { online platforms for the dissemination of knowledge in society; } \\
\text { - development of HEI autonomy; } \\
\text { - financial stabilization of HEI; }\end{array}$ \\
\hline
\end{tabular}


The end of the table 2.4

\begin{tabular}{|l|l|}
\hline 1 & \multicolumn{1}{|c|}{2} \\
\hline & - improving the mechanism of financing and commercialization of \\
university science, ensuring intellectual property rights; \\
- creation of a mechanism of cooperation between the HEI and the labour \\
market; \\
- development of an effective system of internal and external provision \\
and monitoring of the quality of higher education; \\
- support for the economic development of the country through a \\
combination of education, science and business; \\
- creation and development of an innovative ecosystem in the field of \\
higher education; \\
- improving the financing and commercialization of university science; \\
- fundamentalization and universalization of educational training \\
through joint projects of scientific and educational institutions.
\end{tabular}

At the moment, the legal framework of higher education is being modified and reformed in order to build a competitive quality education on innovative ones, which will take a recognized place in the world and European educational space.

The main directions of modernization of the higher education system, which provides for the transition of domestic HEI to the level of innovative universities, are:

introduction of innovation in the development of education;

granting the status of research university to the leading HEI;

improving the availability and quality of education;

continuation of the process of the European integration of higher education.

adaptation of legislation in the field of higher education to the European requirements and bringing the regulatory framework of higher education to modern needs of the economy and its innovative development

the strategic plan of the development of educational branch is approved.

Thus, since the establishment of independent Ukraine until now, the legislation in the field of education has undergone significant transformations, the main vector of which was the attempt to form a qualitative global and European regulatory framework aimed at creating conditions and a favorable environment for transforming traditional HEI.

\subsection{Innovations in education: essence, types, stages of implementation}

The rapid development of innovative technologies is the cause of large-scale educational reforms that are turning education into a productive sector of the economy. The National Doctrine of Education Development states that Ukraine must ensure 
accelerated, advanced innovative development of education by updating the content of education and organizing the educational process in accordance with democratic values, market principles of the economy, modern scientific and technological achievements. Thus, it is a question of introduction of certain innovations in practice of functioning of the national HEI and necessity of essential changes in all kinds of its activity.

In general, the innovative model of society development involves the systematic implementation of scientific achievements in the real sector of the economy, as well as the intensification of innovative activities of organizations and business structures. It is obvious that the most important role in this process should be played by the innovative activity of the HEI. By considering this, an important component of the competitiveness of higher education institutions are future-oriented and progressive development of innovations aimed at creating changes in the education system and maintaining their positive results. In addition, educational institutions that pay attention to innovation are able to adapt to changes in the external environment more quickly, which creates additional competitive advantages.

Under such conditions, as noted in paragraph 2.1, an important priority of the state innovation policy of Ukraine should be to create a favorable innovation climate and provide comprehensive support to existing and, created on the basis of state HEI, small innovation enterprises, technology parks and business incubators. This is especially important for technological universities because in the real sector of Ukraine's economy, despite the available resource potential of the state, the opportunities to increase production due to extensive factors are largely exhausted. One of the factors of innovative development of the country is innovative business in general, as well as its important component - small innovative enterprises, technology parks and business incubators, the success of which in the HEI is confirmed by foreign experience.

Today, higher education must meet the challenges of the time, embodying new requirements, trends, ideas in new educational technologies, forms and structures, methods and means of training. Educational innovations "are an adequate response to the social demands of a post-industrial society of "fast" economy, in which the role of creativity, efficiency of management, ability to react quickly to changes, ability to create new technologies and replace them with the newer ones, to prevent information isolation is increasing" [119].

Economic models of the world's leading countries provide for the use of tools that stimulate innovation in higher education. It is believed that these innovations have a significant impact on the support of the entire innovation system, as they allow to 
maintain a high quality workforce. In particular, the leading US universities invest significant innovative resources in the organization of training facilities for the training of specialists in priority areas that provide future employees with the most decent working conditions [227]. Thus, one of the leading elements of ensuring national competitiveness is the system of higher education. Therefore, the higher education system should be developed on an innovative basis, in particular - to maintain high rates of development and implementation of innovations in the educational process.

Innovative-educational activity of each HEI should begin with the deep critical analysis of all aspects of its scientific-pedagogical and scientific-methodical activity taking into account unrealized potential opportunities, generalization and introduction of the accumulated positive experience in teaching disciplines, acquaintance and studying experience of other leading higher educational institutions (both in Ukraine and abroad). The issues of research and solving current problems of development and implementation of innovations in the field of higher education are set out in many scientific papers. At the same time, scientific publications do not provide analytical generalizations of the organization of innovation activities in modern socio-economic transformations, as well as taking into account the results of integration processes (integration of the higher system of Ukraine into the world educational space).

So, first of all, it is necessary to determine the interpretation of the concept of "educational innovation".

In essence, the processes that are characteristic of the current stage of development of higher education in the world are tolerant of entrepreneurial processes, where any firm or organization that exists in a competitive environment, is looking for effective strategies, ways, tools to gain a competitive advantage. In-depth studies of the sources of competitiveness in business, conducted in the early twentieth century by the Austrian and American economist J. Schumpeter [17], have identified innovation as a key factor.

The etymology of the word has a Latin basis, which means "in the direction of renewal / change." In this regard, the innovative activity of any organization is defined as the creation, search and use of opportunities for new ways of doing business that lead to improved products and services, systems and ways to lead / manage people and organizations.

Historical sources of educational innovations are associated with the emergence of experimental pedagogy in the second half of the nineteenth century. Since the 1960s, the phenomenon of "innovation" has become a key one in characterizing post-industrial formation - its formation and development. 
The question of innovative educational activity has a starting point in defining the meaning of the terms "innovation", "innovative project", "innovative culture", "educational innovation", "innovative educational activity", which allows to establish the essential features of innovation processes in education. Thus, we can assume that educational innovations are the first created, improved or applied educational, didactic, educative, management systems, their components that significantly improve the results of educational activities.

Thus, innovation should be considered as a new novelty in education - in the content, methods, techniques and forms of educational activities and personal education (methods, technologies), in the content and forms of management of the educational system, as well as in the organizational structure of educational institutions, teaching aids and approaches to social services in education, which significantly increases the quality, efficiency and effectiveness of all IAU activities.

As noted in paragraph 2.1., according to the Law of Ukraine "On Innovation" [16], "innovation in education or educational innovation" can be interpreted as newly created (applied) and (or) improved competitive technologies, products or services, and also organizational and technical solutions of production, administrative, commercial or other nature, which significantly increase the quality, efficiency and effectiveness of the educational process. At the same time, the main elements of "educational innovation" are: its carrier (creative personality) that has a certain innovative idea (core of innovation) and conducts an innovative experiment (source of innovation); consumer of innovation - a student or a group of students, listeners (who acquire knowledge in a particular area); as well as institutions that ensure the introduction of innovations in the educational process (educational institutions; scientific, methodological, scientific-methodological institutions; research and production enterprises; state and local education authorities and self-government in the field of education).

The main characteristics that reflect it as a specific category are:

* purposeful changes that make new stable elements (innovations) in the field of education, causing its transition from one qualitative state to another; that is, not all changes in education are innovations, but only those that provoke changes in the goals and results of education (through its content) and change in ways to achieve them (through the forms, nature and organization of the educational process);

* the presence of specific features related to socio-psychological and other aspects of teaching;

* innovative changes can be initiated at any level of the educational system 
(teacher, student, management of an individual educational institution, state and local education authorities and self-government in the field of education);

* innovative changes must be made in the activities and thinking of all participants of the educational process;

* innovation processes in the field of education must be continuous and aimed at continuous improvement of the existing system;

* in order to ensure the process of constant innovative renewal of the educational sphere, it is necessary to implement appropriate mechanisms for managing the quality of education;

* the effectiveness of the implementation of a particular innovation largely depends on the level of susceptibility to innovative changes in the system (which implements the innovation) and the availability of real opportunities for implementation of the innovation (i.e., feasibility).

Based on this, the implementation of innovations should be considered as a structured, logical-oriented process containing the following stages (Fig. 2.2). Thus, the innovation process begins with identifying the need for changes in certain activities of innovative-active university, which takes place due to a combination of stakeholders and the actual HEI, namely, analytical work of specialized scientific organizations, education authorities, leaders of HEI, scientific and pedagogical teams.
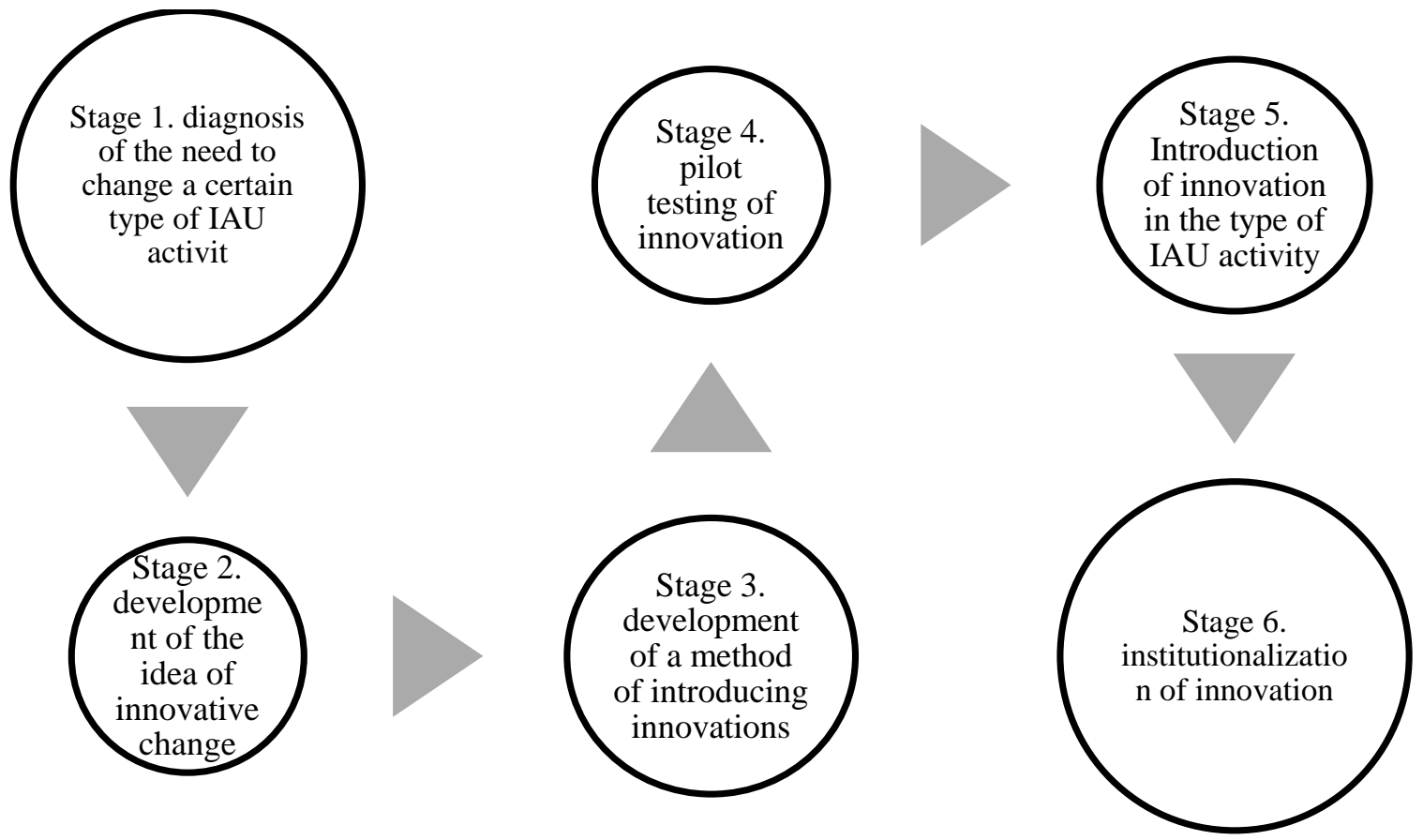

Fig. 2.2. Stages of the process of investment implementation in the activities of IAU

The main directions of the development and implementation of educational 
innovations are the subject of research of many scientists and practitioners. Thus, according to the British educator G. Silver "[106], the typology of educational innovations in the late twentieth and early twenty-first centuries includes the following components:

- Individual and group innovations related to students' needs and professional expectations (e.g., student seminars, laboratory simulations, case studies, trainings, etc.), development of their entrepreneurial skills;

- Initiatives related to the study of certain disciplines and supported by industry associations of specialists and employers, informal cooperation between specialists of related institutions;

- Innovations related to the use of the latest information technologies (e.g., software, cloud technologies, "online resources");

- Innovations related to reforming the content of training programs in order to strengthen their interdisciplinarity, introduction of the dual education;

- Institutional initiatives, in particular decision-making policy on a wide range of issues (for example, on the use of information technology, applied learning), professional development of teachers, establishment of new structures, involvement of managers in assessing the level of development;

- Systemic initiatives, including the creation by the government of new educational institutions (e.g., open, research, innovation universities); financing systemic change, which encourages entrepreneurship and the development of professional skills and abilities of teachers; creation of national schemes to encourage the use of new educational and information technologies; creation of "groups for the promotion" of innovations;

- Assessment innovations (for example, personalized assessment of the quality of education, a new system of financial support for students), etc.

Thus, modern trends in the formation of post-industrial society determine the significant role of educational activities in ensuring the development of the country and society. This necessitates reforming and modernizing the model of HEI and the use of innovative technologies for this process. Innovative changes should be based on the implementation of new vectors of the development of domestic HEI, which include the use of innovative learning technologies, principles, forms and methods of the educational process and management of HEI, etc. The effectiveness of such changes will directly affect the quality and overall level of higher education in the country.

In general, according to the authors, the main difference between modern innovative universities (HEI of a new type) and traditional domestic universities should be defined as follows: 
- first, the ability to respond adaptively to the challenges of the environment by producing certain types of innovations in response to external challenges of any level;

- secondly, the ability to introduce innovative changes in all activities carried out by new universities, namely in education, research, socio-humanitarian (international and communicative) and commercial (implementation of intangible assets in all the above areas of activity within modern regulatory and legal field) sphere of activity.

Innovative changes in higher education should be interpreted as innovations in the form of ideas, tools and technologies that qualitatively improve the process, efficiency and results of educational activities. Therefore, when considering innovations in the context of educational activities, in contrast to business and industrial activities, nonproduct innovations come to the fore, i.e. those that have an intangible nature, but significantly affect activities. Innovations in higher education can be divided into two main groups:

1) permanent modernization of all types of activities through the introduction of innovative ways of providing educational services, research and development, the formation of communication links or commercialization of intangible assets, which are aimed at achieving higher success rates, production and acquisition of knowledge and technology;

2) transformation, i.e. qualitative transformation of all types of HEI, namely, the educational process, supplementing the traditional educational component with elements of research and reorientation of HEI to simply encourage research and exploration, integration with key stakeholders on the basis of entrepreneurial activity.

Also, the innovations introduced in the activities of HEI can be grouped according to the direction of the applied changes in accordance with the basic classification of innovations presented in the Oslo Manual [177].

1) product innovation - the introduction of services that are new or significantly improved in terms of their properties or methods of application;

2) process innovation - the introduction of a new or significantly improved way of providing services;

3) marketing innovation - the introduction of a new method of commercialization of scientific and educational innovations, which includes significant changes in the positioning of services for education or $\mathrm{R} \& \mathrm{D}$, their promotion on the market or in setting sales prices;

4) organizational innovation - introduction of a new method and form of organization of all types of HEI activities, improvement of management HEI and its 
organizational structure of managing and managed subsystems, improvement of the organization of use of all types of HEIs resources, search of new forms of interaction with stakeholders, organizations.

The classification of innovative changes in higher education institutions is given in Fig. 2.3.

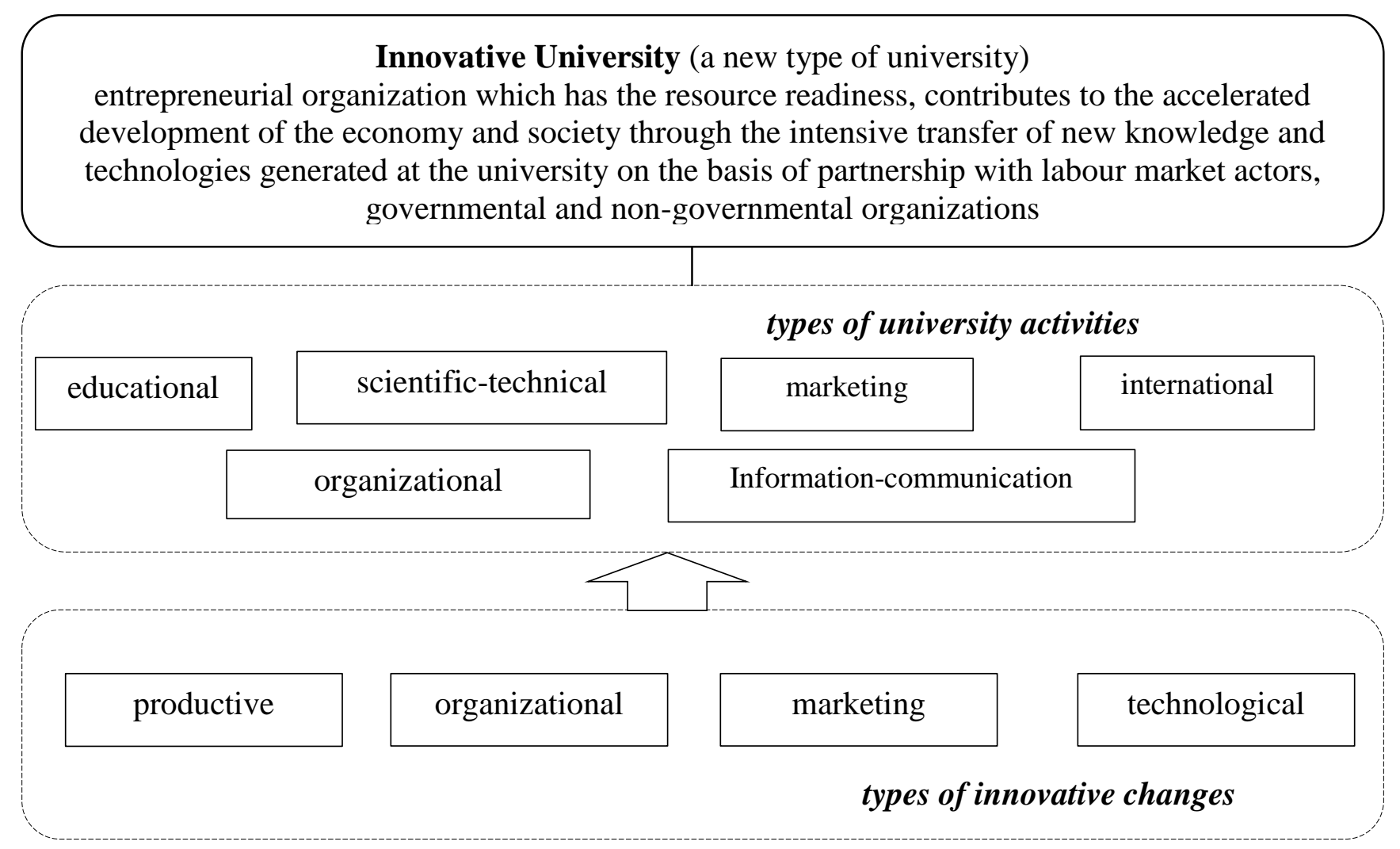

Fig. 2.3. Types of innovative changes in an innovative-active university

It should be noted that the author's position is that all types of innovative changes in certain periods of time and in accordance with the capacity of the university, to the strategic goals of its development, can be applied to all activities of IAU.Let's consider in more detail possible innovations in the course of activity of HEI on the basis of their offered classification.

\section{Organizational innovations}

The organizational type of innovation that can be introduced by universities in their activities is institutional and communicative. Organizational innovations in the institutional vector of development include innovations related to the organization of internal activities of the HEI. This type includes independence in the organization of the educational process, namely the creation of new specialties, the result of which is the acquisition of new knowledge and skills in accordance with the needs of the market and 
stakeholders. As part of such innovations, universities are opening new specialties based on the principles of interdisciplinarity and compliance with changes in the economic environment, especially in the development of IT technologies, which have the most dynamic pace of development.

Thus, universities, on the one hand, respond to the demands of global transformation processes and labour market needs, and on the other hand, form the structure of the labour market and ensure the emergence of new professions. Such universities provide the country's economy with highly qualified representatives of promising and popular specialties. In turn, unclaimed specialties can be modified or closed altogether, which will avoid an excess of unclaimed staff in the labour market. As a result, universities are gaining ground in the development of the productive forces of the industry, the region and the country as a whole.

In addition, organizational innovation can provide a public dialogue. In this area, the development of soft skills is decisive, which is the result of changing the paradigm of the educational process from providing professional knowledge to the formation of a specialist developed both professionally and as a person with creative and communication skills.

Also an innovative type of activity of the HEI is the establishment of cooperation with stakeholders, the main of which are employers. Within the framework of this approach, stakeholders are involved in the educational and scientific process. Employers and professionals from different fields can be involved in shaping the content of educational programs and curricula in accordance with the necessary competencies. It is also possible to be directly involved in the educational process by organizing their own training centres on the basis of HEI or holding lectures, consultations, round tables, seminars, etc. to share experiences and expand practical knowledge.

Cooperation with stakeholders in the process of scientific activity is the development of economic contractual relations, which consists in the implementation of research and development at the request of employers and interested businesses. But the most promising and common way to interact with business is the development of new forms of interaction, including:

- science parks, which are a form of integration of science with industry in the form of research and production complex and the development of science-intensive business;

- business incubators - an innovative form of business support based on HEI, which creates favorable conditions for doing business at the initial stage of development;

- business schools - an organization based on HEI, which provides training in the 
field of business management;

- Fablab laboratories - laboratories of digital production of free access, which provide the ability to manufacture items based on computer models;

- co-working centres - office space that brings together representatives of different professions and specialties, and facilitates the exchange of experience and the implementation of interdisciplinary research and work;

- technology parks - innovation complexes based on the university, which include research organizations and industrial companies to develop and implement innovative projects;

-start-up schools and others.

This type of innovation includes the development of international cooperation through internships and academic mobility, participation in international grant projects for R \& D.

\section{Marketing innovations}

Marketing innovations help to improve the positioning of HEI in the market of educational and scientific services. As part of educational activities, this involves the latest approaches to mastering the market of educational services. The institutional level is represented by the introduction of new forms of testing and development of knowledge, such as external evaluation, school competitions, cooperation with the Small Academy of Sciences and the introduction of competitions for scientific works of the Academy of Sciences, etc. Improving the position in the market of educational services is possible due to new technologies of career guidance, advertising and brand promotion of the university. The types of innovative career guidance activities are summer and winter schools, organization of vocational guidance centres for student youth and university training. The promotion of the university brand is possible due to the dissemination of information in the media space, for which units are created within the HEI for advertising, press centres, media agencies, media communication centres. Universities create their own channels for video broadcasts, Internet television or radio broadcasting, and organize PR and image events.

The measures to promote the results of scientific activities in the form of research are carried out through participation in scientific conferences, publication of research results in the editions that are part of the world's scientometric databases (Web of Science, SCOPUS), which in turn is a factor in creating a positive image of the university.

\section{Technological innovations}

Technological innovations are the introduction of new models and methods of 
teaching and research, which increase the efficiency of the educational and scientific process.

The main type of technological innovation in the field of education is the use of the latest information and computer technologies. The global rapid development and spread of IT technologies is affecting all areas of the population, including higher education. Based on the integration of educational and information technologies, a wide range of distance learning technologies emerges. The form of distance learning as such is also an innovation. And in combination with the use of electronic communication platforms (Zoom, Skype, Google Hangouts, eduMEET and others), HEI have received a progressive form and learning technology that meets the needs of a rapidly changing progressive society. The role of this type of innovation came to the fore during the COVID-19 pandemic, and opens up new opportunities for the educational process and communication.

An important role is also played by information technology, which does not involve the process of direct communication. Such technologies can be grouped into two main classes: educational platforms and management on learning technologies.

Educational platforms in the form of personal automated learning systems (PLS) provide the ability to remotely control learning and fill the learning process. Such platforms combine communication between teachers and students in the form of messaging and the ability to set, perform, pass and test tasks, download files of various formats, test knowledge in various forms and evaluate student work.

The process management information system in HEI includes the possibility of introducing electronic document management and electronic journals, which provides support for the creation and storage of documents, speeding up document management procedures, improving management efficiency and control over the educational process by the university, students and other stakeholders. In addition, universities can implement electronic security systems: access systems, elements of artificial intelligence for personal identification, and so on.

In addition to the direct introduction of technology, technological innovations include the introduction of new teaching methods. These innovations include opportunities to organize educational space by developing new programs in specialties by introducing a competency-based approach to the development and implementation of educational programs based on national qualification frameworks and their consistency with foreign HEI, increasing the number of programs developed with participation and experience. 
In the formation of educational programs, the involvement of students in this process and an innovative form of free choice of disciplines is introduced. This type of innovation refers to the introduction of the concept of "person-centered teaching" in the educational range of universities, which involves the transition from a clearly regulated composition of the educational process to free choice of educational trajectory that is better able to meet individual interests and needs. These innovations involve the use of such types of variable components of the educational program as majors and minors.

Majors are specialized training disciplines that deepen professional training in specialization and form professional competencies.

Minors are professional non-core disciplines that do not provide highly specialized knowledge but contribute to the development of additional specialized knowledge. Minors are elective disciplines that satisfy the interests of students and expand their competencies. However, it should be noted that elective courses are divided into two groups: disciplines that add or expand general competencies and those that add or expand professional competencies (profile and non-profile).

The organization of the educational process must include quality control of training. Technological innovations of the quality assessment process are the introduction of various approaches and subjects of such monitoring:

- internal quality monitoring: by the HEI through the introduction of an internal quality control system and the creation of specialized units; on the part of recipients of education through surveys, questionnaires, rating systems for the activities of research and teaching staff;

- external monitoring - creation of associations of university graduates and receiving feedback; survey of employers; involvement of the state in quality assessment

- creation of a specialized body NAHEQA (National Agency for Higher Education Quality Assurance) and conducting certification and licensing procedures.

Quality control is also introduced in relation to the quality of scientific developments, works within the framework of economic contract and state budget topics by checking the principles of academic integrity and detecting plagiarism with the help of specialized computer software.

To ensure the dissemination and quality of innovation, competitions for budget funding for research are introduced; this increases competition in obtaining funding and helps to improve the quality, uniqueness and scientific novelty of research results and R\&D.

\section{Product innovations}


Product innovations of the HEI in the field of educational activity is training of highly qualified specialists in the competence approach, which allows to obtain competencies relevant to the labour market. Such innovation is possible due to the introduction of organizational and technological types of innovations discussed earlier.

Product innovations of HEI of innovative and scientific spheres of activity of the enterprise consist in carrying out scientific developments which have a product (commodity) stage and are high-tech and experimental. To confirm innovation and quality of developments, product innovations are subject to certification procedures according to the European quality standards.

Effective development of innovative products is possible as a result of the formation of intellectual property centres in the form of technology transfer centres, fables, science parks, etc., which promotes the exchange of knowledge and experience and attracting additional sources of research funding.

\subsection{Concepts and strategies of innovative development of the leading} Ukrainian HEI: experience of realization and methodical maintenance of construction

The system of higher education in Ukraine is characterized by the absence of existing and fully formed innovative universities. The transformation of domestic universities into innovative structures is at an early stage and is a strategic task of most HEI.

To determine the state of implementation of innovative changes in the activities of the HEI of Ukraine and the directions of their scientific and innovative activities, there was conducted the analysis of the development strategies of leading domestic universities for the introduction of innovative changes. 10 leading Ukrainian HEI were selected for the study, among which the best 5 universities were included in the QS World University rating (Taras Shevchenko National University of Kiev[141], N.V. Karazin Kharkiv National University [233], National Technical University of Ukraine "Igor Sikorsky Kyiv Polytechnic Institute" [234], Sumy State University [231] and National Technical University - "Kharkiv Polytechnic Institute" [230]), 3 universities with research status (Lviv Polytechnic National University [229], Ivan Franko National University of Lviv [154], National Economic University named after Vadym Hetman [233]), as well as national universities - Simon Kuznets Kharkiv National University of Economics [228] and Uzhhorod National University [136]. 
The analysis of characteristic features and differences of the strategies / concepts of innovative development of universities was carried out on the basis of the formulated working hypothesis, namely: strategies of innovative-active HEI should be built, firstly, in the context of the specified activities in any field according to the main classification features of innovations. That is, the study of the state of implementation of innovative changes in the practice of leading HEI of Ukraine was carried out according to the proposed approach to classification of innovations into organizational, marketing, technological and product (see Fig. 2.3) and in the "triple helix" model, namely a combination of scientific (acquisition of new knowledge), educational (organization of the educational process) and marketing activities aimed at the commercialization of the developed intellectual resource.

1. Organizational innovations.

The study of the implementation of organizational innovations by domestic HEI on the basis of the analysis of Development Strategies is presented in table 2.5 (Annex A). The analysis of the innovative transformations of organizational type, indicated in the programs in the concepts of development, showed that organizational types of innovative changes are one of the most common in the Ukrainian HEI. Among the organizational innovations of educational direction, the most common are independent development of educational programs in accordance with the trends in the labour market and the interests of stakeholders. The technologies of such innovations are labour market monitoring (Taras Shevchenko National University of Kiev, National Technical University of Ukraine "Igor Sikorsky Kyiv Polytechnic Institute", Ivan Franko National University of Lviv) and opening, by almost all HEI, of promising specialties in demand in the labour market in accordance with current trends in the business environment of economic entities. Most universities are expanding the role of stakeholders in shaping educational programs and involving them in the educational process, helping to train advanced professionals who meet the level of economic and social development. Stakeholders are involved both in the design of educational programs and standards of educational activities (T. Shevchenko NU of Kiev, NTUU KPI, NTU "KhPI", V. Hetman KNEU) and in the direct conduct of educational activities through lectures, round tables, seminars, training centres (I. Franko NU of Lviv, SSU, Lviv Polytechnic National University, S. Kuznets KhNEU). At the same time, the introduction of interdisciplinary training by most universities contributes to the training of highly qualified specialists who will form the productive forces of the region and the country.

Organizational innovations in the scientific aspect of the Ukrainian HEI include the 
involvement of stakeholders in the scientific process, which takes place through cooperation with business in order to identify competitive areas of research, business forums, and perform research on economic contractual relations.

Organizational innovations related to both scientific and innovative activities of the HEI are the development of forms of interaction between the university and business, which is also a mandatory feature of an innovative university and the basis for research and the formation of new knowledge. The most common forms of interaction are research centres and schools (S. Kuznets KhNEU, Lviv Polytechnic National University, NTU "KhPI"), start-ups (Lviv Polytechnic National University, V.N. Karazin KhNU, SHEI Uzhgorod National University ", NTUU KPI). On the basis of such interaction there is both applied development, and creation and the subsequent realization of innovative production which is the result of R\&D. However, none of the Ukrainian HEI at this stage of development has a functioning full-fledged innovation ecosystem, like the world's leading developed universities, which should include a network of innovative enterprises, investors, and innovation centres.

An important activity of innovative universities is the introduction of international cooperation, which is the basis for the country's integration into the global educational and economic space, as well as the international exchange of knowledge and experience. Among the organizational innovations of international orientation, implemented by almost all surveyed HEI, there are the development of curricula and educational process in foreign languages, joint and double degree programs, programs of international academic mobility and internships, participation in international projects (among the most common - Horizon 2020, Erasmus +).

2. Marketing innovations.

Marketing innovations are less developed and widespread among the Ukrainian HEI. The study of the introduction of marketing innovations by domestic HEI on the basis of the analysis of Development Strategies is presented in table 2.6, (Annex A). The most significant are the introduction of new approaches to career guidance work, which is aimed at attracting more talented young people to the number of students and improving the educational process in the HEI. Among the most common forms are: winter and summer schools (T. Shevchenko NU of Kiev, Lviv Polytechnic National University, S. Kuznets KhNEU) and pre-university training centres (SSU, NTU "KhPI", V.N. Karazin KhNU, S. Kuznets KhNEU). Sumy State University has the largest number of marketing innovations, which also provides training for external evaluation and career guidance 
camps, as well as covers scientific activities through cooperation with the Small Academy of Sciences and the introduction of a university centre for scientific and technical creativity of schoolchildren.

Quite common among HEI are marketing innovations in international activities, which consist in joining international organizations and associations, as well as activities to increase positions in international rankings of universities.

Low development of marketing innovations is observed in scientific and innovative activities. Scientific results are disseminated through the participation and organization of scientific and practical conferences, exhibitions, forums, festivals by all universities. Another type of innovative change is the publication of scientific results in the editions that are included into the international databases (Web of Science, SCOPUS), contribute to the international dissemination of knowledge and global recognition of activities.

Among the marketing innovations of innovative activity there are only the promotion of research results in the media and exhibition events (T. Shevchenko NU of Kiev, SSU), competitions of startup projects and business ideas (SSU, Uzhgorod National University). In view of this, in order to ensure innovative development, the Ukrainian universities need to intensify work on marketing research and innovation, which will contribute to the recognition of activities and improve the image of HEI, as well as expanding the base of partners in the business environment.

3. Technological innovations.

Technological innovations are quite common among the Ukrainian HEI, the analysis of which is presented in Table 2.7 (Annex A). In educational activities, all HEI carry out constant work on updating the content of educational programs, giving them signs of innovation, competitiveness, interdisciplinarity in accordance with the update of specialties, which was considered in table 3.4. It is necessary to highlight the introduction of new forms of learning, including blended and distance education, as well as dual learning, which indicates a departure from traditional methods of educational process. But the most significant and widespread innovations of this type are the use of information technology, which corresponds to global trends in the development of IT technologies. Universities have introduced both electronic document management (I. Franko NU of Lviv, NTUU KPI, SSU, NTU “KhPI”, V.N. Karazin KhNU, S. Kuznets KhNEU) and educational platforms, automated training courses and training systems of different types (NTUU KPI, SSU, NTU "KhPI", Lviv Polytechnic National University, S. Kuznets KhNEU, State University 'Uzhhorod National University'). 
Table 2.5

Research of introduction of organizational innovations by domestic HEI on the basis of the analysis of Strategies of development (fragment)

\begin{tabular}{|c|c|c|c|c|c|}
\hline $\begin{array}{l}\text { Kind of innovative } \\
\text { changes }\end{array}$ & I. Franko NU of Lviv & $\begin{array}{c}\text { T. Shevchenko NU } \\
\text { of Kiev }\end{array}$ & NTUU KPI & SSU & NTU "HPI" \\
\hline 1 & 2 & 3 & 4 & 5 & 6 \\
\hline $\begin{array}{l}\text { Internationalization } \\
\text { of educational } \\
\text { activities }\end{array}$ & $\begin{array}{c}\text { Development of } \\
\text { programs with joint } \\
\text { and double diplomas. }\end{array}$ & $\begin{array}{l}\text { Increasing the } \\
\text { number of foreign } \\
\text { partner universities, } \\
\text { "double degree" } \\
\text { programs }\end{array}$ & $\begin{array}{l}\text { Type "Double diploma" } \\
\text { programs with foreign } \\
\text { universities }\end{array}$ & $\begin{array}{l}\text { Double and joint } \\
\text { diploma programs }\end{array}$ & $\begin{array}{l}\text { Creation of joint } \\
\text { educational } \\
\text { programs with } \\
\text { foreign HEI; } \\
\text { compliance of } \\
\text { educational } \\
\text { programs with } \\
\text { international } \\
\text { qualifications } \\
\end{array}$ \\
\hline $\begin{array}{l}\text { Independence in the } \\
\text { organization of the } \\
\text { educational process } \\
\text { taking into account } \\
\text { the needs of the } \\
\text { market and } \\
\text { stakeholders }\end{array}$ & $\begin{array}{l}\text { Compliance of } \\
\text { curricula with the } \\
\text { European and world } \\
\text { standards; } \\
\text { Establishment of the } \\
\text { sociological service of } \\
\text { the University for the } \\
\text { systematic study of } \\
\text { public opinion. }\end{array}$ & $\begin{array}{l}\text { Monitoring the } \\
\text { needs of the labour } \\
\text { market; } \\
\text { Discovery of new } \\
\text { promising scientific } \\
\text { specialties; } \\
\text { taking into account } \\
\text { the needs of the } \\
\text { labour market in } \\
\text { conducting } \\
\text { educational } \\
\text { activities; }\end{array}$ & $\begin{array}{l}\text { Optimization of the list and } \\
\text { content of educational } \\
\text { programs in accordance } \\
\text { with the requirements of } \\
\text { the labour market; } \\
\text { Conduct foresight research } \\
\text { of labour market } \\
\text { development and high-tech } \\
\text { business in the context of } \\
\text { prospects and demand for } \\
\text { specialties and educational } \\
\text { programs of the university }\end{array}$ & $\begin{array}{l}\text { Centre for Adult } \\
\text { Education "Education } \\
\text { for Life", which } \\
\text { implements new } \\
\text { approaches to non- } \\
\text { formal adult education }\end{array}$ & $\begin{array}{l}\text { Discovery of new } \\
\text { specialties in } \\
\text { modern fields of } \\
\text { knowledge; } \\
\text { adaptation of } \\
\text { educational } \\
\text { programs to } \\
\text { professional } \\
\text { standards and } \\
\text { requirements of } \\
\text { employers }\end{array}$ \\
\hline $\begin{array}{l}\text { Participation in the } \\
\text { development of } \\
\text { productive forces of } \\
\text { the industry, region, } \\
\text { country. }\end{array}$ & $\begin{array}{l}\text { Increasing innovation } \\
\text { potential, training of } \\
\text { highly qualified } \\
\text { personnel needed by } \\
\text { society and the state }\end{array}$ & $\begin{array}{l}\text { Ensuring the diverse } \\
\text { development of } \\
\text { students. }\end{array}$ & $\begin{array}{l}\text { Training of highly } \\
\text { qualified employees; } \\
\text { interdisciplinary training }\end{array}$ & $\begin{array}{l}\text { Training of highly } \\
\text { qualified employees; } \\
\text { interdisciplinary training }\end{array}$ & $\begin{array}{l}\text { Compliance of } \\
\text { educational } \\
\text { programs with the } \\
\text { needs of society in } \\
\text { accordance with the } \\
\text { National } \\
\text { Qualifications } \\
\text { Framework }\end{array}$ \\
\hline
\end{tabular}


Continuation of the table 2.5

\begin{tabular}{|c|c|c|c|c|c|}
\hline 1 & 2 & 3 & 4 & 5 & 6 \\
\hline $\begin{array}{l}\text { Foreign language } \\
\text { education }\end{array}$ & $\begin{array}{l}\text { Teaching Master's } \\
\text { Courses and Ph.D. in } \\
\text { English. }\end{array}$ & $\begin{array}{l}\text { Providing teaching of } \\
\text { educational } \\
\text { components and their } \\
\text { blocks in English and } \\
\text { other languages of } \\
\text { the European Union }\end{array}$ & $\begin{array}{l}\text { Providing an increase in the } \\
\text { number of educational } \\
\text { programs with teaching } \\
\text { subjects in English }\end{array}$ & $\begin{array}{l}\text { Opportunity to study in } \\
\text { foreign languages the } \\
\text { disciplines of humanities, } \\
\text { general science and } \\
\text { professional orientation; } \\
\text { expanding cooperation } \\
\text { with the British Council, } \\
\text { the Goethe Institute and } \\
\text { other international } \\
\text { institutions and } \\
\text { organizations to study and } \\
\text { use innovations in foreign } \\
\text { language teaching; } \\
\text { development of the } \\
\text { existing and creation of } \\
\text { new linguistic centres in } \\
\text { English, German, Polish, } \\
\text { French and other foreign } \\
\text { languages. }\end{array}$ & \\
\hline $\begin{array}{l}\text { creation of new } \\
\text { forms of interaction } \\
\text { of the university with } \\
\text { business }\end{array}$ & & & $\begin{array}{l}\text { The «Sikorsky Challenge» } \\
\text { ecosystem organizes the } \\
\text { interaction of four groups of } \\
\text { participants: university } \\
\text { research schools, faculties } \\
\text { and departments, high-tech } \\
\text { companies, investment and } \\
\text { venture funds. } \\
\text { Innovative structures on the } \\
\text { basis of the university } \\
\text { (science park, technology } \\
\text { park, business incubator, } \\
\text { startup school) }\end{array}$ & $\begin{array}{l}\text { Creation of joint } \\
\text { educational-scientific- } \\
\text { production complexes, } \\
\text { common centres, } \\
\text { laboratories with leading } \\
\text { scientific institutions and } \\
\text { companies }\end{array}$ & $\begin{array}{l}\text { Joint research centres } \\
\text { with foreign partners }\end{array}$ \\
\hline
\end{tabular}


Continuation of the table 2.5

\begin{tabular}{|c|c|c|c|c|c|}
\hline 1 & 2 & 3 & 4 & 5 & 6 \\
\hline $\begin{array}{l}\text { involvement of } \\
\text { stakeholders in the } \\
\text { educational process }\end{array}$ & $\begin{array}{l}\text { Involvement of } \\
\text { employers in the } \\
\text { educational process }\end{array}$ & $\begin{array}{l}\text { Involvement of } \\
\text { employers in the } \\
\text { design and evaluation } \\
\text { of learning outcomes; } \\
\text { Active work of public } \\
\text { organizations, } \\
\text { foundations, patrons, } \\
\text { mass media in the } \\
\text { development and } \\
\text { realization of } \\
\text { decisions of } \\
\text { educational and } \\
\text { scientific programs; }\end{array}$ & $\begin{array}{l}\text { Participation of employers } \\
\text { in the development and } \\
\text { implementation of curricula } \\
\text { and programs, } \\
\text { Involvement in the selection } \\
\text { procedure for master's } \\
\text { degree programs, to involve } \\
\text { partner companies in the } \\
\text { selection }\end{array}$ & $\begin{array}{l}\text { Directing the educational } \\
\text { program to the formation } \\
\text { of competencies relevant } \\
\text { to the labour market, by } \\
\text { involving in the formation } \\
\text { of the content of } \\
\text { educational programs and } \\
\text { curricula of expert } \\
\text { councils of employers; } \\
\text { IT training centres of } \\
\text { NetCracker, PortaOne, } \\
\text { MindK, AMS Bridge } \\
\text { successfully operate on } \\
\text { the basis of the university }\end{array}$ & $\begin{array}{l}\text { Involvement of IT } \\
\text { industry specialists } \\
\text { in curriculum } \\
\text { development }\end{array}$ \\
\hline student government & $\begin{array}{l}\text { Strengthening the role } \\
\text { of the University in } \\
\text { society and } \\
\text { development of the } \\
\text { student government }\end{array}$ & $\begin{array}{l}\text { Strengthening the } \\
\text { role of the University } \\
\text { in society and } \\
\text { development of the } \\
\text { student government }\end{array}$ & $\begin{array}{l}\text { Promoting the development } \\
\text { of student government }\end{array}$ & & $\begin{array}{l}\text { Promoting the } \\
\text { development of } \\
\text { student government }\end{array}$ \\
\hline $\begin{array}{l}\text { internships and } \\
\text { academic mobility }\end{array}$ & $\begin{array}{l}\text { Academic mobility of } \\
\text { scientists, teachers and } \\
\text { students; } \\
\text { Outstanding scientists } \\
\text { and personalities are } \\
\text { active participants in the } \\
\text { educational process }\end{array}$ & $\begin{array}{l}\text { Increasing the share } \\
\text { of foreign teachers. }\end{array}$ & $\begin{array}{l}\text { Involvement in academic } \\
\text { programs mobility. } \\
\text { Increasing the number of } \\
\text { University teachers who } \\
\text { teach, including abroad. } \\
\text { Invitation of foreign } \\
\text { specialists to teach } \\
\text { individual courses at the } \\
\text { University }\end{array}$ & $\begin{array}{l}\text { organization of } \\
\text { international academic } \\
\text { mobility programs for } \\
\text { students, graduate } \\
\text { students, and teaching } \\
\text { staff; } \\
\text { additional preparation of } \\
\text { students for participation } \\
\text { in academic mobility } \\
\text { programs (language } \\
\text { training, cross-cultural } \\
\text { adaptation trainings, } \\
\text { information support, etc.); }\end{array}$ & $\begin{array}{l}\text { Promoting academic } \\
\text { mobility and } \\
\text { internships in leading } \\
\text { foreign HEI }\end{array}$ \\
\hline
\end{tabular}


Continuation of the table 2.5

\begin{tabular}{|c|c|c|c|c|c|}
\hline 1 & 2 & 3 & 4 & 5 & 6 \\
\hline International projects & $\begin{array}{l}\text { Development of } \\
\text { international agreements } \\
\text { with effective work } \\
\text { programs. }\end{array}$ & $\begin{array}{l}\text { More active } \\
\text { involvement of } \\
\text { scientific and } \\
\text { scientific-pedagogical } \\
\text { employees of the } \\
\text { University in } \\
\text { participation in } \\
\text { international } \\
\text { competitions under } \\
\text { the programs } \\
\text { HORIZON-2020, } \\
\text { CRDF }\end{array}$ & & $\begin{array}{l}\text { The University is actively } \\
\text { involved in TEMPUS, } \\
\text { Erasmus +, Horizon } 2020 \\
\text { grant projects, OOH, } \\
\text { USAID, DAAD, British } \\
\text { Council programs, } \\
\text { intergovernmental } \\
\text { research projects, grants } \\
\text { from private foundations } \\
\text { and organizations. }\end{array}$ & $\begin{array}{l}\text { Grant projects } \\
\text { Horizon 2020, } \\
\text { STCU, NATO, } \\
\text { CRDF, ERASMUS } \\
+, \text { DAAD }\end{array}$ \\
\hline $\begin{array}{l}\text { Opportunity to } \\
\text { cooperate with } \\
\text { business }\end{array}$ & & $\begin{array}{l}\text { an effective system of } \\
\text { cooperation with } \\
\text { business (Ukrainian } \\
\text { and international } \\
\text { companies) to attract } \\
\text { additional funds for } \\
\text { the development of } \\
\text { the University. }\end{array}$ & $\begin{array}{l}\text { effective links with } \\
\text { high-tech } \\
\text { enterprises and scientific } \\
\text { institutions; } \\
\text { Bringing up to } 80 \% \text { of the } \\
\text { number of graduates, } \\
\text { employed for } \\
\text { specialty }\end{array}$ & $\begin{array}{l}\text { Interaction of scientific and } \\
\text { pedagogical workers with } \\
\text { science-intensive and high- } \\
\text { tech enterprises, } \\
\text { international institutions and } \\
\text { governmental organizations } \\
\text { Most departments have } \\
\text { branches at enterprises } \\
\text { (organizations, institutions) } \\
\text { or located directly on } \\
\text { clinical bases where leading } \\
\text { practitioners are involved in } \\
\text { the educational process, } \\
\text { provide guidance for } \\
\text { student practice, course and } \\
\text { diploma projects, conduct } \\
\text { laboratory Business hub } \\
\text { classes that provide } \\
\text { consulting services for } \\
\text { small and medium } \\
\text { businesses. }\end{array}$ & $\begin{array}{l}\text { Creation of training, } \\
\text { research and } \\
\text { production clusters } \\
\text { to deepen the } \\
\text { connection with the } \\
\text { labour market; } \\
\text { Dual training with IT } \\
\text { companies }\end{array}$ \\
\hline
\end{tabular}


The end of the table 2.5

\begin{tabular}{|c|c|c|c|c|c|}
\hline 1 & 2 & 3 & 4 & 5 & 6 \\
\hline Certification training & & & $\begin{array}{l}\text { improving pedagogical } \\
\text { skills, including the online } \\
\text { platform Professional } \\
\text { Development Endeavors }\end{array}$ & $\begin{array}{l}\text { short-term programs of } \\
\text { advanced training in } \\
\text { various directions,, } \\
\text { educational and } \\
\text { methodical seminars, } \\
\text { seminars-trainings, "round } \\
\text { tables" }\end{array}$ & $\begin{array}{l}\text { "School of Young } \\
\text { Scientists" to } \\
\text { improve the } \\
\text { theoretical, } \\
\text { pedagogical and } \\
\text { methodological } \\
\text { knowledge of } \\
\text { teachers; } \\
\text { methodical schools- } \\
\text { seminars "Modern } \\
\text { pedagogical } \\
\text { technologies in } \\
\text { education" }\end{array}$ \\
\hline $\begin{array}{l}\text { Commercialization of } \\
\text { research results }\end{array}$ & & & & $\begin{array}{l}\text { Improve the system of } \\
\text { commercialization of } \\
\text { intellectual property } \\
\text { rights; } \\
\text { Implement the system } \\
\text { formation of innovative } \\
\text { structures for } \\
\text { commercialization of the } \\
\text { results of applied research } \\
\text { and development (science } \\
\text { and technology parks, } \\
\text { small enterprises such as } \\
\text { spin-offs, engineering } \\
\text { centres, etc.); } \\
\text { concluding dealer } \\
\text { agreements for the } \\
\text { introduction of scientific } \\
\text { and technical products of } \\
\text { the university, in } \\
\text { particular abroad; } \\
\text { sale of licenses for } \\
\text { scientific and technical } \\
\text { products }\end{array}$ & $\begin{array}{l}\text { Establishment of } \\
\text { companies for the } \\
\text { purpose of } \\
\text { commercialization of } \\
\text { intellectual property } \\
\text { rights }\end{array}$ \\
\hline
\end{tabular}


Table 2.6

Research of introduction of marketing innovations by domestic HEI on the basis of the analysis of Strategies of development (fragment)

\begin{tabular}{|c|c|c|c|c|c|}
\hline $\begin{array}{l}\text { Kind of innovative } \\
\text { changes }\end{array}$ & $\begin{array}{l}\text { I. Franko NU of } \\
\text { Lviv }\end{array}$ & T. Shevchenko NU of Kiev & NTUU KPI & SSU & NTU "HPI" \\
\hline $\begin{array}{l}\text { the latest approaches } \\
\text { to career guidance }\end{array}$ & & $\begin{array}{l}\text { Expanding cooperation } \\
\text { with the Small Academy of } \\
\text { Sciences; } \\
\text { Organization and holding } \\
\text { of summer and winter } \\
\text { schools on the basis of the } \\
\text { University for individual } \\
\text { students, other educational } \\
\text { institutions and research } \\
\text { institutions }\end{array}$ & $\begin{array}{l}\text { Expansion of } \\
\text { cooperation with } \\
\text { institutions of secondary } \\
\text { and secondary special } \\
\text { education, the Small } \\
\text { Academy of Sciences; } \\
\text { implementation of the } \\
\text { program of the centre of } \\
\text { professional orientation } \\
\text { of student youth "Future } \\
\text { of Ukraine" (including } \\
\text { the All-Ukrainian } \\
\text { festival engineering } \\
\text { talents "Future of } \\
\text { Ukraine"); faculty of } \\
\text { pre-university training }\end{array}$ & $\begin{array}{l}\text { pre-university education system; } \\
\text { University Centre for Scientific and } \\
\text { Technical Creativity of School Youth, } \\
\text { fruitful cooperation with the Small } \\
\text { Academy of Sciences: scientific work, } \\
\text { sections of the University Centre for } \\
\text { Scientific and Technical Creativity of } \\
\text { School Youth, branches of the Small } \\
\text { Academy of Sciences under the } \\
\text { direction of university staff and } \\
\text { graduate students, sports sections, } \\
\text { creation of specialized trainings, clubs, } \\
\text { preparatory courses, holding university } \\
\text { competitions; } \\
\text { - a regional network of centres for } \\
\text { preparation of youth for external } \\
\text { evaluation (full-time and part-time } \\
\text { preparatory courses, preparation for } \\
\text { external evaluation at centres of } \\
\text { technical creativity of schoolchildren, } \\
\text { distance training courses for external } \\
\text { evaluation, etc.) } \\
\text { - Transformation of the University } \\
\text { Children's Health Centre "Universe" } \\
\text { into a summer camp with the priority } \\
\text { of vocational guidance for high school } \\
\text { students and with summer schools, } \\
\text { thematic changes (teams, groups) of } \\
\text { various directions (IT, robotics, } \\
\text { language component, sports by type, } \\
\text { etc.); }\end{array}$ & $\begin{array}{l}\text { Pre-university } \\
\text { training, }\end{array}$ \\
\hline
\end{tabular}


Continuation of the table 2.6

\begin{tabular}{|c|c|c|c|c|c|}
\hline $\begin{array}{l}\text { Measures to } \\
\text { promote the results } \\
\text { of research }\end{array}$ & & $\begin{array}{l}\text { Promotion of scientific } \\
\text { achievements of the } \\
\text { University through } \\
\text { publications in the media, } \\
\text { participation in regional, } \\
\text { national and international } \\
\text { exhibitions, etc. }\end{array}$ & & $\begin{array}{l}\text { annual holding of all-university } \\
\text { competitions of innovative startup } \\
\text { projects, competitions of NTSA, etc. } \\
\text { for search of new ideas for the } \\
\text { subsequent introduction of the } \\
\text { corresponding scientific and applied } \\
\text { results, development of material and } \\
\text { technical base of researches and } \\
\text { developments; } \\
\text { participation in exhibitions of profile } \\
\text { orientation and thematic investment } \\
\text { forums with presentation of scientific } \\
\text { developments of the university; }\end{array}$ & \\
\hline $\begin{array}{l}\text { scientific } \\
\text { conferences as a } \\
\text { factor in forming a } \\
\text { positive image of the } \\
\text { university. }\end{array}$ & & $\begin{array}{l}\text { Presentation of scientific } \\
\text { achievements of the } \\
\text { University at national and } \\
\text { international scientific, } \\
\text { scientific-practical and } \\
\text { innovative conferences and } \\
\text { exhibitions }\end{array}$ & $\begin{array}{l}\text { Supporting the image of } \\
\text { the university through } \\
\text { the organization and } \\
\text { holding of open events, } \\
\text { representation at } \\
\text { exhibitions, forums, } \\
\text { festivals, etc. }\end{array}$ & $\begin{array}{l}\text { Is an organizer of about } 30 \text { scientific } \\
\text { conferences, some of which host } \\
\text { participants from about } 30 \text { countries, } \\
\text { the materials of three conferences are } \\
\text { indexed by Scopus and / or WoS } \\
\text { databases; }\end{array}$ & $\begin{array}{l}\text { Participation in } \\
\text { scientific and } \\
\text { practical } \\
\text { conferences, } \\
\text { seminars, exhibitions }\end{array}$ \\
\hline $\begin{array}{l}\text { World recognition } \\
\text { of activity }\end{array}$ & $\begin{array}{l}\text { Entry of scientific } \\
\text { publications and } \\
\text { publications into the } \\
\text { world rating systems } \\
\text { and databases. }\end{array}$ & $\begin{array}{l}\text { Continuous monitoring of } \\
\text { the publication of articles } \\
\text { in professional journals } \\
\text { included in the } \\
\text { international databases } \\
\text { (Web of Science, } \\
\text { SCOPUS). }\end{array}$ & $\begin{array}{l}\text { Deepen international } \\
\text { recognition of the } \\
\text { teachers of the } \\
\text { university, namely } \\
\text { obtaining the status of } \\
\text { "European } \\
\text { lecturer at the } \\
\text { University of } \\
\text { Engineering " } \\
\text { (ING.PAED.IGIP) }\end{array}$ & $\begin{array}{l}\text { Passing international accreditation not } \\
\text { less than by } 10 \% \text { of educational } \\
\text { programs, } \\
\text { thematic accreditation of programs by } \\
\text { relevant professional international } \\
\text { institutions (ACCA, International } \\
\text { passport of an engineer, International } \\
\text { e-leaning mark in the field of e- } \\
\text { learning, etc.) and international } \\
\text { accreditation of training programs for } \\
\text { doctors of philosophy } \\
\text { positioning in the group of leaders of } \\
\text { the Ukrainian higher education } \\
\text { according to the international ratings } \\
\text { Webometrics Ranking of World } \\
\text { Universities and uniRank University } \\
\text { Ranking }\end{array}$ & \\
\hline
\end{tabular}


The end of the table 2.6

\begin{tabular}{|c|c|c|c|c|c|}
\hline $\begin{array}{l}\text { International } \\
\text { recognition through } \\
\text { participation in } \\
\text { organizations, } \\
\text { associations, ratings }\end{array}$ & $\begin{array}{l}\text { Promotion of the } \\
\text { University brand } \\
\text { through } \\
\text { participation in the } \\
\text { international } \\
\text { scientific and } \\
\text { educational } \\
\text { organizations; } \\
\text { Increasing } \\
\text { positions in the } \\
\text { leading world } \\
\text { rankings }\end{array}$ & $\begin{array}{l}\text { Intensification of the } \\
\text { University's } \\
\text { participation in } \\
\text { international and } \\
\text { European associations } \\
\text { of research universities } \\
\text { and in the Grand } \\
\text { Charter of Universities }\end{array}$ & $\begin{array}{l}\text { KPI participation in } \\
\text { world university } \\
\text { ratings } \\
\text { Become one of the } \\
450 \text { leading } \\
\text { universities in the } \\
\text { world in the QS rating } \\
\text { system }\end{array}$ & & $\begin{array}{l}\text { Webometrics Ranking } \\
\text { of World Universities } \\
\text { - 8th place in Ukraine; } \\
\text { QS World Universities } \\
\text { Ranking - 701-750 } \\
\text { place, 4th place } \\
\text { among Ukrainian HEI; } \\
\text { Included in the catalog } \\
\text { of the best universities } \\
\text { in the world from the } \\
\text { ratings of THE WUR } \\
\text { and U-multirank }\end{array}$ \\
\hline $\begin{array}{l}\text { Advertising } \\
\text { activities }\end{array}$ & & $\begin{array}{l}\text { programs of PR- } \\
\text { events, production of } \\
\text { promotional materials } \\
\text { and attributes of the } \\
\text { University. }\end{array}$ & & $\begin{array}{l}\text { Information and advertising activities of the } \\
\text { university are implemented by the Centre for } \\
\text { Media Communications and Advertising. Press } \\
\text { Centre, Brand Management and Media Content } \\
\text { Production Group, Computer Design } \\
\text { Technologies Group, Media Broadcasting Centre, } \\
\text { Studio16x9 Student Media Agency, Department } \\
\text { of Journalism and Philology, Resonance } \\
\text { University Newspaper. The "visibility" of the } \\
\text { university in the media space is growing, } \\
\text { including through the production of its own media } \\
\text { content. } \\
\text { Establishment of SSU Media Holding as a } \\
\text { structure that unites and coordinates the activities } \\
\text { of the Press Centre, the Centre for Media } \\
\text { Communications and Advertising, the group for } \\
\text { brand management and production of media } \\
\text { content, the Centre for Media Broadcasts, the } \\
\text { Student Media Agency Studio16x9, relevant IT } \\
\text { departments line studios and TV-studios- } \\
\text { production, video broadcasting systems, Internet } \\
\text { TV and radio broadcasting, publishing houses, } \\
\text { other departments of the university, purely student } \\
\text { media. This includes the implementation of } \\
\text { projects "SSU Television", "Campus - Radio } \\
\text { SSU", the reorganization of the university } \\
\text { newspaper. }\end{array}$ & \\
\hline
\end{tabular}


Table 2.7

Research of introduction of technological innovations by domestic HEI on the basis of the analysis of the Strategies of development (fragment)

\begin{tabular}{|c|c|c|c|c|c|}
\hline $\begin{array}{l}\text { Kind of innovative } \\
\text { changes }\end{array}$ & I. Franko NU of Lviv & $\begin{array}{l}\text { T. Shevchenko NU of } \\
\text { Kiev }\end{array}$ & NTUU KPI & SSU & NTU "HPI" \\
\hline 1 & 2 & 3 & 4 & 5 & 6 \\
\hline $\begin{array}{l}\text { Organization of } \\
\text { educational space }\end{array}$ & $\begin{array}{l}\text { Development and } \\
\text { implementation of } \\
\text { training programs that } \\
\text { are flexible to market } \\
\text { requirements }\end{array}$ & $\begin{array}{l}\text { Development and } \\
\text { implementation of } \\
\text { training programs that } \\
\text { are flexible to market } \\
\text { requirements }\end{array}$ & $\begin{array}{l}\text { Interdisciplinary educational } \\
\text { programs based on the } \\
\text { introduction of flexible training } \\
\text { programs, } \\
\text { development of new training } \\
\text { courses based on results research } \\
\text { work }\end{array}$ & $\begin{array}{l}\text { Integration of educational and } \\
\text { scientific activities through } \\
\text { increasing the role of the research } \\
\text { component in master's educational } \\
\text { programs with the mandatory } \\
\text { allocation of educational components } \\
\text { that provide both the development of } \\
\text { general research competencies, skills } \\
\text { and abilities of interdisciplinary } \\
\text { teamwork; and research } \\
\text { competencies in the relevant } \\
\text { specialty }\end{array}$ & $\begin{array}{l}\text { Constant updating } \\
\text { of academic } \\
\text { disciplines }\end{array}$ \\
\hline $\begin{array}{l}\text { Information } \\
\text { Technology }\end{array}$ & $\begin{array}{l}\text { Introduction of the } \\
\text { newest information } \\
\text { technologies in all } \\
\text { spheres of activity of } \\
\text { the University } \\
\text { (introduction of } \\
\text { electronic document } \\
\text { circulation, training, } \\
\text { information } \\
\text { management systems } \\
\text { of the University). }\end{array}$ & $\begin{array}{l}\text { Ensuring the } \\
\text { implementation of a } \\
\text { large-scale program of } \\
\text { informatization of the } \\
\text { University in order to } \\
\text { optimally and } \\
\text { effectively organize } \\
\text { educational, scientific, } \\
\text { management activities; } \\
\text { - use of elements of } \\
\text { artificial intelligence } \\
\text { identity }\end{array}$ & $\begin{array}{l}\text { Create a digital learning } \\
\text { environment } \\
\text { Integration of information and } \\
\text { computing resources of university } \\
\text { departments on the basis of KPI } \\
\text { Data Centre. } \\
\text { System of upgrade electronic } \\
\text { document management of the } \\
\text { university with a qualified } \\
\text { electronic signature and control } \\
\text { function of executive discipline } \\
\text { Development of the standard } \\
\text { "Electronic archive of the } \\
\text { university" - Unification of } \\
\text { processes of archiving of electronic } \\
\text { copies of paper documents of the } \\
\text { university }\end{array}$ & $\begin{array}{l}\text { the only integrated information } \\
\text { system (IIS), which forms a modern } \\
\text { telecommunication and information } \\
\text { scientific and educational } \\
\text { environment - "virtual university". } \\
\text { Electronic magazines; } \\
\text { information system of electronic } \\
\text { document management }\end{array}$ & $\begin{array}{l}\text { E-learning } \\
\text { projects: } \\
\text { "E-learning } \\
\text { resources", } \\
\text { "Multimedia } \\
\text { workshop", } \\
\text { "Rapid } \\
\text { educational } \\
\text { assistance", "E- } \\
\text { learning space", }\end{array}$ \\
\hline
\end{tabular}


Continuation of the table 2.7

\begin{tabular}{|c|c|c|c|c|c|}
\hline 1 & 2 & 3 & 4 & 5 & 6 \\
\hline Forms of education & $\begin{array}{l}\text { Innovative } \\
\text { technologies in the } \\
\text { educational process }\end{array}$ & & $\begin{array}{l}\text { Development of the elements of } \\
\text { mixed and remote student } \\
\text { training, reformatting of } \\
100 \% \text { educational disciplines } \\
\text { respectively to the requirements of } \\
\text { mixed and } \\
\text { Remote teaching. } \\
\text { Dual learning }\end{array}$ & $\begin{array}{l}\text { Electronic and distance learning; } \\
\text { definition of the model of blended } \\
\text { learning on a full-time basis as basic, } \\
\text { which corresponds to the modern } \\
\text { trend of "blended education"; } \\
\text { to integrate mass on-line courses, } \\
\text { distance courses, separate modules } \\
\text { and separate components of } \\
\text { educational disciplines into the } \\
\text { educational process; }\end{array}$ & $\begin{array}{l}\text { Dissemination of } \\
\text { blended learning } \\
\text { practices; } \\
\text { Dual learning }\end{array}$ \\
\hline $\begin{array}{l}\text { Creating } \\
\text { educational } \\
\text { platforms }\end{array}$ & 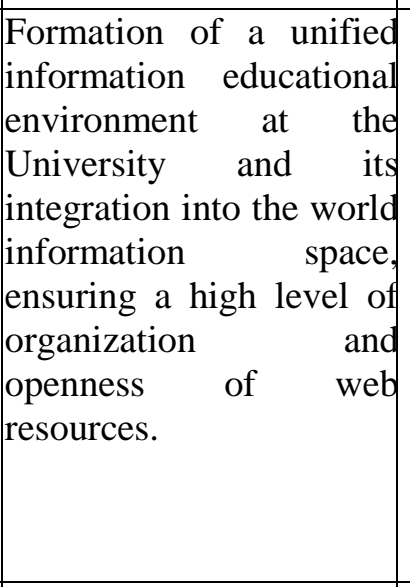 & & $\begin{array}{l}\text { "Electronic campus" - electronic } \\
\text { communication of all participants } \\
\text { of the educational process, } \\
\text { information support of the } \\
\text { educational process; } \\
\text { Providing } 95 \% \text { of academic } \\
\text { disciplines with web resources } \\
\text { (distance courses) for educational } \\
\text { purposes; } \\
\text { system of choice of disciplines; } \\
\text { individual learning trajectories } \\
\text { within the selected educational } \\
\text { program }\end{array}$ & $\begin{array}{l}\text { Automated distance learning } \\
\text { system, consisting of a subsystem } \\
\text { for creating and managing } \\
\text { educational material, a virtual } \\
\text { learning environment and a system } \\
\text { for managing the learning process } \\
\text { through electronic deaneries; } \\
\text { Students' choice of their own } \\
\text { individual learning trajectory; } \\
\text { inclusion in the curriculum of a } \\
\text { wide range of disciplines of free } \\
\text { choice; }\end{array}$ & $\begin{array}{l}\text { Complete e- } \\
\text { learning system, } \\
\text { including } \\
\text { technical, } \\
\text { software, } \\
\text { methodological } \\
\text { and } \\
\text { organizational } \\
\text { support } \\
25 \% \text { - disciplines } \\
\text { of free choice }\end{array}$ \\
\hline $\begin{array}{l}\text { Organization of } \\
\text { quality control of } \\
\text { training }\end{array}$ & $\begin{array}{l}\text { The system of internal } \\
\text { and external evaluation } \\
\text { of the quality of the } \\
\text { educational process. }\end{array}$ & $\begin{array}{l}\text { Collection, analysis and } \\
\text { interpretation of } \\
\text { information on the } \\
\text { quality of education and } \\
\text { teaching, including } \\
\text { surveys of participants } \\
\text { in the educational } \\
\text { process; } \\
\text { External, including } \\
\text { international, } \\
\text { accreditation of } \\
\text { educational programs }\end{array}$ & $\begin{array}{l}\text { Involvement of students in the } \\
\text { discussion of educational } \\
\text { programs, conducting surveys and } \\
\text { taking into account the opinion on } \\
\text { the quality of the educational } \\
\text { process, the system of rating } \\
\text { evaluation of the activities of } \\
\text { scientific and pedagogical } \\
\text { workers; } \\
\text { end-to-end monitoring system and } \\
\text { improving the quality of the } \\
\text { fundamental training: ZNO - }\end{array}$ & $\begin{array}{l}3 \text { levels of quality assurance: } \\
\text { Council for ensuring the quality of } \\
\text { educational activities and the } \\
\text { quality of higher education; } \\
\text { bureau for ensuring the quality of } \\
\text { educational activities and the } \\
\text { quality of higher education } \\
\text { (hereinafter - BEQEA); } \\
\text { laboratory for monitoring the } \\
\text { quality of educational activities; } \\
\text { survey of the entire contingent of } \\
\text { full-time students on the quality of }\end{array}$ & $\begin{array}{l}\text { System of internal } \\
\text { guarantee of } \\
\text { education quality; } \\
\text { Monitoring for } \\
\text { compliance with } \\
\text { licensing and } \\
\text { accreditation } \\
\text { requirements of } \\
\text { the Ministry of } \\
\text { Education and } \\
\text { Science of } \\
\text { Ukraine }\end{array}$ \\
\hline
\end{tabular}


Continuation of the table 2.7

\begin{tabular}{|c|c|c|c|c|c|}
\hline 1 & 2 & 3 & 4 & 5 & 6 \\
\hline & & & $\begin{array}{l}\text { entrance control - semester } \\
\text { certification - rector's control }\end{array}$ & $\begin{array}{l}\text { the organization of educational } \\
\text { activities in the study of academic } \\
\text { disciplines; } \\
\text { ensuring the participation of } \\
\text { employers in the assessment of } \\
\text { general and professional } \\
\text { competencies of graduates }\end{array}$ & \\
\hline $\begin{array}{l}\text { Quality control of } \\
\text { scientific work }\end{array}$ & $\begin{array}{l}\text { Formation of a new } \\
\text { culture of attitude to } \\
\text { intellectual property, } \\
\text { introduction of a } \\
\text { system of plagiarism } \\
\text { prevention at all levels } \\
\text { of the University }\end{array}$ & $\begin{array}{l}\text { Improving the system of } \\
\text { monitoring academic } \\
\text { integrity with the use of } \\
\text { modern information } \\
\text { technologies for } \\
\text { technical verification } \\
\text { and text analysis; }\end{array}$ & & $\begin{array}{l}\text { formation and implementation of the } \\
\text { principles of academic integrity, which } \\
\text { is reflected in the Code of Academic } \\
\text { Integrity, the Code of Corporate } \\
\text { Culture of the University, the } \\
\text { Regulations on Academic Integrity } \\
\text { and Ethics of Academic Relations, the } \\
\text { creation of a group to promote } \\
\text { academic integrity, the University } \\
\text { Commission on Ethics and Conflict } \\
\text { Management. }\end{array}$ & \\
\hline Activity financing & & $\begin{array}{l}\text { cooperation with } \\
\text { business in order to } \\
\text { attract additional funds } \\
\text { for the development of } \\
\text { the University }\end{array}$ & $\begin{array}{l}\text { Reach the level of } 20-25 \% \text { of the } \\
\text { total funds in the structure of the } \\
\text { university budget, received from } \\
\text { foreign economic activity of all } \\
\text { possible sources }\end{array}$ & \begin{tabular}{|l|} 
increase of competitive and grant \\
activity, development of highly \\
intelligent university business; \\
strengthening international grant \\
activities and fundraising as tools \\
for innovative, technological and \\
financial-material support of the \\
university; \\
-increase the share of financial \\
revenues from innovation activities \\
to at least $20 \%$ of the total funding \\
of the university; \\
- attraction of investment sources in \\
the implementation of project \\
activities of the university;
\end{tabular} & $\begin{array}{l}\text { Execution of } \\
\text { R\&D at the } \\
\text { expense of } \\
\text { international } \\
\text { grants; } \\
\text { Provision of paid } \\
\text { services by } \\
\text { scientific and } \\
\text { research } \\
\text { departments of } \\
\text { the university }\end{array}$ \\
\hline
\end{tabular}


The end of the table 2.7

\begin{tabular}{|c|c|c|c|c|c|}
\hline 1 & 2 & 3 & 4 & 5 & 6 \\
\hline Energy efficiency & $\begin{array}{l}\text { Implementation of } \\
\text { energy saving projects }\end{array}$ & $\begin{array}{l}\text { Energy saving program, } \\
\text { costs not less than } 5 \% \\
\text { of the total budget of the } \\
\text { University for the } \\
\text { introduction of energy } \\
\text { saving technologies }\end{array}$ & $\begin{array}{l}\text { Implementation of the University } \\
\text { Energy Efficiency Program; } \\
\text { Reduction of the consumption of } \\
\text { energy resources and water due to } \\
\text { the increase of energy efficiency } \\
\text { of engineering networks and their } \\
\text { equipment, increase of thermal } \\
\text { protection of enclosing designs }\end{array}$ & & \\
\hline Online library & $\begin{array}{l}\text { Electronic library - } \\
\text { resource and } \\
\text { development of own } \\
\text { repository of } \\
\text { publications, its } \\
\text { integration into the } \\
\text { information space of } \\
\text { the city, coutry and the } \\
\text { world }\end{array}$ & $\begin{array}{l}\text { Full-scale digitization of } \\
\text { funds for the use in the } \\
\text { Intranet environment of } \\
\text { the University and } \\
\text { further optimization of } \\
\text { useful areas of the } \\
\text { scientific library }\end{array}$ & $\begin{array}{l}\text { Electronic catalog and image } \\
\text { catalog of NTB printed } \\
\text { publications. } \\
\text { Development of electronic archive } \\
\text { of educational and scientific } \\
\text { materials }\end{array}$ & $\begin{array}{l}\text { OCW SSU and SSU Examiner } \\
\text { project as open electronic resources } \\
\text { of structured collections of } \\
\text { organizational, educational and } \\
\text { methodical materials of disciplines, } \\
\text { organization of Laboratory of data } \\
\text { analysis and digital services to } \\
\text { support qualitative and quantitative } \\
\text { digital research, consulting on } \\
\text { project management (RDM - } \\
\text { Research Data Management), } \\
\text { communication and publication of } \\
\text { research results; }\end{array}$ & \\
\hline
\end{tabular}


Table 2.8

Research of the introduction of product innovations by domestic HEI on the basis of the analysis of Strategies of development (fragment)

\begin{tabular}{|c|c|c|c|c|c|}
\hline $\begin{array}{l}\text { Kind of innovative } \\
\text { changes }\end{array}$ & I. Franko NU of Lviv & $\begin{array}{l}\text { T. Shevchenko NU of } \\
\text { Kiev }\end{array}$ & NTUU KPI & SSU & NTU "HPI" \\
\hline $\begin{array}{l}\text { Formation of } \\
\text { specialists according to } \\
\text { the competence } \\
\text { approach }\end{array}$ & & $\begin{array}{l}\text { introduction of } \\
\text { interdisciplinary } \\
\text { components into } \\
\text { educational programs. }\end{array}$ & & $\begin{array}{l}\text { directing the educational program to the } \\
\text { formation of competencies relevant to } \\
\text { the labour market, by involving in the } \\
\text { formation of the content of educational } \\
\text { programs and curricula of expert } \\
\text { councils of employers; }\end{array}$ & $\begin{array}{l}\text { Training of highly } \\
\text { qualified personnel }\end{array}$ \\
\hline $\begin{array}{l}\text { Carrying out of } \\
\text { scientific } \\
\text { developments which } \\
\text { have a product } \\
\text { (commodity) stage; }\end{array}$ & $\begin{array}{l}\text { Increasing the number of } \\
\text { patented inventions }\end{array}$ & & $\begin{array}{l}\text { Carrying out works in the } \\
\text { fields of nanotechnology, } \\
\text { energy, energy efficiency } \\
\text { of enterprises; }\end{array}$ & $\begin{array}{l}\text { About } 1000 \text { research and development } \\
\text { works are performed annually and } \\
\text { scientific services are provided to order by } \\
\text { more than } 400 \text { enterprises and } \\
\text { organizations of various forms of } \\
\text { ownership. }\end{array}$ & $\begin{array}{l}\text { Production and } \\
\text { implementation of } \\
\text { experimental samples } \\
\text { of new equipment, } \\
\text { technologies; high-tech } \\
\text { products }\end{array}$ \\
\hline $\begin{array}{l}\text { development of } \\
\text { centres, intellectual } \\
\text { property }\end{array}$ & $\begin{array}{l}\text { Scientific investment } \\
\text { projects involving } \\
\text { domestic and foreign } \\
\text { business. }\end{array}$ & $\begin{array}{l}\text { Formation of joint } \\
\text { scientific programs, } \\
\text { consortia for integration of } \\
\text { scientific researches of the } \\
\text { University into the } \\
\text { European and world } \\
\text { research space; } \\
\text { Corporation "Taras } \\
\text { Shevchenko University of } \\
\text { Kyiv Science Park", } \\
\text { further development of } \\
\text { activities on its basis of the } \\
\text { student business incubator. }\end{array}$ & $\begin{array}{l}\text { Innovative ecosystem } \\
\text { "Sikorsky Challenge" } \\
\text { Creation of joint training, } \\
\text { research and production } \\
\text { complexes, common } \\
\text { centres, laboratories with } \\
\text { leading scientific } \\
\text { institutions and companies } \\
\text { Innovative structures on the } \\
\text { basis of the university } \\
\text { (science park, technology } \\
\text { park, business incubator, } \\
\text { startup school); a laboratory } \\
\text { that simulates space } \\
\text { conditions for testing micro- } \\
\text { and nanosatellites; }\end{array}$ & $\begin{array}{l}\text { support of existing and creation of new } \\
\text { educational and training centres in most } \\
\text { specialties, including with educational and } \\
\text { production functions such as translation } \\
\text { centre, training bank, PR agency, } \\
\text { advertising bureau, web design studio, audit } \\
\text { and consulting centre, legal clinic, etc .; } \\
\text { The university has developed scientific } \\
\text { schools that have received recognition for } \\
\text { the world level; in a number of areas } \\
\text { provides full research and production cycle: } \\
\text { basic - applied research - applied } \\
\text { development - prototype - serial production. } \\
\text {-creation of training and production } \\
\text {-associations, basic departments, } \\
\text { laboratories }\end{array}$ & $\begin{array}{l}40 \text { scientific schools } \\
\text { were established; } \\
\text { Joint science parks and } \\
\text { centres with foreign } \\
\text { partners }\end{array}$ \\
\hline $\begin{array}{l}\text { Certification of } \\
\text { acquired knowledge } \\
\text { and scientific products } \\
\text { according to the } \\
\text { European quality } \\
\text { standards }\end{array}$ & & $\begin{array}{l}\text { Implementation of the } \\
\text { European Charter of } \\
\text { Researchers at the } \\
\text { University. }\end{array}$ & & & $\begin{array}{l}\text { Certification of the } \\
\text { quality of educational } \\
\text { services by the } \\
\text { European Organization } \\
\text { for the Evaluation of } \\
\text { the Quality of Higher } \\
\text { Education }\end{array}$ \\
\hline
\end{tabular}


Among the technological innovations that are important in the formation of an innovative type of university, it is necessary to highlight approaches to financing activities. As a result of the analysis of the Strategies, it was revealed that Ukrainian HEI are gradually moving away from the model of financing at the expense of the state budget and funds of individuals. The funding structure includes funds from fundraising (SSU, V.N. Karazin KhNU, Uzhhorod National University), grants (SSU, NTU "KhPI", Lviv Polytechnic National University, V.N. Karazin KhNU, S. Kuznets KhNEU, State University 'Uzhhorod National University'), implementation of innovations and research (SSU, NTU "KhPI", Lviv Polytechnic National University, S. Kuznets KhNEU), which indicates the transition of HEI to the structure of innovative and entrepreneurial type.

The reaction of universities to global trends is also evidenced by the introduction of innovative technologies for energy saving and energy efficiency both to general economic activity (T. Shevchenko NU of Kiev, NTUU KPI, Kyiv National Economic University named after V. Hetman) and to research areas (I. Franko NU of Lviv).

4. Product innovations.

Product innovations in domestic HEI are also not characterized by a wide variety, table 2.8 (Annex B). Such innovations belong to the scientific and innovative spheres of activity and consist in the development of innovations that have a commodity form: patented inventions, experimental samples of new equipment, technologies, high-tech products, implementation of R\&D (I. Franko NU of Lviv, NTUU KPI, SSU, NTU "KhPI", V.N. Karazin KhNU, S. Kuznets KhNEU, State University 'Uzhhorod National University').

Thus, the leading HEI of Ukraine implement innovative changes in their activities, including organizational, marketing, technological and product innovations. However, their development is not at a high level. None of the universities introduces innovations of unique species (technology, product, etc.), and the formation of innovative ecosystems is at an early stage.

All this justifies the relevance of developing methodological approaches to the formation and timely adjustment of the main document of innovative-active activity of the HEI - Strategy of innovative development of the university.

The proposed methodological approach to enhancing the innovative activity of the university is shown in Fig. 2.4. 
The purpose of the proposed approach is to form a strategy, tactics and operational contour of innovative development of HEIs on the basis of decomposition of its activities, development and implementation of proposed innovations, substantiation of appropriate time horizon of innovation implementation and taking into account university resource constraints, business characteristics.

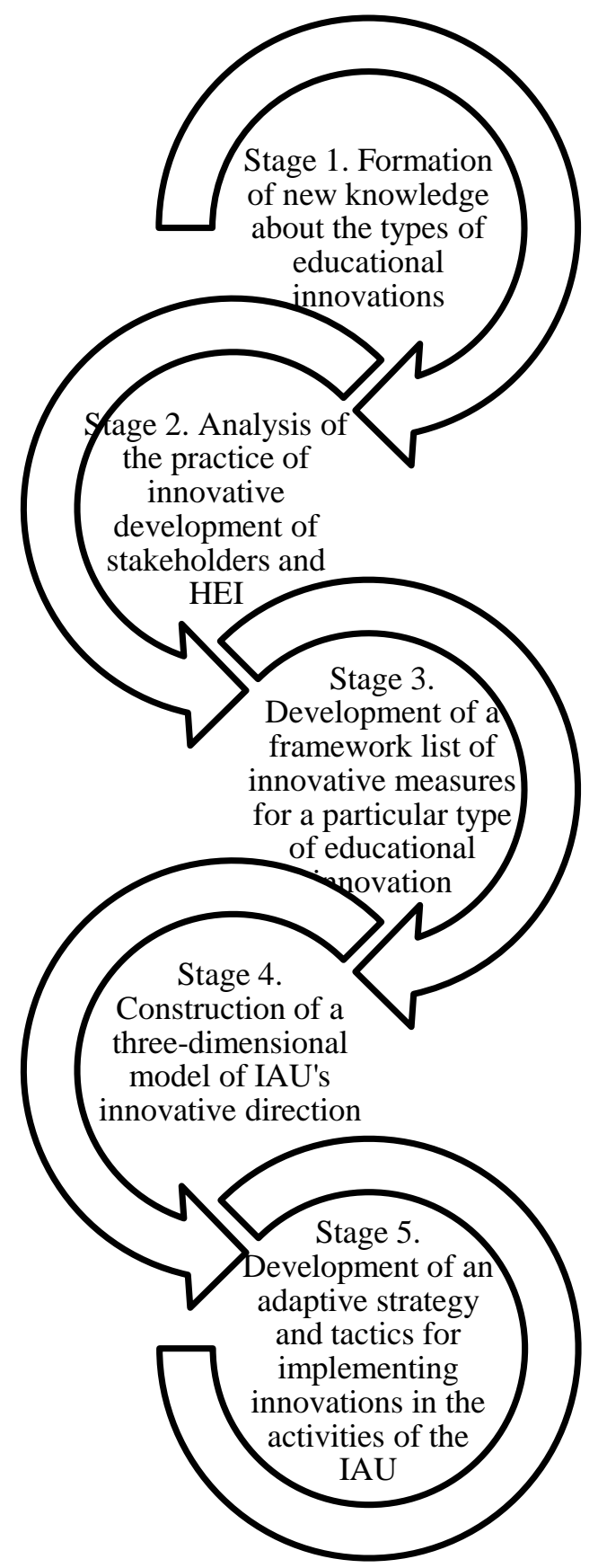

Fig. 2.4. The scheme of the methodical approach of strengthening of innovative activity of a university

To achieve this goal, a list of tasks is formed, the tools for their solution are identified, which are given in table 2.9. 
Table 2.9

\section{Connection of the purpose, tasks, tools of stages of a methodical approach}

\begin{tabular}{|c|c|c|}
\hline Task & Solution tools & Source information \\
\hline \multicolumn{3}{|c|}{$\begin{array}{l}\text { Stage 1. Formation of new knowledge about the types of educational innovations } \\
\text { Objective: to determine the list of educational innovations adequate to the current and future } \\
\text { stages of modernization of the higher education system in the world }\end{array}$} \\
\hline $\begin{array}{l}\text { 1. Analysis of literature sources on } \\
\text { current and future trends in } \\
\text { civilization } \\
\text { 2. Formation of the initial list of } \\
\text { educational innovations } \\
\text { corresponding to the current and } \\
\text { perspective development of a society } \\
\text { and economy }\end{array}$ & $\begin{array}{l}\text { method of logical, } \\
\text { monographic and } \\
\text { morphological } \\
\text { generalization, } \\
\text { comparative analysis }\end{array}$ & $\begin{array}{l}\text { Internet resources, } \\
\text { international and national } \\
\text { information resources, } \\
\text { research of international } \\
\text { non-governmental } \\
\text { organizations (Club of } \\
\text { Rome, Economic Form in } \\
\text { Davos, international } \\
\text { educational organizations) }\end{array}$ \\
\hline \multicolumn{3}{|c|}{$\begin{array}{l}\text { Stage 2. Analysis of the practice of innovative development of stakeholders and HEI } \\
\text { Objective: to form a database of innovation initiatives / activities according to a certain type of } \\
\text { innovation }\end{array}$} \\
\hline $\begin{array}{l}\text { 1. Analysis of innovative } \\
\text { development strategies of leading } \\
\text { foreign and national innovative } \\
\text { universities } \\
\text { 2. Construction of a reference list of } \\
\text { innovative measures at the level of } \\
\text { world and national experience } \\
\text { 2. Analysis of current and future } \\
\text { development needs of the main } \\
\text { stakeholders of the HEI and forms of } \\
\text { interaction with them }\end{array}$ & $\begin{array}{l}\text { method of logical, } \\
\text { monographic and } \\
\text { morphological } \\
\text { generalization, } \\
\text { comparative analysis }\end{array}$ & $\begin{array}{l}\text { Internet resources of the } \\
\text { Ministry of Education and } \\
\text { Science of the countries, } \\
\text { certain HEI, legislative acts } \\
\text { of the countries (National } \\
\text { Doctrines, Strategies of } \\
\text { development of the system } \\
\text { of higher education, sites of } \\
\text { HEI) research of } \\
\text { international supranational } \\
\text { organizations on education, } \\
\text { business, society }\end{array}$ \\
\hline \multicolumn{3}{|c|}{$\begin{array}{l}\text { Stage 3. Development of a framework list of innovative measures for a particular type of } \\
\text { educational innovation } \\
\text { Purpose: Formation of an invariant of innovative measures of a certain type of educational } \\
\text { innovations }\end{array}$} \\
\hline $\begin{array}{l}\text { 1. Construction of an appropriate set } \\
\text { of measures in accordance with a } \\
\text { certain type of innovation } \\
\text { 2. Ranking of innovative measures on } \\
\text { the priority and the possibility of their } \\
\text { application in the practice of a } \\
\text { particular HEI (necessary } \\
\text { stratification of HEI according to } \\
\text { their general orientation) }\end{array}$ & \begin{tabular}{|l} 
generalization method, \\
expert method, \\
method of cognitive \\
modeling, ranking \\
method
\end{tabular} & $\begin{array}{l}\text { The initial set of innovative } \\
\text { measures, } \\
\text { The initial set of types of } \\
\text { educational innovations }\end{array}$ \\
\hline \multicolumn{3}{|c|}{$\begin{array}{l}\text { Stage 4. Construction of a three-dimensional model of IAU's innovative direction } \\
\text { Purpose: to determine the relationship between the types of innovations, types of IAU activities } \\
\text { and its ability to conduct innovation activities }\end{array}$} \\
\hline $\begin{array}{l}\text { 1. Identification of certain activities } \\
\text { of HEI that require the introduction of } \\
\text { innovations } \\
\text { 2. Definition of time horizon } \\
\text { (operational, tactical and strategic) of } \\
\text { the introduction of innovations in a } \\
\text { certain type of activity of HEI }\end{array}$ & $\begin{array}{l}\text { Methods of statistical } \\
\text { analysis, } \\
\text { Methods of process } \\
\text { modeling, }\end{array}$ & \\
\hline
\end{tabular}


The end of the table 2.9

\begin{tabular}{|c|c|c|}
\hline 1 & 2 & 3 \\
\hline $\begin{array}{l}\text { 3. Assessment and forecasting of } \\
\text { resource capacity of implementation } \\
\text { of innovative measures for a certain } \\
\text { type of IAU activity }\end{array}$ & 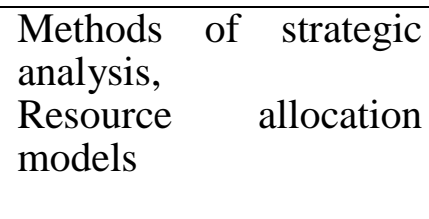 & $\begin{array}{l}\text { HEI Development Strategy, } \\
\text { Statistical reporting of HEI, } \\
\text { Rating of HEI in the national } \\
\text { and international } \\
\text { educational markets }\end{array}$ \\
\hline \multicolumn{3}{|c|}{$\begin{array}{l}\text { Stage 5. Development of an adaptive strategy and tactics for implementing innovations in } \\
\text { the activities of the IAU } \\
\begin{array}{l}\text { Purpose: strengthening the competitive advantages of HEIs on the basis of conducting } \\
\text { innovative and active business activities }\end{array}\end{array}$} \\
\hline $\begin{array}{l}\text { 1. Development of detailed strategies } \\
\text { and tactics for the development of } \\
\text { units that correspond to a certain type } \\
\text { of IAU activity } \\
2 \text {. Formation of a system of key } \\
\text { performance indicators } \\
\text { 3. Development of adaptive strategy } \\
\text { and tactics of IAU development }\end{array}$ & $\begin{array}{l}\text { Methods of strategic } \\
\text { management, } \\
\text { Methods of statistical } \\
\text { analysis, } \\
\text { Modeling methods }\end{array}$ & $\begin{array}{l}\text { HEI Development Strategy, } \\
\text { Statistical reporting of HEI, } \\
\text { Rating of HEI in the national } \\
\text { and international } \\
\text { educational markets }\end{array}$ \\
\hline
\end{tabular}

The proposed methodological approach is a component of the mechanism of construction and operation of innovative-active university which, due to timely implementation of appropriate innovations, will increase the competitiveness of both national HEIs and higher education in general in accordance with the modern paradigm of global higher education to an innovative, entrepreneurial university. The implementation of the approach is planned at the second stage of GDR implementation.

\subsection{Factors of university competitiveness: national experience}

The processes of transformation of HEI from traditional to a new type of universities involves the implementation and introduction of a set of innovations (product, technological, organizational and marketing). Future-oriented innovations aimed at ensuring the progressive development of HEI are a component of the competitiveness of universities. In addition, educational institutions that pay attention to innovation are able to adapt more quickly to changes in the external environment, which also creates additional competitive advantages.

An innovative university should be characterized by leading technologies not only in education and science, but also in other areas, so the introduction of reform changes and innovations is necessary from the standpoint of all previously discussed 
areas of activity, namely: educational, research, marketing, informationcommunication, international and organizational.

The introduction of innovative changes in the activities of the HEI of Ukraine is an investment in strengthening the competitiveness of national universities not only in domestic markets but also in the international educational space. To determine potential and promising areas for further development, it is necessary to assess the current state of the development of domestic HEI and the national higher education system in general and compare it with world indicators. To this end, the study assessed the competitiveness of universities in the context of international comparisons based on global rankings. The information base of the analysis is the components of higher education development and innovation activities of the Global Competitiveness Index rankings according to the methodology of the World Economic Forum and the Global Innovation Index.

According to the World Economic Forum, in 2019, and according to the Global Competitiveness Index, Ukraine ranked only 85th out of 141 countries, ranking between Sri Lanka and Moldova, and lagging behind such countries as Argentina, Macedonia, Albania, Trinidad and Tobago, Jamaica [243]. These data indicate the crisis of Ukraine's economy and its low competitiveness in the global economic space. The analysis of the dynamics of Ukraine's position in the competitiveness rating, which is presented in Fig. 3.5, indicates a consistently low position of the domestic economy and the lack of trends for positive change. The highest position of Ukraine for the entire study period was the 68th place in the ranking in 2005, and in recent years Ukraine did not rise above the 81st place in the ranking [244-262].

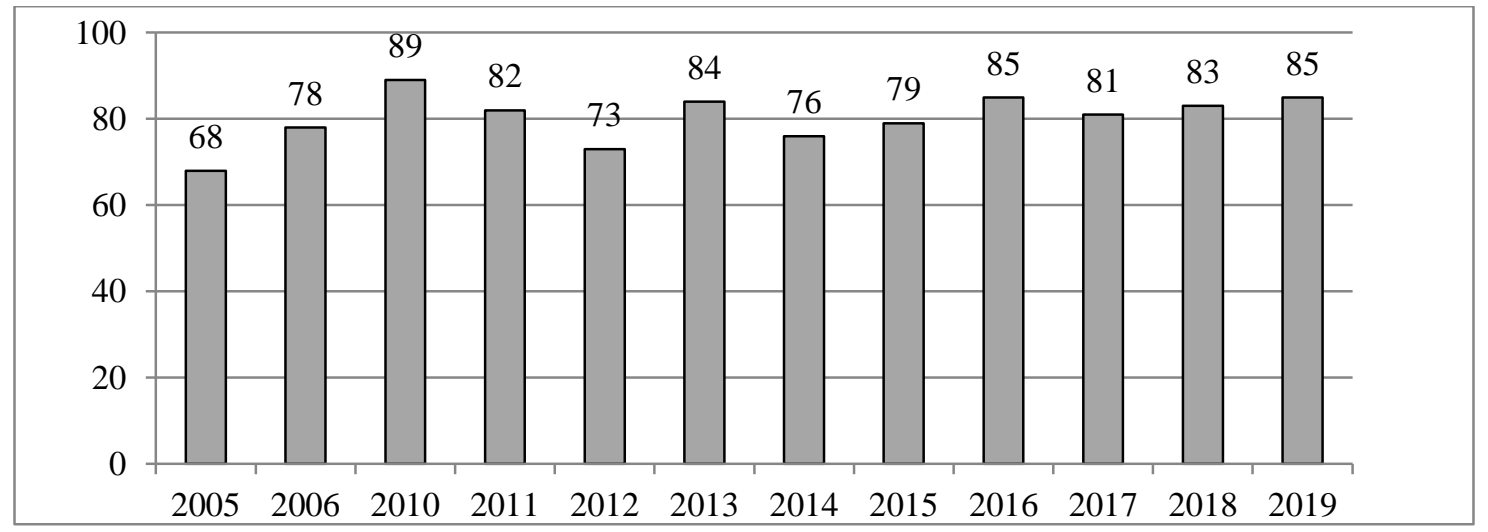

Fig. 2.5. Dynamics of Ukraine's position in the competitiveness rating for 2005-2019 
This state of the country's economy requires finding ways to ensure the economic growth. In the conditions of the formation of knowledge economy, it is necessary to realize cardinal need of social changes in the direction of innovative development. Therefore, the country's innovation capacity (sub-index of the country's competitiveness index) in modern economic conditions takes a leading position among the factors that ensure the process of improving the country's competitiveness, its economic development and achieving higher performance.

According to the World Economic Forum, Ukraine's economy is characterized by a low level of innovation development, which is negatively reflected in the overall level of competitiveness of the country (Fig. 3.6) [241-252].

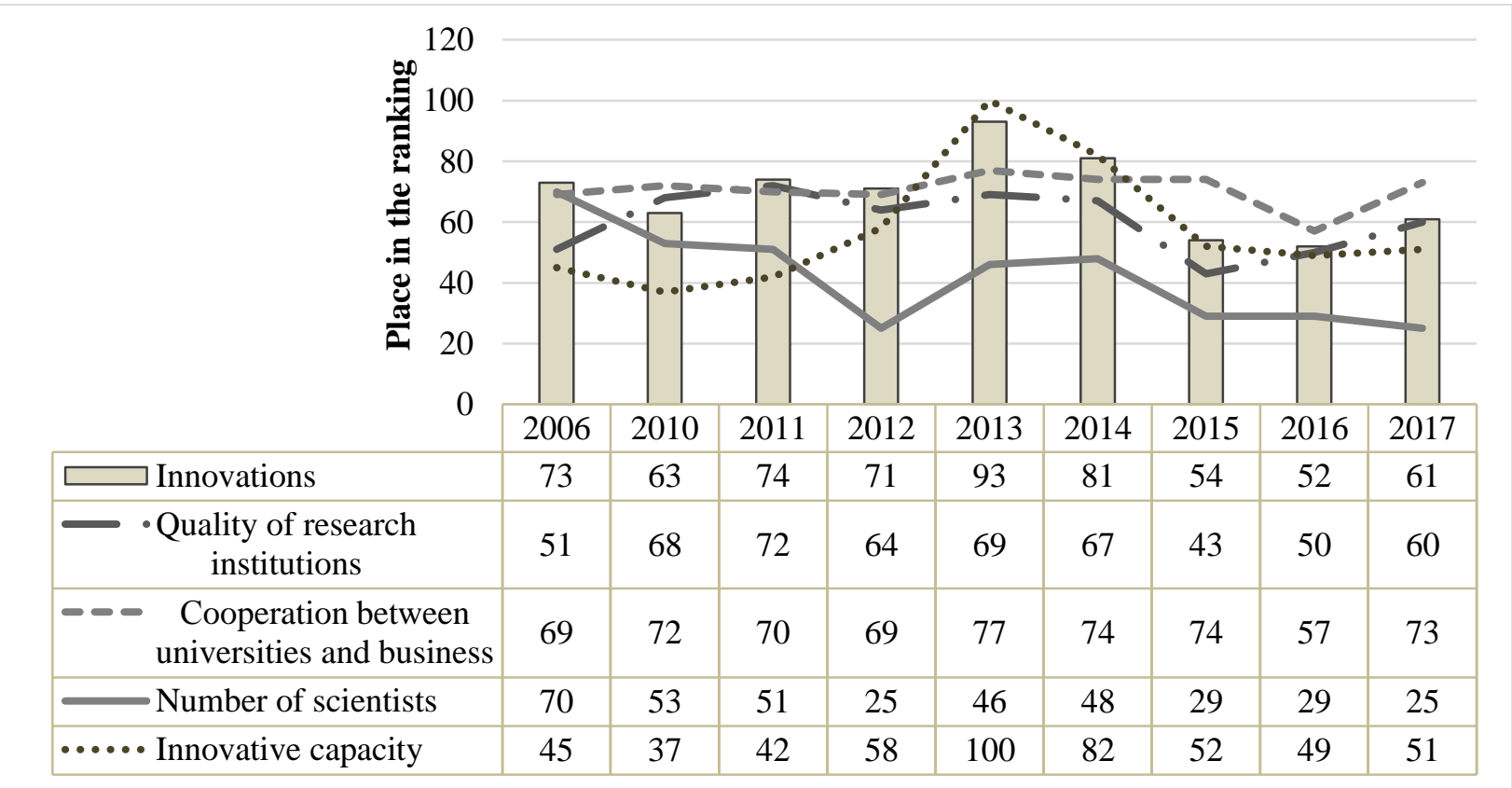

Fig. 2.6. Dynamics of Ukraine's position on the level of development of innovation activity according to the World Economic Forum

It is also possible to analyze the level of innovation development of the country on the basis of the World Intellectual Property Organization according to the Global Innovation Index (GII), which is calculated on the basis of approximately 80 indicators grouped into subgroups according to various aspects of innovation and takes into account such parameters as research, human capital, institutions, infrastructure, business development, knowledge and technology, creativity. According to the World Intellectual Property Organization's innovation ranking, Ukraine ranked the 45th among 131 countries in 2020 (between Thailand and 
Romania, as well as the 30th among 39 European countries) in terms of innovation (Fig. 2.7) [253-262].

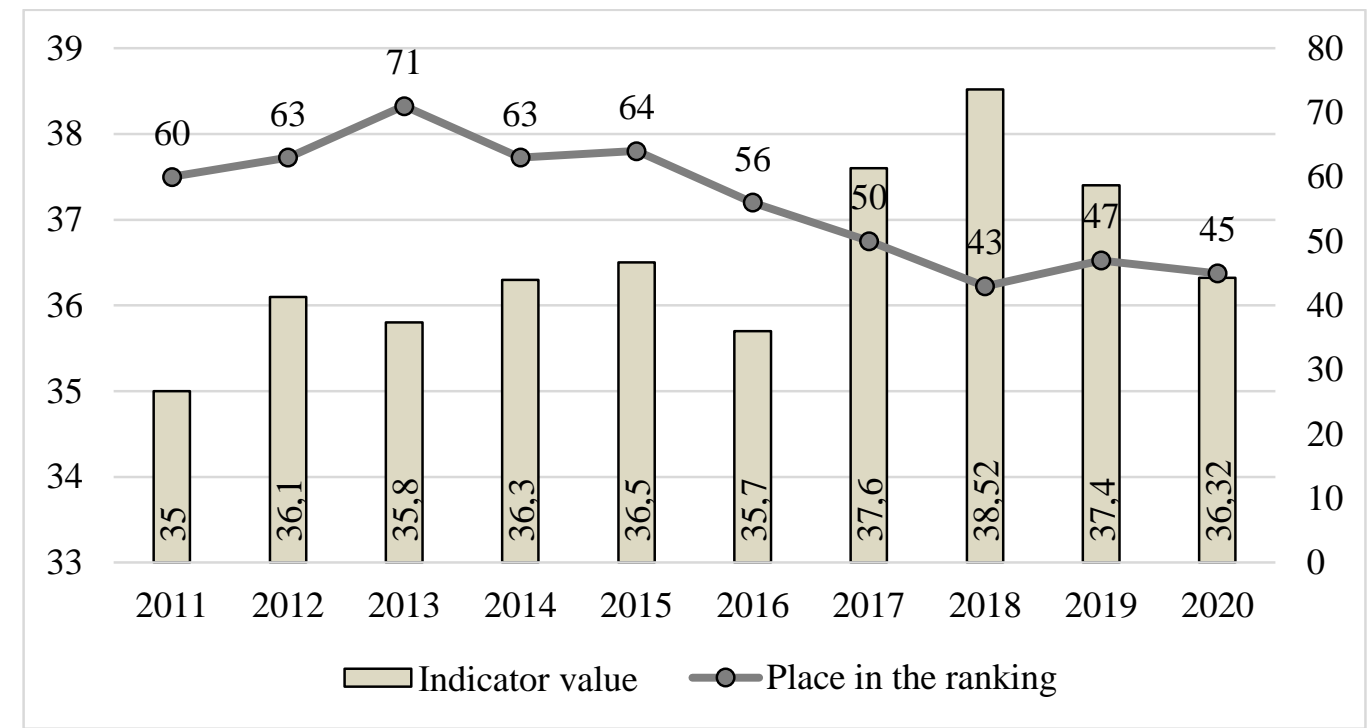

Fig. 2.7. Ukraine's position in the ranking of the World Intellectual Property Organization according to the innovation index

Thus, according to the World Economic Forum and the World Intellectual Property Organization, there is a general positive trend of improving Ukraine's position in terms of innovation, but no significant changes occurred during 20062020. It should be noted that Ukraine has sufficient staff for the development of innovation (the 25th place in the world in the number of scientists in 2017), but unsatisfactory organizational component of innovation, which is reflected in the low quality of research institutions (the 60th place in the ranking) and poor system cooperation in education and business (the 73rd place) needs improvement and reform.

A significant role in the process of ensuring innovation is played by the state of education in the country, especially higher education, which provides staffing and training of intellectual resources, which is the basis for innovation. The quality and state of development of higher education is directly reflected in the level of innovation capacity of the country and has a critical impact on economic development and welfare of the country. According to the ratings of the World Economic Forum [241-252] and the World Intellectual Property Organization [253262] (Fig. 2.8), despite some differences, Ukraine is gradually improving its position in higher education during 2006-2020, and in 2020 it took the 32nd place (out of 131 countries). 


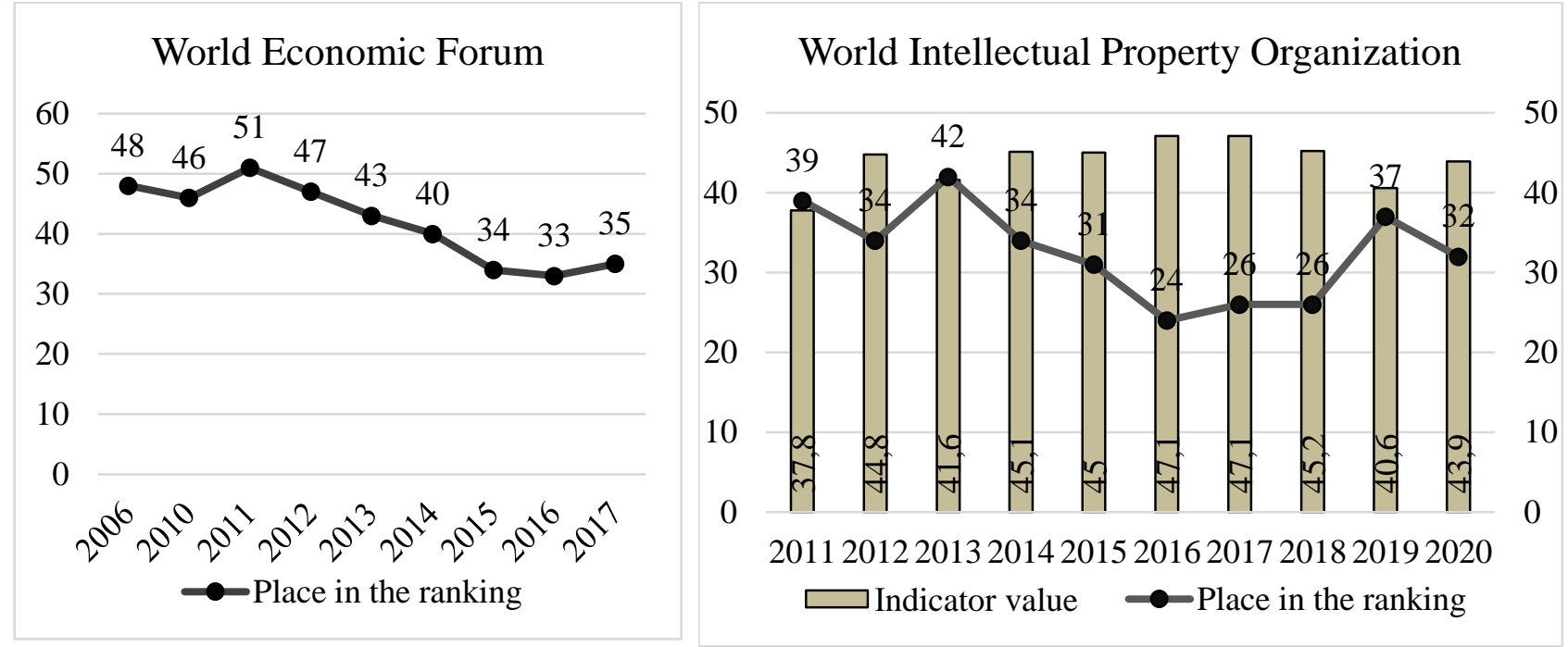

Fig. 2.8. Dynamics of Ukraine's position on the level of development of higher education according to the World Economic Forum and the World Intellectual Property Organization

1. Regarding the components of education systems that are essential for its functioning and evaluation, it is necessary to pay attention to the fact that higher education in Ukraine is widespread, the level of higher education coverage of the traditional official age is consistently one of the highest in the world (Ukraine ranked the 14th in the Global Innovation Index in 2020 with a rate of $82.7 \%$ ); the quantity of graduates in science and technology (the 35th place and 25.3\% in 2020) and the quality of mathematics and science education (the 27th place in 2017), which are key to the development of innovations, and are also at a high level of development (Fig. 2.9 and Fig. 2.10) [253-262].

Level of coverage of higher education

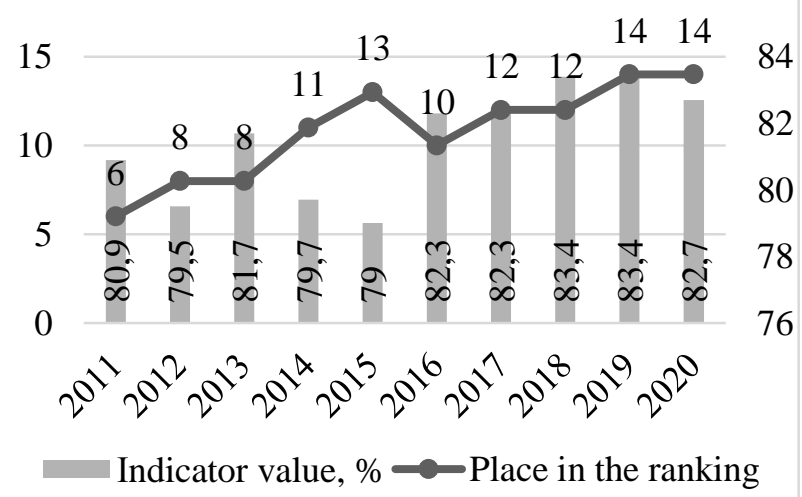

The quantity of graduates in science and technology

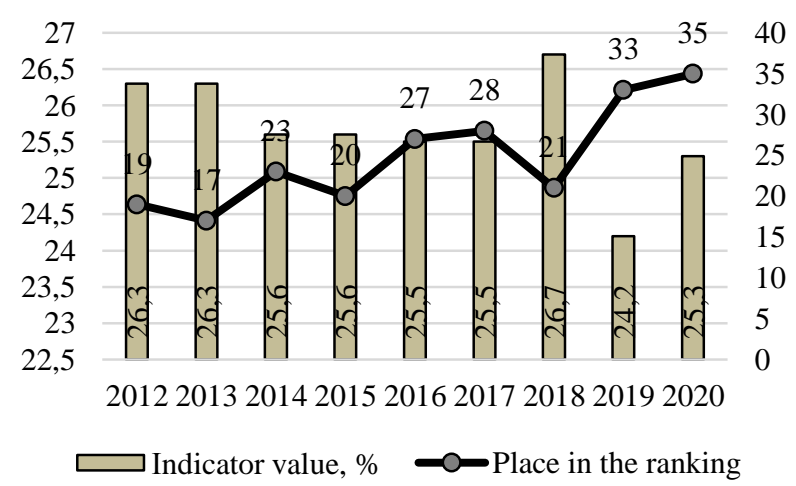

Fig. 2.9. Dynamics of Ukraine's position on the components of higher education according to the World Intellectual Property Organization 
Thus, the quantitative indicators of the higher education system of Ukraine are at a fairly high level. However, the analysis of qualitative indicators reveals problematic aspects of the development of higher education in Ukraine. Thus, in terms of the quality of education, Ukraine ranked only the 56th in 2017 (Fig. 2.10) [242-262], and despite the positive trends in improving this indicator, there was a general deterioration in the quality of domestic higher education compared to 2006.

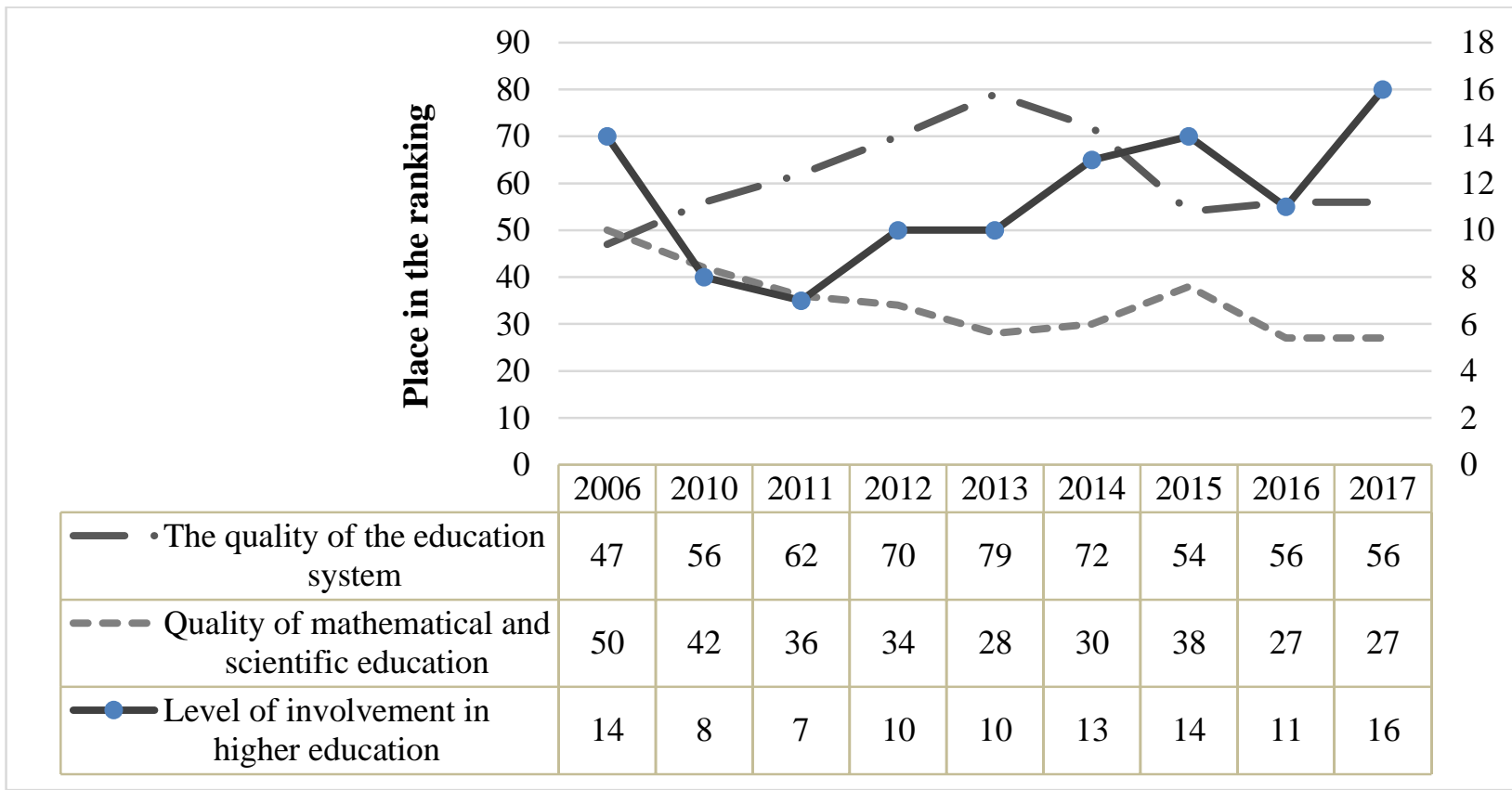

Fig. 2.10. Dynamics of Ukraine's position on the components of higher education according to the World Economic Forum

An integral assessment of the state of development of universities is their positioning in the world rankings, the main of which is QS World University. The estimates of the rating of domestic HEI, which is determined on the basis of places in the ranking of QS World University of the top 3 universities in the country (Fig. 2.11) indicate the low quality of the higher education system of Ukraine. According to this indicator, Ukraine in 2020 ranks 4the 9th among 131 countries, and in recent years there has been a decline in the country's position in the ranking [253-262].

The considered indicators of Ukraine's positioning in the world by the components of higher education testify to the unsatisfactory level of development of the national higher education system and the need to reform it in order to provide higher level educational services and transform the role of universities from the subject of educational services to economic development and ensuring innovation. 


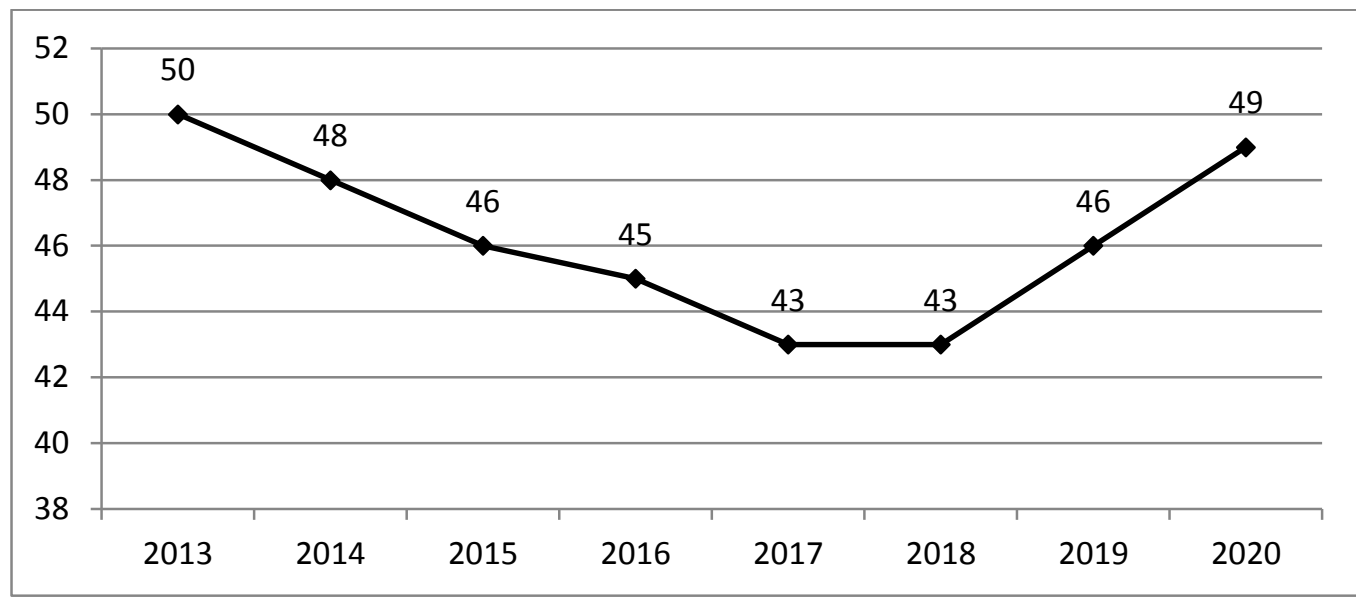

Fig. 2.11. Dynamics of Ukraine's position in the ranking of universities according to the World Intellectual Property Organization

Ukraine's integration into the world educational and scientific space requires compliance of national universities with the European and world requirements, and its success depends on the level of competitiveness of domestic HEIs in both internal and external educational space. According to the rating data, HEI are significantly lower in all respects and are currently almost uncompetitive compared to the world's leading universities. In this regard, the question arises of finding factors to ensure the competitiveness of the Ukrainian universities and the choice of development strategies to improve the efficiency of the national HEI.

Factors in the competitiveness of the Ukrainian universities are certain aspects of activity and elements of the internal and external environment that cause changes in the quality of the functioning of HEI, the growth of activity indicators and ensure the emergence or improvement of competitive advantages.

With the development of market relations and the strengthening of the role of innovative transformations in the process of ensuring the success of the HEI, many factors of achieving competitive advantage, which play a decisive role in the activities of universities, are expanding.

In order to form a system of factors of competitiveness of the national HEI and their analysis, it is proposed to group them according to the following main classification features:

1) the ability to adaptively respond to the manifestation of external challenges of any level by producing certain types of innovations;

2) the ability to implement innovative changes in all activities.

Such grouping will allow to define drivers of the transformational changes of HEI for achievement by them of signs of IAU or improvement of strategic positions 
of the formed domestic IAU.

The main groups of factors for the competitiveness of innovative universities include factors to ensure the adaptability of HEI to changes in the environment (staffing of innovative developments, legislation on the possibility of transition to transformation processes, etc.) and the possibility of introducing innovative changes in HEI (sufficiency of financial resources for innovative implementations, flexibility of the organizational structure and others).

Factors influencing the dynamics of the competitiveness of HEI can be structured by the carriers of their manifestation. Such media include both specific institutions and individual entities. This approach allows us to consider the subjectobject approach in the formation of communicative relations of HEI with the external environment and to position HEI in the educational space at both national and international levels. An example of structuring external factors of influence from the standpoint of the subjectivity of the carriers of the manifestation of the action of these factors is given in Fig. 2.12.

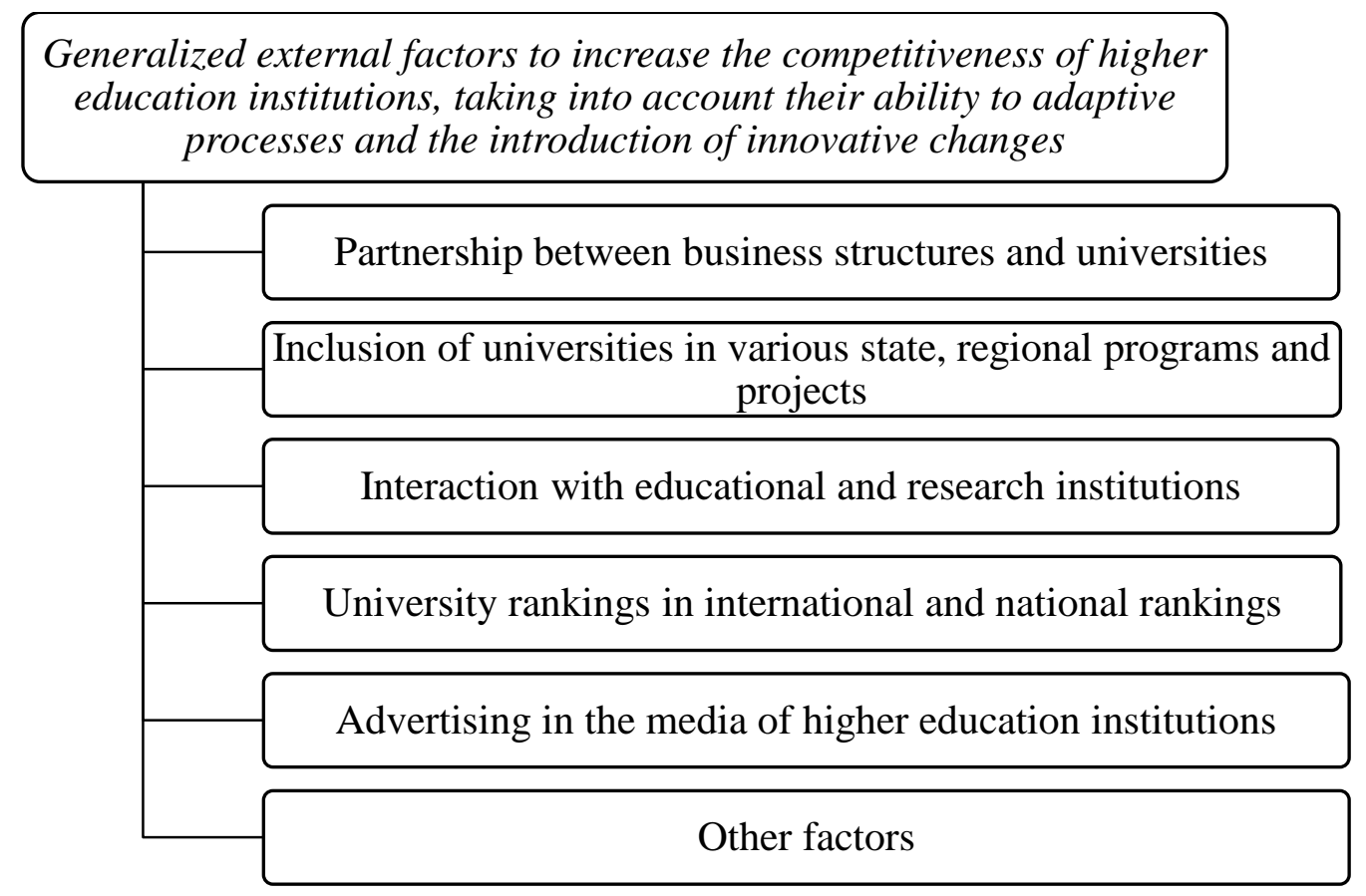

Fig. 2.12. The main external factors that contribute to increasing the competitiveness of HEI [185]

In addition, in order to more accurately identify the ways to develop competitiveness, a classification of factors should be made in terms of activities of innovative universities, namely:

- educational activities - factors to improve the quality of educational services 
through curricula, educational process and teaching staff;

- research - factors influencing the processes of R \& D;

- marketing - factors of opportunities to promote educational, scientific, consulting and other services of the university and ensuring the positioning of the university in the educational environment;

- information and communication - factors of ensuring the social and humanitarian activities of the HEI;

- international - factors in the development of international cooperation and the university's entry into the global educational and scientific space;

- organizational activities - factors influencing the organizational structure and infrastructure of the university.

To analyze the factors that increase the competitiveness of HEI, we will also divide their sets according to the direction of influence, namely external and internal. This division is fundamental, because it determines the strategies and opportunities for further development of the university. Internal factors can be represented as reserves of the development, which fully depend on the level of development and management of the university. In contrast, external factors not only do not depend on the actions of HEI, but, on the contrary, influence the choice of their vector of development, operational decisions and the possibility of introducing innovative changes, i.e. act as a system of restrictions on innovative-active HEI. External factors can be both stimulating and deterrent; in the latter case, there are external threats that require the accumulation of internal development opportunities to support activities.

In addition, the internal factors of ensuring the competitiveness of universities in general have a socio-humanitarian, managerial, resource, educational, scientific and communicative nature. External factors can be economic in nature, political, socio-cultural and partnership in nature. The distribution of factors by their nature is common both to the activities of the university and to ensure adaptability and innovation (for example, resource factors determine the ability to adapt to external changes and implement innovative changes; in addition, such factors are fundamental for all areas of activity of the university).

Thus, the division and analysis of the factors of competitiveness of HEI is possible on the basis of a 4-level model based on the considered main classification features:

Level 1 - classification on the basis of innovative HEI;

Level 2 - classification by the types of HEI; 
Level 3 - classification by the direction of influence;

Level 4 - classification by the nature of influence of the factor.

The general approach to the ranking and analysis of the factors of competitiveness of HEI is presented in Fig. 2.13.

Based on the proposed approach, the distribution and coding of the factors of influence is carried out, according to which it is possible to analyze the full range of competitiveness factors on the basis of transitions between classification features.

It should be noted that the list of competitiveness factors depends on the sectoral orientation of the HEI. Factors of competitiveness, even within the same groups, will be different for technical, natural, humanitarian and other specialized HEI. There may be differences in factors within the HEI - in terms of faculties and specialties, so it is necessary to take into account the characteristics of the industry.

\section{Factors of HEI competitiveness}

I. Classification on the basis of innovative HEI:

1. Factors of adaptability;

2. Factors of innovation

II. Classification by the type of activity of HEI:

1. Educational activities; 4. Information-communication;

2. Research activities; 5. International;

3. Marketing activities; 6. Organizational;

1. Internal factors;

III. Classification by the direction of influence:

2. External factors;

IV. Classification by the nature of influence of the factor:

1. socio-humanitarian, 7. economic,

2. managerial,

8. political

3. resource,

9. sociocultural

4. educational

10. partner

5. наукові

6 комунікативні;

2. Зовнішні фактори;

Fig. 2.13. Methodical approach to ranking of HEI competitiveness factors 
Factors of HEI competitiveness

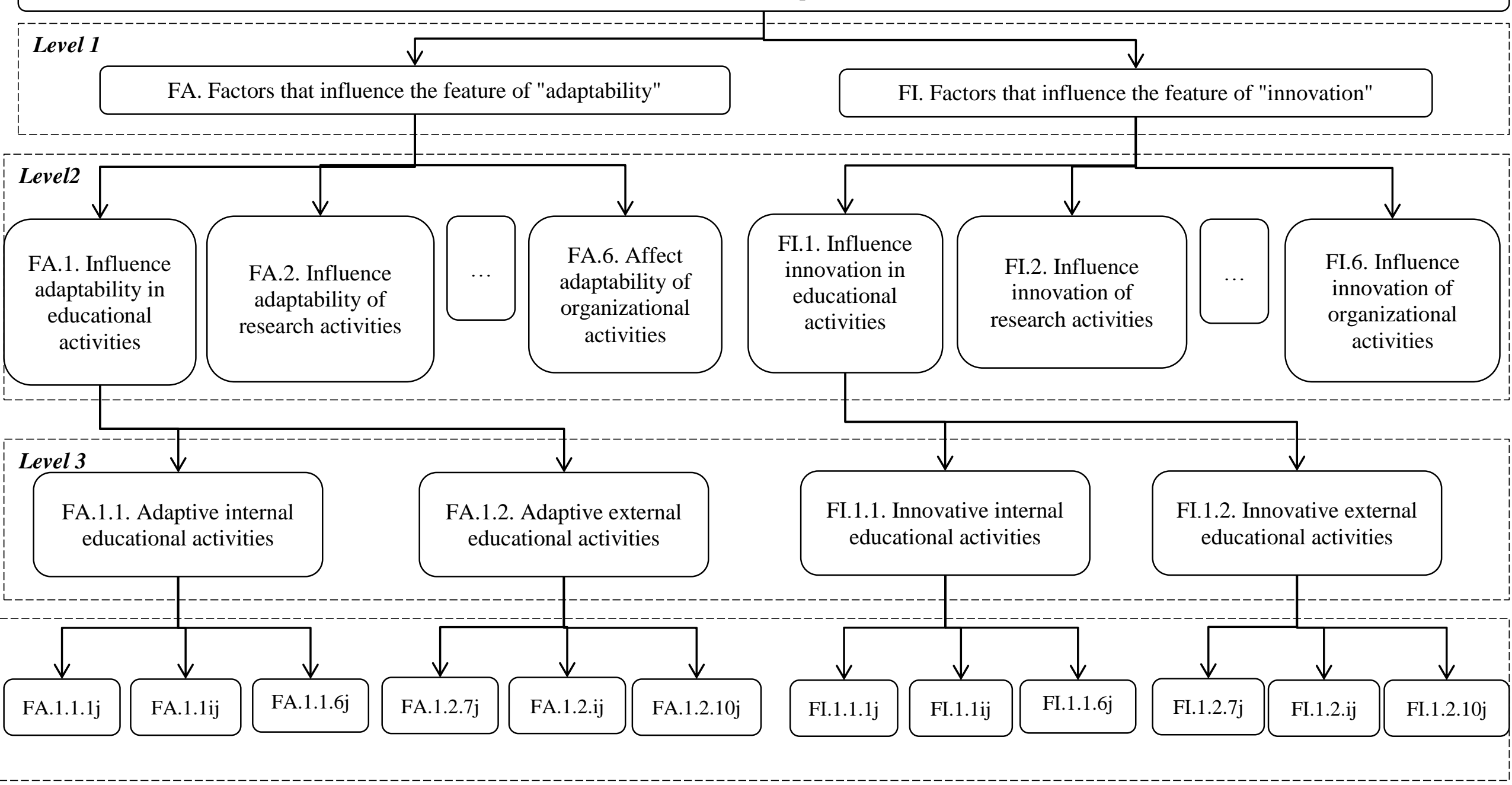

$i \in 1 \ldots 10$ - the nature of the impact

$\mathrm{j} \in 1 \ldots \mathrm{n}-\mathrm{HEI}$ branch of specialization

Fig. 2.14. Approach to the analysis of groups of factors of competitiveness of universities 
A fragment of the approach to the analysis of the groups of factors of competitiveness of universities is presented in Fig. 2.14.

Let's consider in more detail the groups of factors that determine the development of the competitiveness of HEI.

Social-humanitarian factors include developmental factors related to the capabilities, knowledge and personal qualities of all participants in the educational and scientific process (students, teachers, researchers). One of the main factors of this group is the scientific-educational potential and talent of the staff, which is determined by the quality of student training, quality teaching staff, creativity and ability of teachers and researchers to develop and implement innovations, which directly affects the level of innovative development and competitiveness. Determinants in determining the success of HEI are the quality of achievements of teaching staff in professional and research activities, the availability of awards, scientific degree and academic title, experience and ability to teach and research work.

In this group it is also necessary to identify the motivation factor. Motivation of students affects the quality of the educational process, the level of acquired knowledge, recognition of students and the level of their educational component at the national and international levels, which is the basis for the formation of the image of the university. The motivation of teaching and research staff affects both the educational and scientific components of HEI. A high level of motivation ensures the implementation of educational and scientific innovations of a higher level, the maintenance of professional image and the competitiveness of the university staff. The high motivation of the teacher in combination with the motivation of students contribute to the higher involvement of both parties in the educational process and lead to the emergence of better interaction between them with the use of innovative components of education. The personal qualities of the teaching staff, scientific potential and results of researchers are the basis for creating a competitive advantage of HEI as an educational and research organization.

When searching for and analyzing factors influencing competitiveness, it is necessary to consider new types of universities not only as an educational or scientific institution, but as a holistic complex with a scientific and educational mission aimed at forming an innovative, creative and promising society of the new generation. Therefore, the factors of humanitarian orientation are beginning to gain importance, which is to 
ensure equality in all its manifestations from the standpoint of access to educational services and research.

The next generalized group of factors is management factors. It should be noted at once that this group includes factors related to both the management staff and the configuration of the internal organization of HEI. The quality of the management system is manifested in its effectiveness, which consists in the degree of professionalism of decisions, their compliance with existing conditions and the presence of positive consequences of management actions. The effectiveness of the management system lies not only in the practical results of management actions, but also in the formation of a management team that combines the optimal structure of specialists in various fields, integrating into a single team-initiator and coordinator of innovation processes and implementing their results to increase competitiveness.

As for the internal organization of HEI, it is also an element of the management system. The availability of optimal university infrastructure that combines scientific, educational, communication departments and corresponds to modern trends in economic development and public relations directly determines the quality of activities and opportunities to increase competitiveness in the field of innovation. The infrastructure should provide a high level of learning environment for students, combining classroom equipment, providing quality dormitories, access to sports facilities, etc., which in turn will help attract more talented young people to the student membership. The elements of infrastructure development should include not only well-formed units, but also the intangible component of HEI operation, which combines the availability and wellestablished communication channels between departments, teachers and students, the development of information networks and computer systems. This group should also include the introduction of new forms of interaction with business and other organizations to strengthen primarily the scientific and communicative spheres of HEI.

Resource provision is the availability of material and financial resources for all activities of HEI. Despite the prevalence of intangible factors of competitiveness of universities over material ones, resources occupy a leading place in the development process, as they are the basis for R\&D and educational services, attracting professional staff and motivating participants in the educational and scientific process.

Financial resources are more important for achieving competitiveness because the 
transition of an innovative path of development requires significant investments. Funding of the HEI activities is possible on the basis of various sources, including: funding from the state budget, grants, funding under agreements with third-party organizations, student tuition fees. The greater the number of sources of funding and their value (especially other than funding from the budget), the more opportunities for the development of material and technical base and wages are. And this, in turn, generates staff motivation and involvement of leading specialists, as well as increases the quality of research.

The modern material and technical base of the university is of decisive importance first of all for the educational and scientific spheres. Equipping with the latest computer technology, electronic devices, laboratory equipment, classrooms, recreation areas improves the convenience and efficiency of educational activities, ensures the innovativeness of the educational process and its compliance with international standards, quality and reliability of scientific developments which, in turn, affects the attractiveness of HEI in the national educational environment.

Factors of educational competitiveness include the quality of education at HEI. This group includes the availability of educational programs of the latest nature, which are capable of mobility under the influence of changes in the labour market and individual needs of students. It is also important to develop internal standards and procedures for the provision of educational services. In this group, it is important not only to develop the content of programs, but also the ways to convey them to students: introduction of innovative learning technologies, introduction of distance learning and new forms of training.

Factors of scientific competitiveness first of all consist in carrying out the advanced researches directed on the solving actual problems from all spheres of a public life. In addition to the ability to conduct $\mathrm{R} \& \mathrm{D}$, the tendency to implement the results of such research in all areas, of both internal activities of HEI and their commercialization for public use, play a significant role.

Communicative factors are related to the positioning of HEI and its relations with both society and third parties. This group includes the introduction of cooperation with business and other educational institutions. Communicative factors should also include the development of international activities of the university and the internationalization of education, including the education of foreign students; availability of programs of 
academic mobility, internships and international scientific cooperation; participation of students and scientists in projects and programs of international organizations; gained experience of successful international activities in the field of education and science; holding international scientific and practical conferences, seminars, symposia, etc., all of these contribute to the formation of the international image and recognition of the national system of higher education in the world markets of educational services.

External factors influencing the competitiveness of HEI include economic factors, which are primarily related to the level of economic development of the country and are public funding and regulation of the education system; improvement of national methods of rating assessment of activity; establishing a partnership between the authorities and the higher education system; institutional support of the higher education system; this group includes investments from other external sources. One of the main and determining economic factors should be the improvement of regulations on the higher education system, which directly determines the development opportunities and the degree of freedom of decision-making in HEI and should be based on a set of principles, namely: permission of autonomy and self-government of universities; delimitation of rights, powers and responsibilities of the founder (founders), state bodies and local selfgovernment bodies, to the sphere of management to which HEI belongs, governing bodies of HEI and its structural subdivisions; independence from political parties, public and religious organizations (except for higher theological institutions).

Political factors include the country's reputation and authority in the international arena, which directly affects the ability to establish international relations. This group should include domestic political trends, characterized by the general direction of development of the country, the importance of education in this process and the promotion of higher education at the national level. Such nationwide popularization of domestic HEI promotes the development of competitive advantages of the Ukrainian universities primarily in comparison with the foreign HEI and occurs by ensuring public awareness of the country's universities with the involvement of media, Internet resources and modern information technologies, use of advertising products, support of information and analytical portals about the higher education system of Ukraine, etc. The group of political factors includes the state's strategies for the development of international relations. Now the strategy of the European integration is a priority, so the state's support in attracting 
faculty and students from other countries will be a driver of competitiveness in the national and international educational space.

Socio-cultural external factors have become increasingly important in recent years as this group of factors is closely linked to the most pressing issues of today: demographic change, migration, living standards and incomes.

Partner factors are the level of development of HEI's relationship with the environment. This group includes the level of cooperation with business structures, research institutions and other HEIs; participation of the university in various projects, programs, organizations, etc.; advertising and public relations of the university; image, reputation and prestige of HEI; general state of innovative development in the country. Positioning the university in national and international rankings, in turn, also contributes to the formation of a positive image and reputation of HEI. Another factor influencing competitiveness is cooperation with graduates, which is to provide feedback on the quality and compliance of educational services with labour market conditions, promoting and high positioning of HEI, which significantly affects the image of the university.

This group of factors includes the development of international cooperation and international relations of domestic universities, which contribute to strengthening the credibility of national HEIs and improving their position at the international level. The forms of interaction with the environment that positively affect the competitiveness of universities are the accession of the national higher education system to megasystems: the European University Association, the Grand Charter of Universities and the Bologna Process, which is the basis for integration into global and national research-educational space.

Let us consider the factors of competitiveness more specifically, based on the proposed classification features. A fragment of the system of competitiveness factors is presented in table 2.10 .

Let us consider the factors of competitiveness of HEI which affect the ability of universities to adaptive activities and the implementation of innovative transformations in any type of activity of HEI and which are formed according to the hierarchical structure proposed in Fig. 3.10. Their numbering is formed according to the general list:

1 - customer orientation - ensuring the development of international relations and improving the material and technical base (factors of a communicative nature); 
Factors of competitiveness of the Ukrainian universities (fragment)

\begin{tabular}{|c|c|c|c|}
\hline \multicolumn{4}{|r|}{ 1. Factors influencing the feature of "adaptability" } \\
\hline \multirow[t]{8}{*}{1.1.} & \multicolumn{3}{|r|}{ Factors to increase competitiveness in educational adaptability } \\
\hline & 1.1 .1 & \multicolumn{2}{|r|}{ Internal factors for increasing competitiveness in educational adaptability } \\
\hline & & \multirow[t]{2}{*}{ 1.1.1.1 } & $\begin{array}{l}\text { Factors increasing competitiveness in educational adaptability, which are } \\
\text { internal and socio-humanitarian in nature: }\end{array}$ \\
\hline & & & $\begin{array}{l}\text { Experience of teaching staff; } \\
\text { Proportion of teachers with PhD degrees; } \\
\text { The level of motivation of teachers; }\end{array}$ \\
\hline & & \multirow[t]{2}{*}{ 1.1.1.2 } & $\begin{array}{l}\text { Internal factors increasing competitiveness in educational adaptability of } \\
\text { managerial nature: }\end{array}$ \\
\hline & & & $\begin{array}{l}\text { Professionalism of management staff; } \\
\text { Experience in teaching positions of university management staff; } \\
\text { Quality of HEI structuring in accordance with the introduced specialties }\end{array}$ \\
\hline & & \multirow[t]{2}{*}{1.1 .1 .3} & $\begin{array}{l}\text { Internal factors increasing competitiveness in educational adaptability of } \\
\text { resource nature: }\end{array}$ \\
\hline & & & $\begin{array}{l}\text { The amount of public funding; } \\
\text { Cost of education; } \\
\text { The amount of income from tuition fees; } \\
\text { Provision of computer equipment; } \\
\text { Provision of equipment necessary for training; } \\
\text { Availability of free access to the Internet. }\end{array}$ \\
\hline
\end{tabular}

2 - source of financial resources of HEI - mixed financing (factors of resource provision);

3 - innovation and investment potential of HEI - satisfaction of participants in the markets of educational services and labour (factors of resource provision);

4 - strategic management - positioning of integration processes in the market of educational services of HEI (factors of managerial-organizational nature);

5 - labour rationing - stimulating the level of internal labour productivity (factors of resource provision);

6 - internationalization - mobility of students and teachers in international grants and projects (factors of social-humanitarian nature);

7 - monitoring - tracking the complexity of indicators of the level of development 
of HEI (factors of socio-humanitarian nature);

8 - informatization - creation, carrying out, introduction of educational activity concerning the expanded list of specialties and employment of graduates (factors of social-humanitarian character);

9 - quality of training of HEI applicants - compliance with the terms of the license conditions and the image of HEI (educational factors).

The directions of connection of HEI competitiveness factors indicate the dependence of the achievement of one goal (initial) on the achievement of another (final)one. In the first stage, a directed graph between the factors of HEI competitiveness is constructed which is presented in Fig. 2.15.

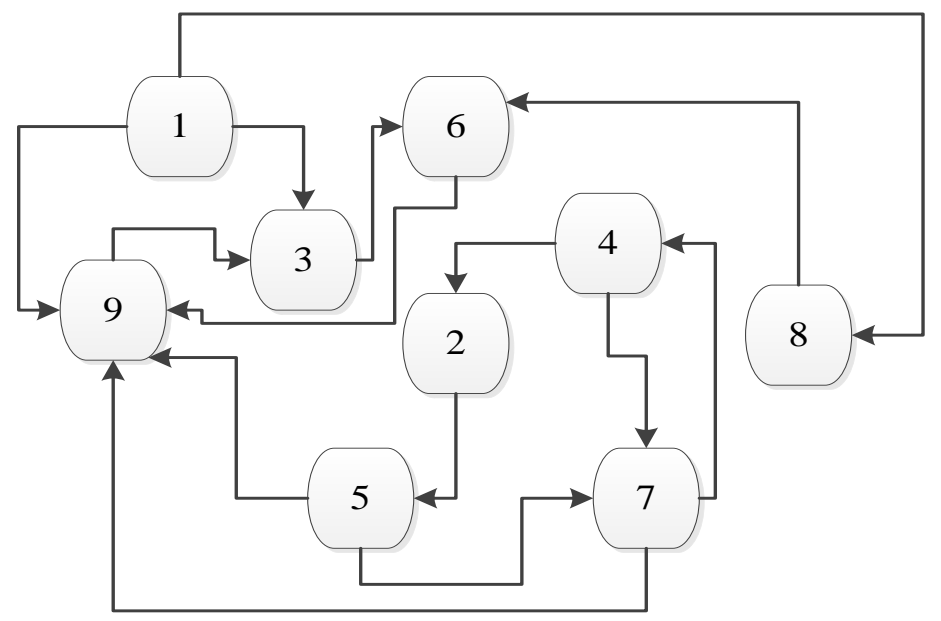

Fig. 2.15. Relationship between HEI competitiveness factors

As a result of the analysis of the directed graph (see Fig. 2.15), the reachability matrix is constructed. Filling the matrix with binary factors of HEI competitiveness is carried out according to the line rule:

$$
d_{i j}=\left\{\begin{array}{c}
1, \text { if from } i \text { it is possible to get to } j \\
0, \text { if not. }
\end{array}\right.
$$

Table 2.11 presents the results of determining the relationship of factors in the choice of areas of competitiveness of HEI, which has the form of a matrix of reach of the directed graph.

Table 2.11 
competitiveness of HEI

\begin{tabular}{|c|l|l|l|l|l|l|l|l|l|l|}
\hline \multicolumn{2}{|c|}{ Factors } & 1 & 2 & 3 & 4 & 5 & 6 & 7 & 8 & 9 \\
\hline 1 & Customer orientation & 1 & 0 & 1 & 0 & 0 & 0 & 0 & 1 & 1 \\
\hline 2 & $\begin{array}{l}\text { Source of financial resources of } \\
\text { HEI }\end{array}$ & 0 & 1 & 0 & 0 & 1 & 0 & 0 & 0 & 0 \\
\hline 3 & $\begin{array}{l}\text { Innovation and investment } \\
\text { potential of HEI }\end{array}$ & 0 & 0 & 1 & 0 & 0 & 1 & 0 & 0 & 1 \\
\hline 4 & Strategic management & 0 & 1 & 0 & 1 & 0 & 0 & 1 & 0 & 0 \\
\hline 5 & Labour rationing & 0 & 0 & 0 & 0 & 1 & 0 & 1 & 0 & 1 \\
\hline 6 & Internationalization & 0 & 0 & 0 & 0 & 0 & 1 & 0 & 0 & 1 \\
\hline 7 & Monitoring & 0 & 0 & 0 & 1 & 0 & 0 & 1 & 0 & 1 \\
\hline 8 & Informatization & 0 & 0 & 0 & 0 & 0 & 1 & 0 & 1 & 0 \\
\hline 9 & $\begin{array}{l}\text { Quality of training of HEI } \\
\text { applicants }\end{array}$ & 0 & 0 & 1 & 0 & 0 & 0 & 0 & 0 & 1 \\
\hline
\end{tabular}

The matrix of reach of the directed graph, presented in Table 2.11, allows us to divide the set of vertices $\mathrm{H}$ into a subset of levels of the hierarchy of factors when choosing the directions of competitiveness of HEI. To this end, all peaks of factors are divided into achievable and previous.

The vertex $h_{-} i$ is called reachable from the vertex $h_{-} j$ if there is a path from $h_{-} j$ to $h \_i$ in the oriented graph. This set is denoted by $R\left(h \_i\right)$. The vertex $h \_j$ is considered preliminary to $h \_i$ if it is possible to achieve $h \_i$ with $h \_j$. This set is denoted by $A\left(h \_i\right)$.

Multiplication of vertices of HEI competitiveness factors

$$
\mathrm{A}\left(h_{i}\right)=R\left(h_{i}\right) \cap A\left(\mathrm{~h}_{\mathrm{i}}\right)
$$

for which the condition of inaccessibility from the remaining vertices of the remaining set $\mathrm{H}$ is fulfilled, and can be denoted as the level of hierarchy. This condition is tested in several iterations by gradually excluding certain higher levels [4].

Determining the levels of the hierarchy of influence is done by checking the fulfillment of condition $(1,2)$, the results of which are given in Table 2.12.

As can be seen from Table 2.12, the criterion equality in the first iteration is performed for factor 1 - customer orientation, which ranks the first in the hierarchy. In the second iteration, the criterion equality is fulfilled for factor 2 - informatization. 
Table 2.12

Determining the levels of the hierarchy of factors in choosing the areas of competitiveness of HEI

\begin{tabular}{|c|c|c|c|}
\hline hi & R(hi) & A(hj) & R(hi)XA(hj) \\
\hline 1 & $1,3,8,9$ & 1 & 1 \\
\hline 2 & 2,5 & 2,4 & 3 \\
\hline 3 & $3,6,9$ & $1,3,9$ & 3 \\
\hline 4 & $2,4,7$ & 4,7 & 3 \\
\hline 5 & $5,7,9$ & 2,5 & 3 \\
\hline 6 & 6,9 & $3,6,8$ & 3 \\
\hline 7 & $4,7,9$ & $4,5,7$ & 4 \\
\hline 8 & 6,8 & 1,8 & 2 \\
\hline 9 & 3,9 & $1,3,5,6,7,9$ & 5 \\
\hline
\end{tabular}

The hierarchy of selection of HEI competitiveness factors is 5-level. The main goal in choosing the factors of competitiveness is the quality of training of HEI applicants.

The next level defines monitoring, i.e. a combination of goals and objectives aimed at forecasting, improving, solving, modeling, analysis, which will serve as a tool in the formation of a comprehensive assessment to improve the competitiveness of HEI.

At the third level there are the following factors: the source of financial resources of HEI; innovation and investment potential of HEI; strategic management; labour rationing; internationalization. Concentration of these factors on one level characterizes a powerful direction of successful development of the directions of improvement of HEI activity.

At the fourth level is informatization, which is an effective tool to ensure the filling of the investment portfolio. Ensuring the increase of HEI prestige, as one of the factors of competitiveness, is possible due to the implementation of financing mechanisms, which depends on the economic development of Ukraine and, thus, the production of quality educational services.

At the highest level of the hierarchy is customer orientation factor, the solution of which is possible with the interaction of all previous factors, which will provide further prospects for the competitiveness of HEI and, thus, meet the needs of the educational services market, which will ensure effective positioning and high competition. 
The study of competitiveness factors uses a problem-oriented approach and identifies 5 levels of available factors established in accordance with the interdependent hierarchical impact, the solution of which will ensure further implementation in the quality of education.

The impact of factors on the competitiveness of HEI involves the formation of conceptual measures aimed at meeting all the needs of consumers of educational services and ensuring continuous innovation development, i.e. achieving the best results as an education market.

Thus, factors influencing the competitiveness of HEI form a system that is characterized by significant internal relationships and synergies. Therefore, the planning of a strategy to increase competitiveness should be based on the comprehensive involvement and influence on the main factors mentioned. In the current conditions and state of development of the national HEIs, more and more attention should be paid to managing their competitiveness, developing action strategies in accordance with the nature of the determinants and areas of activity that require access to a fundamentally better level of development. 


\section{CHAPTER 3. FORMATION OF THE MONITORING SYSTEM AND STRATIFICATION OF THE HIGHER EDUCATION SYSTEM OF UKRAINE AND ITS SUBJECTS}

\subsection{University monitoring and stratification system: methodological basis for construction}

Reforming of the education system in general and higher professional education, in particular, involves constant monitoring of the results of assessing the position of the country's higher education system and HEI in the national and global markets for educational services. This monitoring is especially important in the context of globalization of socio-economic processes; it allows not only to diagnose the peculiarities of the demand for national HEI in the market of educational services, but also to assess the level of competitiveness of higher education and HEI in the international market.

Educational monitoring is aimed at identifying the main factors that shape the attractiveness of higher education and HEI and determine its place in the national and international market of educational services.

Monitoring of educational activities includes control, verification, accounting, evaluation, accumulation of statistical data, their analysis, reflection; identifying the dynamics of educational change and the selection of key players in the market of educational services; changing goals, clarifying educational programs, adjusting the learning process; forecasting further developments.

Objectivity, completeness, systematicity, efficiency and specificity of the obtained results will provide the necessary conditions for the preparation, adoption and implementation of management decisions on the functioning and development of education at all levels.

Monitoring system is the most effective information management system and informed decision-making, which is based on it, in the information economy, when the effectiveness of management of any process depends on reliable, systematic and timely information about the state of the process, its dynamics, objective analysis of such information and forecasting further development.

The general scheme of the monitoring system is shown in Fig. 3.1. 


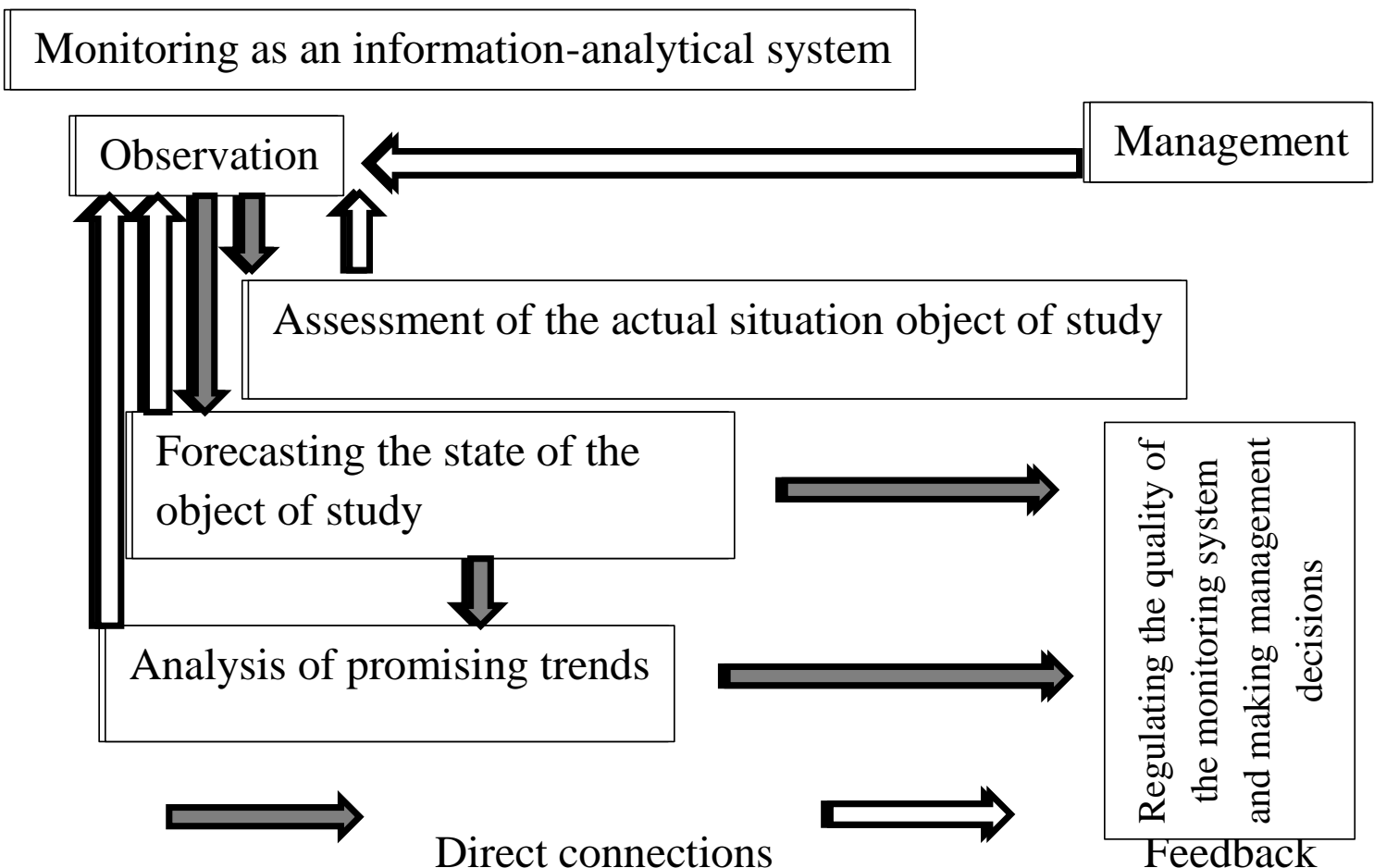

Fig. 3.1. General scheme of the monitoring system

Thus, monitoring acts, on the one hand, as an information-analytical system to perform management functions, and on the other - depends on management. Based on this, monitoring is the basis for the implementation of all management functions, and the monitoring system is the most important attribute of management processes related to solving research problems of a problem, monitoring the state of its development.

A comparative analysis of modern developments [91,67,131,132,194,269,220,221] allowed us to identify three main concepts of forming a monitoring system (Table 3.1).

Table 3.1

\section{Characteristics of concepts of monitoring system formation}

\begin{tabular}{|c|l|}
\hline Concept name & \multicolumn{1}{c|}{ Characteristic } \\
\hline Target & $\begin{array}{l}\text { monitoring system is considered as a problem-oriented system that covers a certain } \\
\text { area of information needs of economists, analysts and practitioners }\end{array}$ \\
\hline Instrumental & $\begin{array}{l}\text { under the monitoring system one means the widespread use of various tools and } \\
\text { methods of collecting and processing information that make up the content of the } \\
\text { database and knowledge base of the system }\end{array}$ \\
\hline Integration & $\begin{array}{l}\text { the monitoring system is considered as a result of regrouping of traditional } \\
\text { information and management functions, which combines elements of socio- } \\
\text { economic statistics, economic analysis and forecasting }\end{array}$ \\
\hline
\end{tabular}


Thus, the system of monitoring and stratification of the Ukrainian universities should be integrated and considered as an information, diagnostic, scientific, prognostic system, the implementation of which is carried out within the management activities of the HEI.

Based on the study of the history of monitoring as a phenomenon and its modern concepts, we can identify the following characteristics that are inherent in monitoring systems (MS):

1) MS is aimed at constant and long-term monitoring of the socio-economic environment;

2) MS includes not only the systematic observation and collection of information about the parameters of socio-economic phenomena and processes, but also the system of evaluation, analysis, forecasting and management decisions;

3) MS has a permanent-contour character, which is an important condition for the effectiveness of its application;

4) in MS the collection of monitoring data is carried out using various methods depending on the studied subsystems;

5) the information received in MS should be a subject to analysis and diagnosis;

6) in MS the monitoring data should be stored for further use in management based on modeling and forecasting of the analyzed situation;

7) MS ensures the effectiveness of monitoring studies through the focus on obtaining adequate and timely information, conducting and using the results of the analysis.

Based on the characteristics of the object of the study, the monitoring system must meet the following principles [88,132] (Fig. 3.2):

1. Purposefulness and integrity. The formation of monitoring system should be purposeful. The goal is the basis of any system, i.e. the system-forming factor. The purposefulness of the monitoring system involves a conscious movement towards a clear and unambiguous goal. It is important to optimally allocate existing resources to ensure the fullest possible achievement of goals. The principle of integrity reveals the inseparability of the triad "management - monitoring - forecasting";

2. Systematic and comprehensive. The monitoring system reflects a systematic approach to solving problems and is a set of subsystems (monitoring at the national and 
international levels), individual elements and relationships between them, which are implemented by solving monitoring problems. Complexity involves the use of a set of monitoring indicators, which comprehensively characterize the object of the study.

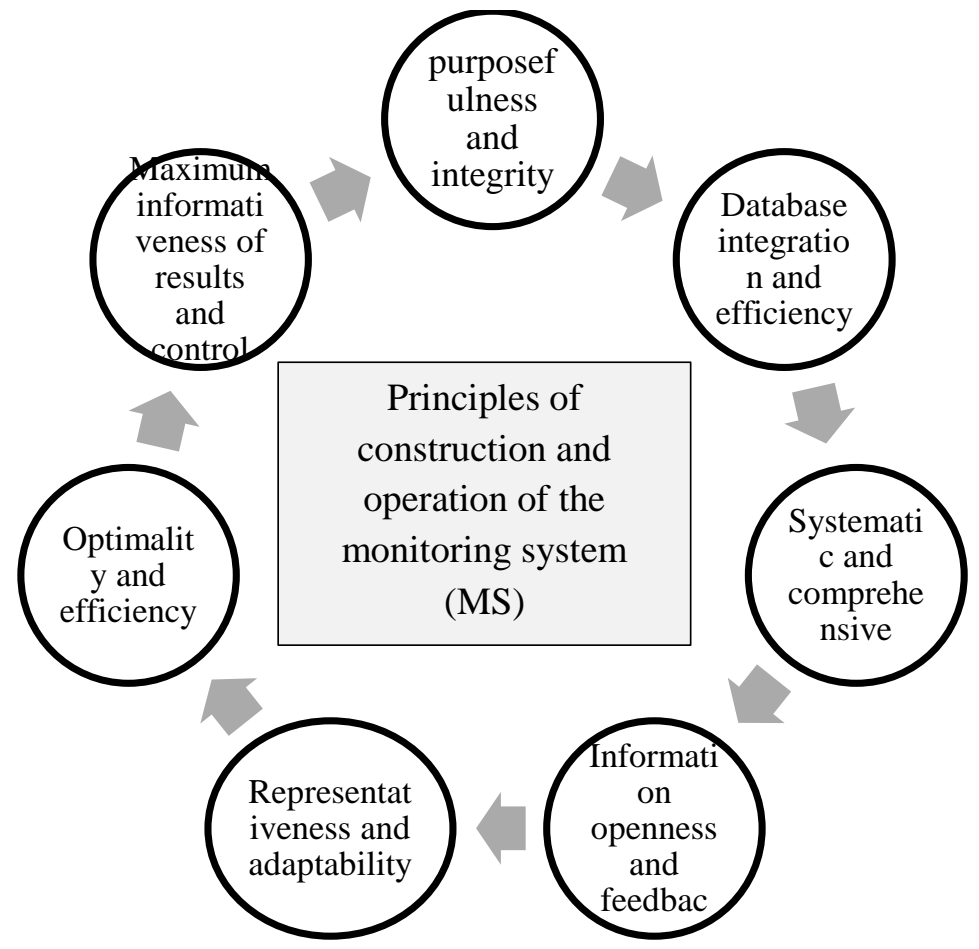

Fig. 3.2. Principles of MS

3. Database integration and efficiency. When developing a monitoring system, it is necessary to form a single database that ensures the efficiency of obtaining information, reliability of its storage, comparability and updating. The efficiency of the monitoring system is considered both in terms of information processing and in terms of management decisions.

4. Representativeness and adaptability. This principle is to select the necessary minimum and sufficient indicators for analysis and forecasting of the object of the study in the monitoring system. At the same time, the selected indicators should be adapted to international comparisons.

5. Information openness and feedback. This principle is a necessary condition for the effectiveness of the monitoring system. The results obtained should be available at all levels of the government. The availability of feedback allows you to make the monitoring system manageable, which provides the ability to adjust monitoring programs by users.

6. Optimality and efficiency. The monitoring system should allow the decisionmaking system to choose the most effective management decision for the development of 
the object of study. At the same time, the monitoring system should aim to improve the quality and efficiency of management decisions.

7. Maximum informativeness of results and control. This principle lies in the constant improvement of the monitoring system through its control and identification of "bottlenecks", obligatory constant updating and development of the information base.

Among other principles of the monitoring system are the continuity of the observation of objects; frequency of withdrawal of information about the changes that occur; comparability of applied monitoring indicators over time.

Based on the above principles, the monitoring system performs the following functions (Fig. 3.3).

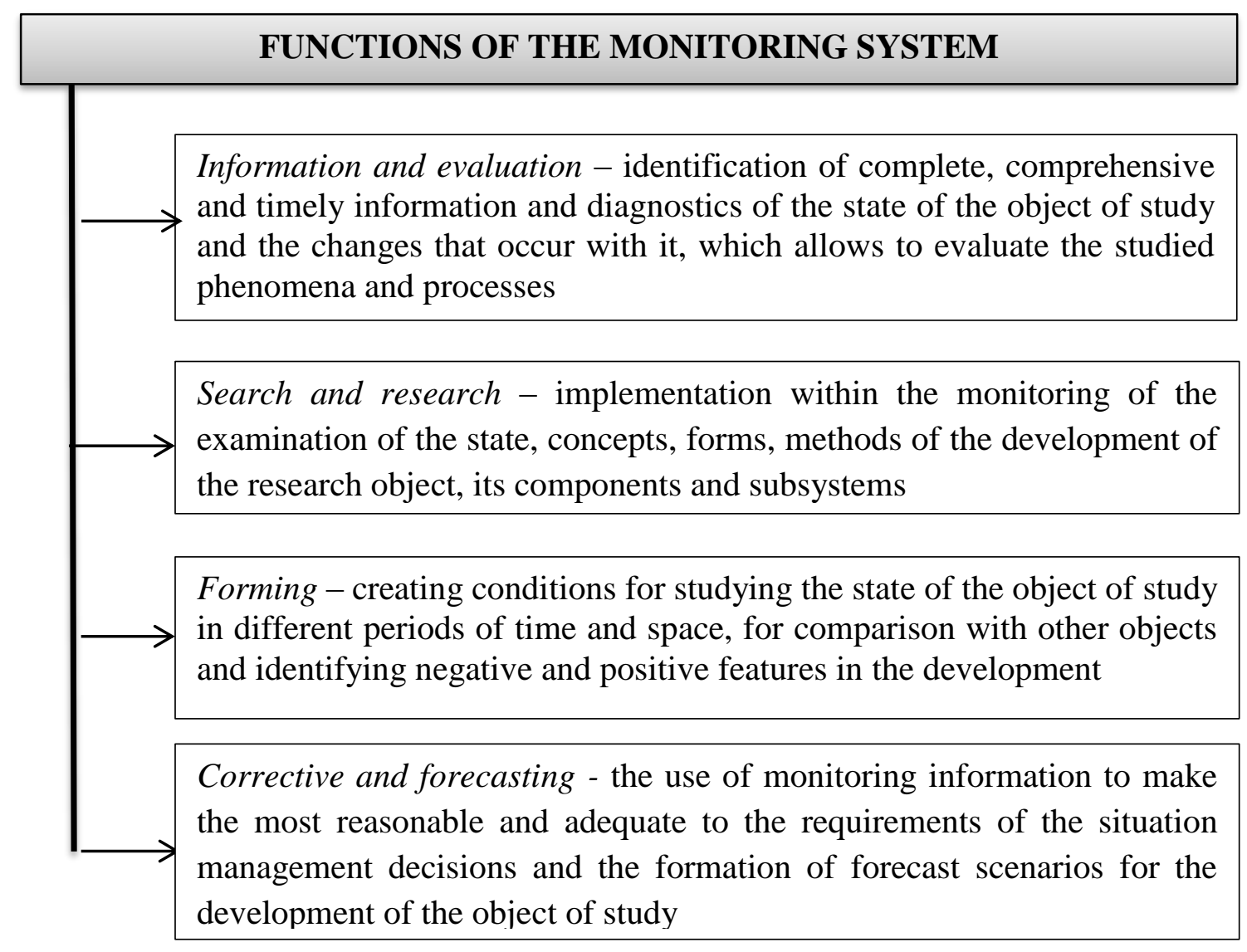

Fig. 3.3. MS functions

Thus, in a generalized form, all functions of the monitoring system are aimed at collecting, processing, analyzing information about phenomena and processes, about the indicators that characterize these phenomena and processes; formation of a single information system and database on the phenomena and processes being studied; 
implementation of communication between information providers and consumers of monitoring results through management decisions.

To perform the functions shown in Fig. 3.3, various monitoring tools are used in the monitoring system. The main methods of the monitoring system are shown in Fig. 3.4.

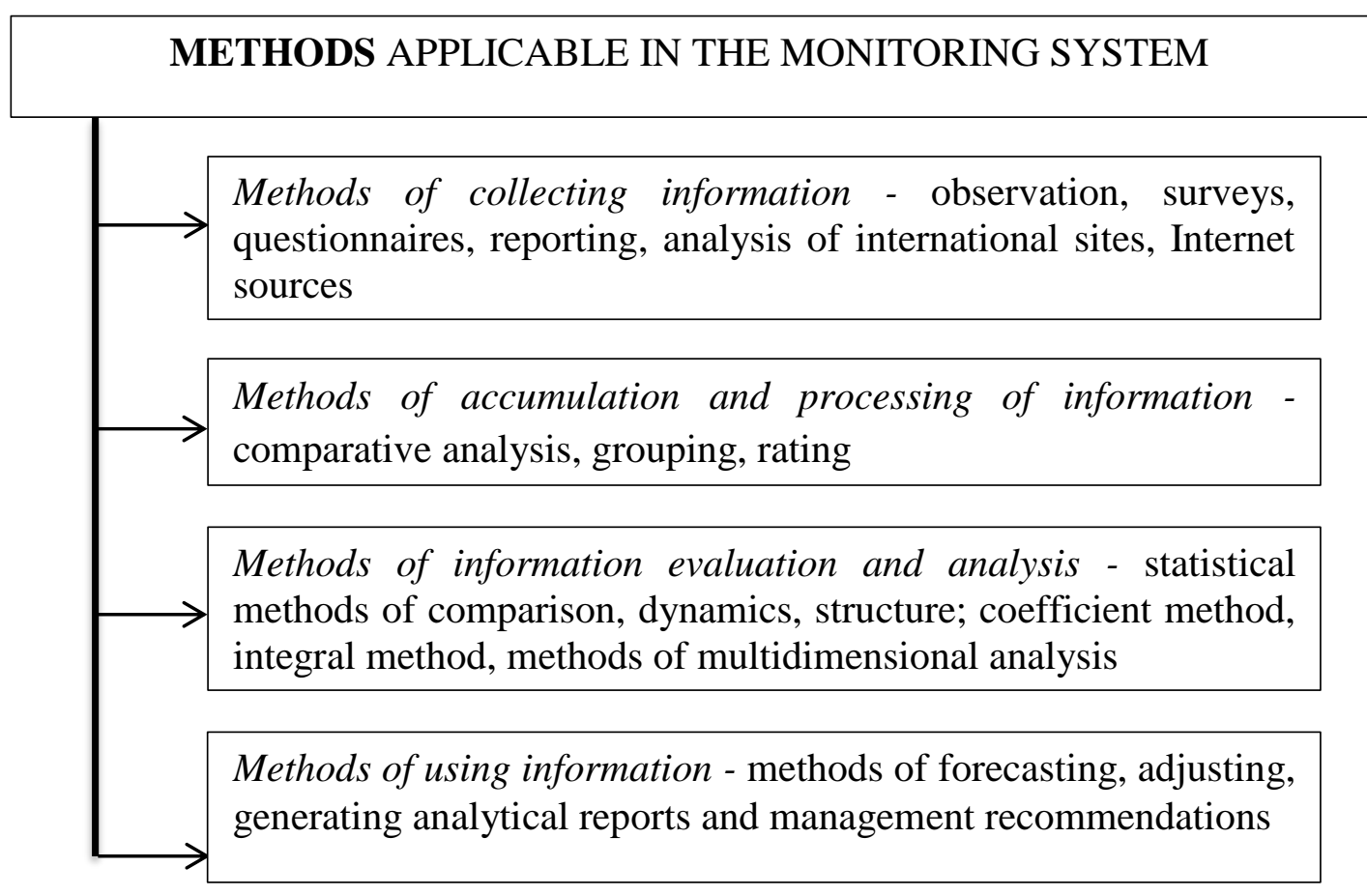

Fig. 3.4. Methods used in the monitoring system

According to these functions, the monitoring system has certain goals and performs certain tasks $[132,194]$ (Table 3.2).

Table 3.2

\section{Goals and objectives performed by the monitoring system (MS)}

\begin{tabular}{|l|l|}
\hline \multicolumn{1}{|c|}{ Goals of the MS } & \multicolumn{1}{|c|}{ Tasks of MS } \\
\hline $\begin{array}{l}\text { Objective 1. Organization of observation, } \\
\text { obtaining reliable and objective information on the } \\
\text { processes in the area under study }\end{array}$ & $\begin{array}{l}\text { 1. Ensuring regular and visual presentation of } \\
\text { information about the processes taking place in the } \\
\text { research area } \\
\text { 2. systematization of information about the state and } \\
\text { development of the object of study }\end{array}$ \\
\hline $\begin{array}{l}\text { Goal 2. Analytical generalization, evaluation and } \\
\text { systematic analysis of the received information, } \\
\text { identification of the reasons of disproportions of } \\
\text { the development of object of research }\end{array}$ & $\begin{array}{l}\text { 1. Reasonable choice and use of statistical and } \\
\text { economic-mathematical methods of information } \\
\text { processing } \\
\text { 2. Development of a forecast for the object of study in } \\
\text { accordance with the identified factors of development }\end{array}$ \\
\hline $\begin{array}{l}\text { Objective 3. Providing management bodies and } \\
\text { interested stakeholders with generalized } \\
\text { information and development of recommendations } \\
\text { for eliminating negative trends and maintaining } \\
\text { positive developments in the research area }\end{array}$ & $\begin{array}{l}\text { 1. Development of a system of indicators that provide a } \\
\text { holistic view of the object of study. } \\
\text { 2. Formation of a system of corrective actions to } \\
\text { improve the quality of the studied process }\end{array}$ \\
\hline
\end{tabular}


Based on the above principles, taking into account the monitoring functions, goals and objectives of monitoring, a system of monitoring and stratification of the Ukrainian universities is formed, the constituent elements of which are presented in table. 3.3. [2,81]

Table 3.3

\section{Components of the monitoring system}

\begin{tabular}{|c|c|}
\hline $\begin{array}{l}\text { Elements of the monitoring } \\
\text { system }\end{array}$ & Characteristics of the elements \\
\hline \multicolumn{2}{|r|}{ Database } \\
\hline $\begin{array}{l}\text { Subjects of the monitoring } \\
\text { system }\end{array}$ & $\begin{array}{l}\text { these are the carriers of the monitoring functions that perform these } \\
\text { functions. They are conventionally divided into two groups: those } \\
\text { who select and process them. Thus, the subjects in the monitoring } \\
\text { system are organizations, structures, and individuals. }\end{array}$ \\
\hline Monitoring indicators & $\begin{array}{l}\text { it is a set of primary and secondary indicators that are able to provide } \\
\text { a holistic view of the state of the object of study, the qualitative and } \\
\text { quantitative changes in it }\end{array}$ \\
\hline Monitoring activities & $\begin{array}{l}\text { it is a set of monitoring procedures, namely: collection, processing, } \\
\text { verification and submission of information (monitoring procedures), } \\
\text { organization and provision of monitoring procedures }\end{array}$ \\
\hline \multicolumn{2}{|r|}{ Knowledge base } \\
\hline Monitoring tools & $\begin{array}{l}\text { it is a set of sources of monitoring information - forms of statistical } \\
\text { reporting, international and national information resources, } \\
\text { questionnaires, etc., which are used by monitoring entities for } \\
\text { evaluation. The tools of monitoring activity are various technical } \\
\text { means used by the subjects of monitoring in their activity. }\end{array}$ \\
\hline Tool support & $\begin{array}{l}\text { it is a system of methods, models, approaches, methodical } \\
\text { recommendations, technologies concerning an estimation of } \\
\text { indicators, control of the quality of data and control of the quality of } \\
\text { carrying out monitoring }\end{array}$ \\
\hline
\end{tabular}

Thus, the composition of the monitoring system is determined by its functional purpose, scope, list of tasks to be solved and the information processing functions, which are defined by the user, assigned to it.

The structure of the MS is a way to establish the interaction of information sources and methods of its processing and analysis. Thus, the basis for the formation of any monitoring system are two main components: a database, i.e. information and analytical support for assessing the functioning and development of the object / process of research and knowledge base, i.e. model, methodological and information support of this process.

In addition, in the information society, the emergence and unprecedented spread of cyber threats in the construction of a monitoring system must take into account two groups of possible risks:

Group 1 - the risk of operation of the object or the monitoring process;

Group 2 - the risk caused by the fact of functioning of the monitoring system itself. 
Concretization and detailing of the causes of risk is achieved by modeling and assessing the functioning of a particular object of monitoring in its real environment. The choice of the risk assessment criteria in the monitoring system is made by taking into account the classification reasons for its occurrence (Fig. 3.5). [164]

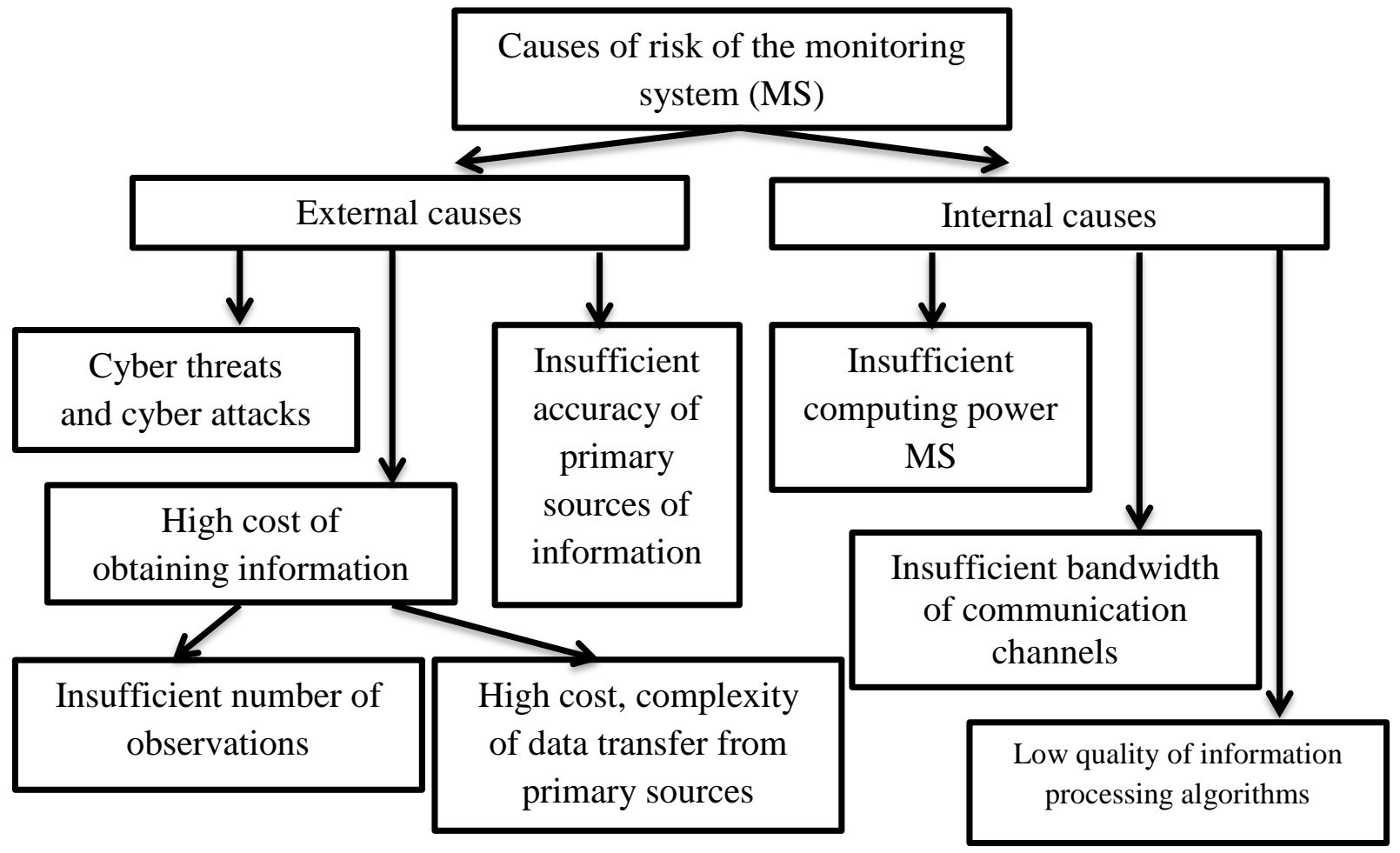

Fig. 3.5. Classification of causes of MS risk

Shown in Fig. 3.5 the reasons may lead to such types of risks due to the functioning of the MS as: low accuracy (lower than necessary) of the monitoring results; insufficient discreteness of information issuance; long data issuance delays; inconsistency of the form of information issuance; the absence of some characteristics (e.g. forecasts) issued by the MS.

In accordance with the content of the MS, its principles, functions and methods, the monitoring system has certain requirements [91,221]:

reliability - the use of information data and a system of monitoring indicators, which most fully and reliably characterize the phenomenon under study;

efficiency - focus on the reduction, collection and processing of information in order to be able to make tactical management decisions, if required by the situation;

regularity - monitoring for a more or less long period with certain intervals of information collection. For strategic management, the duration of monitoring should 
exceed the period for which the strategy is developed, as the task of monitoring includes not only current monitoring and evaluation of strategy implementation, but also evaluation of effectiveness of achieving strategic goals and identifying new strategic issues;

complexity - simultaneous tracking of trends in indicators that characterize different aspects of the object of study (it is possible to monitor each individual indicator, and reduce them to an integrated indicator, which allows you to judge the process of implementing the strategy as a whole);

independence and objectivity. The monitoring system should not depend on subjective factors, which can be considered political interests, because otherwise the requirement of objectivity and reliability is not met.

The construction of monitoring system should be based on a certain organizational technology, i.e. it should include the following procedures (Fig. 3.6) [88].

The methodology of creating a monitoring system in any field of activity, including education, as an important functional subsystem of the management HEI, should be based on its comprehensive definition, formation of the monitoring system in solving problems of increasing competitiveness and innovation of national HEI, principles of creation and functioning of the monitoring system.

Modern transformations of the higher education system in Ukraine and the world as a whole create conditions for strengthening the competitive environment among universities, which, in turn, requires them to seek and develop effective measures to increase their competitive potential. One of the components of the latter is the innovative activity of the university, which is a complex structure and the result of the evolution of its development in retrospective and future periods.

In the context of this problem, it is necessary to build an effective system of monitoring and stratification of universities (SMSU), the results of which are aimed at full disclosure of innovative potential of national HEI, formation or strengthening of entrepreneurial, autonomous and active activities.

Based on the above research, it is proposed a methodical approach to building a system of monitoring and stratification of HEIof Ukraine by the degree of their innovative activity which consists of the following stages:

1 stage. Formation of a methodological basis for building a monitoring system, namely, the development of hypotheses, provisions, principles of system operation; 
Procedure 1. Clarification of the problem situation of monitoring, its structuring, to allocate the basic factors, the purpose
Procedure 2. Defining the boundary of the problem area

(object or process of monitoring) to be investigated, in accordance with the purpose of monitoring
Procedure 3. Designing the structure of the monitoring system, highlighting the content levels of the hierarchy and algorithms for the transition of monitoring results from the lower floor to the upper, to formulate the target monitoring results
Procedure 4. Determination of the indicative set of features (indicators) to be monitored. This set must be

constantly analyzed and adjusted if necessary

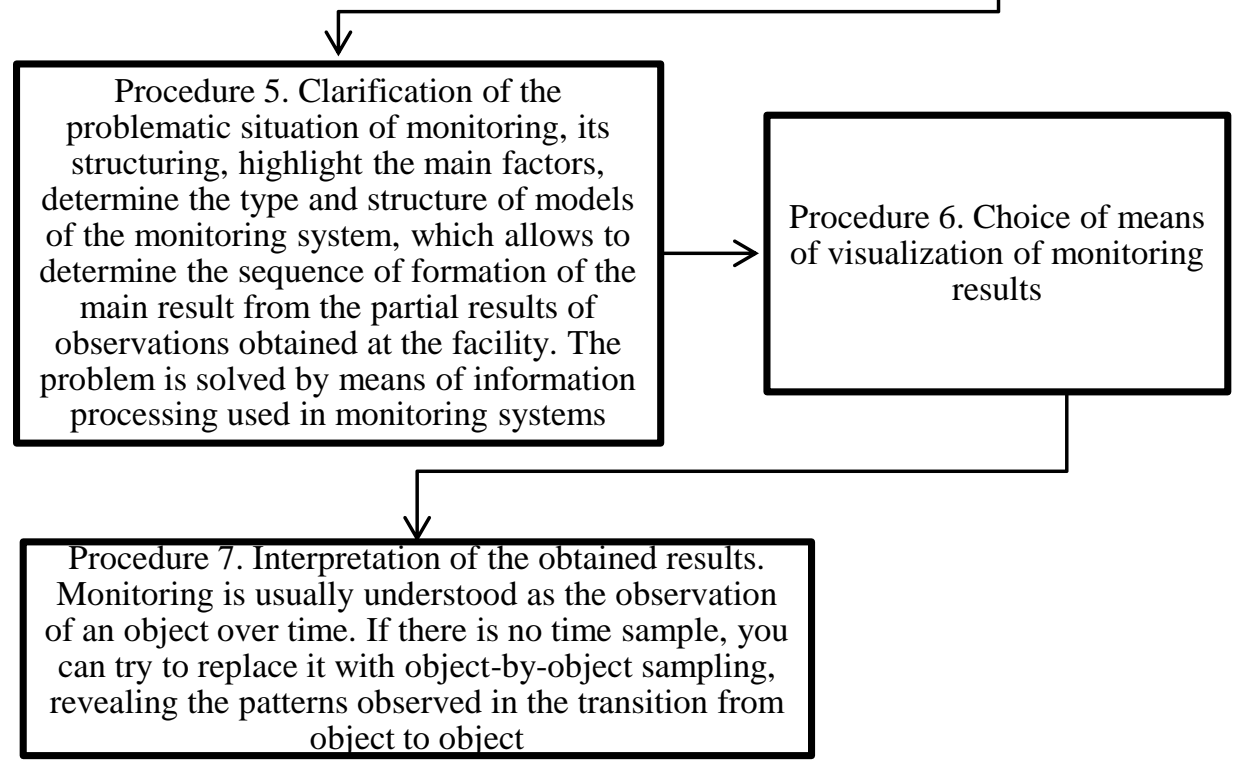

Fig. 3.6. Organizational technology for building a monitoring system

Stage 2. Designing the structure of the system of monitoring and stratification of HEIof Ukraine;

Stage 3. Development of a sound indicator system for assessing the position of the higher education system (HES) of Ukraine and assessing the innovation activity of individual national HEI;

Stage 4. Carrying out of calculations of innovative activity of HEI: clustering of HEI on the level of innovation activity;

Stage 5. Interpretation of the obtained results.

Let us consider in more detail each of the stages of the approach.

1 stage. Construction of the system of monitoring and stratification of universities 
(SMSU) should be based on the proposed system of hypotheses:

Hypothesis 1. Globalization processes in the market of educational services form a single educational space in which the interaction of national higher education systems is observed.

Hypothesis 2. Current trends in the transformation of a traditional university into an entrepreneurial university necessitate a revision of the system of indicators for assessing the innovative activity of HEI.

Hypothesis 3. An effective monitoring system should form the basis for management decisions on the development of an innovative university, including indicators of a complex external environment.

Hypothesis 4. It is expedient to determine the innovative activity of national universities on the basis of the use of the HEI rating system.

To build an effective system of monitoring and stratification of universities (SMSU) a number of provisions is proposed in the study, which are shown in Fig. 3.7.

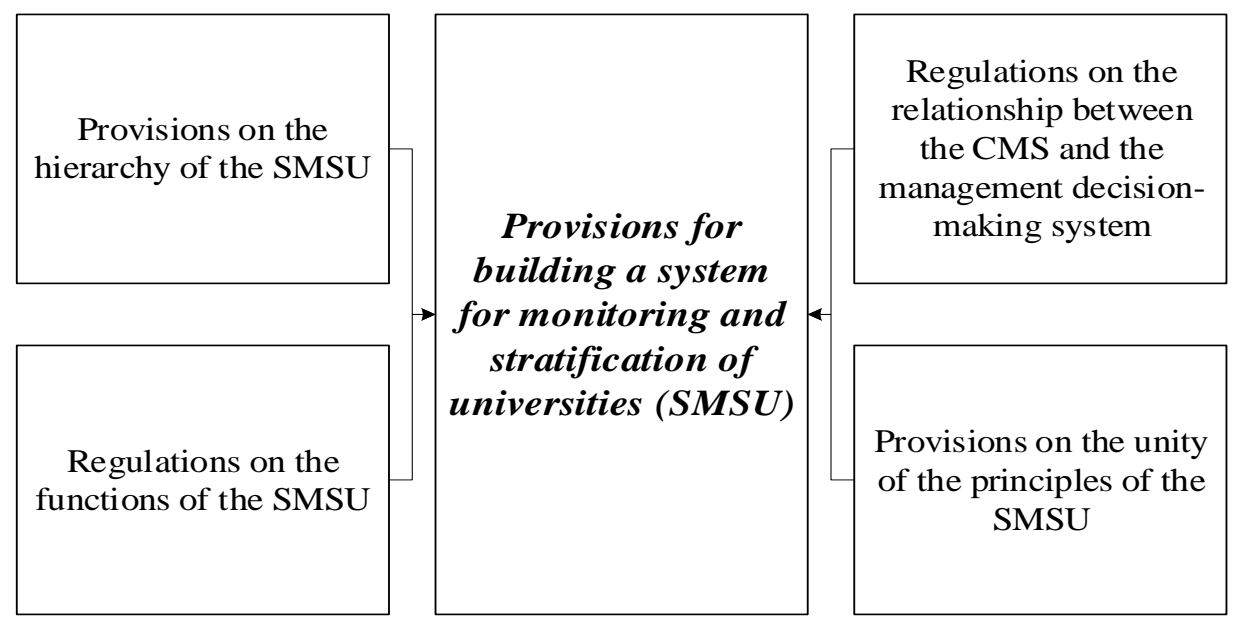

Fig. 3.7. Regulations for the development of a system for monitoring and stratification of universities

\section{Regulation 1. On the hierarchy of SMSU.}

Any monitoring system has a hierarchical two-level structure, which is determined by two directions: the direction associated with the objects of monitoring and the direction associated with the subjects of monitoring (Fig. 3.8). 


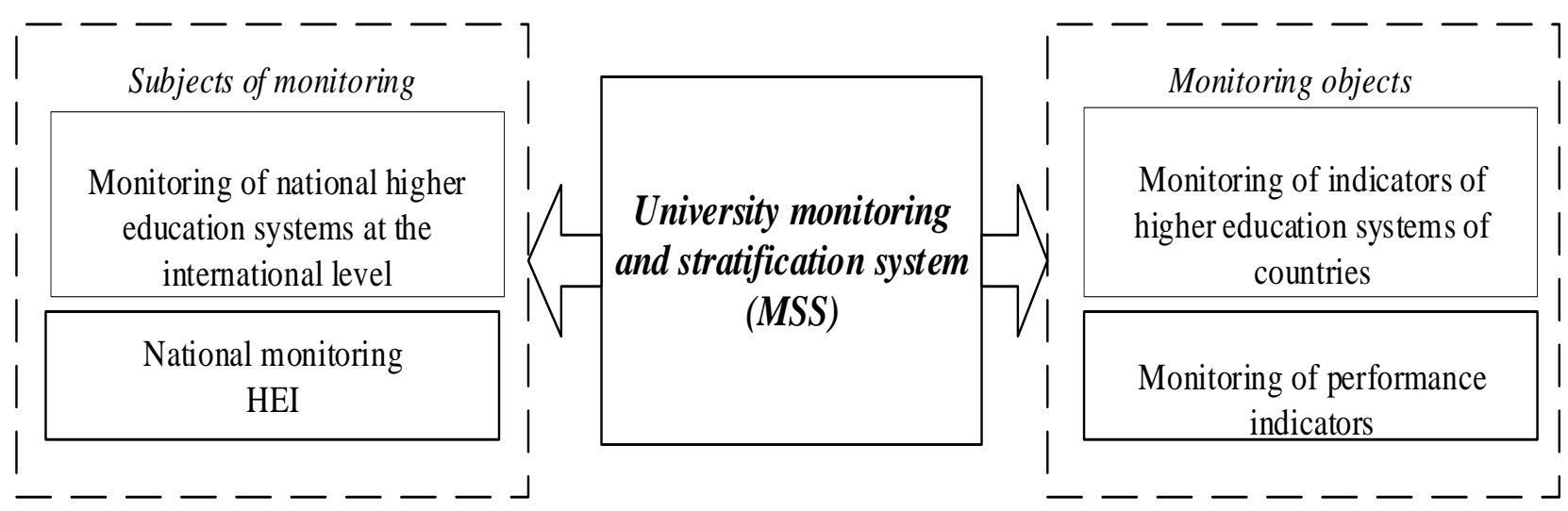

Fig. 3.8. Hierarchical structure of SMSU

It is proposed to monitor and stratify the HEI of Ukraine in two areas:

1. Monitoring of the external, world environment. To assess and analyze the level of innovation of national universities, it is necessary to diagnose the preconditions for the development and functioning of HEI, which have developed in the higher education system of the country on the basis of international rankings. To this end, it is proposed to carry out a spatial-dynamic analysis of the higher education systems in Europe and to position the higher education system of Ukraine among them;

2. Monitoring of the external, national environment. The analysis and stratification of the national HEI is proposed to be carried out on the basis of partial indicators of national rating indicators that reflect educational, scientific and technical, innovative and international activities.

This approach to building a system of SMSU allows to obtain a systematic, new knowledge about the level of innovation activity of the university on the basis of a combination of efforts of the state and a specific HEI.

The general connection of subjects and objects of monitoring and stratification of universities at the national and international levels is presented in Fig. 3.9.

Regulation 2. On the relationship between the monitoring system and the management decision-making system.

Monitoring is considered in two senses, in the narrow sense - it is one of the functions of management, in a broad sense, monitoring acts as an aggregate management function, which combines such functions as diagnostics, planning, forecasting and regulation. In the conditions of constantly changing external environment for increase of 
adaptation of SMSU to external influences it is expedient to consider monitoring not only as separate system, but as the system which is directly connected with the system of decision-making in HEI. That is, it should be implemented in the general management of IAU and integrated into the corporate research and educational system of the university.

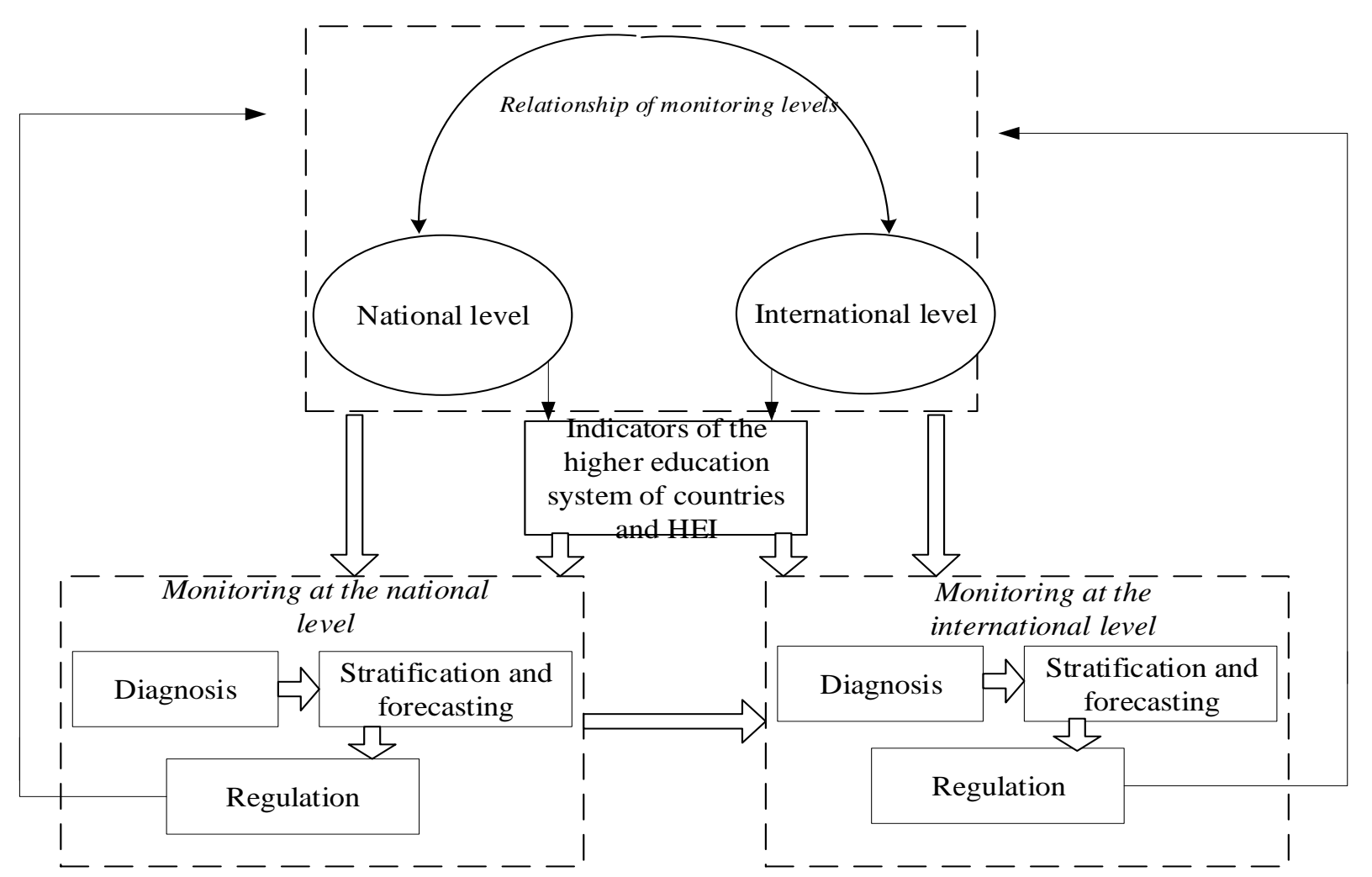

Fig. 3.9. Communication of subjects and objects in the SMSU at the national and international levels

\section{Regulation 3. On the functions of the monitoring system.}

Defining the two-level structure of the monitoring system (national and international level) allows to determine the specifics of standard management functions for each of the monitoring systems.

The following functions are distinguished in the general monitoring system: assessment, analysis, planning and forecasting and regulation. Let us consider them in more detail.

The evaluation function allows on the basis of monitoring to carry out a reasonable and adequate assessment of the national and world educational environment, where the 
factors that determine the creation of innovative universities are formed.

The analysis function allows to identify trends and features of development of the national and international systems of HEI, to conduct dynamic and comparative analyzes of researched indicators, to cluster countries and national HEI indicators that form an innovative component of university development and increase their attractiveness in national and global educational markets services.

The function of planning and forecasting is to build forecasts and scenarios for the development of the national system of higher education in accordance with the principles of innovative-active universities.

The regulatory function is to develop effective actions to increase the innovation component in the activities of HEI by effectively managing their activities.

In addition to these functions, it should be noted that monitoring itself is a function of supporting management decisions and is an instrumental support mechanism for creating an IAU business type.

\section{Regulation 4. On the unity of the principles of building a monitoring system.}

The construction of the monitoring system is carried out according to the following general principles, which were given above: target orientation and specificity; objectivity of monitoring data; continuity of monitoring; minimization of monitoring costs; targeting a specific object area; controllability of the monitoring system; ensuring the completeness and timeliness of information; clarity of information presentation; minimization of the risk of data error (reliability); maximum satisfaction of consumer information requests; maintenance of monitoring and control system.

The conducted theoretical research allows to formulate the following specific principles of formation of SMSU:

openness - information obtained during the operation of SMSU should be open not only to the participants of the system, but also to the interested users - stakeholders. The results of these studies and observations, in one form or another, should be available to all who wish to obtain this information, and different groups of users will have different access rights to it, and, therefore, the form of presentation of information and the degree of its detail should also differ;

purposefulness - provides for the orientation of SMSU on the creation and development of information and analytical support for the management decision-making process for the formation of an innovative university;

continuity - provides for the organization of CMS, in which information about the state of the integrated system or its elements is constant, not interrupted in time, which 
allows you to track changes in the system and respond adequately to them;

reliability - the imitation of this principle is designed to ensure the "tuning" of the SMSU to collect statistically significant data that allow to adequately assess the conditions, processes and results studied;

reliability - refers to both the initial information and the results of monitoring. The implementation of this principle is designed to ensure the confidence of consumers of the "product" of monitoring to the sources of information, methods of obtaining, processing, analysis;

efficiency - the proposed SMSU should promote the reasonable formation of factors that determine the creation of innovative universities;

structured - is to ensure the relationship of information on a system of indicators with the subjects of institutional support for the formation of innovative universities.

So, on the basis of the given principles of formation of SMSU we have that:

1. SMSU must fit organically into the corporate scientific and educational system of the university, the system of information support, control and regulation of the higher education system in Ukraine, contain the information necessary for public administration, reflecting the specifics of the higher education system at both national and international levels;

2. SMSU should contain meaningful information about the system of goals in the formation of innovative-active universities, factors, indicators and indicators of development of innovative-active universities;

3. The basis for the formation of a system of goals and indicators that characterize them are legislation, regulations, programs of public administration in the field of higher education, as well as indicators of the world and European organizations for the development of education and society;

4. Aggregate indicators, which characterize the level of development of universities, should be clear, easy to interpret, accessible for analysis and use in management practice.

Stage 2. According to the above, IASB is a complex system that includes two subsystems: monitoring of higher education systems in the European countries and monitoring of national HEI, Fig. 3.10.

The purpose of the system of monitoring and stratification of universities is a development of information and analytical support for the formation of a mechanism for defining the factors that determine the creation of innovative-active HEI of the entrepreneurial type. 


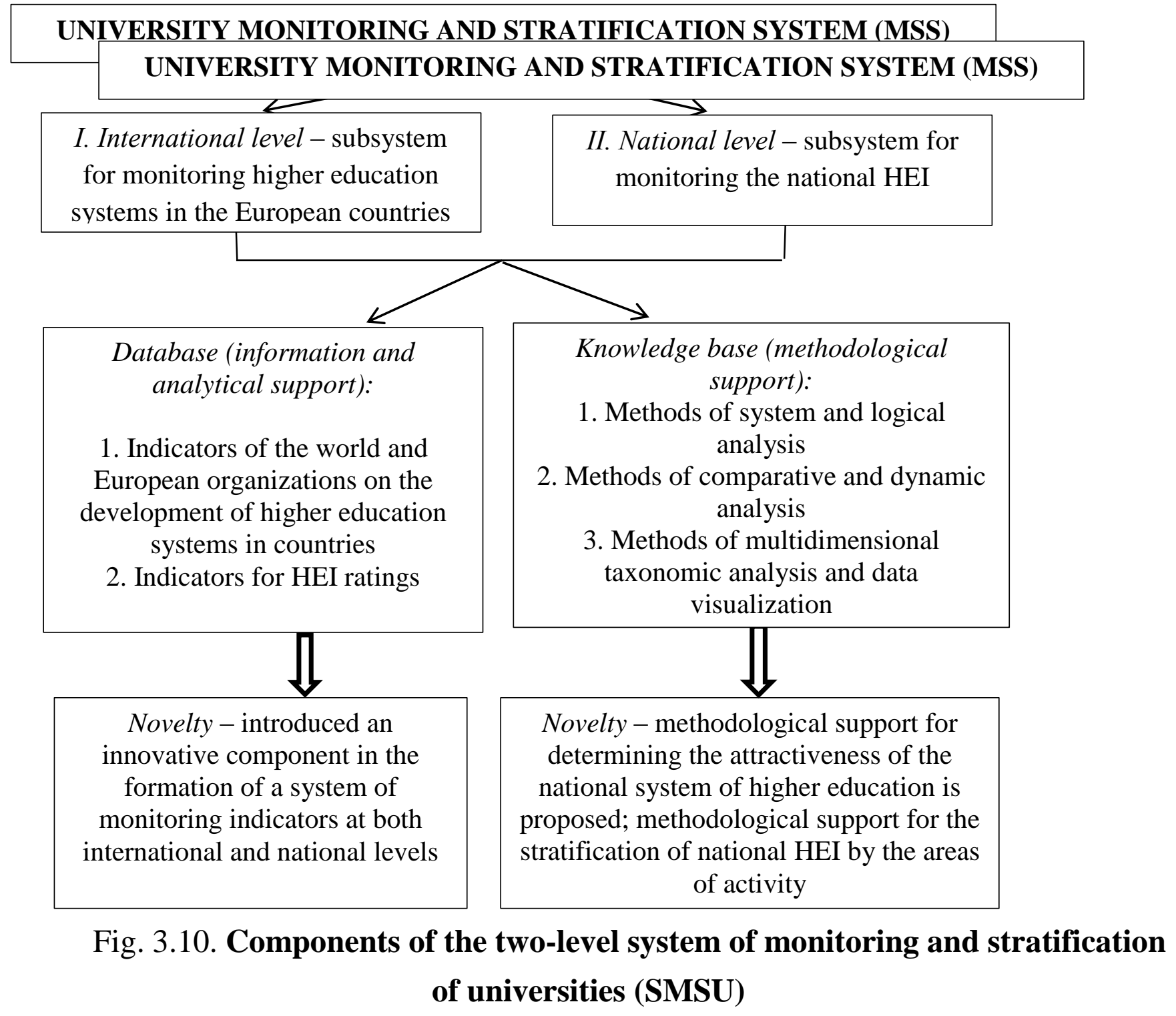

The structure of SMSU consists of two blocks: a database and a knowledge base.

Database - it is a system of indicators which covers the indicators of the system of higher education and HEI in the international and national market of educational services and sources of information on the calculation of these indicators.

The general methodological scheme of forming the database of the monitoring system consists of the following stages [220]:

1) determination of philosophical and methodological grounds for the allocation of indicators;

2) building on their basis a system of criteria;

3) definition of groups or separate indicators for each of the criteria;

4) creating tools. Selection of existing or creation of new methods for determining 
indicators;

5) verification of methods, their justification;

6) equipping with methodological tools (instructions for conducting, processing and interpreting the results, checking quality indicators, etc.).

The main requirements for the indicators in general are [132]:

1) the maximum breadth of coverage of the field of possible problems, results;

2) the possibility of use in management practice;

3) simplicity and reliability of definition.

In addition, it should be taken into account that the information coming from the database of the monitoring system must have the following properties:

objectivity, i.e. to reflect the external objective world, not to depend on the methods of its fixation, any opinion, judgment;

reliability, i.e. to reflect the true state of affairs. Objective information is always reliable, but reliable information can be both objective and subjective. Reliable information helps us make the right decision. Inaccurate information can be for the following reasons: intentional distortion (misinformation) or unintentional distortion of a subjective property; distortion as a result of interference and insufficiently precise means of its fixation;

completeness, i.e. information can be called complete if it is sufficient for understanding and decision-making. Incomplete information may lead to an erroneous conclusion or decision;

accuracy, which is determined by the degree of proximity of information to the real state of the object, process, phenomenon, etc ;;

relevance, i.e. important for the present time, urgent;

usefulness (value), which can be assessed in relation to the needs of specific consumers of information and is assessed by the tasks that can be solved with its help.

The second component of SMSU is the knowledge base, that is, methods, models, technologies, techniques used to process monitoring information

In generalized form, the structure of SMSU and its subsystems includes three main modules:

1. Information collection module (database).

2. Information processing module (knowledge base). 
3. Management decision-making module (management decision-making based on monitoring results).

Let us consider the content of each monitoring subsystem in accordance with the proposed modules, highlighting the purpose, system of indicators, information support and methods used in the processing of source information.

Module 1. Subsystem for monitoring higher education systems in the European countries (Fig. 3.11).

I. Subsystem of monitoring of higher education systems of the European countries

\section{Information collection module}

Purpose - collection of information for the formation of information and analytical support for the study of the state and development of higher education systems in the European countries

System of indicators: gross enrollment rate, (\%), education level index, a total number of national students going abroad for education, a total number of foreign students arriving for higher education, education expenditures from general government expenditures, \%, expenditures on higher education from state expenditures on education, $\%$

Information support: indicators of the world and European organizations for the development of education and society, namely UNESCO, World Economic Forum in Davos, World Bank, Eurostat, World Data Atlas, European Bank for Reconstruction and Development, European University Associations, data from national services / statistical committees

\section{Information processing module}

Purpose - assessment of the position of the higher education system of Ukraine among the European countries

Research methods: monographic, comparative analyzes, methods of logical generalization and structural-logical connections, method of multidimensional taxonomic analysis, method of data visualization, dynamic, comparative analyzes

Management decision-making module

Purpose - determination of Ukraine's position among the European countries in terms of the level of development of the higher education system and trends in this position

Result: identification of trends in the development of the higher education system of Ukraine and development of proposals to enhance the attractiveness of the national higher education system

Fig. 3.11. Contents of modules of the monitoring subsystem of higher education systems of the European countries

The main sources of information for the formation of a database for the monitoring 
system of higher education systems in the European countries were indicators of the world and European organizations for the development of education and society, namely, UNESCO [205], World Economic Forum in Davos [282], World Bank [279] , Eurostat [99], World Data Atlas [280], European Bank for Reconstruction and Development [73], European University Associations [74], national services / statistics committees.

The hypothesis, on which the system of indicators is based, is as follows: the list of indicators should provide a systematic view of the phenomenon of "attractiveness of higher education" from three points of view - mental readiness of society to receive higher education, financial readiness / ability of the government to support higher education, and the readiness of universities as structural elements of the higher education system to provide quality educational and research services.

Stage 3. Based on this, the system of indicators for assessing and analyzing the attractiveness of the country's higher education system (HES) has the following structure (Fig. 3.12).

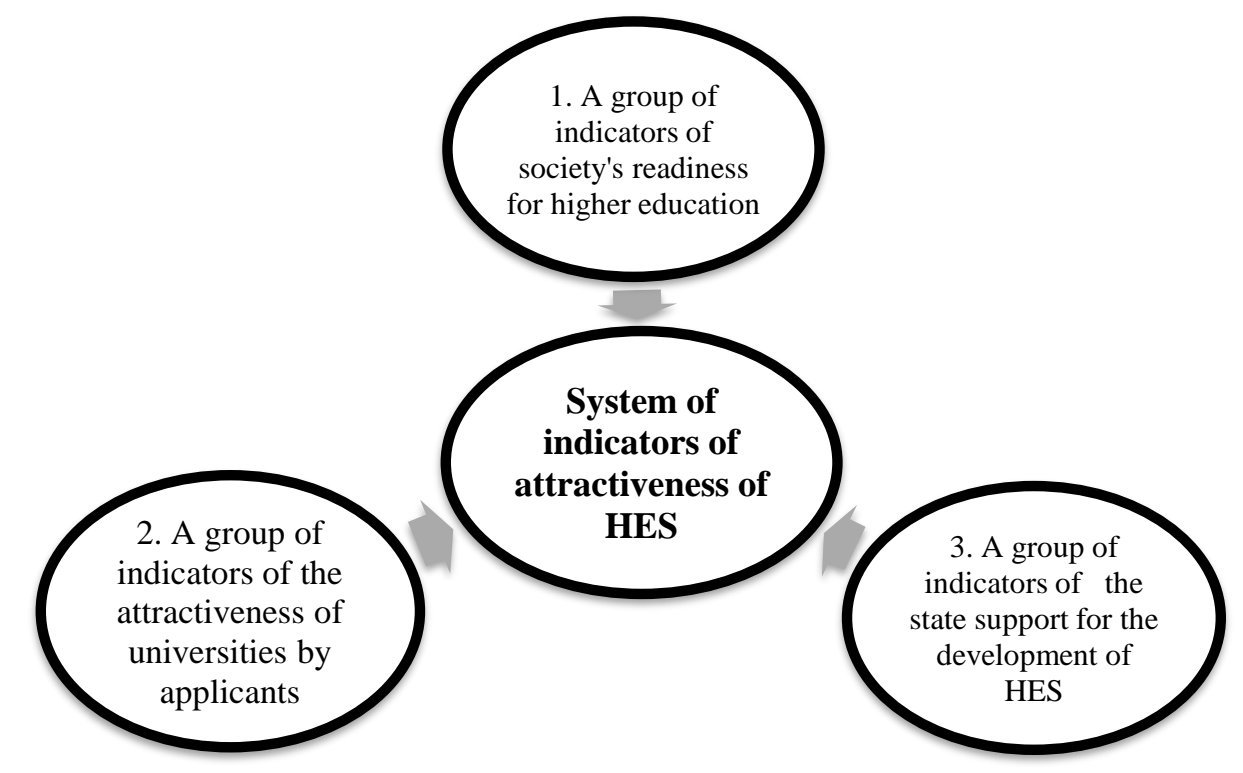

Fig. 3.12. The structure of the indicator system for assessing and analyzing the attractiveness of the country's HES

Each of the groups of indicators for assessing the attractiveness of the country's HES shown in Fig. 3.12 includes certain indicators. Based on the results of the study of the information database on education indicators, the first group of indicators, which characterizes the readiness of society for higher education, shows the nation's desire to 
obtain higher education, includes the following indicators: gross enrollment rate in higher education, X1 (\%) and education level index (X2); the second group of indicators, which shows the attractiveness of HEI for national and foreign applicants due to student mobility indicators, includes the total number of national students going abroad for education, X3 (persons) and the total number of foreign students arriving for higher education, X4 (persons); the third group of indicators, which reflects the state's ability to finance higher education institutions, includes indicators of education expenditures from general government expenditures, X5 (\%) and expenditures on higher education from the state expenditures on education, X6 (\%).

Stage 4. In forming the knowledge base in the study as a tool for grouping countries on the indicator of the attractiveness of the higher education system, it is proposed to use methods of cluster taxonomic analysis. In general, all methods of multidimensional clustering by the method of combining objects into clusters are divided into two groups: divisional, which are aimed at sequential division of the population into individual objects, and iterative, which are aimed at forming clusters based on the conditions. In addition, there is natural and artificial clustering.

The study proposes to use methods of cluster analysis in synthesis, namely, the method of hierarchical (natural) clustering, which allows you to reasonably choose the appropriate number of groups for the studied set of countries, and the method of artificial clustering - k-means, which allows to obtain stable, disparate groupings of objects research. The initial series of analysis were 6 of the above indicators for the period 20132018 , the objects of the study were 28 countries of the Eurozone and Ukraine. The choice of the research objects is conditioned by Ukraine's strategic integration efforts before joining the European Union. The algorithm of cluster analysis is presented in Fig. 3.13.

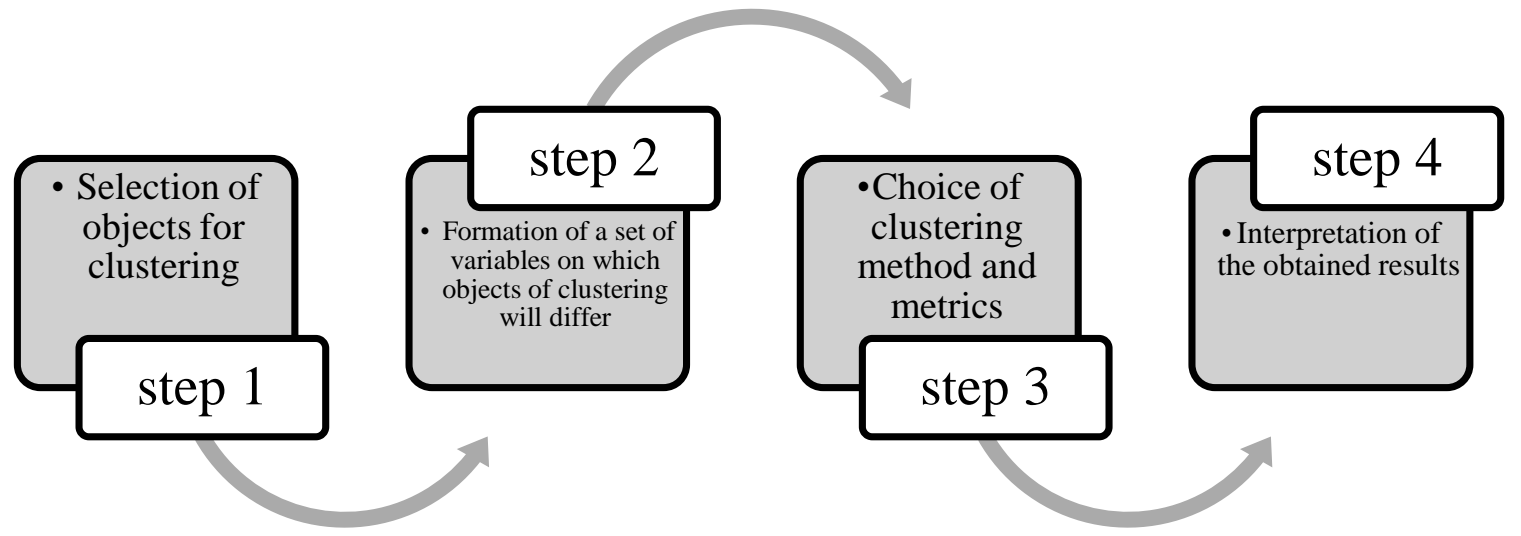

Fig. 3.13. Sequence of clustering steps 
Module 2. Subsystem for monitoring the national HEI (Fig. 3.14).

The main sources of information for the formation of the database for the monitoring system of the national HEI were the components of national and international HEI rankings, namely the TOP-200 rating, the consolidated HEI rating of Ukraine, the HEI rating SCOPUS, the Webometrics rating. [274, 192, 190, 55, 160]

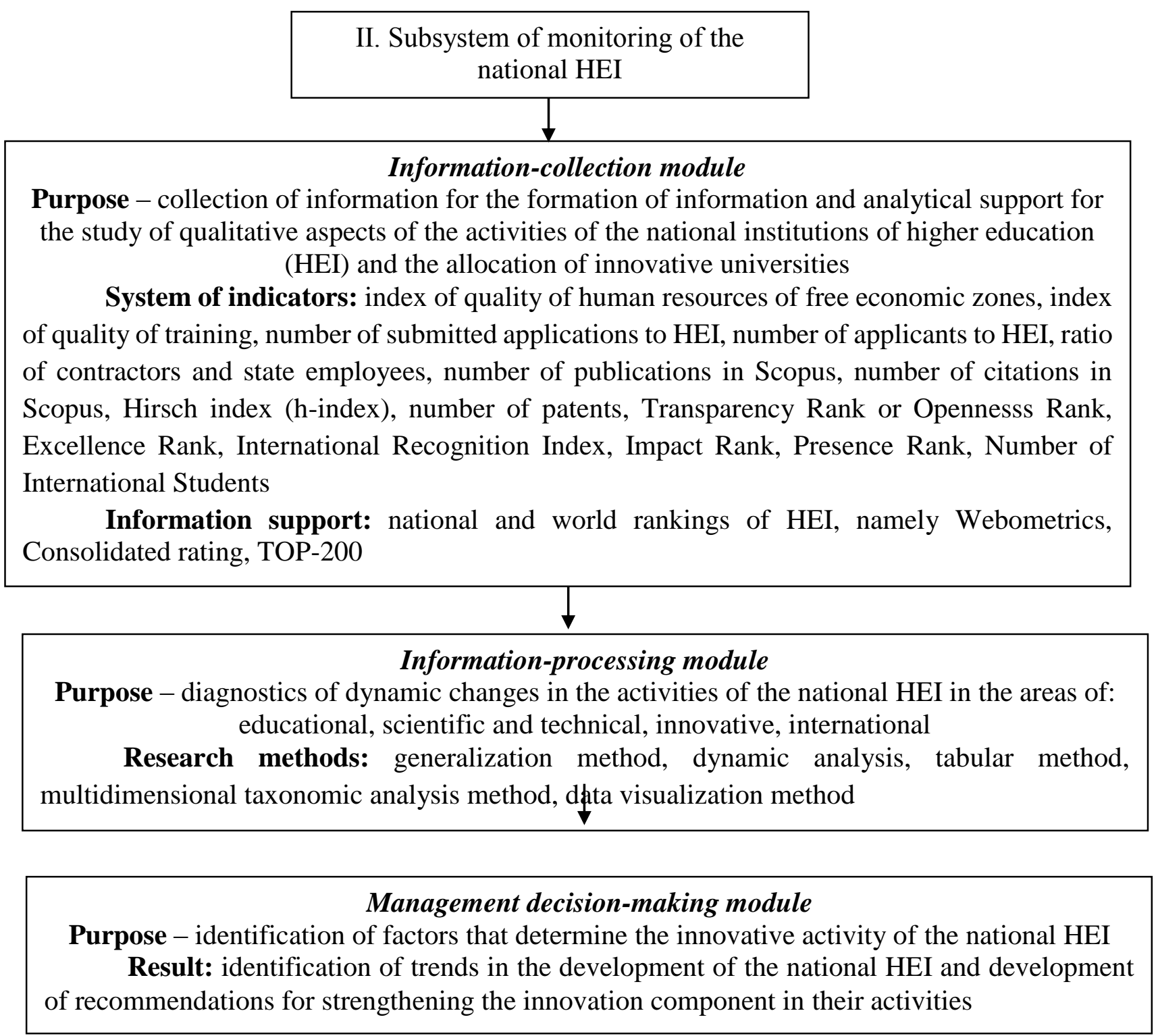

\section{Fig. 3.14. Contents of modules of the monitoring subsystem of national HEI}

The basic principles for determining the ratings of the national HEI are: ensuring full openness, transparency and independence of university rankings. For this purpose, only open data of direct measurements, displayed on the open web resources 
of independent national and international organizations and institutions, are used. Any data or expert assessments of the universities and their governing bodies are not used. The method of calculating university ratings is available to the public in order to verify the results;

taking into account the comprehensiveness, diversity of university activities. To this end, their work is collectively evaluated on a broader base of indicators compared to the known rating systems. In particular, this year's ranking of the Ukrainian universities was calculated on the basis of ten indicators, six of which are international and four are national.

Based on the importance of the European integration processes of higher education in Ukraine, the weights of international performance indicators of universities (results in world rankings, participation of universities in Erasmus + programs of the European Union) are set higher than the weights of the national indicators.

Let us consider in more detail the formation of each of the ratings, table 3.4.

Table 3.4

Formation and components of HEI ratings

\begin{tabular}{|c|c|}
\hline Rating name & Characteristics of the rating \\
\hline & 2 \\
\hline TOP-200 & $\begin{array}{l}\text { The activity of HEI is evaluated with the help of an integrated index, which } \\
\text { contains three complex components: indices of quality of scientific and pedagogical } \\
\text { potential, index of quality of education and index of international recognition. } \\
\text { In total, } 24 \text { indicators of direct measurement with a total weight of } 80 \% \text {, an } \\
\text { indicator of information resources (quality and functional completeness of } \\
\text { university websites) - } 5 \% \text { and expert evaluation with a weighting factor of } 15 \% \text { are } \\
\text { used for the formation of these indices. } \\
\text { Taking into account the need of Ukraine to carry out high-tech, innovative } \\
\text { development of the national economy, the criterion "Innovative activity of } \\
\text { universities" was additionally introduced in } 2015 / 2016 \text { for ranking HEI. This } \\
\text { criterion was quantified by the amount of investment made by private, high-tech } \\
\text { businesses in university start-ups. } \\
\text { In compiling the } 2020 \text { ranking, the experts took into account the current trends } \\
\text { in the development of universities, summarized by the IREG International } \\
\text { Conference in } 2019 \text { and the Berlin Principles, approved by the participants of the } \\
\text { second meeting in } 2006 \text {. }\end{array}$ \\
\hline $\begin{array}{l}\text { HEI rating according to } \\
\text { SCOPUS indicators }\end{array}$ & $\begin{array}{l}\text { The method of determining the rating place includes: number of publications in } \\
\text { Scopus; number of citations in Scopus. } \\
\text { As a result, the rating is based on the definition of the Hirsch index (h-index) } \\
\text { an indicator of the influence of the scientist, based on the number of his articles and } \\
\text { their citations. } \\
\text { The results of the HEI rating are based on the indicators of the Scopus database, } \\
\text { which is a tool for tracking the citation of scientific articles published by an } \\
\text { educational institution or its employees. The Scopus database constantly indexes } \\
\text { more than } 20,000 \text { scientific journals and hundreds of book series. } \\
\text { As of April } 2020 \text {, the Scopus database includes } 176 \text { HEIof Ukraine, which is } 11 \\
\text { educational institutions more than in April } 2019 \text {. }\end{array}$ \\
\hline
\end{tabular}


Continuation of the table 3.4

\begin{tabular}{|c|c|}
\hline 1 & 2 \\
\hline Webometrics rating & $\begin{array}{l}\text { Webometrics ranking of the world's universities is one of the rankings of } \\
\text { the world universities, which analyzes the degree of representation of } \\
\text { universities in the Internet. } \\
\text { The rating has been compiled since } 2004 \text { and is published twice a year. It is } \\
\text { composed of the Laboratory of Cybermetrics of the National Research Council } \\
\text { of Spain. The ranking began with the analysis of } 6,000 \text { universities in } 2004 \text {, and } \\
\text { today analyzes more than } 20,000 \text { higher education institutions and determines } \\
\text { their place according to the degree to which they present their activities on the } \\
\text { Internet, using their own evaluation methodology }\end{array}$ \\
\hline Webometrics rating & 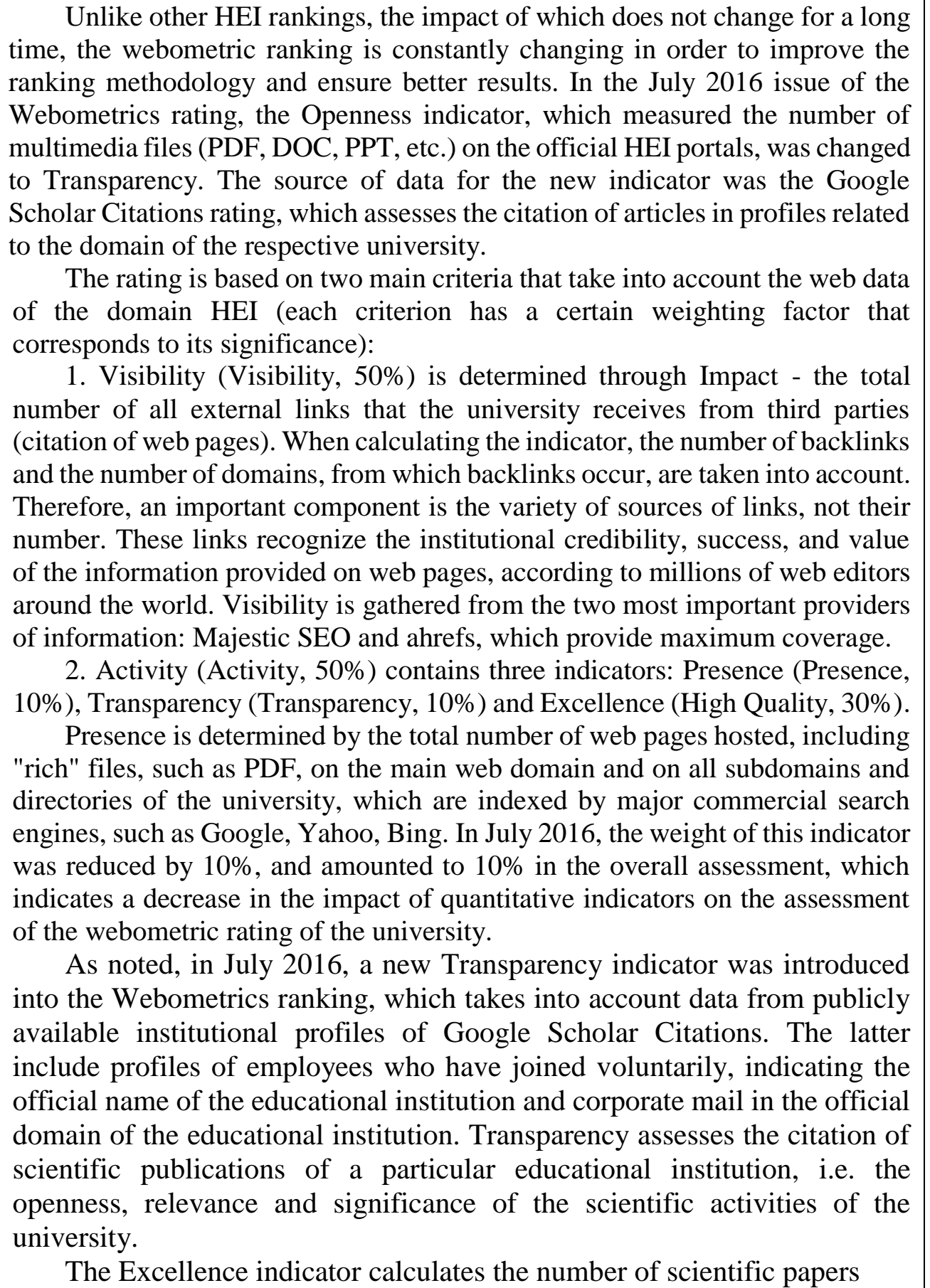 \\
\hline
\end{tabular}


The end of the table 3.4

\begin{tabular}{|c|l|}
\hline 1 & \multicolumn{1}{|c|}{2} \\
\hline \multirow{7}{*}{$\begin{array}{c}\text { published in the influential international journals. The indicator is } \\
\text { limited by counting the publications that are in the top 10 percent of the most } \\
\text { cited in the relevant fields of science. The information is provided by the } \\
\text { SCImago research laboratory. According to July data, the weight of this } \\
\text { indicator has increased from 15\% to 30\% and increases the impact of the } \\
\text { university's scientific contribution to the international scientific progress on } \\
\text { the overall rating. }\end{array}$} \\
$\begin{array}{l}\text { The most authoritative among experts and mass media national and } \\
\text { international rankings of HEI of Ukraine are used as initial data for drawing } \\
\text { up of the consolidated rating of HEI of Ukraine: Top-200 Ukraine, Scopus } \\
\text { and Webometrics, each of which uses various criteria of estimation of higher } \\
\text { educational institutions. The obtained generalized rating summarizes the } \\
\text { rating places of the HEI according to the Top-200 Ukraine, Scopus and } \\
\text { Webometrics. Starting from 2018, the Consolidated Rating of HEI consists } \\
\text { of the following ratings of higher education institutions: "TOP-200 - } \\
\text { Ukraine", "Scopus" and "External Evaluation Ball for Contract". } \\
\text { The rating "External Evaluation Score for a contract" is a rating of EIT } \\
\text { according to the average score of EIT for entrants of the previous year, who } \\
\text { are enrolled in EIT for training at the expense of individuals and legal entities } \\
\text { (contract). } \\
\text { The Webometrics rating is a rating compiled by the Spanish research } \\
\text { group Laboratorio de Internet since 2004. When compiling it, developers } \\
\text { take into account the number of search engine-indexed pages of the higher } \\
\text { education institution's website, external links to it, citation of the resource, } \\
\text { as well as the number of files uploaded to the site, i.e. content and } \\
\text { information activity of the educational institution's website. }\end{array}$ \\
\hline
\end{tabular}

Taking into account the above principles of HEI rating and complexity used in the formation of any rating, in the study to form a system of indicators for assessing innovative active HEI, it is proposed to choose the following indicators for each of the following areas: to the first group of indicators, which characterizes the educational activities of HEI, - quality index of human resources potential of HEI, index of quality of training, number of submitted applications to HEI, number of those who joined HEI, ratio of contractors and state employees; to the second group of indicators, which characterizes the scientific and technical activity, - to choose the number of publications in Scopus, the number of citations in Scopus, the Hirsch index (h-index); to the third group of indicators, which characterizes the innovation activity, -to choose the number of patents, the rank of openness (Transparency Rank or Opennesss Rank), quality rank (Excellence Rank); to the fourth group of indicators, which characterizes the international activity, - to include the 
index of international recognition, the rank of influence (Impact Rank), the rank of presence (Presence Rank), the number of foreign students.

Thus, the developed system of monitoring and stratification of universities (MSS) allows to obtain information for the formation of a systematic view of the phenomenon of "attractiveness of higher education" from three points of view - mental readiness of society to receive higher education, financial readiness / government capacity to support higher education and the readiness of universities, as structural elements of the higher education system, to provide quality educational and research services and develop mechanisms for transforming a traditional university into an innovative-active HEI in order to increase the attractiveness of both the individual university and the SHE as a whole.

\subsection{Development of methodological support for determining the attractiveness} of the national higher education system in the European educational space

Contemporary modernization of the higher education system is aimed at creating business universities, by which scientists [124,186, 40, 99, 143,185,286,287] understand such HEI, which systematically make efforts to overcome limitations in three areas knowledge generation, teaching and practice - by initiating new activities, transformation of the internal environment and modification of interaction with the external environment.

In these conditions, it is important to study the experience of the functioning of higher education systems in the European countries and determine the place of Ukraine among them. To achieve this goal, a methodology for determining the attractiveness of the national system of higher education in the European educational space, taking into account current trends in the transformation of universities into business entities.

This technique contains the following steps, Fig. 3.15.

The goal of the first stage is to form an indicator space of research, which on the basis of a systematic approach would provide a generalized picture of the development of higher education in the country.

The second stage of the methodology is aimed at identifying groups of the European countries (Eurozone countries and Ukraine) that are homogeneous in terms of the level of attractiveness of the higher education system. Provided that each of the countries in the study is a multidimensional object, it is advisable to use the methods of 
mathematical formalization, i.e. those methods that allow you to approximate the processes based on the processing of large arrays of information.

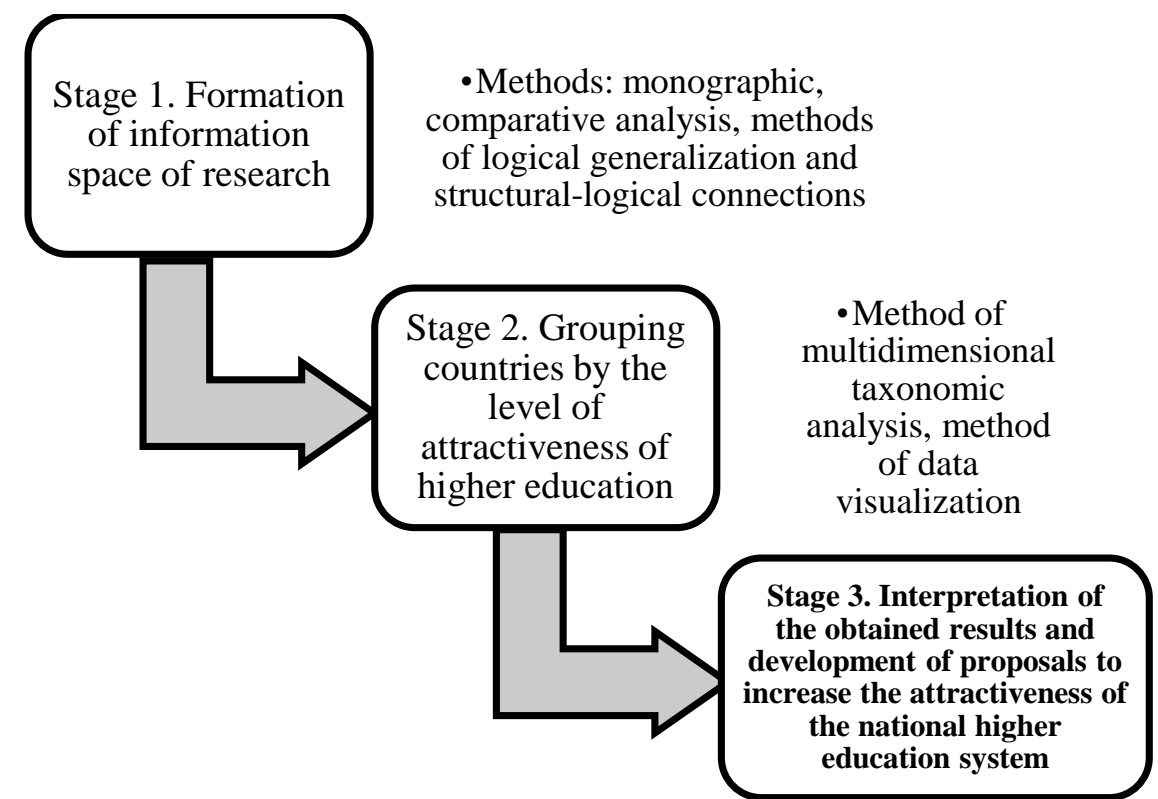

-Dynamic, comparative analysis

\section{Fig. 3.15. The scheme of stages of the methodology for determining the} attractiveness of the national system of higher education

To obtain more objective and qualitative clustering results, the study conducted three experiments:

Experiment 1 - determination of appropriate metrics and appropriate number of cluster groups based on the use of natural clustering methods;

Experiment 2 - clustering of countries by the method of artificial clustering on the basis of the original series represented by the panel data, i.e. for the whole set of countries for the entire study period;

Experiment 3 - clustering of countries by artificial clustering on the basis of the original series, represented by a spatial series for 2013, 2015 and 2017 separately in order to identify migration effects in the formation of cluster groups and identify trends in the higher education systems (HSE) of Ukraine and Eurozone countries.

To implement the first experiment of the clustering process, there was determined the optimal number of clusters of the EU countries and Ukraine according to the attractiveness of SVO on the basis of the use of the hierarchical clustering method. This method involves the use of different rules of hierarchical clustering and the use of different metrics for this cluster [176]. Table 3.5 summarizes the rules and metrics used in the experiments. 


\section{Cluster rules}

\begin{tabular}{|l|l|}
\hline \multicolumn{1}{|c|}{ Name rules } & \multicolumn{1}{|c|}{ The essence of the rule } \\
\hline single Linkage & $\begin{array}{l}\text { the distance between two clusters is defined as the distance between the } \\
\text { two closest objects in different clusters }\end{array}$ \\
\hline complete Linkage & $\begin{array}{l}\text { the distance between clusters is determined by the largest distance } \\
\text { between any two objects in different clusters }\end{array}$ \\
\hline unweighted pair-group average & $\begin{array}{l}\text { the distance between two clusters is defined as the average distance } \\
\text { between all pairs of objects in them }\end{array}$ \\
\hline weighted pair-group average & $\begin{array}{l}\text { is identical to the previous one, it is expedient to use in cases when } \\
\text { unequal sizes of clusters are provided }\end{array}$ \\
\hline unweighted pair-group centroid & $\begin{array}{l}\text { the distance between two clusters is defined as the distance between their } \\
\text { centres of gravity }\end{array}$ \\
\hline weighted pair-group centroid & $\begin{array}{l}\text { is identical to the previous one, except that the calculations use scales to } \\
\text { account for the difference between the sizes of the clusters }\end{array}$ \\
\hline Ward's method & $\begin{array}{l}\text { as the distance between the clusters is taken to increase the sum of the } \\
\text { squares of the distances of the objects to the centres of the clusters } \\
\text { resulting from their combination. Unlike other methods of cluster } \\
\text { analysis, methods of analysis of variance are used to estimate the distance } \\
\text { between clusters in this case. }\end{array}$ \\
\hline \multicolumn{1}{|c|}{ Name metrics } & $\begin{array}{l}\text { is used in cases where it is necessary to give greater weight to more } \\
\text { distant objects }\end{array}$ \\
\hline $\begin{array}{l}\text { Euclidean distance and the } \\
\text { square of Euclidean distance }\end{array}$ & $\begin{array}{l}\text { Euclid's distance calculations. However, for this measure, the impact of } \\
\text { individual emissions is less than when using the Euclidean distance }\end{array}$ \\
\hline Manhattan distance & $\begin{array}{l}\text { should be used when it is necessary to define two objects as different } \\
\text { ones, if they differ in any one dimension }\end{array}$ \\
\hline Chebyshev distance & $\begin{array}{l}\text { is used when it is necessary to increase or decrease the weight related to } \\
\text { the dimension for which the respective objects are very different }\end{array}$ \\
\hline power distance &
\end{tabular}

The choice of the appropriate rule for combining clusters and metrics was made on the basis of the following algorithm:

Step 1 - experiments were performed to select the appropriate rule for clustering;

Step 2 - experiments were performed to change the metrics according to the selected clustering rule.

The criterion for selecting an appropriate experiment was the quality of clustering, i.e. obtaining clear discrimination against countries on the level of attractiveness of their higher education systems and the method of visualization of the obtained results of clustering. Experiments have shown that the use of Ward's method and Euclidean distance metrics allow to obtain a high quality approximation of the studied population based on minimizing the loss of information associated with each merger of objects into clusters.

The results of dendrogram construction for 2013, 2015 and 2017 are shown in Fig. 3.16. The analysis of determining the number of cluster groups based on visual presentation of results (Fig. 3.16) shows that the approximate number of clusters is 3, but 
to enhance the quality of clustering and highlight the attractiveness of higher education systems of certain cluster groups, it is advisable to divide the study into 5 clusters .

Implementation of the second experiment of the clustering process of countries on the basis of the initial series represented by panel data, i.e. for the whole set of countries for the whole study period (2013-2017), the use of artificial clustering method - k-means method [176]. The results of clustering are presented in Fig. 3.17.

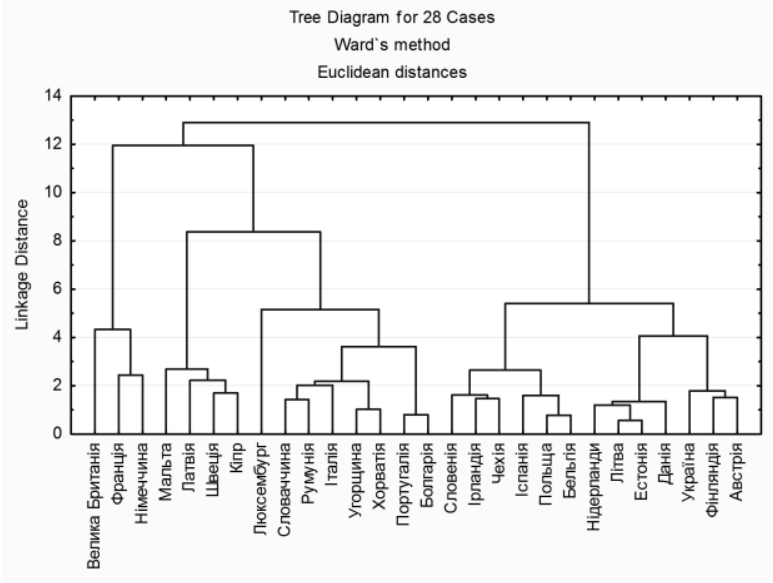

2013

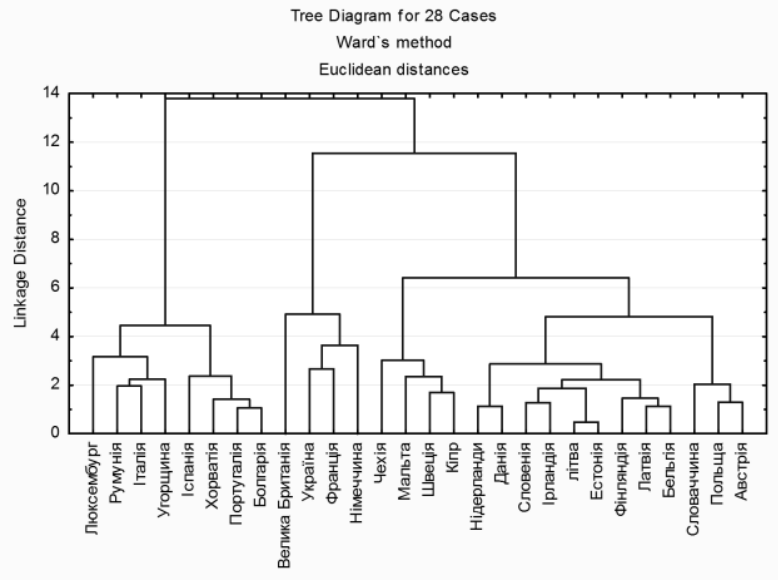

2015

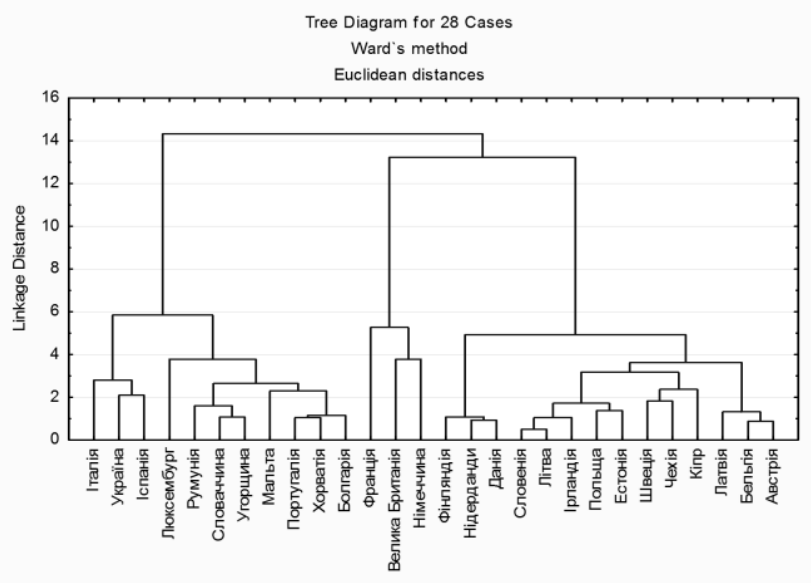

2017

Fig. 3.16. Dendrograms of clustering of the European countries by the level of attractiveness of the higher education system 


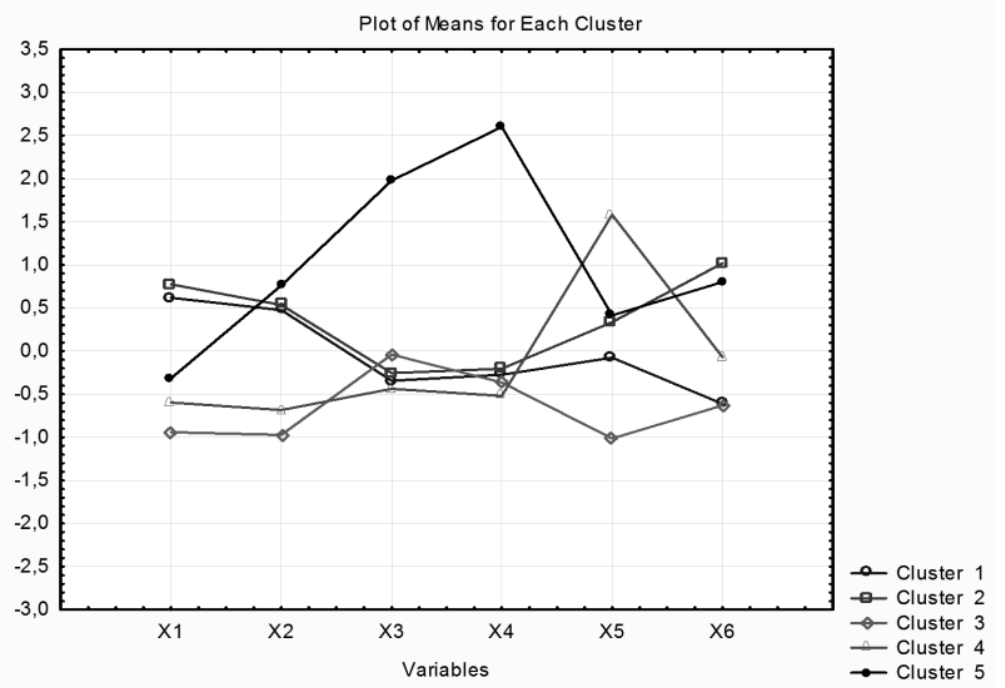

\section{Fig. 3.17. Graphic representation of the average values of indicators by clusters, built on the basis of panel data for the period 2013-2017}

Analyzing the obtained results, we can draw conclusions about the characteristics of the obtained clusters (Fig. 3.17), which are given in table 3.6.

Table 3.6

\section{General characteristics of clusters according to the results of clustering of panel data for the whole studied period}

\begin{tabular}{|c|c|c|}
\hline $\begin{array}{l}\text { Cluster } \\
\text { name }\end{array}$ & Number and characteristics of the cluster & $\begin{array}{l}\text { Countries included in } \\
\text { the cluster for all years } \\
\text { (for some years) }\end{array}$ \\
\hline 1 & 2 & 3 \\
\hline Highest & $\begin{array}{l}\text { Cluster } 5 \text { - cluster of the level of the highest attractiveness of the } \\
\text { higher education system, characterized by a high value of the } \\
\text { indicator of population coverage by higher education, the highest } \\
\text { values of the index of the level of education and student mobility, } \\
\text { especially foreign students arriving in the country for higher } \\
\text { education; high level of expenditures on higher education than total } \\
\text { expenditures on education }\end{array}$ & $\begin{array}{ll}\text { Germany, } & \text { France, } \\
\text { Great Britain } & \end{array}$ \\
\hline High & $\begin{array}{l}\text { Cluster } 2 \text { - cluster of the level of high attractiveness of the higher } \\
\text { education system, characterized by the highest values of the } \\
\text { indicator of higher education coverage and the level of education } \\
\text { index, the average values of student entry and exit mobility and the } \\
\text { highest value of higher education expenditures from total public } \\
\text { expenditures on education }\end{array}$ & 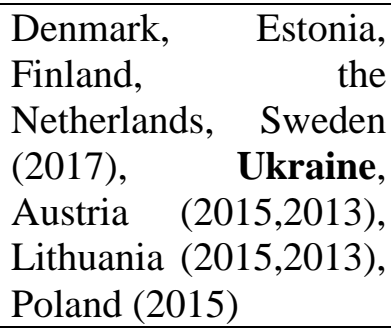 \\
\hline Average & $\begin{array}{l}\text { Cluster } 1 \text { - cluster of the level of average attractiveness of the } \\
\text { higher education system, characterized by the highest values of } \\
\text { indicators of population coverage by higher education and the level } \\
\text { of education index, average values of student entry and exit }\end{array}$ & $\begin{array}{lr}\text { Austria } & (2017), \\
\text { Belgium, } & \text { Bulgaria } \\
(2017), & \text { Czech } \\
\text { Republic, } & \text { Spain, }\end{array}$ \\
\hline
\end{tabular}


The end of the table 3.6

\begin{tabular}{|c|c|c|}
\hline 1 & 2 & 3 \\
\hline & $\begin{array}{l}\text { mobility, low values of education expenditures from general state } \\
\text { expenditures on higher education and low values of higher } \\
\text { education expenditures education from the total cost of education }\end{array}$ & $\begin{array}{lr}\text { Ireland, } & \text { Lithuania } \\
(2017), & \text { Latvia } \\
(2017,2015), & \text { Poland } \\
(2017,2013), & \text { Slovenia }\end{array}$ \\
\hline $\begin{array}{l}\text { Below } \\
\text { average }\end{array}$ & $\begin{array}{l}\text { Cluster } 4 \text { - cluster with below-average attractiveness of the higher } \\
\text { education system, characterized by low values of higher education } \\
\text { coverage indicators and the education level index, the lowest values } \\
\text { of student mobility indicators, the highest values of education } \\
\text { expenditures from general government expenditures and average } \\
\text { expenditures for higher education from education expenditures }\end{array}$ & $\begin{array}{l}\text { Cyprus, Malta, Sweden } \\
(2015,2013), \quad \text { Latvia } \\
(2013)\end{array}$ \\
\hline The lowest & $\begin{array}{l}\text { Cluster 3-cluster with a low level of attractiveness of the higher } \\
\text { education system, characterized by the lowest values of indicators } \\
\text { of higher education coverage and the level of education index, low } \\
\text { level of funding for higher education, low attractiveness of the } \\
\text { national higher education by both national and foreign students }\end{array}$ & $\begin{array}{lr}\text { Croatia, } & \text { Hungary, } \\
\text { Italy, } & \text { Luxembourg, } \\
\text { Portugal, } & \text { Romania, } \\
\text { Slovakia, } & \text { Bulgaria } \\
(2015,2013) & \\
\end{array}$ \\
\hline
\end{tabular}

The analysis of table 3.6 allows us to conclude that for the whole period under the study there is almost the same distribution of countries by cluster groups, i.e. the European countries and Ukraine form stable clusters in terms of the attractiveness of SVO. The changes applied only to Austria, Lithuania, Poland, which downgraded their status in 2017 and moved from the high cluster to the middle, and Latvia, Sweden and Bulgaria, which, in turn, increased the attractiveness of the national higher education system and moved from lower to higher education clusters.

To highlight the country's position on the level of attractiveness of the SHE in the dynamics and study the characteristics of change, the third experiment was implemented, namely, clustering based on the original series, represented by spatial series for 2013, 2015 and 2017 separately. To further isolate the migration effects, based on the application of the k-means method, five homogeneous cluster groups of countries were formed according to the level of attractiveness of the SHE.

The results of the clustering for 2013, 2015 and 2017 are shown in Fig.C.1-C.2 (Annex D). As can be seen from the graphs of k-averages shown in these figures, the greatest similarity of clusters (except for the highest cluster) of countries during 20132017 is observed in terms of X3 and X4, i.e. in terms of student mobility. In the cluster of the highest attractiveness, there is a significant gap in the rate of incoming student mobility compared to other clusters of the countries. This figure is much higher than in other clusters, which indicates the attractiveness of SHE in the countries of the highest cluster 
for foreign students and, thus, confirms the hypothesis about the attractiveness of higher education in these countries.

The results of the third experiment on the clustering of the European countries and Ukraine by the level of attractiveness of SHE, obtained on the basis of the application of the method of K-means (Annex C), are given in table 3.7.

The analysis of distribution of the European countries and Ukraine by cluster groups in the dynamics (Table 3.7) showed that Ukraine in the attractiveness of SVO decreased its position in 2017 compared to 2013 and 2015, due to the loss of competitive positions of the national higher education system and changes in education funding and higher education in particular.

Table 3.7

\section{Distribution of the European countries and Ukraine by cluster groups in 2013, 2015 and 2017}

\begin{tabular}{|c|c|c|}
\hline \multicolumn{3}{|c|}{ I CLUSTER with the highest attractiveness of the SHE } \\
\hline 2013 & 2015 & $2017 \mathrm{p}$ \\
\hline $\begin{array}{l}\text { Germany, France, } \\
\text { The United Kingdom }\end{array}$ & $\begin{array}{l}\text { Germany, France, } \\
\text { The United Kingdom }\end{array}$ & $\begin{array}{c}\text { Germany, France, } \\
\text { The United Kingdom }\end{array}$ \\
\hline \multicolumn{3}{|c|}{ II CLUSTER with high attractiveness of the SHE } \\
\hline $\begin{array}{l}\text { Austria, Denmark, Estonia, } \\
\text { Finland, Lithuania, the } \\
\text { Netherlands, Sweden, Ukraine }\end{array}$ & $\begin{array}{l}\text { Austria, Belgium, Denmark, } \\
\text { Estonia, Finland, Ireland, } \\
\text { Lithuania, the Netherlands, } \\
\text { Poland, Slovenia, Ukraine }\end{array}$ & $\begin{array}{l}\text { Denmark, Estonia, Finland, } \\
\text { Ireland, Lithuania, the } \\
\text { Netherlands, Poland, Slovenia, } \\
\text { Sweden }\end{array}$ \\
\hline \multicolumn{3}{|c|}{ III CLUSTER with medium attractiveness of the SHE } \\
\hline $\begin{array}{c}\text { Belgium, Czech Republic, } \\
\text { Spain, Ireland, Poland, } \\
\text { Slovenia }\end{array}$ & $\begin{array}{c}\text { Cyprus, Czech Republic, } \\
\text { Latvia, Malta, Sweden }\end{array}$ & Spain, Italy, Ukraine \\
\hline \multicolumn{3}{|c|}{ IV CLUSTER with attractiveness of below average of the SHE } \\
\hline $\begin{array}{c}\text { Bulgaria, Croatia, Hungary, } \\
\text { Italy, Luxembourg, Portugal, } \\
\text { Romania, Slovakia }\end{array}$ & $\begin{array}{c}\text { Bulgaria, Spain, Croatia, Italy, } \\
\text { Portugal, Romania, Slovakia }\end{array}$ & $\begin{array}{c}\text { Austria, Belgium, Cyprus, the } \\
\text { Czech Republic, Latvi }\end{array}$ \\
\hline \multicolumn{3}{|c|}{ V CLUSTER with the lowest attractiveness of the SHE } \\
\hline Cyprus, Latvia, Malta & Hungary, Luxembourg & $\begin{array}{c}\text { Bulgaria, Croatia, Hungary, } \\
\text { Luxembourg, Malta, Portugal, } \\
\text { Romania, Slovakia }\end{array}$ \\
\hline
\end{tabular}


Analyzing the table 3.7, we can distinguish the following groups of countries in accordance with the level of stability of the trajectory of the SHE development:

I. Countries with a stable trend of SHE functioning, regardless of which cluster they belong to. Such countries include Germany, Denmark, Estonia, Finland, France, Great Britain, Lithuania, and the Netherlands. It should be noted that these countries are among the highest or high cluster of attractiveness of SHE, i.e. their SHE are stable and these countries do not lose their positions.

The purpose of the third stage of the methodology (Fig. 3.15) is to determine the current position of the country in the European educational space and analysis of the prospects and opportunities for future development of the national higher education system.

Based on the obtained clustering over the years, the analysis of migration changes was performed (Table 3.8), which shows the affiliation to each of the SHE attractiveness clusters of the countries of Europe and Ukraine in the dynamics

Table 3.8

The results of assessing the attractiveness of SHE of the countries in Europe and Ukraine for 2013, 2015, 2017 and the analysis of migration changes

\begin{tabular}{|c|c|c|c|c|}
\hline Country & 2013 & 2015 & 2017 & Migration changes \\
\hline 1 & 2 & 3 & 4 & 5 \\
\hline Austria & II cluster & II cluster & IV cluster & $\mathbf{2} \rightarrow \mathbf{2} \rightarrow \mathbf{4}$ \\
\hline Belgium & III cluster & II cluster & IV cluster & $3 \rightarrow 2 \rightarrow 4$ \\
\hline Bulgaria & IV cluster & IV cluster & V cluster & $4 \rightarrow 4 \rightarrow 5$ \\
\hline Cyprus & V cluster & III cluster & IV cluster & $5 \rightarrow 3 \rightarrow 4$ \\
\hline $\begin{array}{c}\text { The Czech } \\
\text { Republic }\end{array}$ & III cluster & III cluster & IV cluster $p$ & $3 \rightarrow 3 \rightarrow 4$ \\
\hline Germany & I cluster & I cluster & I cluster & $1 \rightarrow 1 \rightarrow 1$ \\
\hline Denmark & II cluster & II cluster & II cluster & $2 \rightarrow 2 \rightarrow 2$ \\
\hline Spain & III cluster $p$ & IV cluster & III cluster & $3 \rightarrow 4 \rightarrow 3$ \\
\hline Estonia & II cluster & II cluster & II cluster & $2 \rightarrow 2 \rightarrow 2$ \\
\hline Finland & II cluster & II cluster & II cluster & $2 \rightarrow 2 \rightarrow 2$ \\
\hline France & I cluster & I cluster & I cluster & $1 \rightarrow 1 \rightarrow 1$ \\
\hline $\begin{array}{c}\text { The United } \\
\text { Kingdom }\end{array}$ & I cluster & I cluster & I cluster & $1 \rightarrow 1 \rightarrow 1$ \\
\hline Croatia & IV cluster & IV cluster & V cluster & $4 \rightarrow 4 \rightarrow 5$ \\
\hline
\end{tabular}


The end of the table 3.9

\begin{tabular}{|c|c|c|c|c|}
\hline 1 & 2 & 3 & 4 & 5 \\
\hline Hungary & IV cluster & V cluster & V cluster & $4 \rightarrow 5 \rightarrow 5$ \\
\hline Ireland & III cluster & II cluster & II cluster & $\mathbf{3} \rightarrow \mathbf{2} \rightarrow \mathbf{2}$ \\
\hline Italy & IV cluster & IV cluster & III cluster & $4 \rightarrow 4 \rightarrow 3$ \\
\hline Lithuania & II cluster & II cluster & II cluster & $2 \rightarrow 2 \rightarrow 2$ \\
\hline Luxembourg & IV cluster & V cluster & V cluster & $4 \rightarrow 5 \rightarrow 5$ \\
\hline Latvia & V cluster & III cluster & IV cluster & $5 \rightarrow 3 \rightarrow 4$ \\
\hline Malta & V cluster & III cluster & V cluster & $5 \rightarrow 3 \rightarrow 5$ \\
\hline The Netherlands & II cluster $p$ & II cluster & II cluster & $2 \rightarrow 2 \rightarrow 2$ \\
\hline Poland & III cluster & II cluster & II cluster & $3 \rightarrow 2 \rightarrow 2$ \\
\hline Portugal & IV cluster & IV cluster & V cluster & $4 \rightarrow 4 \rightarrow 5$ \\
\hline Romania & IV cluster & IV cluster & V cluster & $4 \rightarrow 4 \rightarrow 5$ \\
\hline Slovakia & IV cluster & IV cluster & V cluster & $4 \rightarrow 4 \rightarrow 5$ \\
\hline Slovenia & III cluster & II cluster & II cluster & $\mathbf{3} \rightarrow \mathbf{2} \rightarrow \mathbf{2}$ \\
\hline Sweden & II cluster & III cluster & II cluster & $2 \rightarrow 3 \rightarrow 2$ \\
\hline Ukraine & II cluster & II cluster & III cluster & $\mathbf{2} \rightarrow \mathbf{2} \rightarrow \mathbf{3}$ \\
\hline
\end{tabular}

II. Countries with an unstable trend in the development of SHE, which, in turn, are divided into countries which:

are changing the trajectory of SHE development for the better - Spain, Ireland, Italy, Poland, Slovenia, and Sweden;

are changing the trajectory of SHE development for the worse - Austria, Belgium, Bulgaria, the Czech Republic, Croatia, Hungary, Luxembourg, Portugal, Romania, Slovakia, and Ukraine ;

are with insufficient potential for the development of SHE to linger in a higher cluster of attractiveness of SHE. Such countries include Belgium, Cyprus, Latvia and Malta.

That is, it can be stated that only 8 of the 28 countries (29\%) involved in the study, which have the highest and high level of attractiveness of higher education systems in the transformation of the global higher education system, keep their high rating positions; SHE of 6 countries, which is $21 \%$, have improved their attractiveness in the national and global educational markets; 14 countries $(50 \%)$ have unstable trajectories of attractiveness or lose it, which indicates the need for the state support to create an environment for the 
development of innovative universities.

Thus, as a result of research the following results were obtained:

1. A methodological approach aimed at determining the international position of the higher education system of Ukraine in terms of its attractiveness in the national and European educational markets has been developed. The assessment of the attractiveness of the SHE of Ukraine was carried out on the basis of a comparative analysis with 27 countries of the European Union. The choice of many of these countries is justified by Ukraine's integration efforts for implementation in the European community;

2. The difference of the proposed methodological approach is contained in its exploratory nature. It is based on three experiments aimed at:

substantiation of expedient metrics and rules of grouping of research objects in cluster groups;

conducting clustering on the basis of panel data for the period 2013-2017; conducting spatial clustering separately for 2013, 2015 and 2017.

3 . The analysis of the results of 2 experiments allowed to determine the overall level of attractiveness of the SHE of Ukraine for 5 years and to determine that the national SHE is in a cluster of high attractiveness, characterized by the highest value of higher education coverage and education index, average values of student entry and outbound mobility and the highest value of higher education expenditures out of total public expenditures on education. But the results of Experiment 3 proved that in our country, unfortunately, there is a negative trend towards the loss of international positions. Thus, in 2017, Ukraine fell into the 3rd cluster - a cluster of medium attractiveness of the SHE. That is, the combination of the results of experiments 2 and 3 revealed the latent reasons for the formation of a negative trend. In these conditions, the state and the Ministry of Education and Science of Ukraine should create a stimulating basis and environment for real autonomy of universities, and their transformation into innovative, entrepreneurial educational institutions and further systematic modernization of the national structure of higher education. 


\subsection{Development of methodological support for the assessment and} stratification of national HEI according to the level of innovation activity

The purpose of the methodology for the assessment and stratification of HEI of Ukraine is to determine the level of innovative activity of HEI and the formation of homogeneous universities at this level. The scheme of methodologies is shown in Fig. 3.18 .

Block 1. The evaluation of national educational institutions was carried out according to the selected indicators (see paragraph 3.1) in terms of each component for the period 2012-2013, 2014-2015 and 2018-2019. Based on the results of the analysis, integrated indicators were calculated, the value of which provides information on stratification and assessment of the level of innovative-active HEIbefore and after the enactment of the Law on Higher Education (2014), and to date.

Block 2. To construct an integrated indicator for the assessment of innovative-active HEI, it is proposed to use the method of taxonomy [176], which allows to reduce the set of features of the studied phenomenon to one synthetic feature.

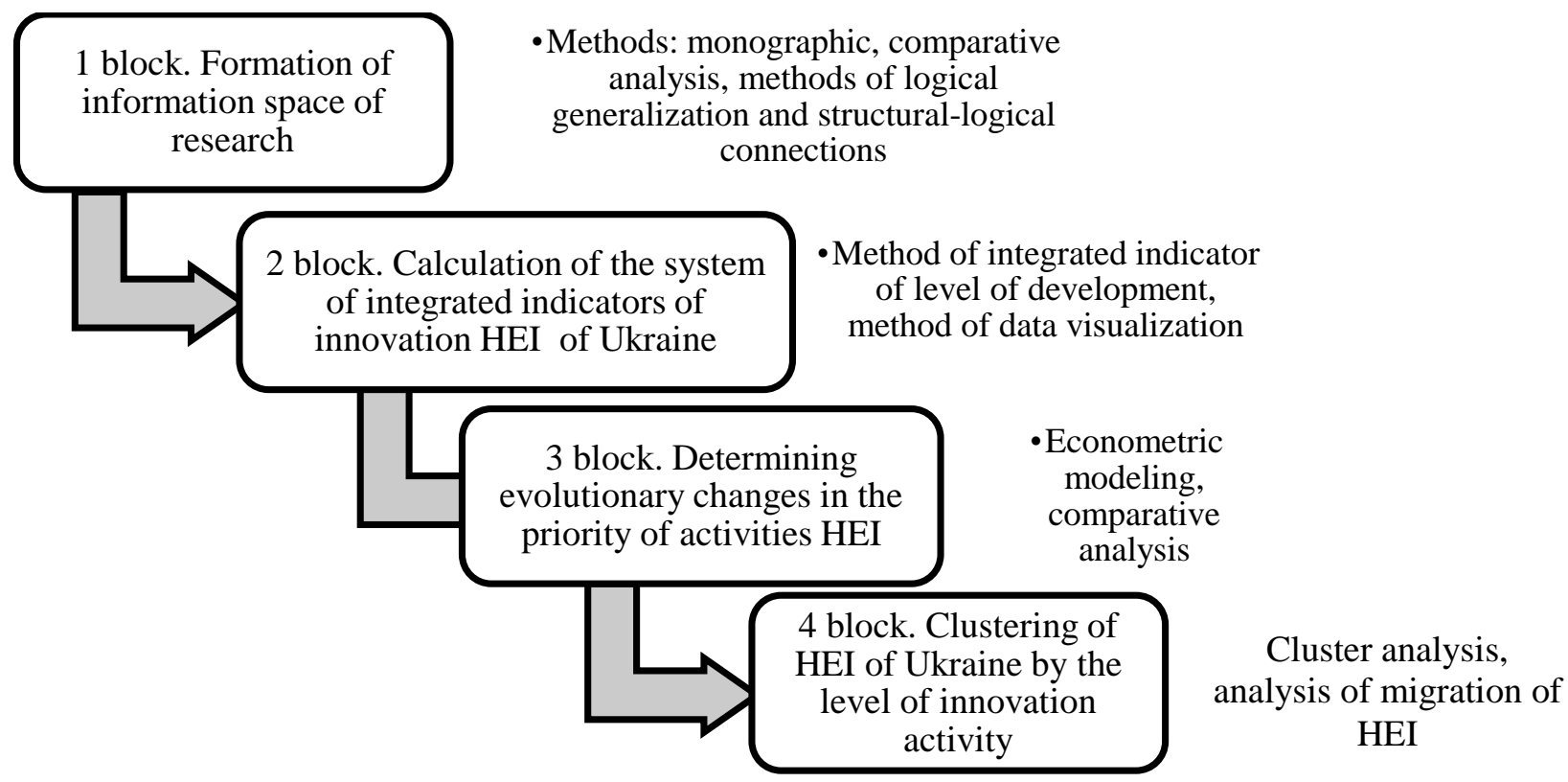

Fig. 3.18. Scheme of the stages of methodological support for determining the attractiveness of the national system of higher education 
The algorithmic model for calculating the integrated indicator by the taxonomy method is presented in Fig. 3.19.

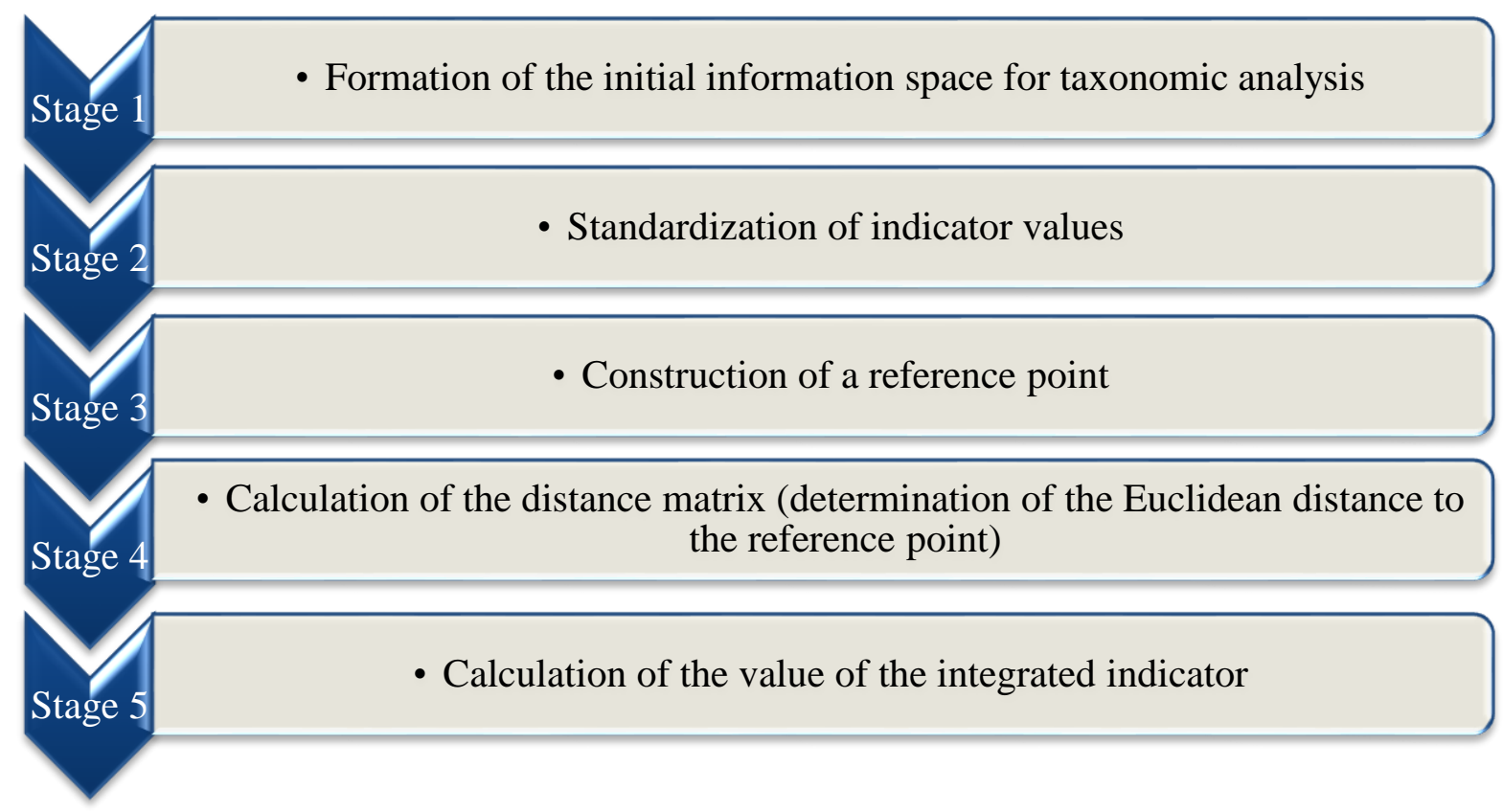

Fig. 3.19. Algorithmic model for calculating the integrated indicato

Obtaining an integrated indicator for evaluating an innovative-active institution of higher education is based on the formula (3.1):

$$
Q_{i}=\frac{c_{i}}{\bar{c}+3 \cdot S}, \quad c_{i}=\sqrt{\sum_{j=1}^{m}\left(z_{i j}-z_{j e}\right)^{2} \cdot w_{j}}, \bar{c}=\frac{1}{T} \sum_{i=1}^{n} c_{i}, \quad S=\sqrt{\frac{1}{n-1} \sum_{i=1}^{n}\left(c_{i}-\bar{c}\right)^{2}},
$$

where $c_{i}$-distance from the reference point; $z_{j e}$ - the reference value of the $\mathrm{j}$-th indicator which is formed as follows: $z_{j e}=\max _{i} z_{i j}$, if the $\mathrm{j}$-th sign is a stimulant, $z_{j e}=\min _{i} z_{i j}$, if the $\mathrm{j}$-th sign is a destimulator; $w_{j}$ - weight value of the $\mathrm{j}$-th indicator; $j=[1 \div m] ; i=$ $[1 \div n], z_{i j}$ - standardized value of the $\mathrm{j}$-th indicator for the $\mathrm{i}$-th object, obtained by the formula (3.2):

$$
z_{i j}=\frac{x_{i j}-\bar{x}_{j}}{\sqrt{\frac{1}{n-1} \sum_{i=1}^{n}\left(x_{i j}-\bar{x}_{j}\right)^{2}}}
$$


where $x_{i j}$ - the value of the $\mathrm{j}$-th indicator for the $\mathrm{i}$-th object, $\bar{x}_{j}$ - the average or reference value of the $j$-th indicator.

The integrated indicator obtained by this method is a normalized value, i.e. varies from 0 to 1 , which allows to determine the trend of its value as for each component of institutional autonomy, and for all components in general.

By using this method we obtain a system of integrated indicators containing the following set:

$$
\left\{I_{\text {total }}, I_{\text {educ }}, I_{\text {sc-tech }}, I_{\text {innov }}, I_{\text {inter }},\right\}
$$

where $I_{\text {total }}$ - the general integral indicator of innovative activity of HEI;

$I_{e d u c}-$ local integrated indicator that characterizes educational activities;

$I_{s c-t e c h}$ - local integrated indicator that characterizes scientific and technical activities;

$I_{\text {innov }}$ - local integrated indicator that characterizes innovation activity;

$I_{\text {inter }}-$ local integrated indicator that characterizes international activity.

Table 3.9 shows the dynamics of the overall integrated indicator for assessing the innovative activity of the higher education institutions of Ukraine; calculations of the local integrated indicators by the type of activity of IAU are given in Annex D (Table D.1-D.4).

Table 3.9

\section{Dynamics of the general integral indicators of an estimation of educational activity of HEI}

\begin{tabular}{|c|c|c|c|c|}
\hline HEI & $\begin{array}{l}2012- \\
2013\end{array}$ & $\begin{array}{l}2014- \\
2015\end{array}$ & $\begin{array}{l}2018- \\
2019\end{array}$ & $\begin{array}{c}\text { The rate of } \\
\text { change in } 2019 \\
\text { compared to } \\
2012, \%\end{array}$ \\
\hline 1 & 2 & 3 & 4 & 5 \\
\hline Berdyansk State Pedagogical University & 0.473 & 0.422 & 0.496 & 1.050 \\
\hline Berdyansk University of Management and Business & 0.428 & 0.468 & 0.503 & 1.176 \\
\hline Bila Tserkva National Agrarian University & 0.415 & 0.492 & 0.515 & 1.241 \\
\hline Bukovynian State Medical University & 0.399 & 0.413 & 0.468 & 1.173 \\
\hline Bukovynian State University of Finance and Economics & 0.476 & 0.462 & 0.472 & 0.993 \\
\hline $\begin{array}{l}\text { Ukraine Open International University of Human } \\
\text { Development }\end{array}$ & 0.471 & 0.433 & 0.379 & 0.804 \\
\hline $\begin{array}{l}\text { Vinnytsia State Pedagogical University named after } \\
\text { Mykhailo Kotsyubynskyj }\end{array}$ & 0.462 & 0.473 & 0.421 & 0.912 \\
\hline Vinnytsia National Agrarian University & 0.451 & 0.425 & 0.440 & 0.975 \\
\hline National Pirogov Memorial Medical University & 0.482 & 0.436 & 0.479 & 0.992 \\
\hline
\end{tabular}


The end of the table 3.9

\begin{tabular}{|c|c|c|c|c|}
\hline 1 & 2 & 3 & 4 & 5 \\
\hline $\begin{array}{l}\text { Kyiv State Academy of Water Transport named after } \\
\text { Hetman Petro Konashevych-Sahaydachniy }\end{array}$ & 0.415 & 0.350 & 0.499 & 1.204 \\
\hline Kyiv Medical University UANM & 0.570 & 0.401 & 0.607 & 1.066 \\
\hline Kyiv International University & 0.557 & 0.409 & 0.413 & 0.741 \\
\hline National Economic University named after Vadym Hetman & 0.599 & 0.423 & 0.525 & 0.876 \\
\hline Kyiv National Linguistic University & 0.348 & 0.353 & 0.341 & 0.981 \\
\hline Kyiv National University of Trade and Economics & 0.519 & 0.356 & 0.298 & 0.574 \\
\hline Kyiv National University of Construction and Architecture & 0.454 & 0.402 & 0.493 & $\mathbf{1 . 0 8 7}$ \\
\hline Taras Shevchenko National University of Kyiv & 0.695 & 0.728 & 0.644 & 0.927 \\
\hline Kyiv National University of Culture and Arts & 0.481 & 0.374 & 0.535 & 1.111 \\
\hline $\begin{array}{l}\text { Kyiv National I. K. Karpenko-Kary Theatre, Cinema and } \\
\text { Television University }\end{array}$ & 0.424 & 0.402 & 0.466 & 1.098 \\
\hline Kyiv National University of Technology and Design & 0.497 & 0.379 & 0.387 & 0.779 \\
\hline Borys Hrinchenko Kyiv University & 0.452 & 0.335 & 0.426 & 0.942 \\
\hline $\begin{array}{l}\text { Kyiv University of Law of the National Academy of } \\
\text { Sciences of Ukraine }\end{array}$ & 0.485 & 0.329 & 0.510 & 1.052 \\
\hline \multicolumn{5}{|l|}{.... } \\
\hline Simon Kuznets Kharkiv National University of Economics & 0.431 & 0.328 & 0.395 & 0.917 \\
\hline Kharkiv National Medical University & 0.360 & 0.382 & 0.454 & 1.260 \\
\hline H.S. Skovoroda Kharkiv National Pedagogical University & 0.434 & 0.308 & 0.357 & 0.822 \\
\hline
\end{tabular}

The analysis of the overall integrated indicators for assessing the innovative activity of HEI (see Table 3.9) showed that not all higher education institutions have a positive growth rate in the 2018-2019 academic year compared to the 2012-2013 academic year. The HEI that have the maximum tendency to increase are highlighted in bold in the table and they form the core of the national system of higher education. The calculation of the local integrated indicators by the type of activity of the HEI (Annex D) showed that most higher education institutions have a positive dynamics in terms of educational activity, but the opposite trend is observed for other local indicators.

The revealed tendency of change of integral coefficients will allow to allocate those indicators and local indicators in the field of educational, scientific and technical, international and innovative activities to which it is necessary to pay attention when making administrative decisions on increase of innovative activity of certain HEI.

Block 3. Econometric modeling was used to assess the impact of local integrated indicators of evaluation of educational, scientific, technical, innovative and international activities on the overall integrated indicator of evaluation of innovative-active HEI. The calculation results of the parameters of the models of dependence of the general indicator of the development of innovative-active HEI on the local integrated ones are presented in table 3.10 . 
The results of building an economic and mathematical model

\begin{tabular}{|c|c|c|c|c|c|}
\hline & $\mathrm{b}^{*}$ & Std. Err. of $b^{*}$ & $\mathrm{~b}$ & Std. Err. of b & p-value \\
\hline \multicolumn{6}{|c|}{ Academic year 2012-2013 $\left(\mathrm{R}^{2}=0.753\right)$} \\
\hline Intercept & & & 0.079 & 0.017 & 0.0001 \\
\hline$I_{e d u c}$ & 0.363 & 0.038 & 0.254 & 0.026 & 0.0005 \\
\hline$I_{s c-t e c h}$ & 0.362 & 0.038 & 0.189 & 0.019 & 0.0005 \\
\hline$I_{\text {innov }}$ & 0.586 & 0.0365 & 0.233 & 0.015 & 0.0032 \\
\hline Inter & 0.448 & 0.037 & 0.165 & 0.014 & 0.0041 \\
\hline \multicolumn{6}{|c|}{ Academic year 2014-2015 $\left(\mathrm{R}^{2}=0.796\right)$} \\
\hline Intercept & & & 0.023 & 0.012 & 0.0651 \\
\hline$I_{e d u c}$ & 0.345 & 0.041 & 0.212 & 0.025 & 0.0025 \\
\hline$I_{s c-t e c h}$ & 0.323 & 0.040 & 0.255 & 0.032 & 0.0035 \\
\hline$I_{\text {innov }}$ & 0.482 & 0.033 & 0.247 & 0.017 & 0.0002 \\
\hline$I_{\text {inter }}$ & 0.422 & 0.033 & 0.236 & 0.018 & 0.0012 \\
\hline \multicolumn{6}{|c|}{ Academic year 2018-2019 $\left(\mathrm{R}^{2}=0.841\right)$} \\
\hline Intercept & & & 0.057179 & 0.021598 & 0.008795 \\
\hline$I_{e d u c}$ & 0.243852 & 0.044906 & 0.196137 & 0.036119 & 0.001470 \\
\hline$I_{s c-t e c h}$ & 0.369495 & 0.043423 & 0.322592 & 0.037911 & 0.001789 \\
\hline$I_{\text {innov }}$ & 0.550734 & 0.043445 & 0.493694 & 0.015280 & 0.003470 \\
\hline$I_{\text {inter }}$ & 0.460407 & 0.045032 & 0.231784 & 0.022671 & 0.004280 \\
\hline
\end{tabular}

Thus, the system of economic and mathematical models of the impact of educational, scientific, technical, innovative and international activities on the general level of innovative-active educational institution are as follows:

For the academic year 2012-2013:

$I_{\text {total }}=0.079+0.254 * I_{\text {educ }}+0.189 * I_{\text {sc-tech }}+0.233 * I_{\text {innov }}+0.165 * I_{\text {inter }}$

For the academic year 2014-2015:

$I_{\text {total }}=0.023+0.212 * I_{\text {educ }}+0.255 * I_{\text {sc-tech }}+0.247 * I_{\text {innov }}+0.236 * I_{\text {inter }}$

For the academic year 2018-2019:

$I_{\text {total }}=0.057+0.196 * I_{\text {осв }}+0.323 * I_{\text {sc-tech }}+0.494 * I_{\text {innov }}+0.232 * I_{\text {inter }}$

Based on the results of the constructed models, the following conclusions can be made:

1) in the academic year 2012-2013, the general activity of the HEI was significantly influenced by educational activities, and then by innovative activities. The rating of the impact of the analyzed activities on the innovative activity of the HEI is presented in the 
form of a tuple:

$$
\left\{I_{\text {educ }} \rightarrow I_{\text {innov }} \rightarrow I_{\text {sc-tech }} \rightarrow I_{\text {inter }}\right\}=I_{\text {total }}
$$

2) in the academic year 2014-2015, in connection with the changes that took place in the educational space (adoption of the law "On Higher Education"), innovative-active level of educational institution depended on scientific and technical activities, i.e. the system of influence was as follows:

$$
\left\{I_{\text {sc-tech }} \rightarrow I_{\text {innov }} \rightarrow I_{\text {inter }} \rightarrow I_{\text {educ }}\right\}=I_{\text {total }}
$$

3) in the academic year 2018-2019, the level of innovative-active HEI is influenced by the innovative activity of the university:

$$
\left\{\boldsymbol{I}_{\text {innov }} \rightarrow I_{\text {sc-tech }} \rightarrow I_{\text {inter }} \rightarrow I_{\text {educ }}\right\}=I_{\text {total }}
$$

All this confirms the fact that innovation today is the dominant factor in the development of higher education, the most important factor in its successful modernization in the global transformation of the higher education system. If earlier HEIcould function successfully by concentrating attention mainly on educational potential, today there is a necessity of their interaction with stakeholders that allows to form the university of entrepreneurial type.

Block 4. We will stratify higher education institutions at the national level by year using the clustering method. The initial information of stratification was made by 4 local integrated indicators on 193 institutions of higher education, it is proved that it is expedient to classify the initial set into 3 groups (Fig. 3.20).

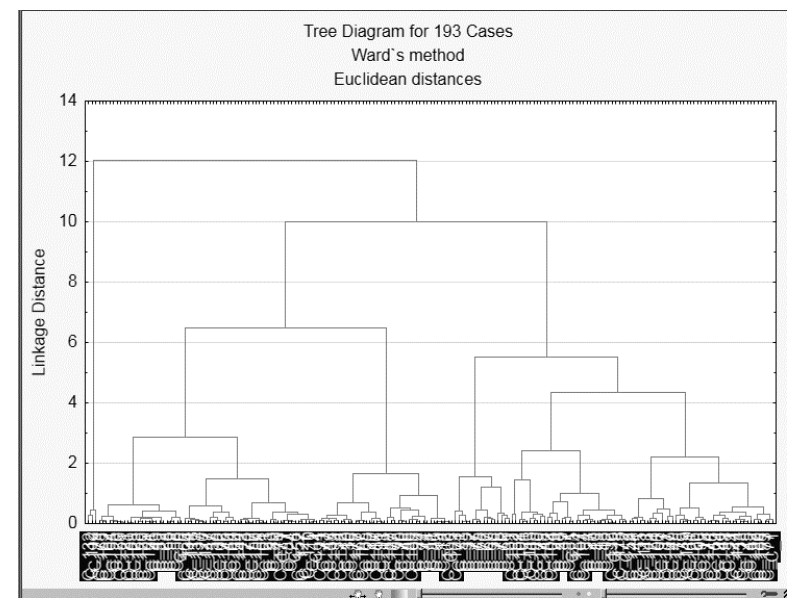

Fig. 3.20. Dendrogram of stratification of higher education institutions for the academic year 2012-2013 
The stratification of HEI was carried out for the of 2014-2015 and 2018-2019. The results of the stratification of HEI are presented in Annex D and the fragment - in Table 3.11.

Table 3.11

The results of stratification of innovative-active HEI of Ukraine (fragment)

\begin{tabular}{|c|c|c|}
\hline \multicolumn{3}{|c|}{ Academic years } \\
\hline 2012-2013 & 2014-2015 & $2018-2019$ \\
\hline 1 & 2 & 3 \\
\hline \multicolumn{3}{|c|}{1 cluster of HEI with the highest innovation and activity } \\
\hline Berdyansk University of & Berdyansk University of & Berdyansk University of \\
\hline Management and Business, & Management and Business, & Management and Business, \\
\hline Bukovynian State University of & Bukovynian State University of & Bukovynian State University of \\
\hline Finance and Economics, E. & Finance and Economics, E. & Finance and Economics, E. \\
\hline Pirogov Vinnytsia National & Pirogova Vinnytsia National & Pirogov Vinnytsia National \\
\hline Medical University, Kyiv & Medical University, National & Medical University., Vinnytsia \\
\hline International University, Kyiv & 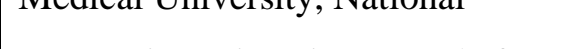 & National Technical University, \\
\hline $\begin{array}{l}\text { National Economic University } \\
\text { named after Vadym Hetman, }\end{array}$ & $\begin{array}{l}\text { Economic University named after } \\
\text { Vadym Hetman. Taras Shevchenko }\end{array}$ & National Economic University \\
\hline Kyiv National Linguistic & National University of Kyiv, & named after Vadym Hetman, \\
\hline University, National Technical & National Academy of Statistics, & $\begin{array}{l}\text { Taras Shevchenko National } \\
\text { University of Kviv Lviv State }\end{array}$ \\
\hline University "Kharkiv Polytechnic & Accounting and Auditing, National & University of Physical Culture, \\
\hline University of Ukraine "Kyiv & $\begin{array}{l}\text { Academy of Management, } \\
\text { Bogomolets National Medic }\end{array}$ & National Academy of Statistics, \\
\hline Polytechnic Institute", National & University, Kharkiv Polytechnic & $\begin{array}{l}\text { Accounting and Auditing, } \\
\text { National Academy of }\end{array}$ \\
\hline $\begin{array}{l}\text { University "Kyiv-Mohyla } \\
\text { Academy ", Lviv Polytechnic }\end{array}$ & National University, National & Management, Bogomolets \\
\hline National University, National & $\begin{array}{l}\text { Technical University of Ukraine } \\
\text { "Kviv Polvtechnic Institute" }\end{array}$ & National Medical University, \\
\hline University of Life and & National University "Kyiv-Mohyla & National Technical University \\
\hline $\begin{array}{l}\text { Environmental Sciences of } \\
\text { Ukraine, Yaroslav the Wise }\end{array}$ & Academy", V. Karazina KhNU et & National Technical University of \\
\hline National University of Law, etc. & & $\begin{array}{l}\text { Ukraine "Kyiv Polytechnic } \\
\text { Institute" and others. }\end{array}$ \\
\hline \multicolumn{3}{|c|}{ 2nd cluster of HEI with average innovative activity } \\
\hline Lviv National Agrarian & Kyiv National Linguistic & Ivan Franko National University \\
\hline University, Lviv National & University, Kyiv National & of Lviv, Mariupol State \\
\hline University of Veterinary & University of Culture and Arts, & University, International \\
\hline Medicine and Biotechnology & Lutsk National Technical & University of Economics and \\
\hline named after S Gzhytsky, Ivan & , Lviv Institute of & Humanities, National \\
\hline Franko National University of & Economics and Tourism, & Metallurgical Academy of \\
\hline Mykolayiv National & Ternopil National University of & Ukraine, National Aviation \\
\hline Agrarian University, & Economics, Ukrainian State & University, \\
\hline International University of & University of Chemical & Ternopil National University of \\
\hline Economics and Humanities, & Technology, Kharkiv National & Economics, Ukrainian State \\
\hline National Aviation University, & Automobile and Road University, & University of Chemical \\
\hline National Aerospace University. & Kherson State University, & Technology, Kharkiv National \\
\hline kovsky "Kharkiv & Chernihiv National Technological & Automobile and Road \\
\hline Aviation Institute" and others. & sity, Petro Mohyla Black & University, Kherson State \\
\hline & Sea State University and others. & University, Chernihiv National \\
\hline & & $\begin{array}{l}\text { University of Technology and } \\
\text { others. }\end{array}$ \\
\hline \multicolumn{3}{|c|}{3 rd cluster of HEI with low innovation activity } \\
\hline Vinnytsia State Pedagogical & State University of Economics and & Vinnytsia State Pedagogical \\
\hline & Technology of Transport, & sity named after Mykhailo \\
\hline Mykhailo Kotsyubynsky, & Dniprodzerzhynsk State Technical & Kotsyubynsky, Vinnytsia \\
\hline
\end{tabular}


The end of the table 3.11

\begin{tabular}{|l|l|l|}
\hline \multicolumn{1}{|c|}{1} & \multicolumn{1}{|c|}{2} & \multicolumn{1}{|c|}{3} \\
\hline Vinnytsia National Agrarian & University, Dnipropetrovsk State & National Agrarian University, \\
University, Glukhiv National & Institute of Physical Culture and & Glukhiv National Pedagogical \\
Pedagogical University, State & Sports, Donbas State Machine- & University, \\
University of Economics and & Building Academy, Donbas & Dniprodzerzhynsk State \\
Technology of Transport, & National Academy of Civil & Technical University, Donbas \\
Donbass State Engineering & Engineering and Architecture, & State Academy of Mechanical \\
Academy, Donbass National & Donbas State Technical & Engineering, Donbas National \\
Academy of Civil Engineering & University, & Academy of Civil Engineering \\
and Architecture, Ivano- & Donetsk State Music Academy & and Architecture, Donbas State \\
Frankivsk National Technical & named after S Prokofiev, Donetsk & Pedagogical University, \\
University of Oil and Gas, & State University of Management, & V.O. Sukhomlinskiy National \\
Lviv National Medical & Classical Private University, & University of Mykolaiv, \\
University named after Danylo & Kremenets Regional Humanitarian & International University of \\
Halytsky, V.O. Sukhomlinskiy & and Pedagogical Academy. Taras & Science and Technology, \\
National University of Mykolaiv, & Shevchenko, V.O. Sukhomlinskiy & International University of \\
International University of & National University of Mykolaiv, & Finance, National Aerospace \\
Science and Technology, & International University of Science & University. ME Zhukovsky \\
International University of & and Technology, International & "Kharkiv Aviation Institute", \\
Finance and others. & University of Finance and others. & Odessa National Maritime \\
& & University and others. \\
\hline
\end{tabular}

In the academic year 2014-2015, such positions as Petro Mohyla Black Sea State University $(2 \rightarrow 3)$, Odessa National University of Economics $(2 \rightarrow 3)$, Kyiv National University of Culture and Arts $(1 \rightarrow 2)$, Kyiv National I. K. Karpenko-Kary Theatre, Cinema and Television University $(1 \rightarrow 2)$, Taras Shevchenko National University of Luhansk $(1 \rightarrow 2)$ erred in their position on innovation and activity. Such changes were related to the adoption of the new Law of Ukraine "On Higher Education", the development of the Concept for the development of higher education for the period 20152025, which set new goals and performance ratios for higher education on the way to the European and global educational space for ensuring high-tech and innovative development of the country, the needs of society. Today the main task of innovative-active activity of the university is to acquire scientific knowledge by conducting research and development and their direction on creation and introduction of new competitive technologies, ensuring innovative development of society and training of specialists of innovative type which, in turn, plays an important role in formation the ranking of the university among other HEI.

Thus, the stratification of the HEI of Ukraine allowed to obtain the following results:

a set of national HEI is defined, which constantly carry out various innovations in certain types of their activity. As a result, they are the leading HEI that are included in the 
world rankings and occupy high positions in the national rankings. Such HEI are the driving force of further development of national HEI in the direction of integration into the world educational and scientific space;

the obtained values of the integrated indicators of the HEI of Ukraine establish not only the rating of universities according to the level of their innovative activity, but can also be used as reference values for HEI with a lower rating. That is, on the basis of the obtained values in further research, there will be formed systems of management decisions to support and further strengthen the innovation activity of a particular HEI within their resource constraints.

\subsection{Educational migration: challenges and threats to the higher education system and the activities of innovative-active HEI}

One of the characteristic modern trends in the development of the higher education system is the rapid growth of student migration. Today, more and more young people, choosing a future profession, have the opportunity to study in both domestic and foreign educational institutions. When choosing an educational institution, a certain number of entrants choose educational institutions of neighboring regions, countries because of the higher status and level of education than where they live. For a certain group of such entrants and students it is, first of all, a desire to live in a more developed and economically successful country in the future, others receive education abroad in order to return to their country and develop it, but there are also those who go only through the HEI brand, or to be away from the family. It should be noted that a certain part of young people go abroad to receive not the first higher education, but in order to improve the existing one, or to get a second education. It should be noted that this topic is relevant for Ukraine, as there are several major student centres in the country, where applicants from other regions come to receive higher education.

The prerequisites for educational migration are many factors, therefore, it is advisable to first analyze the essence of the term "educational migration" and related categories. Educational migration is the subject of research by a number of scholars, who mainly consider it in the context of the problems of interethnic interaction and adaptation in a multicultural environment. Scientific works of such domestic scientists as L.I. 
Beztelesna [44], K.S. Brenzovych, O.C. Grinkevich [51, 97, 98], L.A. Zhurakovska [288], E.M. Libanova, I.L. Petrova, L.V. Semiv [212, 215], E.V. Stadny, I. Khomyshyn [224, 104], V.M. Filatov [83] and many others, are devoted to the analysis of the impact of European integration processes on the domestic economy, labour market, assessment of labour and educational migration. In their research, scientists analyze the professional and migration intentions of applicants and students, the role of education as a tool of migration policy and integration policy, pay attention to the mechanisms of adaptation of migrants to the national system of higher education.

Summarizing the existing results of research by scientists in the field of educational migration, we can provide the following definitions of the essence of this category (Table $3.12)$.

Table 3.12

\section{The essence of the category "educational migration"}

\begin{tabular}{|c|c|}
\hline Author & Characteristics of the category "educational migration" \\
\hline $\begin{array}{l}\text { V.M. Filatov , J.V. } \\
\text { Romashova [83], } \\
\text { S.V. Ryazantsev [208], } \\
\text { K.M. Alieksieieva [33] }\end{array}$ & $\begin{array}{l}\text { unites the spatial movements of people wishing to receive education in a } \\
\text { territory other than their permanent place of residence. At the same time, } \\
\text { the separation of educational migration as a component of educational } \\
\text { migration is considered inappropriate, as educational migration is a broader } \\
\text { concept }\end{array}$ \\
\hline $\begin{array}{l}\text { O.S. Grinkevich [96], } \\
\text { T.G. Vasyltsiv [84] }\end{array}$ & $\begin{array}{l}\text { it is a mass socio-cultural phenomenon associated with the movement of } \\
\text { people outside the region or country of residence in order to improve their } \\
\text { educational level, to acquire new knowledge. The terms related to } \\
\text { educational migration, namely "cross-border education" and "academic } \\
\text { mobility", are additionally used by the expert community to denote the } \\
\text { processes of human movement for research and teaching in scientific circles }\end{array}$ \\
\hline I. Romanenko [200] & $\begin{array}{l}\text { is mainly temporary resettlement for the purpose of receiving education and } \\
\text { advanced training outside the administrative-territorial unit of permanent } \\
\text { residence }\end{array}$ \\
\hline $\begin{array}{l}\text { K. S. Brenzovich [51], } \\
\text { L. O. Pysmenna [170] }\end{array}$ & $\begin{array}{l}\text { is the movement of people between countries in order to obtain education } \\
\text { at different levels, regardless of the period of stay outside the country of } \\
\text { origin }\end{array}$ \\
\hline K.S. Brenzovich [51] & $\begin{array}{l}\text { educational migration covers the movement of people who belong to } \\
\text { different age groups, they are consumers of educational services in another } \\
\text { country, participants in academic exchange programs outside the host } \\
\text { country }\end{array}$ \\
\hline O.D. Vykhovanets [87] & $\begin{array}{l}\text { consists of two types of relocation: relocation, i.e. the return of scientists, } \\
\text { entrepreneurs, professionals who have previously gone to study or intern } \\
\text { abroad, and scientific and educational migration, i.e. migration of students } \\
\text { and trainees between countries to gain new competencies and inclusion in } \\
\text { international network labour, research and communicative relations }\end{array}$ \\
\hline L.Semiv [215] & $\begin{array}{l}\text { projects the impact of international educational migration on territorial } \\
\text { economic systems }\end{array}$ \\
\hline L.I. Beztelesna [44] & $\begin{array}{l}\text { educational migration as a tool for implementing strategic human capital } \\
\text { management }\end{array}$ \\
\hline
\end{tabular}


Thus, summarizing the different characteristics of educational migration, it can be noted that all researchers understand educational migration as a set of movements of people of different ages in order to obtain education at different levels and for different periods.

Educational migration covers both internal and external movements and is always aimed at acquiring new professional or scientific competencies, regardless of the prospects for further migration or return.

The related concepts of educational migration are also the concepts of "academic mobility", "cross-border education", "educational migration", "emigration through education".

Thus, the study [51] notes that the provision of educational services by a foreign institution of higher education (HEI) (export of services), the so-called "cross-border education", does not always lead to the movement of the consumer of the service abroad. The latest methods of e-learning allow you to acquire knowledge remotely while being in your country. Such training, according to the author [59], is almost devoid of the features of educational migration, as it does not involve the integration of the learner into another cultural space, reduces the possibility of educational migration into labour, and, therefore, the consequences of this type of education will have mostly personal effect.

Defining the meaning of the concept of "student migration", it can be considered narrower than the concept of "educational migration", as the latter includes training in educational institutions of different levels, covers the trips of both students and teachers. Student migration can be both individual (i.e. self-organized) and academic (within international academic exchange programs). Thus, student migration can be defined as the conscious temporary movement of people outside the country of their citizenship in order to obtain knowledge and obtain a higher education degree.

Educational migration, which is formed on the exchange of students between countries, is positive for the development of education and science, and enriches both countries with knowledge. Specialists return home and use their experience in the national economy, raising the intellectual level of their country. At the same time, there is a set of such migrants who do not plan to return home and, therefore, such processes are called "brain drain".

With the increase in the outflow of future entrants and students to study abroad, the 
issues of generalization and analysis of the impact of educational migration processes on the market of higher education of the host country and on the market of educational services of the donor country are becoming increasingly important. At the same time, when studying educational migration, one should take into account both positive and negative consequences. Researchers [198] propose the following scheme of distribution of opportunities / challenges and threats that are inherent in educational migration (Fig. 3.21).

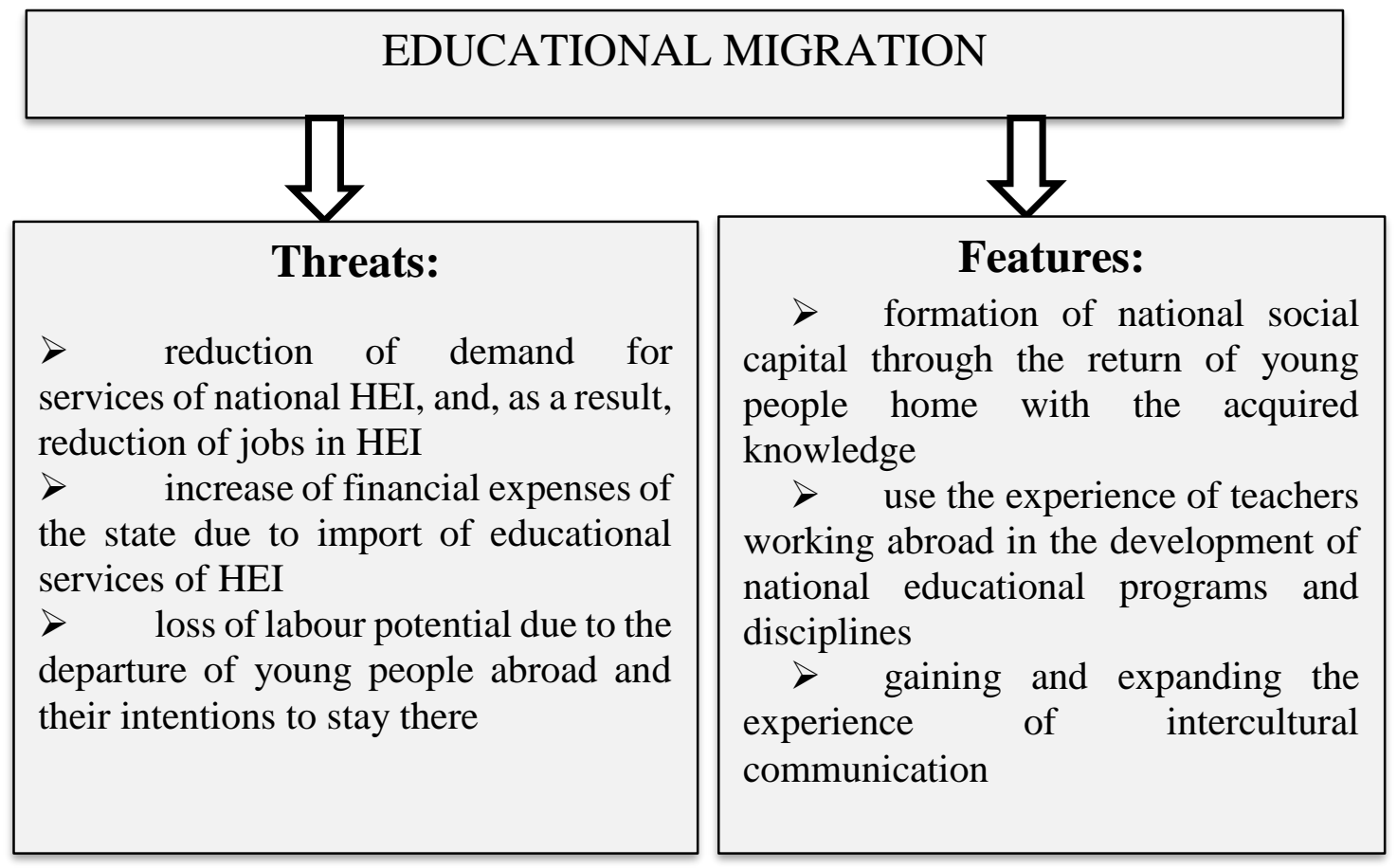

Fig. 3.21. Threats and potential opportunities for educational migration

Figure 3.21 shows the most pressing threats and opportunities for educational migration in the modern world. According to the World Education Monitoring Report [158], there is a two-way link between migration and education, the main point of which is that:

for countries from which migrants leave, the prospects of emigration reduce the incentives to invest in national education, the probability of migration among educated people to obtain a second education or even move to permanent residence and work abroad increase;

for host countries, the legal framework for providing migrants with the right to education is being improved, national training programs are being revised to attract 
foreign students, and student mobility is being encouraged through the internationalization of higher education.

According to the experts [212], modern educational migration has led to the emergence of the fifth wave of migration. Recently, the volume and intensity of migration has increased both for movements between regions and abroad. Ukrainian students, scientists and researchers migrate in order to implement individual educational, academic, research programs in foreign HEI. At the same time, the author [212] suggests using educational migration as one of the indicators of migration in general. This makes some sense, as those who migrate to study are increasingly seeking employment in the region or country where they study. As motivations for educational migration, L.K. Semiv notes that in the context of the European integration and growth of migration processes, the central aspect that determines the balance between academic mobility and educational migration is to identify and take into account the main motives of educational migrants inside and outside the country. These motives characterize the socio-economic, political, socio-demographic conditions of educational migration and are decisive in the ratio of outgoing and incoming educational migrants $[42,212]$.

At the same time, it should be noted that the main motivating factors of educational migration in the Ukrainian society are the problem of employment of freelance graduates, incomes received by graduates in certain specialties, unemployment rate, militarypolitical situation in the country. In addition to the above conditions of motivational impact, the peculiarity of the environment of educational migration is also determined by the general migration situation and policy in the regions and the country as a whole (indicator of migration growth or reduction within interstate migration), the level and quality of life of the population of the country and individual regions (according to the human development index).

Qualitative characteristics of external educational migration according to certain criteria are given in table 3.13 [42].

Migration is characterized by a complex of socio-cultural, demographic, political and economic factors. Thus, the definition of the main indicators, factors and consequences of educational migration, taking into account its types, is a necessary condition for substantiating the directions and tools to improve the efficiency of public administration of these processes. 
Table 3.13

\section{Characteristics of the types of external educational migration}

\begin{tabular}{|c|c|}
\hline $\begin{array}{c}\text { Types of educational migration by } \\
\text { criteria }\end{array}$ & Characteristic \\
\hline \multicolumn{2}{|r|}{ Criterion 1 - age } \\
\hline Among potential entrants & $\begin{array}{l}\text { Carried out among young people under } 18 \text { to obtain their first } \\
\text { higher education }\end{array}$ \\
\hline Youth migration & $\begin{array}{l}\text { Carried out mainly among young people under } 30 \text {, among } \\
\text { young professionals for a second higher education or training }\end{array}$ \\
\hline \multicolumn{2}{|r|}{ Criterion 2 - time } \\
\hline Irreversible migration & $\begin{array}{l}\text { Getting an education abroad in order to move to a permanent } \\
\text { residence in another country after that }\end{array}$ \\
\hline Temporary migration & Return of the migrant to the homeland after education \\
\hline Pendulum migration & $\begin{array}{l}\text { Periodic crossing of the country's borders by a migrant when } \\
\text { he comes home for vacation, internship, etc. }\end{array}$ \\
\hline Rotational (exchange) migration & $\begin{array}{l}\text { Regular replacement (exchange) of educational migrants in } \\
\text { the host country by immigrants from the donor country }\end{array}$ \\
\hline \multicolumn{2}{|r|}{ Criterion 3 - the level of legalization } \\
\hline Legal migration & $\begin{array}{l}\text { Carried out under the terms of an agreement granting a } \\
\text { migrant full legalization in the country of study in accordance } \\
\text { with national and international law }\end{array}$ \\
\hline Semi-legal migration & $\begin{array}{l}\text { Legalization of migrants' stay in the country for the purpose } \\
\text { of study and possible illegal employment and further stay in } \\
\text { the country of study }\end{array}$ \\
\hline \multicolumn{2}{|r|}{ Criterion 3 - level of qualification } \\
\hline Primary migration & Migration of people with secondary education \\
\hline Intellectual migration & $\begin{array}{l}\text { Migration of people mainly with a high level of education } \\
\text { (level of education "bachelor", "master") }\end{array}$ \\
\hline \multicolumn{2}{|c|}{ Criterion 4 - method of implementation } \\
\hline Organized migration & $\begin{array}{l}\text { Carried out with the participation of the state, public } \\
\text { organizations, specialized business structures or universities }\end{array}$ \\
\hline Unorganized migration & $\begin{array}{l}\text { Individual migration of potential entrants or students of the } \\
\text { HEI }\end{array}$ \\
\hline
\end{tabular}

Peculiarities of modern international educational migration, which are the scale and dynamism of migration processes, diversification of the geographical structure of educational migration, strengthening national and international regulation of international educational migration processes, form certain advantages and disadvantages for both donor and recipient countries. In the table 3.14 [42] shows the main consequences of educational migration in certain areas of research of this process.

The structure of educational migration consists of several flows of movement:

1) educational immigration, which includes movement in order to obtain secondary, 
secondary special and higher education;

2) immigration for the purpose of obtaining the second higher and subsequent degrees of education, scientific degree, passing of scientific internship;

3) immigration for professional development (language courses, seminars, trainings, retraining or certification programs, business education and MBA degree, etc.).

In this study, the emphasis is on the first type of movement of movements, in particular, movement for higher education.

Table 3.14

\section{Consequences of educational migration in the areas of research}

\begin{tabular}{|c|c|}
\hline $\begin{array}{l}\text { For the donor country under the conditions of return } \\
\text { of educational migrants to their homeland }\end{array}$ & $\begin{array}{l}\text { For the recipient country in case of non-return } \\
\text { of educational migrants to their homeland }\end{array}$ \\
\hline \multicolumn{2}{|c|}{ The direction of research is educational } \\
\hline $\begin{array}{l}\text { There is a stimulation of the development of the } \\
\text { national educational market and improving the } \\
\text { quality of educational services in order to attract } \\
\text { foreign students and the interest of national entrants } \\
\text { to get an education in their country }\end{array}$ & $\begin{array}{l}\text { There is a dynamic development of the market } \\
\text { of educational services, the provision of } \\
\text { educational services is a profitable business, } \\
\text { stimulates the constant improvement of the } \\
\text { quality of HEI in order to attract foreign } \\
\text { applicants. }\end{array}$ \\
\hline \multicolumn{2}{|c|}{ The direction of research is innovative } \\
\hline $\begin{array}{l}\text { The possibility of involving national entrants and } \\
\text { students in the latest educational technologies, } \\
\text { knowledge and innovations, technology transfer is } \\
\text { increasing }\end{array}$ & $\begin{array}{l}\text { The development of scientific and technical } \\
\text { potential of the recipient country through the } \\
\text { acquisition of highly qualified personnel }\end{array}$ \\
\hline \multicolumn{2}{|c|}{ The direction of research is scientific } \\
\hline \multicolumn{2}{|c|}{ There is an expansion of scientific international contacts } \\
\hline \multicolumn{2}{|c|}{ The direction of research is branch } \\
\hline $\begin{array}{l}\text { There is a development of science-intensive } \\
\text { industries, scientific enterprises are created, the } \\
\text { development of scientific and technical potential of } \\
\text { the country is stimulated }\end{array}$ & $\begin{array}{l}\text { Development of international scientific } \\
\text { contacts, which leads to increasing the } \\
\text { scientific and technical potential of the country }\end{array}$ \\
\hline \multicolumn{2}{|c|}{ The direction of research is socio-cultural } \\
\hline \multicolumn{2}{|c|}{$\begin{array}{c}\text { There is an accession to world culture and European values; knowledge of foreign languages is } \\
\text { improved }\end{array}$} \\
\hline \multicolumn{2}{|c|}{ The direction of research is labor } \\
\hline $\begin{array}{l}\text { The national labor market receives specialists with a } \\
\text { high level of knowledge. On the other hand, there is } \\
\text { a shortage of professionals with the competencies } \\
\text { needed by national employers, resulting in an } \\
\text { imbalance in the national labor market. }\end{array}$ & $\begin{array}{l}\text { Tensions in the labor market are growing due } \\
\text { to competition between residents and non- } \\
\text { residents. On the other hand, the national labor } \\
\text { market is provided with highly qualified } \\
\text { personnel }\end{array}$ \\
\hline \multicolumn{2}{|c|}{ The direction of research is demographic } \\
\hline $\begin{array}{l}\text { The nation is aging due to the temporary outflow of } \\
\text { young people }\end{array}$ & $\begin{array}{l}\text { The demographic structure of the population is } \\
\text { being optimized through the infusion of a } \\
\text { generation of young people }\end{array}$ \\
\hline
\end{tabular}


Table 3.15 shows the dynamics of the number of foreign students who went abroad and came to the countries of the European Union and Ukraine in 2013-2017 [205].

Table 3.15

\section{Dynamics of international educational mobility in Europe and Ukraine}

\begin{tabular}{|l|c|c|c|c|c|c|}
\hline \multirow{2}{*}{ Country } & \multicolumn{3}{|c|}{$\begin{array}{c}\text { The total number of HEI students who } \\
\text { go abroad for education, thousand } \\
\text { people }\end{array}$} & \multicolumn{3}{c|}{$\begin{array}{c}\text { The total number of HEI students } \\
\text { arriving for higher education, } \\
\text { thousand people }\end{array}$} \\
\cline { 2 - 7 } & 2013 & 2015 & 2017 & 2013 & 2015 & 2017 \\
\hline Austria & 15.8 & 17.3 & 19.2 & 70.9 & 67.7 & 74.0 \\
\hline Belgium & 12.7 & 13.5 & 15.0 & 48.7 & 56.5 & 45.0 \\
\hline Bulgaria & 24.9 & 24.3 & 25.1 & 11.6 & 11.8 & 13.7 \\
\hline Cyprus & 26.3 & 25.5 & 24.5 & 4.8 & 6.5 & 10.5 \\
\hline $\begin{array}{l}\text { The Czech } \\
\text { Republic }\end{array}$ & 12.6 & 12.5 & 13.2 & 40.1 & 41.7 & 44.3 \\
\hline Germany & 120.5 & 117.1 & $\mathbf{1 2 2 . 2}$ & 196.6 & 228.8 & 258.9 \\
\hline Denmark & 52.9 & 5.0 & 5.3 & 29.5 & 32.3 & 33.6 \\
\hline Spain & 30.0 & 35.0 & $\mathbf{4 1 . 4}$ & 56.4 & 49.8 & 64.9 \\
\hline Estonia & 4.2 & 4.3 & 3.9 & 1.9 & 2.9 & 3.9 \\
\hline Finland & 8.3 & 9.3 & 10.9 & 21.9 & 23.1 & 24.2 \\
\hline France & 76.7 & 86.7 & $\mathbf{8 9 . 4}$ & 228.6 & 239.4 & 258.4 \\
\hline The United & 28.6 & 31.5 & $\mathbf{3 5 . 3}$ & 416.7 & 430.8 & 435.7 \\
Kingdom & & & & & & 25.7 \\
\hline Greece & 33.9 & 37.2 & $\mathbf{3 7 . 0}$ & 27.6 & 23.7 & 25.1 \\
\hline Croatia & 8.5 & 8.8 & 9.7 & 0.5 & 0.8 & 4.8 \\
\hline Hungary & 8.8 & 10.6 & 12.3 & 20.7 & 21.7 & 28.6 \\
\hline Ireland & 16.4 & 15.1 & 14.9 & 12.9 & 15.8 & 20.0 \\
\hline Italy & 50.3 & 60.9 & $\mathbf{7 4 . 3}$ & 82.5 & 90.4 & 97.6 \\
\hline Lithuania & 12.0 & 11.3 & 10.4 & 3.9 & 5.0 & 5.8 \\
\hline Luxembourg & 9.0 & 10.1 & 11.0 & 2.9 & 3.2 & 3.3 \\
\hline Latvia & 6.4 & 5.8 & 5.3 & 3.5 & 5.3 & 6.1 \\
\hline Malta & 1.9 & 1.2 & 1.1 & 0.6 & 0.8 & 1.2 \\
\hline The & 13.6 & 15.2 & 18.4 & 68.9 & 86.2 & 96.3 \\
Netherlands & & & & & & 63.9 \\
\hline Poland & 23.3 & 23.9 & $\mathbf{2 4 . 9}$ & 27.8 & 44.0 & 63.9 \\
\hline Portugal & 11.3 & 12.2 & 14.0 & 14.5 & 16.9 & 22.2 \\
\hline Romania & 32.6 & 32.3 & $\mathbf{3 6 . 0}$ & 21.6 & 23.1 & 27.5 \\
\hline Slovakia & 33.2 & 31.5 & $\mathbf{3 2 . 4}$ & 10.2 & 10.9 & 10.8 \\
\hline Slovenia & 2.6 & 2.7 & 3.2 & 2.6 & 2.4 & 3.1 \\
\hline Sweden & 18.1 & 17.4 & 16.6 & 25.4 & 26.7 & 28.7 \\
\hline Ukraine & 42.5 & 68.2 & $\mathbf{7 7 . 6}$ & 49.7 & 57.6 & 52.8 \\
\hline & & & & & & \\
\hline
\end{tabular}

According to the dynamics of international educational mobility (Table 3.15), the leading countries in terms of the inflow of foreign students among the European countries 
are the United Kingdom, Germany, France, Italy, the Netherlands, Austria, Spain, Poland, Ukraine, Belgium and the Czech Republic.

These countries together accept about 1.5 million students a year and accumulate $85 \%$ of the European educational migrants. Almost all of these European countries have a tendency to increase the number of foreign students annually for the period from 2013 to 2017.

As for the outbound educational mobility of students, most students go abroad to study from Germany, France, Ukraine, Italy, Spain, Greece, Romania, Great Britain and Slovakia. Every year about 0.5 million people go abroad to the European countries, i.e. more than $58 \%$ of students. As we can see, population of the countries tends to migrate to study in neighbouring countries with the most prosperous and promising situation in higher education and employment in the region.

To assess the attractiveness of higher education, we compare the trend of the ratio of the number of incoming and outgoing students by country in 2017 and 2013, Fig. 3.22.

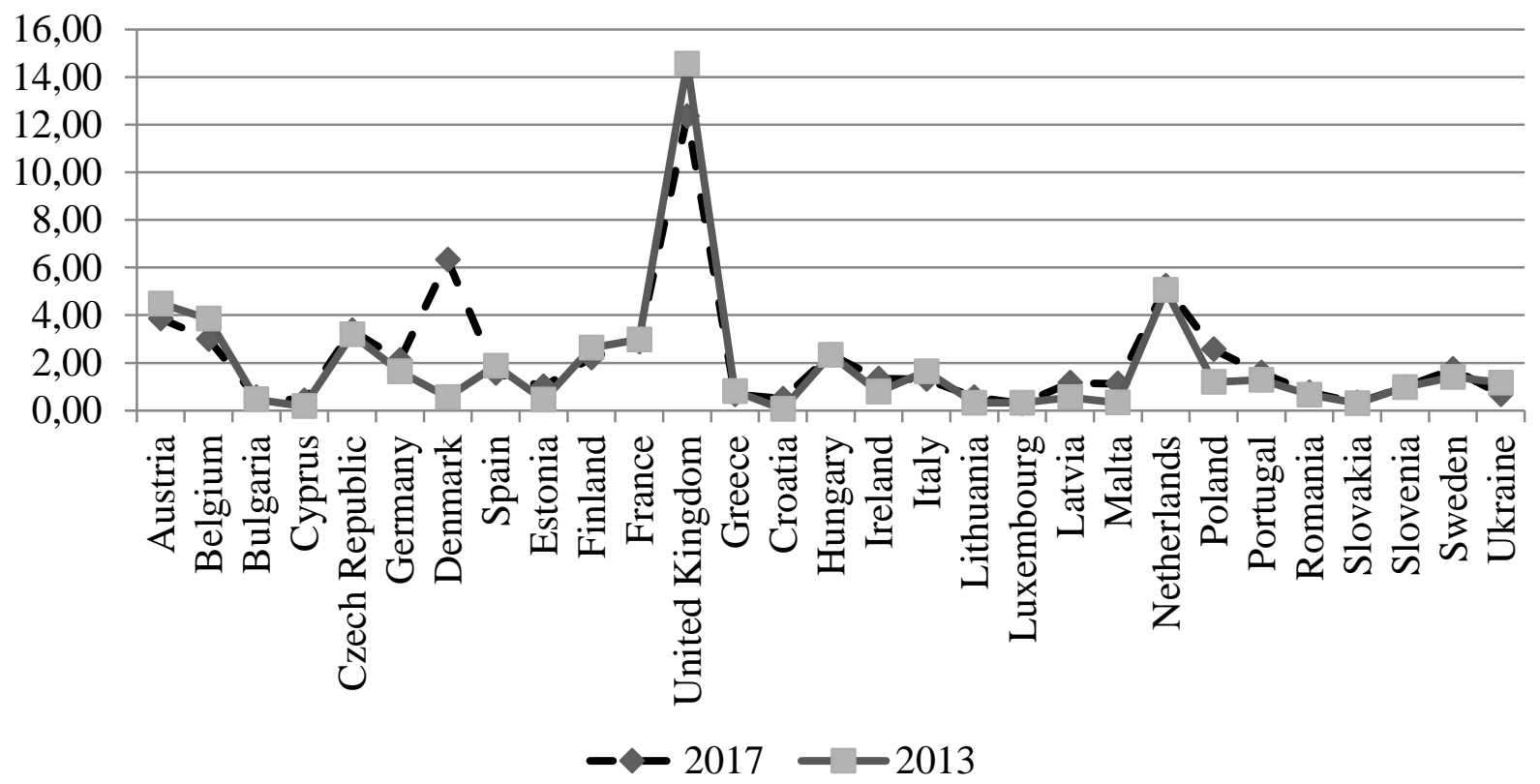

Fig. 3.22. The ratio of incoming and outgoing students by the European countries and Ukraine

As can be seen from Fig. 3.22, the trend in Europe and Ukraine in the ratio of students arriving and leaving in 2017 coincides with 2013. No significant changes took 
place in any country except Denmark, where in 2017 there was a significant increase in the analyzed ratio. If this ratio is more than 1 , it indicates the attractiveness of the country's higher education system for foreign students due to the high level of development of the higher education system in the country. This situation is observed only in some countries, such as Austria, Belgium, the Czech Republic, Germany, Denmark, Spain, Estonia, Finland, France, Great Britain, Hungary, Ireland, Italy, Latvia, Malta, the Netherlands, Poland, Portugal, Sweden. At the same time, only in Great Britain, the Netherlands and Denmark this ratio is much higher than 1 and even 2 times. As for Ukraine, the ratio between students arriving for study and students leaving abroad is 0.68 in 2017, it decreased compared to 2015 by 0.16 points, and compared to 2013, in which the country's higher education system was of higher level of attractiveness for foreign students - by 0.49 points. This trend of declining interest of foreign students in the higher education in Ukraine is explained by socio-political instability in the country.

Figure 3.23 shows the dynamics of the number of students in Ukraine who go abroad to study [205].

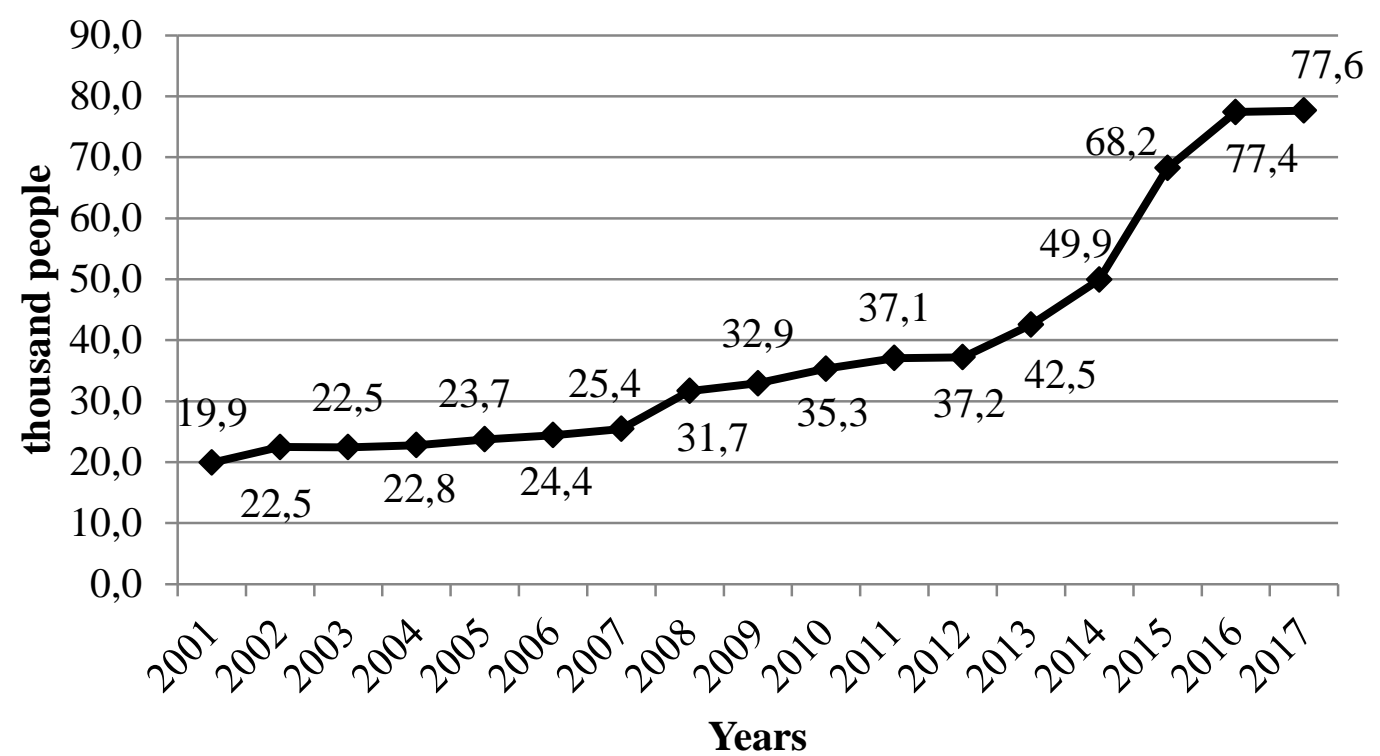

\section{Fig. 3.23. Dynamics of the number of Ukrainian students going abroad}

As can be seen from Fig. 3.23, during 2001-2017 the number of the Ukrainian students abroad is growing steadily, but until 2012, when the socio-economic situation in the country was more stable, the process of educational migration in the direction of going abroad to study developed quite slowly - in on average 6\% per annum, and after 2012 the number of those who went to study in other countries increased quite a lot -2.1 times and 
reached 77.6 thousand people.

Figure 3.24 shows the dynamics of the number of students who come to study in Ukraine [205].

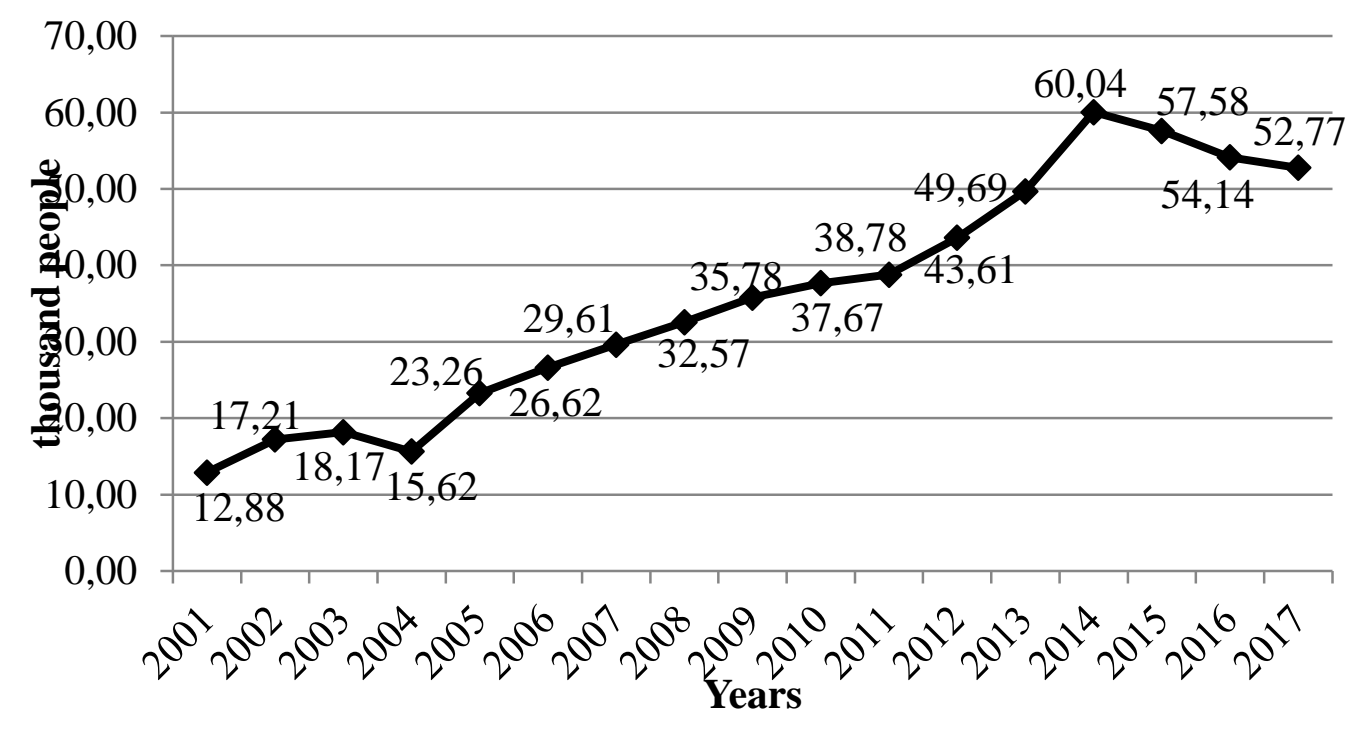

Fig. 3.24. Dynamics of the number of foreign students coming to Ukraine

Considering the dynamics of growth of students (Fig. 3.24), who came to receive higher education in Ukraine, we can distinguish two stages:

Stage 1 - extensive growth, the period of 2001-2014. During this time, the number of foreign students increased 4.7 times and amounted to 60 thousand people;

Stage 2 - a downward trend, the period of 2015-2017, during which the number of foreigners decreased by $12 \%$.

All this proves once again that educational migration depends not only on the quality of education, but also on political and economic stability in the country.

Fig. 3.25, according to the data [203, 205], shows a comparison of the total migration growth of the population of Ukraine and the migration growth of students who leave Ukraine and come to Ukraine to study from 2001 to 2017.

Fig. 3.25 shows that during 2001-2013 the same trend was observed in the migration movement both for the entire population of the country and for the educational migrants. From 2001 to 2005 there was a decrease in arrivals in Ukraine, both in general and for education, and since 2005 the trend has changed - a positive increase in migration was observed until 2014, and since 2015 there has been a sharp decline in foreign students, 
which is explained by the consequences of the political crisis and the instability of the socio-political situation in the country.

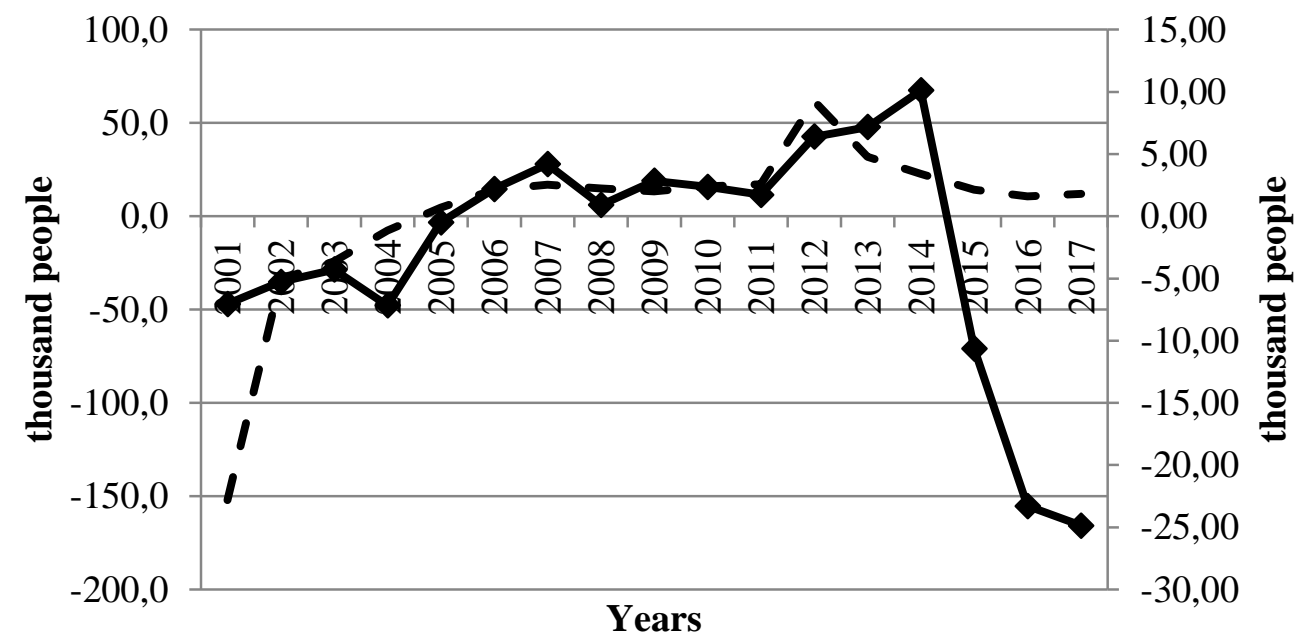

- - Total migration increase, thousand people

$\sim$ Educational migration increase, thousand people

Fig. 3.25. Comparison of the general and educational migration growth in dynamics

The number of foreign students who were already in Ukraine for 2011-2019 is presented in Fig. 3.26. [113]

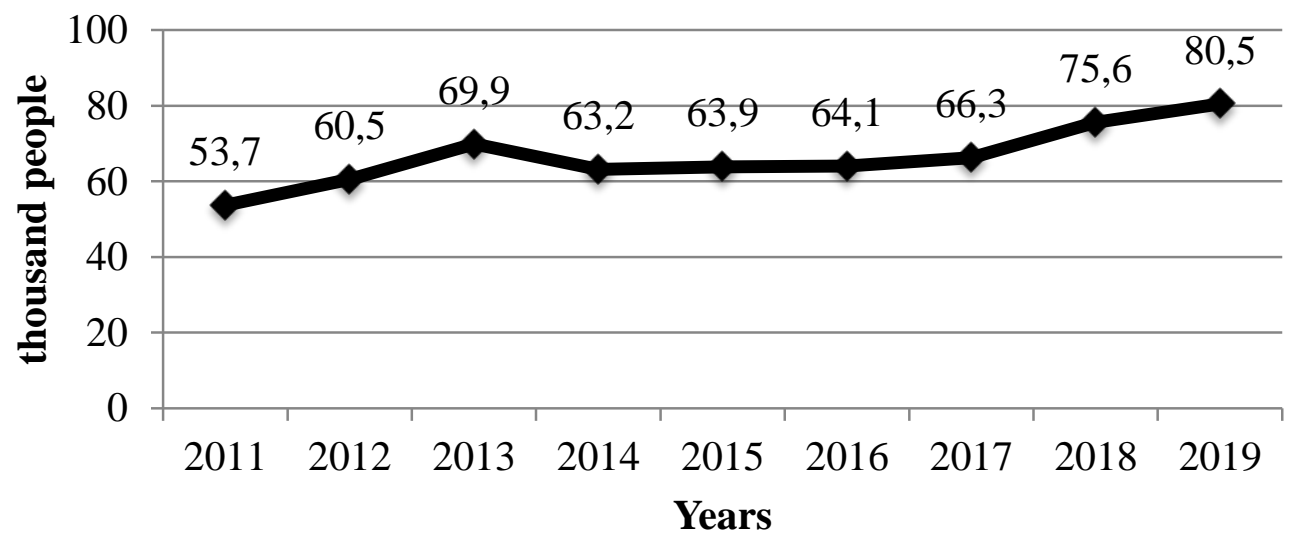

Fig. 3.26. Number of foreign students in Ukraine from 2011 to 2019

Fig. 3.26 shows that in 2015-2017 there was a slow growth of foreign students, but since 2017 the number of foreign students began to grow faster. Thus, the number of foreign students in Ukraine in 2018 amounted to 75,605 people, and in 2019 - 80,470 
people. At the same time, according to researchers, [113] the number of Ukrainians studying abroad has begun to lose its past growth. These changes in the dynamics of student migration indicate a certain stabilization of the situation in Ukraine and confidence in the future of young people studying in our country.

The dynamics of the ratio of students arriving in Ukraine and leaving Ukraine who leave and come to study is shown in Fig. 3.27.

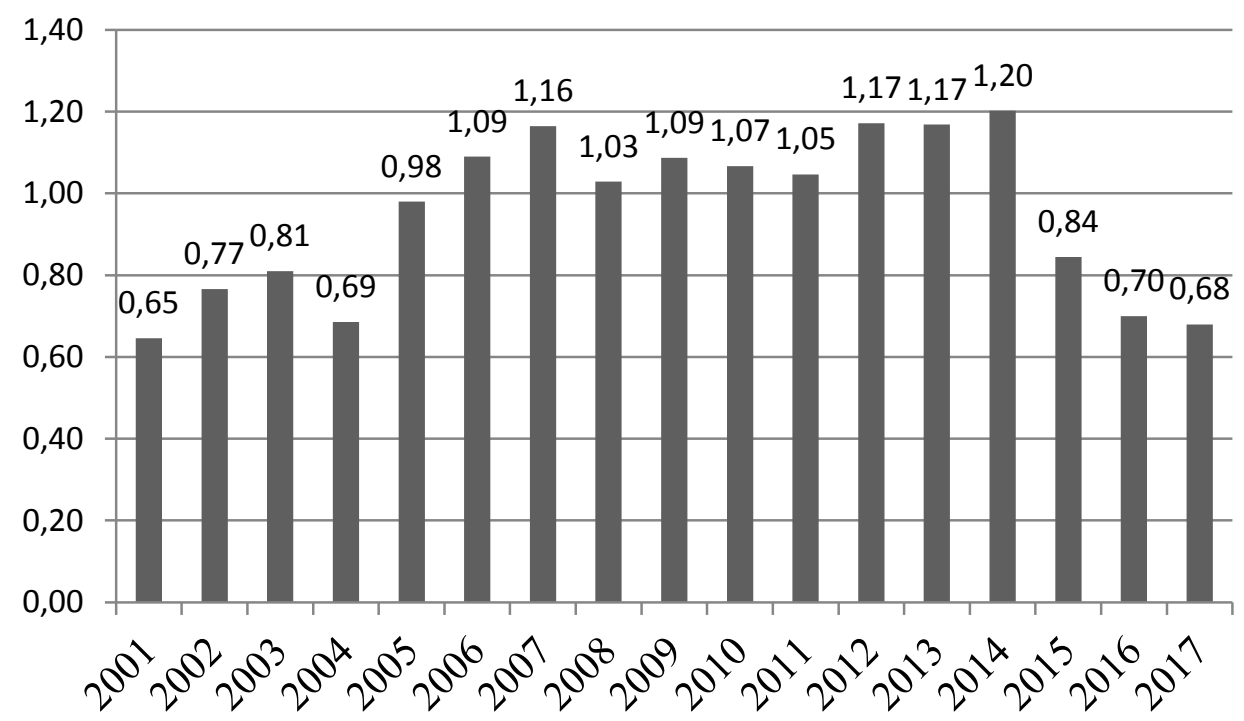

Fig. 3.27. Dynamics of the ratio of students arriving in Ukraine and leaving Ukraine

Fig. 3.27 shows that from 2006 to 2014 the number of foreign students who studied in Ukraine exceeded the number of the Ukrainians who went to study abroad. This means that it was during this period that Ukraine's higher education system was attractive to both foreign and national students. The events of 2014 influenced this trend towards its deterioration. According to the study [113], the situation began to improve after 2017.

In the study, it is advisable to conduct a comparative analysis of educational emigration and immigration. Thus, 13 times more people go to America to study than to leave, to Great Britain - 16 times, to Australia - 22 times, to France - 4 times, to the Czech Republic - 3 times, to Ukraine - only 0, 7 times according to the data of 2017 [205, 237]. Such data on Ukraine indicate, on the one hand, the accelerated integration of the national education system into the world, as students often go abroad in the form of academic migration, which involves returning to Ukraine after completing the curriculum. On the 
other hand, educational migration threatens the brain drain and the loss of an extremely efficient segment of our country's human capital. Official statistics do not cover data on the share of young people who stay there permanently after studying abroad, but observations of the labour market and educational processes in border regions most clearly characterize the impact of migration processes in education on the economy.

In general, the positive dynamics of changes in the number of educational migrants observed in recent years and their distribution between the European countries and Ukraine not only indicate a steady demand for professionals in the European and global labour markets, but are also the indicators of adaptability of educational systems. Political and social transformations taking place at the local and global levels determine the ability of states to compete for talented prospective entrants.

According to the dynamics of the number of foreign students in Ukraine (Fig. 3.26), it is not clear how many students came to study in Ukraine for the first time. To shed light on this issue, let us consider the dynamics of the number of registered invitations for foreign applicants (Fig. 3.28). [113]

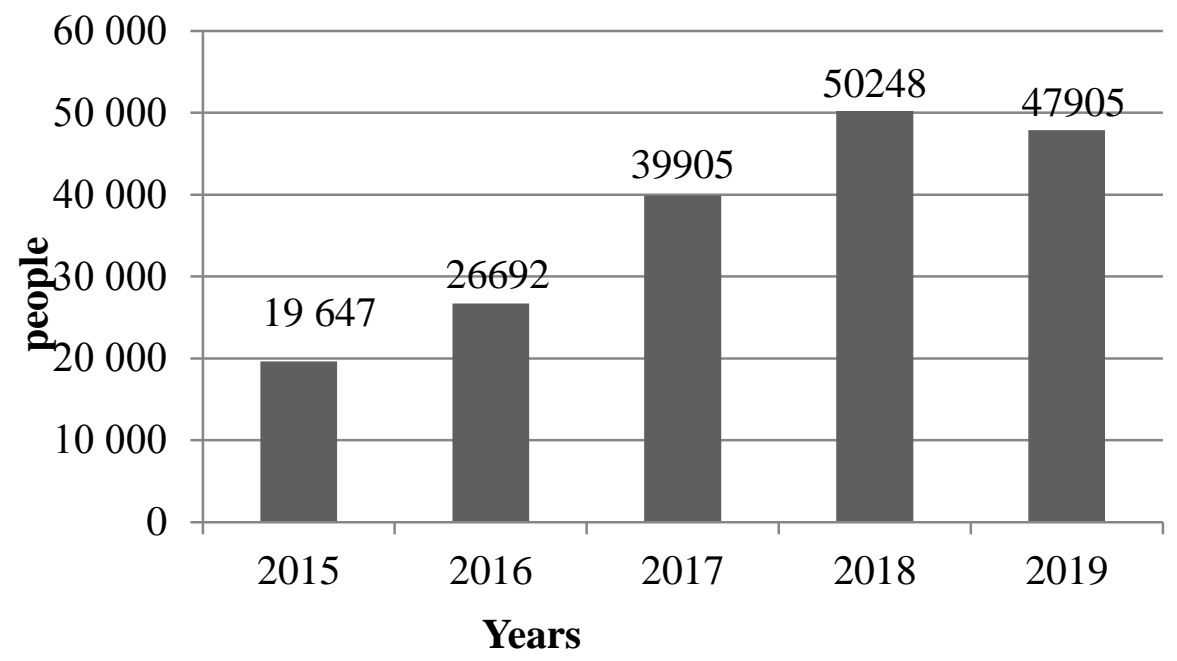

\section{Fig. 3.28. Number of registered invitations for foreign applicants by year}

The dynamics of registered invitations for foreign students (Fig. 3.28) shows how many invitations to study were issued in the HEI of Ukraine in order to learn the language for the further study in Ukraine. The overall dynamics tends to increase, except for the last 2019, in which the number of applicants decreases, in contrast to the data in Fig. 3.26. There is also a discrepancy between how many students study and how many of them 
come to enroll over the years. However, these statistics explain the partial increase and decrease in the total number of foreign students. For example, the invitations to study in 2016 were issued by 7045 more than in 2015, while the total number of foreign students increased by only 60 people. This discrepancy is due to the fact that a certain number of students dropped out under any circumstances (completion of the course, expulsion, academic leave), in addition, some of 7045 people received an invitation to join the HEI, and another - to learn the language .

In 2017, the number of registered invitations increased, which affected the total number of foreign students. The number of invitations increased by $49.5 \%$ compared to the last year. The following year, the growth continued, but not as intensively in proportion, only by about $25 \%$. A certain slowdown in the number of people who were issued invitations in 2018 was the first warning before the fall in the number of people that occurred in 2019. Considering this fact, the number of people who received invitations in 2019 decreased, and the number of foreign students increased, which requires a more detailed analysis of the dynamics of the number of registered invitations. It has already been mentioned that this indicator includes both those who will study in the HEI and those who come for language training (Fig. 3.29) [113] for the purpose of further education from the next academic year.

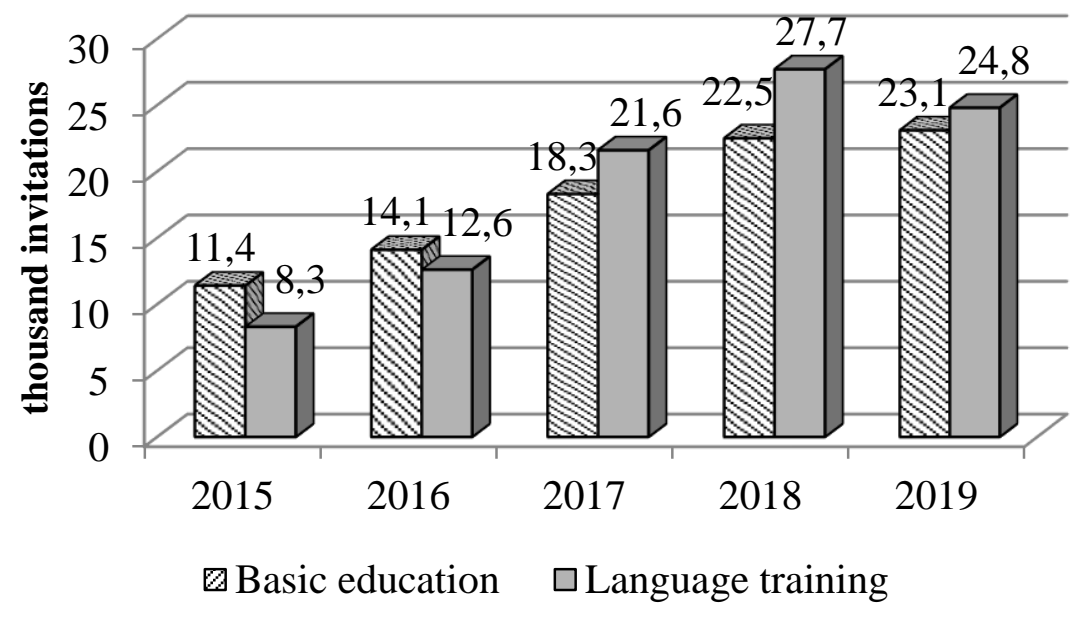

Fig. 3.29. Number of registered invitations for study purposes in 2015-2019

Figure 3.29 presents more detailed statistics of issued invitations for foreign students, classified by purpose of study. We have that in 2019, compared to 2015, the number of invitations to basic education has more than doubled, which indicates an 
increase in the attractiveness of Ukraine as a centre of education.

The dynamics of invitations of foreigners to language training is growing until 2018, and in 2019 this indicator is declining, which indicates that in the future there will be a decrease in the number of issued invitations for basic education. The fact that in 2018 Ukraine issued 27,705 invitations for language training, and the number of invitations to basic education in 2019 was lower than this figure (23,138 invitations), also shows that future students have changed their attitude to continuing their studies in Ukraine. Undoubtedly, the decision on further education is influenced not only by the socioeconomic and political conditions in Ukraine, but also by what is happening in foreign countries, as we have seen in the example of the dynamics of the Ukrainian students studying abroad.

Let's analyze the structural characteristics of educational migration. This analysis should take into account the fact that the distribution of foreign students by country of origin and education, by formats, degrees and profile of education largely determines the effects of educational migration flows between the countries of origin and education of students.

Thus, small countries that do not have diversified education systems often have higher mobility of students and especially graduate students who plan to stay and work in foreign research centres, which are among the leading in this field. Among the developed countries with the highest proportion of students studying abroad, in the total number of students are Iceland, Ireland and Greece [53].

Students from many countries study in Ukraine, but there are countries that are leaders among those who come to study in our country. Analyzing the dynamics for 4 years of registered invitations for foreign students, we can identify the top countries by origin of foreign applicants, which form the total number of foreign students in Ukraine (Fig. 3.30) [113].

Fig. 3.30 presents not only the countries that are leaders in the number of invitations received for foreigners, but also how many invitations were received during 2016-2019. As can be seen from Fig. 3.30, the number of such invitations increased in 2017 and 2018, but in 2019 this trend decreased for students from India, Morocco, Turkmenistan, Ghana and Egypt. 


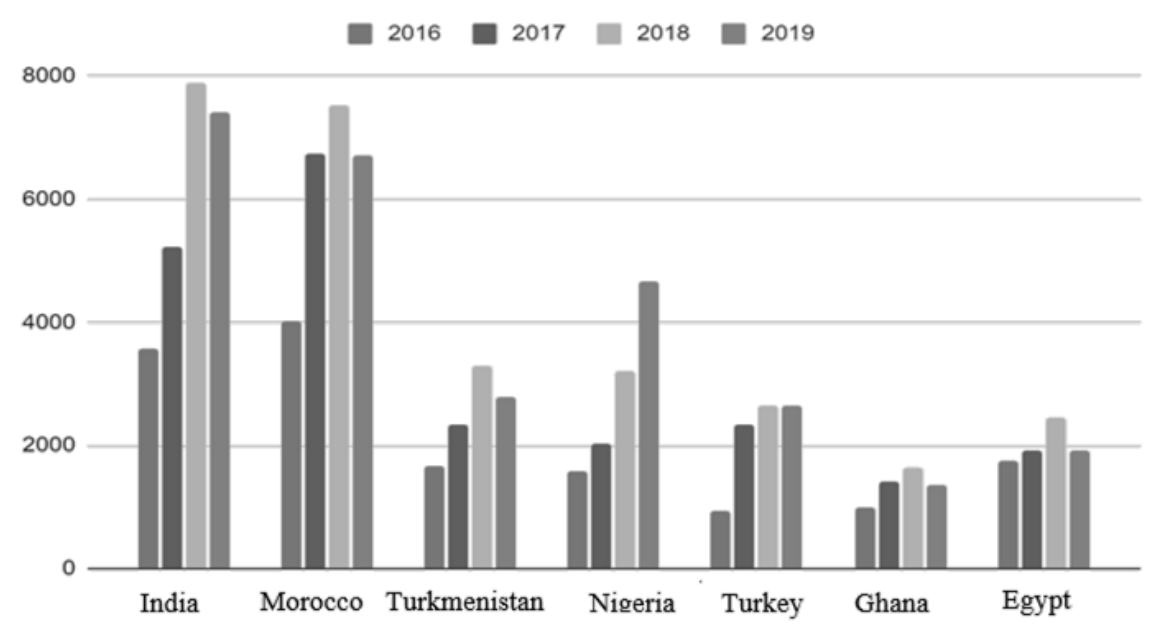

Fig. 3.30. Top 6 countries by origin of foreign entrants to whom the invitation was registered in 2016-2019

The structure of countries by origin of the foreign students studying in Ukraine as of the academic year 2019-2020 is shown in Fig. 3.31 [113].

As can be seen from Fig.4.31, the main influx of foreign students to Ukraine is observed from India (23\%) and Morocco (10\%). Students from the post-Soviet countries, who entered the top 10 countries by origin of the foreign students in Ukraine in 2019, account for $17 \%$. As for the dynamics of the share of students from the post-Soviet countries, according to the data [110], it decreased from $29.47 \%$ in $2017-2018$ to $21.52 \%$ in 2019-2020, i.e. by almost $8 \%$ over 3 academic years.

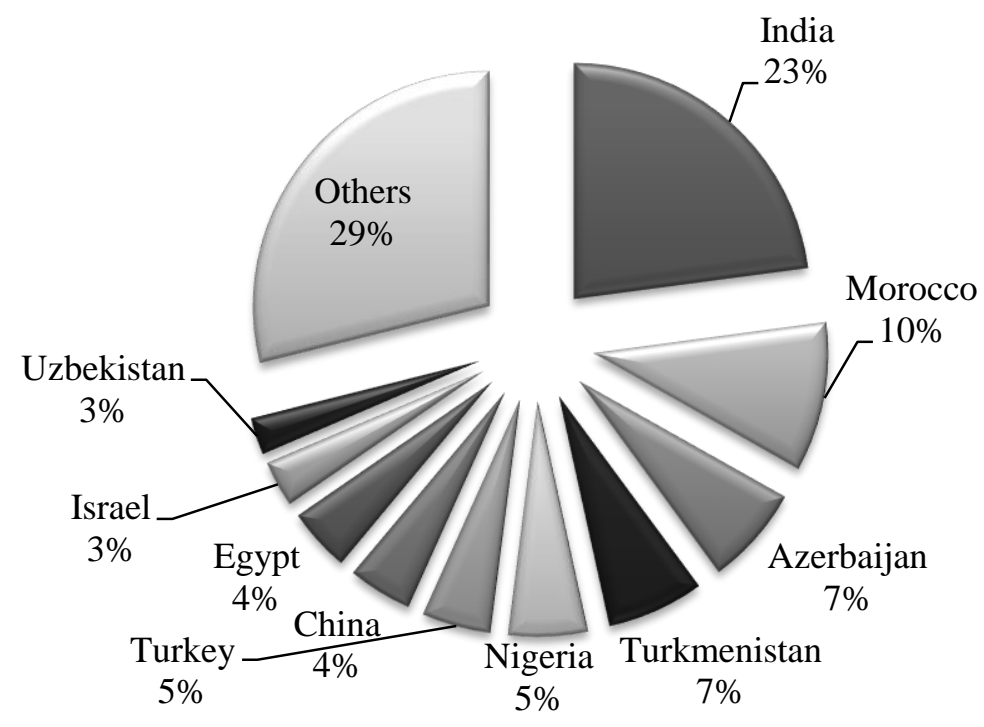

Fig. 3.31. Distribution of foreign students studying in Ukraine by the countries of arrival 
The distribution of foreign students entering Ukraine from all post-Soviet countries is shown in Fig. 3.32.

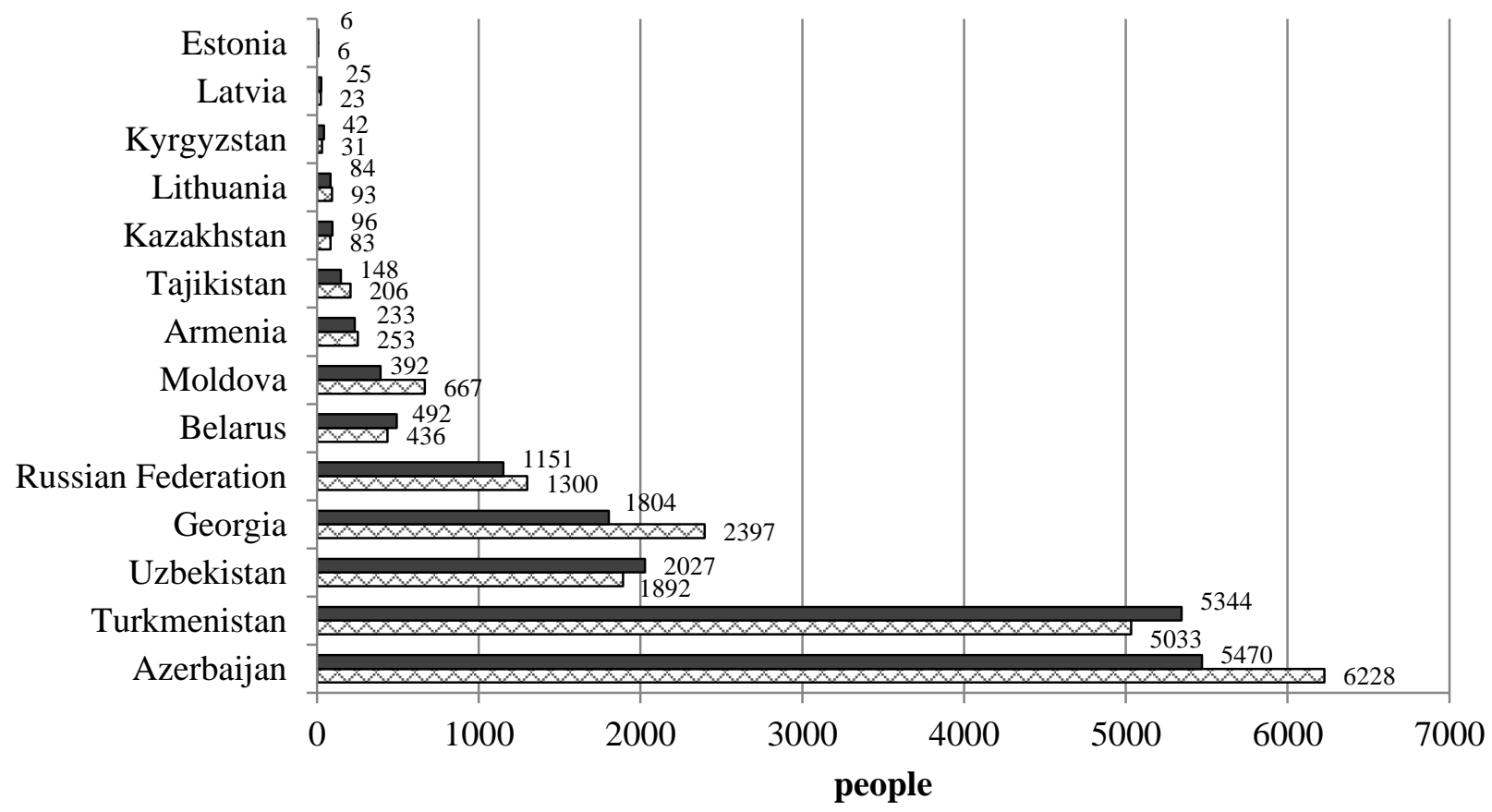

口2019-2020 $⿴ 2018-2019$

Fig. 3.32. Changing the number of foreign students from the post-Soviet countries in the academic years 2018-2020

As can be seen from Fig. 3.32, in the last academic year there was the largest decrease in incoming foreign students from Azerbaijan (by 758 people), Georgia (by 593 people), Moldova (by 275 people) and the Russian Federation (by 149 people). This decrease in the number of foreign students who come to Ukraine for higher education occurs against the background of an increase of almost 3 times the number of foreign students who teach foreign students.

The dynamics of such HEI by academic years is shown in Fig. 3.33. [113]

With regard to the forms of HEI that provide training for foreign students, it should be noted that in the academic year 2019-2020 there were 317 public HEI, 108 - private and 30 - communal. The distribution of foreign students according to these forms of HEI is as follows: $88.91 \%$ of foreign students study in state HEI, $10.89 \%$ - in private HEI, and $0.2 \%$ - in communal ones [113].

According to the levels of education, foreign students are distributed as follows (as 
of the 2019-2020 academic year): master's degree - 50.69\%; bachelor - 35.88\%; specialist - 11.51\%; junior specialist - 0.99\%; Doctor of Philosophy - 0.93\%. This distribution indicates that the level of education in the Ukrainian HEI is quite high, as foreign students receive a bachelor's degree in other countries, and to obtain a master's degree they study in the HEI of Ukraine.

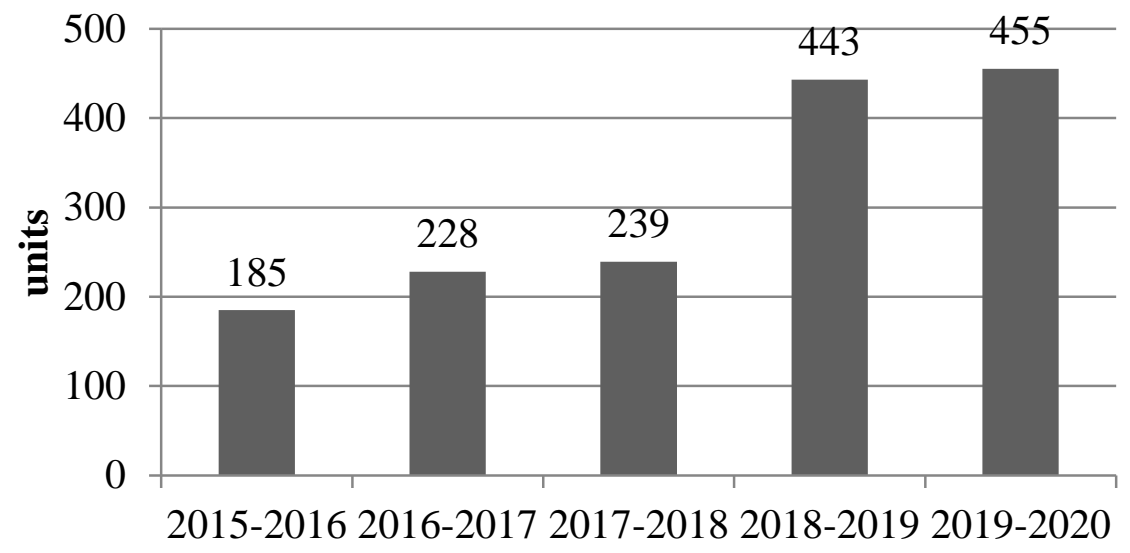

Fig. 3.33. Dynamics of the number of HEI institutions in Ukraine that teach foreign students

In general, Ukraine is the most attractive for higher professional education. This indicator can be expanded due to the development of the pre-university training system, which has developed in developed countries into a powerful springboard for migrants who want to study in popular specialties.

Despite the fact that the number of foreign graduate students in Ukraine is extremely small $(0.93 \%)$ compared to the developed countries, their presence already indicates a good trend in education. For countries with a developed system of higher education (Switzerland, the UK), this figure ranges from 41 to $43 \%$, despite the fact that these countries have a high level of payment for postgraduate and doctoral studies [53]. The small fate of such students in Ukraine may be explained not so much by the insufficient level of quality of training, but by the fundamental differences between academic degrees, titles and their recognition and compliance in the country of origin of a foreign graduate or doctoral student. Such restrictions on academic mobility are becoming one of the main factors in the low number of foreign graduate and doctoral students in the Ukrainian universities.

If we consider the structure of the countries where the Ukrainian students go to 
study, then according to the Development Fund of the International Organization for Migration (IOM) [264], most Ukrainian students studied in Poland in 2017 - 34.7 thousand people; the number of the Ukrainian students in Russia decreased, but remained quite high - 15.3 thousand people. The third place takes the number of the Ukrainian students in Germany - 6.1 thousand people. The desire to get education abroad is often linked to the desire of young people to open their way to the international labour market. According to a survey [269] conducted via the Internet in 2018 among 1,000 Ukrainians studying in Poland, only $6 \%$ of them intended to return to Ukraine after graduation. The increase in educational migration is also indirectly confirmed by the fact that families of the Ukrainian labour migrants are reunited in their countries of residence. This is probably due to the rapid growth in the number of the Ukrainian students in the countries where numerous Ukrainian diasporas have been formed as a result of labour migration. For example, in 2000, only 40 Ukrainians studied in the Italian universities, and in 2017 - 2.8 thousand, i.e. 70 times more [162].

Summarizing the results of the analysis of educational migration, we can conclude that the education of foreign students in national educational institutions is not only the image of the country, but also an important component of investment from abroad in the economy. As of January 1, 2020, 80,470 foreign students from 158 countries were studying in the Ukrainian higher education institutions. According to the Ukrainian State Centre for International Education of the Ministry of Education and Science of Ukraine, in 2019, the total cost of education, accommodation, insurance, paperwork, food, transportation and other needs of foreign students studying in Ukraine reached more than 570 million dollars. That is, in the academic year 2019/2020 each foreign student brought income to the region or country in the amount of 7,083.4 dollars. Thus, if the innovative activity of the HEI in the direction of attracting foreign students is not supported, the country, as a whole, will lose a significant amount of revenue to the state budget.

In the context of globalization, educational migration is one of the main trends of today, and its impact on the development of national markets for educational services is significant. As the analysis showed, in modern conditions Ukraine acts mainly as a country-donor for students of foreign HEI. Since foreign students are one of the factors of attractiveness of the higher education system and a sign of innovative and active HEI, the state policy in the field of education should be aimed at: 
support for academic mobility in Ukraine as one of the most effective forms of educational migration;

ensuring the balance of the processes of educational emigration and immigration with a focus on stimulating the export of educational services;

consideration of educational migration as an intensive resource for the development of scientific, innovative and cultural potentials of the state;

introduction of constant monitoring of educational migration processes in the country by studying migration flows;

inclusion of migration policy in the policy of promoting the return of migrants to their countries of origin, creation of a database of graduates of foreign HEI, creation of a bank of vacancies for this category of graduates.

Of course, any country must effectively use the socio-economic and cultural-social benefits of educational migration, and, above all, it will increase the competitiveness of national HEI in the market of educational services by supporting and developing innovative components of universities. 


\section{CHAPTER 4. CONCEPTUAL-METHODOLOGICAL BASIS OF CONSTRUCTION OF AN INNOVATIVE-ACTIVE UNIVERSITY}

\subsection{Modern paradigm of higher education system development and formation of theoretical basis for building an innovative-active university}

Socio-economic transformations of the late XX - early XXI centuries, which are characterized by the processes of progressive globalization, the emergence of information society and knowledge-based society, necessitate a paradigm shift in higher education, a search for new approaches, technologies, forms, methods of educational process, criteria for the selection of scientific and pedagogical staff, and form the basis of innovative and autonomous activities of higher education institutions (HEI).

Education is a powerful factor in the socio-economic development of society. The development of society in general and the state in particular depends on the level of education in understanding the possession of certain knowledge with the possibility of their effective use for personal, intrinsically motivated and social needs which should not be inconsistent with each other. Such criteria of the representative of society are formed through educational technologies. The structure of the world higher education is characterized by diversity, but two trends still dominate (Table 4.1).

Table 4.1

\section{Trends in the organizational support of higher systems education in the world [168]}

\begin{tabular}{|c|c|c|}
\hline Trend & Characteristic & Countries \\
\hline $\begin{array}{lll}\text { Unitary } & \text { or } & \text { single } \\
\text { system } & & \end{array}$ & $\begin{array}{l}\text { higher education is provided by } \\
\text { universities or their respective } \\
\text { institutions. Such institutions } \\
\text { offer both general academic } \\
\text { degrees and professionally } \\
\text { oriented programs of various } \\
\text { durations and levels. }\end{array}$ & $\begin{array}{l}\text { such is the education in Italy, Spain, Austria, } \\
\text { Finland, Sweden. Some experts single out the } \\
\text { countries with "integrated" universities which } \\
\text { include specialized secondary and higher } \\
\text { education institutions (Sweden and Spain) and } \\
\text { the countries belonging to the post-socialist } \\
\text { area. }\end{array}$ \\
\hline $\begin{array}{ll}\text { Binary or } & \text { dual } \\
\text { system with a } \\
\text { traditional } \\
\text { university sector }\end{array}$ & $\begin{array}{l}\text { is based on the concept of the } \\
\text { university and a separate non- } \\
\text { university sector of higher } \\
\text { education which has a clearly } \\
\text { defined structure }\end{array}$ & $\begin{array}{l}\text { such an education system is typical of most } \\
\text { developed countries of the world, where along } \\
\text { with the university sector there are numerous } \\
\text { specialized institutions. Such European } \\
\text { countries as Belgium, Great Britain, Greece, } \\
\text { Denmark, Ireland, the Netherlands, Norway, } \\
\text { Germany, France, Switzerland and others have } \\
\text { a binary system of higher education. }\end{array}$ \\
\hline
\end{tabular}

Tendencies towards a comprehensive (unified) university system, together with the development of a strong non-university higher education sector, have contributed to a 
broader interpretation of the term "university" which differs from the traditional European university definition of intensive cooperation, teaching and having success in it, where much attention is paid to individual learning. This trend is clearly observed today mainly in the universities of those countries that are actively implementing the process of creating an information society.

The middle of the XXth century was characterized by the transition of civilization to a new stage of development which manifested itself in the emergence of new features in the economic, political and cultural life of the developed countries and the formation of global trends (Fig. 4.1).

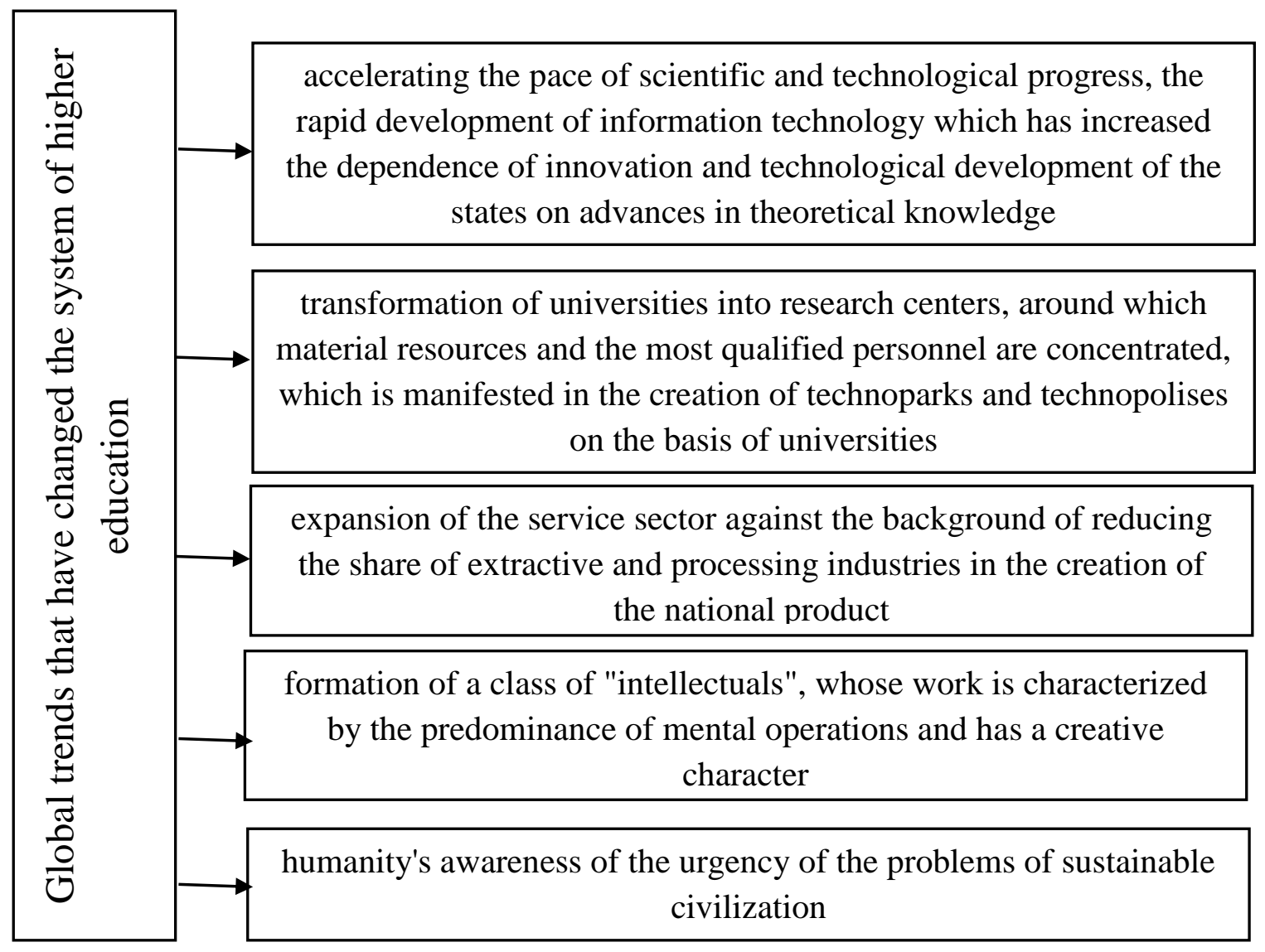

Fig. 4.1. Global trends that have changed the system of higher education

Under these conditions, the centre of modern developments of scientists are: research of promising and effective forms, teaching methods to enhance the quality of education (Gaebel M., 2018; Taneja P., 2018) [89, 239]; creation of universities of 
innovative type, determination of dominants of their development, processes of internationalization of universities and knowledge economy (Becker B. A., 2018; Kumar S., 2018) [40, 143]; research of trends in the development of the higher education system (Grenčíková A. 2017; Estermann T., 2013) [99, 72]; quality management in higher education institutions (Seyfried M. \& Pohlenz P., 2018) [216], Elken M. \& Stensaker B., 2018) [71]; building a corporate scientific and educational system of HEI and implementation of protocols of global computer systems in the PKI system (Oppliger R., 2005) [167].

The university as a social institution depends on society, it serves the society that builds it. Instead, society relies on functional support, and therefore, the mission of the university is determined by internal trends in society.

A traditional university should perform the functions of a cultural centre, an accumulator of cultural heritage of the peoples of the country and the world, education and upbringing of cultural heritage, i.e. everything related to the creation, accumulation and transfer of integrated knowledge about nature, personality and society, forming a person with high ethical and spiritual qualities. In particular, classical universities:

1. Are becoming centres of telecommunications and the promotion of new information technologies, significantly increase their role as information centres. This, in its turn, increases their role as coordination and expert centres in the scientific, educational and technological spheres, promotes integration with academic research institutions.

2. Are strengthened as centres of interdisciplinary research, especially in the sciences of nature and society (ecology, natural resources, management, economics); that allows to set the task of solving major complex problems, in particular, regional and sectoral levels that require new approaches to sphere of exact sciences.

3. In the framework of globalization processes are strengthening their role as centres of international cooperation, while gaining new opportunities to support basic research [10]. Therefore, the world's leading classical universities bring together experts from all major fields of science, which provides a synergistic effect of knowledge development, especially in the most relevant interdisciplinary areas. At the same time, there is a change in the usual tasks of development of the post-industrial society (the experience of solving which has been worked out for a century) to solve the problems of a new, based on knowledge of socio-economic system, i.e. an information society. 
The main goal of modern education is competitiveness of graduates, especially since this indicator is one of the most important in determining the quality index of the institution. At the same time, global transformations of information and communication processes allow free access to scientific and educational resources without the mediation of universities, provide prompt and flexible use of knowledge through advanced information and telecommunications technologies, promote distance learning and selfeducation. Therefore, universities today need to actively defend their positions in all areas of the mass communication system, being involved in the development of its various segments, taking into account their main advantages. Thus, the competitiveness of HEIdirectly depends on the universities' change of the vector of development from conservative to progressive, from subordinate to the state to autonomous.

Table. 4.2 shows the evolutionary changes that are taking place in universities in accordance with the transformational changes in society.

Table 4.2

\section{The evolution of goals and objectives that improve the quality and efficiency of education and training of future professionals}

\begin{tabular}{|c|l|}
\hline Stage & \multicolumn{1}{c|}{ Goals and objectives } \\
\hline \multirow{4}{*}{$\begin{array}{c}\text { Key tasks of } \\
\text { traditional } \\
\text { education }\end{array}$} & $\begin{array}{l}\text { improving the quality and efficiency of teacher education and training in } \\
\text { member countries in the context of new requirements of the "knowledge } \\
\text { society" }\end{array}$ \\
\cline { 2 - 3 } & skills development for the knowledge society \\
\cline { 2 - 3 } & ensuring equal access to ICT \\
\cline { 2 - 3 } & increasing the share of people engaged in technical and natural areas \\
\cline { 2 - 3 } $\begin{array}{c}\text { Goals and } \\
\text { ebjectives in the } \\
\text { context of } \\
\text { globalizationt use of resources }\end{array}$ & $\begin{array}{l}\text { The goal of "Improving equal access to education" was to perform such tasks } \\
\text { as: creating an open educational space; making education attractive; support of } \\
\text { the active citizenship, equal opportunities and social harmony }\end{array}$ \\
\cline { 2 - 3 } & $\begin{array}{l}\text { The task of "Creating an open educational space" was to simplify the access to } \\
\text { education for all age groups which was planned to achieve, primarily, by } \\
\text { developing information and orientation guides and creating a system of so-called } \\
\text { to another - the Europeans must be able to accumulate their previous educational } \\
\text { achievements and be confident that the obtained credits and qualifications will be } \\
\text { recognized throughout the EU. } \\
\text { The goal of "Openness of the EU education to the world" in the context of the } \\
\text { fundamental need to increase the relevance of the labour market and the challenges } \\
\text { of globalization includes: strengthening the links between industry and research } \\
\text { and society as a whole; development of entrepreneurial spirit; intensification of } \\
\text { foreign language teaching; enhanced mobility and exchanges; strengthening the } \\
\text { European cooperation }\end{array}$ \\
\hline
\end{tabular}


The end of the table. 4.2

\begin{tabular}{|c|l|}
\hline & $\begin{array}{l}\text { ensuring equal access to ICT, which was planned to be achieved not only by } \\
\text { providing appropriate equipment and wide communication capabilities (Internet / } \\
\text { Intranet), but also by high-quality software. The problem of involving young } \\
\text { people in the study of science and mathematics was planned to be solved by } \\
\text { updating the content of science and mathematics education at the secondary school } \\
\text { level, and strengthening the ties with industry and business. }\end{array}$ \\
\hline $\begin{array}{c}\text { Priority goals of } \\
\text { education in the } \\
\text { information } \\
\text { society }\end{array}$ & $\begin{array}{l}\text { formation of those people who study, the view of education as a process that does } \\
\text { not stop throughout working life }\end{array}$ \\
\cline { 2 - 3 } & $\begin{array}{l}\text { formation of the ability to continuous self-education with the use of information } \\
\text { technology }\end{array}$ \\
\hline
\end{tabular}

The autonomy of the university determines its practical and pragmatic orientation. Thus, within the framework of this approach, the model of "entrepreneurial university" is developed and implemented, i.e. universities are actively looking for innovative forms of educational and scientific activities.

The foundations of understanding the entrepreneurial, innovatively active university were laid by Burton Clark, who published his article "Creating Entrepreneurial Universities, Organizational Pathways of Transformation" in 1998 [90]. Among the key characteristics of such a university, he highlighted the willingness of universities to adapt to changing conditions and the active search for ways of such adaptation in all areas of its activities. Possessing these characteristics, the university seeks to adapt its research, teaching and learning, as well as methods, forms of knowledge transfer to current and future needs of the economy and society. M. Gibbons (1998) in his research [90] proved that such changes in the activities of universities depend on the changes that have occurred in the 21 st century in the process of knowledge creation. He connects this with the emergence of a distributed system of production and dissemination of knowledge, argues that research and training is no longer an institutional priority only for universities, but they require broad interaction with society, its various stakeholders through the involvement of modern information and communication technologies.

Under these requirements, the conceptual approach to the management of innovative universities should be based not only on the principles of general management theory, but also on modern approaches and concepts of management of organizations aimed at comprehensively meeting individual requirements and needs of consumers in terms of their vocations, interests and abilities in more effective ways compared to other HEI. This is the approach to management that will ensure the sustainability of the educational organization 
and society as a whole which, accordingly, determines the relevance of research in this area. The generalization of various views and understandings of phenomena and processes in education has led to the emergence of various concepts and conceptual approaches in the theory of management of educational organizations, the results of which are presented in table 4.3.

Table 4.3

\section{Comparative characteristics of different concepts and conceptual approaches in the theory of university management}

\begin{tabular}{|l|l|}
\hline \multicolumn{1}{|c|}{ Conceptual approach to management } & $\begin{array}{c}\text { The essence of the concept of "management of educational } \\
\text { organization" in terms of approach }\end{array}$ \\
\hline $\begin{array}{l}\text { An approach based on the criteria of economic } \\
\text { efficiency of the educational organization }\end{array}$ & $\begin{array}{l}\text { Educational organization is a closed, mechanistic, rational } \\
\text { system, the management of which is aimed at ensuring its } \\
\text { effectiveness }\end{array}$ \\
\hline $\begin{array}{l}\text { An approach based on the criteria of pedagogical } \\
\text { effectiveness of the educational organization }\end{array}$ & $\begin{array}{l}\text { An educational organization is a semi-open, organic, natural } \\
\text { system, the management of which is aimed at integrating the } \\
\text { constituent elements in order to optimize its functioning. } \\
\text { Human relations and managerial behaviour are dominant in } \\
\text { the management of an educational organization in the view of } \\
\text { this concept. }\end{array}$ \\
\hline $\begin{array}{l}\text { An approach based on the criteria of flexibility of The educational organization is an open and adaptive system, } \\
\text { in the process of management of which the main importance } \\
\text { conceptually based on the theory of development } \\
\text { management, development of organizational } \\
\text { structures, the theory of chance, institutional } \\
\text { development }\end{array}$ & $\begin{array}{l}\text { order to ensure its flexibility and adaptability. } \\
\text { in approach based on the criteria of relevance of }\end{array}$ \\
$\begin{array}{ll}\text { An aducational organization is a holistic system of interacting } \\
\text { the educational organization, which is } \\
\text { conceptually based on the provisions of } \\
\text { existentialism, dialectical method, critical realisment in } \\
\text { and the theory of human relations }\end{array}$ & $\begin{array}{l}\text { elements. The process of managing this organization should } \\
\text { be based on the consciousness and criticality of the subjects, } \\
\text { relevance }\end{array}$ \\
\hline
\end{tabular}

Different scientific approaches can be used to solve the problems of IAU as a social institution and business organization. The most common of them are: conceptual; processfunctional; systemic; synergetic; situational. We will conduct a critical analysis of these approaches based on the task of the study, namely, the construction of an innovative university (Table 4.4).

As noted above, modern universities face stiff competition from institutions that provide educational and training services online. The reason for the latter is usually the lack of effective interaction between freelancers and employers' organizations, consumers of higher education and, as a consequence, the emergence of a persistent myth about the 
obsolescence of competencies acquired in universities from the real sectors of economy, government and society.

Table 4.4

\section{Characteristics of the most common scientific approaches used in the management of educational organizations at the present stage}

\begin{tabular}{|c|c|c|c|}
\hline Approach & The essence of the approach & Benefits & Disadvantages \\
\hline 1 & 2 & 3 & 4 \\
\hline Conceptual & $\begin{array}{l}\text { According to the studied } \\
\text { conceptual approaches, the } \\
\text { goals of management of } \\
\text { educational organizations are } \\
\text { to ensure both economic } \\
\text { efficiency and flexibility and } \\
\text { adaptability of the } \\
\text { organization to the } \\
\text { requirements of entities and } \\
\text { the environment. }\end{array}$ & $\begin{array}{l}\text { Based on the criteria of flexibility and } \\
\text { relevance of activities in view of the } \\
\text { fact that they emphasize the openness } \\
\text { of educational organizations as } \\
\text { systems and their subject orientation } \\
\text { and purposefulness which takes into } \\
\text { account both the characteristics of } \\
\text { educational services and the approach } \\
\text { to management by creating conditions } \\
\text { for interaction elements of the system }\end{array}$ & $\begin{array}{l}\text { Requires a focus on } \\
\text { meeting the individual } \\
\text { needs of educational } \\
\text { customers }\end{array}$ \\
\hline $\begin{array}{l}\text { Process and } \\
\text { functional }\end{array}$ & $\begin{array}{l}\text { The approach is based on the } \\
\text { application within the } \\
\text { organization of a system of } \\
\text { processes together with their } \\
\text { identification and interaction, } \\
\text { as well as their management } \\
\text { to obtain the desired result }\end{array}$ & $\begin{array}{l}\text { - focus on the overall result of the } \\
\text { educational process; } \\
\text { - coordination of actions of different } \\
\text { functional subdivisions of the } \\
\text { university within the process; } \\
\text { - transparency and removal of barriers } \\
\text { between units; } \\
\text { - reduction of costs for the provision of } \\
\text { educational services; } \\
\text { - increasing the efficiency and } \\
\text { effectiveness of the educational } \\
\text { organization; } \\
\text { - identifying opportunities for } \\
\text { purposeful improvement of higher } \\
\text { education processes }\end{array}$ & $\begin{array}{l}\text { - responsibilities and } \\
\text { criteria for successful } \\
\text { management make } \\
\text { sense only in the } \\
\text { context of a specific } \\
\text { process; } \\
\text { - the complexity of } \\
\text { managing functionally } \\
\text { mixed teams; } \\
\text { - increased dependence } \\
\text { of the result on the } \\
\text { personal qualities of } \\
\text { employees of the } \\
\text { educational } \\
\text { organization }\end{array}$ \\
\hline Systemic & $\begin{array}{l}\text { System approach - a } \\
\text { methodology for studying } \\
\text { objects as systems. The system } \\
\text { consists of two components: } \\
\text { the external environment } \\
\text { which includes input, system } \\
\text { output, communication with } \\
\text { the external environment, and } \\
\text { the internal structure - a set of } \\
\text { interconnected components } \\
\text { that ensure the process of } \\
\text { influence of the subject of } \\
\text { management on the object, } \\
\text { input processing in the output } \\
\text { and achievement of system } \\
\text { goals }\end{array}$ & $\begin{array}{l}\text { - enables detailed structural and factor } \\
\text { analysis which allows to identify } \\
\text { intersystem relationships, } \\
\text { interdependent behaviour of the } \\
\text { elements; } \\
\text { - makes it possible to determine the } \\
\text { goals and criteria of management and } \\
\text { subordination of the established criteria } \\
\text { to the general mission of the university; } \\
\text { - considers all elements of the system } \\
\text { in its entirety and interconnectedness; } \\
\text { - focuses on poorly structured problems } \\
\text { and finding the best solution }\end{array}$ & $\begin{array}{l}\text { - the complexity of } \\
\text { management which } \\
\text { depends on the number } \\
\text { of changes in the } \\
\text { system and its } \\
\text { environment; } \\
\text { - requires high } \\
\text { professionalism of staff } \\
\text { and the use of } \\
\text { expensive technologies } \\
\text { and automated control } \\
\text { systems }\end{array}$ \\
\hline Situational & $\begin{array}{l}\text { The situational approach } \\
\text { focuses on the fact that the } \\
\text { suitability of different } \\
\text { management methods is } \\
\text { determined by the specific } \\
\text { situation that arose at a } \\
\text { particular time }\end{array}$ & $\begin{array}{l}\text { - the ability to combine specific } \\
\text { techniques and concepts with specific } \\
\text { situations to most effectively achieve } \\
\text { the goals of the educational } \\
\text { organization; } \\
\text { - provides a high level of adaptability of } \\
\text { management and development of the } \\
\text { university; }\end{array}$ & $\begin{array}{l}\text { - There is no single best } \\
\text { way to manage an } \\
\text { object. } \\
\text { - deep knowledge of } \\
\text { professional } \\
\text { management tools that } \\
\text { have proven that their } \\
\text { effectiveness is } \\
\text { required }\end{array}$ \\
\hline
\end{tabular}


The end of the table 4.4

\begin{tabular}{|c|c|c|c|}
\hline 1 & 2 & 3 & 4 \\
\hline Synergetic & $\begin{array}{l}\text { Synergetics is a science that } \\
\text { studies processes in unstable } \\
\text { systems, stages of transition } \\
\text { from a state of order to a state } \\
\text { of chaos. } \\
\text { The main concepts of } \\
\text { synergetics are instability, } \\
\text { order parameters and the } \\
\text { principle of subordination, } \\
\text { the attractor system, as well } \\
\text { as the corresponding } \\
\text { mathematical apparatus }\end{array}$ & $\begin{array}{l}\text { - allows to comprehend problems of } \\
\text { interdisciplinarity of preparation of } \\
\text { students (expansion of the } \\
\text { nomenclature of disciplines of a } \\
\text { humanitarian cycle); } \\
\text { - provides interpenetration of } \\
\text { humanitarian and non-humanitarian } \\
\text { (natural science and technical) } \\
\text { knowledge; } \\
\text { - provides opportunities for each } \\
\text { subject of education to determine the } \\
\text { individual trajectory of education, the } \\
\text { pace of learning; } \\
\text { - allows you to achieve a certain } \\
\text { level of education; } \\
\text { - stimulates the independence of choice } \\
\text { and decision-making by the individual }\end{array}$ & $\begin{array}{l}\text { - with a lack of } \\
\text { democratic principles } \\
\text { of functioning } \\
\text { (institutions), } \\
\text { insufficient intensity of } \\
\text { public interaction, such } \\
\text { an innovative } \\
\text { infrastructure will } \\
\text { function unproductively } \\
\text { - missing required } \\
\text { achievements in the } \\
\text { field of functional } \\
\text { activity of the brain, } \\
\text { thinking } \\
\text { and consciousness, } \\
\text { - problematic } \\
\text { quantitative assessment } \\
\text { of parameters and } \\
\text { characteristics of these } \\
\text { processes }\end{array}$ \\
\hline
\end{tabular}

Compiled by the author on the basis $[80,50,134,226,169]$

All this necessitates the adaptation of HEI to new conditions, and, as noted by Henry Eyring and Clayton Christensen in [263] the need to change the structure of university DNA from within on the basis of permanent innovation.

If the specifics of innovation are well studied for business structures, then the entrepreneurial, innovative activities of universities is a phenomenon of the late XX - early XXI centuries. Its emergence is directly related to the processes of comprehensive globalization, autonomy of HEI activities against the background of reducing public funding for their operation which transforms once state-owned economic entities into business structures, changing approaches, methods, types of their activities.

In addition, the evolution of universities, which is expressed primarily in the evolution of the mission of their activities, is directly related to the industrial revolutions (Fig. 4.2).

The articles of such scientists as Mokyr, J. (2002), Etzkowitz, H. (2011), Etzkowitz, H. and Viale, R. (2010), Xu, Q., Wanyan, S., Yang, H. and Chen, J. (2000), Campbell, DJ (2005), Romano, A. (2009), Margherita, A. and Secundo, G. (2011), Ropke, J. (1998), Carayannis, EG and Campbell, D.F. (2012), Guerrero, M., Toledano, N. and Urbano, D. (2011) are devoted to the studies of the role of universities in society, the causes, 
characteristics and forms of interaction between universities, economics and society in the development of civilization.

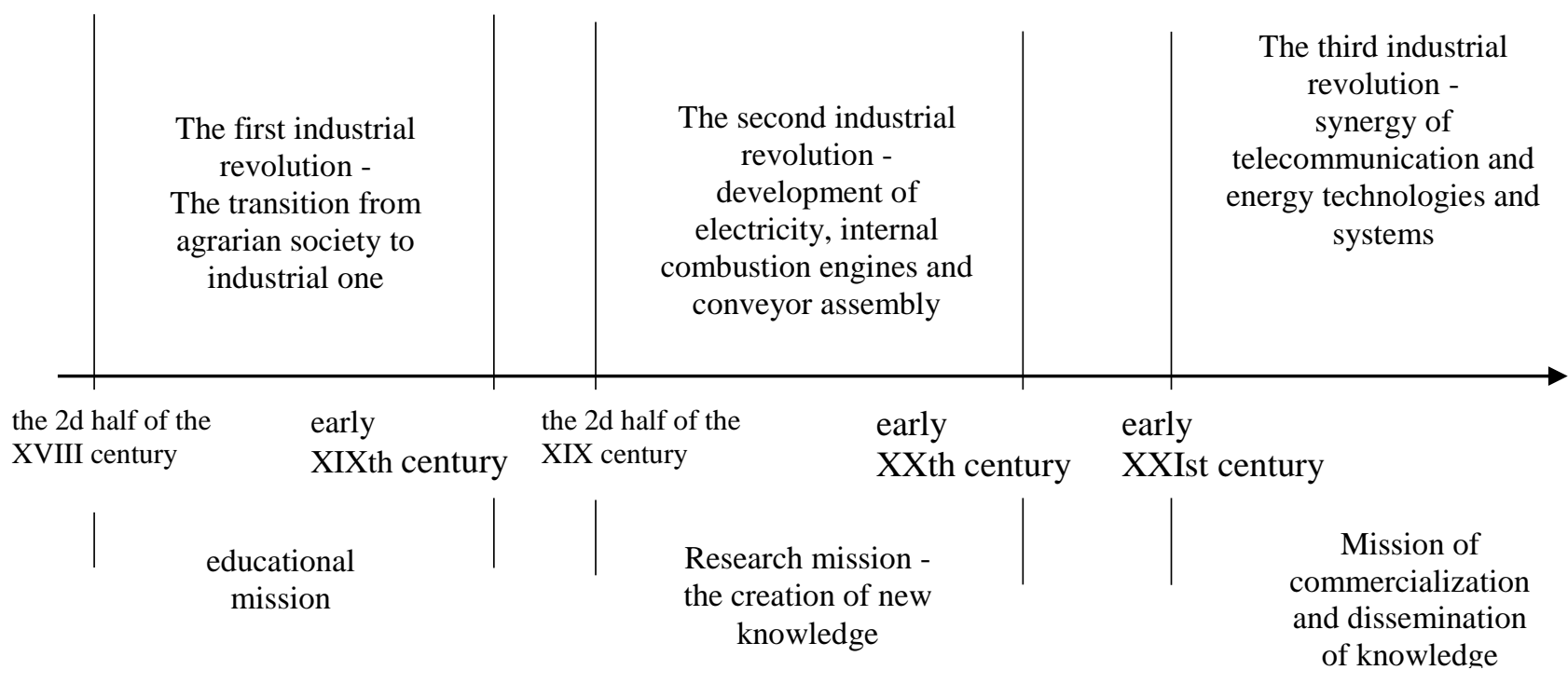

Fig. 4.2. The evolution of industrial revolutions and university missions

(developed by the authors on the basis of $[214,163,285,54,210]$ )

The analysis of these works allowed to form an evolutionary model of spirals which includes the main stakeholders of the interaction of universities (Fig. 4.3), namely:

- a simple spiral corresponds to the educational mission of universities. The main purpose of universities is to accumulate, preserve and transfer knowledge;

- the double spiral arose from the interaction of universities with industry and transformed the educational mission of universities into research by adding the function of generating / creating new knowledge. Academic and industry interactions have become the basis of joint innovations and created the preconditions for the formation of an entrepreneurial university. However, the main activity of universities was educational activities;

- the triple spiral of interactions reflects a new view of the university, its academic system which is based on new models of cooperation between industry consortia, university relations and government agencies. There is a university of entrepreneurial type, a distinctive feature of which is the versatility and interconnectedness of its activities on the basis of various innovations. In these circumstances, its mission is not only to create new knowledge, but also to commercialize and disseminate them in scientific, industrial and social circles; 


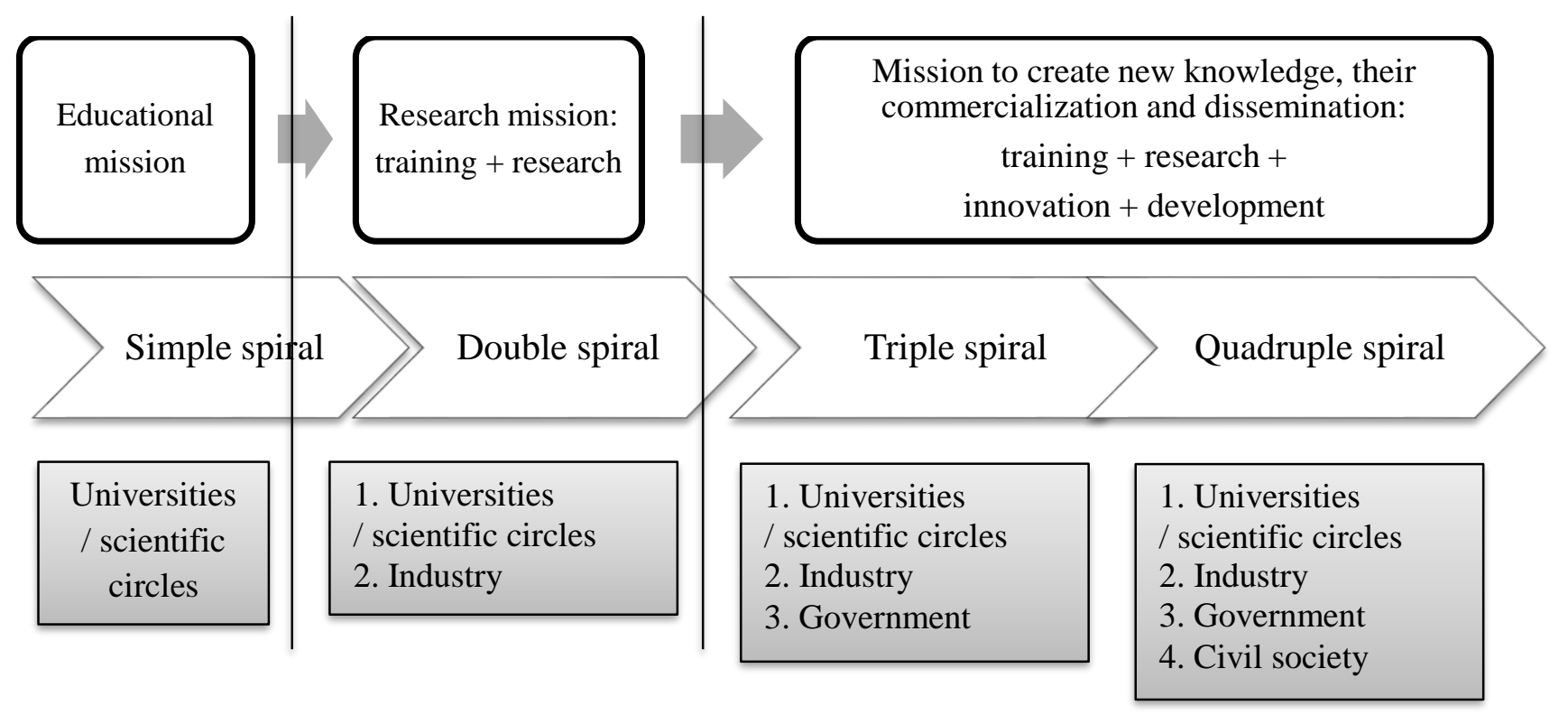

Fig. 4.3. An evolutionary model of spirals of university interaction with economy and society (developed by the authors on the basis of [214, 163, 285, 54, 210])

- the quadruple spiral is a modification of the triple one and supports its mission. The fourth participant in the relationship is civil society which allows to maintain a democratic approach to innovation, the essence of which is the social responsibility of policies and practices for the creation and implementation of innovations for future generations.

Based on the theory of knowledge [146], it is known that innovation, firstly, requires knowledge that is disseminated among a large number of different participants who make a significant contribution to the innovation process; secondly, knowledge is not always easy to pass on, as it is often hidden and people-embodied. That is, the innovation process is an iterative process of the emergence of new knowledge from existing one in new forms. Of all the subprocesses of cognition, namely the creation, exchange, acquisition, transmission and application of knowledge, the creation of knowledge has the most dominant impact on innovation. Thus, among the stakeholders of the quadruple spiral of university, interaction plays a key role and adaptation to the task of creating entrepreneurial thinking, stimulating business creation and the use of ideas in society is the key to their survival.

Thus, at the beginning of the XXI century a new paradigm of university development was formed - business-type universities, which is that universities are 
designed to serve society, primarily by supporting the economy and improving the quality of life of its citizens [31]. The new paradigm radically changes the culture of responsibility and the value system of the university, as evidenced by the spread of management approach and the use of the principle of value for money in higher education systems around the world. The competitiveness and relevance of the university's existence is assessed mainly in accordance with its contribution to the economic development of countries and humanity as a whole. To adjust to the new paradigm, some adaptation is needed - adaptation of the university's relations with the surrounding society / major stakeholders, adaptation of its internal processes, core values, search for new innovative foundations for its development in modern conditions.

Currently, there are two different approaches to understanding the essence of entrepreneurial, innovative-active university.

The first approach treats it as an institution that does everything possible to develop science, invent new technologies and stimulate new markets and industries, and the entrepreneurial aspect of universities is associated exclusively with business and commercialization of their intellectual property. This view is largely supported by the views of the international community (e.g. the Organization for Economic Co-operation and Development (OECD)), which views universities as sources of technological innovation and "growth engines". At the same time, the criteria for the university's innovation are the number of national and international patents filed, their citation in the development of new patents, the impact of patents, and so on. Under these conditions, various rankings were built, in particular, the rating of Reuters, which was compiled in collaboration with Clarivate Analytics "TOP-100 most innovative universities in the world" [222]. Following the results of 2019, for the fifth year in a row, three universities occupy leading positions in this area - Stanford University, Massachusetts Institute of Technology and Harvard University. The list of countries with the largest number of innovative universities in the TOP-100 is the United States (46 universities), Germany (9), France (8), the United Kingdom (6), South Korea (6), Japan 6).

The second approach considers more broadly innovative and active activities of the university as a set of new initiatives in the organization and development of leadership; experiments in pedagogy, organization of knowledge, introduction of new forms of education and development of relevant business and society demands of academic 
programs; interaction of internal and external stakeholders; interdisciplinary research activities related to the acquisition of new knowledge, methods and commercialization of their results. This approach is related to the concept of entrepreneurship that focuses on two key tasks: the formation of an enterprising person and the development of entrepreneurial thinking [31].

Supporting the imperatives of the second approach, in the study under the Innovative-Active University (IAU) we understand a business organization that has the resource readiness, namely, the readiness of the management system, the readiness of human, educational, scientific, financial, organizational potential, to promote accelerated economic development and society through intensive transfer of new knowledge and technologies generated at the university through partnership with labour market actors, governmental and non-governmental organizations. In this context, the dominants of IAU are:

- science as a tool for generating new knowledge on the basis of integration with the external environment, primarily with high-tech enterprises;

- education as a way to bring knowledge to people, the formation of the intellectual potential of society;

- interaction with industry, government, society as a means of concerted efforts to ensure the stable development of the nation and civilization (Fig. 4.4).

The need to develop an innovative component of higher education, as noted in Section 3, is one of the strategic priorities of the country's development in accordance with the Association Agreement between Ukraine and the EU, the Law of Ukraine of July 1, 2014 № 1556-VII "On Higher Education", National Doctrine of Education, National Strategy for the Development of Education in Ukraine for 2012-2021, Concepts for the Development of Education in Ukraine for the period 2015-2025, Conceptual foundations for reforming public funding and university management. In these conditions, the innovative activity of HEI and the formation of autonomous, entrepreneurial universities of innovative type is one of the forms of integration of the higher education system of Ukraine into the European and world educational and scientific space, maintaining its competitiveness and attractiveness by permanently improving the quality of education, scientific and educational innovations, introduction of information technologies and creation of anti-corruption systems. 


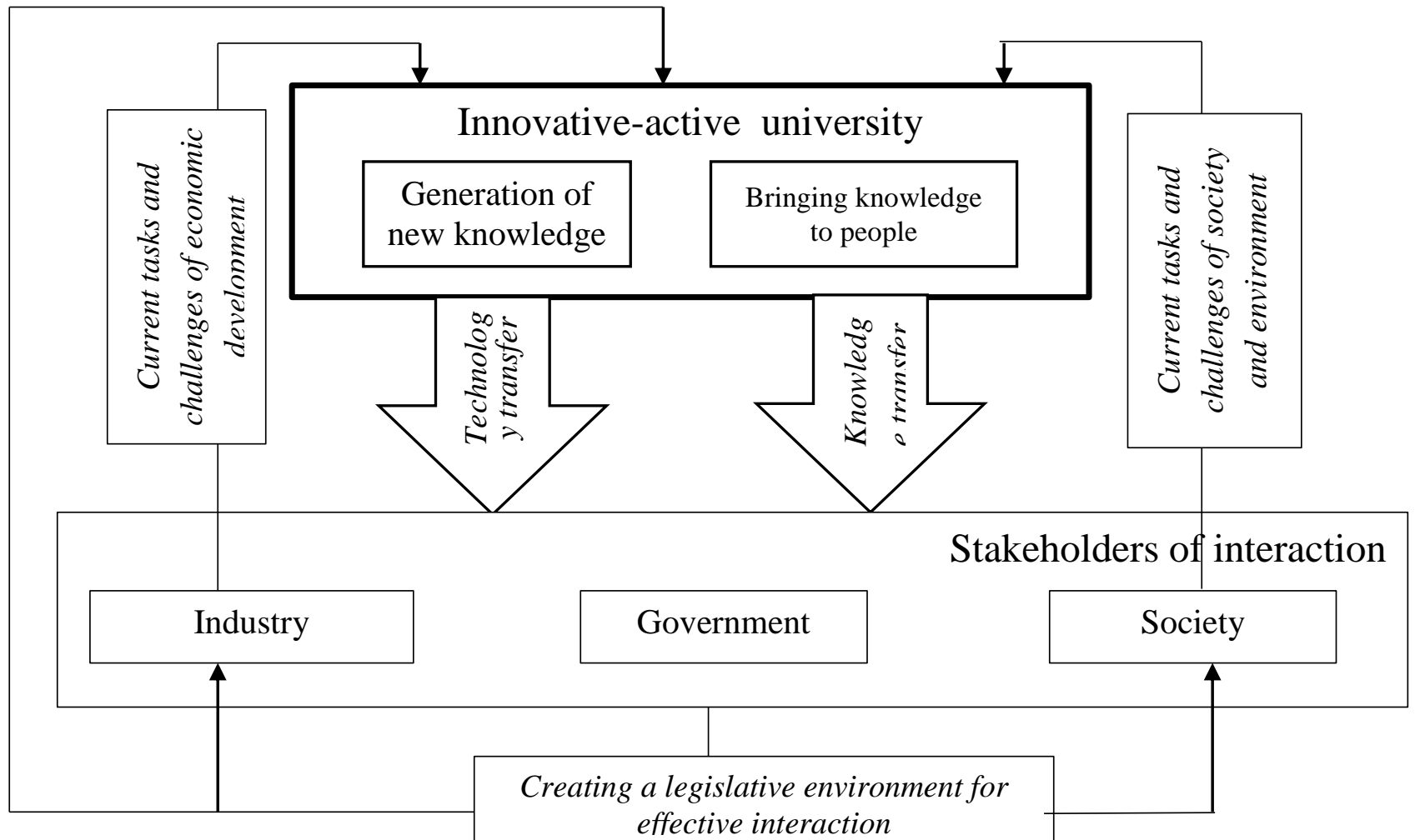

Fig. 4.4. Operational model of university interaction with stakeholders (source: developed by the authors)

The analysis of trends in the development of the higher education system in Ukraine, the study of evolutionary trends in the transformation of its legal framework, the experience of leading universities in the country led to the conclusion that the current stage of development of the national higher education system is accompanied by a number of systemic problems and contradictions, including:

1) the contradiction between the need for significant financial resources to ensure a high level of competitiveness of the HEI of Ukraine and the reduction of public funding for higher education;

2) the contradiction between the significant (excess) number of HEI in the educational space of the state and the tendency to reduce the number of applicants due to declining demographic trends and educational migration;

3 ) the contradiction between the state's need for highly qualified personnel to ensure the development of the economy and society and the intensification of international intellectual migration which leads to the outflow of educated and highly qualified specialists;

4) the contradiction between the growing level of digitalization of society and the 
insufficient level of protection of information technology and support of educational and scientific security in the conditions of hybridity and synergy of modern cyber threats;

5) contradictions between the existence in the legal field of laws declaring the autonomy of HEIand at the same time the absence of bylaws and documents regulating their implementation and providing mechanisms for the practical implementation of financial autonomy of HEI;

6) contradictions between the high level of competition between domestic HEIand their desire for integration into the world educational space;

7) the contradiction between the reduction of public funding and the growing need for resources HEI in the implementation of scientific, innovative, inventive activities.

These contradictions form, the main one for Ukraine and the world, educational space problem - the need for a significant rethinking of the forms, methods and practices of activities HEI in accordance with the challenges of the current stage of civilization.

Based on this, the HEI of Ukraine faces the task of finding tools, ways, approaches to permanent transformation from a traditional university to an entrepreneurial, innovative and active structure of the country's higher education system (Fig. 4.5).
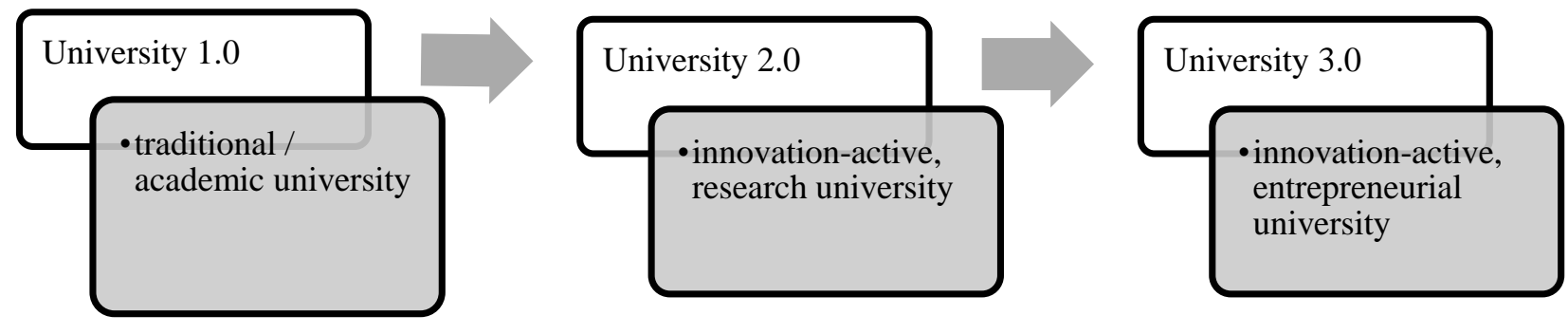

Fig. 4.5. Vector of transformation of university activity in accordance with the modern trends in the development of the world system of higher education

The conceptual bases of origin and development of IAU contain two groups of approaches:

- general scientific approaches that declare the direction of scientific research, highlight its specific aspect and do not clearly indicate the specifics of research tools. They form the basis of any research by determining the general paradigm of obtaining new knowledge;

- specific scientific approaches / concepts that reflect the features of scientific research by clearly defining the possibility of using appropriate scientific principles, 
statements, categories, tools, methods, etc. In this study, the focus of retaining new knowledge is the processes of construction and operation of an innovative university.

Based on the purpose and objectives of the study and based on a critical analysis of general scientific approaches (Table 5.5), the study proposes the use of the following approaches:

1. The process, or functional, approach. Management is seen as a process, as a sequence of continuous interconnected actions aimed at ensuring the success of the organization. Such actions are defined as management functions. Therefore, the management process is presented as a set, as the total sum of such functions. In general, the process approach emphasizes the importance of taking into account the interdependence of management functions;

2. The system approach emphasizes the interdependence of individual parts of the organization, as well as the interdependence of the organization and the environment. The application of systems theory to the management of IAU allows us to consider the educational organization in the unity of its components, which are also inextricably intertwined with the outside world, and promotes integration.

The beginning of the application of new methods of management of education and educational institutions was laid by realization of ideas of the system approach. The need for such implementation in solving management problems is justified by the formation of ideas about education as a complex social system that has its own substructures, phenomena, processes, between which there are various connections and relationships. The educational subsystem (process), which is central to any university, defines its overall structure as a social organization and structure. In its turn, this process has a complex multilevel structure and consists of a set of components (subprocesses), among which are, for example: individual educational processes - the interaction of specific teachers and specific groups of students, the set of which forms a general educational process; learning processes in certain disciplines; learning processes by cycles of specialties and branches of knowledge, flows and groups, etc.; educational process as a whole; processes outside educational work; educational process as a whole (as the unity of education and upbringing). The output of the "university" system is the results of education;

3. The situational approach involves the use of opportunities for direct application of science to specific situations and conditions. The central element of this approach is the 
situation - a specific set of circumstances that significantly affect the activities of the organization at a given time. Given the general similarity of management processes, the situational approach allows, for significant variation of specific techniques used by managers, to effectively achieve the planned results of the organization. In turn, the effectiveness of these specific techniques and concepts of management is determined by their adequacy to the current specific situations.

Specific scientific concepts are aimed at determining the characteristics of certain areas of research and the peculiarities of the application of scientific techniques. The concepts of S. Slaughter and L. Leslie (introduction of the term "academic capitalism"), B. Clark, M. Gibbons (the concept of "business university"), G. Chesbro (the concept of "open innovation" and G. Itzkowitz (the concept of "triple helix") should be considered as the fundamental works for understanding the need to form and obtain new knowledge about the construction and specifics of IAU development (Table 4.5).

Table 4.5

\section{Specific scientific concepts of construction and functioning of IAU}

\begin{tabular}{|c|c|c|}
\hline Period & Concept name & Content concept \\
\hline 1997 & $\begin{array}{l}\text { "Academic } \\
\text { Capitalism" } \\
\text { (S. Slaughter and } \\
\text { L. Leslie) }[222]\end{array}$ & $\begin{array}{l}\text { Considers the change of the classical university model under the } \\
\text { influence of globalization due to the introduction of elements of } \\
\text { market structure in the activities of universities }\end{array}$ \\
\hline 1998 & $\begin{array}{l}\text { The concept of } \\
\text { "business } \\
\text { university" } \\
\text { B. Clark [56], } \\
\text { M. Gibbons [127] }\end{array}$ & $\begin{array}{l}\text { Defines an entrepreneurial university through a set of conditions } \\
\text { (characteristics), including: strengthened guiding core } \\
\text { (administration), expanded periphery of development (provides a } \\
\text { high degree of decentralization), diversified funding base, stimulated } \\
\text { academic structures and integrated business culture }\end{array}$ \\
\hline 2003 & $\begin{array}{l}\text { The concept of } \\
\text { "open innovation", } \\
\text { G. Chesbro [56] }\end{array}$ & $\begin{array}{l}\text { Defines open innovation as "valuable ideas that can come both from } \\
\text { the company and from outside and can be provided in the market as } \\
\text { a result of actions of the company and other structures"; and the } \\
\text { paradigm of open innovation - as innovation policy and innovation, } \\
\text { in which "external ideas can and should be used along with their own, } \\
\text { as well as" internal "and" external "ways of entering the market with } \\
\text { their more advanced technologies." Open innovation is the use of } \\
\text { targeted knowledge flows to accelerate internal innovation processes, } \\
\text { as well as to expand markets for more efficient use of innovation. }\end{array}$ \\
\hline $\begin{array}{c}1998- \\
2011\end{array}$ & $\begin{array}{l}\text { The concept of } \\
\text { "triple } \\
\text { spirals " } \\
\text { G. Itskovica [111] }\end{array}$ & $\begin{array}{l}\text { Under the University of Entrepreneurship one means a higher } \\
\text { education institution that, in addition to traditional sources of } \\
\text { funding, actively develops and uses patents, research and other areas } \\
\text { of contractual cooperation with private enterprises as effective tools } \\
\text { for expanding sources of funding and investment in the university }\end{array}$ \\
\hline
\end{tabular}


Modern education today is impossible without an appeal to the individual. Personally-oriented learning ensures the development and self-realization of the individual, meeting his educational, spiritual and cultural needs, to be competitive in the labour market. That is why the task of a university is to help students understand the essence of the chosen profession, its requirements for the performer, goals, content and functions of professional activity, possible individual strategies for professional duties, specifics of professional skills and ways to master it, methods of creative adaptation to content and structure. activities [6]. Improving the quality of education and ensuring its mobility, competitiveness in the labour market require further improvement of the organization of the educational process in universities on the basis of humanity, personality-oriented pedagogy and include:

development and self-development of a student as a subject of cognitive and subject activity;

focus on abilities and inclinations, interests, values and subjective experience, should create opportunities for each student to realize themselves in different activities;

student independence in designing a selective vector of education;

the main purpose of modern education is education as a set of educational competencies, individual abilities and is the most important means of formation of spiritual, intellectual qualities of a student, forms an individual perception of the world;

opportunities for its creative transformation, extensive use of subjective experience in the interpretation or evaluation of facts, phenomena, events of the surrounding reality on the basis of personality-oriented learning, developing the student's personality, creating conditions for his self-development, self-expression.

The marketing approach involves the orientation of the control subsystem of the management system to the consumer in solving any problem, taking into account their needs and requests [226]. It is the marketing approach to management that ensures the balancing of the interests of IAU, stakeholders and society (Table 4.6).

hus, based on the above research and proposals, the activities of the innovativeactive university should be based on the following conceptual approaches (Fig. 4.6). 
Table 4.6

\section{Essential characteristics of existing concepts of marketing approach to}

\section{management, applied to educational organizations}

\begin{tabular}{|c|c|c|}
\hline $\begin{array}{l}\text { The concept of } \\
\text { marketing approach to } \\
\text { management }\end{array}$ & The essence of the concept & $\begin{array}{l}\text { Features of application of the management } \\
\text { concept in the educational organization }\end{array}$ \\
\hline $\begin{array}{l}\text { The concept of } \\
\text { production } \\
\text { intensification }\end{array}$ & $\begin{array}{l}\text { At the heart of the concept of } \\
\text { intensification of commercial } \\
\text { efforts is the approach "from the } \\
\text { inside out". It is based on the } \\
\text { interests of production. Her main } \\
\text { focus is on the product. The } \\
\text { ultimate goal - profit, by increasing } \\
\text { sales, is achieved through the sale } \\
\text { and promotion of goods }\end{array}$ & $\begin{array}{l}\text { Management of educational and scientific } \\
\text { activities of educational organizations } \\
\text { according to this concept is based on the } \\
\text { principles of typical educational programs for } \\
\text { training applicants of a certain educational } \\
\text { level, which provides a standardized approach } \\
\text { to the training of future professionals through } \\
\text { specialization of educational institutions, } \\
\text { distribution of functions among employees and } \\
\text { unification of educational processes. }\end{array}$ \\
\hline $\begin{array}{l}\text { Clean marketing } \\
\text { concept }\end{array}$ & $\begin{array}{l}\text { This concept is that the company's } \\
\text { achievement of its global goals } \\
\text { depends on identifying the needs } \\
\text { and demands of target markets and } \\
\text { on more effective compared to } \\
\text { competing consumer satisfaction. } \\
\text { The concept of marketing uses an } \\
\text { "outside-inside" approach. It is } \\
\text { driven by the market, focuses on } \\
\text { consumer needs, uses } \\
\text { comprehensive marketing efforts to } \\
\text { increase profits by satisfying } \\
\text { consumers }\end{array}$ & $\begin{array}{l}\text { Management in HEI is aimed at maximizing the } \\
\text { needs of consumers / stakeholders of } \\
\text { educational services through research, } \\
\text { segmentation and implementation of a set of } \\
\text { marketing approaches in management, i.e. } \\
\text { involves active adaptation to the changing } \\
\text { needs of potential customers of educational } \\
\text { services - applicants, students and employers }\end{array}$ \\
\hline Logistics concept & $\begin{array}{l}\text { The concept of logistics is a system } \\
\text { of views on the rationalization of } \\
\text { economic activity by optimizing } \\
\text { material flows }\end{array}$ & $\begin{array}{l}\text { Management in an educational organization is } \\
\text { based on the rational use of management and } \\
\text { marketing achievements in educational and } \\
\text { research activities aimed at bringing } \\
\text { educational services to the end user and } \\
\text { achieving the latter satisfaction not only from } \\
\text { receiving services but also service from the } \\
\text { educational organization in the future }\end{array}$ \\
\hline $\begin{array}{l}\text { The concept of socio- } \\
\text { ethical marketing }\end{array}$ & $\begin{array}{l}\text { The essence of the concept is that } \\
\text { the company must identify the } \\
\text { needs and interests of target } \\
\text { markets, and then provide higher } \\
\text { consumer value in more efficient, } \\
\text { than competitors, ways that } \\
\text { improve the well-being not only of } \\
\text { the customer but also society as a } \\
\text { whole }\end{array}$ & $\begin{array}{l}\text { Management in an educational organization is } \\
\text { based on the comprehensive satisfaction of the } \\
\text { requirements and needs of consumers in view } \\
\text { of their vocations, interests and abilities in a } \\
\text { more effective, compared to other universities, } \\
\text { way, which ensures consumer loyalty to higher } \\
\text { education, leads to continuity of education } \\
\text { ("lifelong learning"), the very sustainability of } \\
\text { the development of the educational } \\
\text { organization and society as a whole }\end{array}$ \\
\hline
\end{tabular}




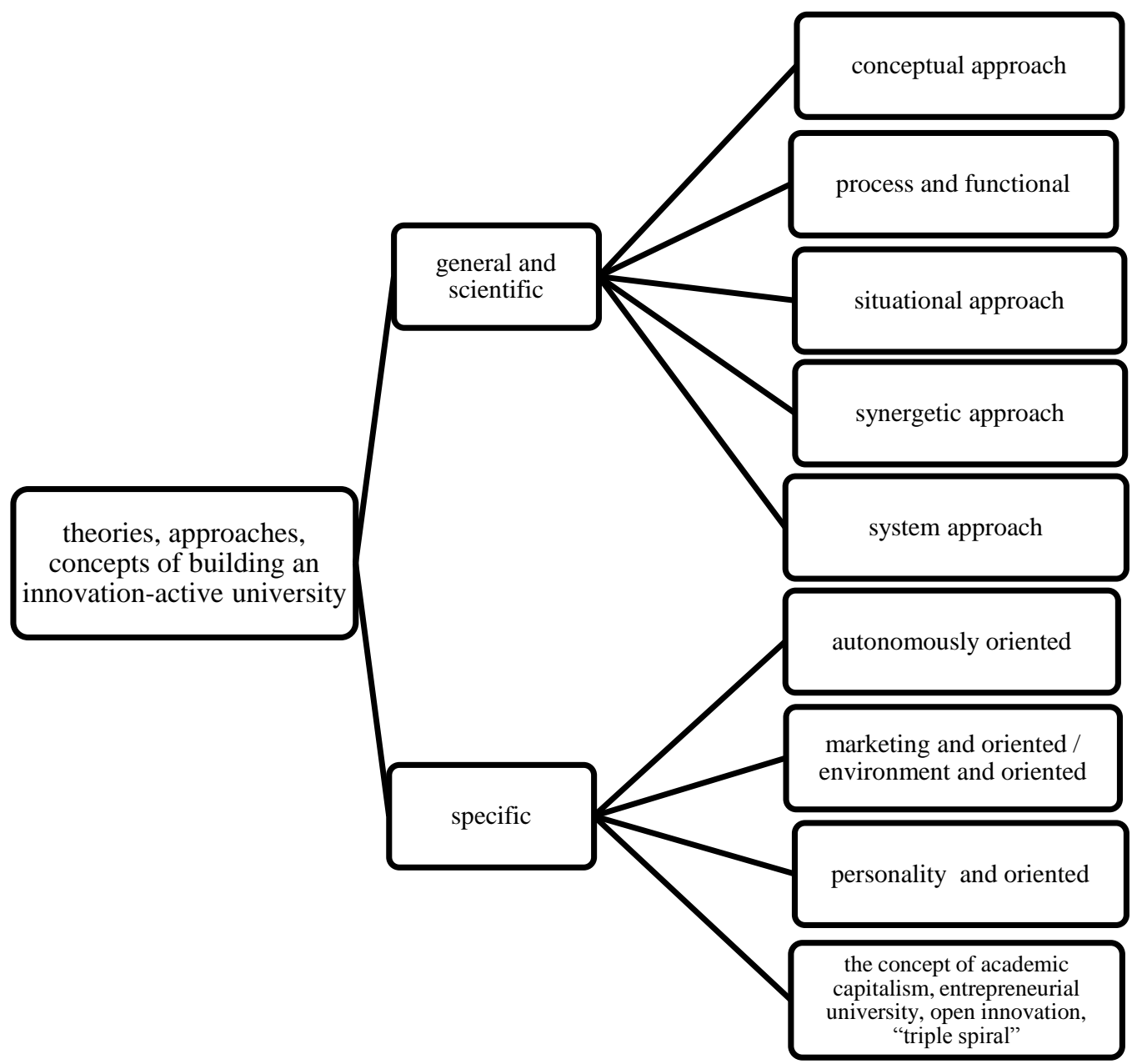

Fig. 4.6. Conceptual approaches to the construction of IAU

In the table 4.7 the connection of the offered approaches and directions of the application in research is resulted.

Table 4.7

\section{Relationship between the proposed approaches and areas of application in the study}

\begin{tabular}{|l|l|}
\hline \multicolumn{1}{|c|}{ Approach / concept } & \multicolumn{1}{|c|}{ Areas of application } \\
\hline \multicolumn{1}{|c|}{1} & \multicolumn{1}{|c|}{2} \\
\hline $\begin{array}{l}\text { conceptual and process- } \\
\text { functional approaches }\end{array}$ & $\begin{array}{l}\text { to develop elements of the methodology for constructing a } \\
\text { mechanism for the transformation of HEI into an innovative type of } \\
\text { university }\end{array}$ \\
\hline system approach & $\begin{array}{l}\text { to form a comprehensive view and develop new knowledge about the } \\
\text { phenomenon of "autonomous and innovative university", its } \\
\text { components and relationships between them, to develop a system of } \\
\text { information and analytical evaluation of the components of the } \\
\text { mechanism, to build technology for strategic development of } \\
\text { innovative universities on the basis of quality assurance education; to }\end{array}$ \\
\hline
\end{tabular}


The end of the table 4.7

\begin{tabular}{|l|l|}
\hline \multicolumn{1}{|c|}{1} & \multicolumn{1}{|c|}{2} \\
\hline situational approach & $\begin{array}{l}\text { build technology and develop an information security system in the } \\
\text { world-class KNOS University }\end{array}$ \\
\hline synergetic approach & $\begin{array}{l}\text { to form a system for monitoring the components of the mechanism of } \\
\text { transformation of HEI }\end{array}$ \\
\hline $\begin{array}{l}\text { autonomous-oriented } \\
\text { approach }\end{array}$ & $\begin{array}{l}\text { to identify possible threats to the construction of an electronic } \\
\text { document management system HEI }\end{array}$ \\
$\begin{array}{l}\text { to determine the level of development of educational, scientific, } \\
\text { technical, innovative and international activities of domestic } \\
\text { universities, to develop an adaptive system to strengthen the } \\
\text { components of the mechanism of transformation of HEI through the } \\
\text { introduction of e-government based on the use of X-509 standards, } \\
\text { processes of educational services in the conditions of modern } \\
\text { cyberthreats and application of technologies of cyberspace }\end{array}$ \\
\hline $\begin{array}{l}\text { environmental-situational } \\
\text { approach and marketing- } \\
\text { oriented }\end{array}$ & $\begin{array}{l}\text { to build a management system for the development of the HEI } \\
\text { educational environment of innovative type }\end{array}$ \\
\hline $\begin{array}{l}\text { concepts of academic } \\
\text { capitalism, entrepreneurial } \\
\text { university, open innovation, } \\
\text { "triple helix" }\end{array}$ & $\begin{array}{l}\text { for the formation of a comprehensive view and the development of } \\
\text { new knowledge about the phenomenon of "autonomous and } \\
\text { innovative-active university" }\end{array}$ \\
\hline
\end{tabular}

Thus, on the basis of the conducted researches the following results are received:

- global trends, which have influenced the change of the higher education system and led to a change in the paradigm of the functioning of the Higher Education Act, have been identified. It is proved that the competitiveness of HEIdirectly depends on the universities' change of the vector of development from conservative to progressive, from subordinate to the state to autonomous one;

- it is substantiated that the conceptual approach to the management of innovative universities should be based not only on the principles of general management theory, but also on modern approaches and concepts of management of organizations aimed at comprehensive satisfaction of individual requirements and needs of consumers in terms of their vocations, interests and abilities in more effective ways compared to other HEI. This approach to management will ensure the sustainability of the educational organization and society as a whole;

- on the basis of generalization of the world experience, the evolution of industrial revolutions and missions of universities is developed, which reflects a vector of 
transformation of their activity from educational mission to mission of commercialization and distribution of knowledge;

- it is determined that the new paradigm of development of universities - universities of entrepreneurial type- is that universities are designed to serve society, primarily by supporting the economy and improving the quality of life of its citizens. It radically changes the culture of responsibility and the value system of the university. The competitiveness and relevance of the university's existence is assessed mainly in accordance with its contribution to the economic development of countries and humanity as a whole. To adapt to the new paradigm, some adaptation is needed - adaptation of the university's relations with the surrounding society / major stakeholders, adaptation of its internal processes, core values, search for new innovative foundations for its development in modern conditions;

- against the background of the analysis of two key approaches to understanding the essence of entrepreneurial, innovative-active university, its interpretation has been improved. Thus, the innovative-active university (IAU) means an entrepreneurial organization that has the resource readiness, namely, the readiness of the management system, the readiness of human, educational, scientific, financial, organizational potential, to promote accelerated economic development and society through intensive transfer of new, knowledge and technologies generated at the university on the basis of partnership, with labour market actors, governmental and public organizations;

- an operational model of the university's interaction with stakeholders has been developed, which, unlike the existing ones, is based on technology transfer and knowledge transfer and is aimed at finding effective forms of such interaction;

- a conceptual basis for the construction of the IAU is developed, which contains a definition of the problem, the contradictions that exist in the national system of higher education; the classification of conceptual approaches is offered and the directions of their application for the purposes of research are defined.

\subsection{Development of the concept of formation of innovative-active university}

Based on the analysis of item 5.1 and taking into account that the innovative activity of HEI and the formation of autonomous, entrepreneurial universities of innovative type 
is one of the strategic directions of the development of the higher education system of Ukraine, the study developed conceptual principles of construction and functioning of an innovatively active university (IAU), which determine the basis for the process of transformation of a traditional university into the latest innovative-active structure that operates on the basis of interaction with stakeholders and is characterized by a high level of competitiveness in the domestic and global educational market.

Formation scheme of conceptual foundations of construction and functioning of innovatively active university contains a set of logically related stages, shown in Fig. 4.7.

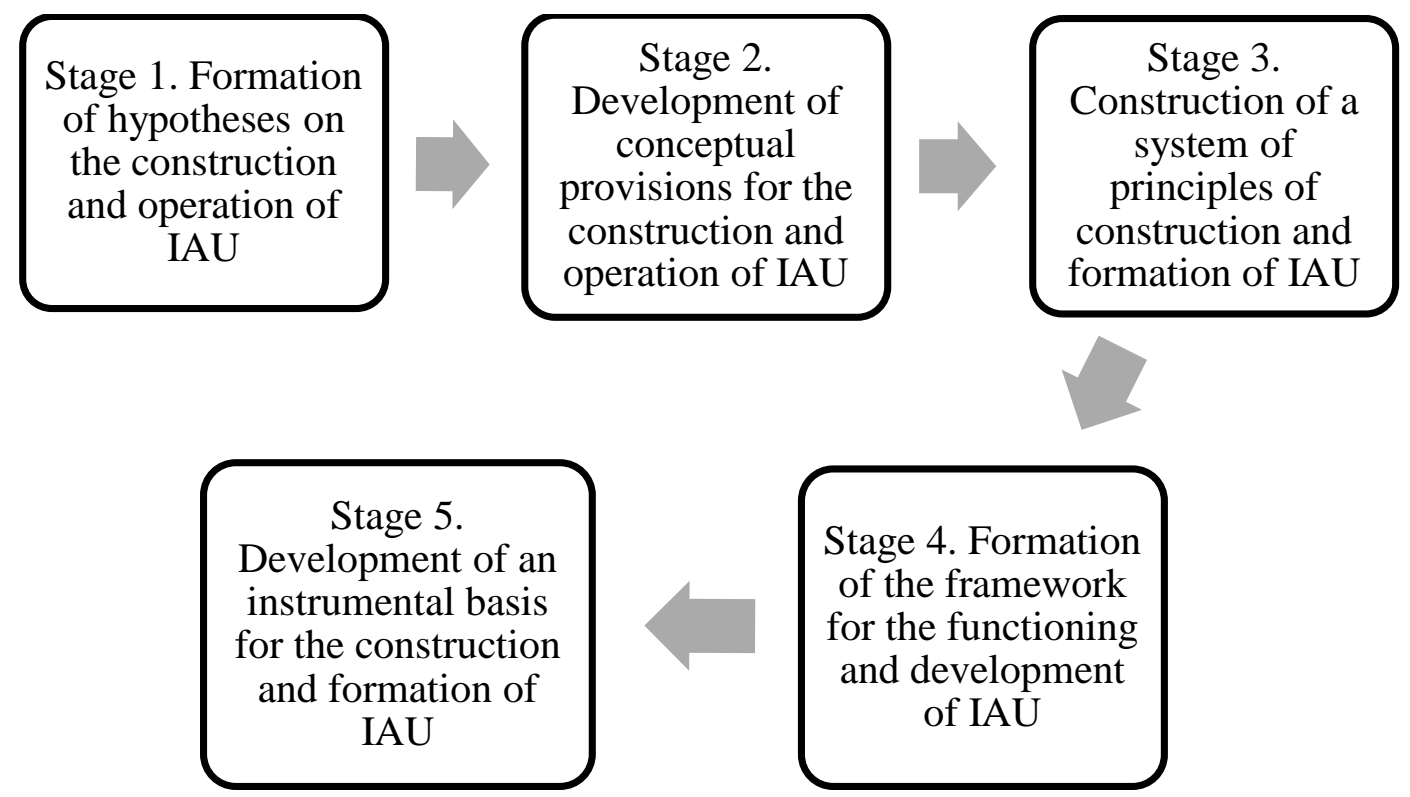

Fig. 4.7. Scheme of development of conceptual bases of construction and functioning of innovatively active university

Let us consider in detail their content.

\section{Stage 1. The formation of hypotheses of construction and functioning of IAU.}

Construction and testing of hypotheses as forms of development of scientific knowledge within the formation of conceptual foundations of construction and functioning of IAU should take place as a complex phenomenon that provides purposeful, multivariate and reasoned search for the desired result in conditions of uncertainty. In this regard, the paper proposes statements that underlie the construction and formation of an innovative type of university and hypotheses, which together form the methodological basis for developing the conceptual foundations of an innovatively active university (Table 4.8). 


\section{Methodological basis for the formation of the concept of construction and operation of IAU}

\begin{tabular}{|c|c|}
\hline Assertion & Working hypothesis \\
\hline $\begin{array}{l}\text { 1. The creation of business-type } \\
\text { universities is a key area of } \\
\text { development and growth of the } \\
\text { level of competitiveness of the } \\
\text { higher education system of the } \\
\text { world and Ukraine }\end{array}$ & $\begin{array}{l}\text { 1. The level of competitiveness of the higher education system is } \\
\text { a key factor in strengthening the competitiveness of the state } \\
\text { through the formation of innovative autonomous universities } \\
\text { which create a quality and attractive for domestic and foreign } \\
\text { consumers educational product }\end{array}$ \\
\hline $\begin{array}{l}\text { 2. The role of HEI in the } \\
\text { innovation process significantly } \\
\text { goes beyond the development of } \\
\text { innovations, but also aimed at } \\
\text { their commercialization, which } \\
\text { has a significant impact on the } \\
\text { development of society. }\end{array}$ & $\begin{array}{l}\text { 2. The tendency to reduce the number of entrants within the } \\
\text { national higher education system, provoked by the demographic } \\
\text { crisis and increasing the attractiveness of foreign education, must } \\
\text { be reversed by the objective regularity of innovative activity of } \\
\text { HEI aimed at improving the quality of educational services, } \\
\text { scientific and technical developments and international image }\end{array}$ \\
\hline $\begin{array}{l}\text { 3. IAU is a complex and } \\
\text { structured system that combines } \\
\text { the intellectual potential of HEI, } \\
\text { as well as its financial and } \\
\text { organizational resources. }\end{array}$ & $\begin{array}{l}\text { 3. The creation of an innovative type of university presupposes the } \\
\text { presence of a synergetic effect of three components - the } \\
\text { concentration of talents, the availability and sufficiency of } \\
\text { resources and effective management. }\end{array}$ \\
\hline $\begin{array}{l}\text { 4. The development of } \\
\text { innovative universities should } \\
\text { take place on the basis of } \\
\text { effective interaction of } \\
\text { universities with major } \\
\text { stakeholders. }\end{array}$ & $\begin{array}{l}\text { 4. The formation of an innovative university depends on the } \\
\text { combination of efforts of the state, which creates the legal basis, } \\
\text { and a specific institution of higher education that actively seeks } \\
\text { ways, forms and tools to increase its image attractiveness in both } \\
\text { national and European market of educational services }\end{array}$ \\
\hline $\begin{array}{l}\text { 5. The transformation of a } \\
\text { traditional university into an } \\
\text { innovative one should be carried } \\
\text { out through the development of } \\
\text { the latest tools, namely, } \\
\text { mechanisms, technologies, } \\
\text { methods and models. }\end{array}$ & $\begin{array}{l}\text { 5. The mechanism of transformation of HEI into a world-class } \\
\text { university should cover the main directions of its activity, namely, } \\
\text { educational, scientific-technical and innovative, international, and } \\
\text { its effectiveness involves the development of conceptual- } \\
\text { methodical and model-information tools that will allow such } \\
\text { transformation on systemic principles }\end{array}$ \\
\hline $\begin{array}{l}\text { 6. The quality of education is a } \\
\text { key component of the } \\
\text { development of all components } \\
\text { of IAU. }\end{array}$ & $\begin{array}{l}\text { 6. Internal quality assurance of education is an important } \\
\text { component of strategic management of innovative development } \\
\text { and competitiveness of the higher education system at the } \\
\text { institutional and state levels }\end{array}$ \\
\hline $\begin{array}{l}7 . \text { In the conditions of } \\
\text { information society and global } \\
\text { digitalization of the processes of } \\
\text { civilization development, the } \\
\text { activity of IAU should be based } \\
\text { on the principles of ensuring a } \\
\text { high level of protection of } \\
\text { information flows and resources. }\end{array}$ & $\begin{array}{l}\text { 7. The effective functioning of an innovative university should be } \\
\text { ensured by a corporate scientific and educational information } \\
\text { system that is a tool to prevent corruption and protect the main } \\
\text { business processes of providing educational services and corporate } \\
\text { information in the context of the spread of cyberspace } \\
\text { technologies. }\end{array}$ \\
\hline
\end{tabular}

Thus, the hypotheses are the result of the implementation of the first stage and embody the essence of the scientific process of forming the conceptual foundations of the construction and operation of innovative universities. 
Stage 2. The development of conceptual regulations for the construction and operation of IAU.

Based on the need to prove the hypotheses, the study on the basis of generalization and thorough refinement [204, 136] formed the key provisions of innovative-active universities in the modern paradigm of higher education, namely:

Regulation 1. The main activities of IAU are educational, scientific, technical, marketing and international activities, which are combined with a high level of innovation and are carried out on the basis of the latest modern technologies and management principles. The main purpose of scientific and technical activities in the context of its innovative content is the generation of new knowledge, educational - the use of new knowledge in the educational process and the formation of intellectual potential of society, marketing - commercialization of knowledge and innovation through interaction with stakeholders and image of the university, international - the development of international cooperation and integration of the university into the world scientific and educational space (Fig. 4.8)

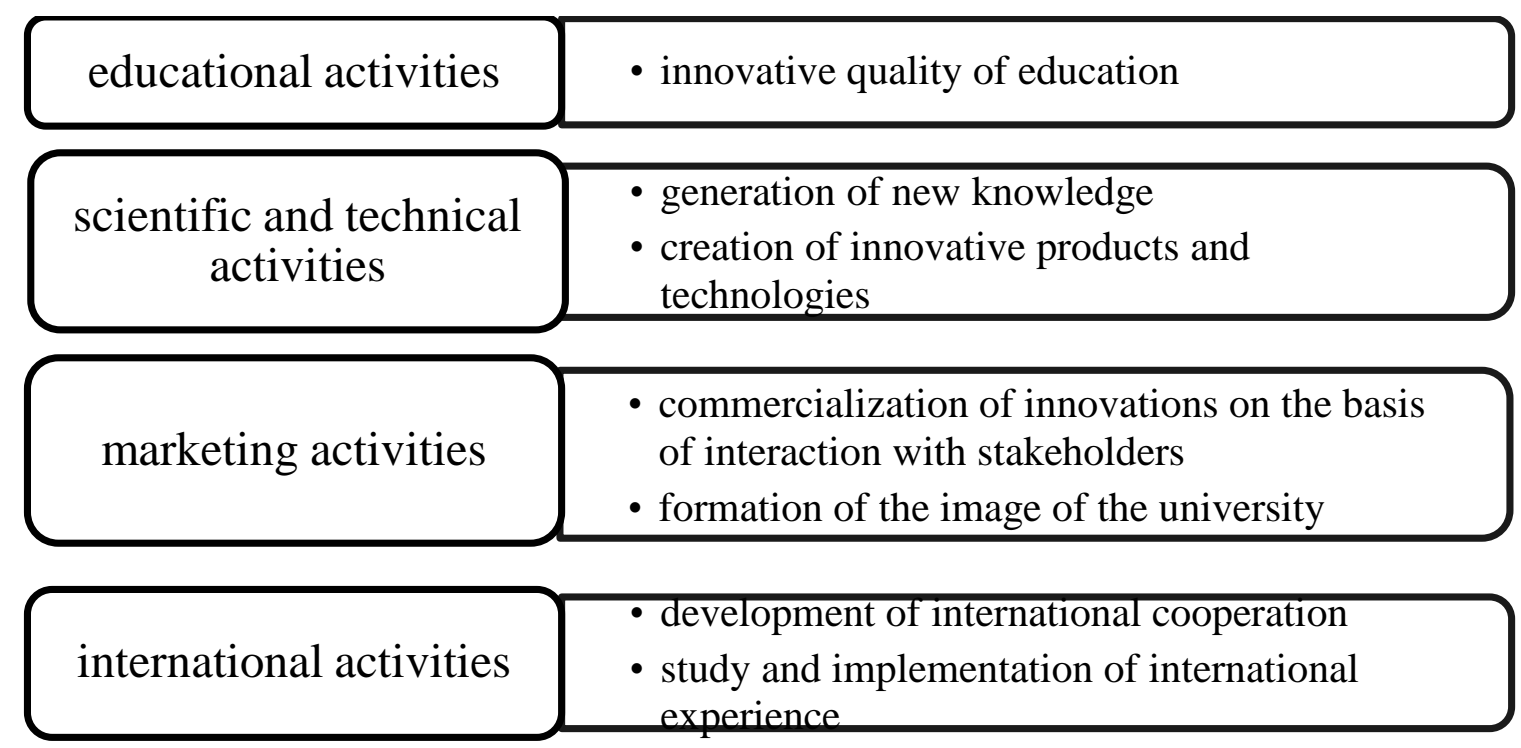

Fig. 4.8. Key innovative results of the main activities of IAU

Regulation 2. The basis for ensuring the effective implementation of the main activities of IAU is its organizational structure and information flows which form a favourable environment for the implementation and development of innovations. Under these conditions, it is advisable to distinguish two supporting activities of IAU: organizational and information-communicative (Fig. 4.9). 
Herewith, supportive activities can also be carriers of innovation. In particular, the purpose of organizational activities in the context of its innovative nature is to improve the organizational structure of the university. At the same time, the innovative orientation of information and communication activities is manifested in the creation of the latest corporate research and educational systems based on modern information technologies and platforms.

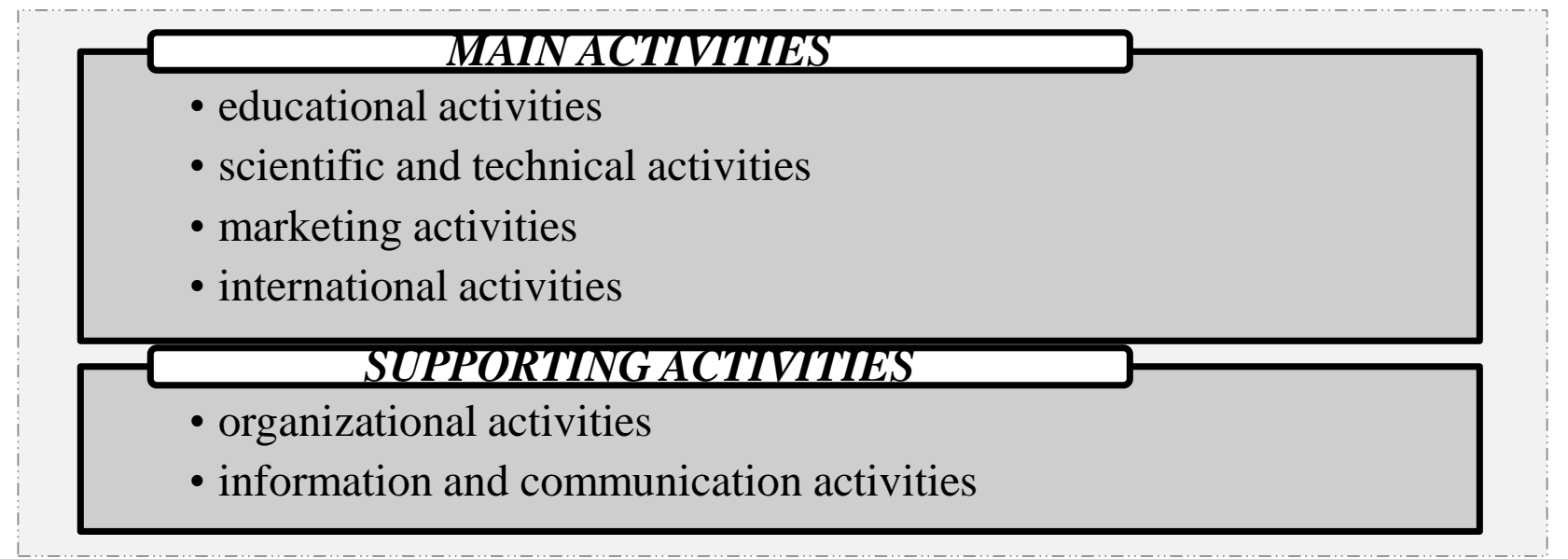

Fig. 4.9. Relationship between the main and supporting activities of IAU

Regulation 3. Effective educational activity of IAU is ensured by strategic partnership with state and regional structures, business representatives, leading higher education institutions in Ukraine and abroad, public institutions, alumni community, which is a necessary condition for its development as a centre of production and transfer of new knowledge to society.

Regulation 4. The key task of IAU is to form students' innovative entrepreneurial thinking and creative competencies, i.e. the ability to independently acquire new knowledge and professional skills. The scientific-educational and entrepreneurial cycle of education of students should be aimed at creating value-added potential in business and society in the form of basic and professional competencies acquired by them.

Regulation 5. The permanent dynamics of changes in educational standards must meet the requirements of the accelerated reproduction of large-scale and continuous innovation in the economy and society and must be aimed at meeting the current and future needs of human development. Such changes should be based on effective and constant interaction of the university with stakeholders based on the involvement of practitioners in the educational process and monitoring of current and future socio- 
economic trends. That is, the quality standards of research and educational activities are a function of the ever-changing requirements for product and other innovations.

Regulation 6. Scientific activity in IAU is carried out within the framework of basic and applied research, the customers and consumers of the results of which are stakeholders (state, labour market actors, society) through the effective technology of transfer of scientific results.

Regulation 7. The traditional linear model of scientific and technical research (Fig. 4.10 , a) should be replaced by a contour aimed at a constant close cooperation with the real sector of the economy and society both in finding orders for scientific and technical development and in the commercialization of new knowledge and technologies (Fig. 4.10, b). The difference between the latter is in the combination of components "customer" and "consumer".

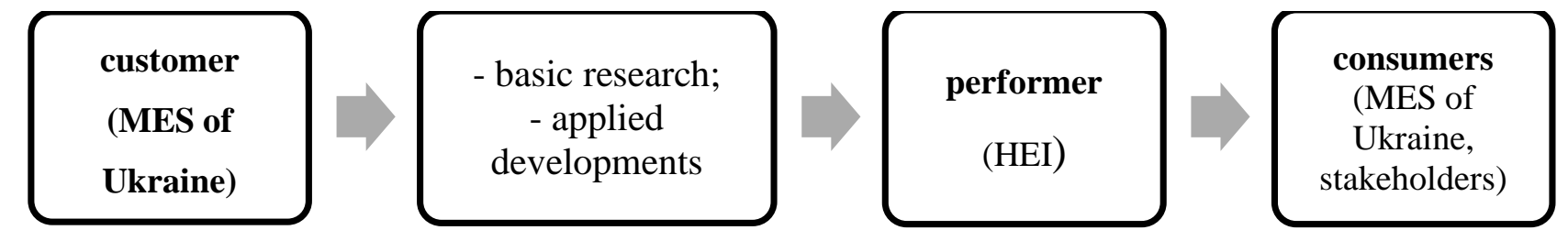

a) the traditional linear model of scientific research

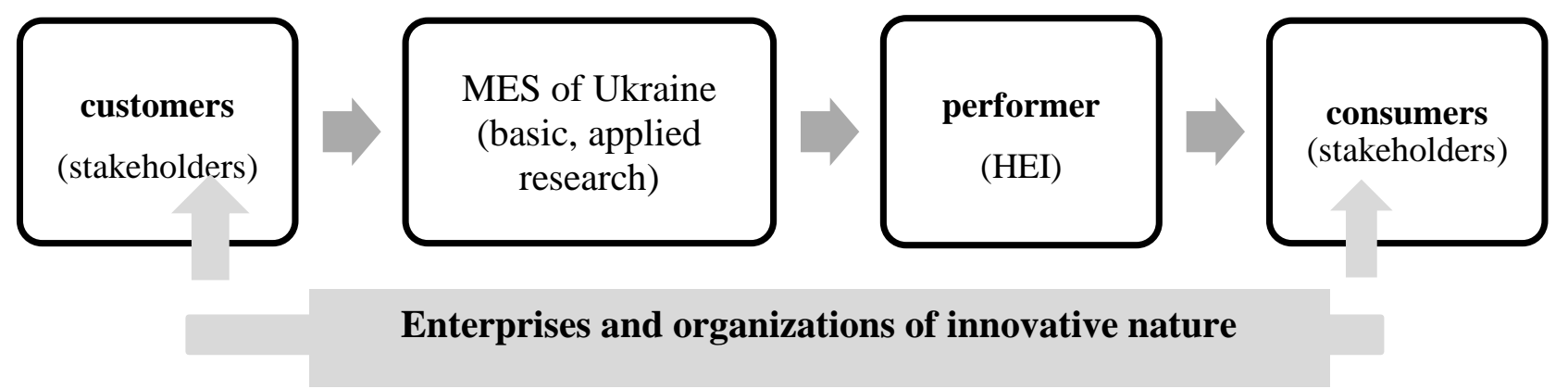

b) a model for conducting research on the basis of interaction with stakeholders

Fig. 4.10. Transformation of the model of scientific and technical research

Regulation 8. The human resources of HEI, which represents its intellectual potential and is the basis of all IAU activities, should be transformed in the direction of readiness to acquire and apply entrepreneurial skills, which allows for a full cycle of reproduction of new knowledge - from research tools to generate new ideas to creation of research samples of product innovations, and its bringing to society and the basis of commercialization and technology transfer. 
Regulation 9. The transformation of the organizational structure of IAU should be of a dual nature:

1. modernization of the existing structure by creating new units engaged in business activities (institutes, own microfirms, consulting units, etc.) both on the basis of its own resource base and by creating joint structures with stakeholders;

2. introduction of new business functions within the existing divisions.

All this will allow the transition from a traditional to an innovative university, which has close ties with stakeholders and in the face of reduced public funding has the opportunity to diversify the sources of funding for their activities.

Regulation 10. Adaptation of IAU to global processes of information society and digitalization should be carried out in two directions:

1) external adaptation, i.e. the creation of information communications between the university and stakeholders in order to increase the rate of diffusion of new knowledge and technologies in the business environment and society;

2) internal adaptation that contains two components:

a) increasing the level of automation and informatization of educational processes in order to improve the quality of education and the introduction of distance and blended learning;

b) creation of corporate scientific and educational systems (KSES) as platforms for protection of corporate information from cyber attacks and implementation of the anticorruption system in the educational sphere.

Thus, the conceptual provisions proposed in the study form the result of the second stage of developing the foundations for the construction and operation of an innovative university.

Stage 3. Construction of a system of principles of construction and formation of IAU.

Systemic changes that accompany the transformation of traditional universities and ensure a high level of competitiveness of higher education in the higher education system of Ukraine and the world should take place on the basis of principles, laid as the foundation for the construction and operation of IAU. In this regard, the study proposes a system of principles (Fig. 4.11).

Let us consider in more detail their content. Thus, in the system of principles of 
construction and functioning of the innovative-active university, in our opinion, it is expedient to allocate the following:

1) principles that form the basis of interaction of innovative-active university with stakeholders - subjects of the external environment (state, business, civil society), namely: the principle of strategic orientation of scientific research on global trends and urgent needs of the state economy provides that the implementation of scientific and scientific-technical activities of IAU should be based on continuous monitoring of global and national trends in economic and social development and study the needs of key stakeholders in order to identify current problems and challenges as basic areas of HEI research;

\begin{tabular}{|c|c|}
\hline \multicolumn{2}{|c|}{$\begin{array}{c}\text { Principles of functioning and development of innovatively active } \\
\text { university }\end{array}$} \\
\hline $\begin{array}{l}\text { Principles of interaction with the } \\
\text { subjects of the external environment }\end{array}$ & $\begin{array}{l}\text { Principles that determine internal } \\
\text { processes and development }\end{array}$ \\
\hline $\begin{array}{l}\text { strategic orientation of scientific research } \\
\text { on global trends and urgent needs of the } \\
\text { state economy } \\
\text { promoting sustainable innovative } \\
\text { development of society } \\
\text { strategic partnership between the } \\
\text { university, the state, research institutions, } \\
\text { industry and business } \\
\text { integration into the international } \\
\text { educational and scientific community }\end{array}$ & $\begin{array}{l}\text { unity of educational, scientific and other } \\
\text { processes of the university on the basis of } \\
\text { innovation; } \\
\text { flexible and personalized learning; } \\
\text { academic integrity and quality of } \\
\text { education; } \\
\text { call-based learning; } \\
\text { lifelong learning; } \\
\text { development of entrepreneurial thinking; } \\
\text { built-in mobility; } \\
\text { ensuring a high level of cybersecurity }\end{array}$ \\
\hline
\end{tabular}

Fig. 4.11. The system of principles of construction and functioning of innovationactive university

the principle of promoting sustainable innovative development of society by training specialists in innovative formation, formation of students and staff skills and competencies of an entrepreneurial nature, generation of new knowledge and technologies 
and their transfer on the basis of interaction with stakeholders;

the principle of strategic partnership between the university, the state, research institutions, industry and business, implementation of which is due to close cooperation and formation of a system of relations between actors-participants of the "triple spiral" (state - university - business), which ensures the creation of a favourable innovation environment in which universities interact with the real economy and society as in search orders for scientific and technical developments, as well as in the commercialization of new knowledge and technologies.

the principle of integration into the international educational and scientific community certifies that the innovative nature of IAU should be largely ensured through the study and implementation of international best practices in educational, scientific and other activities of the HEI, as well as on the basis of active cooperation with international partners, joint research, etc.

2) principles that determine the functioning and development of the internal environment of IAU, which include:

the principle of unity of educational, scientific and other processes of the university on the basis of innovation substantiates the innovative nature of all types of IAU activities as an effective factor in achieving competitive advantages by the university, advanced development of HEI and ensuring a high level of its competitiveness in the world and national educational space;

the principle of flexible and personalized learning provides that the educational process of IAU is based on a combination of training modules of high academic standard, the content of which is offered by stakeholders and created in cooperation with stakeholders with the formation of an individual trajectory of higher education;

the principle of academic integrity and quality of education, the implementation of which should ensure the responsible implementation of the norms of academic integrity, compliance with the quality of education, which reflects the compliance of learning outcomes, educational processes and institutional conditions of IAU with the current goals of personal development and society;

the principle of learning based on challenges provides for the creation of an educational environment in IAU, where methods, tools, technologies and infrastructure of the educational process are formed on the basis of innovation, and innovation in education 
is stimulated by applicants, industry, government and public institutions;

the principle of lifelong learning is to ensure the continuity of updating knowledge and competencies on the basis of the integrity of the processes of formal, non-formal and informal lifelong learning and provides for the continuity of the transition from youth education to adult one;

the principle of development of entrepreneurial thinking - its implementation is aimed at the formation of students, faculty and other employees of innovative entrepreneurial thinking, creative competencies, and the ability to apply the acquired knowledge and skills in the process of finding innovative ways and methods of solving the most complex problems of today;

the principle of built-in mobility provides for the organic integration of physical, virtual and mixed mobility of students, teachers and staff of stakeholders in all activities of IAU, which will take advantage of international experience in education and research, the formation of organizational and corporate culture of the university, etc.;

the principle of ensuring a high level of cybersecurity is based on the need for innovative and active university to use modern information resources, platforms and technologies that allow to ensure a high level of protection of the HEI information system from cyber threats and anti-corruption.

Thus, the developed system of principles is the result of the third stage of development of conceptual bases of construction and functioning of the innovative-active university.

\section{Stage 4. Formation of the framework for the functioning and development of} IAU.

An important component of the conceptual foundations of the functioning and development of innovative universities are the frameworks (English framework framework, structure) [201], the formation of which in this study is proposed in the following sequence (Fig. 4.12).

\begin{tabular}{|c|c|c|c|c|c|}
\hline $\begin{array}{l}\text { 1. Defining } \\
\text { the purpose } \\
\text { of IAU }\end{array}$ & $\begin{array}{l}\text { 2. Formation of } \\
\text { tasks of IAU } \\
\text { activity }\end{array}$ & $\gamma$ & $\begin{array}{l}\text { 3. Characteristics of } \\
\text { the directions of } \\
\text { innovation activity } \\
\text { of IAU }\end{array}$ & 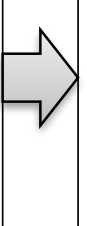 & $\begin{array}{l}\text { 4. Formation of } \\
\text { the framework of } \\
\text { IAU activity }\end{array}$ \\
\hline
\end{tabular}

Fig. 4.12. The process of forming the framework for the functioning of IAU 
Therefore, based on the above provisions and principles, it can be affirmed that the key goal of IAU activity is the formation and development of IAU as a subject of market relations in the context of interaction of the university with the economy and society on the basis of intensive transfer of new knowledge and technologies generated at the university.

To achieve this goal it is necessary to solve such tasks (Table 4.9).

Table 4.9

\section{List and content of tasks}

\begin{tabular}{|c|c|}
\hline The name of the task & The content of the task \\
\hline $\begin{array}{l}\text { 1) ensuring the innovative } \\
\text { content of education }\end{array}$ & $\begin{array}{l}\text { combining basic education with the formation of innovative thinking } \\
\text { and entrepreneurial competencies of students }\end{array}$ \\
\hline $\begin{array}{l}\text { 2) ensuring the quality of } \\
\text { education }\end{array}$ & $\begin{array}{l}\text { on the basis of a combination of competency approach, creating an } \\
\text { individual trajectory of higher education and interaction with } \\
\text { employers }\end{array}$ \\
\hline $\begin{array}{l}\text { 3) conducting applied and } \\
\text { basic research and } \\
\text { development }\end{array}$ & $\begin{array}{l}\text { focus on solving urgent tasks identified as priorities at the national } \\
\text { and global levels }\end{array}$ \\
\hline $\begin{array}{l}\text { 4) development of } \\
\text { international cooperation }\end{array}$ & $\begin{array}{l}\text { a set of measures and forms of integration of the university into the } \\
\text { world scientific and educational space }\end{array}$ \\
\hline $\begin{array}{l}\text { 5) development of innovation } \\
\text { infrastructure }\end{array}$ & $\begin{array}{l}\text { formation of the infrastructure of the full innovation cycle of } \\
\text { educational and scientific activities (from the idea to the launch of the } \\
\text { finished innovative product) on the basis of strategic partnership with } \\
\text { the state and stakeholders }\end{array}$ \\
\hline $\begin{array}{l}\text { 6) formation of innovative } \\
\text { corporate culture of the } \\
\text { university }\end{array}$ & $\begin{array}{l}\text { a set of collective basic ideas necessary and sufficient to adapt to } \\
\text { changes in the external environment and create a competitive internal } \\
\text { environment of the university }\end{array}$ \\
\hline $\begin{array}{l}\text { 7) diversification of } \\
\text { university funding sources }\end{array}$ & $\begin{array}{l}\text { formation of discretionary (formed at own discretion), multichannel } \\
\text { base of receipts and active fundraising }\end{array}$ \\
\hline $\begin{array}{l}\text { 8) creation of an adaptive } \\
\text { university management } \\
\text { system }\end{array}$ & flexible organizational structure and high quality staffing \\
\hline $\begin{array}{l}\text { 9) introduction of } \\
\text { fundamentally new } \\
\text { educational technologies }\end{array}$ & $\begin{array}{l}\text { integration of education, science and innovation; informatization of } \\
\text { the process of teaching and learning on the basis of information } \\
\text { security and anti-corruption }\end{array}$ \\
\hline
\end{tabular}

As you can see, the key component that combines the selected tasks and determines the target direction of the university-type business, is the innovative orientation of all its activities (Fig. 4.13). 


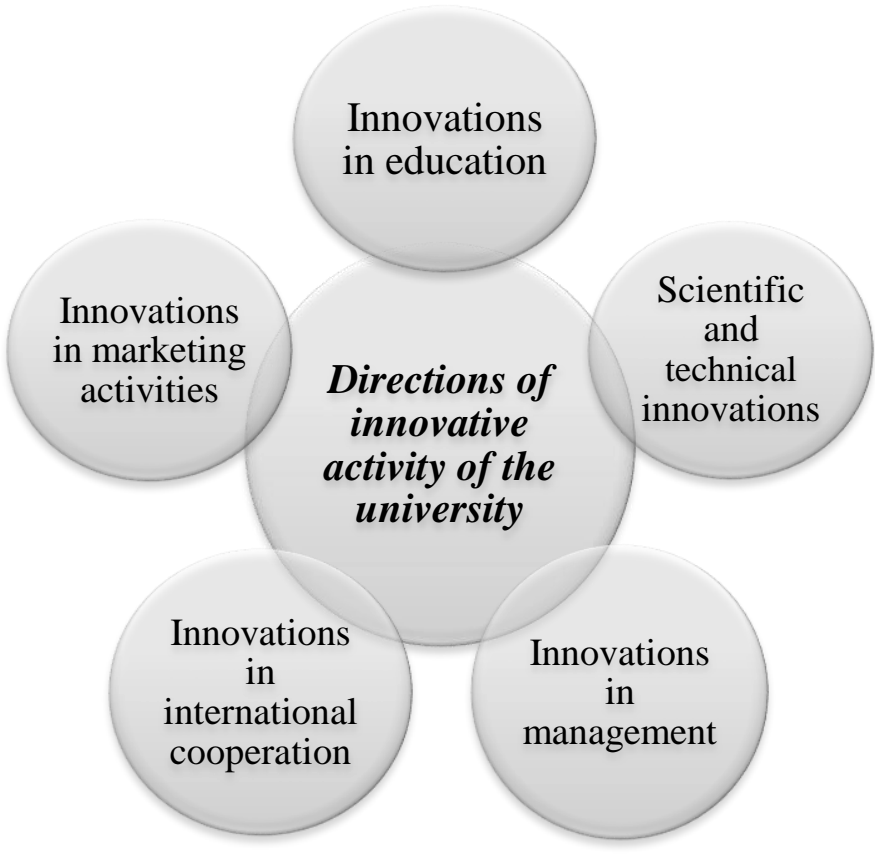

Fig. 4.13. System-forming directions of IAU innovation activity (generalized by the authors according to [14, 13], expanded and supplemented)

Thus, innovations in education include:

- formation of entrepreneurial skills in the teaching staff of the university, which can be achieved through regular training, participation in research and projects, active development of cooperation with stakeholders, etc.;

- development and inclusion in the curricula of new specialties that are relevant and in demand in the labour market, the latest areas of training and retraining of higher education;

- formation of an individual trajectory of higher education;

- introduction into the educational process of training courses and disciplines related to the formation of entrepreneurial competencies of applicants for higher education;

- introduction into the educational process of disciplines and forms of education aimed at mastering the skills of independent work, development of creative abilities and the ability to critically process the amount of input information;

- use in the learning process of the latest technologies and forms that involve collective or independent creative participation of applicants;

- introduction into the educational process of modern information tools and instruments, including technologies and distance learning platforms. 
The implementation of such areas as scientific and technical innovations requires a combination of research and design activities and considers that within IAU it is possible to implement a full cycle of research, from generating ideas to bringing to market a prototype or a finished innovative product. This requires IAU to have an appropriate modern and efficient infrastructure, and can be implemented primarily by creating business structures based on interaction with stakeholders (micro-firms, production of research samples, prototyping, etc.). The results of scientific and technical innovations include innovative knowledge-intensive technologies, products, patents, scientific and technical services, etc.

Innovations in management should be focused on increasing the efficiency of the university by optimizing staffing, material and financial support. The main tasks of realization of this direction of innovative activity are:

1) formation and development of the intellectual potential of IAU, capable of implementing innovative projects of varying complexity by creating a favourable environment and systems of incentives and motivation of staff;

2) training and retraining for various areas of business on the basis of interaction with stakeholders;

3) provision of information and consulting services for university stakeholders;

3) diversification and optimization of IAU funding sources;

4) formation of an organizational structure that meets the requirements and strategic goals of IAU;

5) use of modern information technologies and resources on the basis of ensuring a high level of cybersecurity KSES.

The target areas of innovations in marketing activities of the university promotes the university in the market of educational services, commercialization of research and development ideas and developments, patenting and licensing, creating a university brand, implementing measures to improve the image of the university, etc.

Innovative activity of the university in the context of its international cooperation aimed, on the one hand, at the introduction of modern international experience in the educational process, and on the other - at the integration of HEI into the international educational space. In this regard, the key objectives of this area of innovation should include: 
- study and implementation of international experience in improving the quality of education;

- creation and implementation of joint master's and postgraduate programs with foreign partner educational institutions;

- development of academic mobility, internships and grant activities, participation in joint research projects, etc .;

- Improving the attractiveness of HEI in the international educational space in order to attract foreign students and increase the position of the university in international educational rankings.

Thus, the combination and effective implementation of the selected areas of innovation of HEI will ensure a high level of its competitiveness and compliance with the requirements of modern global challenges.

Therefore, based on the results of research, we believe that the framework of innovative-active university, in our opinion, should include, on the one hand, constituent components of the environment of its activity, and on the other-factors supporting their functioning and development (table 4.10).

To the components of the internal environment of IAU functioning it is proposed to include the university management system, a set of key processes that implement the main types of its activities (namely, educational, scientific, technical, marketing and international) and organizational structure that ensures the effective functioning of HEI.

At the same time factors that support the successful operation of key components of innovative-active university, should include the following:

factors that shape corporate culture and ethics on the basis of innovation and entrepreneurship;

factors that contribute to the formation and development of entrepreneurial skills of the university staff;

factors that ensure the formation and development of students' entrepreneurial skills.

Thus, we can conclude that the targeted impact of the selected factors, primarily, is aimed at improving the quality of education through the development of entrepreneurial skills and higher education and strengthening the entrepreneurial component in educational and other processes, which is one of the key tasks of IAU. 


\section{Framework for the functioning and development of an innovative university}

\begin{tabular}{|c|c|}
\hline Components of IAU functioning environment & Component support factors \\
\hline $\begin{array}{l}\text { University management system } \\
\text { - mission; - strategy; - professional management; - } \\
\text { independence - autonomy; - flexibility - adaptability } \\
\text { to changes in environmental conditions }\end{array}$ & \multirow[b]{2}{*}{$\begin{array}{l}\text { Factors in the formation of corporate culture } \\
\text { and ethics: } \\
\text { - teaching staff; } \\
\text { - students; } \\
\text { - researchers and other employees of the university; } \\
\text { - code of professional ethics and academic integrity; } \\
\text { - university attitude to entrepreneurship; } \\
\text { - university system of awards and incentives for } \\
\text { students, faculty, researchers and other university } \\
\text { staff, etc. }\end{array}$} \\
\hline $\begin{array}{l}\text { Educational process } \\
\text { - bachelor's and master's educational programs, } \\
\text { doctoral studies; } \\
\text { - separate courses in disciplines of entrepreneurial } \\
\text { character; } \\
\text { - advanced training and deepening courses; } \\
\text { - entrepreneurship courses for beginners - } \\
\text { schoolchildren, housewives, ordinary citizens, etc. } \\
\text { - research in accordance with the needs and orders of } \\
\text { stakeholders; } \\
\text { - information and consulting services }\end{array}$ & \\
\hline $\begin{array}{l}\text { Marketing activities: } \\
\text { - creating a brand of the university, } \\
\text { - measures to promote the university in the market of } \\
\text { educational services; } \\
\text { - commercialization of research results, patenting and } \\
\text { licensing; } \\
\text { - measures to improve the image of the university. }\end{array}$ & $\begin{array}{l}\text { Factors of formation and development of } \\
\text { entrepreneurial skills in the staff: } \\
\text { - involvement of university staff in the activities of } \\
\text { stakeholders; } \\
\text { - constant and regular professional development of } \\
\text { faculty and other staff; } \\
\text { - participation of teachers in international programs, } \\
\text { projects, academic mobility, joint research; } \\
\text { - monitoring of current and future socio-economic } \\
\text { trends in society. }\end{array}$ \\
\hline $\begin{array}{l}\text { International activities: } \\
\text { - implementation of foreign experience in the } \\
\text { educational process; } \\
\text { - integration into the international educational and } \\
\text { scientific space }\end{array}$ & \multirow{2}{*}{$\begin{array}{l}\text { Factors of formation and development of } \\
\text { entrepreneurial skills of students: } \\
\text { - academic disciplines aimed at the formation of } \\
\text { entrepreneurial competencies; - modern methods of } \\
\text { teaching and learning; - application of innovative } \\
\text { educational technologies; } \\
\text { - involvement of practicing entrepreneurs in the } \\
\text { educational process; - use of modern information } \\
\text { technologies and tools; - "double diploma" } \\
\text { programs; - academic mobility; } \\
\text { - participation of students in workshops, } \\
\text { conferences and other events to share experiences, } \\
\text { etc. }\end{array}$} \\
\hline $\begin{array}{l}\text { The organizational structure: } \\
\text { - Creation of innovation-oriented divisions: business } \\
\text { incubators, centres for creation of new firms, science } \\
\text { parks, etc. independently and in interaction with } \\
\text { stakeholders; } \\
\text { - introduction of new business functions within the } \\
\text { existing divisions }\end{array}$ & \\
\hline
\end{tabular}

Thus, the formed framework of functioning and development of the innovativeactive university is a result of realization of the fourth stage of development of conceptual bases of construction and functioning of the innovative-active university.

That is, on the basis of the conducted researches, the conceptual basis of construction and functioning of innovative-active university is formed, namely: 
A number of contradictions have been identified and systematized, which determine the existence of the main problem of development of the world and national higher education system in the 21 st century, namely, the need for significant rethinking of forms, methods and practices of HEI in accordance with modern challenges in the innovativeactive, entrepreneurial structure, the activities of which are contained in the interaction of the university with the economy, public administration and society;

1. The analysis of the evolution of approaches to understanding the new mission of the university led to the conclusion that at the beginning of the 21 st century a new paradigm of development of universities was formed - business universities, the operation of which requires the university to adapt its relations with society / major stakeholders, adapt its internal processes, basic values, a search for new innovative bases of its development in modern conditions;

2. Based on the analysis of key concepts of transformation of a traditional university into an entrepreneurial, autonomous-innovative organization, a number of hypotheses for the construction of an innovative-active university and a system of conceptual provisions and principles of its functioning have been developed;

3. The framework bases of functioning and development of the innovative-active university are formed, containing the list of components of the internal environment and the factors providing their support on the basis of development of business and innovation.

\subsection{The mechanism of functioning of innovative-active university: conceptual and methodological support}

The generalizing stage of process of the development of conceptual bases of construction and functioning of innovative-active university acts the fifth stage «Development of an instrumental basis for the construction and formation of IAU».

The instrumental basis of the study should be presented in the form of a mechanism. The meaning of the term "mechanism" has a number of interpretations. Thus, the academic dictionary [223] considers three options for defining the mechanism:

a device that transmits or converts motion;

an internal structure, system of something;

a set of states and processes that make up a certain physical, chemical and other 
phenomenon.

In economic research, the term "mechanism" is very common, mainly from the standpoint of a systems approach. Thus, in the "Explanatory Dictionary of the Economist" [94] a mechanism is defined as a set of processes, techniques, methods, approaches or the implementation of certain actions to achieve the goal; in the encyclopedic dictionary of economics and law [290] presents the term "economic mechanism", which is a set of organizational structures and specific forms and methods of management, including legal norms by means of which the economic laws operating in concrete conditions, process of reproduction are realized; according to the authors [142], the concept of mechanism control reflects the set of means of influence of the subject on the controlled object, along with this, timely and balanced use of various means and tools of influence are of a great importance; according to Yu.A. Andriychuk [36], mechanism is a system of processes, techniques and methods that become an important tool for achieving both short- and longterm goals through making the right and timely decisions.

Thus, the mechanism of construction and operation of IAU will be understood as a system of interconnected and interdependent methods, techniques and tools that determine the process of creation, transformation, operation and development of innovative-active university, aimed at ensuring and maintaining a high level of competitiveness in the educational area of the country and the world.

Based on the management theory, any tool - method, model, technique, technology, mechanism, - is a part of the management system and decision-making process / an object of the study. Therefore, based on the theory of cybernetics and a systems approach, the study developed a management system for innovative-active university (Fig. 4.14).

So, an object of the system management is the process of formation and development of IAU, which includes the main and supporting types of its activities (see paragraph 4.2).

Management entities represent the management of the university within the hierarchical levels of its organizational structure (rector, vice-rectors, deans, heads of departments, etc.).

The resource base of IAU activity, which forms the entrance to the system, consists of two components:

traditional resources, used by both classical HEI and business-type universities; 
MAIN ACTIVITIES

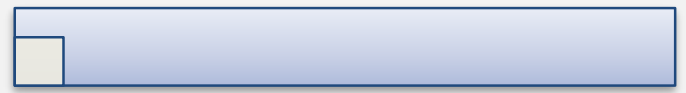

educational activities

$\square$ scientific and technical activities

$\square$ marketing activities

$\square$ international activities
SUPPORTING ACTIVITIES

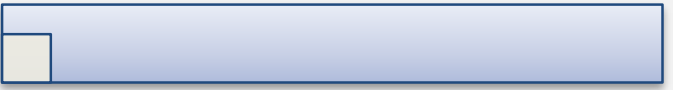

organizational activities

information and communication activities

Innovative nature of $L A U$ activities

Fig. 4.14. Management systems of innovative-active university

innovative-active resources, arising within the framework of interaction with stakeholders, the involvement of which allows IAU to identify and understand the needs of stakeholders to ensure the accelerated reproduction of large-scale and continuous innovation in the economy and society, to attract private funds for innovation and, thus, diversify the revenue base (Fig. 4.15).

RESOURCES OF

TRADITIONAL

NATURE

INNOVATIVE

ACTIVE

RESOURCES
- students

- teaching staff

- staff of HEI

- material-technical base

- sources of public funding

- representatives of business and industry

- international partners

- representatives of public organizations

- bodies and institutions of local, regional and state administration

- grant financing, fundraising

Fig. 4.15. The structure of the input resource base of IAU

Entrance, that is, the result of the IAU management system is the effective activity 
of IAU, which is determined by the level of economic effect obtained by the university and indicators of efficiency (return) of its resource base.

Feedback is provided through the reaction of stakeholders to the results of IAU, which is monitored and analyzed by the subjects of management at the appropriate levels, which serves as a basis for them to exercise adequate management influence on the object of management in order to increase the efficiency of IAU.

IAU activities are carried out in an environment with a high level of dynamism and stochasticity, characterized by the presence of systemic fluctuations, the sources of which are:

trends in the development of the world system of higher education;

socio-economic situation in the country;

technological structure of the national economy;

the legal framework of the country as a whole and the educational space;

ratings of the higher education system of the country and individual HEI;

demographic situation;

level of educational migration;

the level of digitalization in society.

Thus, the management system of the innovative-active university reflects the state and dynamics of the object of management, allows to take into account the influence of the external environment, as well as to receive and respond to feedback from key stakeholders with whom HEI interacts.

The methodological basis for the formation of the mechanism of construction and operation of IAU are the following principles (Fig. 4.16).

Let us consider in detail their content.

1) the principle of systematization determines that the innovative-active university is a complex system within which various activities are implemented, which have both basic and supporting nature, but at the same time they are all combined with innovative content and focus. In this regard, within the framework of this principle in the mechanism of construction and operation of IAU all types of its activities are considered as interconnected elements that provide a systemic innovative nature of the higher education institution; 


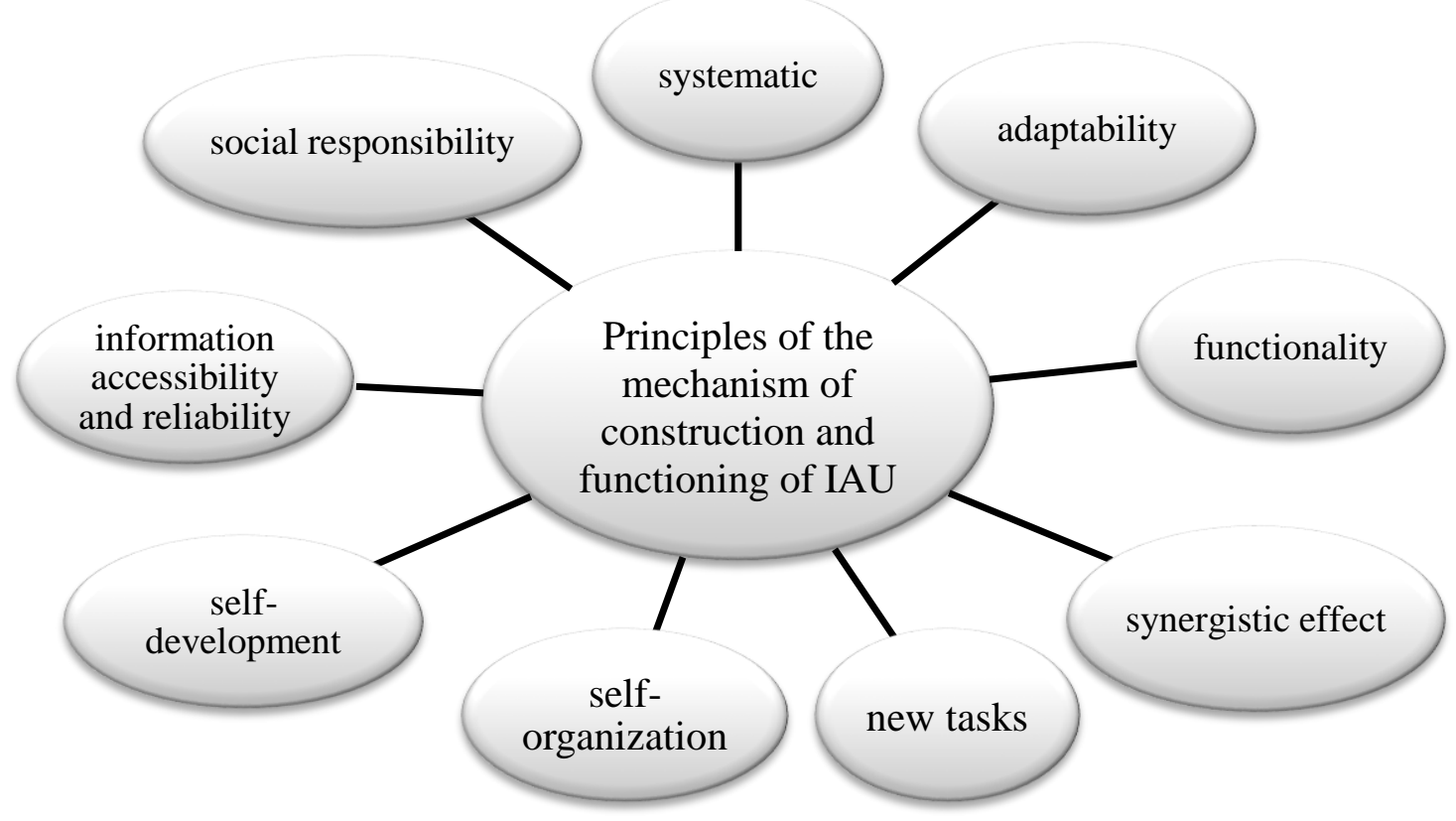

Fig. 4.16. Principles of the mechanism of construction and functioning of innovative-active university

2) the principle of adaptability determines the focus of the mechanism to ensure the balance of external and internal opportunities for IAU development, where external opportunities are generated by the market environment, and internal - reflect the ability of the IAU management system to restructure its elements and relationships between them according to external environment transformation and internal transformations;

3 ) the principle of functionality indicates that each of the main and supporting activities of IAU performs a certain function and ensures the achievement of relevant key innovation results, thus, enabling the innovative nature of not only individual activities, but also university as a whole;

4) the principle of synergistic effect is a logical addition to the previous one and assumes that since each of the main and supporting activities must be innovative, the growth of innovation within each activity will increase the overall level of university efficiency as a whole;

5) the principle of new tasks is that in the conditions of evolution of the external environment, receiving feedback from stakeholders and other significant changes, the activity of an innovative university can receive new qualitative characteristics, on the basis of which there are new opportunities and prospects for the development of all activities; 
6) the principle of self-organization testifies to the ability of innovative-active university to independently provide support for the conditions of functioning, i.e. selfsupport of the exchange of resources both within the HEI and between the university and the external environment;

7) the principle of self-development is that the innovative-active university is in constant development, and this provides for the independent provision of conditions for improving the efficiency of resource use and innovative development of HEI;

8) the principle of information accessibility and reliability is achieved by providing IAU management entities with the necessary, complete, objective and comparable information on the processes of innovative development in the external and internal environment;

9) the principle of social responsibility. IAU's effective activity is ensured by strategic partnership with state and regional structures, business representatives, leading higher education institutions in Ukraine and abroad, public institutions, the alumni community, which determines the formation of social responsibility of the university to society for educational, product and other innovations, for the knowledge transferred to new generations, the newest created technologies and other results of innovative activity of HEI.

The proposed principles together determine the structural composition of the mechanism, its tasks and model tools for their solution.

Provided that the innovative-active HEI operates in the external national and world educational and scientific space, the content of the mechanism of its functioning and the permanence of its renewal depends on the key factors of the external environment, namely:

- the purpose of the development of the system of higher education of Ukraine;

- global trends in the development of higher education system;

- legislative and regulatory framework of Ukraine, in particular, which regulates the functioning of the higher education system.

Thus, based on the content of the proposed conceptual principles of construction and operation of innovative-active university, management system of innovative-active university and developed principles, the study developed a mechanism for construction and operation of innovative-active university (Fig. 4.17). 
the purpose of the development of the system of higher education of Ukraine

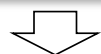

global trends in the development of higher education $\square$ legislative and regulatory

framework of

Ukraine

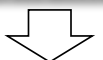

\section{Analysis and assessment of the external environment of IAU operation}

Stage 1. Assessment of the international position of the HEI of Ukraine

Stage 2. Evaluation and positioning of HEI of Ukraine according to the degree of innovation activity

Stage 3. Assessment of the ability of universities to build an innovative organization innovative organization

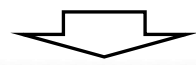

\section{Analysis and development of directions of transformation of the internal environment of IAU functioning}

Stage 4. Assessment and analysis of retrospective trends in the development of HEI

Stage 5. Construction of reference strata by the type of activity (on the example of the largest innovative universities in the world and Ukraine)

Stage 6. Assessment of the level of innovation of HEI on the basis of comparative analysis and identification of strengths and weaknesses

Stage 7. Development of directions of transformation of HEI activity in innovative-active university

Fig. 4.17. The mechanism of construction and functioning of an innovative university 
According to the purpose, tasks of each of the offered stages, in the mechanism are allocated:

- the contour of the external environment that combines stages 1-3 of the mechanism. Its content orientation corresponds to the problems of analysis and assessment of the external environment of the functioning of innovative universities;

- the contour of the internal environment that includes stages 4-7 of the mechanism which reveal the essence of the modification of the main and IAU supporting activities.

Let us consider the content of the stages of the mechanism in the following tuple $<$ the purpose of the stage - the task of the stage - the tools for solving the problem >.

\section{Stage 1. Assessment of the international position of the SVO of Ukraine.}

The purpose of the stage is to determine Ukraine's position among the European countries in terms of the level of development of the higher education system and to assess trends in this position.

Within this stage, the assessment of the position of the higher education system of Ukraine among the European countries is carried out. To implement it, a number of tasks are solved, the relationship of which with the tools is presented in Fig. 4.18.

Thus, within the solution of task 1.1 in accordance with the chosen goal using the methods of monographic, comparative analysis, logical generalization is the formation of information space research which, on the basis of a systematic approach, allows to diagnose and characterize the higher education system of a country. To do this, the study proposes the formation of a system of indicators of attractiveness of higher education systems (HSE) which includes:

a group of indicators of society's readiness for higher education;

a group of indicators of the attractiveness of universities by applicants;

a group of indicators of state support for the development of HEI, each of which includes a substantiated list of evaluation indicators.

The solution of task 1.2 is aimed at forming homogeneous groups of the European countries (the Eurozone countries and Ukraine) with a certain level of attractiveness of higher education based on the application of economic and mathematical tools, in particular, the method of multidimensional taxonomic analysis. To do this, it is planned to conduct three experiments, the result of which is the formation of five clusters of the studied countries according to the level of attractiveness of HEI. 


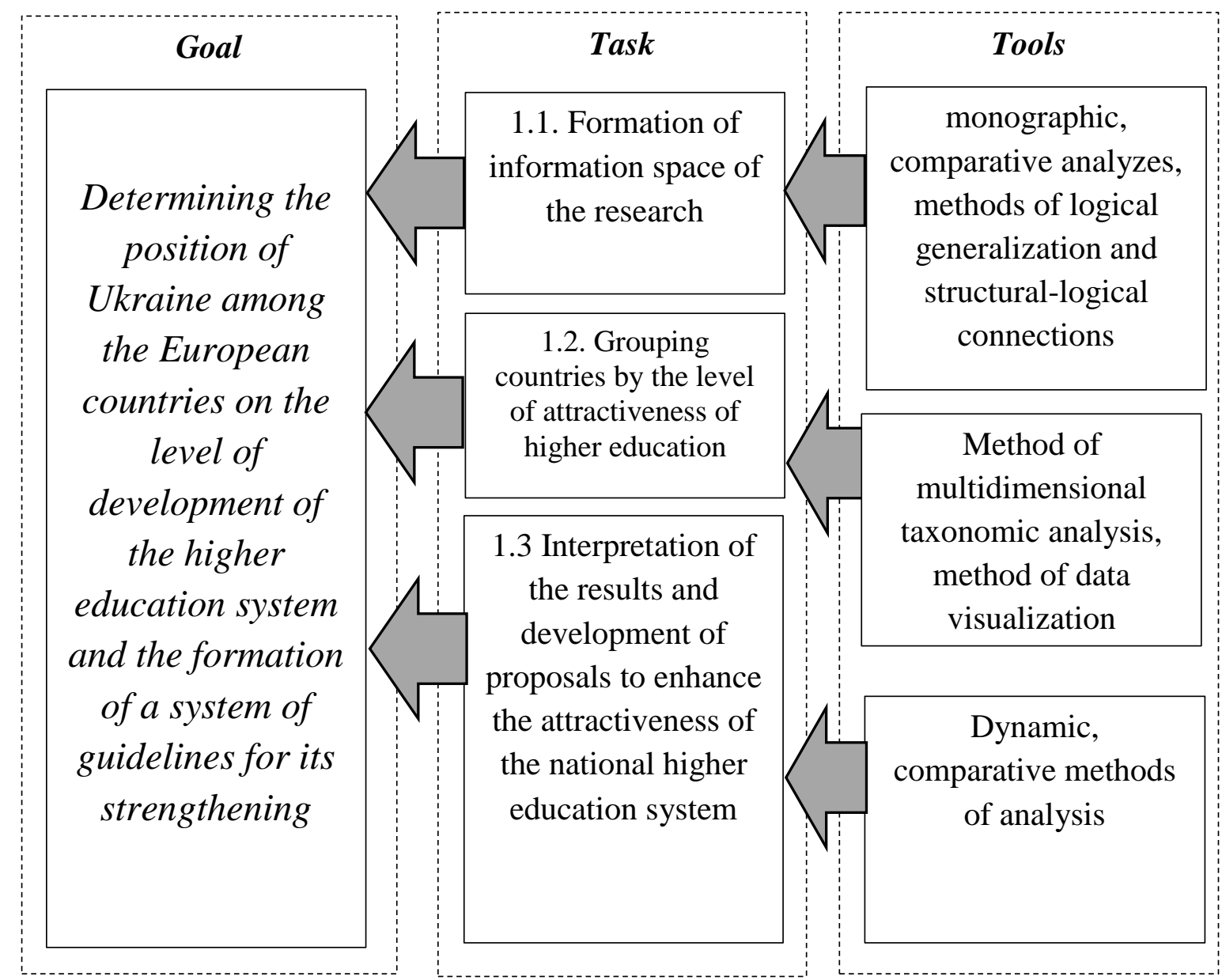

Fig. 4.18. The relationship between the goals, objectives and tools of the first stage

The content of task 1.3 is to determine the current position of the selected country in the area of study, which is proposed to supplement the analysis of migratory changes in the dynamics. This allows grouping countries in accordance with the level of sustainability of the trajectory of HEI development and to form recommendations aimed at ensuring the growth of the level of attractiveness of the national higher education system. The exploratory nature of the experiments made it possible to determine that the HEI of Ukraine is in the cluster of a high level of attractiveness, but during the analyzed period there was a negative trend towards the loss of international positions. Thus, the combination of the results of scientific experiments revealed the latent reasons for the formation of a negative trend. In these conditions, the state and the Ministry of Education and Science of Ukraine should create a stimulating basis and environment for real autonomy of universities, and their transformation into innovative, entrepreneurial educational institutions and further systematic modernization of the national structure of 
higher education.

The methodological basis for the implementation of the tasks of the first stage of the mechanism is:

methodical approach to building a system of monitoring and stratification of universities (SMSU);

guidelines for determining the attractiveness of the national higher education system.

Thus, the result of the implementation of the first stage of the mechanism is a comprehensive assessment of the international position of the higher education system of Ukraine in the European educational space and the development of recommendations for its further improvement.

Stage 2. Evaluation and positioning of HEI of Ukraine according to the degree of innovation activity.

The purpose of the second stage is to determine the level of innovative activity of HEIand the formation of homogeneous universities at this level. Within this stage, a system of integrated indicators for assessing the innovative activity of HEIis being formed, which is the basis for stratification of higher education institutions at the national level relative to the level of their innovative activity.

The relationship between the goals, objectives and tools of this stage is shown in Fig. 4.19.

The solution of task 2.1 is aimed at forming a system of indicators that characterize the level of innovative activity of HEIand provide the possibility of their stratification, for which it is proposed to use the methods of monographic, comparative analysis, logical generalization and construction of structural-logical connections. In this regard, the study proposes to form four groups of indicators for the assessment of HEIby the type of their activity, and to determine the list of indicators for each group:

for the first group of indicators, which characterizes the educational activity of HEI, - the index of quality of human resources of HEI, the index of quality of training, the number of applications submitted to HEI, the number of those who joined HEI, the ratio of contractors and state employees;

to the second goup of indicators, which characterizes the scientific and technical activity, - the number of publications in Scopus, the number of citations in Scopus, Hirsch 
index (h-index);

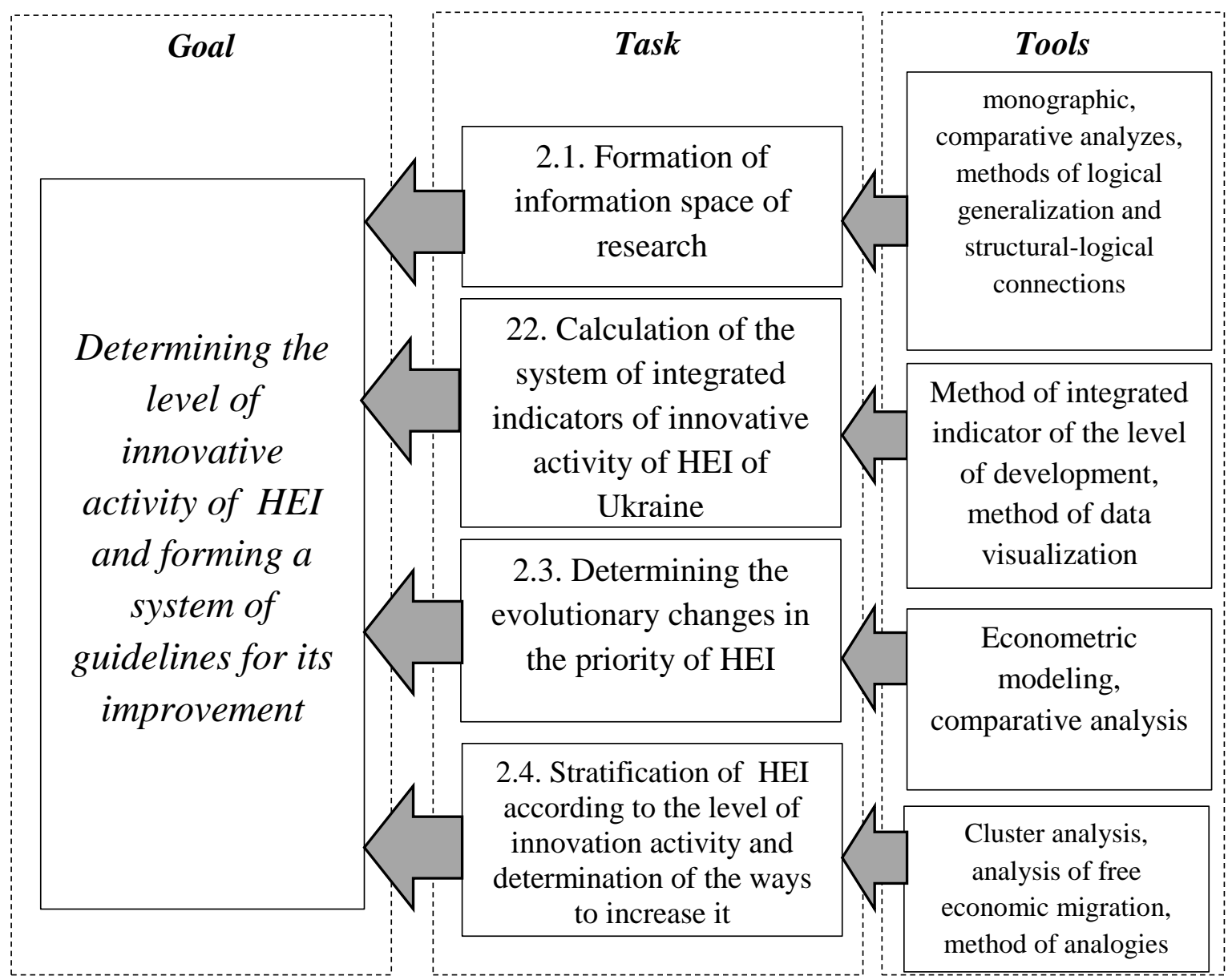

Fig. 4.19. Relationship between goals, objectives and tools of the second stage

to the third group of indicators, which characterizes the innovation activity, - the number of patents, the rank of openness (Transparency Rank or Opennesss Rank), quality rank (Excellence Rank);

to the fourth group of indicators, which characterizes the international activity, - the index of international recognition, the rank of influence (Impact Rank), the rank of presence (Presence Rank), the number of foreign students.

Within the solution of task 2.2 there is a construction and calculation of a system of integrated indicators of the level of innovative activity of HEI by using an algorithmic model based on the method of taxonomic analysis, which includes a general indicator of efficiency of HEI and a set of local integrated indicators formed by the activities (educational, scientific and technical, innovative and international). This approach will 
allow a comprehensive analysis of the values and dynamics of the integrated indicators of evaluation of innovative and active institutions of higher education in Ukraine.

The solution of task 2.3 aims to determine the evolutionary changes in the priority of the activities of HEIby building a set of economic and mathematical models of the dependence of the overall development of innovative active resources HEI from the local integrated indicators by using econometric modeling methods to determine which activities cause a significant impact on the overall level of development of HEI.

Within the framework of solving task 2.4, the higher education institutions of Ukraine are stratified by the level of their innovation activity by years using the clustering method and the selection of target clusters for the migration of HEI in accordance with their opportunities to become world-class universities. The initial information for stratification consists of 4 local integrated indicators of HEI by the types of activity that were calculated for 193 institutions of higher education, which allows to classify the initial set of HEIinto 3 clusters:

1st cluster - HEI with the highest innovation and activity;

2nd cluster - HEI with an average innovation and active activity;

3rd cluster - HEI with a low innovation activity.

It is proposed to use the obtained values of integrated indicators of activity HEI of Ukraine to build a rating of universities by their level of innovation activity, as well as reference values for HEI to form a system of management decisions to support and further strengthening of their innovative activity within resource constraints.

The methodological basis for the implementation of the tasks of the second stage of the mechanism is:

methodical approach to building a system of monitoring and stratification of universities (SMSU);

methodical recommendations on stratification of HEI of Ukraine according to the level of their innovative activity.

Thus, the result of the implementation of the second stage of the mechanism is a comprehensive multifaceted assessment of the level of innovation activity of HEI of Ukraine and their positioning within the formed groups of innovatively active universities, which is the basis for developing recommendations for choosing a strategy for innovative development. 


\section{Stage 3. Assessment of the ability of universities to build an innovative} organization.

The purpose of the third stage of the mechanism is to form a system of factors influencing the competitiveness of national HEI and their comprehensive analysis. Within this stage, the development of a complex system of factors of competitiveness of the university on the basis of the formed features of classification, as well as its transformation into a hierarchical structure using the methods of systemic and morphological analysis.

The relationship between the goals, objectives and tools of this stage is shown in Fig. 4.20.

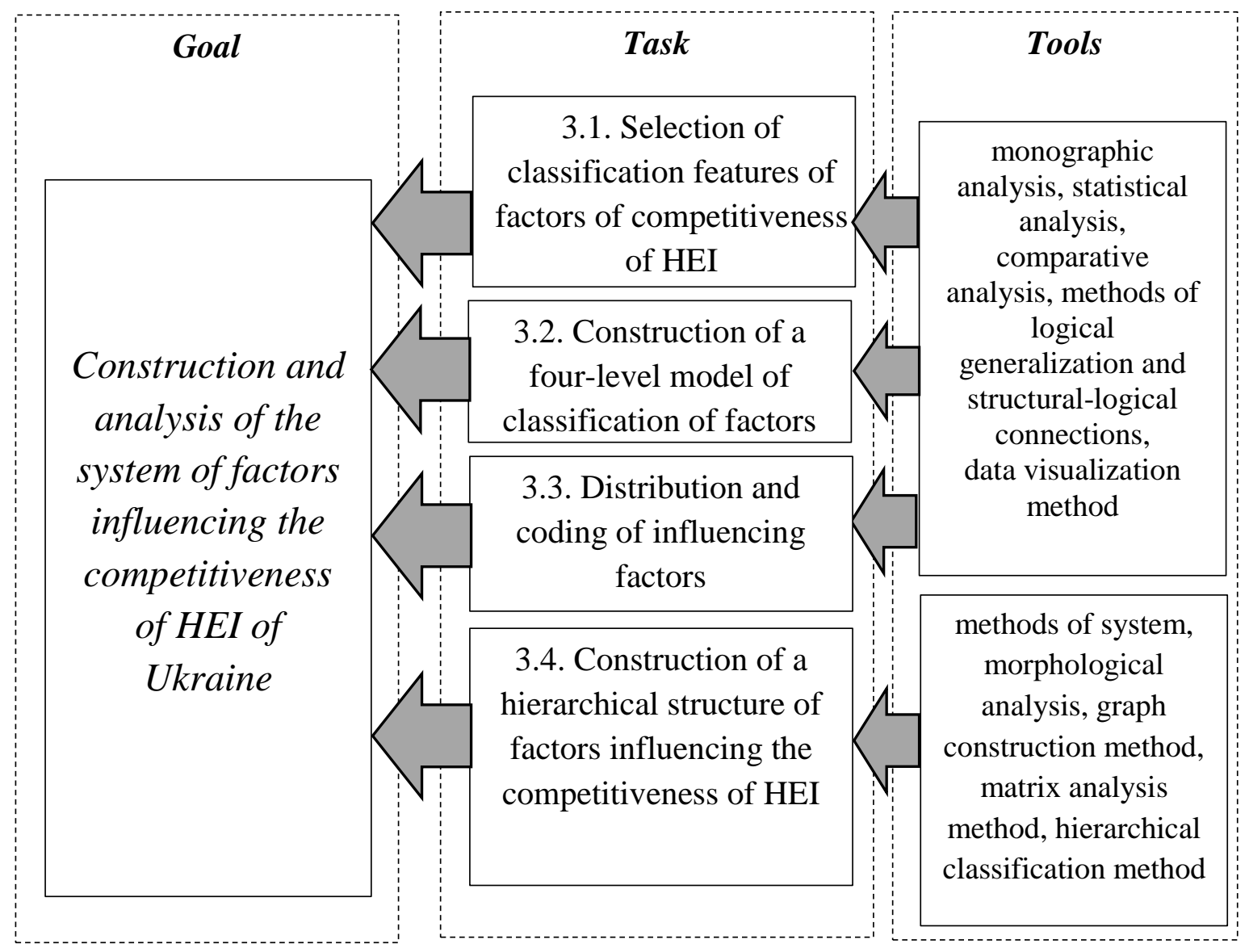

Fig. 4.20. Relationship between goals, objectives and tools of the third stage

As classification features for the formation of the detailed system of factors of competitiveness of HEI in research it is offered to use (task 3.1):

- $\quad$ signs of innovative HEI, i.e. factors of ability to adaptive response and factors of ability / ability to implement innovations;

- $\quad$ types of activity of HEI - educational, scientific and technical, marketing, 
international, organizational, information and communicative;

- the direction of influence of the factor - internal and external;

- the nature of the influence of the factor - socio-humanitarian, managerial, resource, educational, scientific, communicative, economic, political, socio-cultural and partnership.

According to the defined classification features in the course of solving task 3.2 there is the formation of a 4-level model of distribution of factors of competitiveness of HEI which, in turn, serves as a basis for the formation of a full range of factors of competitiveness of HEI.

Building a system of factors / indicators for a particular factor of competitiveness is the content of solving task 3.3 and involves building a hierarchical structure of their relationships. To do this, it is proposed to implement the following steps:

1) grouping of certain factors is done according to the impact on the competitiveness of HEI, their numbering is proposed to be submitted according to the general list:

1 - customer orientation - ensuring the development of international relations and improving the material and technical base;

2 - source of financial resources of HEI - mixed financing;

3 - innovation and investment potential of HEI - satisfaction of participants in the markets of educational services and labour;

4 - strategic management - positioning of integration processes in the market of educational services of HEI;

5 - labour rationing - stimulating the level of internal labour productivity;

6 - internationalization - mobility of students and teachers in the international grants and projects;

7 - monitoring - tracking the complexity of indicators of the level of development of HEI;

8 - informatization - creation, carrying out, introduction of educational activity concerning the expanded list of specialties and employment of graduates;

9 - the quality of training of HEI applicants

1) construction of a directed graph between the factors of HEI competitiveness;

2) construction of the reachability matrix based on the results of the analysis of the directed graph; 
3) determination of levels of hierarchy of factors at a choice of directions of HEI competitiveness.

The methodological basis for the implementation of the tasks of the third stage of the mechanism is: methodical approach to the classification of factors and factors of competitiveness of HEI.

That is, the result of the third stage of the mechanism is a complex system of factors influencing the competitiveness of HEI, which is characterized by significant internal relationships and synergistic effects and is the basis for building a list of factors to increase innovation activity of the university in accordance with the nature of the determining factors and areas of activity and taking into account the available resource constraints.

Stage 4. Assessment and analysis of retrospective trends in the development of HEI (by the type of activity).

The purpose of the fourth stage of the mechanism is to assess and analyze the retrospective dynamics of the level of innovation activity of HEI on the basis of the developed system of internal monitoring indicators that characterize the main and supporting activities of innovative-active university. To achieve this goal, a number of tasks are solved, the relationship of which with the tools is presented in Fig. 4.21.

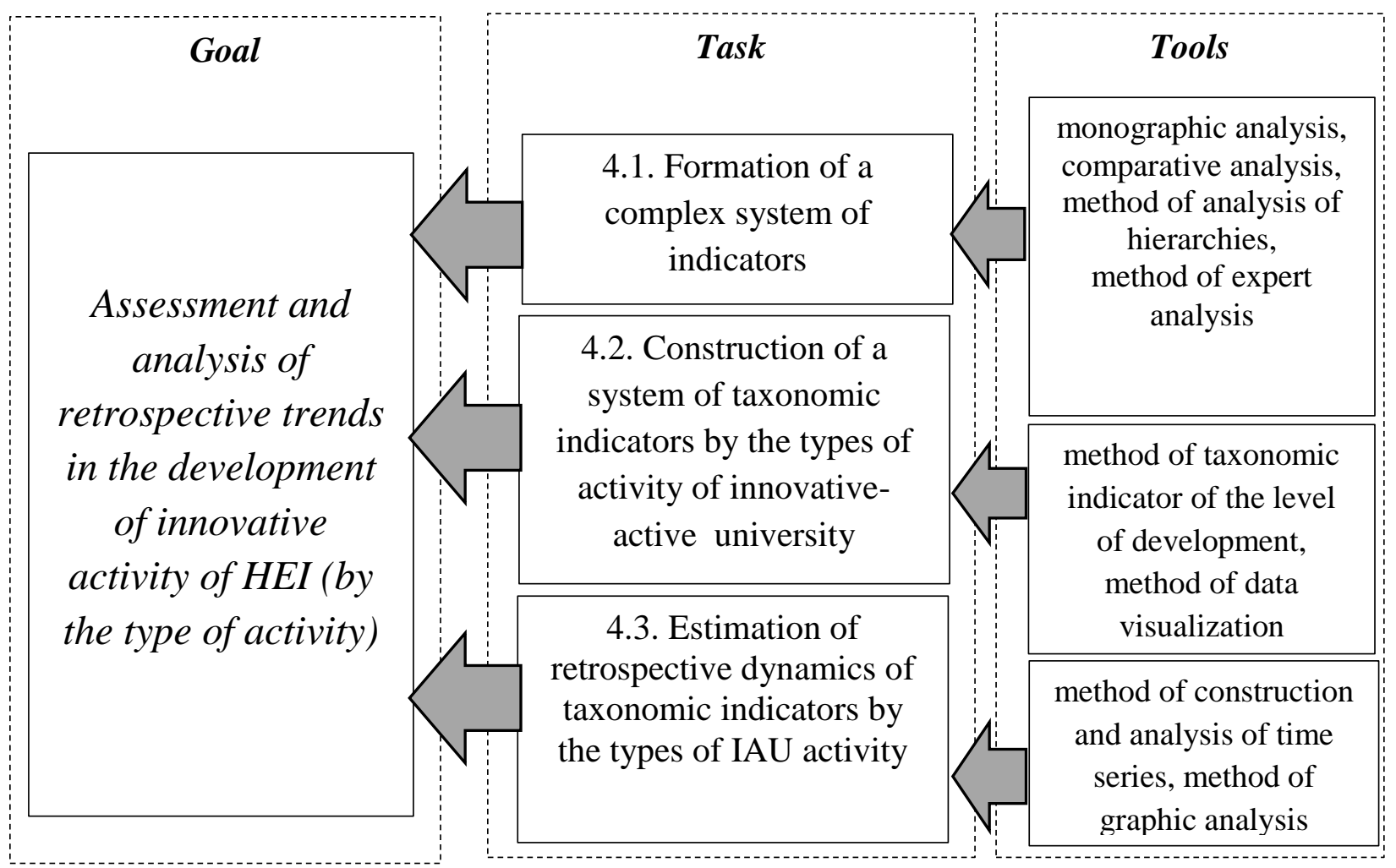

Fig. 4.21. Relationship between goals, objectives and tools of the fourth stage 
The content of task 5.1 is contained in the formation of a complex system of indicators, which is the basis for assessing retrospective trends in the implementation of basic (educational, scientific, technical, international and marketing) and supporting (organizational, information and communication) activities of innovative university. To do this, the study proposes the use of methods of analysis of statistical reporting, monographic, comparative analysis, the method of analysis of hierarchies and heuristic methods.

Within the solution of task 5.2 there is a construction of a two-level system of taxonomic indicators for assessing the level of HEI innovation, where the first level is formed by the local integrated indicators that characterize the level of innovation by the main and supporting activities of IAU, and at the second level - there is a construction of the general integrated indicator which provides an opportunity to comprehensively assess the dynamics of changes in innovation activity of the university in retrospect.

The solution of task 4.3 is aimed at analyzing the retrospective dynamics and identifying key trends in the development of innovation activity within the main and supporting activities of innovative-active university on the basis of the developed set of integrated indicators.

The methodological basis for the implementation of the tasks of the fourth stage of the mechanism is methodological support for creating a complex system of monitoring and adaptive system adjustment of indicative parameters of strategic development of the university of innovative type, the functional focus of which is assessment and analysis of IAU (by its activities) modern packages of applications and information shells.

Thus, the implementation of the fourth stage of the mechanism is the construction of a set of integrated indicators and the analysis of retrospective trends in the development of innovative-active university in the context of the main and supporting activities.

Stage 5. Construction of reference executions by types of activity (on the example of leading, innovatively active universities of the world and Ukraine).

The purpose of the fifth stage of the mechanism is to develop a system of reference penalties that reflect the level of development of innovation activity in terms of the main and supporting activities of the university type of business. Within this stage, the analysis of the positions of HEI in the most important world and national rankings, the selection of reference HEI with the highest rating positions and, accordingly, the performance 
indicators which are the basis for the formation of reference losses by the type of innovative-active university. The relationship between the goals, objectives and tools of this stage is shown in Fig. 4.22.

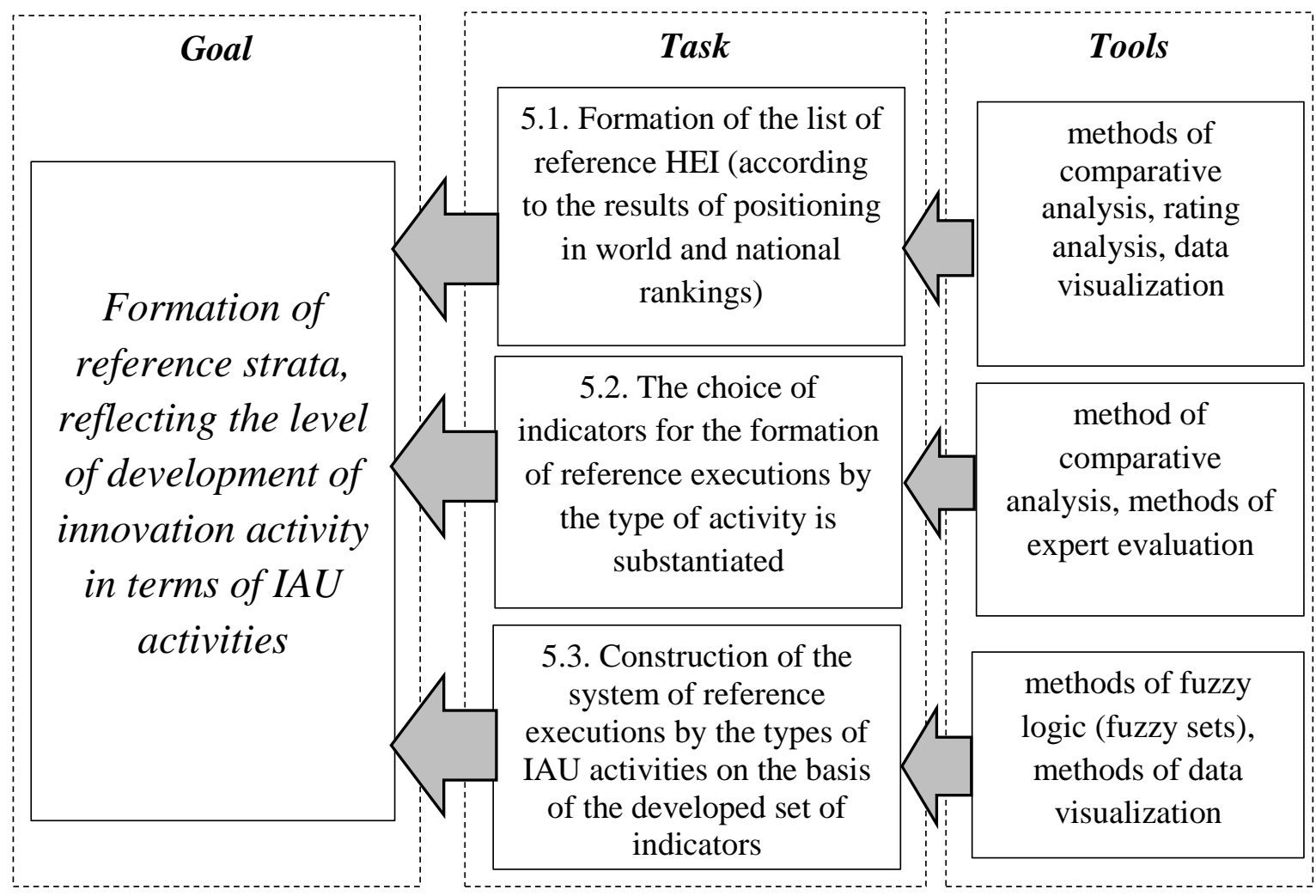

Fig. 4.22. Relationship between goals, objectives and tools of the fifth stage

Thus, within the solution of problem 5.1, an analysis of the positioning of HEI in the key world and national rankings is performed, the results of which are the basis for forming a set of universities with the highest ranking positions and, accordingly, can be included in the list of reference HEI.

The implementation of task 5.2 is aimed at forming a sound system of indicators that provide an opportunity to assess the level of innovation activity of reference HEI in the context of their main and supporting activities based on the use of methods of comparative analysis and expert evaluation.

Based on the calculation of the selected indicators for the largest innovative universities in the world and Ukraine, the formation of reference strata by the type of activity of IAU takes place (task 5.3).

The methodological basis for the implementation of the tasks of the fifth stage of the mechanism are methodological recommendations for building a system of reference 
penalties for the activities of innovative-active university on the basis of the use of rating analysis and economic-mathematical methods.

Thus, the result of the implementation of the fifth stage of the mechanism is a set of reference strata that characterize the level of development of the largest innovative universities in the world and Ukraine by the type of activity.

Stage 6. Assessment of the level of innovation of HEI on the basis of comparative analysis and identification of strengths and weaknesses.

The purpose of the sixth stage of the mechanism is to form a comprehensive assessment of the level of innovation of HEI based on a combination of methods of comparative and strategic analysis, assessment of the impact of competitiveness factors and identification of resource constraints and innovative development potential of the university. To achieve this goal, a number of tasks are solved, the relationship of which with the tools is presented in Fig. 4.23.

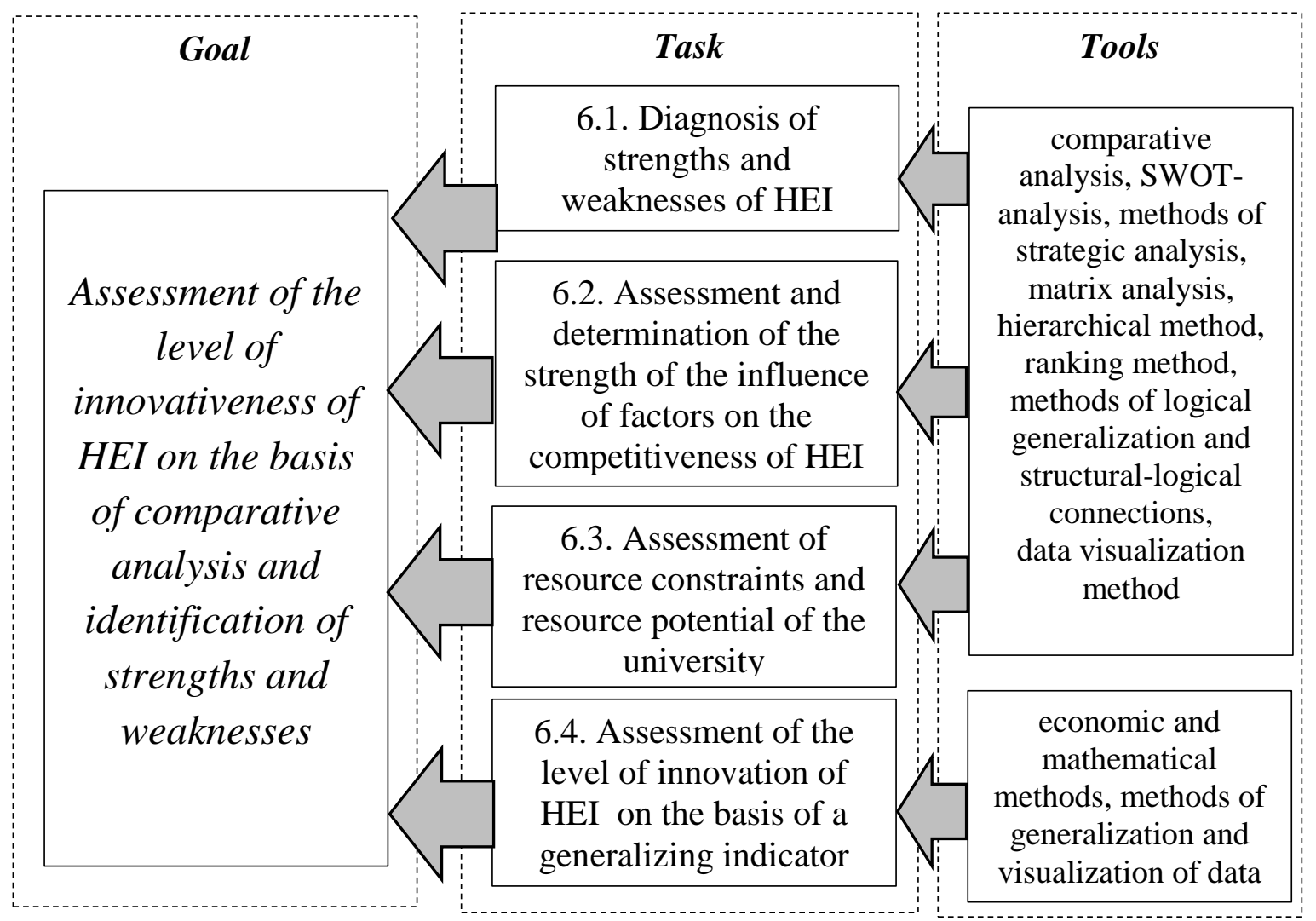

Fig. 4.23. Relationship between goals, objectives and tools of the sixth stage

Within the solution of task 6.1 there is a diagnostics of strengths and weaknesses of innovative activity of HEI by means of the comparative analysis and the analysis of 
deviations of actual values of the indicators calculated for the kinds of activity of innovative-active university from the values of reference strata that will allow to define the kinds of HEI activity requiring access to a fundamentally better qualitative level of innovative development.

The solution of task 6.2 is aimed at assessing and determining the strength of the influence of competitiveness factors on the efficiency of HEI, their ranking and formation of a set of determining factors of competitiveness based on the methods of hierarchical classification, graphing and matrix analysis.

The implementation of task 6.3 involves assessing the resource constraints and development potential of an innovative university. The importance of its solution is due to the high level of dependence of the choice of directions of transformation of the traditional university into innovative one and is active on its ability to effectively use all available types and attract potential resources. In this regard, it is advisable to use the methods of SWOT-analysis and economic-mathematical modeling.

Within the solution of task 6.4 there is a construction of the complex generalizing indicator of an estimation of the innovation level of HEI on the basis of a combination of three estimating components:

assessment of the priority type / types of IAU activities that require access to a fundamentally better level of innovative development;

building a system of key factors influencing the competitiveness of the university and establishing a system of key performance indicators (KPI);

formation of a model of resource allocation for the introduction of innovations in a certain type of HEI on the basis of assessing the resource potential of innovative HEI development.

The methodological basis for the implementation of the tasks of the sixth stage of the mechanism is:

methodological support for building a hierarchical structure of factors influencing the competitiveness of HEI;

tools for diagnosing the potential and (self) evaluation of the effectiveness of the participation of internal stakeholders of the university of innovative type in the processes of ensuring the quality of education, which allows to determine the real and potential capabilities of HEI to conduct innovative activities; 
methodical approach to the construction of a general indicator for assessing the level of innovation of HEI;

optimization model of resource allocation.

Thus, the result of the sixth stage of the mechanism is a comprehensive assessment of the innovation level of HEI, which is the basis for strategy and tactics to ensure its innovative development in terms of resource constraints and the results of which are used to develop a system of internal key performance indicators (KPI).

\section{Stage 7. Development of directions of transformation of activity of HEI in} innovative-active university.

The purpose of the seventh stage is to form a strategy, tactics and operational contour of innovative development of HEI on the basis of decomposition of its activities, justification of appropriate time horizon for innovation and taking into account resource constraints of the university to strengthen its competitive advantages and form and maintain its entrepreneurial characteristics. The relationship between the goals, objectives and tools of this stage is shown in Fig. 4.24.

Thus, the solution of task 7.1 is aimed at forming an initial list of educational innovations adequate to the current and future development of society and the economy based on the analysis of literature sources on current and future trends in civilization.

Within the solution of task 7.2 it is expedient to allocate two directions:

1) construction of a reference list of innovative measures based on the analysis of innovative development strategies of leading foreign and national innovative universities;

2) analysis of current and future development needs of the main stakeholders of HEI and the used forms of interaction with them.

The implementation of task 7.3 is aimed at forming an invariant of innovative measures in terms of types of educational innovations, which involves the implementation of the following steps:

- construction of an appropriate set of measures in accordance with a certain type of innovation;

- ranking of innovative measures according to the level of their priority and the possibility of their application in the practice of the studied HEI.

Within the solution of task 7.4, a three-dimensional model of IAU innovation direction is built on the basis of determining the relationship between the types of 
innovations, IAU activities and its ability to innovate based on a combination of statistical, strategic analysis and economic-mathematical modeling.

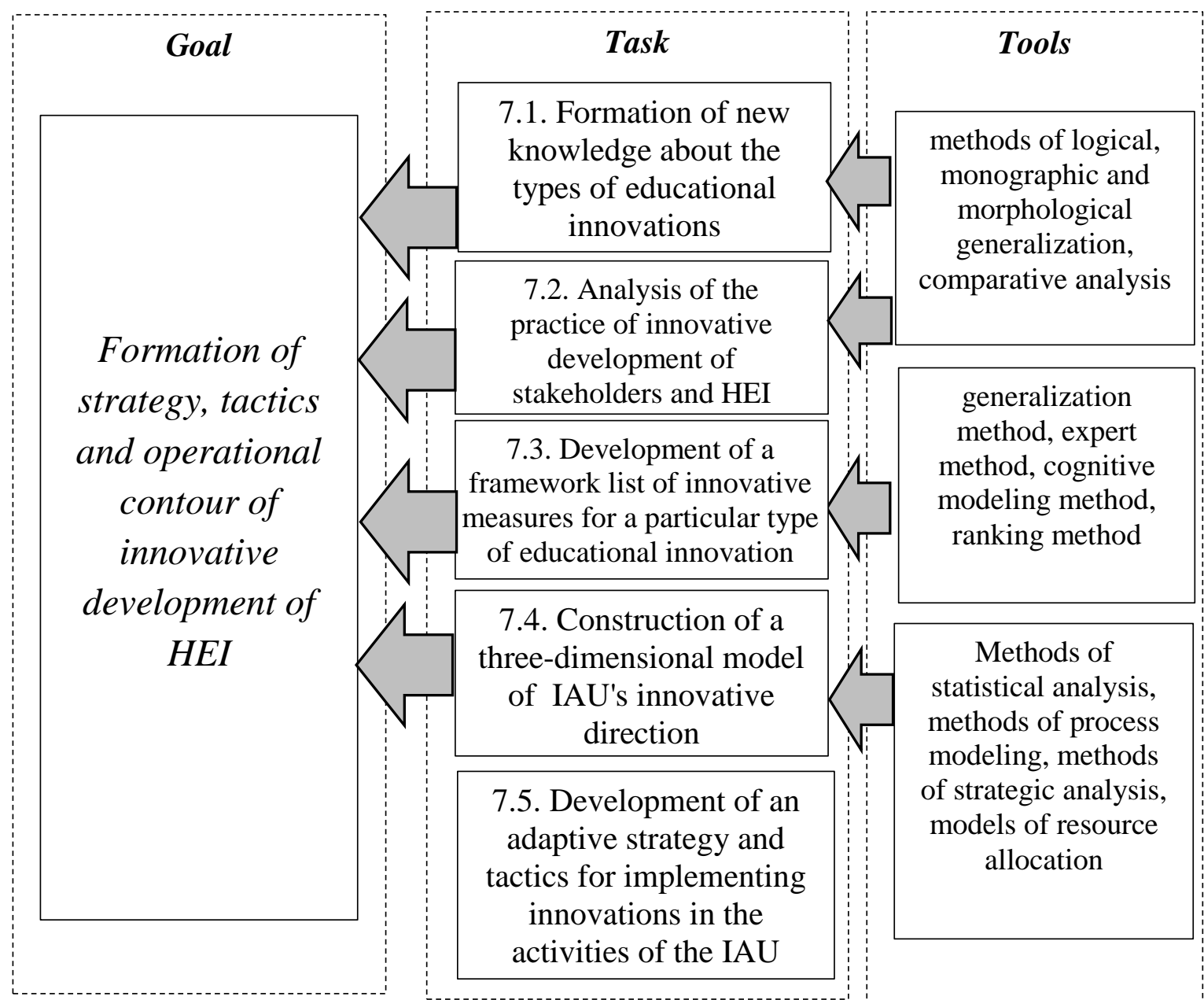

Fig. 4.24. The relationship between the goals, objectives and tools of the seventh stage

Solving task 7.5 involves developing an adaptive strategy and tactics for implementing innovations and justifying the appropriate time horizon for their implementation based on the formation of a system of key performance indicators (KRI) of innovative-active university, on the basis of decomposition of its activities and taking into account available resource constraints.

The methodological basis for the implementation of the tasks of the seventh stage of the mechanism is a methodical approach to strengthening the innovative activity of the university.

Thus, the result of the seventh stage of the mechanism is the development of 
detailed strategies and tactics for the development of units of innovative-active university, corresponding to a certain type of its activities, as well as a list of strategic, tactical and operational measures aimed at achieving target values of key performance indicators (KPI), and the implementation of which is aimed at strengthening the competitive advantages of the university and the formation and maintenance of its business characteristics.

Thus, within the framework of the conducted researches, the conceptual and methodological support of the mechanism of construction and functioning of the innovatively active university is formed, namely:

1) the meaning of the concept "mechanism of construction and functioning of IAU" is defined, which is proposed to be understood as a system of interconnected and interdependent methods, techniques and tools that determine the process of creation, transformation, functioning and development of innovative-active university, the level of its competitiveness in the educational space of the country and the world;

2) based on the theory of cybernetics and a systems approach, the study developed a management system for innovative-active university, which reflects the state and dynamics of the control object, allows to take into account the impact of the environment, as well as to receive and respond to feedback from key stakeholders, with which the innovative-active university interacts;

3) within the framework of the development of the methodological basis for the formation of the mechanism of construction and functioning of IAU, a list of key principles of the mechanism is proposed, their content is revealed;

4) on the basis of the developed conceptual bases of construction and functioning of innovative-active university, management system of innovative-active university and certain principles, the maintenance of stages of the mechanism of construction and functioning of innovative-active university is revealed, which are distributed between contour of the external environmenta (combines stages 1-3 of the mechanism) and the contour of the internal environment (combines stages 4-7), behind the motorcade < the purpose of the stage - the task of the stage - the tools for solving the problem >. The methodical basis of the realization of the tasks of stages of the mechanism of construction and functioning of IAU is formed. 


\section{CHAPTER 5. MANAGING THE DEVELOPMENT OF THE EDUCATIONAL ENVIRONMENT OF AN INNOVATIVE HIGHER EDUCATION INSTITUTION ON THE BASIS OF QUALITY ASSURANCE}

\subsection{Global changes and transformation of universities}

Integration of the Ukrainian system of higher education into the European education field maps out the developmental pathways of the higher education institutions in Ukraine. Integration and globalization changes in the modern world initiate altering the demands and social expectations of the society towards the education system in general, giving priority to 1) the integration process of the national education system with the European and world educational fields; 2) the elaboration of education based on the human-centered approach principles and competence-based approach in teaching; 3) the improvement of physical facilities; 4) the implementation of new information technologies in management and teaching; 5) the creation of conditions for the personal and professional development of the subjects of the educational process

The social order of society to the higher education system is determined by public demands for knowledge-based capital, for providing all social and economic fields with skilled professionals. The changes in the external environment dictate the need for transformation and development of local educational environments, in particular higher education institutions.

With the intensive development of science and technology, the global development of the economy and society takes place. The key factors of this development are innovation, competitiveness, quality.

The World Economic Forum in Davos mentioned the beginning of the fourth industrial revolution [219]. Klaus Schwab outlined the three major aspects that clearly determine it: 1) the pace of development (rather an exponential pace, new technology itself synthesizes more advanced and effective technologies in an interdependent world); 2) the latitude and the depth (it is based on the digital revolution and combines various technologies that cause unprecedented paradigm changes in the economy, business, society, each individual); 3) the systemic impact (it involves holistic external and internal 
transformations of all systems across countries, companies, industries and society as a whole) [219].

New technologies and universal innovations play the most important role in these revolutionary changes. Many actual scientific studies define modern society and the modern economy as innovative.

In his research, H.P. Klimov reveals an innovative society as one that constantly searches, develops, implements innovations, and, due to this, moves forward all the time. An innovative society is "a society that is not just open to innovation. It continuously generates innovations of different types and levels. Its functioning depends entirely on the speed of the introduction of new knowledge in all spheres of public life. Such a society is the most dynamic and sustainable, but with one condition: it must correctly assess the consequences of the introduction of each innovation and exclude those that pose a threat to human life" [135].

The economic context of innovation is reflected in the transition to an innovation economy and economy of knowledge.

"An innovative economy is based on scientific knowledge, innovations that become a key factor of competitiveness, the perception of new systems and technologies, the ability to implement them, plays an important role in the system of national management" [157].

The development of innovative processes, in particular in society and the economy, also affects the development of the educational sector. More relevant is the relationship in the chain of "education" - "science" ("innovation") - "business" - "society".

The transition to an innovation economy and innovation society sets the building patterns for innovation ecosystems in business and educational environments.

According to Fedulova L.I., Marchenko O.S. "The innovation ecosystem is a set of organizational, structural and functional components (institutions) and their relationships involved in the creation and application of scientific knowledge and technologies that determine the legal, economic, organizational and social conditions of the innovation process and ensure the development of innovative activities both at the enterprise level and at the level of the region and the country as a whole on the principles of selforganization" [81].

The Report Summary for the Annual Meeting of the New Champions, 
"Entrepreneurial Ecosystems Around the Globe and Company Growth Dynamics" at the World Economic Forum (September, 2013) identified the components of the entrepreneurial (innovation) ecosystem, namely: 1) available markets; 2) human capital workforce; 3) financing and finance; 4) the system of support for mentors' advisers; 5) regulatory framework and infrastructure; 6) education and training; 7) major universities as catalysts; 8) culture support. We see that in this structure an important place is given to education and universities.

The challenges of our time are to build institutional innovation ecosystems, in particular in higher education. Ukrainian scientists Sbruiev A.A., Fedulova L.I., Marchenko O.S., Lanovska G.I., and foreign scientists Adner R., Wang P., Audretsch D.B., Wessner C., Bramwell A., and others devoted their work to this study.

The innovation ecosystem of higher education is interpreted by Sbrueva A.A. "as an interactive community of individuals, groups and organizations, which is a network co-evolutionary structure and aims to develop and implement innovations in high school at the institutional, national, and global levels through the formation and development of a creative, innovation-friendly educational environment" [209].

Lanovska H.I. believes that "an innovation ecosystem is a synergy of the state, entrepreneurial and research environment using organizational, regulatory, educational, methodological and financial resources and the introduction of a mechanism for the transfer of knowledge in order to transform into innovative products" [5)].

Considering the structural model of the university's innovation system, L. Fedulova distinguishes the following ingredients: a) government/policy; b) innovative entrepreneurship: incubators, startups, technoparks; c) teachers-scientists, creative groups of students, inventors; d) public and start-up capital; e) investors (venture capital), business angels; professional associations and network groups; b) innovation centers, technology transfer centers; g) competence centers [81].

In accordance with the changes in the external environment, together with the development of innovative society, the formation of an innovative economy and knowledge economy, the system of higher education in Ukraine is developing, higher education institutions, and their educational environments are being transformed.

The draft National Strategy for Education Development in Ukraine has updated the mission and vision of higher education by 2030, which aims to create a competitive 
national higher education system focused on the development of educational, scientific, innovative.

The mission of higher education is to ensure sustainable innovative development of Ukraine through the training of highly qualified specialists, the creation and sharing of knowledge, the formation of the intellectual, social, and spiritual capital of society, ready for the challenges of the future [233].

The vision of higher education in Ukraine is a competitive system of various higher education institutions, which, through cooperation with scientific institutions and the entrepreneurial sector, forms the professional and scientific, and educational potential of the nation on the basis of continuous professional and personal development, focused on the highest achievements and practices, integrated into the world educational and research space [236].

The strategic development of higher education should take place with the gradual transformation of higher education institutions from classical academic universities to higher education institutions of innovative type.

The draft of "National Strategy for Education Development in Ukraine until 2030" states that the development of research, industry-specific, and virtual universities is trending.

Thus, the core of higher education is defined as research universities "that carry out training in many fields of knowledge, provide in-depth thorough theoretical training, acquisition of competencies necessary for scientific research and practical activities, in cooperation with scientific organizations carry out fundamental and applied research in priority and promising areas of development of science and technology, actively involve students in the implementation of scientific research, development of applied research projects" [236].

The main tasks and peculiarities of higher education institutions of the industry direction are that they should become the main provider of innovations, applied scientific and technical developments for the needs of the public and private sectors. In such universities, students are actively involved in the development and implementation of new technologies, techniques, methods, etc. In the structure of such HEIs, there are startup centers, business incubators, production units [236].

In turn, "virtual universities can train in many or individual specialties, exist as a 
separate online platform, or be a virtual duplicater of a traditional university. Their objectives are to expand access to higher education and educational process opportunities [236].

The Universities of the new generation should: combine the functions of highquality pre-emptive training of specialists in demand in the labor market; carry out innovative scientific research at the request of the state and business; create conditions for applicants of higher education and scientific-pedagogical workers on the development and implementation of high-tech innovative products, technologies, and services, to create business incubators at the university [174].

Kirby D., Clark B., Humboldt W., Zghurovskyi M., Yefimov V., Laptev A., Konstantinov G., Filonovich S., Romanowskyi O.et al. have conducted their research work in the field of transformation. There is a gradual transition from classical universities with one educational mission to innovative universities: research universities with two missions (education and research), and entrepreneurial universities with three missions (education, research, commercialization of innovations).

As noted in the Analytical Note of the National Institute for Social Research (2015), "a modern innovative or entrepreneurial university is primarily not an economic or managerial educational institution producing certified entrepreneurs or managers, but above all a higher education institution of natural science and engineering and technological profile, teachers, students and postgraduates of which are able to implement their innovative developments, implement the results of their research and development in the economy. by creating new enterprises" [118].

\subsection{Ensuring the quality of education as a factor in the development of the educational environment of an innovative type of higher education institution}

The transition to innovative universities (research, entrepreneurial) will ensure the competitiveness and quality of higher education at the request of the development of an innovative society and an innovative economy. On the one hand, innovative universities will provide better training of competitive personnel of the new generation for various areas of management. On the other hand, such universities will become centers for the 
creation of innovative products and technologies for the development of the economy and society.

Meanwhile, ensuring the quality of education in general and the quality of higher education in particular is one of the priorities of the national system of higher education in Ukraine due to its active reforming process, and entering the European educational space. At another point, self-sustained quality assurance is in connection with the quality of the educational environment of higher education institutions, namely with the availability of appropriate conditions, influences, and opportunities for quality training of higher education specialists and, as a result, with the quality of qualifications obtained, personal and professional development, success in the social and professional sphere.

The category "quality of education" is complex and is described in the scientific literature with the help of different approaches. Ukrainian scientists I. Annienkova, V. Bakhrushin, G. Yelnykova, G. Dmitrenko, V. Kremin, T. Lukina, V. Lunyachek, A. Lyashenko, S. Nikolayenko, A. Ovcharuk, Y. Romanenko, and others have devoted their studies to education quality. Among foreign scientists this category was studied by E. Korotkov, M. Potashnik, P. Tretiakov (Russia), C. Boll, L. Harvey, D. Green, R. Barnett, J. Brennnan, R. Williams, R. Harris, D. McNamara (Great Britain), Ch. McClain (United States), E. van Kemenade (Netherlands), S. Harris Hemmert (Germany) and others.

O. Liashenko characterizes the quality of education as a systemic object: the quality of the goal, the quality of the pedagogical process, and the quality of the result [147]. T. Lukina, when determining the quality of education among its internal components, distinguishes the quality of the basic conditions, the quality of the implementation of the educational process, the quality of the results of the educational process [152].

Yu.A. Romanenko understands the quality of education "as a multidimensional model of social norms and requirements for an individual and educational environment in which its development takes place and the education system that implements them at certain stages of human learning" [199]. He believes that a systematic study of the quality of higher education involves the study of a set of problems that covers: a) clarifying the essence of basic concepts of the quality of education (its definition, structural components, properties, criteria, and norms, etc.); b) determining of procedures and indicators of assessment of the quality of education (as an educational process, as its result and a 
functional system); c) monitoring and making management decisions to ensure the established standards of quality of education at all levels [199].

The concept of the quality of higher education is considered as "a complex characteristic that reflects the range and the level of educational services provided by the education system in accordance with the interests of a person, society, state" [70]. "This is a systemic category that covers the concepts of "the quality of learning" and "the quality of training". The first is multi-complex, it involves a certain level of qualification of teachers, the state of the material and laboratory base, qualities and quantities of scientific and methodological literature, modern curricula, the quality of professional student practices, etc. The quality of training is the ability of a student, a future specialist to meet the requirements of the field of the national economy, to fulfill the tasks which he/she is completing in a higher education institution" [70].

The general characteristics of the quality of higher education are the compliance of educational processes, conditions, and results with the target priorities of higher education stakeholders. "The quality, although difficult to determine, is mostly the result of interaction between teachers, students, and the educational environment of the institution. Quality assurance should ensure the educational environment in which program content, learning capabilities, and resource support meet this goal" [225].

The quality of higher education is "a concept that covers all aspects of the activities of a higher education institution: educational and academic programs, scientific and research work, teaching staff and students, educational and material base and resources" [183].

In the Law of Ukraine "On Higher Education", the quality of higher education is defined as "compliance of the conditions for conducting educational activities and the results of training with the requirements of legislation and standards of higher education, professional and / or international standards (if any), as well as the needs of interested parties and society, which is ensured through the implementation of procedures of internal and external quality assurance" [180].

Particular attention is paid to the problem of quality management of higher education.

So, V. Kachalov, T. Lukina, and others distinguish the managerial approach to determining the category of quality of education. In accordance with this approach, the 
quality of education is considered as an object of managerial influence simultaneously from several positions: from the point of view of the quality of the educational system, the quality of the educational process, and the quality of the graduate's personality [70].

According to $\mathrm{Yu}$. Romanenko, "as a category of management, the quality of education defines strategies for influencing certain indicators of the functioning of the educational system and chooses possible ways of its changes and development" [199].

Ensuring the quality of education at the university represents "an ongoing process of assessment (evaluation, monitoring, provision, maintenance, and improvement) of the quality of the higher education system" [183].

In accordance with the Standards and Guidelines for Quality Assurance in the European Higher Education Area (ESG, 2015), higher education institutions form an internal quality assurance system. This system provides for the introduction of certain procedures according to ten standards: 1.1 Policy for quality assurance; 1.2 Design and approval of programmes; 1.3 Student-centred learning, teaching, and assessment; 1.4 Student admission, progression, recognition and certification; 1.5 Teaching staff; 1.6 Learning resources and student support; 1.7 Information management; 1.8 Public information; 1.9 On-going monitoring and periodic review of programmes; 1.10 Cyclical external quality assurance [225].

Ensuring the quality of education at the innovation university also provides for the provision and support of the formation of an internal innovation ecosystem, the development of the educational environment for the innovative activities of participants in educational and scientific processes.

Quality assurance is an important factor in the development of the educational environment of a higher education institution, a condition for its quality.

Let us pay attention to the definition of the concept of "the educational environment of a higher education institution" (Table 5.1).

As you can see, the most common understanding of the educational environment of a higher education institution is represented by the definition of its essence as a system of conditions, resources, influences on the personal and professional formation, and personality development. 
Table 5.1

Definition of the term "the educational environment of a higher education institution"

\begin{tabular}{|l|l|}
\hline \multicolumn{1}{|c|}{ Determination of the EE of the HEI } & Author, Source \\
\hline \multicolumn{1}{|c|}{1} & 2 \\
\hline $\begin{array}{l}\text { A developing spatial continuum that combines a complex of objective } \\
\text { components (scientific and pedagogical schools, people, subjects in the } \\
\text { relationship and interaction of their general and special properties) and } \\
\text { subjective characteristics of participants in the educational process }\end{array}$ & \\
\hline $\begin{array}{l}\text { The general, aggregate, united, integral factor of personality development, } \\
\text { which plays a decisive role in the modification of behavior, which unfolds as a } \\
\text { consequence of planned and unplanned environmental factors, contributes to } \\
\text { personal and professional development. That is, the LE of a university is a set } \\
\text { of conditions for the education of a person, developed purposefully and } \\
\text { spontaneously in an institution that performs educational functions. }\end{array}$ \\
\hline $\begin{array}{l}\text { Multilevel system of conditions that provide optimal parameters of educational } \\
\text { activity in the target, content, procedural, effective, resource aspects. }\end{array}$ & P. Fedorova [86] \\
$\begin{array}{l}\text { The conditions of the educational environment are a system of opportunities } \\
\text { (internal and external, dynamic and static) necessary for the successful } \\
\text { development of the professional competence of future specialists. }\end{array}$ \\
\hline $\begin{array}{l}\text { The system of influences and conditions of personality formation according to } \\
\text { a given sample, as well as opportunities for its own development, contained in } \\
\text { the social and spatial, and objective environment }\end{array}$ & A. Yasvin [283] \\
\hline $\begin{array}{l}\text { The most important additional resource of professional development of the } \\
\text { student's personality and self-realization; } \\
\text { the area of joint activity of educational subjects, where certain connections and } \\
\text { relationships are established between them and elements of educational } \\
\text { systems, ensuring the implementation of personal and social goals of education; } \\
\text { it is based on the principles of openness, activity, diversity of sources, stability, } \\
\text { comfort, and self-organization. P.80 }\end{array}$ & \\
\hline
\end{tabular}

A more detailed analysis of this concept made it possible to determine that the educational environment of a higher education institution is determined in many aspects, namely:

1) as an object/phenomenon:

a system (V. Yasvin, A. Vinevskaia, M. Bratko), 
a set of subsystems (V. Masterova, components - Ye. Vasilieva), factors (V. Novykov, phenomena - O. Kernitskyi), a set of spiritual and material conditions of an institution (Shapran Yu.P., Shapran O.I. );

developing continuum (O. Artyukhina); formation (Bratko);

a pedagogical phenomenon (O. Artyukhina, O. Kernytskyi), a socio-cultural phenomenon (I. Arendachuk);

area of reality (P. Fedorova),

multi-subject and interdisciplinary systematic structure (M. Bratko),

social and pedagogical phenomenon (T. Meng), psychological and pedagogical reality (I. Arendachuk),

2) according to the system characteristics of an object/phenomenon:

ordered, integral (as a set of components, A. Vinevskaia),

multi-object, multi-subject (Bratko),

multilevel (A. Vinevskaia),

complex (as a system) (Bratko),

interconnected (as a system) (Bratko),

multidimensional (as a phenomenon) (T.V. Meng);

3) according to the essence of the object / phenomenon:

influence (V. Yasvin),

conditions (O. Artyukhina, A. Vinevskaia, P. Fedorova, Yasvin),

resource (Mykytiuk, I. Haba),

a factor (O.Artyukhina, Bratko, V. Novykov),

opportunities (P. Fedorova).

Thus, it can be determined that the "quality of higher education" is a dimensional integral characteristic of institutional goals, conditions, educational processes, resources, and results. The quality of higher education at the institutional level (level of a higher education institution) is a multidimensional integral characteristic of the mission, goals, conditions, processes, resources of higher education institutions, formal and informal results related to personal and professional development, the success of higher education subjects; their compliance with individual and social needs, institutional, state, international standards.

Considering the relationship of categories "environment", "space", "system", V. 
Kremen draws attention to the fact that for different systems their environment is usually not identical [138]. V. Bykov emphasizes the fact that it is very important to understand, find out - in relation to which system its environment is considered, because, in general, what is the environment for one system is not an environment for others that are part of the set of target spaces. That is, the category environment is associated with a significant surrounding space of the system in which this system operates, develops and / or is studied.

"In the educational environment of an educational institution, there may be and, as a rule, are created several educational environments, some components of which with the same indicators (for example, the same means of learning) can be included and associated with several educational environments and simultaneously with the educational spaces of different educational institutions" [138].

Exploring the development of an environment approach, one can see what systems the concept of the environment in education was studied, namely: educational system (educational environment), educational system (educational, learning environment), information system (information and educational environment); development systems (innovation environment); social system (socio-cultural environment) etc.

In our study, we will look at the educational environment in the context of: 1) higher education systems; 2) concepts of innovation university; 3) system of internal quality assurance of education.

The educational environment of a higher education institution is a complex, holistic, dynamic, open, multilevel, multidimensional system of conditions, influences, opportunities, interaction with which directly or indirectly contributes / supports / encourages personal and professional development and self-development of the educational process subjects to meet their educational needs, labor market requirements and society.

The educational environment of the University of innovation type is a system of the value-based, target, socio-psychological, informational, organizational and activity, spatial and objective (physical and virtual) conditions, opportunities, and resources that affect the quality and results of educational, scientific, innovative, entrepreneurial activities of university subjects, their personal and professional development and selfrealization at the individual, institutional, sectoral levels [174]. 
An innovative educational environment is being formed and developed in an innovative type of higher education institution.

In the context of considering the innovative educational space of the region, Ye. Bachynska considers the innovative environment in two areas: as an environment, an area within which there are agreed rules of innovation activity, and as a holistic system, the result of which is the latest ideas and original technologies [37].

L. Vashchenko defines the mission of an innovative educational environment, which consists of generating innovative flows and increasing the innovative potential of each educational institution and the system as a whole, preserving both local and administrative innovations [272].

A number of Ukrainian scientists consider the innovative educational environment as a factor of quality education and personality development at different levels of education (preschool, secondary school, higher education), training of future specialists in higher education institutions (M. Bychko, L. Vashchenko, A. Katashov, V. Leliukh, N. Razina, N. Tkachuk, O. Shapran, O. Tsuniak, etc.).

Exploring the problem of preparing masters of primary education, O. Tsuniak argues that "the innovative educational environment is a system of pedagogical conditions of personal and professional development of the individual, which includes the territory within which the rules of innovation activity and the latest ideas, original pedagogical technologies used in the professional training of future masters of primary education and contribute to the improvement of their professional competence [268].

S. Lytvynova, researching the development of the educational environment of the general secondary education institution, draws attention to the fact that the innovative educational environment combines purposefully created organizational and pedagogical, procedural and technological, information resources and on a single value-target basis provides innovation as a way and mechanism for the formation of components of pedagogical culture, the formation of the subjective position of future teachers and the content of forms, methods and content techniques, technologies aimed at the formation of pedagogical culture [153].

The peculiarity of the innovative educational environment of a higher education institution is the target orientation of its development to create conditions, opportunities, resources for deploying the innovative potential of participants in the educational process 
and higher education institutions in general.

The quality of the educational environment of a higher education institution is characterized by the quality of its components. In scientific and pedagogical literature, considerable attention is paid to the structure and content of the educational environment. Let us consider them in the time dynamics of formation.

H. Kovalev (1993) in the structure of the educational environment sees: 1) physical environment, 2) human factors, 3) training program [283].

V. Yasvin (1997, 2001), considering the educational environment at the local level (educational institution), distinguishes four components: 1) subjects of the educational process; 2) social component; 3) spatial and objective component; 4) technological (or psychedidactic) component. As you can see, the scientist distinguishes separate components of the subjects of the educational process and various activities necessary for learning and development (technological, psychodidactic) [283];

Y. Kulyitkin, S. Tarasov (2001) in the educational environment of any educational institution consider the following components of the structure: 1) spatial and semantic, 2) meaningful and methodical, 3) communication and organizational [140]. Associations of teachers, initiative groups, etc.). In this list of components, there is a communication component, which in turn reflects: the characteristics of the educational environment, the communication sphere, and organizational conditions (features of management culture, the presence of creative associations of teachers, initiative groups, etc.).

H. Belenko (2011), exploring the cultural and educational environment of a higher education institution and its impact on the formation of professional competence of the future teacher, highlights the following subsystems: 1) logistical; 2) socio-psychological; 3) informational [43].

Ye. Vasilieva (2011) considers the structure of the educational environment in the context of management and evaluation, which contains the components: 1) subject and object, 2) functional and target; 3) technological; 4) diagnosis and effective. A special thing in the provided structure is the diagnostic and effectiveness component, which is important for the management and evaluation processes [273].

O. Horchakova (2011), considering the peculiarities of the environment approach to the management of educational activities, considers the following components of the educational environment of the educational institution: social and psychological, 
informational, pedagogical, cognitive, communicative, spatial and objective [105].

V. Novykov (2012) in the formation of the basic structure of the professional and personal stimulating environment of higher education, represents its generalized component composition as follows: 1) value and semantic; 2) informational and content; 3) organizational and actional; 4) spatial and objective [166]. The special thing is the inclusion of the first component, which reflects the elements of the organizational culture of the institution (attributes, values, mission, traditions of higher education).

O. Artiukhina (2012) believes that during the design and monitoring of the dynamics of the educational environment of the department of a medical higher education institution, its structure contains components: 1) scientific; 2) logistical; 3) ecological and hygienic; 4) educational and methodological; 5) communicative [35], which corresponds to the specifics of the department's activities and education.

M. Bratko (2015), exploring the functions of the educational environment, reveals the following components: 1) personal, 2) axiological and semantic, 3) informational and content, 4) organizational and actional, 5) spatial and objective [47].

David E. Anstrand, Edward E. Kirkbride believe that the educational environment includes the social environment, the educational environment, and the physical environment. The social environment contains forms and connects the educational and physical environment. The educational environment defines relationships, activities, and time. The physical environment is a "place" where training takes place - in or outside the classroom.

The presented review allows us to get an idea that most often scientists consider the structure of the educational environment in the dimensions: spatial and objective environment, social environment, learning environment, and activities of the subjects. Considerable attention is gradually gaining information and communication component, which, in our opinion, is associated with the formation of the information society, the growth of cognization, and the informatization of society.

Based on the analysis and generalization of recent works, in particular, M. Bratko [49], O. Horchakova [105] on the structure and content of the educational environment, our previous research (H. Poliakova [171]) and following the vector of quality assurance, we identified the following components of the educational environment of a higher education institution: value-oriented (leadership and vision), socio-psychological 
(stakeholder), information and communication (information), content, organizational and activity (functional), spatial and objective (physical and virtual).

The defined components of the educational environment of the University acquire a new meaning in the modern conditions of educational transformations since their content is based on the implementation of integration processes of higher education into the European educational environment, human-centered and competence approaches, intensive informatization of education, the transformation of the university of innovative type. In modern conditions of constant and rapid changes, the distinguished components of the educational environment are dynamic, their content changes in accordance with the defined development strategies of HEI, taking into account internal and external resources [171].

When agreeing on the concepts of the quality of higher education and the quality of the components of the educational environment, the relationship can be traced, namely: compliance of the results with educational goals is consistent with the value-orientation component of the educational environment; the quality of educational programs - with meaningful and methodological; the quality of processes - with organizational and actional; the quality of interaction between participants in the educational process and the environment - with the socio-psychological; quality of educational programs - with information and communication, and spatial and objective.

We will consider the development of the educational environment of the University as: 1) the process of progressive coevolution of its components at different levels of the organizational management structure, taking into account changes and priorities of the development of the external environment, which is aimed at meeting the established standards of quality of education, meeting the educational needs of stakeholders of higher education, personal and professional development and self-development of educational process subjects; 2) the result of controlled and unmanaged quantitative and qualitative changes in the states of its components.

We will reveal the content of the components of the educational environment, taking into account the goals and objectives of the development of the educational environment of an innovative type of higher education institution and in accordance with the Standards and Recommendations for Quality Assurance in the European Higher Education Area (ESG) (Table 5.2). 
Table 5.2

Structure and content of development of components of educational environment of an institution of higher education of innovative type in the context of internal quality assurance (according to ESG standards)

\begin{tabular}{|c|c|c|c|}
\hline $\begin{array}{c}\text { Compo } \\
\text { nents }\end{array}$ & $\begin{array}{c}\text { The tasks of } \\
\text { development of EE at } \\
\text { HEI }\end{array}$ & Component Contents & $\begin{array}{c}\text { ESG standards } \\
{[225]}\end{array}$ \\
\hline 1 & & 2 & 3 \\
\hline 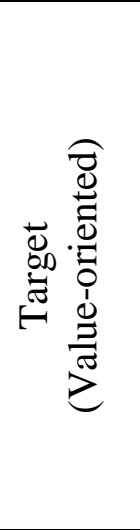 & $\begin{array}{l}\text { Formation of quality } \\
\text { policy in the subjects } \\
\text { of educational process } \\
\text { and scientific, } \\
\text { innovative activity }\end{array}$ & $\begin{array}{l}\text { a) quality policy; } \\
\text { b) policy of creation and commercialization } \\
\text { of innovations, innovative products, the } \\
\text { introduction of innovations in the } \\
\text { educational process; } \\
\text { c) goals, values, priorities, models of } \\
\text { behavior to ensure, maintain and improve } \\
\text { quality on an innovative basis; } \\
\text { d) focus on achieving personal and } \\
\text { corporate success of innovatively active } \\
\text { HEI }\end{array}$ & $\begin{array}{ll}1.1 . & \text { Quality } \\
\text { Assurance } & \text { Policy }\end{array}$ \\
\hline 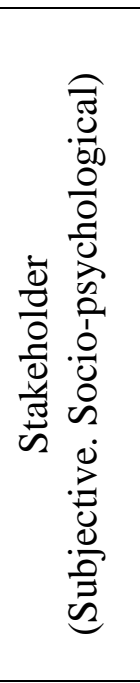 & $\begin{array}{lr}\text { Supporting } & \text { the } \\
\text { development } & \text { of } \\
\text { educational process } \\
\text { subjects in accordance } \\
\text { with their educational } \\
\text { needs, the } \\
\text { requirements of the } \\
\text { educational services } \\
\text { market }\end{array}$ & $\begin{array}{l}\text { a) Internal stakeholders - (students, } \\
\text { postgraduates, teachers, heads and } \\
\text { employees of departments, administration) } \\
\text { b) external stakeholders (representatives of } \\
\text { the business environment, labor market, } \\
\text { public, partners, state management, etc.); } \\
\text { c) expectations, needs, requests, motives, } \\
\text { stakeholder requirements; } \\
\text { d) the socio-psychological climate of an } \\
\text { innovative type of HEI; } \\
\text { e) attention to the personal and professional } \\
\text { development of students; } \\
\text { f) attention to the quality and development } \\
\text { of scientific and pedagogical staff }\end{array}$ & $\begin{array}{l}\text { 1.3. Student } \\
\text { centered learning, } \\
\text { teaching and } \\
\text { evaluation } \\
\text { 1.5. Teaching } \\
\text { staff }\end{array}$ \\
\hline 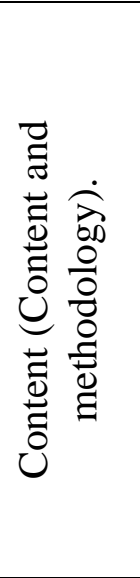 & $\begin{array}{l}\text { Ensuring the quality of } \\
\text { educational programs } \\
\text { in accordance with } \\
\text { national and } \\
\text { international standards }\end{array}$ & $\begin{array}{l}\text { a) high-quality content of educational } \\
\text { programs; } \\
\text { b) variability of the content of the selective } \\
\text { component of educational programs; } \\
\text { c) introduction of research work into } \\
\text { educational programs; } \\
\text { d) taking into account the needs, } \\
\text { satisfaction of internal and external } \\
\text { stakeholders in the development of } \\
\text { educational programs; } \\
\text { e) educational and methodological support } \\
\text { of the educational process. }\end{array}$ & $\begin{array}{l}\text { 1.2. Development } \\
\text { and approval of } \\
\text { programs } \\
\text { 1.6. Learning } \\
\text { resources and } \\
\text { student support }\end{array}$ \\
\hline
\end{tabular}


The end of the table 5.2

\begin{tabular}{|c|c|c|c|}
\hline 1 & 2 & 3 & 4 \\
\hline 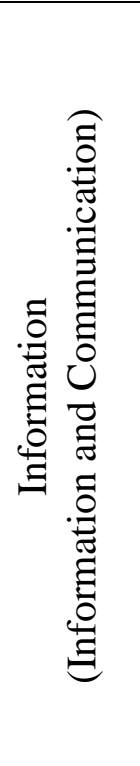 & $\begin{array}{l}\text { Supporting and } \\
\text { developing the image } \\
\text { of higher education } \\
\text { institutions in the } \\
\text { national and world } \\
\text { educational } \\
\text { environment. } \\
\text { Building of a system } \\
\text { of effective external } \\
\text { and internal } \\
\text { communications. } \\
\text { Integration into the } \\
\text { international and } \\
\text { educational antic andironment } \\
\text { scientific envis }\end{array}$ & $\begin{array}{l}\text { a) Normative, instructional, regulatory } \\
\text { information related to the performance of } \\
\text { the functions of higher education } \\
\text { institutions regarding innovation activities } \\
\text { and quality assurance of education, } \\
\text { dissemination of scientific and technical } \\
\text { information; } \\
\text { b) communication processes of internal and } \\
\text { external information exchange; } \\
\text { c) information infrastructure, access to } \\
\text { information, network communications; } \\
\text { d) access to open world information } \\
\text { resources of scientific research; } \\
\text { e) coverage of the processes and results of } \\
\text { the development of the educational } \\
\text { environment of hem. }\end{array}$ & $\begin{array}{l}\text { 1.7. Information } \\
\text { management } \\
1.8 \text { Public } \\
\text { information }\end{array}$ \\
\hline 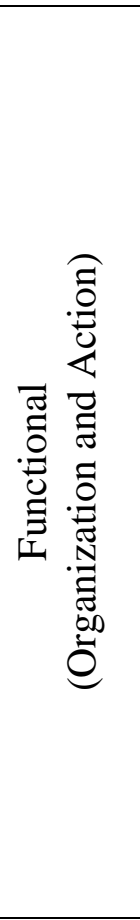 & $\begin{array}{l}\text { Creating favorable } \\
\text { conditions } \\
\text { qualitative } \\
\text { performance and } \\
\text { functions in the areas } \\
\text { of } \\
\text { scientific, innovative } \\
\text { processes }\end{array}$ & $\begin{array}{l}\text { a) A variety of forms, methods, methods of } \\
\text { educational, research, innovation activities } \\
\text { of teachers, students, heads of different } \\
\text { levels of higher education; } \\
\text { b) student-centered pedagogical } \\
\text { (educational, methodological, } \\
\text { organizational, educatory, scientific, } \\
\text { innovative) activities of teachers; } \\
\text { c) human-centered management activities } \\
\text { of scientific and pedagogical staff at all } \\
\text { levels of management of higher education } \\
\text { institutions; } \\
\text { d) planning, monitoring, and self- } \\
\text { assessment of the quality of educational, } \\
\text { research, innovation activities and its } \\
\text { results by the subjects of the educational } \\
\text { process; } \\
\text { e) procedures for internal and external } \\
\text { quality assurance of education }\end{array}$ & $\begin{array}{l}\text { 1.3. Student- } \\
\text { centered learning, } \\
\text { teaching and } \\
\text { evaluation } \\
1.9 \text { Ongoing } \\
\text { monitoring and } \\
\text { periodic review of } \\
\text { programs } \\
1.4 \text { Enrollment, } \\
\text { achievements, } \\
\text { recognition and } \\
\text { attestation } \\
\text { students of } \\
1.10 \text { Cyclical } \\
\text { external quality } \\
\text { assurance }\end{array}$ \\
\hline 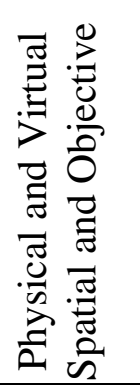 & $\begin{array}{l}\text { Developing physical } \\
\text { and virtual educational } \\
\text { environment } \\
\text { universities }\end{array}$ & $\begin{array}{l}\text { a) Physical and virtual spatial and objective } \\
\text { environment (educational buildings and } \\
\text { dormitories), } \\
\text { b) logistical support of educational and } \\
\text { scientific processes; } \\
\text { c) infrastructure of the educational } \\
\text { environment of HEIs (startup centers, } \\
\text { coworkings, scientific parks, etc.) }\end{array}$ & $\begin{array}{l}\text { 1.6. Learning } \\
\text { resources and } \\
\text { student support }\end{array}$ \\
\hline
\end{tabular}


Table 5.2 shows that the coevoluation development of educational environment components is aimed at ensuring appropriate quality standards, the description of which is determined by a higher education institution.

\subsection{The essence and technology of managing the development of the educational environment of higher education institutions of innovative type on the basis of ensuring the quality of education}

We define the educational environment of an innovative type of higher education institution as a complex holistic, dynamic, open, multi-level, multidimensional system of conditions, influences, opportunities and resources for personal and professional development and self-development of educational process subjects on the basis of innovative activities and ensuring the quality of education.

For the development of the educational environment of universities, ensuring the competitiveness of universities as a whole, meeting the needs and requirements at the level of society, customers and consumers of education, universities, subjects of the educational process, coordination and direction of activities of heads, scientific and pedagogical workers of structural units, applicants for higher education are important. This requires the search for new approaches to managing the development of the educational environment of a higher education institution, making changes based on systemic innovation processes.

Scientists A. Vinevska, I. Haba, O. Kernytskyi, O. Koshevoy, O. Yaroshynska devoted their works to the issues of designing, modeling, creation of the educational environment of higher education institutions.

For example, I. Haba believes that "design is the process in which conditions for a reflexive and innovative environment are created, which provides the possibility of a free creative search for a unique solution to the educational and professional problem inactivity" [102].

The problem of managing the educational environment of educational institutions was investigated by Ukrainian scientists M. Bratko, L. Martynets, etc.

L. Martynets singles out the management of the educational environment of 
professional development of teachers, which is defined as "the purposeful, planned and systematic impact of the management of a comprehensive educational institution on certain components of its educational environment, aimed at creating conditions for the systematic improvement of the professional characteristics of teachers in the process of continuous education and self-education" [156].

M. Bratko defines "the management of the educational environment of higher education as a complex type of intellectual activity aimed at regulating processes and modifying the components of the educational environment of higher education institutions, which is associated with the identification and resolution of the problems of the educational environment of higher education institutions, which ensures the existence of its integrity and achieves the set educational goals of higher education institutions" [47].

In order to form and develop the educational environment of an innovative institution of higher education, an appropriate management system should be built. This management system should take into account: 1) changes in the external environment at the global (world), national, industry levels (educational and field of training); 2) features of the formation of an innovation ecosystem; 3) processes and procedures of the internal quality assurance system of education; 4) needs of external and internal stakeholders; 4) ensuring compliance with international and national standards of education quality (Fig. 5.1) [171].

Management of the development of the educational environment of an innovative higher education institution and its characteristics should be:

a) strategic - aimed at fulfilling the mission, strategic goals, objectives, plans for the activities and development of a higher education institution, its transformation to an innovative type of institution, ensuring the quality of education;

b) adaptive, which involves the interaction of the manager and managed subsystems on the basis of coordination of the development strategies of a higher education institution and the specifics of its departments, motives, and capabilities of participants in the educational process, taking into account the conditions of the external and internal environment to achieve a common goal through the processes of self-organization and current feedback; 


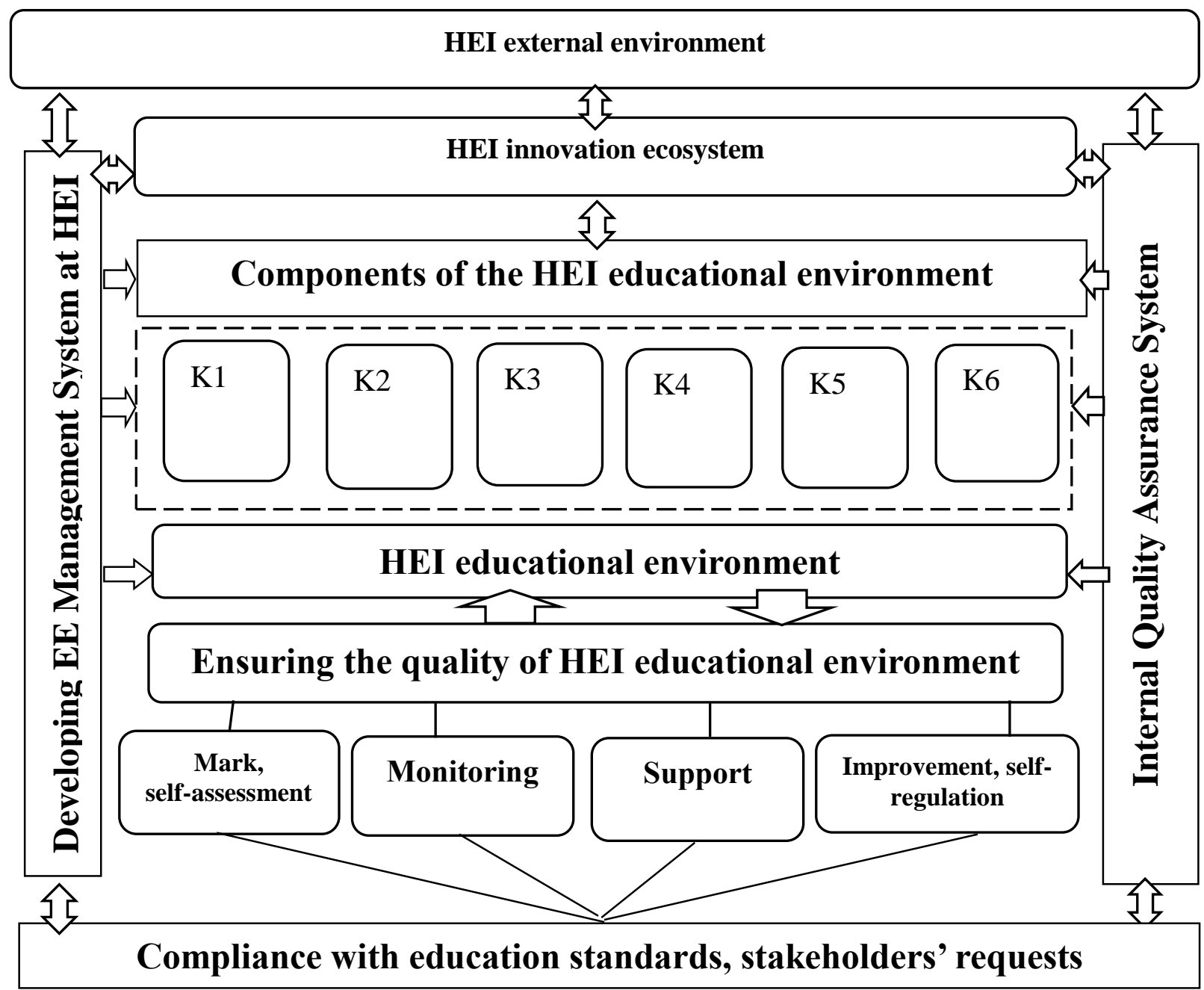

Fig. 5.1. Subject field of management of the development of the educational environment of higher education institutions of innovative type on the basis of quality assurance of education, where

K1 - value-orientation component, K2 - subjective, socio-psychological component, K3 - content and methodology component, K4 - information and communication component, K5 - organizational and actional component, K6 - spatial and objective component.

c) marketing - focused on quality assurance in the areas of activity of higher education institutions in accordance with the order of employers and society, on the promotion of their own brand and image in the external competitive educational environment and innovation ecosystem; marketing and monitoring, which involves the study of the external and internal environment of higher education institutions as a marketing environment, conducting marketing and monitoring research that form the informational basis for managing the quality of educational, scientific, innovative 
activities and the quality of higher education;d) competence oriented - such that, on the one hand, is carried out by competent specialists in the field of education management, on the other - aimed at ensuring the training of competent, competitive graduates of higher education institutions capable of professional activity in changing conditions of innovative economy and knowledge economy;

e) client-oriented (stakeholder), which is based on research of the positions of internal and external stakeholders, which allows determining the quality of educational services in the training of specialists with higher education, their demand in the labor market, the level of commercialization of created innovative technologies and products;

e) reflexive, which provides for the implementation by subjects of the sociopedagogical system of higher education institutions rethinking the processes, results, means of their achievement; identify ways to improve the quality of processes and results;

h) complex - one that systematically covers different directions and levels of activity of a higher education institution [173];

e) team - the main characteristics of which are: the presence of a management team (head, deputy head, heads of structural units, active members of the team); joint (collective) performance of managerial functions; matrix organizational management structure; effective team interaction; actual resources that contribute to team interaction (material, technical, informational, financial) [175].

By its essence, managing the development of the educational environment, a higher education institution of innovative type is change management, which involves the transition from its current to the desired state of quality.

The components of the system of management of the development of the educational environment of a higher education institution of innovative type are:

1) principles on which it is based (purposefulness, openness, adaptability, customeroriented);

2) development management entities, which include stakeholders; namely, internal stakeholders - students, teachers, heads of different levels of management of higher education; external stakeholders - employers, scientists, representatives of the academic community, business environment, public administration, etc.

3) functions that determine the content of management (collegial / joint definition of strategic goals of the development of the educational environment; strategic, current 
planning and design of the development of the educational environment; organization and cooperation of actions for the development of the educational environment; monitoring and self-esteem of processes and results of the development of the educational environment; regulation of processes and results of the development of the educational environment in accordance with the goals);

4) the organizational structure that ensures the construction of interaction between participants in the management process (by hierarchy and level of responsibility - head, deputy head, heads of structural and functional departments, teachers, students; by type matrix organizational structure);

5) tools that allow you to implement management functions (framework program, qualifier models);

6) criteria by which the results of the management process are evaluated.

Management of the development of the educational environment of an innovative type of higher education institution, we define as a purposeful interaction of the management and managed subsystems of a higher education institution in order to transfer the components of the educational environment into a system of conditions, opportunities and resources to a qualitatively new state for personal and professional development and self-realization of educational, research, innovation, entrepreneurial processes.

When building management of the development of the educational environment of an innovative type of higher education institution on the basis of quality assurance, it is worth turning to recognized quality management models. These models include:

1) Model of the European Quality Management Fund (EFQM - European Foundation for Quality Management).

The EFQM Model is a globally recognised management framework that supports organisations in managing change and improving performance. The EFQM Model structure is based on the simple but powerful logic of asking three questions: 1) WHY "Why" does this organisation exist? What purpose does it fulfill? Why this particular strategy (DIRECTION; 2) HOW - "How" does it intend to deliver on its Purpose and its Strategy (EXECUTION); 3) WHAT - "What" has it actually achieved to date? "What" does it intend to achieve tomorrow (RESULTS) [240].

A model that meets the requirements of the TQM (Total Quality Management) 
concept. A core definition of total quality management (TQM) describes a management approach to long-term success through customer satisfaction. In a TQM effort, all members of an organization participate in improving processes, products, services, and the culture in which they work [277]. This model is aimed at the quality of the approach to the leadership of the organization, based on the participation of all its members, and aimed at achieving long-term success by meeting consumer requests and benefits for all members of the organization and society.

2) Model of the quality management system that meets the requirements of the international standard DSTU ISO 9001:2015 (ISO 9001:2015, IDT) Quality Management Systems. International standards ISO series 9000 are standards describing the requirements for the quality management system of organizations and enterprises; these are standards for managing the quality of products, and not on the products themselves; provide for control and quality assurance of production at various technological stages - from order processing to shipment of goods.

These quality management models in organizations are used in various sectors of the economy, including education.

When developing a system for managing the development of the educational environment of a higher education institution of innovative type and self-assessment of the quality of its functioning, it is worth choosing a basic model of quality management. This will determine key goals, approaches, principles, indicators, indicators of change management.

To develop and implement a system for managing the development of the educational environment of a higher education institution on the basis of ensuring the quality of education, we offer such a tool as a framework program.

A framework program is a multifunctional form, the purpose of which is to model the basis for the gradual development and implementation of a management system for the development of the educational environment, as well as to identify the quality of processes and results of management influence in achieving development goals.

The components of such a framework program are: 1) stages of implementation of the management system for the development of the educational environment; 2) tasks of each stage; 3 ) indicators of the implementation of the stage; 4) assessment of the quality of the stage implementation. 
We will reveal the content of the framework program for the implementation of management of the development of the educational environment of an innovative institution on the basis of ensuring the quality of education.

\section{Stage I. Target.}

Stage tasks. Formation of a strategy for the development of the educational environment on the basis of quality policy and innovation.

Stage indicators. Defining the purpose, tasks, principles of development of the educational environment of a higher education institution on the basis of quality assurance. Existence of strategy of development of the educational environment, target orientations, values. Involvement of internal and external stakeholders in determining the strategy of educational environment development, policy to ensure its quality, innovation policy. Selection of a basic model of quality management in a higher education institution.

Score from 0 to 1 .

\section{Stage II. Prognostic.}

Stage tasks. Formation of conceptual, methodological principles of management of the development of the educational environment on the basis of ensuring the quality of education.

Stage indicators. Having (developing) a management system for the development of the educational environment of higher education institutions. Having (developing) a quality management system. Having (developing) a model of the innovative educational environment. Having (developing) a criterion basis for assessing the quality of the educational environment: standards, indicators, quality indicators. Identification of groups of key internal and external stakeholders.

Score from 0 to 1 .

\section{Stage III. Organizational}

Stage tasks. Determine the degree of organization of development management on the basis of quality assurance.

Stage indicators. Existence and functioning of the organizational structure of management of the development of the educational environment in a higher education institution and collegial governing bodies by matrix type. Distribution of internal quality assurance functions by hierarchical levels of organizational management structure. Support of management of development of the educational environment (normative and 
instructive, organizational and methodical, informational and analytical). Involvement of internal and external stakeholders in the processes of managing the development of the educational environment.

Score from 0 to 1

\section{Stage IV. Functioning.}

Task stage. Implementation of management processes for the development of the educational environment and internal quality assurance procedures.

Stage indicators. Implementation of the functions of managing the development of the educational environment of a higher education institution. Implementation of educational environment development functions. Implementation of internal quality assurance processes and procedures (according to ESG). Formation of organizational culture aimed at innovative development, the readiness of participants in the educational process for change, and self-development. Management of innovation, innovation, technology. Information management, internal and external communications. Human resources development management. Resource management.

Score from 0 to 1

\section{Stage Va. Monitoring and self-assessing the processes.}

Stage tasks. Periodic determination of the degree of implementation of processes and procedures for managing the development of the educational environment. Monitoring and self-assessment of activities and results in the formation and development of the innovative educational environment at all levels of the organizational structure of management.

Stage indicators. Conducting marketing-monitoring and socio-psychological research on the quality of processes and results of the educational environment. Involvement of internal and external stakeholders) in decision-making in the areas of educational environment, development to ensure quality and improve it. Coverage of monitoring and self-assessment results according to the indicators defined in the management system of educational environment development. Making decisions and taking measures to improve the processes and results of the development of the educational environment.

Score from 0 to 1 .

Stage Vb. Monitoring and self-esteem of results. 
Stage tasks. Periodic determination of the degree of realization of the results of the management of the development of the educational environment.

Stage indicators. Results for internal stakeholders. Results for external stakeholders. Results for society. Key performance results.

Score from 0 to 1 .

\section{Stage VI. Improving the processes and results.}

Stage tasks. Regulation and improvement of the quality of processes and results of the development of the educational environment.

Stage indicators. Implementation of measures to regulate the processes and results of the development of the educational environment in accordance with the

Score from 0 to 1

The scale of evaluation of the stage of management of the development of the educational environment of a higher education institution of innovative type is interpreted as follows: 0-0.25 - insufficient level; 0.26-0.50 - low level; 0.56-0.75 - medium level; 0.76-0.90 - optimal level; 0.91-1 - high level.

The main result of managing the development of the educational environment of an innovative type of higher education institution on the basis of quality assurance is coevoluation qualitative changes in the components of the educational environment.

To determine the state of these qualitative changes in accordance with the priority tasks, we use such a tool as a qualimetric model.

The basis for the development of this model is a qualimetric approach (from the "qualifier" - quality, "metrio" - measure), which provides for a quantitative description of the quality of objects or processes (quantitative quality assessment) [110].

The offered qualimetric model of development of components of the educational environment of a higher education institution contains:

1) quality measurement objects - components of the educational environment of the higher education institution;

2) value $(\mathrm{m}, \mathrm{v})$ - the significance of the object for the target result, which is calculated by the method of expert evaluations;

3 ) criteria for the quality of development of educational environment components;

4) reference, desired values of criteria for the development of components of the educational environment in accordance with the development goals; 
5) actual significance of criteria for the development of the educational environment components in accordance with development goals;

6) coefficient of conformity $(\mathrm{K})$ - co-implementation of the obtained actual values of the criteria for the development of components of the educational environment from the desired in accordance with the development goals.

The basic qualimetric model of the development of components of the educational environment of a higher education institution of innovative type is presented in Table 5.3.

Table 5.3

\section{Qualimetric model of the development of components of educational environment}

\section{of a higher education institution of innovative type}

\begin{tabular}{|c|c|c|c|c|c|c|}
\hline $\begin{array}{c}\text { Components of } \\
\text { the educational } \\
\text { environment }\end{array}$ & 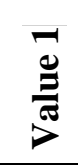 & $\begin{array}{l}\text { Groups of indicators of the state and } \\
\text { development of the HEI educational } \\
\text { environment }\end{array}$ & 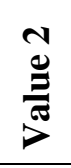 & 递 & 胥 & 离 \\
\hline 1 & 2 & 3 & 4 & 5 & 6 & 7 \\
\hline \multirow{2}{*}{$\begin{array}{c}\text { Target } \\
\left(\mathrm{P}_{1}=\mathrm{m}_{1}\left(\mathrm{v}_{1} * \mathrm{~K}_{1}+\right.\right. \\
\left.+\mathrm{v}_{2} * \mathrm{~K}_{2}\right)\end{array}$} & \multirow{2}{*}{$\mathrm{m}_{1}$} & The definition of HEI mission, vision, values & $\mathrm{V}_{1}$ & & & $\mathrm{~K}_{1}$ \\
\hline & & $\begin{array}{l}\text { The definition of HEI strategic goals, policies, } \\
\text { tasks of development }\end{array}$ & $\mathrm{v}_{2}$ & & & $\mathrm{~K}_{2}$ \\
\hline \multirow{5}{*}{$\begin{array}{l}\text { Stakeholder } \\
\left(\mathrm{P}_{2}=\mathrm{m}_{2}\left(\mathrm{v}_{3} * \mathrm{~K}_{3}+\right.\right. \\
+\mathrm{v}_{4} * \mathrm{~K}_{4}+\mathrm{v}_{5} * \mathrm{~K}_{5}+ \\
\left.\mathrm{v}_{6} * \mathrm{~K}_{6+} \mathrm{v}_{7} * \mathrm{~K}_{7}\right)\end{array}$} & \multirow{5}{*}{$\mathrm{m}_{2}$} & The quality of students' groups & $\mathrm{V}_{3}$ & & & $\mathrm{~K}_{3}$ \\
\hline & & The quality of the scientific and pedagogical staff & $\mathrm{V}_{4}$ & & & $\mathrm{~K}_{4}$ \\
\hline & & The team of external stakeholders of universities & $\mathrm{V}_{5}$ & & & $\mathrm{~K}_{5}$ \\
\hline & & $\begin{array}{l}\text { The quality of pedagogical communication and } \\
\text { interaction of educational process subjects }\end{array}$ & $\mathrm{V}_{6}$ & & & $\mathrm{~K}_{6}$ \\
\hline & & $\begin{array}{l}\text { The quality of interaction and partnership with } \\
\text { customers and consumers of educational services, } \\
\text { innovative products }\end{array}$ & $\mathrm{V}_{7}$ & & & $\mathrm{~K}_{7}$ \\
\hline \multirow{3}{*}{$\begin{array}{c}\text { Content } \\
\text { (Content and } \\
\text { Methodology }) \\
\left(\mathrm{P}_{3}=\mathrm{m}_{3}\left(\mathrm{v}_{8 *} \mathrm{~K}_{8}+\right.\right. \\
+\mathrm{V}_{9 *} \mathrm{~K}_{9+\mathrm{v} 10^{*}} \mathrm{~K}_{10+}\end{array}$} & \multirow{3}{*}{$\mathrm{m}_{3}$} & The quality of the content of educational programs & $\mathrm{V}_{8}$ & & & $\mathrm{~K}_{8}$ \\
\hline & & $\begin{array}{l}\text { The quality of educational and methodological } \\
\text { support (including electronic multimedia and } \\
\text { interactive support) }\end{array}$ & $\mathrm{V}_{9}$ & & & $\mathrm{~K}_{9}$ \\
\hline & & $\begin{array}{l}\text { The consideration of needs of internal and external } \\
\text { stakeholders in the development of educational } \\
\text { programs }\end{array}$ & $\mathrm{V}_{10}$ & & & $\mathrm{~K}_{10}$ \\
\hline \multirow{6}{*}{ 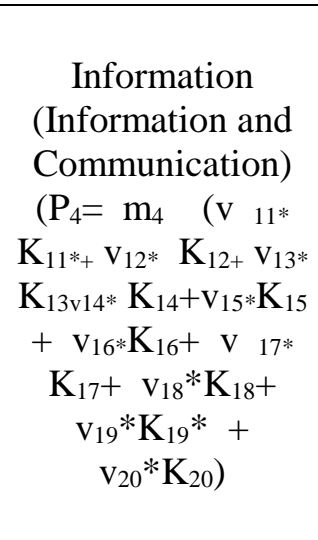 } & \multirow{6}{*}{$\mathrm{m}_{4}$} & $\begin{array}{l}\text { The support of the corporate information system of } \\
\text { an institution }\end{array}$ & $\mathrm{V}_{11}$ & & & $\mathrm{~K}_{11}$ \\
\hline & & The support of the HEI site and social networks & $\mathrm{v}_{12}$ & & & $\mathrm{~K}_{12}$ \\
\hline & & $\begin{array}{l}\text { The quality of regulatory and instructional support, } \\
\text { information resources of innovative directions of } \\
\text { activity }\end{array}$ & $\mathrm{V}_{13}$ & & & $\mathrm{~K}_{13}$ \\
\hline & & $\begin{array}{l}\text { The marketing and monitoring support for the } \\
\text { development of the HEI educational environment }\end{array}$ & $\mathrm{V}_{14}$ & & & $\mathrm{~K}_{14}$ \\
\hline & & $\begin{array}{l}\text { The communication processes of internal and } \\
\text { external information exchange }\end{array}$ & $\mathrm{V}_{15}$ & & & $\mathrm{~K}_{15}$ \\
\hline & & $\begin{array}{l}\text { The quality of international communications and } \\
\text { partnerships }\end{array}$ & $\mathrm{V}_{16}$ & & & $\mathrm{~K}_{16}$ \\
\hline
\end{tabular}


The end of the table 5.3

\begin{tabular}{|c|c|c|c|c|c|c|}
\hline 1 & 2 & 3 & 4 & 5 & 6 & 7 \\
\hline & & $\begin{array}{l}\text { The quality of coverage of the information on } \\
\text { processes and results of EE development }\end{array}$ & $\mathrm{V}_{17}$ & & & $\mathrm{~K}_{17}$ \\
\hline \multirow{8}{*}{$\begin{array}{c}\text { Functional } \\
\text { (Organizational and } \\
\text { Action) } \\
\left(\mathrm{P}_{5}=\mathrm{m}_{5 *}\left(\mathrm{v}_{20} * \mathrm{~K}_{20+}\right.\right. \\
\mathrm{v}_{21+} \mathrm{K}_{21+} \mathrm{V}_{23} * \mathrm{~K}_{23+} \\
\mathrm{v}_{24 *} \mathrm{~K}_{24+} \mathrm{V}_{25 *} \mathrm{~K} \\
25 * \mathrm{v}_{26+} \mathrm{K}_{26+} \mathrm{v}_{27} \\
\left.\mathrm{~K}_{27}\right)\end{array}$} & \multirow{8}{*}{$\mathrm{m}_{5}$} & $\begin{array}{l}\text { The quality of the organization of the educational } \\
\text { process }\end{array}$ & $\mathrm{v}_{20}$ & & & $\mathrm{~K}_{20}$ \\
\hline & & $\begin{array}{l}\text { The quality of student-centered learning, teaching, } \\
\text { and evaluation }\end{array}$ & $\mathrm{V}_{21}$ & & & $\mathrm{~K}_{21}$ \\
\hline & & $\begin{array}{l}\text { The quality of scientific, innovative activity of } \\
\text { teachers and students }\end{array}$ & $\mathrm{v}_{22}$ & & & $\mathrm{~K}_{22}$ \\
\hline & & $\begin{array}{l}\text { The quality of professional development and } \\
\text { training of scientific and pedagogical staff }\end{array}$ & $\mathrm{v}_{23}$ & & & $\mathrm{~K}_{23}$ \\
\hline & & $\begin{array}{l}\text { The quality of international activity of students, } \\
\text { teachers }\end{array}$ & $\mathrm{v}_{24}$ & & & $\mathrm{~K}_{24}$ \\
\hline & & $\begin{array}{l}\text { The quality of academic mobility of students, } \\
\text { teachers }\end{array}$ & $\mathrm{v}_{25}$ & & & $\mathrm{~K}_{25}$ \\
\hline & & The quality of student self-government & $\mathrm{V}_{26}$ & & & $\mathrm{~K}_{26}$ \\
\hline & & $\begin{array}{l}\text { The quality of support of educational process } \\
\text { subjects }\end{array}$ & $\mathrm{v}_{27}$ & & & $\mathrm{~K}_{27}$ \\
\hline \multirow{3}{*}{$\begin{array}{l}\text { Physical and Virtual } \\
\text { (Spatial and } \\
\text { Objective) } \\
\left(\mathrm{P}_{6}=\mathrm{m}_{6} *\left(\mathrm{v}_{28} * \mathrm{~K}_{28+}\right.\right. \\
\left.\mathrm{V}_{29+} \mathrm{K}_{29+} \mathrm{V}_{30} * \mathrm{~K}_{30}\right)\end{array}$} & \multirow{3}{*}{$\mathrm{m}_{6}$} & $\begin{array}{l}\text { The material and technical conditions of the } \\
\text { educational process }\end{array}$ & $\mathrm{V}_{28}$ & & & $\mathrm{~K}_{28}$ \\
\hline & & Computing and networking support & $\mathrm{V}_{29}$ & & & $\mathrm{~K}_{29}$ \\
\hline & & The design and equipment of study rooms & $\mathrm{v}_{30}$ & & & $\mathrm{~K}_{30}$ \\
\hline \multirow{4}{*}{ 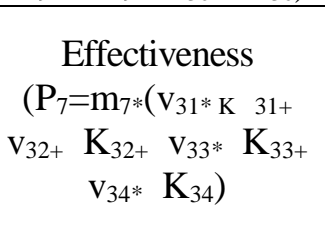 } & \multirow[t]{4}{*}{$\mathrm{m}_{7}$} & The satisfaction of internal stakeholders & $v_{31}$ & & & $\mathrm{~K}_{31}$ \\
\hline & & The satisfaction of external stakeholders & $\mathrm{V}_{32}$ & & & $\mathrm{~K}_{32}$ \\
\hline & & The quality of learning outcomes & $\mathrm{V}_{33}$ & & & $\mathrm{~K}_{33}$ \\
\hline & & $\begin{array}{l}\text { The quality of results of scientific and innovative } \\
\text { activity }\end{array}$ & $\mathrm{v}_{34}$ & & & $\mathrm{~K}_{34}$ \\
\hline
\end{tabular}

The general assessment of the quality of the development of the educational environment of a higher education institution of innovative type ( D ) is determined by the formula: $\mathrm{D}=\mathrm{P}_{1}+\mathrm{P}_{2}+\mathrm{P}_{3}+\mathrm{P}_{4}+\mathrm{P}_{5}+\mathrm{P}_{6}+\mathrm{P}_{7}$.

The scale for assessing the quality of educational environment development is interpreted as follows: 0-0.25 - insufficient level; 0.26-0.50 - low level; 0.56-0.75 medium level; 0.76-0.90 - optimal level; 0.91-1 - high level.

The qualimetric model of the development of components of the educational environment of an innovative educational institution is a tool for planning, monitoring, and self-assessment of the development of the educational environment. The obtained assessment allows identifying the level of quality of individual components of the educational environment and the level of quality of the educational environment as a whole in accordance with the established goals. This data is the basis for management decisions on further quality improvement actions. 
Thus, we can conclude that the work considers the problem of managing the development of the educational environment of an innovative type of higher education institution on the basis of ensuring the quality of education. The relevance of this problem is due to global changes, the beginning of the fourth industrial revolution, the development of an innovative society, and an innovative economy. Global trends in changes are driven by changes in various sectors of the economy and society, in particular, they direct the development of the educational sector, the reform of national higher education systems, the transformation of higher education institutions. Under the influence of changes in the external educational environment, there is a need to build appropriate changes in the local educational environments of higher education institutions. This process becomes effective subject to targeted development management.

Attention is paid to innovative processes in higher education. The concept of the innovation ecosystem of higher education, the innovative educational environment is considered. The essence of the innovation ecosystem of the institution of higher education is the interaction of educational process subjects, representatives of the business environment, a network of formations associated with the creation and distribution of innovative products and technologies.

The analysis of the transformation of higher education institutions in the context of transition to an innovative society and innovative economy made it possible to allocate a new generation of higher education institutions (innovative type) - research and entrepreneurial universities. The mission of such universities is not only educational activities but mainly scientific, innovative, entrepreneurial, formation, and commercialization of new knowledge, innovative products, technologies.

A key factor in the transformation of higher education institutions, which contributes to their development and competitiveness in the educational services market, is the quality assurance of education. It is determined that the general characteristics of the quality of higher education are the compliance of educational processes, conditions, and results with the targeted priorities of stakeholders of higher education, international and national quality standards.

In the course of consideration of the category "educational environment of a higher education institution", studying approaches to determining its structure, its definition has been clarified. The concept of the educational environment of the university of innovative 
type, which is a system of value-target, socio-psychological, informational, organizational-activity, spatial and objective (physical and virtual) conditions, opportunities, and resources that affect the quality and results of educational, scientific, innovative, the entrepreneurial activity of the university subjects, their personal and professional development and self-realization at the individual, institutional, branch levels.

The concept of the educational environment of the university has been clarified, which we consider in two aspects: 1) as a process of progressive coevolution of its components; 2) as a result of controlled and unmanaged quantitative and qualitative changes in the states of its components.

The structure and content of the components of the educational environment of the institution of higher education of innovative type in the context of internal quality assurance (according to ESG standards) and the tasks of their development have been clarified and revealed: 1) target (value-oriented); 2) stakeholder (subjective, sociopsychological); 3) content (content and methodology); 4) information (information and communication); 5) functional (organizational and action); 6) physical and virtual (spatial and objective).

The subject field of management of the development of the educational environment of a higher education institution of innovative type on the basis of ensuring the quality of education, which contains: taking into account the environmental conditions, is distinguished; formation of an internal innovation ecosystem; construction of an internal quality assurance system for education, implementation of relevant procedures (assessment, self-assessment, monitoring, support, continuous improvement, and self-regulation).

The essence of managing the development of the educational environment of an innovative higher education institution as a purposeful interaction of the governing and managed subsystems of a higher education institution in order to transfer the components of the educational environment into a system of conditions, opportunities, and resources to a qualitatively new state for personal and professional development and self-realization of educational, research, innovation, entrepreneurial processes is determined.

The main characteristics and components of the system of management of the development of the educational environment of a higher education institution of 
innovative type are revealed: principles, subjects, functions, organizational structure, tools, criteria.

A framework program is a tool for managing the development of the educational environment of an innovative type of higher education institution. Its application allows to gradually develop and implement a system of management of the development of the educational environment of an innovative type of higher education institution, to determine and evaluate the quality of each stage according to certain indicators. The framework program contains seven stages: Stage I - target, stage 2 - prognostic, stage 3 organizational, stage IV - functioning, stage V - monitoring and self-assessing the processes and results, stage VI - improving the processes and results.

To determine the main result of managing the development of the educational environment of an innovative type of higher education institution - coevolution of qualitative changes in the components of the educational environment, we have developed a basic qualimetric model. This qualimetric model contains: components of the educational environment, the significance (value) of each of them for the development of the educational environment; criteria by which it is possible to assess the quality of their development; reference and actual values of the manifestation of criteria. The general assessment of the quality of development of the educational environment of the institution of higher education of innovative type according to the qualimetric model has a measurement scale and allows to set the level of development (insufficient, low, medium, optimal, high). The qualimetric model is a tool for planning, monitoring, and selfassessing the development of the educational environment.

Further research will be in the development of submodels for the development of the educational environment of an innovative type of higher education institution for their use at different levels of organizational management structure. 


\section{CHAPTER 6. DEVELOPMENT OF THE CONCEPT OF SECURITY AND ANTI-CORRUPTION IN THE CORPORATE GOVERNANCE SYSTEM IN THE PROVISION OF EDUCATIONAL SERVICES IN HIGHER EDUCATION INSTITUTIONS}

\subsection{Development of a conceptual framework for building a corporate} governance system in the provision of educational services at a university based on anti-corruption

The basic component of the proposed methodology is a corporate information and education system based on the Open Systems Interconnection Basic Reference Model, which uses open protocols to ensure the security of information resources of the corporate information and education system (CIES). CIES can refer to critical cybernetic systems that affect not only the conditions of the Ministry of Education and Science of Ukraine, and / or the economic and political environment of national security [80]. In addition, the analysis $[80,159,60,61,207,100]$ showed that with the development of an active innovative university, CIES can be considered as a synthesis of information and communication systems and cybernetic physical systems, which allows to form possible attacks from two directions of cyber attack vectors. This integration is the result of advances in information and communication technology (ICT) to improve interoperability with physical processes. All these definitions emphasize the constant and intense interaction between cyber and the physical world. However, their development has determined a new direction in the development and / or modification of old threats,

Thus, to prevent or maintain a security loop in cyberphysical processes for the analysis of deviations from normal operation and / or hacking of the system requires a unified approach to building a classification of threats, taking into account their synergy and hybridity to all components of security: information security (IS), cybersecurity (CyberSec) and safety of information (SI), in terms of their presentation with the methods of social engineering and lack of funds to ensure the required level of security.

Studies in [62] have shown that almost all protocols provide open-ended operation, which significantly reduces the possibility of security (provision of security services) at 
all levels of ISO / OSI models. In the table. 6.1 presents the main protocols to ensure the circulation and processing of information resources (IR) KIOS.

Table 6.1

\section{Basic protocols for ensuring the circulation and processing of IR CIES}

\begin{tabular}{|c|c|c|}
\hline Level & Information & Protocols \\
\hline $\begin{array}{l}\text { Applied: } \\
\text { access to network services }\end{array}$ & Data & $\begin{array}{l}\text { HTTP, gopher, Telnet, DNS, DHCP, SMTP, SNMP, } \\
\text { CMIP, FTP, TFTP, SSH, IRC, AIM, NFS, NNTP, } \\
\text { NTP, SNTP, XMPP, FTAM, APPC, X.400, X.500, } \\
\text { AFP, LDAP, SIP, IETF, RTP, RTCP, ITMS }\end{array}$ \\
\hline $\begin{array}{l}\text { Presentation: } \\
\text { data representation and } \\
\text { encoding }\end{array}$ & Data & $\begin{array}{l}\text { IMAP, POP3, SMB, MFTP, BitTorrent, e2k, } \\
\text { PROFIBUS and many others. }\end{array}$ \\
\hline $\begin{array}{l}\text { Session: } \\
\text { session management }\end{array}$ & Data & $\begin{array}{l}\text { ASN.1, XML, TDI, XDR, NCP, AFP, ASCII, } \\
\text { Unicode }\end{array}$ \\
\hline $\begin{array}{l}\text { Transport: } \\
\text { secure and reliable point-to- } \\
\text { point connection }\end{array}$ & Blocks & $\begin{array}{l}\text { ASP, ADSP, DLC, Named Pipes, NBT, NetBIOS, } \\
\text { NWLink, Printer Access Protocol, Zone Information } \\
\text { Protocol, SSL, TLS, SOCKS, PPTP }\end{array}$ \\
\hline $\begin{array}{l}\text { Network: } \\
\text { route definition and IP } \\
\text { (logical addressing) }\end{array}$ & Packages & $\begin{array}{l}\text { TCP, UDP, NetBEUI, AEP, ATP, IL, NBP, RTMP, } \\
\text { SMB, SPX, SCTP, DCCP, RTP, STP, TFTP }\end{array}$ \\
\hline $\begin{array}{l}\text { Channel: } \\
\text { MAC and LLC (physical } \\
\text { addressing) }\end{array}$ & Staff & $\begin{array}{l}\text { IPv4, IPv6, ICMP, IGMP, IPX, NWLink, NetBEUI, } \\
\text { DDP, IPSec, ARP, SKIP }\end{array}$ \\
\hline $\begin{array}{l}\text { Physical: } \\
\text { cable, signals, binary } \\
\text { transmission }\end{array}$ & Bits & $\begin{array}{l}\text { ARCnet, ATM, DTM, SLIP, SMDS, Ethernet, FDDI, } \\
\text { Frame Relay, LocalTalk, Token Ring, PPP, PPPoE, } \\
\text { StarLan, WiFi, PPTP, L2F, L2TP, PROFIBUS }\end{array}$ \\
\hline
\end{tabular}

However, studies $[61,62,207,77,30,78]$ indicate the need to strengthen security requirements based on web technologies, and the use of commercial solutions for the construction of automatic information protection system (AIPS).

To ensure preventive measures to combat the elements of corruption based on the introduction of electronic circulation and elements of e-learning in modern educational institutions, it is proposed to use PKI (Public Key Infrastructure, public key infrastructure) based on digital signature (DS) based on the X.509 standard. .

The use of a cryptographically stable mechanism based on a digital signature (DS) 
allows for the formation of the Concept of Security and Anti-Corruption in Educational Institutions. The Concept should be considered as a methodological basis for security at different levels of government, the hierarchy of which is proposed on the basis of [100].

The security of the innovative university is implemented at the following levels:

at the strategic level - the university management - creating conditions for the impossibility of making corrupt changes in the governing documents for the organization of the educational process, providing basic utilities and communication services of the university, living conditions of students and transparency of educational services. Ensuring effective control over the implementation of the schedule of the educational process at the faculties of the university;

at the operational level - the management of the faculty, departments and services involved in the service delivery system - prevention of corrupt changes in the objectivity of student assessment in the learning process, accrual of scholarships (grants, etc.). Organization of examinations during the entire cycle of the educational process, creation of conditions for effective control over the implementation of the schedule of the educational process in the specialties of the faculty, prevention of corruption in the departments and services of the university;

at the tactical level - the management of departments - increasing the level of objectivity of assessment of students in certain disciplines, creating conditions for transparent choice by students of academic disciplines from the block of the selective component of the educational process. Formation of conditions for effective control over the implementation of the schedule of the educational process by teachers of departments.

The concept of security and anti-corruption is presented in Fig. 6.2, a, b, c.

The first level describes the overall corporate strategy of the university and its functional strategies in ensuring the security of confidential (personal) data in the provision of educational services to students. At this level, in accordance with the synergetic approach, the general concept of CIES security is considered and the goals and objectives of cybersecurity are formed. Functional strategies of one level have horizontal links and are coordinated at the level of goals with further detailing at the next level of the strategic set.

At the second level, the corporate strategy of information security in CIES is formed, the goals and objectives of the main business processes are determined, which 


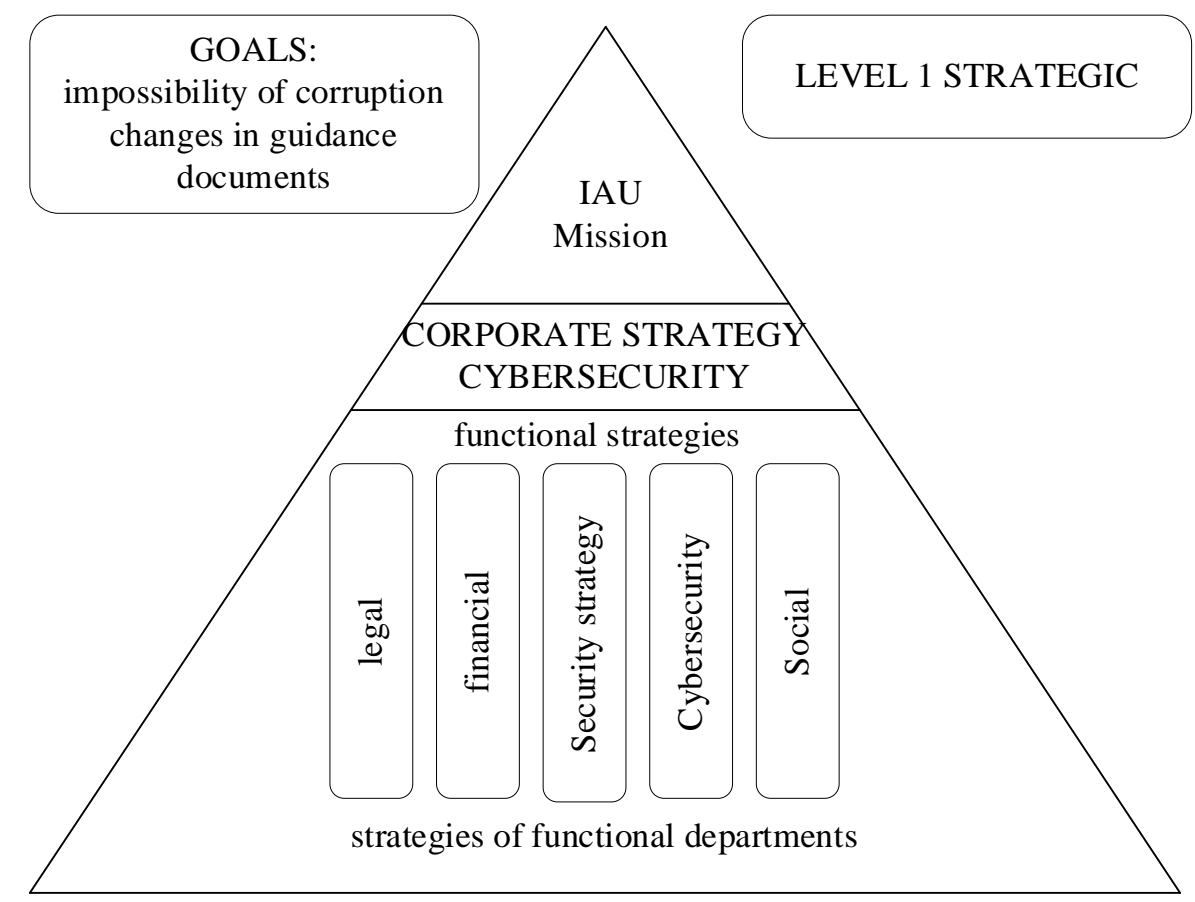

a)

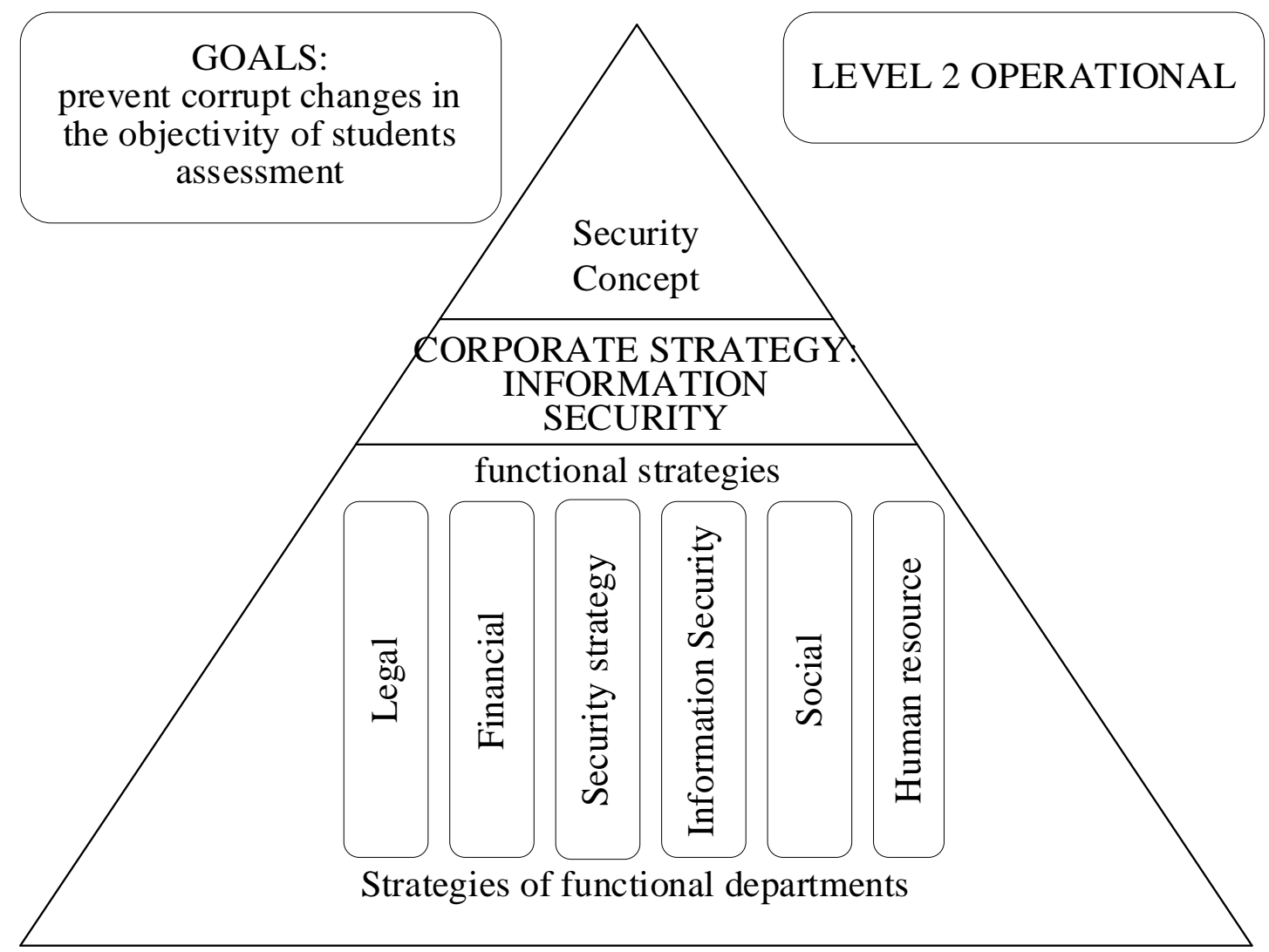

b) 


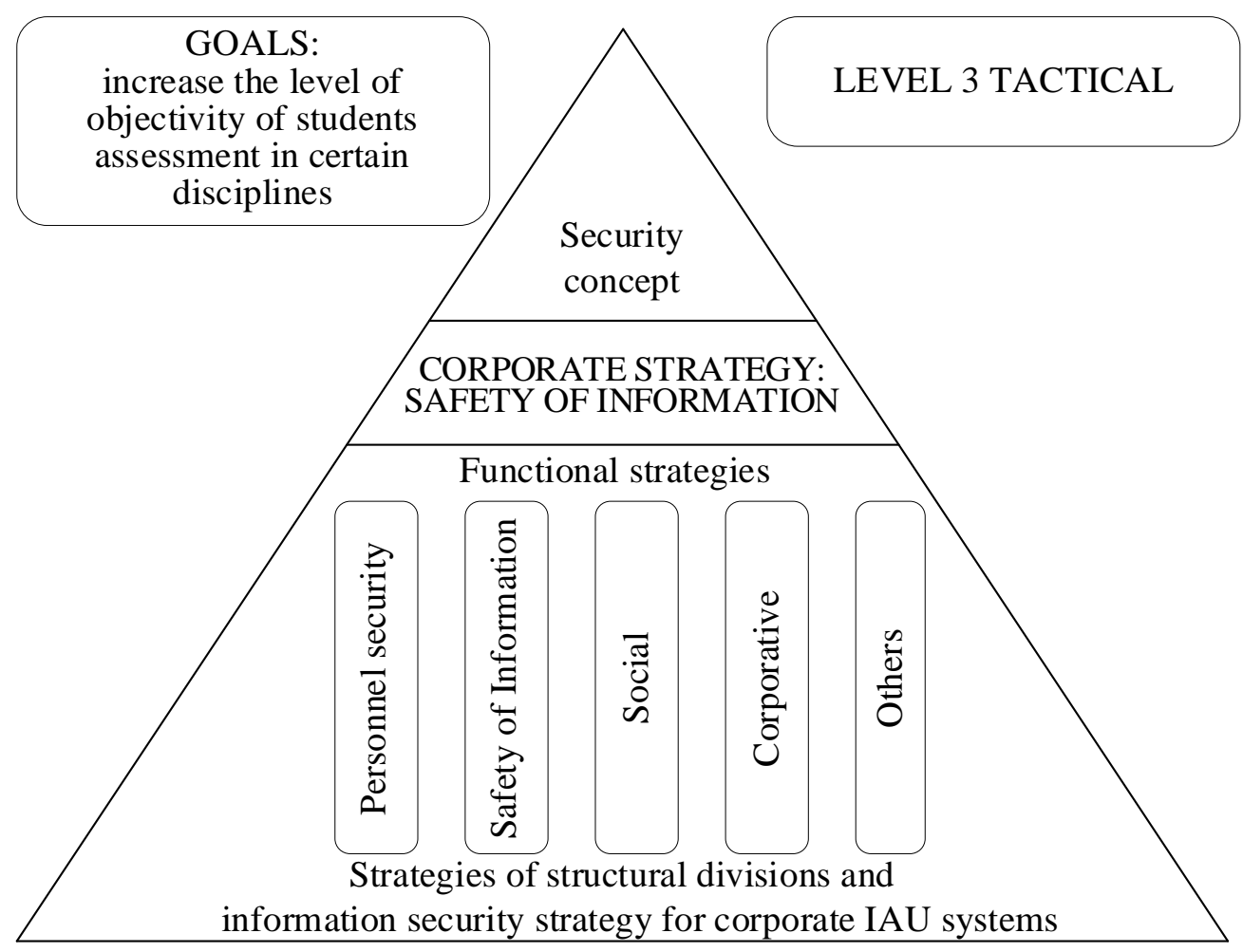

c)

Fig. 6.2. Anti-corruption concept:

\section{a - strategic level; b - operational level; c - tactical level}

are related to the protection of personal data of legal and physical partners of the university in providing educational services.

At the third level, an adaptive system of protection of CIES information resources is formed on the basis of modern security mechanisms. It is recommended to use commercial cryptographic systems to prevent cryptocurrencies.

The proposed approach takes into account not only the main functions of the hierarchical management structure of the CIES of the information-active university (IAU), their goals and objectives, but also to ensure the fight against elements of corruption and complex hybrid threats based on the construction of AIPS. The main elements of AIPS is the Certification Center (CS), which provides not only authentication / authorization, but also automatic control of electronic document management, which significantly reduces the risks of corruption schemes at all levels of IAU management.

In addition, the LDAP server, which is part of the CS, allows you to securely authorize/authenticate CIES users.

This approach provides securities services to public authorities, local governments, 
enterprises, institutions and organizations of any form of ownership, as well as individuals. In fig. 6.3 shows a physical virtual network for the deployment of a comprehensive information security system (CISS) based on the PKI infrastructure [281, $68,75,77,78,83]$.

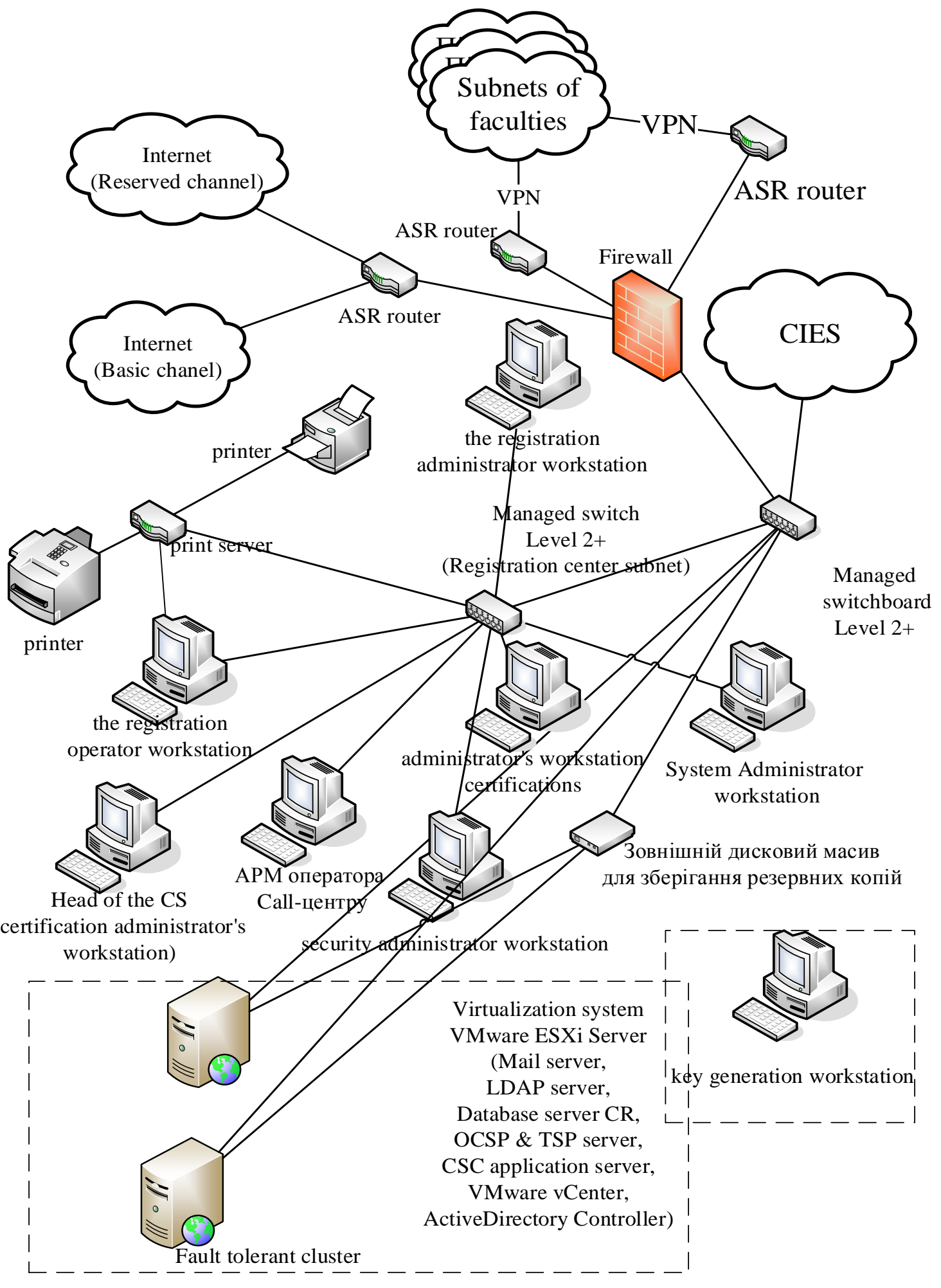

Fig. 6.3. Physical network infrastructure PKI 
To verify the securities, a key certificate is used - an electronic document issued by the confirming center (CA) or the authorized person of the CA and which confirms that the securities verification key belongs to the owner of the certificate verification key certificate $[281,68,75,77,78,83]$.

In fig. 6.4 shows a variant of the structural scheme of CIES of the information-active university, taking into account the main functions of management and security of information resources (IR CIES) in the face of hybrid threats and possible corruption schemes.

As a rule, CIES is formed on the basis of web technologies that allow to meet the requirements of informativeness, openness and accessibility to IR CIES.

Therefore, in addition to ensuring the authenticity of CIES-based IR, to ensure the confidentiality and integrity of IR, it is proposed to use the commercial implementation of crypto-code structures of McEllis and Niederwright. This approach will provide not only the required level of cryptocurrency in the emergence of a full-scale quantum computer, the efficiency of cryptocurrencies at the level of block-symmetric ciphers, reliability, but also counter cryptocurrencies based on encryption standards. The basics of practical construction of crypto-code constructions of McEllis and Niederwright on modified elliptical codes and loss codes are considered in [160].

Thus, the proposed approach to the provision of basic security services allows to ensure the required level of security of IR, and to counter modern cyber threats, both external and internal.

The conceptual synergetic model of CIES security (corporate information and educational system, CIES) of IAU is formed on the basis of private models: improved models of CIES infrastructure and violator, synergetic model of threats that allow to assess the level of security.

The improved CIES infrastructure model is described by the model:

$$
G^{C I E S}=\left\{\left\{O^{C I E S}\right\},\left\{L^{C I E S}\right\},\left\{I_{A}\right\}\right\},
$$

where $\left\{\mathrm{O}^{\mathrm{CIES}}\right\}$ is the set of environment objects that describe the elements of the CIES infrastructure and their affiliation to the levels of the ISO / OSI model,

$\left\{\mathrm{L}_{\mathrm{CIES}}\right\}$ is the set of relationships between the elements of the infrastructure, which 
is determined by the adjacency matrix $A^{C I E S}=\left\|a_{i j}{ }^{C I E S}\right\|$.

\section{$\left\{I_{A}\right\}$ - set of elements of information assets.}
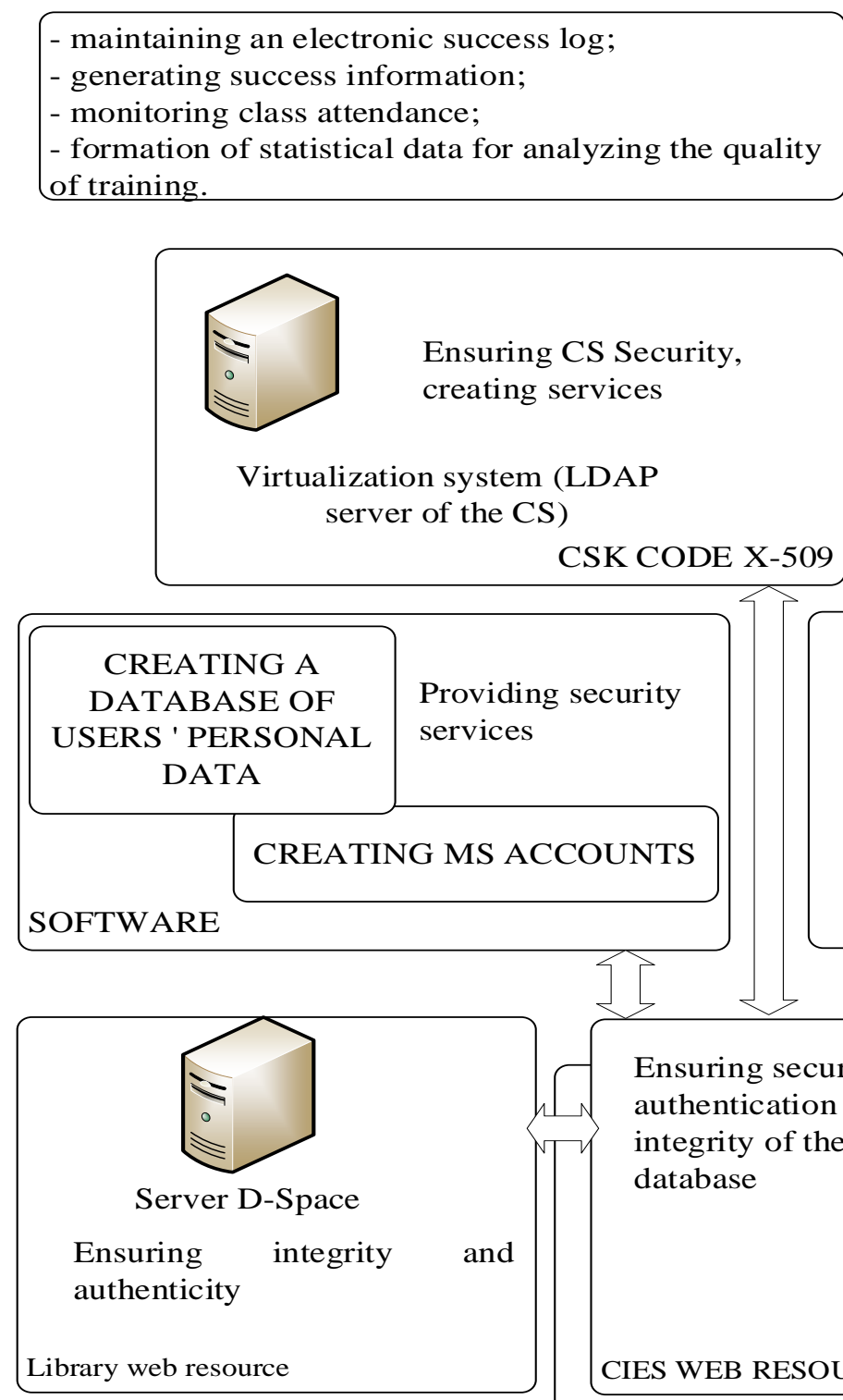

CIES WEB RESOURCES

University web resource 35

creating and ensuring authorization security

Web resources of university departments and services

CSK CODE X-509

Ensuring secure database

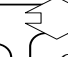

creating and ensuring user authorization security

STUDENT'S PERSONAL ACCOUNT

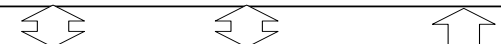

creating and ensuring user authorization security

WEB RESOURCE TEACHER'S PERSONAL ACCOUNT
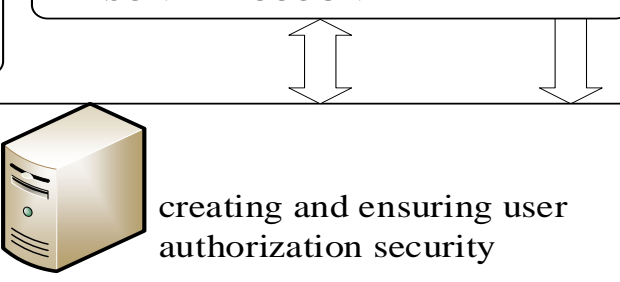

creating and ensuring user authorization security

System database server Personal learning system authentication of CIES users, integrity of the CIES

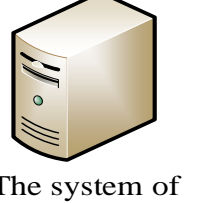
virtual transactions ((Mail server,

LDAP Server, CIES database server, WWW server) creating and ensuring authorization security

Faculty web resource Web resources of departments I5 उ5 द5 b5 creating and ensuring user authorization security University dorm web resources

Fig. 6.4. A variant of the structural scheme of CIES of the information-active university 
Each item $I_{A_{i}} \in\left\{I_{A}\right\}$ described by a vector

$$
I_{A_{i}}=\left(\text { Type }, A^{C}, A^{I}, A^{A}, A^{A v}\right) .
$$

Type - a type of information asset, described by a set of basic values

$$
\text { Type }=\{P l D, S t O, O I, Y I, P D, S I\},
$$

where $P l D$ - payment documents, StO - statistical reports, $O I$ - public information, $Y I$ control (regulatory) information, $P D$ - personal data of CIES users, SI - scientific information (know-how).

$A^{C}$ - confidentiality,

$A^{I}$ - integrity,

$A^{A}$ - authenticity, availability

$A^{A v}$ - continuity - properties of information to be provided. Take the value 1 - if the property is needed, 0 - otherwise.

Each item $O_{l} \in\left\{O^{C I E S}\right\}$, described by the vector:

$$
O_{l}=\left\{Y^{C I E S}, I O^{R}\right\}
$$

where $Y^{C I E S}$ is the level of the hierarchy of the information structure, which is determined by the set

$$
Y^{C I E S}=\{F L, N L, O S L, D B L, B L\}
$$

where $F L$ - is the physical layer, $N L$ - is the network layer, $O S L$ - is the level of operating systems (OS), $D B L$ - is the level of database management systems, $B L$ - is the level of technological applications and services.

To specify the type of connection and the existing relationship of the $\mathrm{IO}^{\mathrm{R}}$ between information assets and objects of the environment, the rule is used:

$$
I O^{R}=\left\|I O{ }_{i l}^{R}\right\|
$$

where $I O_{i l}^{R}$ - reflects the presence and type of connection between the $\mathrm{i}$-th information 
asset and the 1-th object of the environment. With $\forall i \in\left\{I_{A}\right\}$, a $\forall l \in\left\{O^{C I E S}\right\}$ :

$$
I O_{i l}^{R}=\left\{\begin{array}{c}
0, \quad \text { there is no connection } \\
\text { cs, enables and saves } \\
p t, \text { processes or transmits } \\
\text { so, supports functioning }
\end{array}\right.
$$

The synergetic model of threats can be formally presented in the form of:

$$
T h M_{\text {syn }}^{\text {CIES }}=\left\{\left\{D F^{C I E S}\right\},\left\{T_{r i s k}\right\},\left\{T_{P}\right\},\left\{T_{U}\right\},\{V H\}\right\} .
$$

Many sources of CIES security threats are represented by the tuple

$$
D F^{\text {SIES }}=\left\{V^{N S}, V^{A S}\right\},
$$

in which $V^{N S}$ is a class of natural sources of threats,

$$
V^{A S}=\left\{V^{A C S}, V^{A I S}, V^{A S I}\right\} \text { - a class of anthropogenic threats, }
$$

where $V^{A C S}$ - is a set of cybersecurity threats, $V^{A I S}$ - is a set of information security threats, $V^{A S I}$ - is a set of information security threats.

Trisk - qualitative indicator of risk,

$T p$ - set of basic terms of probability of realization of at least one threat of the $j$-th asset,

$T_{U}$ - set of basic terms of loss from realization of threat ui,

$\mathrm{VH}$ - set of destructive states of CIES infrastructure elements, which means undesirable and unplanned situation element of CIES in which he found himself as a result of the implementation of one or more threats.

To obtain a synergistic effect of increasing the level of information security, it is necessary to take into account the complexation of threats:

$$
D F^{C I E S}=\left\{V^{N S}\right\} \cup\left\{V^{A S}\right\} \text {, where }\left\{V^{A S}\right\}=\left\{V^{A C S}\right\} \cap\left\{V^{A I S}\right\} \cap\left\{V^{A S I}\right\}
$$

Each element of a set of threats $D F_{i} \in\left\{D F^{C I E S}\right\}$, can be represented by such a vector 
of values

$$
D F_{i}\left(T, T_{p}, p r_{i j}, r_{m o t i v}\right) \text {, }
$$

where $T$ - is the time of successful realization of the threat,

$T p$ - is the set of basic terms of probability of realization of at least one threat to the $j$-th asset,

$p r_{i j}$ - is the probability of realization of at least one threat $j$-th asset, $i$ - threat, $\forall i \in n, n$ - the number of threats, $j$ - information resource (asset), $\forall j \in m, \mathrm{~m}$ number of assets;

$r_{\text {motiv }}$ - the probability of motivating the attacker to implement the threat.

The estimation of the probability of realization of the $\mathrm{i}$-th threat to the $\mathrm{j}$-th asset is determined on the basis of taking into account the links between the sources of threats and the elements of CIES, which is given by the matrix $A^{D F}=\left\|a_{i j}^{D F}\right\|$, dimension $\mathrm{n}$ by $\mathrm{m}$, where $\mathrm{n}$ is the number of threats, $m$ - number of assets. For each $\mathrm{i}$-th threat to the $\mathrm{j}$-th asset, the probability of realization is determined $p r_{i j}$ on the basis of which the accumulated statistical data specific to the given region and operating conditions (in quantitative and / or qualitative form), or by an expert way.

The calculation of the probability of realization of at least one threat for each asset is performed by the formula:

$$
p_{r j}=1-\prod_{i=1}^{m}\left(1-p r_{i j}\right)
$$

where $p_{r j}$ is the probability of realization of at least one threat to the $\mathrm{j}$-th asset.

It is assumed that in the case of implementation for the $\mathrm{j}$-th asset at least one of the threats from the set $V^{A S}=\left\{V^{A C S}, V^{A I S}, V^{A S I}\right\}$, the loss is equal to the value of the asset based on the details of assets and careful selection of current threats:

$$
q_{j}=u_{j}
$$


It is believed that threats can be implemented independently of each other, then the risk price $R_{j}$ for each $\mathrm{j}$-th asset is determined by the formula:

$$
R_{j}=p r_{i j} \times q_{j}
$$

The cost of total risk is equal to the sum of the risk prices of all assets:

$$
R_{\text {поли }}=\sum_{j=1}^{n} R_{j} .
$$

Thus, the probability of realization of the medium $p r_{j}$, with the domain $P=[0,1]$ is given by the set of basic terms

$T_{p}=\{$ unrealized, minimal, medium, high, critical $\}=\left\{\alpha_{x 1}, \alpha_{x 2}, \alpha_{x 3}, \alpha_{x 4}, \alpha_{x 5}\right\}$.

We will define the formal improved model of the malefactor taking into account offers in works $[6,8]$ in which categories and actions of malefactors are defined:

$$
G_{I A}^{C I E S}=\left\{\text { aid }_{i}, T_{I A}, S_{\text {max }_{i}}, p r_{i j}, r_{\text {motiv }}\right\} \forall i \in n, \forall j \in m,
$$

where aid $_{i} \in\{$ aid $\}$ - violator identifier, $T_{I A}$ - time of successful threat implementation, $S_{\max }$ - probable damage to the system, $p r_{i j}$ - the probability of realization of at least one threat to the $\mathrm{j}$-th asset, $\mathrm{i}$ - threat, $\forall i \in n, \mathrm{n}$ - the number of threats, $\mathrm{j}$ - information resource (asset), $\forall j \in m, \mathrm{~m}$ - number of assets; $r_{m o t i v}$ - the probability of motivating the attacker to implement the threat.

To assess threats, we use many sources of threats, which include sources of four types:

$$
D F^{C I E S}=\left\{V^{N S}, V^{A S}, T S, P I, N I\right\},
$$

where TS - technical means and systems; PI - intentional violators; NI unintentional violators (malefactors).

Thus, the proposed model allows to take into account the complexation of threats, their synergy and hybridity, to form preventive measures based on the analysis of the criticality of threats and critical points in the elements of the infrastructure of CIES. 


\subsection{Development of a model for ensuring anti corruption and simulation modeling}

Corruption means any actions that violate the regulations and development of any field of activity through the use of public opportunities to pursue personal or corporate interests to the detriment of public $[108,213,165]$.

Thus, corruption in the field of education will be understood as the activities of persons authorized to perform state functions, aimed at the illegal use of their powers to obtain material goods, services, benefits and other advantages. In this case, the interests do not necessarily have to be material, they can be intangible, when actions are made in accordance with some ideas or for ideological reasons.

Scenarios of behavior of participants in the corruption process and anti-corruption bodies can be presented in the form of a mathematical model.

The purpose of the model of behavior of various participants in corruption is, above all, the possibility of scenario modeling of the behavior of the parties.

This, in the end, influences the choice of the direction of anti-corruption actions and the investment of limited financial resources in anti-corruption programs.

To achieve this goal requires the solution of the following tasks:

- identify the basic concepts used in the models of behavior of participants in corruption, which directly affect the decision to direct funds to prevent and protect against corruption, as well as assumptions and limitations of the model;

- develop mathematical models of behavior of the parties to the conflict that affect the adoption or change of previously adopted decisions to prevent corruption;

- perform simulation based on the developed mathematical model to confirm the logic of the behavior of the parties to the conflict and assess the impact of their behavior on the use of anti-corruption budget.

The analysis allowed to form a list of basic concepts and concepts used in describing the processes in anti-corruption systems, which should be used in the developmental model of behavior of participants in corruption.

In the table. 6.2 presents the basic concepts related to financial strategies in anticorruption systems, which underlie the interaction of participants in the corruption process in a dynamic model of behavior. 
The formed concepts are included in the mathematical model, because they reflect the nature of the interaction of participants in the corruption process and affect the distribution of limited funds to combat corruption.

Table 6.2

\section{Basic concepts in the models of behavior of participants in corruption}

\begin{tabular}{|c|c|}
\hline Concept & Definition \\
\hline Reputation & $\begin{array}{l}\text { Authoritative and universally recognized name or position for merit, } \\
\text { achievement, reliability, etc. In this case, the reputation belongs to the public } \\
\text { prestige of the university. }\end{array}$ \\
\hline Vulnerability $(\mathrm{Vul})$ & The level of reliability of the university's anti-corruption system. \\
\hline Security vectors $\left(V_{i}\right)$ & $\begin{array}{l}\text { Types of corruption are externally visible and accessible resources of the } \\
\text { university that can be used to implement corrupt agreements and subsequently } \\
\text { assessed against the potential damage that may be caused to the reputation of } \\
\text { the university. }\end{array}$ \\
\hline $\begin{array}{l}\text { Anti-Corruption } \\
\text { Opportunities }\left(C^{D}\right)\end{array}$ & $\begin{array}{l}\text { Existing resources to be allocated to increase the level of protection of } \\
\text { university assets from corrupt transactions. }\end{array}$ \\
\hline $\begin{array}{l}\text { Opportunities for } \\
\text { initiators of corruption } \\
\left(C^{A}\right)\end{array}$ & $\begin{array}{l}\text { Part of the resources of corrupt officials available for distribution among } \\
\text { university staff. }\end{array}$ \\
\hline Part of investment $(F I)$ & $\begin{array}{l}\text { Part of the university's capabilities is designed to protect the university's assets } \\
\text { from corrupt deals. }\end{array}$ \\
\hline $\begin{array}{l}\text { Part of corruption deals } \\
\left(A F^{i}\right)\end{array}$ & $\begin{array}{l}\text { The number of used corruption agreements that corrupt officials make } \\
\text { according to the types of corruption. }\end{array}$ \\
\hline $\begin{array}{l}\text { Successful corruption } \\
\text { deals }\left(A_{i}^{S}\right)\end{array}$ & Acts of corruption that achieved the set goal and brought the expected result \\
\hline $\begin{array}{l}\text { Anti-Corruption } \\
\text { System }(D A P) \text { Profits }\end{array}$ & $\begin{array}{l}\text { Cash income from the implementation of anti-corruption agreements, which } \\
\text { in turn increases the reputation of the university, increasing its financial } \\
\text { performance. }\end{array}$ \\
\hline $\begin{array}{l}\text { Profits of corrupt } \\
\text { officials }\left(\boldsymbol{C}^{\boldsymbol{A}}\right)\end{array}$ & Monetary advantage obtained as a result of corrupt agreements. \\
\hline
\end{tabular}

The construction of the model of behavior of the parties to the conflict is based on 
the assumptions and limitations presented in Figure 6.5.

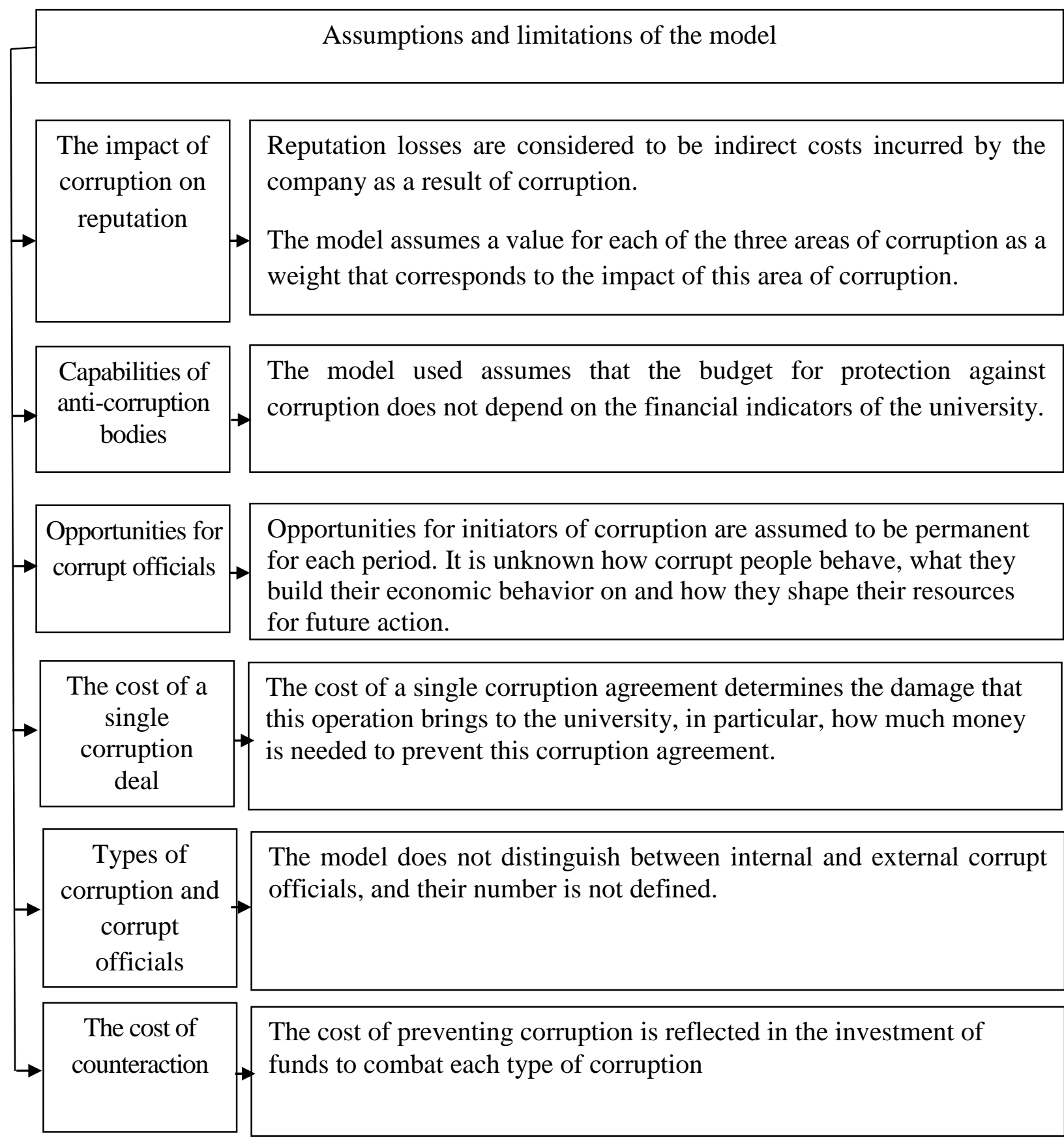

Fig. 6.5. Assumptions and limitations of the behavior model of the parties to the conflict

The model does not include various financial indicators and approaches, such as: cost-benefit analysis, risk analysis, net present value (NPV), annual forecast of losses (ALE) from corruption, etc. The reason for this is that financial analysis would require a 
more sophisticated model, including empirical data, to provide more accurate research results. These issues can be considered as areas for future research.

The model focuses on the dynamics of interaction between participants in the corruption process to identify strategies used in the process of combating corruption.

It describes the behavior of the anti-corruption party, which tries to hinder the implementation of a corrupt operation, which can affect the reputation of the university, which ultimately leads to financial losses.

The formation of the model is limited to three possible areas of corruption - the admissions committee (type 1 corruption), current educational activities (type 2 corruption) and administrative activities (type 3 corruption). Anti-corruption must be implemented in each of the areas. Anti-corruption is considered effective if the relevant corruption transactions are prevented or detected.

The model consists of three submodels - submodels of the corruptor, submodels of the environment for the implementation of corruption and submodels of the anticorruption side, the relationship between which is shown in Fig. 6.6.

The anti-corruption model is a mechanism for preventing or detecting corrupt transactions. In each period of time, the anti-corruption party decides to direct the available funds to prevent corruption operations of one kind or another. It is assumed that the opposing party has the necessary means to influence each of the types of corruption, and their capabilities are sufficient for the additional efforts required in the event of a threat to the reputation of the university in the event of corruption.

The anti-corruption party organizes the prevention (or disclosure) of corruption agreements with the help of anti-corruption tools, which are reflected in the blocks of success of corruption agreements. The result of the resistance ultimately affects the reputation of the university, which can be assessed by financial results. The block of success of the corruption agreement is determined by the probability that this agreement will be successfully implemented and not disclosed in the future. For each unit, the success of anti-corruption actions is calculated. The allocation of funds to combat corruption of one type or another is calculated on the basis of the share of successfully conducted anticorruption actions on a particular type of corruption.

The reputation of the university is assessed in relative units. It is adjusted based on the results of detected or prevented corruption agreements on all types of corruption. 


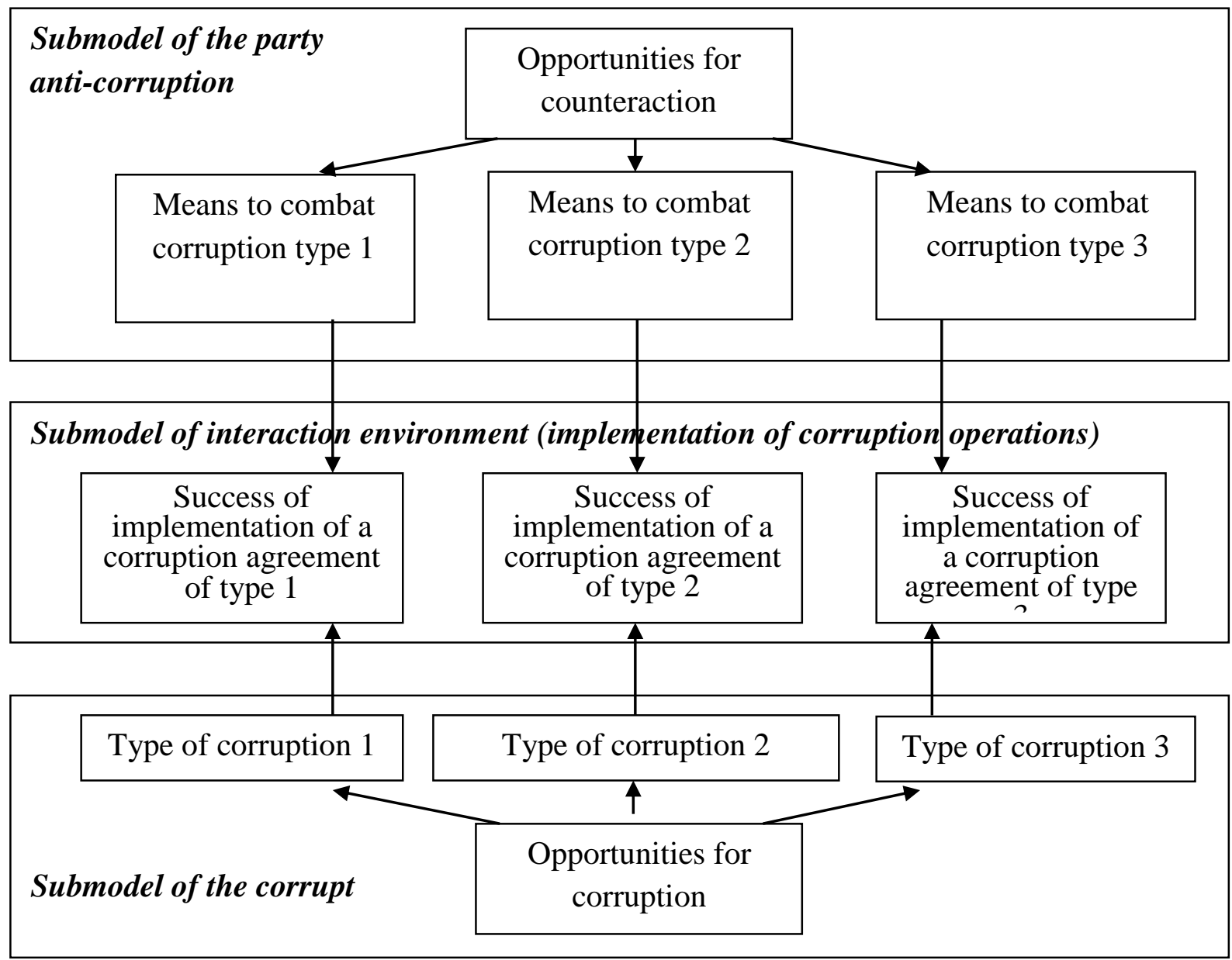

Fig. 6.6. The general structure of the anti-corruption model

In the case of a successful fight against corruption, the reputation of the university grows, while successful corruption agreements lead to the loss of reputation.

The financial indicators of the university are determined based on expert assessments of the monetary value of each reputation score.

The corrupt person aims to commit a corrupt agreement and makes some efforts to do so.

It should be noted that the same person may be interested in committing various types of corrupt agreements. However, mostly its focus on one or another type of corruption is fixed for a specific period of time.

He can base his actions on information obtained from both official sources and informally transmitted information. It should also be borne in mind that the corrupt will try to implement corrupt transactions that will bring him more profit (direct or indirect) than the money spent on such an operation. 
The effectiveness of corrupt officials can be defined as the sum of all successful corruption deals multiplied by the profits from the deal.

To reflect the interaction of corrupt officials and the anti-corruption side, each of which has certain opportunities and makes appropriate decisions, implemented a third submodel - a submodel of the interaction environment. The main variables of this model are the probability of successful corruption deals for each type of corruption. These probabilities are determined, in turn, by the level of effectiveness of anti-corruption measures on a particular type of corruption. High values of probability for a particular type of corruption indicate the existing weaknesses in ensuring counteraction for this type.

The main relationships between the previously described variables determine the essence of the relationship between the participants in the counteraction process, which leads to a change in the investment scenario and the redistribution of university funds for anti-corruption measures. The formal representation of these relations is given below in the form of a system of algebraic and differential equations.

Given the presence of feedback in the real interaction of the parties to the anticorruption process (amplifying and damping circuits), it would be necessary to indicate the time for each variable, but such a record will significantly complicate the system of equations.

The basic relations for each submodel are as follows:

- submodel of the counteraction side:

$$
\begin{aligned}
& A_{i}^{R S}(t)-A_{i}^{R S}(t-1)=\left(R_{i}-D_{i}\right) \Delta t, R_{i}=A_{i}^{S} / T^{R A}, \\
& F I_{i}=A_{i}^{R S} / \sum_{i=1}^{3} A_{i}^{R S}, \frac{d(R e p)}{d t}=B U-E R, B U=\left\{\begin{array}{c}
A d / T^{B U R} \text { if } A d>0 \\
0 \text { if } A d \leq 0
\end{array},\right. \\
& E R=\left\{\begin{array}{c}
\left|A d / T^{R L}\right| \text { if } A d<0 \\
0 \text { if } A d \geq 0 \quad A d=I R-\operatorname{Rep}, I R=R^{B}-\sum_{i=1}^{3} V_{i} \times V u l_{i},
\end{array}\right. \\
& D F P=(R M R * \operatorname{Rep})+B F P, \frac{d(D A P)}{d t}=I F P
\end{aligned}
$$

where $R_{i}$ - increase in the number of successfully conducted corruption agreements on a 
specific type of corruption for the time required by the opposing party to report on the conducted corruption agreements;

$D_{i}$ - the number of reported corruption agreements reported divided by the time required to prevent those agreements;

$A_{i}^{R S}$ - successful corruption deals that became known;

$A_{i}^{S}-$ successful corruption deals;

$T^{R A}$ - the time required to report corruption transactions;

$N^{D A}$ - number of prevented corruption agreements;

$T^{D}$ - time to prevent corruption;

$F I_{i}-$ part of the funds directed to counteract corruption on the i-th type;

Rep-reputation;

$T^{B U R}$ - time to strengthen the reputation;

$T^{R L}$ - time of loss of reputation;

$R^{B}$ - basic (initial) reputation;

$V_{i}$ - the value of a corruption agreement of type $\mathrm{i}$;

$V u l_{i}$ - the probability of success of a corruption agreement by i-th type;

$D F P$ - financial indicators of the anti-corruption side;

$R M R C$ - the ratio of reputation to cash rate;

$B F P$ - basic financial indicators;

$D A P$ - accumulated profit of the anti-corruption party;

$I F P$ - increase in financial performance,

$\Delta t-$ the time interval between successive corruption deals.

- submodel of interaction environment:

$$
\begin{aligned}
& V u l_{i}=\left(C^{A} \times A F_{i} \times C^{U A}\right)-\left(C^{D} \times F I_{i}\right), \\
& S A_{i}=\left\{\begin{array}{c}
\left(C^{A} * A F_{i}\right)-\left(\left(C^{D} * A F_{i}\right) / C^{U A}\right) \text { if } V u l_{i}>0 \\
0 \text { if } V u l_{i} \leq 0
\end{array} .\right.
\end{aligned}
$$

where $\mathrm{C}^{\mathrm{A}}$ - opportunities for corrupt officials; $A F_{i}$ - part of corruption agreements 
of type i; $C^{U A}$ - the cost of one corruption deal; $C^{D}$ - the possibilities of the opposition.

- submodel of the corrupt:

$$
\begin{gathered}
A_{i}^{A S}(t)-A_{i}^{A S}(t+1)=B_{i} \cdot \Delta t, \\
B_{i}=A_{i}^{S} / T^{R A}, V_{i}{ }^{P}(t)=A_{i}^{A S}(t-1), S_{i}=\left\{\begin{array}{l}
0 \text { if } A_{i}^{A S}-V_{i}{ }^{P}<1 \\
1 \text { if } A_{i}^{A S}-V_{i}{ }^{P} \geq 1
\end{array},\right. \\
A_{i}^{F}=S_{i} \times A_{i}^{A S} / \sum_{i=1}^{3} S_{i} \times A_{i}^{A S}, P^{A}=\sum_{i=1}^{B} B_{i} \times C^{U A}, \frac{d(A A W)}{d t}=I A W,
\end{gathered}
$$

where: $A_{i}^{A S}$ - accumulated successful corruption agreements of type $\mathrm{i} ; A_{i}^{S}$ - successful corruption agreements of type $\mathrm{i} ; V_{i}{ }^{P}$ - previous value of type i corruption; $S_{i}$ - switch between types of corruption $\mathrm{i} ; P^{A}$ - productivity of corrupt officials; $B_{i}$ - corruption by type i; $A A W$ - accumulation of welfare of corrupt officials; IAW - increase the welfare of corrupt officials.

The resulting system of equations describes the behavior of the corrupt and the anticorruption parties, the interaction of which determines the direction of investment in the anti-corruption system, as well as moments of change in the direction of funding.

The following were selected as initial data for the simulation experiment: preliminary data on the distribution of corruption by type, the ratio of funds of corrupt and anti-corruption, zero initial level of income from corruption, the probability of successful counteraction to corruption of these types.

In particular, it was assumed that the ratio between corruption agreements of the first, second and third types is 1: 0.75: 0.5 . The proposed simulation model is based on the ratio of the number of recorded cases of corruption. The limit value of this ratio was 1: 1: 1. A similar remark can be made about the ratio of funds for the implementation of corruption agreements and anti-corruption, while the average value of the income of a corrupt official from a single corruption agreement was estimated at 1,000 USD. The model is scalable in terms of cost, which is a reasonable assumption in the face of possible inflation.

Figures 6.7, 6.8 presents the results of simulation modeling of the behavior of 
participants in the corruption process. Figure 6.7 shows the cumulative growth of the wellbeing of corrupt officials. Figure 6.8 presents the results of simulation of successfully conducted corruption agreements for all three types of corruption.

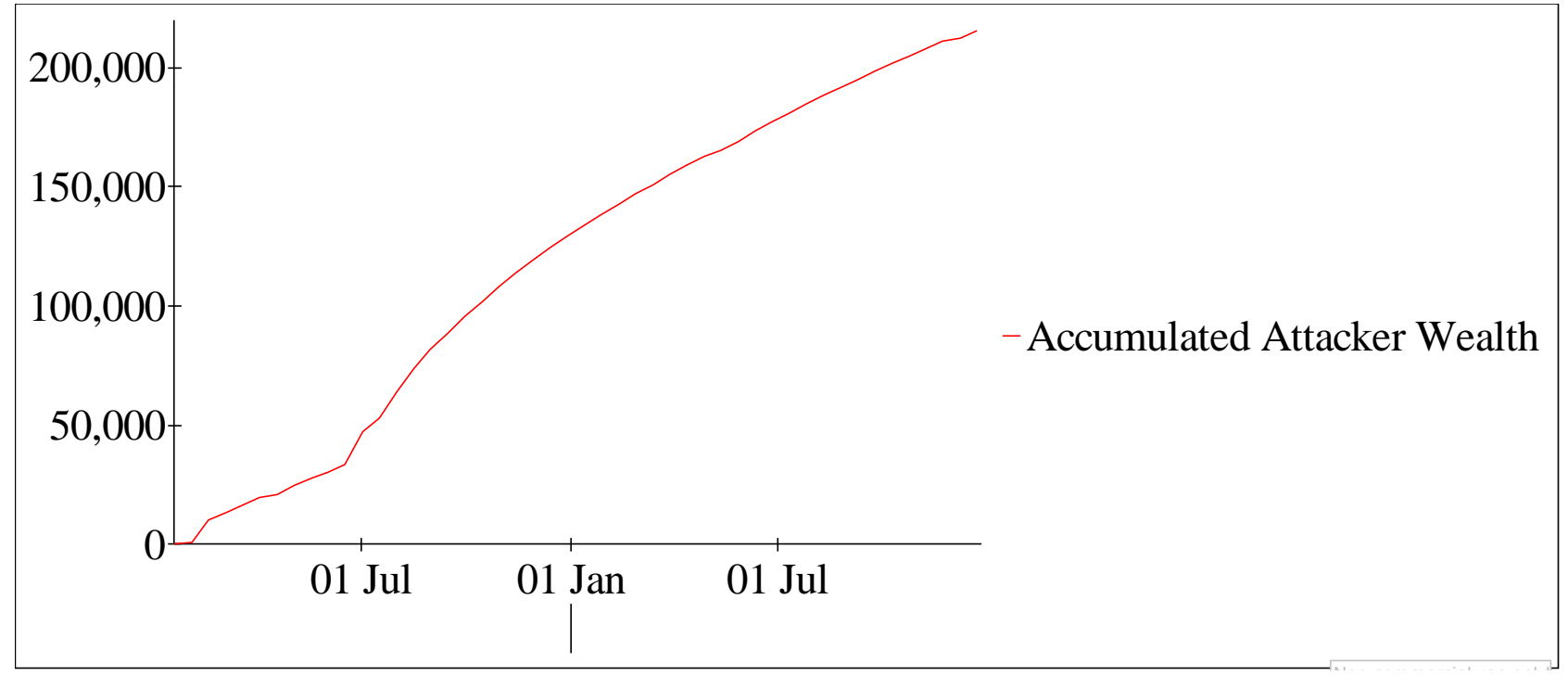

Fig. 6.7. Income growth of corrupt officials (1,000 USD)

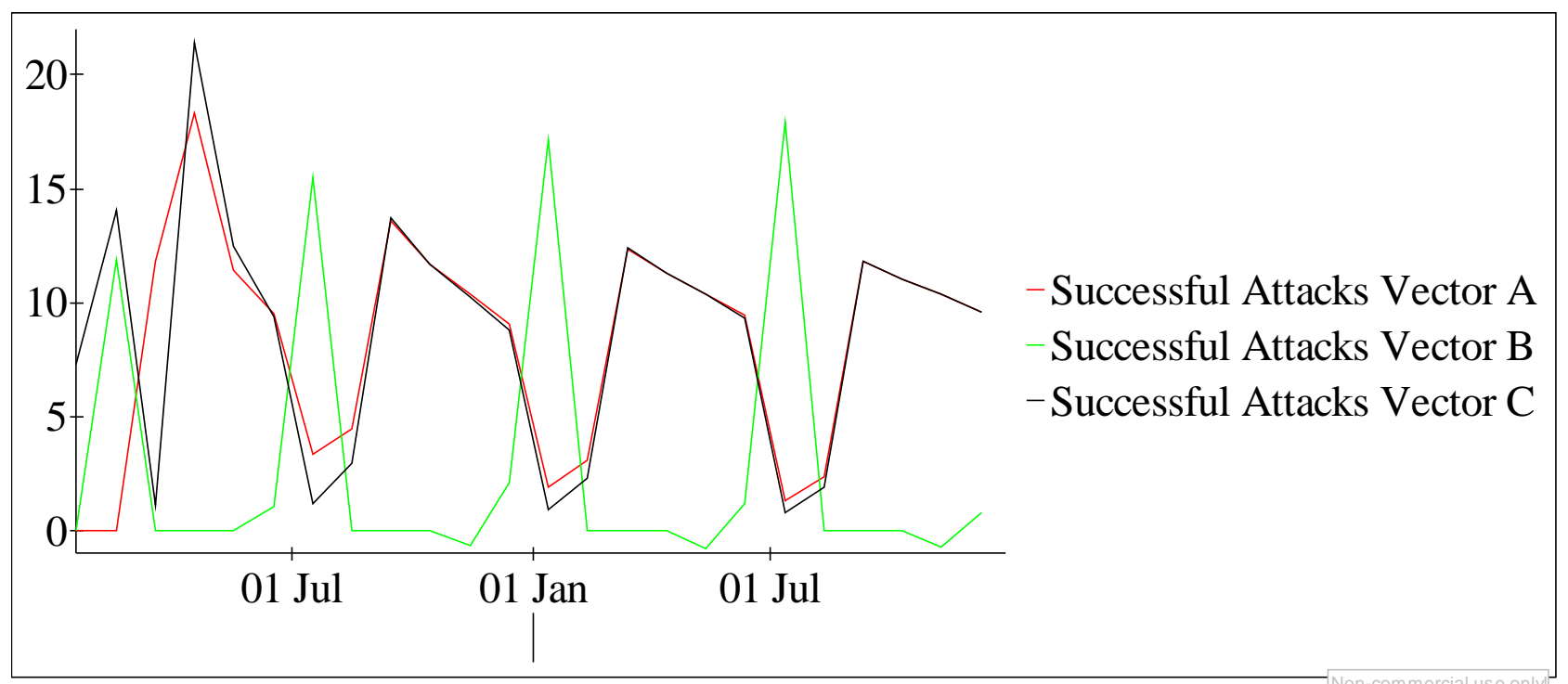

Fig. 6.8. Distribution of successful corruption agreements by types of corruption: type 1 corruption - Vector A; type 2 corruption - Vector B; corruption of the kind 3 - Vector $C$

An interesting feature can be noted on this graph. The number of successful corruption agreements on the second type of corruption (current educational process) increases sharply in January and June, ie during the session. But the first type of corruption 
agreements (corruption related to the work of the selection committee) fall sharply after the end of the work of the selection boards. A similar trend is observed for corruption of the 3rd type - administrative corruption.

This can be partly explained by the fact that the main part of the violations may be related to the settlement of students in the dormitory, and the lists for settlement in the dormitory are formed during the work of the admissions committee.

\subsection{Synergetic model of threats to the security components of cybersystems}

To form a threat model usually use an adapted model of the CIA triad (confidentiality, integrity, availability), which is the basis for its further modifications of practical models. However, in the conditions of post-quantum cryptography (in the conditions of the appearance of a full-scale quantum computer), US experts question the provision of the required level of security by modern symmetric and asymmetric cryptosystems [76, 78]. In addition, the use and rapid growth of "G" technologies can significantly change the vector of use of cyberspace as the main channel of information transmission between cybersystems and information and communication systems, which include CIS systems, which significantly reduces security and can virtually reduce it to zero. . In such conditions, it is necessary to consider in complex threats - their complexation and hybridity, leading to a synergistic effect with a further increase in the probability of realization of the threat on the basis of synthesis with the methods of social engineering. In [197], the authors proposed a fundamentally new approach to the methodology of building security systems based on a synergistic model of threats, which provides the formation of methodological foundations for building a classifier of modern threats to cyberphysical systems. In fig. 6.9 the structural scheme of synergetic model of synthesis threats on information-critical cybernetic systems (on an example of the organizations of banking sector) and on CFS is offered.

However, the consideration of threats to the banking sector fully coincides with possible attacks on CIES in the context of the creation of AIU. Thus, the vector of threats to critical cybernetic systems together with cyberphysical systems allows to predict the 
conditions of their actions, as well as the possible actions of insiders higher education institutions.

According to the ISO / IEC 27001: 2013 standard, threats are divided into intentional, accidental and / or environmental. Typical examples are technical failures, unauthorized actions, software interference, physical damage, compromising functions, etc. However, the standard, like other international regulations, does not consider the synergy and hybridity of modern threats, their integration with social engineering methods, which significantly increases the risk of realizing the threat.

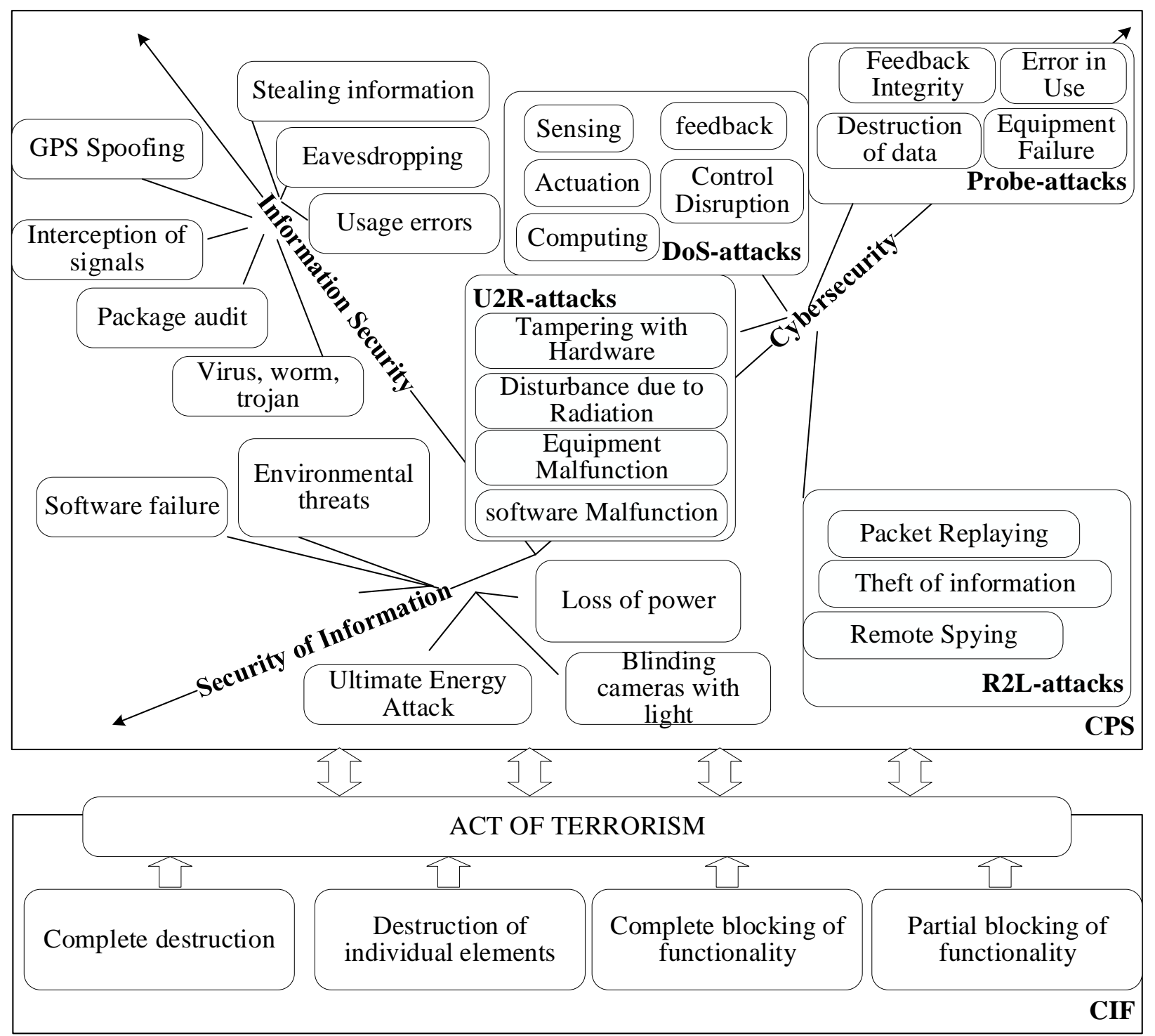

Fig. 6.9. Block diagram of a synergetic model of synthesis threats on CPS and CIF 
The proposed approach takes into account the possibilities of modern threats, their synergy and hybridity, the possibility of integration with the methods of social engineering. To build a classifier of threats to cyberphysical systems in Fig. 6.10 offers a block diagram of the methodological foundations of this classifier [218].

Consider in more detail the proposed approach to the formation of the threat classifier. At the first stage, experts are asked, using their experience, to form tuples of the threat classifier based on 5 platforms. The first platform determines the level of criticality of the threat (critical, high, medium, low, very low), which allows step 5 to calculate the economic "profitability" of critical threats.

The second platform determines the attitude to the component of security (information security (IS), cybersecurity (CyberSec), safety of information (SI), which

STEP 1. FORMATION OF METRIC FACTORS OF THREATS

$$
w_{j}^{C P S C I F}=\frac{1}{K} \sum_{i=1}^{N} \sum_{k=1}^{K} w_{j}^{C P S C I F}{ }_{i k}
$$

STEP 2. FORMATION OF WEIGHT COEFFICIENTS OF THE MANIFESTATION OF THREATS

$$
\alpha_{i}^{C P S C I F}, i \in[0,067 ; 0,133 ; 0,2 ; 0,267 ; 0,333]
$$

STEP 3. DETERMINING THE IMPLEMENTATION OF EACH THREAT

$$
w_{j}^{C P S C I F}{ }_{i} P_{j}^{C P S C I F}{ }_{i}=\frac{1}{K} P_{j}^{C P S C I F} \sum_{i}^{N} w_{j}^{C P S C I F}{ }_{i k} \text {, где } P_{j}^{C P S C I F}{ }_{i} \in\left\{\alpha_{i}^{C P S C I F}\right\}
$$

STEP 4. DETERMINING THE IMPLEMENTATION OF THREATS ON THE SECURITY SERVICE

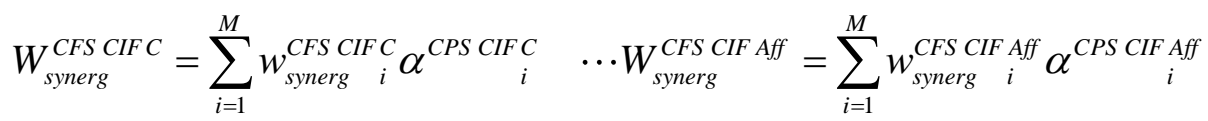

STEP 5. DETERMINATION OF TOTAL THREATS TO THE COMPOSITION OF SECURITY

$$
W_{\text {synerg }}^{I S}=\sum_{i=1}^{N}\left(\sum_{i=1}^{M} w_{\text {synerg }}^{C F S C I F C} \cap \sum_{i=1}^{M} w_{\text {synerg }}^{C F S}{ }_{i} \cap \sum_{i=1}^{M} w_{\text {synerg }}^{C F S C I F A} \cap \sum_{i=1}^{M} w_{\text {synerg }}^{\text {CFS CIF Au }} \cap \sum_{i=1}^{M} w_{\text {synerg }}^{\text {CFS CIF Aff }}\right) \alpha_{i}^{C P S C I F}
$$

STEP 6. DETERMINING THE ECONOMIC COSTS OF ATTACK PREVENTION

$$
\operatorname{Tr}_{R}^{C P S C I F A}=\left\{\operatorname{Tr}_{i} \mid\left(P_{i}^{A}-C_{i}^{A}\right)>0\right\} \forall T r_{i} \in \operatorname{Tr} \Rightarrow \operatorname{Tr}_{L}^{C P S C I F}=\arg \max _{\forall T_{i} \in T_{C}^{D}} K_{l}^{D} \cdot K_{l}^{A}
$$


allows in step 5 to assess the synergistic effect on some of the components of threats. integrity, confidentiality, accessibility, authenticity and involvement), which allows step 4 to assess the impact of several threats on security services, and to determine the vector of the direction of impact on infrastructure elements.

The fourth platform determines the nature of the areas of threat (regulatory, organizational, engineering).

The fifth platform provides an assessment of the focus on the elements of the infrastructure and allows you to "identify" critical points in the integrated information security system (IISS).

Thus for objectivity of judgments of experts we use weight coefficients of competence of experts $\left(k_{k}\right)$ are resulted in tab. 6.3.

The total assessment of the $\mathrm{i}$-th threat is determined by the number of experts according to the expression:

$$
x_{i}=\frac{\sum_{k=1}^{K} x_{k} \times k_{k}}{K},
$$

where $x_{k}$ - is the assessment of the k-th expert influencing the i-th threat; $k_{k}$ - the level of competence of the expert; $K$ - number of experts.

Table 6.3

\section{Weighting of experts' competence}

\begin{tabular}{|c|l|c|}
\hline $\begin{array}{c}\text { No. } \\
\text { of } \\
\text { salary }\end{array}$ & \multicolumn{1}{|c|}{ Qualification of experts } & $\begin{array}{c}\text { Weight coefficient } \\
\text { value }\left(k_{k}\right)\end{array}$ \\
\hline 1 & international expert in the field of IS, CS, SI & 1.0 \\
\hline 2 & national expert in the field of IS, CS, SI & 0.95 \\
\hline 3 & certified international specialist in the field of IS, CS, SI & 0.9 \\
\hline 4 & Full Doctor of Science in IS, CS, SI & 0.9 \\
\hline 5 & Director of security & 0.85 \\
\hline 6 & Doctor of Philosophy in IS, CS, SI & 0.8 \\
\hline 7 & security officer & 0.7 \\
\hline 8 & System Administrator & 0.6 \\
\hline 9 & Security Engineer & 0.5 \\
\hline 10 & postgraduate student in the field of IS, CS, SI & 0,4 \\
\hline
\end{tabular}


A measure of consistency of expert assessments is the variance, which is determined by the expression:

$$
\sigma_{x}^{2}=\frac{1}{K} \sum_{k=1}^{K} k_{k}\left(x_{k}-x_{i}\right)^{2}
$$

The statistical probability of the obtained results $1-\alpha_{\mathrm{i}}$, is: $\left[x_{i}-\Delta, x_{i}+\Delta\right]$, where the value of $x_{i}$ is distributed according to the normal law with center in $x_{i}$ and dispersion $\sigma_{x}^{2}$. Then $\Delta$ is defined by the expression:

$$
\Delta=t \sqrt{\sigma_{x}^{2} / N}
$$

where $t$ - is the value of the Student's distribution for $K-1$ degrees of freedom.

To form metric (weight) threat factors (Fig. 6.10) and their impact on security services, we introduce the following notation:

$j$ - security service for both ICS and CPS. Basic security services:

$C$ - confidentiality; $I$ - integrity; $A$ - availability; $A u$ - authenticity, $A f f$ - involvement. Thus, a tuple of security services is formed in the classifier $j=\{C, I, A, A u, A f f\} ; N$ - the number of threats; $K$ - the number of experts who participated in the expert threat assessment; $\{i\}_{1}^{N}$ - stream number of the i-th threat; $\{k\}_{1}^{K}$ - stream number of the expert.

To assess the hybrid and synergistic components of the impact of modern threats, we use the following sequence of actions:

1 step. Determining the average expert assessment of all threats to a particular security service

$$
w_{\text {ICS }}^{j}=\frac{1}{K} \sum_{i=1}^{N} \sum_{k=1}^{K} w_{\text {ICS } i k}^{j}, \quad w_{C P S}^{j}=\frac{1}{K} \sum_{i=1}^{N} \sum_{k=1}^{K} w_{C P S \text { Sik }}^{j},
$$

where $w_{\text {ICS } i k}^{j}$ - the value of the metric coefficient set by the $\mathrm{k}$-th expert for the $\mathrm{i}$-th threat of the $\mathrm{j}$-th security service for ICS,

$w_{C P S i k}^{j}$ - the value of the metric coefficient set by the $\mathrm{k}$-th expert for the $\mathrm{i}$-th threat of the $\mathrm{j}$-th security service for CRS. 
2 steps. Formation of weights of conditions of manifestation of threats for ICS and CPS (tab.6.4):

$$
\alpha_{i}^{I C S}, i \in[0,067 ; 0,133 ; 0,2 ; 0,267 ; 0,333], \alpha_{i}^{C P S}, i \in[0,067 ; 0,133 ; 0,2 ; 0,267 ; 0,333] .
$$

Table 6.4

The choice of weights $\alpha_{i}$ manifestation of the i-th threat

\begin{tabular}{|c|l|}
\hline$\alpha_{i}$ & \multicolumn{1}{c|}{ conditions of manifestation } \\
\hline 0.067 & the threat appears no more than once every 5 years \\
\hline 0.133 & the threat appears no more than once a year \\
\hline 0.2 & the threat appears no more than once a month \\
\hline 0.267 & the threat appears no more than once a week \\
\hline 0.333 & the threat is manifested daily \\
\hline
\end{tabular}

3 steps. Determining the implementation of each threat for ICS and CPS:

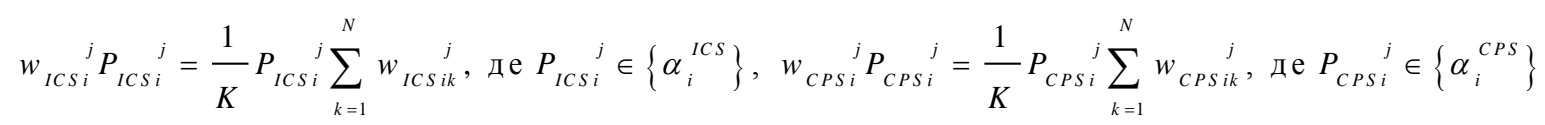

For each security service and i-th threat:

- for ICS:

$$
\begin{aligned}
& w_{I C S i}{ }^{C} \alpha_{I C S i}{ }^{C}=\frac{1}{K} \alpha_{I C S i}{ }^{C} \sum_{k=1}^{K} w_{I C S i k}{ }^{c} \text { - privacy service ; } \\
& w_{\text {ICS }}^{I} \alpha_{\text {ICS }}^{I}=\frac{1}{K} \alpha_{I C S i}{ }^{I} \sum_{k=1}^{K} w_{I C S \text { ik }}{ }^{I} \text { - integrity service; } \\
& w_{I C S i}{ }^{A} \alpha_{I C S i}{ }^{A}=\frac{1}{K} \alpha_{I C S i} \sum_{k=1}{ }^{K} w_{I C S i k}{ }^{A} \text { - accessibility service; } \\
& w_{\text {ICSi }}{ }^{A u} \alpha_{I C S i}{ }^{A u}=\frac{1}{K} \alpha_{I C S i}{ }^{A u} \sum_{k=1}^{K} w_{\text {ICS } i k}{ }^{A u}-\text { authenticity service, } \\
& w_{I C S i}^{A f f} \alpha_{I C S i}^{A f f}=\frac{1}{K} \alpha_{I C S i}{ }_{\text {Iff }}^{A} \sum_{k=1}^{K} w_{I C S i k}^{A f f} \text { - involvement service, }
\end{aligned}
$$


where $w_{I C S i}^{C}, w_{I C S i}^{I}, w_{I C S i}^{A}, w_{I C S i}^{A u}, w_{I C S i}^{A f f}$ - expert weighting factors of security services: confidentiality, integrity, accessibility, authenticity and involvement;

$\alpha_{I C S i}^{C}, \quad \alpha_{I C S i}^{I}, \alpha_{\text {ICS } i}^{A}, \quad \alpha_{I C S i}^{A u}, \alpha_{I C S i}^{A f f}$ - weighting factor of security service: confidentiality, integrity, availability, authenticity and reliability of the attack of the i-th threat.

- for CRS:

$$
\begin{aligned}
& w_{C P S i}^{C} \alpha_{C P S i}^{C}=\frac{1}{K} \alpha_{C P S i}^{C} \sum_{k=1}^{K} w_{C P S i k}^{C} \text { - privacy service; } \\
& w_{C P S i}^{I} \alpha_{C P S i}^{I}=\frac{1}{K} \alpha_{C P S i}^{I} \sum_{k=1}^{K} w_{C P S i k}^{I}-\text { integrity service; } \\
& w_{C P S i}^{A} \alpha_{C P S i}^{A}=\frac{1}{K} \alpha_{C P S i}{ }^{A} \sum_{k=1}^{K} w_{C P S i k}^{A}-\text { accessibility service; } \\
& w_{C P S i}^{A u} \alpha_{C P S i}^{A u}=\frac{1}{K} \alpha_{C P S i}^{A u} \sum_{k=1}^{K} w_{C P S i k}^{A u} \text { - authenticity service, } \\
& w_{C P S i}^{A f f} \alpha_{C P S i}^{A f f}=\frac{1}{K} \alpha_{C P S i}^{A f f} \sum_{k=1}^{K} w_{C P S i k}^{A f f} \text { - involvement service, }
\end{aligned}
$$

where $\underset{{ }_{C P S i}}{C}, w_{C P S i}^{I}, w_{C P S i}{ }^{A}, w_{C P S i}^{A u}, w_{C P S i}^{A f f}$ - expert weighting factors of security services: confidentiality, integrity, accessibility, authenticity and involvement;

$\alpha_{C P S i}{ }^{C}, \quad \alpha_{C P S i}{ }^{I}, \quad \alpha_{C P S i}{ }^{A}, \alpha_{C P S i}^{A u}, \alpha_{C P S i}^{A f f}$ - weighting factor of security service: confidentiality, integrity, availability, authenticity and reliability of the attack of the i-th threat.

4 steps. Determining the implementation of several threats to the security service:

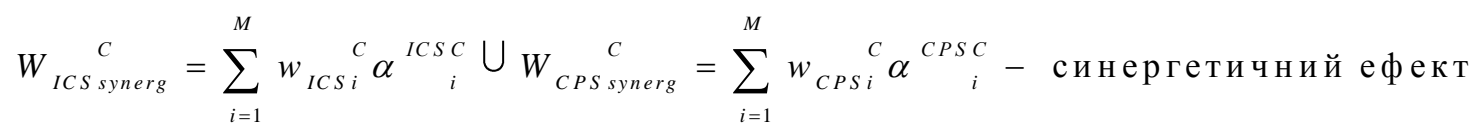

$$
\begin{aligned}
& \text { на послугукон фіденційність; }
\end{aligned}
$$

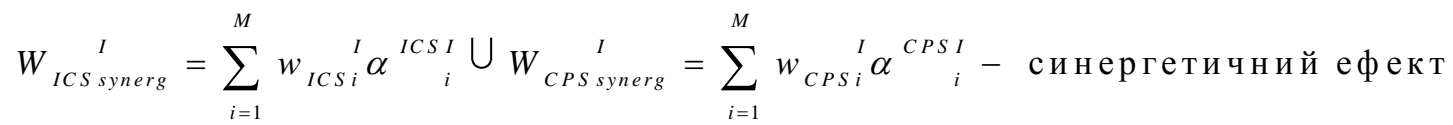




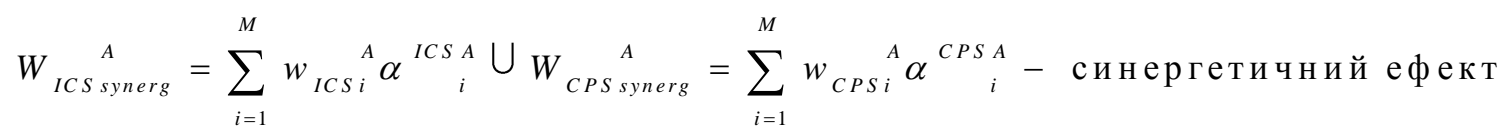

на послугу доступність;

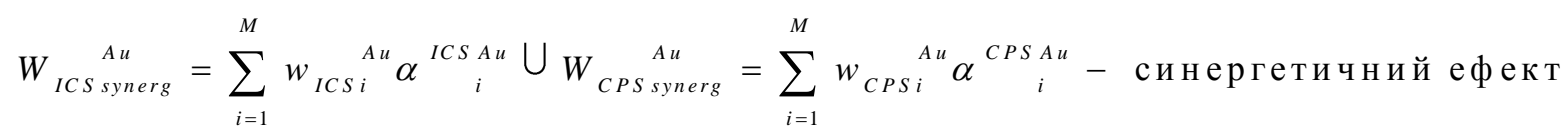

на послугу автентичність;

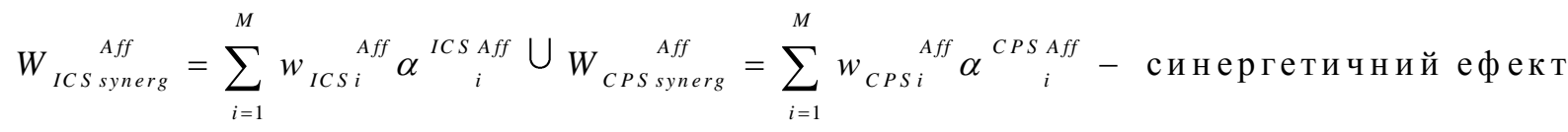
на послугу причастність.

where $M$ - is the number of multiple threats selected by the expert from the set $\{i\}_{i}^{M}$, which is a subset of the whole set of classifier threats, ie $M \leq N$.

When forming metric coefficients, it is considered that the obtained results are independent threats, in case of their dependence (coincidence of tuples of threats) it is necessary to use the expression to determine the full probability of dependent events:

$$
P(A B)=P(A)+P(B)-P(A B) .
$$

5 steps. Determination of the total threat by security components taking into account expression (6.19):

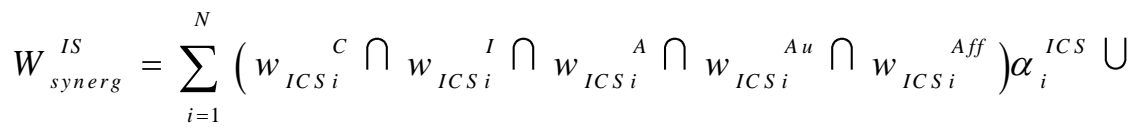

$$
\begin{aligned}
& \cup \sum_{i=1}^{N}\left(w_{C P S i}^{C} \cap w_{C P S i}{ }^{I} \cap w_{C P S i}{ }^{A} \cap w_{C P S i}^{A u} \cap w_{C P S i}^{A f f}\right) \alpha_{i}^{C P S} \\
& W_{\text {synerg }}^{C S}=\sum_{i=1}^{N}\left(w_{\text {ICS } i}^{C} \cap w_{\text {ICS } i}^{I} \cap w_{\text {ICS } i}^{A} \cap w_{\text {ICSi }}^{A u} \bigcap_{w_{\text {ICS }}{ }^{A f f}}\right) \alpha_{i}^{I C S} \cup \\
& \cup \sum_{i=1}^{N}\left(w_{C P S i}{ }^{C} \cap w_{C P S i}{ }^{I} \cap w_{C P S i}{ }^{A} \cap w_{C P S i}{ }^{A u} \cap w_{C P S i}^{A f f}\right) \alpha_{i}^{C P S}
\end{aligned}
$$

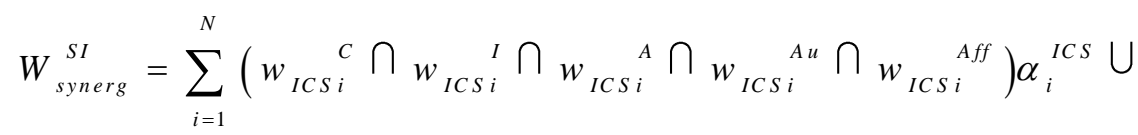

$$
\begin{aligned}
& \cup \sum_{i=1}^{N}\left(w_{C P S i}^{C} \cap w_{C P S i}^{I} \cap w_{C P S i}{ }^{A} \cap w_{C P S i}^{A u} \cap w_{C P S i}^{A f f}\right) \alpha_{i}^{C P S}
\end{aligned}
$$

To determine the generalized synergistic threat: 


$$
W_{\text {synerg }}^{I S, C S, S I}=W_{\text {synerg }}^{I S} U_{W_{\text {synerg }}^{c S}}^{C S} U_{W_{\text {synerg }}^{\text {sI }}}^{\text {II }} .
$$

To determine the generalized synergistic threat given its hybridity for ICS:

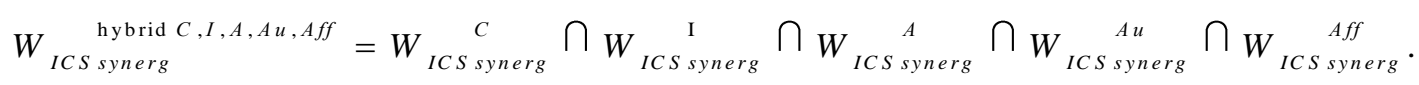

To determine the generalized synergistic threat given its hybridity for CPS:

$$
W_{C P S \text { synerg }}^{\text {hybrid } C, A, A u, A f f}=\underset{C P S \text { synerg }}{C} \cap W_{C P S \text { synerg }}^{\mathrm{I}} \cap W_{C P S \text { synerg }}^{A} \cap W_{C P S \text { synerg }}^{A u} \bigcap_{W_{C P S \text { synerg }}^{A f f}}^{A} .
$$

To determine the generalized hybrid synergistic threat:

$$
W_{\text {synerg }}^{\text {hybrid } I S, C S, S I}=W_{I C S \text { synerg }}^{\text {hybrid } C, I, A, A u, A f f} \cup W_{C P S \text { synerg }}^{\text {hybrid } C, I, A, A u, A f f} .
$$

6 steps. Determining the economic costs of preventing an attack.

The introduction of cost indicators of threats allows to implement an algorithm for building a rating of potential threats and the importance of information resources to be protected.

Both sides of the attack are determined by the importance (rating) of attacks, which are economically feasible.

Step 1. Identification of attacks, the effect of which exceeds the cost of their implementation:

$$
\operatorname{Tr}_{R}^{A}=\left\{\operatorname{Tr}_{i} \mid\left(P_{i}^{A}-C_{i}^{A}\right)>0\right\} \forall T r_{i} \in T r
$$

where $T r_{R}^{A}$ - many potential threats, the implementation of which is effective for the attacker; $T r_{i}$ - threat to the i-th information resource; $P_{i}{ }^{A}$ - assessment of the cost of success of the attack on the $i$-th resource by the attacker; $C_{i}{ }^{A}-$ the cost of an attack on the i-th resource by the attacker;

Step 2. Determining the direction of protection that provides the effect is higher than the cost of providing them. 


$$
\operatorname{Tr}_{C}^{D}=\left\{\operatorname{Tr}_{j} \mid\left(P_{i}^{D}-C_{i}^{D}\right)>0\right\} \forall T r_{j} \in T r
$$

where $\operatorname{Tr}_{C}^{D}$ - many threats against which it is economically feasible to build protection; $P_{i}{ }^{D}$ - assessment of the cost of loss of the i-th information resource for the defense; $C_{i}{ }^{D}-$ the cost of protection of the $\mathrm{i}$-th information resource for the defense;

Step 3. Determining the importance factors for attackers. Defined as a fraction of the gain from the total amount of gain that can be obtained potentially in the implementation of the whole set of threats to attackers:

$$
K_{i}^{A}=\frac{P_{i}^{A}-C_{i}^{A}}{\sum_{i=1}^{M}\left(P_{i}^{A}-C_{i}^{A}\right)}, \forall T r_{i} \in T r_{R}^{A}, M=\left|T r_{R}^{A}\right|,
$$

where $K_{i}^{A}$ - rating coefficient (importance) of the threat of the i-th information resource; $M$ - the power of many selected potentially effective threats to the attacking party.

Step 4. Determining importance factors for defenders. Defined as the share of winnings from the total amount of winnings that can be obtained potentially in the implementation of the whole set of protective measures:

$$
K_{j}^{D}=\frac{P_{i}^{D}-C_{i}^{D}}{\sum_{i=1}^{N}\left(P_{i}^{D}-C_{i}^{D}\right)}, \forall T r_{j} \in T r_{C}^{D}, N=\left|T r_{C}^{D}\right|,
$$

where $K_{j}^{D}$ - rating coefficient (importance) of building protection of the $\mathrm{j}$-th information resource.

Step 5. The selection of critical threats based on the assessment of the product of the coefficients of importance of the attacker and attacker is the maximum:

$$
T r_{l}=\arg \max _{\forall T_{r_{l} \in T_{C}^{D}}} K_{l}^{D} \cdot K_{l}{ }_{l} .
$$


Thus, the main difference of the proposed approach is the ability to take into account not only the opinion of experts, but also to form an objective assessment and integration of threats, which allows to form their synergistic effect, and hybridity. In addition, the use of the ISO model in the classifier allows to "identify" critical places in the infrastructure of not only cyberphysical systems, but also in the synthesis with Internet technologies of cyberspace and technologies "G". This approach intuitively allows you to focus on the weaknesses of comprehensive protection, taking into account the economic costs of low funding and "profitability" of the attack by attackers.

\subsection{Development of methodological principles for building and managing CIES in the fight against corruption}

Operational interaction of the decision-maker with the corporate information and educational system is one of the main operations of the entire technological cycle of management of innovative-active university, which is considered as a business system. At the same time, the characteristics of man as an element of the contour are increasingly becoming a bottleneck in operational management in such a structure of means and methods of human-machine interaction [57, 138, 147].

The way out of this situation is to create a semiotic structure of the corporate information system, which allows you to:

- collection and integration of information about potential opportunities and threats to the normal functioning and sources of their implementation;

- processing and storage of this information with acceptable degrees of aggregation;

- automatic and (or) human-machine assessment of the state of the security level and the environment of business processes with forecasting the emergence of new opportunities and types of threats;

- automatic and (or) human-machine search for solutions by choice of control means, initiated by assessments of the state of the controlled object and the environment of its operation, as well as unfavorable forecasts of development trends;

- automatic and (or) human-machine optimization in terms of money spent and time of found and recommended solutions; 
- human-machine decision-making with the ability to call for analysis of both the data that underlie the search for proposed solutions for management, anti-corruption, and the logic used, and mathematical methods on which the search for proposed solutions was based.

The semiotic approach investigates the scheme in which the governing body knows: - not always a certain set of parameters $\{x\}$ that characterize the current state of the control object and its operating environment;

- a set of ways to divide $\{\mathrm{x}\}$ into classes of states $\mathrm{K}=\{\mathrm{k} 1, \mathrm{k} 2, \ldots, \mathrm{kz}\}$, which require decision-making;

- set of solutions for finding solutions $\{M\}$;

- many solutions for finding solutions on models - $\{\varphi\}$.

In the implementation of such a scheme dynamically formed sets $\{k\}$ and $\{M\}$, with the possibility of obtaining the necessary solutions in a reasonable time, but the nature of the solutions - qualitative.

The system of anti-corruption contour of business processes should be based on the concept of human-machine management. This statement stems from an analysis of the many functions assigned to the system, existing approaches to automating decisionmaking processes, and the availability of decision-makers who are teamed up.

Analysis of the tasks to be solved in decision-making systems with intelligent mechanisms for automatic search of anti-corruption tools shows that:

- the formal apparatus that describes the processes of recognizing situations, making and making decisions in a fleeting environment with elements of uncertainty, must be extremely flexible;

- decision-making and decision-making processes are based not only on quantitative characteristics, but also on factors that do not always have quantitative measures (psychological, moral, etc.).

Therefore, the preparation of information for decision-making on the means of combating corruption should be considered as a creative act of choice from a set of possible solutions. In this case, quantitative factors are combined with the heuristic abilities inherent in ECM, which forms the decision. Decisions are formed on the basis of two components of development and decision-making- formal and creative;

- special attention should be paid to the decision-making procedure itself, ie it is 
important to know which components of the management process should be controlled by decision maker (DM), and which can be performed by computers;

- An important place is occupied by the problem of human-computer communication. This problem has two sides-meeting the information needs of the information available in the system and participating in the decision-making process. A natural requirement for the means of presenting information is their informativeness and ease of use of the language of communication-proximity to the language of professional vocabulary and its slang. The form of communication should be dialogical;

- the problem of training or adaptation of the developed system to the manifestation of new acts of corruption requires the development of a special procedure that allows the issuance of information presented formally (algorithmically) and informally (expertly). Such a procedure should be human-machine in nature and acceptable for a large class of situations;

- the problem of designing and generating different versions of software decisionmaking systems requires the development of special human-machine design technology within this class of systems.

Given the nature of the systems of this type, based on the ability to adapt and build purposeful behavior, we will distinguish between two types of information in the corporate system [64]:

- information that carries out the purposeful behavior of the system by organizing the processes of recognizing the manifestations of corruption, finding and making decisions on counteraction;

- information that is elements of processing by the above processes.

The first type of information is called system knowledge about the subject area of management - models, problems, algorithms.

The second type of information is called data on the state of the system, object and environment of threats - parameters of the system, object, environment and scope of these parameters.

Analysis of decision-making processes allowed to base the concept on the following concepts $[184,64]$ :

- global logical model of knowledge as a set of tasks, models and ways of their use for the organization of processes of purposeful recognition of situations of manifestation 
of corruption, development and decision-making on counteraction;

- area of interpretation of the global logical model of knowledge as a structured and ordered dynamic set of attributes that characterizes the parameters of the business process system, object and operating environment;

- team of system analysts, experts, which, using the means of recognition and communication, can identify and describe the elements of the global logical model of knowledge and the scope of its interpretation to the extent sufficient to solve problems that can be posed in any problem situation.

The following characteristics of the model should be taken into account when developing the concept:

Expertise- as a basis for the formation of the goals of the business process system, models that are the area of decision search, search rules and decision-making to protect the contour of business processes

Associativity - as a basis for automatic accumulation, generalization of information and adaptation of the university as a business system to a changing environment.

Multi-alternative - as a basis for displaying all possible ways of finding solutions.

Semiotics - as a basis for the development of mechanisms for the integration of disparate information about the object of protection against corruption and the environment of its formation.

Communication- as a basis for the implementation of dialogic means of communication between the system and DM.

Virtuality - as a basis for reflecting the globality of information, which is characterized by territorial disunity and multilevel sources of obtaining, storing and using information.

Effectiveness - as a basis for the implementation of the model of ensuring the required level of security in software and hardware environments.

The resulting model has a number of new properties, for example, it is both a means of solving problems arising before the system, and a methodology for designing and implementing such systems. The team of experts has both formal and informal knowledge of the subject area of management. In this case, each expert performs a certain educational function in the team. This allows it to easily construct and populate a knowledge model, allocate a specific local logical knowledge model, and access global knowledge and data 
models. The presence of experts allows in addition to procedures for recognition, development and decision-making also to build:

- procedures for identifying consistent knowledge, using dynamically changing groups of experts; to create expert models of decision-making for different classes of problematic situations of corruption;

- model any combination of centralized and decentralized decision making; achieve greater commonality, which allows you to implement different methods of solving problems. In addition, such a team has the opportunity to formalize communication between experts and build on this basis standard means of communication. With the help of these funds, various modes of interaction are organized - from the explicit appeal of one expert to another to the implicit appeal, when the addressee is determined by the function performed by him. The presence of many tasks, models and knowledge of how to use them in certain situations of development and decision-making allows you to develop a single means of describing such information and the organization of their use by the system. Linguistic and software support tools are used as such tools: languages for determining the logical model of knowledge (LKM) and manipulating the elements of the logical model of knowledge (KMM). Definition of knowledge involves the introduction of new types of information, such as model, task. Knowledge manipulation is based on planning solutions for finding solutions in the global knowledge model by using, first of all, the goal-setting mechanism. This concept is in good agreement with the nature of complex human-machine decision-making systems and allows, using the knowledge of experts and programmers:

- to form knowledge about possible types of corruption for the corresponding contour of business processes;

- to build models of recognition, classification of a condition, goal-setting, development and acceptance of administrative decisions concerning counteraction to corruption;

- to build a functionally complete set of computational algorithms that characterizes a specific area of anti-corruption;

- "fill" the anti-corruption software system with specific content;

- design and generate system software and organize its problem orientation.

Summarizing the above, we can conclude that this concept is fully consistent with the 
problems of managing complex social objects, methods and theories of building large control software packages, security systems for business processes. Ensuring the necessary level of anti-corruption contour of business processes will be considered as a human-machine activity to determine the state of the protected object. This requires decision-making related to search and selection through purposeful coordination of behavior patterns of all participants in the business process, embedded in the database $-M_{1}$ and existing in DM - $M_{2}$.

Model representation is determined by knowledge of methods and mechanisms to combat corruption, the goals and limitations of the parties, objective and subjective preferences for the choice of ways to achieve goals and assess the degree of their applicability. The interactivity of human interaction with the system is organized by introducing the concept of human-machine situation, which requires decision-making Sy and defines this concept of a set of attributes. The nature of this activity, on the one hand, is set by a person by managing the processes of setting the task of monitoring the progress of its decision. On the other hand, the system clarifies the correctness of the tasks, offers alternative ways to solve them, using the "knowledge and experience" of finding solutions, reflected in its model. Thus, man and system interact as partners,

Symbiosis will be optimal only when the system is organized in the mode of "intellectual" human advisor. The system performs routine functions of automatic recognition of situations, as well as the search for countermeasures based on information obtained from both experts and using system knowledge.

This knowledge exists in the system in the form of two types of structured sets \{computational and theoretical-multiple\}, \{dialogic and expert (logical-algebraic and logical-linguistic \}) models for recognizing the situation of possible corruption and finding ways to counteract it. situations for which an algorithm can be found that connects the required parameters with the given, and the search for options is not very large.The second type of models is used to find solutions that are highly dependent on situations and where the search is extremely large. and set-theoretic models are analogs of computational operations in finding solutions, and dialogic and expert - analogues of solution search methods.

The capabilities of each of the interacting parties of the business process are determined by the completeness of behavior models, decision-making procedures and the model basis of decision-making procedures. In this case, the processes of decision-making 
and behavior are considered as semiotic (symbolic). The sequence of steps used in this case (related to causal, temporal, spatial and other relations) of finding control solutions for each problem situation is considered as the logic of finding solutions.

At each step of the interaction of DM and the decision support system of one of the parties, a request is formed in the form of a problem situation and (or) a subset of algebraic operations of the model in accordance with the logic of finding solutions. The task of the decision-making system is to find the interpretation of these operations in terms of its model, their implementation and in the appropriate formation of the request. Formal representation of the model of DM behavior in operational decision-making is given by the expression

$$
M_{1}=\langle B T, D M, I T>,
$$

where $B T=\left\langle L_{B T}, A C S, \Theta\right\rangle-$ behavior theory (system knowledge model);

$D M=\left\langle x^{z}, b^{z}, f^{z}, p^{z}\right\rangle-$ information model of data describing the system;

$I T=\left\langle U I_{1}, . C I_{2}\right\rangle-$ interpretation of BT in DM.

Here $L_{B T}=L_{K D L} \cup L_{D D L}$-the language of description of the model of behavior, which is a combination of languages for determining knowledge and data;

$A C S$ - axioms of theory;

$\Theta$-rules for deriving statements in theory;

$x^{z}, b^{z}$ - set of variables and state constants;

$f^{z}, p^{z}$ - the set of functional and predicate state variables;

$U I_{1}$-user-defined interpretation of the elements of the knowledge model of the system, which determines the expert compliance of the rule of correspondence between the syntactic structure of the elements of the $L_{B T}$ language and their content in this area (semantics of DM);

$\mathrm{CI}_{2}$ - machine interpretation of elements, which expertly sets the algorithm for establishing the correspondence between the semantic structure of the elements of the $L_{B T}$ language and their truth at each current moment of finding solutions (pragmatics).

Formal model of behavior of the participant of the business process depending on 
the restrictions imposed on the rules of derivation of statements $\Theta$,can be described by means of logic of first-order predicates, production and algorithmic systems. Indeed, in the logic of predicates there are no restrictions on the application of inference rules. Any derivation rule applies to any statement already derived, if the statement allows its use. In production systems, which are also based on the logic of predicates, there are additional conditions for the applicability of a particular derivation rule. These conditions may change during the operation of the production system depending on the receipt of certain information in the output process. In algorithmic systems, the sequence of application of rules is defined unambiguously. The language of first-order predicate logic and the language of information processing algorithms are used as the language of description of control theory.

The connection of the model of behavior with problem situations and tasks of search of decisions is reached by the account of logical sequence of stages of work of ATS and allocation of set of decision-making procedures characteristic of DM.

This set of procedures can be represented in the form of such a sequence (Fig. 6.11).

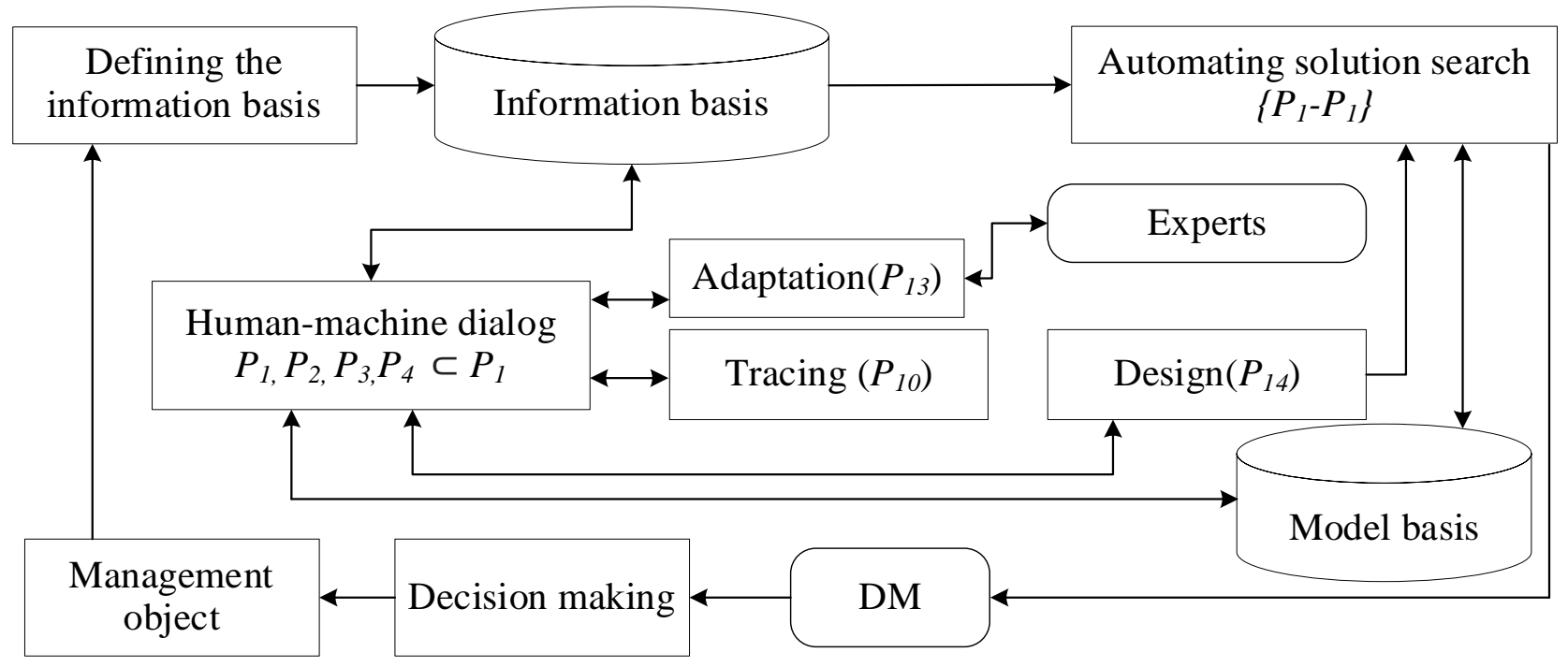

Fig. 6.11. The structure of the relationship of corporate procedures information and educational system in the fight against corruption

Situation classification procedure:

$$
P_{l}=\left\langle S, J, K_{p}, K_{s}\right\rangle
$$


where $S$ - a situation given by some relation on the set of elements I:

$J$ - the set of expert preferences for the choice of classification rules, given on the set $\left\{\mathrm{S} \times K_{s}\right\}$;

$K_{p}$ - set of classification rules -decision-making procedures;

$K_{s}$ - many classes of situations for which there are models for finding solutions;

-model classification procedureallows you to identify the many models of decisionmaking, organizing calculations on which you can find the necessary solutions to ensure the required level of anti-corruption:

$$
P_{2}=\left\langle S, K_{s}, A_{l}, M_{l}\right\rangle
$$

where $A_{l}$ - is the set of alternatives for choosing solutions for finding solutions, the weights of which depend on $S$ and $K_{s}$, may seem like a person in an interactive mode of operation with the system; $\mathrm{M}_{1}$ - a set of models for finding solutions;

-the procedure for forming strategies for the purpose of finding solutionsallows you to define many local and (or) global goals of the business process system that need to be achieved with the help of solutions found in this class of situations:

$$
P_{3}=\left\langle S, K_{s}, G, C r, S t r\right\rangle
$$

where $G$-the set of current goals facing the control system; $\mathrm{Cr}$ - a set of criteria for achieving goals (both goals and criteria may vary and change over time); Str- a set of strategies for the purpose of finding solutions;

- $\quad$ procedure for finding targeted management decisions allows you to organize the search for solutions for each of the problem situations in accordance with the goals and criteria for ensuring the security of the contour of business processes:

$$
P_{4}=\left\langle S, S t r, M_{1}, R_{G}\right\rangle,
$$

where $R_{G}$ - the set of target control solutions that can be found in the solution search model (knowledge base) $M_{l}$, configured for the current situation $s_{i} \in S$ when using the strategy $s t r_{i} \in S t r$. 
This procedure performs two functions - scheduler of computational sequence of search of decisions and the solver.

The first function is to form a crucial sequence of programs, the second - to organize the implementation of these programs and obtain control recommendations in a specific computing environment;

- procedure for determining the possible results of the implementation of decisionsallows you to set the achievability of local and (or) global management goals in the implementation of certain decisions to combat corruption. This is done by organizing calculations on the model of the allowable decision area $-M_{A D A}$, defining this area $-O_{A C A}$, in accordance with the objectives of $G$ and the criteria - $C r$, characteristic of this level of decision-making. This procedure is specified

$$
P_{5}=\left\langle S, R_{G}, G, C r, M_{A D A}, O_{A C A}, R_{G I}>\right.
$$

where $R_{G l}$ - the set of those management decisions which are satisfactory consequences, ie consequences at which realization local and (or) global management purposes can be reached;

- procedure for substantiation of decisions allows you to assess the quality of decisions (their optimality) by organizing calculations on the model of determining the optimal decision-making area $\left(M_{O D A}\right)$ to select the area of optimal management decisions $\left(O_{O D}\right)$ in accordance with the objectives and criteria. The tuple element $R_{G I}$ is a set of those control solutions that satisfy the $O_{O D}$ and can be primarily recommended for implementation. This procedure

$$
P_{6}=\left\langle S, R_{G 1}, G, C r, M_{O D A}, O_{O D}, R_{G 2}>\right.
$$

- decision synthesis procedure allows you to reduce the number of simultaneously recommended countermeasures, regardless of how many situations are analyzed simultaneously by the system. In addition, the procedure ranks the issued DM solutions both on the information obtained from the procedures $P_{5}, P_{6}$ and using the many advantages of "narrowing" the set $\mathrm{R}_{\mathrm{G}}$. These benefits can be set expertly. The procedure is specified in the form

$$
P_{7}=\left\langle S, R_{G 2}, O_{A C D}, O_{O D R}, R\right\rangle,
$$


Information for $\mathrm{DM}$ after this procedure is issued in the form $<\{S\}=>\left\{R, O_{A C D}, O_{O D R}\right\}$. Dession maker can relate the current situation to the required solutions based on their affiliation with $O_{A C D}$ or $O_{O D R}$ by specifying $R_{G 2}$;

- decision selection procedure allows you to organize the process of humanmachine interaction in order to make a single decision to be implemented. In this case, the DM can choose one of the recommended means of counteraction or take its own, different from the recommended, RG, which he must notify the system. If $R_{G} \cap \bar{R}=0$, then this solution can be implemented. Here $\bar{R}=R_{G} \cap R_{G 1} \cap R_{G 2}$-many solutions are forbidden. Formally, this procedure

$$
P_{8}=\left\langle S, R, \bar{R}, R_{G}\right\rangle,
$$

- procedure for evaluating the results of implementation of decisions allows to estimate efficiency of the accepted and realized decisions for the purpose of correction (in the mode of training or self-study) of model of knowledge of system and transfer of a part of the information of a kind $\{<$ situation $>-<$ decision $>\}$ from the field of decisionmaking to the field of automatic implementation of the decision, this procedure:

$$
P_{9}=\left\langle S, R \cup R G, M_{1}, P_{13}\right\rangle \text {, }
$$

where $P_{13}$-procedure of training (self-learning) of the system and correction of its model of knowledge $M_{1}$;

- decision tracing procedureallows you to monitor the logic of machine reasoning in finding solutions and the information base used. This procedure returns the DM property of observation, ie the ability to establish any relationship on the elements of decision-making procedures. The tracing procedure is based on the modification of the ordered sequence of $P_{1}-P_{9}$ procedures. The modification is to introduce in each procedure $\mathrm{Pi}$ a statement about the correctness of obtaining the results with its help. Formally, this procedure:

$$
P_{10}=\left\langle\mu_{1}: P_{1}, \mu_{2}: P_{2}, \ldots, \mu_{9}: P_{9}, \text { Cor }\right\rangle,
$$

where $\mu_{1}, \mu_{2}, \ldots, \mu_{9}$-conditions of execution (statement of correctness) of procedures $P_{l}$, $P_{2}, \ldots, P_{9}$, respectively, are written in the form $\mu_{i}: P_{i}$. With the help of elements of this 
tuple, a person has the opportunity by interacting with the system to psychologically believe in the correctness of the solutions found. Statements belonging to Cor determine the consistency of the logic underlying the model and procedures of the computer and DM, ie they allow the system to notify DM that the next cycle of search and decisionmaking is complete;

- information dialogue procedure organizes human-machine interaction of DM with the system in order to obtain the information it needs. This procedure:

$$
P_{11}=\left\langle P_{1}, P_{2}, P_{3}, P_{4}\right\rangle \text {, }
$$

where $P_{1}-P_{4}-$ the procedures in which the following substitutions are made are considered: $S / R_{D}, M_{1} / M_{A}, C / C_{D}, G / G D ; R / R_{0}$;

$R_{D}$ - a set of requests coming from DM;

$\mathrm{M}_{\mathrm{A}} \in \mathrm{M}_{1}$ - many models of answer search by areas of query definition;

$S t r_{D}-$ a set of strategies for the purpose of finding solutions ranked by a set of $M_{A}$;

$G_{D}$ - set of current goals;

$R_{0}-$ the set of responses issued by the DM when the system responds to a request;

- procedure for determining the information base for decision making communicates with the information collection system in order to organize the processing of this information and record it in the information model (database) of systems. Formally, this procedure:

$$
P_{12}=\left\langle S, P_{1}, P_{2}, P_{3}, P_{4}, M_{1}, M_{D}\right\rangle,
$$

where $M_{D}$-information model that preserves the current state of the object;

- adaptation / training procedure allows you to organize automated setup of the system to the area of counteraction. This procedure:

$$
P_{13}=\left\langle L_{L}, E_{K}, E_{D}\right\rangle \text {, }
$$

where $L_{L}$-the mechanism of correction of models of bases of knowledge and data (means of the description of knowledge and data) that allows to connect the information in its machine representation; $E_{K}, E_{D}$ - many elements of the level of the model of knowledge 
and data;

- automated design procedure, or, alternatively, a dialog system of automated design of the anti-corruption system. For DM and systems analysts, this is the procedure:

$$
P_{14}=\left\langle S, L_{D K L}, L_{D M L}, L_{L D L}, M^{C o m p}\right\rangle,
$$

where $S$-design situation from the class of situations of human-machine design, which reflects the subject-oriented formulation of the problem of building an information-model base;

$L_{D K L}, L_{D M L}, L_{D D L}$ - language tools for describing the elements of the model knowledge base and data;

$M^{\text {Comp }}$ - machine representation of information-model basis.

Figure 6.12 shows the structural and logical scheme of the methodological foundations of the construction of CIES IAU in the fight against corruption. To build a conceptual synergetic security model of CIES IAU, we use the advanced classification of threats to cyberphysical (CFS) and information and communication systems (ICS), proposed in [218].

Thus, offering a structural and logical scheme of methodological principles of construction of CIES IAU in the fight against corruption allows to automate the process of control of electronic documents and e-education services at all levels of the hierarchical structure of university management. The main mechanisms of automation are services based on the use of CSC and commercial implementation of cryptographic algorithms. This approach provides the necessary level of security services, effective control of anticorruption in today's cyber threats (both internal and external).

The main limitations of the modeling are the subjectivity of the choice of types of corruption and assessment of current threats to corporate networks of universities.

Further development is to conduct research to increase the level of anti-corruption in the IAU on the basis of a pilot project to implement the principles of building and managing a corporate information and educational system of innovative and active university. 
Advanced cyberphysical threat classifier (CFS) and information and communication systems (ICS)

$$
\begin{aligned}
& W_{\text {ICS synerg }}^{C}=\sum_{i=1}^{M} w_{\text {ICS } i}{ }^{C} \alpha^{I C S C}{ }_{i} \cup W_{C P S \text { synerg }}^{C}=\sum_{i=1}^{M} w_{C P S i}{ }^{C} \alpha_{i}^{C P S C} \quad \ldots \\
& W_{I C S \text { synerg }}^{A f f}=\sum_{i=1}^{M} w_{I C S i}^{A f f} \alpha_{i}^{I C S A f f} \cup W_{C P S \text { synerg }}^{A f f}=\sum_{i=1}^{M} w_{C P S i}^{A f f} \alpha_{i}^{C P S A f f}
\end{aligned}
$$

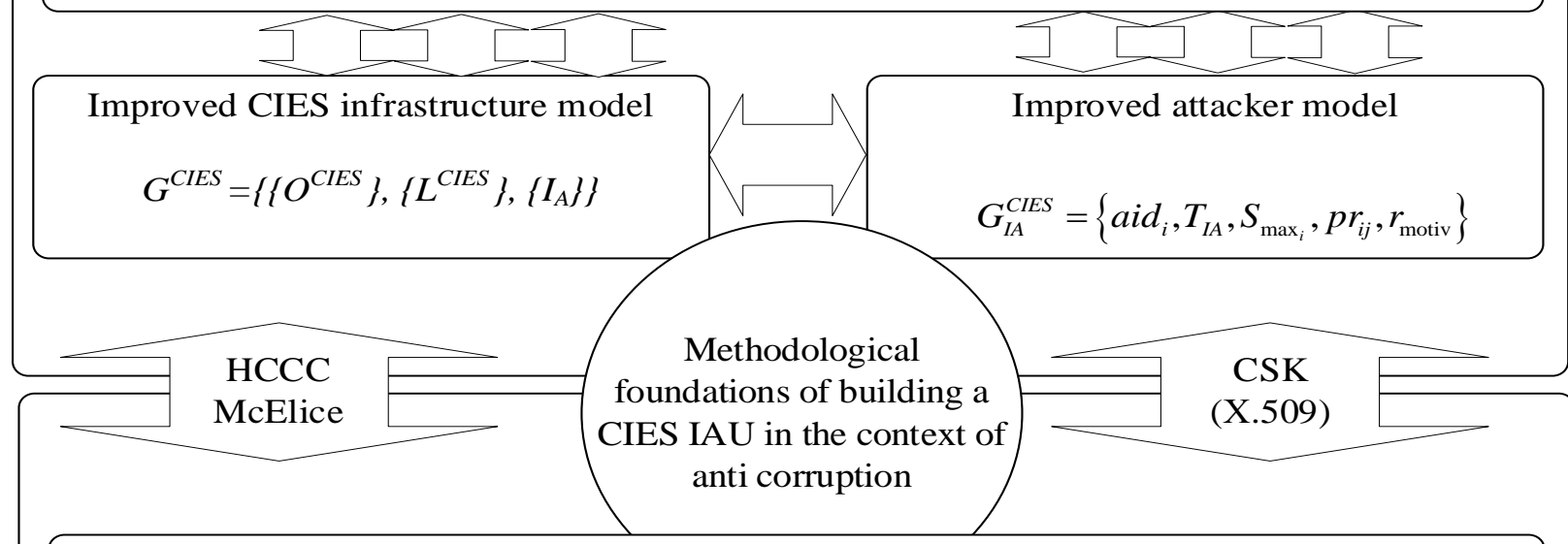

$$
\begin{aligned}
& \text { Submodel from the counteraction side } \\
& \frac{d\left(A_{i}^{R S}\right)}{d t}=R_{i}-D_{i}, R_{i}=A_{i}^{S} / T^{R A}, F I_{i}=A_{i}^{R S} / \sum_{i=1}^{3} A_{i}^{R S}, A d=I R-R e p, \\
& I R=R^{B}-\sum_{i=1}^{3} V_{i} \times V u l_{i}, D F P=\left(R M R^{*} R e p\right)+B F P, \frac{d(D A P)}{d t}=I F P
\end{aligned}
$$

Interaction environment submodel
$V u l_{i}=\left(C^{A} \times A F_{i} \times C^{U A}\right)-\left(C^{D} \times F I_{i}\right)$
$S A_{i}=\left\{\begin{array}{c}\left(C^{A} * A F_{i}\right)-\left(\left(C^{D *} A F_{i}\right) / C^{U A}\right) \\ 0 \text { if } V u l_{i}>0\end{array}\right.$

Submodel of a corrupt official

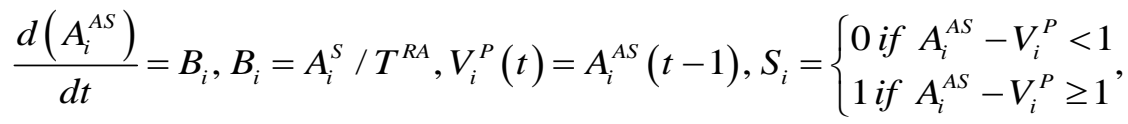

$$
\begin{aligned}
& A_{i}^{F}=S_{i} \times A_{i}^{A S} / \sum_{i=1}^{3} S_{i} \times A_{i}^{A S}, P^{A}=\sum_{i=1}^{B} B_{i} \times C^{U A}, \frac{d(A A W)}{d t}=I A W .
\end{aligned}
$$

Anti-corruption model in IAU

MODEL OF BEHAVIOR OF THE DECISION MAKER

$$
M_{1}=\langle B T, D M, U T>
$$

Fig. 6.12. Structural and logical scheme of methodological bases of CIES IAU construction in the conditions of anti-corruption conditions 


\subsection{Technology of building a modified electronic document management system at the university}

The creation of an internal university system of document management elements, which is aimed at improving the effectiveness of control over the provision of educational services by higher education institutions, objectivity in assessing the learning process and preventing corruption in the HEI is based on HEI. This approach is mandatory in the context of the creation / transition to a free enterprise of a new entrepreneurial type innovative-active university.

Accordingly, the technology of building an electronic document management system (EDMs) is proposed, which is aimed at preventing corruption in the provision of educational services (Fig. 6.13).

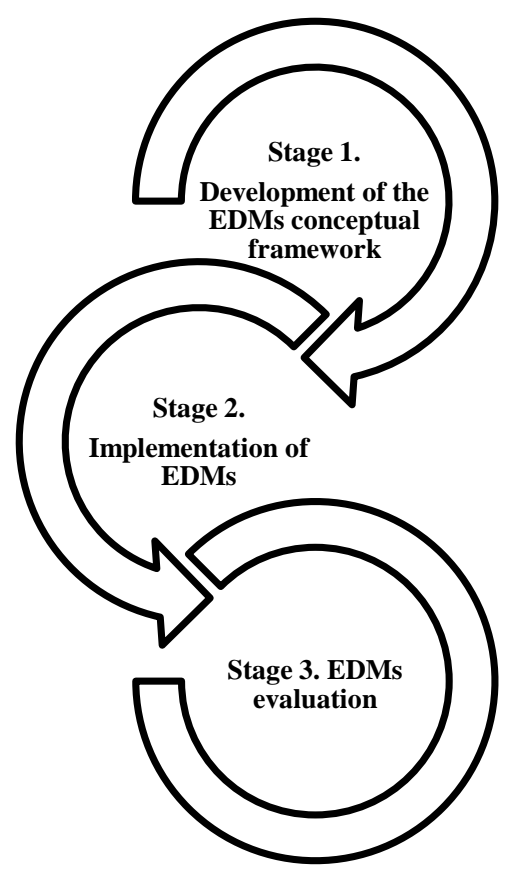

Fig. 6.13. Scheme of technology for building an electronic document management system

Technology construction of electronic document management systemis an element of the management and decision-making system in the CIES of the university. Its content consists of management procedures related to the collection, movement, storage, processing, analysis of information, providing it to structural units and individual jobs of employees of the HEI. On these grounds, the study developed a set of tasks in accordance 
with the proposed stages of technology.

Stage 1. Development of conceptual bases of the project:

- substantiation of the need to introduce new global approaches to prevent corruption based on the use of modern cryptographic mechanisms to provide basic security services in the IAU electronic document management system;

- analysis of the world experience of deployment and implementation of the electronic document management system of the university in the provision of educational services;

- formation of the methodology of the hierarchical management system for the provision of IAU educational services;

- construction of conceptual bases of development of software and technical component of electronic document management system.

Stage 2. Project implementation:

- development of the necessary software adapted to the corporate system of higher education institutions on the basis of CISS "Code X.509";

- development of the necessary documentation on the use of document management software and the use of special software CISS "Code X.509" in CIES IAU;

- formation of basic requirements, technical specifications for the implementation of the system CISS "Code X.509" in the corporate network of HEI;

- formation of relevant guiding documents for the implementation of a system of effective control over the provision of educational services;

- introduction of changes to job descriptions of relevant officials, to control the use and operation of the electronic document management system;

- holding conferences, round tables, master classes, which contribute to the overall objectives of the system of control in all parts of the organization and management of educational services to students, free control of the objectivity of student assessment throughout the cycle, providing household and other services for time spent at the university in order to prevent corruption at all levels of the university management system;

- conducting information / promotion campaigns for faculty on the implementation of the anti-corruption system in the provision of IAU educational services, assessment of support by the management of the HEI on the implementation of the anti-corruption system, monitoring changes in the efficiency of electronic document management;

- conducting trainings with students of the HEI on the benefits of using the 
electronic document management system of the HEI, aimed at preventing corruption;

- coverage of the developed system of electronic document management as a means of preventing corruption in social networks, regional mass media;

- publication of the results of the proposed system on the project website.

Stage 3. Project evaluation:

- conducting discussions / round tables with all parts of the HEI on the efficiency of the electronic document management system, built on anti-corruption principles on the basis of a modified system of electronic document management HEI in the provision of educational services;

- making changes, clarifications in the guiding documents on the use of a modified system of electronic document management;

- monitoring the efficiency of the system during the introductory campaign, conducting examination sessions;

- conducting master classes / trainings with representatives of the strategic, tactical and operational level of management HEI on the use of the proposed system of electronic document flow of HEI in the provision of educational services;

- conducting informational / educational interactive events among students of higher education institutions to discuss the basics of creating a system of control over the objectivity of assessment and prevention of corruption in all parts of the hierarchical system of management of educational services;

- conducting debates among the public to discuss the implementation of relevant changes in the process of providing educational services;

- discussion of the possibility of implementing the developed system in the universities of the Ministry of Education and Science of Ukraine.

The proposed approach provides for the formation of a cybernetic system based on public key technology, which allows you to confidently fight corruption in the HEI on the basis of technical solutions without human intervention.

Thus, the following conclusions can be drawn:

1. The analysis of threats in the conditions of rapid growth of computing resources, both cyber technologies and "G" technologies, used in modern CIES of a higher education institution (HEI) showed their vector of focusing on integration with social engineering methods to obtain new characteristics such as synergy and hybridity. The entry of mankind into the era of post-quantum cryptography (the emergence of a full-scale 
quantum computer) puts more stringent security requirements in both ICS and CPS, which form the core of KIOS. In the conditions of possible security chaos (breaking by quantum algorithms of symmetric and asymmetric cryptosystems) the synergetic model of threats which allows to provide complexing of threats on security components: IS, CyberSec, SI comes to the fore in the analysis of the current state of security.

2 . The proposed concept of combating corruption not only takes into account current trends in e-education, goals and objectives, but also provides counteraction to the elements of corruption and complex hybrid threats. The basis for combating corruption is the digital signature of the CSK on the basis of the X-509 standard, which also provides a security service - authentication. To ensure the confidentiality and integrity of security services, it is proposed to use the commercial implementation of crypto-code constructions of McEllis and Niederwright on MES and unprofitable codes. This approach provides the necessary levels of reliability, efficiency and cryptocurrency, as well as countering cryptocurrencies.

3. The proposed synergetic model of KIOS security allows not only to take into account the synergy and hybridity of modern threats, but also to form preventive measures based on timely detection of critical points in the CIES infrastructure and the formation of AIPS.

4. The scheme of the unified classifier is offered taking into account synergetic model of threats and economic expenses for maintenance of necessary level of safety. This approach allows to form the methodological basis for its construction and confirms its unification. The proposed classifier provides an intuitive approach to understanding its structure, allows you to generate critical threats, identify critical points in the construction of ICS / CPS (CIES) infrastructure, to ensure the formation of preventive measures in terms of cost savings on CISS, with low computational and human costs.

5. An anti-corruption model has been developed, which reflects the scenarios of behavior of participants in the corruption process and anti-corruption bodies. The main result of the simulation of scenarios of behavior of the parties to the corruption process is the dynamics of the distribution of corruption agreements over time and by type of corruption. This allows for the effective redirection of the university's limited resources to anti-corruption measures. 


\section{REFERENCES}

1. Nacional'na doktryna rozvytku osvity u HHI stolitti // Osvita Ukrai'ny. - 2001. - № 1. - S. 22-55.

2. Nacional'nyj Standart Ukrai'ny DSTU ISO 9001:2015 (ISO 9001:2015, IDT) Systemy upravlinnja jakistju. VYMOGY. Vydannja oficijne [Elektronnyj resurs]. - Kyi'v : DP «UkrNDNC», 2016. - 22 s. $\quad$ - Rezhym dostupu : https://khoda.gov.ua/image/catalog/files/\%209001.pdf.

3. Polozhennja pro doslidnyc'kyj universytet : zatv. postanovoju Kabinetu Ministriv Ukrai'ny vid 17.02.2010 r. № $163 . \quad$ URL: https://zakon.rada.gov.ua/laws/show/163-2010-\%D0\%BF\#Text (data zvernennja: 11.12.2020).

4. Pro akredytaciju vyshhyh navchal'nyh zakladiv : postanova Kabinetu Ministriv Ukrai'ny vid 01.06.1992 r. № 303. URL: https://zakon.rada.gov.ua/laws/show/303-92\%D0\%BF/ed19920601\#Text (data zvernennja: 07.12.2020).

5. Pro vyshhu osvitu : Zakon Ukrai'ny vid 01.07.2014 r. № 1556-VII. URL: https://zakon.rada.gov.ua/laws/show/1556-18\#Text (data zvernennja: 11.12.2020).

6. Pro vyshhu osvitu : Zakon Ukrai'ny vid 17.01.2002 r. № 2984-III. URL: https://zakon.rada.gov.ua/laws/show/2984-14\#Text (data zvernennja: 07.12.2020).

7. Pro vnesennja zmin do dejakyh zakoniv Ukrai'ny shhodo vdoskonalennja osvitn'oi' dijal'nosti u sferi vyshhoi' osvity: Zakon Ukrai'ny № 392-IX vid 18.12.2019 [Elektronnyj resurs]. - Rezhym dostupu : https://zakon.rada.gov.ua/laws/show/39220\#Text

8. Pro vprovadzhennja kredytno-modul'noi' systemy organizacii' navchal'nogo procesu : nakaz Ministerstva osvity i nauky Ukrai'ny vid 30.12.2005 r. № 774. URL: https://zakon.rada.gov.ua/rada/show/v0774290-05\#Text (data zvernennja: 10.12.2020).

9. Pro zabezpechennja dal'shogo rozvytku vyshhoi' osvity v Ukrai'ni : ukaz Prezydenta Ukrai'ny vid 25.09.2008 r. № 857/2008. URL: https://zakon.rada.gov.ua/laws/show/857/2008\#Text (data zvernennja: 09.12.2020).

10. Pro zatverdzhennja Nacional'noi' ramky kvalifikacij : postanova Kabinetu Ministriv Ukrai'ny vid 23.11.2011 r. № 1341. URL: https://zakon.rada.gov.ua/laws/show/1341-2011-\%D0\%BF\#Text (data zvernennja: 
11.12.2020).

11. Pro zatverdzhennja Planu dij shhodo zabezpechennja jakosti vyshhoi' osvity Ukrai'ny ta i'i' integracii' v jevropejs'ke i svitove osvitnje spivtovarystvo na period do 2010 r. : nakaz Ministerstva osvity i nauky Ukrai'ny vid 13.07.2007 r. № 612. URL: https://zakon.rada.gov.ua/rada/show/v0612290-07\#Text (data zvernennja: 10.12.2020).

12. Pro zatverdzhennja Polozhennja pro instytucijnu formu zdobuttja zagal'noi' seredn'oi' osvity: Nakaz Ministerstva osvity i nauky Ukrai'ny vid 23.04.2019 r. № 536 (zarejestrovano v Ministerstvi justycii' Ukrai'ny 22 travnja 2019 r. za № 547/33518) [Elektronnyj resurs]. - Rezhym dostupu : https://zakon.rada.gov.ua/laws/show/z054719\#Textl

13. Pro zatverdzhennja Programy dij shhodo realizacii' polozhen' Bolons'koi' deklaracii' v systemi vyshhoi' osvity i nauky Ukrai'ny na 2004-2005 roky : nakaz Ministerstva osvity i nauky Ukrai'ny vid 23.01.2004 r. № 49. URL: https://zakon.rada.gov.ua/rada/show/v0049290-04\#Text (data zvernennja: 09.12.2020).

14. Pro zahody shhodo vdoskonalennja systemy vyshhoi' osvity Ukrai'ny : ukaz Prezydenta Ukrai'ny vid 17.02.2004 r. № 199/2004. URL: https://zakon.rada.gov.ua/lashs/shosh/199/2004\#Teht (data zvernennja: 09.12.2020)

15. Pro innovacijnu dijal'nist': Zakon Ukrai'ny vid 04 lypnja 2002 r. № 40-IV // Vidomosti Verhovnoi' Rady Ukrai'ny. - 2002. - № 36. - S. 266

16. Pro licenzuvannja dijal'nosti z nadannja osvitnih poslug : postanova Kabinetu $\begin{array}{llllll}\text { Ministriv Ukrai'ny vid } 08.08 .2007 & \text { r. № } & 1019 . & \text { URL: }\end{array}$ https://zakon.rada.gov.ua/laws/show/1019-2007-\%D0\%BF (data zvernennja: 10.12.2020).

17. Pro licenzuvannja osvitnih poslug : postanova Kabinetu Ministriv Ukrai'ny vid 29.08.2003 r. № 1380. URL: https://zakon.rada.gov.ua/laws/show/1380-2003$\%$ D0\%BF\#Text (data zvernennja: 10.12.2020).

18. Pro licenzuvannja, atestaciju ta akredytaciju navchal'nyh zakladiv : postanova Kabinetu Ministriv Ukrai'ny vid 12.02.1996 r. № 200. URL: https://zakon.rada.gov.ua/laws/show/200-96-\%D0\%BF/ed19960212\#Text (data zvernennja: 07.12.2020).

19. Pro naukovu i naukovo-tehnichnu dijal'nist' : Zakon Ukrai'ny vid 26.11.2015 r. № 848-VIII. URL: https://zakon.rada.gov.ua/laws/show/848-19\#Text (data zvernennja: 
11.12.2020).

20. Pro Nacional'nu strategiju rozvytku osvity v Ukrai'ni na period do 2021 roku : zatv. Ukazom Prezydenta Ukrai'ny vid 25.06.2013 r. № 344/2013. URL: https://zakon.rada.gov.ua/laws/show/344/2013\#Text (data zvernennja: 11.12.2020).

21. Pro nevidkladni zahody shhodo zabezpechennja funkcionuvannja ta rozvytku osvity v Ukrai'ni : ukaz Prezydenta Ukrai'ny vid 04.07.2005 r. № 1013/2005. URL: https://zakon.rada.gov.ua/laws/show/1013/2005\#Text (data zvernennja: 09.12.2020).

22. Pro osvitu : Zakon URSR vid 23.05.1991 r. №1060-HII. URL: https://zakon.rada.gov.ua/laws/show/1060-12/ed19910523\#Text (data zvernennja: 07.12.2020).

23. Pro osvitu: Zakon Ukrai'ny vid 05.09.2017 № 2145-VIII. [Elektronnyj resurs]. - Rezhym dostupu : https://zakon.rada.gov.ua/ laws/show/2145-19\#Text.

24. Pro perelik naprjamiv ta special'nostej, za jakymy zdijsnjujet'sja pidgotovka fahivciv u vyshhyh navchal'nyh zakladah za vidpovidnymy osvitn'o-kvalifikacijnymy rivnjamy : postanova Kabinetu Ministriv Ukrai'ny vid 24.05.1997 r. № 507. URL: https://zakon.rada.gov.ua/laws/show/507-97-\%D0\%BF\#Text (data zvernennja: 07.12.2020).

25. Pro utvorennja Nacional'nogo agentstva iz zabezpechennja jakosti vyshhoi' osvity : postanova Kabinetu Ministriv Ukrai'ny vid 15.04.2015 r. № 244. URL: https://zakon.rada.gov.ua/laws/show/244-2015-\%D0\%BF\#Text (data zvernennja: 11.12.2020).

26. Proekt: model' systemy zabezpechennja jakosti osvitn'oi' dijal'nosti ta jakosti vyshhoi' osvity u HEI. [Elektronnyj resurs]. - Rezhym dostupu : http://onu.edu.ua/pub/bank/userfiles/files/international/QUAERE/Model_yad.pdf

27. .Bajnazarova O. O. Provedennja monitoryngu jakosti osvity z vykorystannjam informacijno-komunikacijnyh tehnologij / O. O. Bajnazarova // Upravlinnja osvitoju. 2009. - № 18 (114). - S. 6-7.

28. Academic Ranking of World Universities (ARWU) [Електронний ресурс]. Режим доступу : http://www.shanghairanking.com/ARWU-Methodology-2020.html.

29. Aktual'nye kiberugrozy - 2018. Trendy i prognozy (2019), Positive technologies, [Online].

URL: https://www.ptsecurity.com/ruru/research/analytics/cybersecurity-threatscape-2018/ (Dostup Ijun' 30, 2020). 
30. Alexey Tsyganenko, Sergey Evseev, Stanislav Milevsky. Using false codes in the structure of Niederreiter's Cryptocodes / / Brief report on the work of the 1st International Conference on Intelligent Systems and information technologies (Isit 2019), Odessa, Ukraine, August 19-24, 2019, pp. 17-19.

31. Altbach P. G. Trends in Global Higher Education: Tracking an Academic Revolution / P.G. Altbach, L Reisberg, L. E. Rumbley // UNESCO 2009 World Conference on Higher Education. - Paris, 5-8 July, 2009.

32. Altbach P.G. The Road to Academic Excellence : The Making of WorldClass Research Universities. Direction in Development / P.G. Altbach, J.Salmi. - Режим доступу: https://openknowledge.worldbank.org/handle/10986/2357

33. Andrjushkevich O. A. Formirovanie predprinimatel'skih universitetov v innovacionnoj jekonomike / O. A. Andrjushkevich, I. M. Denisova // Jekonomicheskaja nauka sovremennoj Rossii. - 2014. - № 3 (66). - S. 7-2

34. Armstrong L. A New Game in Town: Competitive Higher Education / L. Armstrong // The new media and institutions of higher education and learning. - New York: Routledge, 2002. - Chapter 6. - P. 147-156.

35. Artyuhina A. I. Obrazovatelnaya sereda vyisshego uchebnogo zavedeniya kak pedagogicheskiy fenomen : monogr./ A.I. Artyuhina. - Volgograd :Izd-vo VolGMU, 2006. -237 s.

36. Avtonomija ta vrjaduvannja u vyshhij osviti: monografija / Avt.: Vorobjova O.P., Gorec'ka T.O., Dem'janenko N.M., Kalashnikova S.A., Kovalenko O.M., Lugovyj V.I., Sych O., Sljusarenko O.M., Talanova Zh.V., Tkachenko V.P. - K.: Instytut vyshhoi' osvity NAPN Ukrai'ny, 2015. - 192 s.

37. Bachynska Ye. M. Mekhanizm formuvannia innovatsiinoho osvitnoho prostoru v rehioni. Pedahohika i psykholohiia, 1(54), 2007, 79 - 88

38. Barber M. Nakanune shoda laviny. Vysshee obrazovanie i grjadushhaja revoljucija. Voprosy obrazovanija. 2013. № 3. S. 152-229.

39. Becker B. A. Open innovation concept: integrating universities and business in digital age / B. A. Becker, E. Cornelia. Journal of Open Innovation: Technology, Market, and Complexity. 2018. Volume 4., Issue 12. P.16. URL: https://jopeninnovation.springeropen.com/track/pdf/10.1186/s40852-018-0091-6

40. Berdahl. R. Thoughts About Academic Freedom, Autonomy and 
Accountability. Режим доступу: http://www.magnacharta.org/resources/files/Berdahl_2010Thoughts_Abou_Academic_Freedom_Autonom y_and_Accountability.pdf

41. Bezgin K. S. Formuvannja innovacijno-aktyvnogo seredovyshha spivtvorchosti: organizacijno-upravlins'kyj aspekt / K. S. Bezgin, I. V. Panchenko // Ekonomika i organizacija upravlinnja. - 2019. - № 4 (36). - S. 7-20.

42. Bezzubko L., Topchij K. Osvitnja migracija v Ukrai'ni. Galyc'kyj ekonomichnyj visnyk. 2020. №4(65). URL : http://elartu.tntu.edu.ua/handle/lib/32745

43. Bielienka H. V. Kulturno-osvitnie seredovyshche VNZ yak chynnyk formuvannia profesiinoi kompetentnosti maibutnoho pedahoha. Onovlennia zmistu, form ta metodiv navchannia $i$ vykhovannia v zakladakh osvity : nauk. zapysky RDHU. Rivne: RDHU, 2011, 1 (44), 17-21.

44. Bishimbaeva S. K. Kljuchevye pokazateli ocenki i kriterii innovacionnosti universiteta kak jelementy sistemy menedzhmenta kachestva / S. K. Bishimbaeva, K. K. Nurasheva, A. A. Nurmuhanbetova // Mezhdunar. nauch.-issled. zhurnal. - 2017. - № 11 (65). - Ch. 4. - S. 136-142.

45. Bodnar B. Je. Systemy upravlinnja jakistju za standartom ISO 9000 u vyshhyh navchal'nyh zakladah / B. Je. Bodnar, O. O. Matusevych // Visnyk Dnipropetr. nac. un-tu zalizn. transp. im. akad. V. Lazarjana. - 2012. - Vyp. 40. - S. 167-172.

46. Bowen, B. M., Devarajan, R., and Stolfo, S. (2011). "Measuring the human factor of cyber-security," in 2011 IEEE International Conference on Technologies for Homeland Security (HST), 230-235.

47. Bratko M. Upravlinnia osvitnim seredovyshchem vyshchoho navchalnoho zakladu: sutnist poniattia] Osvitolohiia. 2014. 3. 81-88. Retrieved from: http://nbuv.gov.ua/UJRN/ocvit_2014_3_15

48. Bratko M. V. (Soroka) Sutnisnyi zmist poniattia «osvitnie seredovyshche vyshchoho navchalnoho zakladu». Pedahohichna osvita. 2012, 1(18), 50-55.

49. Bratko M. V. Osvitnie seredovyshche vyshchoho navchalnoho zakladu : funktsionalnyi aspekt. Pedahohichnyi protses: teoriia i praktyka, 1-2 (46-47), 2015, 11 17.

50. Britanskij Ctil' : zhurnal [Elektronnij resurs]. - 2005. - № 5. - Rezhim dostupu : http://www.albioncom.ru/articles/school/britanskiy_stil/ 
51. Budushhee vysshej shkoly v Rossii: jekspertnyj vzgljad. Forsajt-issledovanie 2030 : analiticheskij doklad / pod red. V.S. Efimova. Krasnojarsk : Sibirskij federal'nyj universitet, 2012. 182 s. URL: http://foresight.sfu-kras.ru/sites/foresight.sfukras.ru/files/_Doklad_Vysshaya_shkola_-_2030_ekspertnyy_vzglyad_2012_0.pdf

52. Butova N. O. Sutnist' i struktura ponjattja «jakist' osvitn'ogo procesu» u filosofs'kij ta psyhologo-pedagogichnij literaturi [Elektronnyj resurs] / N. O. Butova // Naukovyj visnyk Donbasu. - 2012. - № 1. - Rezhym dostupu : http://nbuv.gov.ua/UJRN/nvd_2012_1_2.

53. Capenko Y. P. Mezhdunarodnaja studencheskaja mygracyja. URL : https://cyberleninka.ru/article/n/mezhdunarodnaya-studencheskaya-migratsiya/viewer

54. Cassiman, B., Veugelers, R. (2006). In search of complementarity in innovation strategy: internal R\&D and external knowledge acquisition. Manage Sci. 52 (1), pp.68-82 DOI: $10.1287 / \mathrm{mnsc} .1050 .0470$

55. Centr mizhnarodnyh proektiv «Jevroosvita». URL : http://euroosvita.net/reytworld/

56. Clark B. Creating Entrepreneurial Universities, Organisational Pathways of Transformation / B. Clark. - Oxford/New York : Pergamon Elsevier, 1998. - 163 p.

57. Colville, S. (2009). The human factor in information security: an internal threat - who can you trust these days? INF. Security. Technical Representative.14, 186196.doi:10.1016 / J. ISTR.2010.04.004.

58. Colwill, C. (2009). Human factors in information security: the insider threat who can you trust these days? Inf. Secur. Tech. Rep. 14, 186-196. doi: 10.1016/j.istr.2010.04.004.

59. Crow M. M. The American Research University System as America's de facto Technology Policy / M. M. Crow, C. Tucker // Science and Public Policy. - 2001. - Vol. 28. - Is.1. - P. 2-10.

60. Current cyber threats-2017: Trends and Forecasts (2018), Positive Technologies, [online]. URL: https://www.ptsecurity.com/ru-ru/research/analytics / (accessed June 30, 2020).

61. Current cyber threats-2018: Trends and Forecasts (2019), Positive Technologies, [online]. URL: https://www.ptsecurity.com/ruru/research/analytics/cybersecurity-threatscape-2018 / (accessed June 30, 2020). 
62. Current cyber threats: results of 2019 (2020), Positive Technologies, [online]. URL: https://www.ptsecurity.com/ru-ru/research/analytics/cybersecurity-threatscape2018 / (accessed June 30, 2020)

63. D’Antoni S. The virtual university: Models and messages [Електронний pecypc]. Режим доступу http://unesdoc.unesco.org/images/0014/001465/146558e.pdf.

64. Decree of the President of Ukraine «On the national strategy for the development of education in Ukraine for the period up to 2021", dated June 25, 2013 URL: https://закон.рада.правительство.иа/законы/показать/344/2013\#Текст

65. Dehghan Nabi Allah. Presentation of Creativity and Innovation Model at Army Officer Universities of the Islamic Republic of Iran Based on Imam Khomeini's Prophets / Dehghan Nabi Allah, Fathi Samad, Hooshiar Akbar // Journal of Scientific Research on Military Management. - 2012. - No. 48. - P. 158-113.

66. Dobroskok I. Monitoryng jakosti vyshhoi' osvity: definityvnyj analiz// Gumanitarnyj visnyk DVNZ «Perejaslav-Hmel'nyc'kyj derzhavnyj pedagogichnyj universytet imeni Grygorija Skovorody»: nauk.-teoret. zb.. 2008. №16. S. 50-57.

67. Doroga k akademicheskomu sovershenstvu: Stanovlenie issledovatel'skih universitetov mirovogo klassa / pod red. F. Dzh. Al'tbaha, D. Salmi; per. s angl. - M.: Izdatel'stvo «Ves' Mir», 2012 - 416 s.

68. Dudikevich V. B., Maksimovich V. N., Mikitin G. V. Strategy of security of Cyberfysical Systems / / Information Technologies in management, education, science: monograph/ ed. by V. S. Ponomarenko - Kh.: FOP publishing house V. V. Petrov, 2016.464 P. (pp. 286-300).

69. Elken Mari \& Stensaker Bjørn (2018). Conceptualising 'quality work' in higher education, Quality in Higher Education, 24(3), 189-202, DOI: 10.1080/13538322.2018.1554782

70. Entsyklopediia osvity. Akad. ped. nauk Ukrainy; holov. red. V.H.Kremen; [pidhot.: Avsheniuk N.M. ta in.]. Kyiv : Yurinkom Inter, 2008. 1036 s.

71. Estermann T.(2013). Setting the context: University Autonomy \& Funding in Europe: ATHENA Workshop Ukraine -Fostering Sustainable and Autonomous $\begin{array}{lllll}\text { Higher } & \text { Education } & \text { Institutions, } & 6 & \text { November }\end{array}$ URL:http://www.eua.be/events/past/2013/ATHENA-Workshop-Ukraine/ 
Presentations.aspx

72. Etzkowitz H. The Triple Helix: University-Industry-Government Innovation In Action / H. Etzkowitz. - London : Routledge, 2008. - 164 p.

73. European Commission - Organisation for Economic Co-operation and Development) (EC-OECD). A Guiding Framework for Entrepreneurial Universities. URL:https://www.oecd.org/site/cfecpr/EC-

OECD\%20Entrepreneurial\%20Universities\%20Framework.pdf

74. Eurostat. URL: https://ec.europa.eu/eurostat/data/database

75. Evseev S. and others. Development and analysis of game theoretical models of interaction between security agents. // Eastern European Journal of Corporate Technologies. 2020. 2/4(104). P. 15-29.

76. Evseev S. and others. Development of an improved method for compressing video information resources in navigation and motion control systems. // Eureka: physical sciences and technology, No. 5. - 2020. pp. 31-42.

77. Evseev S. and others. Improvement of methods for assessing project risks in the implementation of automated information components of non-commercial organizational and technical systems. //Eureka: physical sciences and technology, No. 1 - 2020. pp. 48-55

78. Evseev S., Ponomarenko V., Raevneva O. (2017). Assessment of the functional effectiveness of the corporate scientific and educational network based on comprehensive service quality indicators. // Eastern European Journal of Corporate Technologies, 6/2 (90), P.4-15 http://journals.uran.ua/eejet/article/view/118329

79. Evseev Sergey, Korolev Roman, Tkachev Andrey, Laptiev Alexander, Opirsky Ivan, Solovyova Olga. Modification of the S-box algorithm (OFM), which provides an increase in cryptographic strength in the post-quantum period. International Journal of advanced trends in Computer Science and engineering. Volume 9, No. 5, September - October 2020 P/8725-8729.

80. Fathutdynov R.A. Ynnovacyonnыj menedzhment / R.A. Fathutdynov ; 4-e yzd. - SPb. : Pyter, 2003. - $400 \mathrm{~s}$.

81. Fedulova L. Innovatsiina ekosystema universytetu. Visnyk KNTEU, 2016, 4, $162-177$.

82. Fedulova L.I., Marchenko O.S. Innovatsiini ekosystemy: sutnist ta 
metodolohichni zasady formuvannia. Ekonomichna teoriia ta pravo. 2015, 2(21)

83. Filatov V.M., Romashova Ja. V. Specyfichni oznaky osvitn'oi' migracii' ta i'i' misce $\mathrm{v}$ strukturi migracijnyh potokiv. Efektyvna ekonomika. 2014. № 2. URL : http://www.economy.nayka.com.ua/?op=1\&z=2785

84. Formuvannja seredovyshha osvitn'oi' migracii' naselennja Karpats'kogo regionu: pidhid do ocinjuvannja. Metodychni rekomendacii'. Za nauk. redakcijeju d.e.n., prof. T. G. Vasyl'civa. L'viv : DU «Instytut regional'nyh doslidzhen' imeni M.I. Dolishn'ogo NAN Ukrai'ny». 2019. 32 c. URL : http://ird.gov.ua/irdp/p20190038.pdf

85. Free Universities. Putting the Academic Freedom Index Into Action / K.Kinzelbach, I.Saliba, J.Spannagel, \& R.Quinn. From Report of Gllobal Public Policy Institute [електронний pecypc]. https://www.gppi.net/media/KinzelbachEtAl_2020_Free_Universities.pdf

86. Fëdorova P. S. Orhanyzatsyia obrazovatelnoi sredы sovremennoho vuza: psykholohycheskyi aspekt / P. S. Fëdorova // Yaroslavskyi pedahohycheskyi vestnyk. 2011, 3 - Tom II (Psykholoho-pedahohycheskye nauky), 238-241.

87. Galicin V.K. Sistemy monitoringa. K.: KNEU, 2000. 232 s.

88. Galicyn V. K., Suslov O. P., Samchenko N. K. Konceptual'ni zasady monitoryngu. Biznes Inform. 2013. №9. S. 330-335.

89. Galvao Anderson. Triple helix and its evolution: a systematic literature review [Електронний ресурс] / Galvao Anderson, Mascarenhas Carla, Marques Carla, Ferreira João, Ratten Vanessa // Journal of Science and Technology Policy Management. - 2019. - № 10 (3). - P. 812-833. - doi:10.1108/jstpm-10-2018-0103. - Режим доступу : https://www.emerald.com/insight/content/doi/10.1108/JSTPM-10-2018-0103/full/html

90. Giorgio Marinoni, Hilligje van't Land, Trine Jensen. “The impact of COVID19 on higher education around the world", IAU Global Survey Report, the International Asso-ciation of Universities, May 2020. [Електронний ресурс]. - Режим доступу : https://www.iau-

aiu.net/IMG/pdf/iau_covid19_and_he_survey_report_final_may_2020.pdf

91. Glavnye otlichija sistem obrazovanija SShA i Velikobritanii [Jelektronnyj resurs]. - Rezhim dostupa : https://www.ef.ru/blog/language/glavnye-otlichija-sistemobrazovanija-velikobritanii-i-ssha/

92. Golubev S.V. Social'no-predprinimatel'skij vuz: vozmozhnost' razvitija dlja 
regional'nyh vuzov / S.V. Golubev // Obshhestvennye nauki. Vserossijskij nauchnyj zhurnal. - 2010. - № 4. - S. 11-21.

93. Goncharov S.M., Kushnir N.B. Tlumachnyj slovnyk ekonomista [Za red. prof. S.M. Goncharova]. Kyi'v : Centr uchb. lit., 2009. 264 s.

94. Gorbatjuk O. V. Osobystisno orijentovanyj pidhid do navchannja v VNZ u suchasnyh umovah // Zbirnyk naukovyh prac' Kam'janec'-Podil's'kogo nacional'nogo universytetu im. Ivana Ogijenka. Serija: Pedagogika. 2014. Vyp. 20. S. 252-253.

95. Grischuk R., Evseev S., Shmatko A. Methodology of building an information security system for banking information in automated banking systems. monograph: Premier Publishing s.r.o., 2018. - 284 P.

96. Grudzinskij A.O. Universitet kak predprinimatel'skaja organizacija / A.O. Grudzinskij // Sociologicheskie issledovanija. - 2004. - № 4. - S. 113-121.

97. Gryn'kevych O. S. Upravlinnja konkurentospromozhnistju vyshhoi' osvity v Ukrai'ni: instytucijnyj analiz i monitoryng. L'viv: LNU imeni Ivana Franka. 2018. URL: https://www.lnu.edu.ua/wp-content/uploads/2018/08/dis_hrynkevych.pdf

98. Gryn'kevych O.S. Osvitnja migracija v Ukrai'ni ta sviti: instytucijne seredovyshhe ta naprjamy derzhavnogo reguljuvannja. Social'no-ekonomichni problemy suchasnogo periodu Ukrai'ny. 2013. Vyp. 3(101). S. 254-264.

99. GSPEA. Institutional Autonomy and the Protection of Higher Education from Attack: A research study of the Higher Education Working Group of the Global Coalition to Protect Education from Attack (December 2013) [електронний ресурс]. Режим доступу: https://protectingeducation.org/publication/institutional-autonomy-andthe-protection-of-higher-education-from-attack

100. Guide to restoring cybersecurity events. [Online]. URL: https://nvlpubs.nist.gov/nistpubs/...NIST.SP.800-184.pdf (accessed February 1, 2020)

101. Gusak L.Je. Koncept avtonomii' universytetu v konteksti globalizacijnyh procesiv: istorychnyj aspekt / L.Je. Gusak, L.A. Martyrosjan // Balkan Scientific Review. - 2020. - T. 4., № 1(7). - S.17-22.

102. Haba I. M. Sotsialno-psykholohichni osoblyvosti proektuvannia osvitnoho seredovyshcha vnz u konteksti rozvyvalnoho potentsialu. Visnyk Chernihivskoho natsionalnoho pedahohichnoho universytetu. Seriia: Psykholohichni nauky. 2015, 128, 
103. Haba I. M. Vplyv osvitnoho seredovyshcha VNZ na profesiinyi rozvytok osobystosti. Problemy zahalnoi ta pedahohichnoi psykholohii : zbirnyk naukovykh prats Instytutu psykholohii im. H.S. Kostiuka APN Ukrainy / [za red. S.D. Maksymenka]. K., 2011. T. XIII. Ch. 6, 74-82.

104. Homyshyn I. Prychyny ta naslidky osvitnih migracij. URL : http://science.lpnu.ua/sites/default/files/journal-paper/2019/sep/18377/18.pdf

105. Horchakova O.A. Seredovyshchnyi pidkhid do upravlinnia navchalnym zakladom v umovakh polikulturnosti / O.A. Horchakova // Visnyk Cherkaskoho universytetu. Vypusk 209. Chastyna 1. Seriia Pedahohichni nauky. Cherkasy. 2011, 8-15.

106. Horta Hugo. Global and national prominent universities: internationalization, competitiveness and the role of the State / Horta Hugo // Higher Education. - 2009. - No. 58. - P. 387-405.

107. Hryshchuk R., Construction methodology of information security system of banking information in automated banking systems : monograph / R. Hryshchuk, S. Yevseiev, A.Shmatko //- Vienna.: Premier Publishing s. r. o., 2018. - 284 p.

108. Huisman J., Smolentseva A., Frumin I. (Ed.) (2018). 25 years of transformation of higher education systems in post-Soviet countries. Reform and continuity. Palgrave Studies Global Higher Education. URL: https://doi.org/10.1007/9783-319-52980-6

109. IAU - COVID-19 Global Impact Survey [Електронний ресурс]. - Режим доступу https://www.iauaiu.net/IMG/pdf/iau_covid19_and_he_survey_report_final_may_2020.pdf

110. Ielnykova H. V., Borova, O. M. Kasianova, H. A. Poliakova ta in. Adaptyvne upravlinnia: sutnist, kharakterystyka, monitorynhovi systemy: Kolektyvna monohrafiia / Za zah. red. H. V. Yelnykovoi. Chernivtsi: Tekhnodruk, 2009, 572 s.

111. Il'nyc'kyj D. O. Akademichne pidpryjemnyctvo $\mathrm{v}$ systemi chynnykiv mizhnarodnoi' konkurentospromozhnosti nacij [Elektronnyj resurs]. - Rezhym dostupu : https://ir.kneu.edu.ua/bitstream/handle/2018/30759/yevro_resurs13.pdf? sequence $=1 \&$ is Allowed $=\mathrm{y}$

112. ILO Sectoral Brief: COVID-19 and the education sector. [Електронний pecypc]. - Режим доступу : https://www.ilo.org/sector/Resources/ 
publications/WCMS_742025/lang--en/index.htm

113. Informacijnyj bjuleten' №19 z pytan' zovnishn'oekonomichnoi' dijal'nosti: vplyv COVID-19 na dijal'nist' HEI [Elektronnyj resurs]. - Rezhym dostupu : http://forea.kpi.ua/

114. Innovacii' u vyshhij osviti: vitchyznjanyj i zarubizhnyj dosvid: navch. posib. / I. V. Art'omov, I. P. Studenjak, J. J. Golovach, A. V. Gus'. - Uzhgorod : PP «AUTDORShARK», 2015. - $360 \mathrm{~s}$.

115. Innovacii' v osviti i nauci okremyh krai'n Jevropy, Azii' ta Ameryky: informacijnyj bjuleten' naukovogo proektu «Innovacijnyj universytet - instrument integracii' v jevropejs'kyj osvitnij i naukovyj prostir» [Elektronnyj resurs] / Za zag. red. I.V. Art'omova. - Uzhgorod : PP «AUTDOR-ShARK», 2005. - Vyp. 4. - 205 s. Rezhym dostupu : https://www.uzhnu.edu.ua/uk/infocentre/get/9721

116. Innovacijnyj universytet: koncepcija stanovlennja i rozvytku : monografija [Elektronnyj resurs] / I.V. Art'omov, I.P. Studenjak, S.I. Ustych ta in.; za zag. red. I.V. Art'omova. - Uzhgorod : DVNZ «UzhNU», 2016. - Vyp. 30. Serija «Jevrointegracija: ukrai'ns'kyj vymir». $\quad-\quad 524 \quad$ s. $\quad$ Rezhym dostupu https://dspace.uzhnu.edu.ua/jspui/bitstream/lib/22130/1/\%D1\%96\%D0\%BD\%D0\%BD \%D0\%BE\%D0\%B2\%D0\%B0\%D1\%86_\%D1\%83\%D0\%BD\%D1\%96\%D0\%B2\%D0 $\%$ B5\%D1\%80_.PDF

117. Innovating Pedagogy 2014. Exploring new forms of teaching, learning and assessment, to guide educators and policy makers. Open University Innovation Report 3 / Mike Sharples and others. - The Open University, 2014. - 41 p. - Режим доступу: http://www.openeducationeuropa.eu /sites/default/files/news/Innovating_Pedagogy_2014.pdf

118. Innovatsiini doslidnytski universytety yak chynnyk modernizatsii osvitnonaukovoi sfery ta rozbudovy suspilstva znan. Analitychna zapyska. Natsionalnyi instytut sotsialnykh doslidzhen. 15.01.2014 Rezhym dostupu: https://niss.gov.ua/doslidzhennya/gumanitarniy-rozvitok/innovaciyni-doslidnickiuniversiteti-yak-chinnik-modernizacii

119. Inozemni studenty v Ukrai'ni: statystychni dani, 2020. / Ukl. : O. O. Shapovalova. Kyi'v: UDCMO. $2020.60 \quad$ s. $\quad$ URL: https://iraq.mfa.gov.ua/storage/app/sites/36/uploaded-files/student2020.pdf 
120. IUBH Universities of Applied Sciences [Електронний ресурс]. - Режим доступу https://graphics.reuters.com/EUROPE-UNIVERSITYINNOVATION/010091N02HR/index.html

121. Iwinska J. University autonomy: A practical handbook. / J. Iwinska, L.Matei. - Budapest: Central European University. - 74 p.

122. Kachalova L. P. Ynnovacyonnaja obrazovatel'naja sreda kak faktor formyrovanyja pedagogycheskoj kul'turы u studentov vuza - budushhyh uchytelej / L. P. Kachalova, D. V. Kachalov // INTERNATIONAL JOURNAL OF APPLIED AND FUNDAMENTAL RESEARCH. - 2011. - № 9. - S. 34-36.

123. Karpov A.O. Sovremennыj unyversytet kak drajver эkonomycheskogo rosta: modely y myssyy. Voprosы эkonomyky. 2017. № 3. C. 58-76.

124. Karpov A.O. Sovremennыj unyversytet: sreda, partnerstva, ynnovacyy / A.O. Karpov // AlmaMater. Vestnyk Vыsshej shkolы. - 2014. - № 8. - S. 8-12.

125. Kazakov V. G. Kachestvo obrazovanyja / V. G. Kazakov. - Orenburg : VD «A.M.R.», 2001. - $142 \mathrm{~s}$

126. Kerr C. Higher Education Cannot Escape History, Issues for the Twenty-first Century / C. Kerr. - Albany: State University of New York Press, 1994. - 247 p.

127. Kljachko T. Germano-rossijskaja i anglosaksonskaja sistemy obrazovanija [Jelektronnyj resurs] / T. Kljachko. - Rezhim dostupu : https://postnauka.ru/video/19570

128. Kochan Roman, Evseev Sergey, Korolev Roman, Milevsky Stanislav, Ireifidge Imad, Gancharczyk Tomasz and Shklyarczyk Rafal. Development of methods for improving cryptographic transformations in block-symmetric code. 5th IEEE International Symposium on intelligent and wireless systems within the framework of international conferences on intelligent data collection and advanced computing systems. September 17-18, 2020 pp. 130-138.

129. Kolodiziev O. Project finance risk management for public-private partnership / O. Kolodiziev, V. Tyschenko, K. Azizova // Investment Management and Financial Innovations. - 2017. - № 14(4). - P. 171-180.

130. Konanchuk D. Goryzontы razvytyja vыsshego obrazovanyja. [Elektronnyj resurs]. - Rezhym dostupu : http://trends.skolkovo.ru/2015/09/gorizontyi-razvitiyavyisshego-obrazovaniya/

131. Koncepcija innovacijnogo rozvytku DVNZ «Uzhgorods'kyj nacional'nyj 
universytet» na 2015-2025 rr. Uzhgorod, 2016. URL: https://www.uzhnu.edu.ua/uk/infocentre/get/8662 (data zvernennja: 24.11.2020).

132. Konceptual'no-metodologichni osnovy proektuvannja metodiv i zasobiv diagnostyky osvitnih rezul'tativ u vyshhyh navchal'nyh zakladah: monografija / Za zag. red. V. I. Lugovogo, O. G. Jaroshenko. Kyi'v : «Pedagogichna dumka», 2014. 234 s.

133. Kononova I.V. Analiz pidhodiv do upravlinnja pidpryjemstvom u suchasnyh umovah / I.V. Kononova // Prometej. - 2013. - № 1(40). - S. 146-151.

134. Konstantinov G. N. Chto takoe predprinimatel'skij universitet / G. N. Konstantinov, S. R. Filonovich // Voprosy obrazovanija, 2007. - № 1. - S. 49-62.

135. Kontseptualni zasady stanovlennia innovatsiinoho suspilstva v Ukraini : monohrafiia / kol. avt.: H. P. Klimova, S. M. Ivanov, L. S. Shevchenko ta in. ; za red. Yu. Ye. Atamanovoi, H. P. Klimovoi. Kh. : Pravo, 2015, 452 s

136. Koroleva S. V. Upravlenie kachestvom v obrazovanii: uchebnometodicheskoe posobie / S. V. Koroleva. - Ekaterinburg: [b. i.], 2018. - 360 s.

137. Kotsemir M. N., Abroskin A. S., Dirk M. Innovation concepts and typology - an evolutionary discussion : basic research program. National Research University Higher School of Economics, 2013. 49 p.

138. Kremen V. H., Bykov Yu. Katehorii "prostir" i "seredovyshche": osoblyvosti modelnoho podannia ta osvitnoho zastosuvannia. Teoriia i praktyka upravlinnia sotsialnymy systemamy. 2013, 2, 3-16.

139. Kremer S., Carayon P., and Clem J. (2009). Human and organizational factors in computer and information security: paths to vulnerabilities. By calculating. Pp. 28, 509-520.doi: 10.1016/j.cose.2009.04.006. doi: 10.1016/j.cose.2009.04.006.

140. Kuliutkyn Yu. Obrazovatelnaia sreda y razvytye lychnosty / Yu. Kuliutkyn, S. Tarasov. // Novыe znanyia. Zhurnal po problemam obrazovanyia vzroslykh. - 2001. № 1. [Эlektronnыi resurs] - Rezhym dostupa: http://www.znanie.org/jornal/ n1_01/ obraz_sreda.html.

141. Kyrijenko O. Rezul'taty vseukrai'ns'kogo onlajn opytuvannja «Reformuvannja osvity zseredyny: tochka zoru predstavnykiv osvitjans'kogo seredovyshha» sered naukovo-pedagogichnyh pracivnykiv ta administracii' zakladiv vyshhoi' osvity traven'--cherven' 2018 r. / O. Kyrijenko; kerivnyk doslidzhennja : S. Zajec'. - Kyi'v : Derzhavna naukova ustanova «Instytut modernizacii' zmistu osvity», 
2018. $-43 \mathrm{~s}$.

142. Labuns'ka S.V., Sobakar M.V. HEI jak platforma dlja rozrobky innovacijnogo produktu: na prykladi udoskonalennja metodychnyh pidhodiv do upravlinnja vytratamy innovacijnoi' dijal'nosti pidpryjemstva / Naukovyj pogljad: ekonomika ta upravlinnja. 2020. № 3(68). S. 145-152.

143. Labunska S.V., Sobakar M.V. Justification of creation, identification and evaluation of intangible assets on the platform of innovative HEI. Економічний розвиток i спадщина Семена Кузнеця : тези доповідей Міжнародної науково-практичної конференції, м. Харків, 26-27 листопада 2020p. С. 210-211.

144. Lanovska H.I. Innovatsiina ekosystema: sutnist ta pryntsypy. Ekonomika i suspilstvo. Mukachivskyi derzhavnyi universytet. 2017, 11, 257-262

145. lekseeva K. M. Osobennosti i perspeaktivy obrazovatel'noj migracii v jepohu global'nyh transformacij. Vestnik Mosk. un-ta. Ser. 18. Sociologija i politika. 2012. № 4 . S. 113-136.

146. Leydesdorff Loet. The Knowledge-Based Economy and the Triple Helix Model [Електронний ресурс] / Leydesdorff Loet. - Amsterdam : University of Amsterdam, Amsterdam School of Communications Research, 2014. - Режим доступу : https://www.leydesdorff.net/arist09/arist09.pdf

147. Liashenko O.I. Yakist osvity yak osnova funktsionuvannia y rozvytku suchasnykh system osvity. Pedahohika i psykholohiia. 2005, 1(46), 5-12.

148. Ljashenko O. V. Organizacijno-metodychni zasady monitoryngu jakosti osvity / O. V. Ljashenko // Pedagogika i psyhologija. - 2007. - № 2. - S. 34-40.

149. Loi M. The third mission of universities: An investigation of the espoused values / M. Loi, M. C. Di Guardo // Science and Public Policy. - 2015.- Vol. 42. - P. 855870.

150. Lokshytna O. I. Monitoryng jakosti osvity: svitovi dosjagnennja ta ukrai'ns'ki perspektyvy / O. I. Lokshytna. - Kyi'v : K.I.S, 2004. - 240 s.

151. Lukina T. Monitoryng v osviti. Jakist' v osviti: vyznachaty, shhob ocinyty / T. Lukina // Upravlinnja osvitoju. - 2004. - № 22 (94). - S. 1-5.

152. Lukina T. Monitorynh v osviti. Yakist v osviti: vyznachaty, shchob otsinyty. Upravlinnia osvitoiu. 2004, 22 (94), 1-5.

153. Lytvynova S. Rozvytok navchalnoho seredovyshcha zahalnoosvitnoho 
navchalnoho zakladu yak naukova problema. Naukovyi visnyk Melitopolskoho derzhavnoho pedahohichnoho universytetu; I. Anosov (hol. red.). Seriia: Pedahohika. Melitopol, 2014, 1(12), 39-47.

154. Majer G. V. Klassicheskie universitety: sovremennost' i perspektivy / G. V. Majer, M. D. Babanskij // Universitetskoe upravlenie. - 2000. - № 2 (13). - S. 21.

155. Marginson S. Dynamics of national and global competition in higher education / S. Marginson // Higher Education. - 2006. - № 52 (1). - P. 1-39.

156. Martynets L.A. Upravlinnia osvitnim seredovyshchem profesiinoho rozvytku uchyteliv u zahalnoosvitnomu navchalnomu zakladi : Monohrafiia. Vinnytsia: DonNU imeni Vasylia Stusa, 2017. 408 s.

157. Maslennikov Ye.I., Kuznietsov E.A., Safonov Yu.M., Filyppova S.V. ta inshi. Innovatsiina ekonomika: teoretychni ta praktychni aspekty: monohrafiia Vyp. 1/ za red. d.e.n., dots. Ye.I. Maslennikova. Kherson: Hrin D.S., 2016, 854 s.

158. Migracija v Ukrai'ni: cyfry i fakty, 2019. URL: https://iom.org.ua/sites/default/files/iom-ukraine_facts-ukr_2019.pdf

159. Milov O., Grebenyuk O., Nalyvaiko O., Nemkova E., Opirsky I., Pasko I., Kh. Rzaev A. Saliy, Sinitsina U., Solovyova O. Development of the spatial and temporal structure of the methodology for modeling the behavior of antagonistic agents of the security system/ edited by the Eastern European Journal of Corporate Technologies 2020. 6/2 (108) 2020. pp. 30-52.

160. Milov O., Hrebeniuk A., Nalyvaiko A., Nyemkova E., Opirskyy I., Pasko I., Rzayev Kh., Salii A., Synytsina U., Soloviova O. Development of spatial-time structure of methodology for modeling the behavior of antagonistic agents of the security system/ в редакції, Eastern-European Journal of Enterprise Technologies 2020. 6/2 ( 108 ) 2020. Р. 30-52.

161. Mokyr, J. (2002). Innovation in an historical perspective: tales of technology and evolution, in Steil, B., Victor, G. and Nelson, R.R. (Eds.): Technological Innovation and Economic Performance, Princeton University Press, Princeton. P.23-46

162. Monitoring i ocenka vnedrenija gibkoj formy upravlenija $\mathrm{v}$ vuzah: analiticheskij otchet [Jelektronnyj resurs]. - Astana : AO «Informacionno-analiticheskij centr» Ministerstva nauki i obrazovanija respubliki Kazahstan, 2016. - 312 s. - Rezhim dostupa 
http://iac.kz/sites/default/files/49._monitoring_i_ocenka_vnedreniya_gibkoy_formy_v_v uzah.pdf

163. Moodie G. On justifying the different claims in academic freedom // Minerva. - L., 1996. - Vol. 34. - №2. - P. 139.

164. Morgulec' O.B. Upravlinnja vyshhym navchal'nym zakladom jak sub'jektom rynku : monografija / O. B. Morgulec'. - K. : KNUTD, 2017. - 454 s.

165. Muzalevskaya O. A. Manifestations of corruption in the education system [Electronic resource]:

access mode: http://www.mosgu.ru/nauchnaya/publications/SCIENTIFICARTICLES/2006/Ma zulevskaja/

166. Novykov V.N. Obrazovatelnaia sreda vuza kak professyonalno y lychnostno stymulyruiushchiy faktor [Elektronnyiy resurs]. "Psihologicheskaya nauka i obrazovanie", $2012,1$. Rezhym dostupa: http://www.psyedu.ru/files/articles/psyedu_ru_2012_1_2776.pdf

167. Ordorika I. The Limits of University Autonomy: Power and Politics at the Universidad Nacional Autónoma de México / I. Ordorika // Higher Education. -2003. Vol. 46, Is.3. - p. 361-388/

168. Ouэn H. Pryzvanye - lyder: Polnoe rukovodstvo po эffektyvnomu liderstvu / H. Ouэn. - Dnepropetrovsk : Balans Byznes Buks, 2005. - 384 s.

169. Parsjak K. Pobudova systemy upravlinnja jakistju osvitnih poslug u strukturnomu pidrozdili vnz / K. Parsjak // Visnyk ekonomichnoi' nauky Ukrai'ny. - 2013. - № 2. - S. 124-127.

170. Plotnykov M. TQM 14 bazovыh polozhenyj menedzhmenta na osnove kachestva / M. Plotnykov // Menedzhment y menedzher. - 2008. - № 11-12. - S. 66-68.

171. Poliakova H. A. Diialnist kafedry $\mathrm{v}$ konteksti rozvytku osvitnoho seredovyshcha zakladu vyshchoi osvity. Teoretychnyi ta naukovo-metodychnyi chasopys «Vyshcha osvita Ukrainy». Tematychnyi vypusk «Ievropeiska intehratsiia vyshchoi osvity Ukrainy v konteksti Bolonskoho protsesu». 2013, 3 (dodatok 2), 103-108.

172. Poliakova H.A. Adaptyvnist osvitnoho protsesu v systemi vnutrishnoho zabezpechennia yakosti v zakladi vyshchoi osvity. Adaptyvni protsesy v osviti : zbirnyk materialiv 6-ho Vseukrainskoho naukovoho forumu z mizhnarodnoiu uchastiu; [za nauk. red. H. V. Yelnykovoi, M. L. Rostoky; red. kol. z zah. pytan: L. O. Luzan, O. O. 
Pochuieva, Z. V. Riabova]. Kharkiv, Machulyn, 2021, 3, 66-68.

173. Poliakova H.A. Sutnist upravlinnia innovatsiinym rozvytkom vyshchoho navchalnoho zakladu. Innovatsiinyi rozvytok vyshchoi osvity: hlobalnyi ta natsionalnyi vymiry zmin : materialy II Mizhnarodnoi naukovo-praktychnoi konferentsii (26-27 bereznia 2015 roku, m. Sumy). - Tom I. Sumy : Vyd-vo SumDPU imeni A.S. Makarenka, 2015, 336 - 339.

174. Poliakova H.A., Bilokonenko H.V. Rozvytok osvitnoho seredovyshcha innovatsiino-aktyvnoho universytetu: osoblyvosti ta kryterii. Problemy ekonomiky. 2020, 4(46), 279-293.

175. Poliakova H.A., Danylenko I.S. Rozvytok komandnoho liderstva v osvitnomu seredovyshchi zakladu osvity. Zbirnyk naukovykh prats «Pedahohichni nauky», 2020, 92-93, $14 \neg 20$

176. Poljakova G. A. Organizacijna struktura ta vzajemodija v system adaptyvnogo upravlinnja vnutrishnim zabezpechennjam jakosti u HEI / G. A. Poljakova // Adaptyvni systemy upravlinnja v osviti : zbirnyk materialiv IV Vseukrai'ns'kogo naukovogo forumu; uporjad. M. L. Rostoka; red. kol.: G. V. Jel'nykova (golova), G. Ju. Kravchenko, L. O. Luzan, M. L. Rostoka,. Z. V. Rjabova. - Harkiv : Machulyn : FOP Ozero G. V., 2019. - S. 27-30.

177. Ponomarenko V. Autonomy of Higher Education System: In What Direction We Are Moving? / V. Ponomarenko, O. Rayevnyeva, K. Stryzhychenko // Asian Journal of Applied Sciences. - 2016. - Vol. - Is.05. - P. 1179-1185

178. Ponomarenko V., Rayevnyeva O., Stryzhychenko K. Investigation of Demand and Stability of Ukrainian Educational Market. // Asian Journal of Applied Sciences (ISSN: 2321 - 0893) Volume 03 - Issue 01, February 2015 - P. 50-58 . - Режим доступу: https://ajouronline.com/index.php/AJAS/article/view/2187

179. Ponomarenko V., Rayevnyeva O., Yermachenko V., Aksonova I. and Brovko O. (2021). Digitalization as a development factor of innovative-active university. Problems and Perspectives in Management, 19(4), 213-231. doi:10.21511/ppm.19(4).2021.18

180. Pro vyshchu svitu. Zakon Ukrainy (2014). Vidomosti Verkhovnoi Rady (VVR), 2014, № 37-38, st.2004. Rezhym dostupu: https://zakon.rada.gov.ua/laws/show/1556-18\#Text 
181. QS Graduate Employability Rankings [електронний ресурс]. - Режим доступу: https://www.topuniversities.com/employability-rankings/methodology

182. QS World University Rankings [електронний ресурс]. - Режим доступу: https://www.topuniversities.com/qs-world-university-rankings

183. Quality assurance and accreditation: A glossary of basic terms and definitions, compiled by Vlăsceanu, L., Grünberg, L., \& Pârlea, D. (2007). Bucharest: UNESCO. Retrieved from: http: //unesdoc.unesco.org/images/0013/001346/134621e.pdf [in English].

184. Quality Management of education in higher educational institutions [text]: Textbook.: in 2 parts. Part 1: Theoretical foundations of the formation of quality management systems for providing educational services / Col. Auth.; for zag . edited by CHL.- COR. of the National Academy of Sciences of Ukraine V. S. Zagorsky. Lviv : LRIDU Nadu publ., 2011, 136 p. (in Russian).

185. Rayevnyeva O. Assessment of institutional autonomy of higher education institutions: methodical approach. / Olena Rayevnyeva, Iryna Aksonova and Viktoriia Ostapenko // Knowledge and Performance Management. - 2018. - Vol. 2- Is.1 . - P. 7284.

186. Rayevnyeva O. V., Brovko O. I. Modeli universytets'koi' avtonomii' zakladiv vyshhoi' osvity // Vzdelávanie a spololčnost' III. Medzinárodný nekonferenčný zborník. Prešov, 2018. S. 109-116. URL: http://www.pulib.sk/web/kniznica/elpub/doku-1 ment/Bernatova10/subor/Rayevnyeva_Brovko.pdf

187. Rayevnyeva O., Aksonova I., Ostapenko V. Formation interaction and adaptive use of purposive forms of cooperation of university and enterprise structures. Innovative Marketing. 2018. Volume 14. Issue 3. P. 44-56. URL: https://businessperspectives.org/journals/innovative-marketing/issue-296/formationinteraction-and-adaptive-use-of-purposive-forms-of-cooperation-of-university-andenterprise-structures

188. Rayevnyeva O., Stryzhychenko K. Autonomy of the system of higher education in the conditions of integration of Ukraine into the European educational area // Problems and Perspectives in Management. Volume 16, Issue \#3, 2018 - P. 501-510. Режим доступу: https://businessperspectives.org/author/olena-rayevnyeva

189. Rayevnyeva O.V. Avtonomija universytetu i evoljucijni etapy i'i' rozvytku. / 
O. V. Rayevnyeva, K. Stryzhychenko // Efektyvna ekonomika. - 2016. - № 2. - Rezhym dostupu: http://www.economy.nayka.com.ua/pdf/2_2016/3.pdf

190. Rejtyng luchshyh unyversytetov myra po versyy Quacquarelli Symonds [Elektronnyj resurs]. - Rezhym dostupu : https://gtmarket.ru/ratings/qs-world-universityrankings

191. Rejtyng predprynymatel'skyh unyversytetov y byznes-shkol - 2019 : ЭKSPERT (Analytycheskyj centr) [Elektronnyj resurs]. - Rezhym dostupu : http://www.acexpert.ru/analytics/ratings/reyting-predprinimatelskih-universitetov-ibiznes-.html).

192. Rekomendacii' dlja pokrashhennja jakosti vyshhoi' osvity v Ukrai'ni [Elektronnyj resurs]. - Rezhym dostupu : https://cutt.ly/ZhmJO3s

193. Revak I. O. Corruption: Theoretical and methodological foundations of research: monograph / I. O. Revak. LVI:: Lvduvs Publ., 2011, 220 P. (In Russian).

194. Rezul'taty zagal'nonacional'nogo opytuvannja «Perspektyvy ta potreby rozvytku universytetiv Ukrai'ny u procesi reformuvannja vyshhoi' osvity u konteksti jevropejs'koi' integracii'» / za zag. red S. Kalashnikovoi'. - Kyi'v : Instytut vyshhoi' osvity NAPN Ukrai'ny, 2019. - 77 s.

195. Richnyj zvit Nacional'nogo agentstva iz zabezpechennja jakosti vyshhoi' osvity za 2019 rik / za zag. red. prof. Sergija Kvita. - Kyi'v : Nacional'ne agentstvo iz zabezpechennja jakosti vyshhoi' osvity, 2020. - 244 s.

196. Rimskij V.L. Korrupcija v sisteme obrazovanija Rossii [Jelektronnyj resurs]: - Rezhim dostupa: https://imrussia.org/media/pdf/Research/Vladimir_Rimsky__Corruption_of_the_Russia n_Education_System.pdf

197. Rimsky. V. L. Corruption in the Russian education system [Electronic resource]:

access mode: https://imrussia.org/media/pdf/Research/Vladimir_Rimsky_Corruption_of_the_ Russian_Education_System.pdf

198. Rjazancev S.V. Trudovaja mygracyja v stranah SNG y Baltyy. Moskva : Formula prava. 2007. $576 \mathrm{~s}$.

199. Romanenko Yu. A. Yakist osvity: sutnist poniattia ta otsiniuvannia. Naukovi pratsi Donetskoho natsionalnoho tekhnichnoho universytetu. Seriia: Pedahohika, 
psykholohiia ta sotsiolohiia, 2009, № 3 (145).

200. Romanovs'kyj O. O. Bazovi ponjattja ta vyznachennja pidpryjemnyc'kogo VNZ [Elektronnyj resurs] / O. O. Romanovs'kyj // Efektyvna ekonomika - 2012. - № 12. - Rezhym dostupu : http://www.economy.nayka.com.ua/?op=1\&z=1628.

201. Romanovs'kyj O.O. Fenomen pidpryjemnyctva v universytetah svitu: monografija / O.O. Romanovs'kyj - Vinnycja : Nova Knyga, 2012. - 504 s.

202. Sajt Derzhavnoi' sluzhby statystyky Ukrai'ny. URL : http://www.ukrstat.gov.ua/

203. Sajt JuNESKO. URL : https://en.unesco.org/themes/education/databases

204. Salmy Dzhamyl'. Sozdanye unyversytetov myrovogo klassa / Dzhamyl' Salmy; per. s angl. - Moskva : Yzdatel'stvo "Ves' Myr", 2009 - 132 s.

205. Salyhova Y. S. Predprynymatel'skye unyversytetы y osobennosty formyrovanyja samoobuchajushhyhsja organyzacyj v rossyjskoj эkonomyke / Y. S. Salyhova // Putevodytel' predprynymatelja. - 2015. - № 25. - S. 358-370.

206. Sardak S. E. Structure of the environment and levels of management of socioeconomic systems / S. E. Sardak // Problems of creating information technologies. 2018. - № 28. - pp. 57-64.

207. Sardak S. Э. Struktura sredы у urovnej upravlenyja socyal'noэkonomycheskyh system / S. Э. Sardak // Problemы sozdanyja ynformacyonnыh tehnologyj. - 2018. - № 28. - S. 57 - 64.

208. Savenkova Ju.S. Upravlenye konkurentosposobnost'ju vuza v sovremennыh socyal'no-эkonomycheskyh uslovyjah [Elektronnyj resurs] / Ju.S. Savenkova, A.A. Sovetkyna // Voprosы obrazovanyja. - 2009. - № 4. - S. 182-199. - Rezhym dostupu : https://cyberleninka.ru/article/n/upravlenie-konkurentosposobnostyu-vuza-vsovremennyhsotsialno-ekonomicheskih-usloviyah

209. Sbruieva, A. A. Innovatsiina ekosystema vyshchoi osvity: determinanty ta zmistovi kharakterystyky [Tekst] / A. A. Sbruieva // Profesiino-tvorcha i dukhovna samorealizatsiia osobystosti $\mathrm{v}$ evrystychnii osviti : materialy Vseukrainskoi naukovopraktychnoi konferentsii z mizhnarodnoiu uchastiu (Sumy, 19-20 lystopada 2015 r.). Sumy : SumDPU imeni A. S. Makarenka, 2015. - S. 96-100. Rezhym dostupu: https://repository.sspu.sumy.ua/bitstream/123456789/3681/1/Сбруєва_Інноваційна\%20 екосистема\%20вищої\%20освіти.pdf 
210. Schulte P. The entrepreneurial university: a strategy for institutional development // Higher Education in Europe. - 2004. - Vol. 29. - Is.2. - P. 187-193.

211. Selezneva N. A. Kachestvo vыsshego obrazovanyja kak obъekt systemnogo yssledovanyja : lekcyja-doklad / N. A. Selezneva. - Moskva : Yssled. centr problem kachestva podgotovky specyalystov, 2008. - $95 \mathrm{~s}$.

212. Semiv L.V. Osvitnja migracija jak faktor rozvytku terytorial'nyh migracijnyh system: nacional'nyj ta jevropejs'kyj aspekt. Social'no-ekonomichni problemy suchasnogo periodu Ukrai'ny. 2013. Vyp. 3(101). S. 244-253.

213. Senivoliba J.A. and Boachen, B. E. (2015). Manifestation of corruption in higher education: the role of the university administrator // Scientific journal of Educational Research and reviews, Volume 1 (3), pp. 78-88, July 2015, pp. 78-88. URL: http://pearlresearchjournals.org/journals/rjesr/index.html

214. Seniwoliba J. A. and Boahene, B.E. (2015). Manifestation of corruption in higher education: the role of the University administrator // Research Journal of Educational Studies and Review Vol. 1 (3), pp. 78-88, July, 2015, pp.78-88. URL: http://pearlresearchjournals.org/journals/rjesr/index.html

215. Sergeeva K. N. Formyrovanye konkurentosposobnoj ynnovacyonnoj эkosystemы unyversyteta: dys. ... kand. эkon. nauk : spec. 08.00.05 «Эkonomyka y upravlenye narodnыm hozjajstvom (upravlenye ynnovacyjamy)»/ K. N. Sergeeva. Moskva : B. v., 2015. - 221 s.

216. Shah Ali Ahmad. Identifying the Dimensions of Innovative University to Presentation a Model (Case Study: Islamic Azad University) / Shah Ali Ahmad, Robab jafarzadeh Ghadimi, Taraneh Enayati, Mohammad Salehi // Iranian journal of educational Sociology. - 2018. - Volume 1, Number 8. - P. 115-134.

217. Shevchenko L.S. Typologizacija innovacijnoi' dijal'nosti ta innovacij v osvitnij sferi / L.S. Shevchenko [Elektronnyj resurs]. - Rezhym dostupu : https://ndipzir.org.ua/wp-content/uploads/2014/01/Shevchenko.pdf

218. Shmatko O., Balakireva S., Vlasov A., Zagorodnaya N., Korol O., Milov O., Petrov O., Pokhasiy S., Rzaev H., Khvostenko V.. Development of methodological foundations of the threat classifier for designing cyberphysical systems. Eastern European Journal of Corporate Technologies. 2020.3/9 (105) pp. 6-19. URL: http://journals.uran.ua/eejet/article/view/205702 
219. Shvab K. Chetvertaia prombshlennaia revoliutsyia. Эksymo, 2016, 288 s. URL: http://loveread.ec/contents.php?id=66348

220. Shynderovskaja Y.Ju. Konceptual'nыj podhod k opredelenyju ponjatyja «regyonal'nыj socyal'no-эkonomycheskyj monytoryng»// Visnyk Hmel'nyc'kogo nacional'nogo universytetu. 2009. №3, T.1. S. 194 - 198.

221. Shyshkyn A. Sushhnost', zadachy y pryncypы monytorynga socyal'noэkonomycheskyh processov $\mathrm{v}$ regyone// Эkonomyka Severo-Zapada: problemы у perspektyvы razvytyja. 2004. №1(19). S.16-30.

222. Sporn B. Building Adaptive Universities: Emerging Organisational Forms Based on Experiences of European and US Universities. / B. Sporn // Tertiary Education and Management. - 2001. - Vol. 7. - № 2. - P. 121-134.

223. Sravnytel'nыj analyz obrazovatel'nыh system SShA, Germanyy, Japonyy, Yndyy y Kytaja [Эlektronnыj resurs]. - Rezhym dostupa : https://www.politforums.net/culture/1297927919.html

224. Stadnyj Je. Ukrai'ns'ki studenty za kordonom: fakty ta stereotypy. CEDOS. 2017. URL: https://cedos.org.ua/uk/osvita/ukrainski-studenty-za-kordonom-fakty-tastereotypy

225. Standards and Guidelines for Quality Assurance in the European Higher Education Area (ESG). K.: CS Ltd., 2015, 32 p.

226. Stankevych I.V. Konceptual'nyj pidhid do upravlinnja navchal'novyrobnychoju dijal'nistju osvitn'oi' organizacii' // Naukovyj visnyk Hersons'kogo derzhavnogo universytetu. - 2015. - Vypusk 12. - Chastyna 3. - S. 83-88.

227. Starostina A.O. Vykorystannja intelektual'noi' vlasnosti naukovciv universytetu v ramkah koncepcii' vidkrytyh innovacij: mozhlyvosti i ryzyky dlja Ukrai'ny / A.O. Starostina, V.A. Kravchenko, L.M. Nazvanova // Visnyk Kyi'vs'kogo nacional'nogo universytetu imeni Tarasa Shevchenka. Serija "Ekonomika". — Vypusk 144. - 2013. - 68 c. - S. 47-51

228. Strategichnyj plan rozvytku Harkivs'kogo nacional'nogo ekonomichnogo universytetu na 2013 - 2020 roky, Harkiv. Vyd. HNEU, 2013. URL: https://www.hneu.edu.ua/wp-content/uploads/2018/10/Strategic-Plan-HNEU-20132020-years.pdf (data zvernennja: 24.11.2020).

229. Strategichnyj plan rozvytku L'vivs'koi' politehniky do 2025 roku. URL: 
https://lpnu.ua/2025 (data zvernennja: 24.11.2020).

230. Strategichnyj plan rozvytku NTU "HPI" na 2019-2025 roky. URL: https://www.kpi.kharkov.ua/ukr/ntu-hpi/strategichnyj-plan-rozvytku-ntu-hpi-na-20192025-roky/ (data zvernennja: 23.11.2020).

231. Strategichnyj plan rozvytku Sums'kogo derzhavnogo universytetu na 2020 2026 roky: projekt. Sumy, $2019 . \quad$ URL: https://news.sumdu.edu.ua/images/announcements/2019/2019-10-28/SumDU-Strategy2026.pdf (data zvernennja: 23.11.2020).

232. Strategija innovacijnogo rozvytku Ukrai'ny na 2010-2020 roky v umovah globalizacijnyh vyklykiv [Elektronnyj resurs]. - Rezhym dostupu : http://kno.rada.gov.ua/komosviti/control/uk/publish/article?art_id=47920\&cat_id=460

233. Strategija rozvytku DVNZ «Kyi'vs'kyj nacional'nyj ekonomichnyj universytet imeni Vadyma Get'mana» na 2016-2020 roky. Kyi'v - 2016. URL: https://kneu.edu.ua/userfiles/general_information/sr2016_2020.PDF (data zvernennja: 25.11.2020).

234. Strategija rozvytku Nacional'nogo Tehnichnogo Universytetu Ukrai'ny «Kyi'vs'kyj politehnichnyj instytut imeni Igorja Sikors'kogo» na 2020-2025 roky: proekt. Kyi'v, 2020. URL: https://osvita.kpi.ua/sites/default/files/downloads/2020-2025strategy.pdf (data zvernennja: 23.11.2020).

235. Strategija rozvytku vyshhoi' osvity v Ukrai'ni na 2021-2031 roky / Ministerstvo osvity i nauky Ukrai'ny. Kyi'v, 2020. 71 s. URL: https://mon.gov.ua/storage/app/media/rizne/2020/09/25/rozvitku-vishchoi-osviti-vukraini-02-10-2020.pdf (data zvernennja: 11.12.2020).

236. Stratehiia rozvytku vyshchoi osvity v ukraini na 2021 - 2031 roky (Proiekt). Kyiv, 2020.

Retrieved from: https://mon.gov.ua/storage/app/media/rizne/2020/09/25/rozvitku-vishchoi-osviti-vukraini-02-10-2020.pdf

237. Students'ka migracija: de ukrai'ns'ka molod' shukaje krashhogo zhyttja. URL: https://daily.rbc.ua/ukr/show/studencheskaya-migratsiya-ukrainskaya-molodezh1430144645.htm

238. Systemy finansovogo monitoryngu. Metodologija proektuvanja: Monografija/ za red.. O.V. Mozenkova. H.: VD «INZhEK», 2005. 152 s. 
239. Teich A. H. Research Competitiveness and National Science Policy / A. H. Teich; J. S. Hauger, C. McEnaney (eds). - Washington : DC, Strategies for Competitiveness in Academic Research, American Association for the Advancement of Science, 2000.

240. The EFQM Model. Retrieved from: https://efqm.org/efqm-model/

241. The Global Competitiveness Report 2006-2007. World Economic Forum. URL: http://www3.weforum.org/docs/WEF_GlobalCompetitivenessReport_2006-07.pdf (дата звернення: 01.12.2020).

242. The Global Competitiveness Report 2010-2011. World Economic Forum. URL: http://www3.weforum.org/docs/WEF_GlobalCompetitivenessReport_2010-11.pdf (дата звернення: 01.12.2020).

243. The Global Competitiveness Report 2011-2012. World Economic Forum. URL: http://www3.weforum.org/docs/WEF_GCR_Report_2011-12.pdf (дата звернення: 01.12.2020).

244. The Global Competitiveness Report 2012-2013. World Economic Forum. URL: http://www3.weforum.org/docs/WEF_GlobalCompetitivenessReport_2012-13.pdf (дата звернення: 01.12.2020).

245. The Global Competitiveness Report 2013-2014. World Economic Forum. URL: http://www3.weforum.org/docs/WEF_GlobalCompetitivenessReport_2013-14.pdf (дата звернення: 01.12.2020).

246. The Global Competitiveness Report 2014-2015. World Economic Forum. URL: http://www3.weforum.org/docs/WEF_GlobalCompetitivenessReport_2014-15.pdf (дата звернення: 01.12.2020).

247. The Global Competitiveness Report 2015-2016. World Economic Forum. URL: http://www3.weforum.org/docs/gcr/2015-2016/Global_Competitiveness_Report_ 2015-2016.pdf (дата звернення: 01.12.2020).

248. The Global Competitiveness Report 2016-2017. World Economic Forum. URL: $\quad$ http://www3.weforum.org/docs/GCR2016-2017/05FullReport/TheGlobal CompetitivenessReport2016-2017_FINAL.pdf (дата звернення: 01.12.2020).

249. The Global Competitiveness Report 2017-2018. World Economic Forum. URL: $\quad$ http://www3.weforum.org/docs/GCR2017-2018/05FullReport/TheGlobal CompetitivenessReport2017\%E2\%80\%932018.pdf (дата звернення: 01.12.2020). 
250. The Global Competitiveness Report 2018. World Economic Forum. URL: http://www3.weforum.org/docs/GCR2018/05FullReport/TheGlobalCompetitivenessRep ort2018.pdf (дата звернення: 01.12.2020).

251. The Global Competitiveness Report 2019. World Economic Forum. URL: http://www3.weforum.org/docs/WEF_TheGlobalCompetitiveness Report2019.pdf (дата звернення: 01.12.2020).

252. The Global Competitiveness Report. [Електронний ресурс]. - Режим доступу http://www3.weforum.org/docs/WEF_TheGlobalCompetitivenessReport2019.pdf

253. The Global Innovation Index 2011: Accelerating Growth and Development is the result of a collaboration among INSEAD and Knowledge Partners. URL: https://www.globalinnovationindex.org/userfiles/file/GII-2011_Report.pdf (дата звернення: 02.12.2020).

254. The Global Innovation Index 2012: Stronger Innovation Linkages for Global Growth. URL: https://www.wipo.int/edocs/pubdocs/en/economics/gii/gii_ 2012.pdf (дата звернення: 02.12.2020).

255. The Global Innovation Index 2013: The Local Dynamics of Innovation. URL: https://www.wipo.int/edocs/pubdocs/en/economics/gii/gii_2013.pdf (дата звернення: 02.12.2020).

256. The Global Innovation Index 2014: The Human Factor in Innovation. URL: https://www.globalinnovationindex.org/userfiles/file/reportpdf/GII-2014-v5.pdf (дата звернення: 02.12.2020).

257. The Global Innovation Index 2015: Effective Innovation Policies for Development. URL: https://www.wipo.int/edocs/pubdocs/en/wipo_gii_2015.pdf (дата звернення: 02.12.2020).

258. The Global Innovation Index 2016: Winning with Global Innovation. URL: https://www.wipo.int/edocs/pubdocs/en/wipo_pub_gii_2016.pdf (дата звернення: 02.12.2020).

259. The Global Innovation Index 2017: Innovation Feeding the World. URL: https://www.wipo.int/edocs/pubdocs/en/wipo_pub_gii_2017.pdf (дата звернення: 02.12.2020).

260. The Global Innovation Index 2018: Energizing the World with Innovation. 
URL: https://www.wipo.int/edocs/pubdocs/en/wipo_pub_gii_2018.pdf (дата звернення: 02.12.2020).

261. The Global Innovation Index 2019: Creating Healthy Lives-The Future of Medical Innovation. URL: https://www.globalinnovationindex.org/userfiles/ file/reportpdf/gii-full-report-2019.pdf (дата звернення: 02.12.2020).

262. The Global Innovation Index 2020: Who Will Finance Innovation? Cornell University, INSEAD, and WIPO (2020). URL: https://www.wipo.int/ edocs/pubdocs/en/wipo_pub_gii_2020.pdf (дата звернення: 02.12.2020).

263. The Leiden Ranking [Електронний pecypc]. - Режим доступу : https://www.leidenranking.com/.

264. The Open University [Електронний pecypc]. - Режим доступу : http://www.open.ac.uk/

265. The shape of things to come: Higher education global trends and emerging opportunities to 2020 [Електронний pecypc] // British Council. - 2012. - Режим доступу

https://www.britishcouncil.org/sites/default/files/the_shape_of_things_to_come_higher_ education_global_trends_and_emerging_opportunities_to_2020.pdf.

266. TheCenter. The Top American Research Universities. Quality Engines: The Competitive Context for Research / J. Lombardi, D. Craig, E. Capaldi, D. Gater, S. Mendonça. From An Annual Report from The Lombardi Program on Measuring University Performance Universities [електронний ресурс]. - Режим доступу: https://mup.umass.edu/sites/default/files/mup-pdf/MUP-Publication-2001Quality-Engines-The-Competitive-Context-for-Research-Universities.pdf

267. TQM - Total Quality Management. Retrieved from: https://www.kpms.ru/General_info/TQM.htm

268. Tsiuniak O.P. Innovatsiine osvitnie seredovyshche yak chynnyk profesiinoho stanovlennia maibutnikh mahistriv pochatkovoi osvity. innovatsiina pedahohika. 2019, 14. T. 1., 175-178

269. Ukrai'ns'ke studentstvo v Pol'shhi: polityka zaluchennja, integracii' ta motyvacii' i plany studentstva. URL : https://cedos. org.ua/en/articles/ukrainski-studentyv-polshchi-politykyzaluchennia-intehratsii-ta-motyvatsiia-i-plany-studentiv

270. University of the future A thousand year old industry on the cusp of profound 
change [Електронний pecyp]. - Режим доступу : http://www.ey.com/Publication/vwLUAssets/University_of_the_future/\%24FILE/Unive rsity_of_the_future_2012.pdf

271. Universytet u suchasnomu suspil'stvi: misija, problemy, vyklyky : monografija [Elektronnyj resurs] / Za zag. red. G.I. Kalinichevoi'. - Chernigiv : ChNTU, 2019. $\quad-\quad 252 \quad$ s. $\quad$ Rezhym dostupu

https://istu.edu.ua/fileadmin/media/Naukova_diyalnist/Konferentsiy_2018.11.30/Monoh rafiia_2018.11.30.pdf

272. Vashchenko L. Innovatsiine seredovyshche pisliadyplomnoi pedahohichnoi osvity. Pisliadyplomna osvita. 2012, 1, 37-40.

273. Vasyleva E. Yu. Obrazovatelnaia sreda vuza kak obъekt upravlenyia y otsenky. Unyversytetskoe upravlenye. 2011, 4, 76-82.

274. Verdenhofa O.R. Parametry ta modeli avtonomii' universytetiv / O.R. Verdenhofa, I.S. Kalenjuk, L.I. Cymbal // Mizhnarodna ekonomichna polityka. - 2018. № 1(28). - S.109-127.

275. Vostroilov A. V. Innovacionnyj universitet: opyt razvitija / A. V. Vostroilov, V. I. Belousov, V. E. Shevchenko // Upravlenie issledovanijami i innovacijami. - 2006. - № 5. - S. 33-44.

276. Vprovadzhennja lokal'nyh system upravlinnja jakistju v ukrai'ns'kyh universytetah : Analitychnyj zvit / za zag. red. T. V. Finikova, V. I. Tereshhuka; Mizhnarod. blagod. Fond «Mizhnarodnyj fond doslidzhen' osvitn'oi' polityky». - Kyi'v : Takson, 2018. $-88 \mathrm{~s}$.

277. WHAT IS TOTAL QUALITY MANAGEMENT (TQM)? Retrieved from: https://asq.org/quality-resources/total-quality-management

278. WIPO. Global Innovation Index 2020. [електронний ресурс]. - Режим доступу: https://www.wipo.int/global_innovation_index/en/2020

279. World Data Atlas. URL: https://knoema.com/atlas

280. World Economic Forum. URL: https://www.weforum.org/

281. X. 509: Information Technologies-interrelation of open systems - reference book: structures of certificates of public keys and attributes [electronic resource]. - Access mode: https://www.itu.int/rec/T-REC-X.509/en

282. X.509 : Information technology - Open Systems Interconnection - The 
Directory: Public-key and attribute certificate frameworks [Electronic resource]. - Access mode : https://www.itu.int/rec/T-REC-X.509/en

283. Yasvin V. A. Obrazovatelnaya sreda: ot modelirovaniya k proektirovaniyu. 2-e izdanie / V. A. Yasvin. - M.: Smyisl. - 2001. - 368 s.

284. Yckovyc G. Trojnaja spyral'. Unyversytetы - predpryjatyja - gosudarstvo. Ynnovacyy v dejstvyy / G. Yckovyc; per. s angl., pod red. A.F. Uvarova. - Tomsk : TUSUR, 2010. $-238 \mathrm{~s}$.

285. Yevseiev S. and other "Development of an advanced method of video information resource compression in navigation and traffic control systems". "EUREKA: Physical Sciences and Engineering”, № 5. - 2020. P. 31-42.

286. Yevseiev S., Rayevnyeva O., Ponomarenko V., Milov O. Development of methodological principles for the construction of a corporate information-educational system of innovative-active university in the framework of anti-corruption activities. Eastern-European Journal of Enterprise Technologies. Information technology. Industry control systems. 2020. Vol.5, No 2(107). C. 6-28.

287. Yuzhuo Cai, Jinyuan Ma and Qiongqiong Chen. Higher Education in Innovation Ecosystems. Sustainability.2020, №12. P. 43-76. DOI:10.3390/su1211437

288. Zagvozdkin V. Opyt razrabotki i primenenija standartov obrazovanija za rubezhom / V. Zagvozdkin. - Moskva : Verdana, 2008. - $280 \mathrm{~s}$.

289. Zhurakovs'ka L.A. Tendencii' osvitn'oi' migracii' v konteksti globalizacii' ekonomichnogo rozvytku. Demografija ta social'na ekonomika. 2014. № 1(21). URL : https://dse.org.ua/arhcive/21/20.pdf

290. Эncyklopedycheskyj slovar' эkonomyky y prava. URL: https://dic.academic.ru/contents.nsf/dic_economic_law/ 
ANNEX 
The Times Higher Education international rating system. THE Impact Ranking for external evaluation of an innovatively active business university in the market of educational services

\begin{tabular}{|c|c|c|c|c|}
\hline & Research & Leadership & Propaganda & Teaching \\
\hline 1 & 2 & 3 & \begin{tabular}{|c|}
4 \\
\end{tabular} & 5 \\
\hline $\begin{array}{l}\text { SDG } 1 \text { - lack of } \\
\text { poverty }\end{array}$ & $\begin{array}{l}27 \% \text { : weighted index of } \\
\text { citation of articles } \\
\text { related to poverty } \\
(10 \%) \text {; number of } \\
\text { publications related to } \\
\text { poverty }(10 \%) \text {; the share } \\
\text { of scientific papers co- } \\
\text { authored with authors } \\
\text { from low-income } \\
\text { countries }(7 \%)\end{array}$ & $\begin{array}{l}\text { Proportion of students receiving } \\
\text { financial aid }(27 \%) \\
\text { Freelance programs against } \\
\text { poverty }(23 \%) \text { : } \\
\text { Tasks for admission of students } \\
\text { who fall into the lower } 20 \\
\text { percent of household income in } \\
\text { the country (4.6\%) } \\
\text { Graduation targets for students } \\
\text { in the lower 20 percent of } \\
\text { household income in the country } \\
\text { (4.6\%) lor students from the } \\
\text { Support for ste } \\
\text { poorest families to enable them } \\
\text { to complete free economic } \\
\text { education (including food, } \\
\text { housing, transport, legal } \\
\text { services) (4.6\%) } \\
\text { Programs to help students in the } \\
\text { lower } 20 \text { percent of household } \\
\text { income in the country to } \\
\text { successfully complete their } \\
\text { studies (4.6\%) } \\
\text { Support schemes for poor } \\
\text { students from low-income } \\
\text { countries (including offering } \\
\text { free education or grants) (4.6\%) }\end{array}$ & 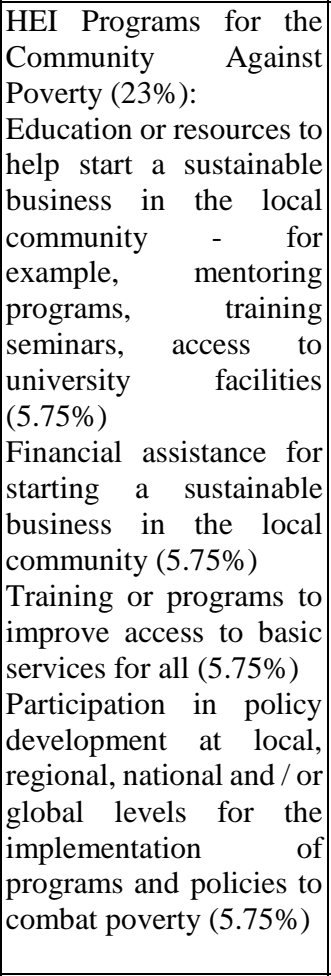 & \\
\hline SDG 2 - zero hunger & $\begin{array}{l}\text { Hunger research }(27 \%) \text { : } \\
\text { Proportion of research } \\
\text { papers in the top } 10 \\
\text { journals identified by } \\
\text { Citescore }(10 \%) \text {; } \\
\text { weighted index of citing } \\
\text { articles }(10 \%) \text {; number } \\
\text { of publications (2014- } \\
2018)(7 \%)\end{array}$ & $\begin{array}{l}\text { Student hunger }(23 \%) \text { : } \\
\text { Student food insecurity } \\
\text { program }(5.75 \%) \\
\text { Intervention to combat hunger } \\
\text { among students }(5.75 \%) \\
\text { Sustainable food choices for all } \\
\text { students (vegetarian and vegan) } \\
(5.75 \%) \\
\text { Healthy and affordable food } \\
\text { choices for everyone on campus } \\
(5.75 \%)\end{array}$ & \begin{tabular}{|l|} 
National famine (27\%) \\
Ensure food security and \\
sustainable agriculture \\
with knowledge, skills or \\
technology for local \\
farmers and food \\
producers (6.75\%) \\
Activities for local \\
farmers and food \\
producers to connect and \\
knowledge transfer \\
$(6.75 \%)$ \\
Access to HEI measures \\
for locals and food \\
producers to improve \\
sustainable farming \\
practices (6.75\%) \\
Priority purchase of \\
products from local, \\
sustainable sources \\
$(6.75 \%) \quad$ \\
\end{tabular} & $\begin{array}{l}\text { Proportion of graduates } \\
\text { who obtain a degree } \\
\text { (bachelor, master, PhD) } \\
\text { related to any aspect of food } \\
\text { sustainability, within the } \\
\text { agricultural course, among } \\
\text { the total number of } \\
\text { graduates in the field of } \\
\text { food sustainability }(23 \%)\end{array}$ \\
\hline $\begin{array}{l}\text { SDG } 3 \text { - ensuring good } \\
\text { health and well-being }\end{array}$ & $\begin{array}{l}\text { Health and wellness } \\
\text { research }(27 \%) \\
\text { Proportion of research } \\
\text { papers reviewed or } \\
\text { downloaded }(10 \%)\end{array}$ & \multicolumn{2}{|c|}{$\begin{array}{l}\text { Cooperation and medical services }(38.4 \%) \\
\text { Smoking ban policy }(8 \%) \\
\text { Collaborate with local or global health authorities to } \\
\text { improve health and well-being }(7 \%) \\
\text { Community outreach programs to improve health and } \\
\text { well-being }(7 \%)\end{array}$} & \\
\hline
\end{tabular}


Continuation of Annex A Continuation of the table A.1

\begin{tabular}{|c|c|c|c|c|}
\hline \multirow[t]{2}{*}{1} & 2 & 3 & 4 & 5 \\
\hline & $\begin{array}{l}\text { Proportion of scientific } \\
\text { papers cited in clinical } \\
\text { guidelines }(10 \%) \\
\text { Number of publications } \\
(7 \%)\end{array}$ & \multicolumn{2}{|c|}{$\begin{array}{l}\text { Access to sexual and reproductive health services for students } \\
(7 \%) \\
\text { Free mental health support for students and NPP }(7 \%) \\
\text { Community access to university sports facilities }(2.4 \%)\end{array}$} & $\begin{array}{l}\text { Proportion of medical } \\
\text { graduates }(34.6 \%) \text {, ie the } \\
\text { proportion of HEI } \\
\text { graduates who obtain a } \\
\text { degree in a health-related } \\
\text { profession. }\end{array}$ \\
\hline $\begin{array}{l}\text { SDG } 4 \text { - quality } \\
\text { education }\end{array}$ & $\begin{array}{l}\text { Early age research and } \\
\text { lifelong learning }(27 \%) \\
\text { Proportion of research } \\
\text { papers reviewed or } \\
\text { downloaded }(10 \%) \\
\text { Share of scientific } \\
\text { papers in the top } 10 \\
\text { journals identified by } \\
\text { Citescore }(10 \%) \\
\text { Number of publications } \\
(7 \%)\end{array}$ & $\begin{array}{l}\text { Share of first generation } \\
\text { students }(30.8 \%)\end{array}$ & $\begin{array}{l}\text { Lifelong learning activities (26.8\%) } \\
\text { Access to educational PHEI (5\%) } \\
\text { Educational activities open to the } \\
\text { general public (lectures, special } \\
\text { educational courses }(5 \%) \\
\text { Educational activities that provide } \\
\text { professional training for non-HEI } \\
\text { students (5\%) } \\
\text { Educational activities in the local } \\
\text { community, including schools (5\%) } \\
\text { Policy to ensure that these activities } \\
\text { are open to all }(6.8 \%) \text {. }\end{array}$ & $\begin{array}{l}\text { Proportion of graduates } \\
\text { with a teacher's } \\
\text { qualification (15.4\%), ie } \\
\text { the proportion of graduates } \\
\text { who obtain a degree that } \\
\text { would allow them to teach } \\
\text { in primary school in their } \\
\text { country. }\end{array}$ \\
\hline \multirow[t]{2}{*}{$\begin{array}{l}\text { SDG } 5 \text { - commitment } \\
\text { to gender equality and } \\
\text { non-discrimination }\end{array}$} & $\begin{array}{l}\text { Research }(27 \%) \\
\text { Share of total university } \\
\text { research authored by } \\
\text { women }(10 \%) \\
\text { Proportion of articles on } \\
\text { gender equality in } 10 \\
\text { percent of journals } \\
\text { identified by Citescore } \\
(10 \%) \text { Number of publications } \\
\text { on gender equality }(7 \%)\end{array}$ & \begin{tabular}{|l|} 
Share of first generation \\
female students $(15.4 \%)$ \\
Measures for student \\
access $(15.4 \%)$ \\
Tracking the level of \\
application, acceptance \\
and completion for \\
female students $(1.6 \%)$ \\
Policy regarding the \\
level of applications, \\
admission, admission \\
and participation of \\
female students $(4.6 \%)$ \\
Provision of appropriate \\
women's access \\
schemes, such as \\
mentoring $(4.6 \%)$ \\
\end{tabular} & $\begin{array}{l}\text { Measuring women's progress }(15.3 \%) \\
\text { Non-discrimination policy for women } \\
(1.95 \%) \\
\text { Non-discrimination policy for } \\
\text { transgender people }(1.95 \%) \\
\text { Maternity and paternity policy that } \\
\text { supports women's participation }(1.9 \%) \\
\text { Available childcare services for } \\
\text { students }(1.9 \%) \\
\text { Available childcare services for staff } \\
(1.9 \%) \text { for women } \\
\text { Mentoring schemes for wo percent of female } \\
\text { involving at least } 10 \text { pern } \\
\text { students (1.9\%) } \\
\text { Tracking the percentage of female } \\
\text { graduates compared to male and } \\
\text { schemes to bridge the gap (1.9\%) }\end{array}$ & $\begin{array}{l}\text { Proportion of women } \\
\text { receiving educational } \\
\text { degrees (11.5\%) } \\
\text { (bachelor's degree in: } \\
\text { STEM; medicine; arts, } \\
\text { humanities and social } \\
\text { sciences.) }\end{array}$ \\
\hline & & \begin{tabular}{|l|} 
Encouraging the \\
submission of \\
applications in areas \\
where women are \\
underrepresented $(4.6 \%)$ \\
Share of women in \\
senior positions $(15.4 \%)$ \\
\end{tabular} & $\begin{array}{l}\text { Policy for the protection of those } \\
\text { who report discrimination }(1.9 \%)\end{array}$ & \\
\hline $\begin{array}{l}\text { SDG } 8 \text { - creating } \\
\text { decent working } \\
\text { conditions and } \\
\text { economic growth }\end{array}$ & $\begin{array}{l}\text { Economic growth and } \\
\text { employment survey } \\
(27 \%) \\
\text { Share of articles in the } \\
\text { top } 10 \text { magazines } \\
\text { identified by Citescore } \\
(14 \%) \\
\text { Number of publications } \\
(13 \%)\end{array}$ & \multicolumn{2}{|c|}{$\begin{array}{l}\text { Employment practice }(19.6 \%) \\
\text { Payment of the subsistence minimum for staff and teachers } \\
(2.45 \%) \\
\text { Recognition of trade union and labor rights }(2.45 \%) \\
\text { Policy on the cessation of discrimination in the workplace } \\
(2.45 \%) \\
\text { Policies against modern-day slavery, forced labor, human } \\
\text { trafficking and child labor }(2.45 \%) \\
\text { Guarantees of equal rights of employees working in } \\
\text { contractors ( } 2.45 \%) \\
\text { Wage equity policy, including commitment to measure and } \\
\text { address wage disparities among women }(2.45 \%) \\
\text { Measuring or tracking the pay scale by article }(2.45 \%) \\
\text { The process of appealing by employees of decisions on rights } \\
\text { and remuneration }(2.45 \%) \\
\text { Costs per employee }(15.4 \%) \\
\text { Proportion of employees working on secure contracts (19\%) }\end{array}$} & $\begin{array}{l}\text { Proportion of students who } \\
\text { are employed (19\%) }\end{array}$ \\
\hline
\end{tabular}


Continuation of Annex A

Continuation of the table A.1

\begin{tabular}{|c|c|c|c|}
\hline 1 & 2 & 3 & 5 \\
\hline $\begin{array}{l}\text { SDG } 9 \text { - industry, } \\
\text { innovation and } \\
\text { infrastructure }\end{array}$ & 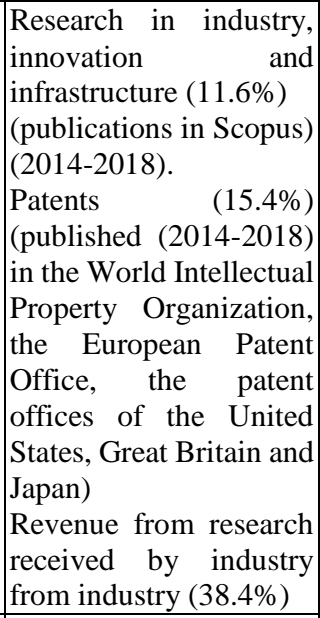 & $\begin{array}{ll}\text { Number of university } \\
\text { branches } & (34.6 \%) \\
\text { (registered at least three } \\
\text { years ago by continuing } \\
\text { companies } & \text { set up to } \\
\text { exploit } & \text { intellectual } \\
\text { property } & \text { derived from } \\
\text { HEI) } & \end{array}$ & \\
\hline \multirow[t]{2}{*}{$\begin{array}{l}\text { SDG } 10 \text { - reduction of } \\
\text { inequalities }\end{array}$} & $\begin{array}{l}\text { Inequality reduction } \\
\text { research }(27 \%) \\
\text { Share of articles in the } \\
\text { top } 10 \text { magazines } \\
\text { identified by Citescore } \\
(10 \%) \\
\text { Weighted index of } \\
\text { citations of articles of } \\
\text { HEI }(10 \%) \\
\text { Number of publications } \\
(7 \%)\end{array}$ & $\begin{array}{l}\text { Students and staff with disabilities }(23 \%) \text { : } \\
\text { Proportion of students with disabilities }(11.5 \%) \\
\text { Share of employees with disabilities }(11.5 \%) \\
\text { Anti-discrimination measures }(19 \%) \text { : } \\
\text { Non-discriminatory reception policy }(1.9 \%) \\
\text { Monitor the level of submission of applications and admission } \\
\text { of underrepresented groups }(1.9 \%) \\
\text { Programs for recruitment of students and staff from } \\
\text { underrepresented groups }(1.9 \%)\end{array}$ & $\begin{array}{l}\text { First generation students } \\
(15.5 \%) \\
\text { Higher education students } \\
\text { at all levels from } \\
\text { developing countries (low- } \\
\text { and middle-income } \\
\text { countries as defined by the } \\
\text { World Bank) (15.5\%) }\end{array}$ \\
\hline & & $\begin{array}{l}\text { Anti-discrimination and harassment policy for staff and } \\
\text { students }(1.9 \%) \\
\text { Presence of a committee, office or officer on diversity and } \\
\text { equality }(1.9 \%) \\
\text { Mentoring, counseling or peer support programs for students } \\
\text { and staff from underrepresented groups }(1.9 \%) \\
\text { Facilities for people with disabilities }(1.9 \%) \\
\text { Support services for people with disabilities }(1.9 \%) \\
\text { Access schemes for people with disabilities }(1.9 \%) \\
\text { Policy or strategy for the placement of people with disabilities, } \\
\text { including adequate funding }(1.9 \%)\end{array}$ & \\
\hline $\begin{array}{l}\text { SDG } 11 \text { - sustainable } \\
\text { cities and communities }\end{array}$ & $\begin{array}{l}\text { Survey of sustainable } \\
\text { cities and communities } \\
(27 \%) \\
\text { Share of articles in the } \\
\text { top } 10 \text { magazines } \\
\text { identified by Citescore } \\
(10 \%) \\
\text { Weighted citation index } \\
\text { of HEI articles }(10 \%) \\
\text { Number of publications } \\
(7 \%)\end{array}$ & $\begin{array}{l}\text { Support for art and heritage }(22.6 \%) \text { : } \\
\text { Public access to large university buildings }(3.75 \%) \\
\text { Public access to free economic libraries }(3.75 \%) \\
\text { Public access to museums, galleries or works of art of the Free } \\
\text { Economic Zone }(3.75 \%) \\
\text { Public access to open and green plantations }(3.75 \%) \\
\text { Carrying out of art actions for representatives of the public, } \\
(3,8 \%) \\
\text { Recording and preservation of local heritage (3.8\%) } \\
\text { Expenditures on art and heritage (15.3\%) } \\
\text { Targets for sustainable work trips }(3.9 \%) \\
\text { Promoting sustainable relocation (3.9\%) } \\
\text { Encouragement of distance work, remote work or reduction of } \\
\text { working weeks (3.9\%) } \\
\text { Affordable housing for students (3.9\%) } \\
\text { Affordable housing for staff (3.9\%) } \\
\text { Priorities for pedestrians on campus (3.9\%) } \\
\text { Cooperation with local authorities to address planning issues, } \\
\text { including the provision of affordable housing for local } \\
\text { residents (3.9\%) } \\
\text { Construction according to sustainable standards (3.9\%) } \\
\text { Construction on sites (3.9\%) }\end{array}$ & \\
\hline
\end{tabular}


Continuation of Annex A

The end of the table A.1

\begin{tabular}{|c|c|c|c|c|}
\hline 1 & 2 & 3 & 4 & 5 \\
\hline $\begin{array}{l}\text { SDG } 12 \text { - responsible } \\
\text { consumption and } \\
\text { production }\end{array}$ & $\begin{array}{l}\text { Research on responsible } \\
\text { consumption and } \\
\text { production }(27 \%) \\
\text { Share of articles in the } \\
\text { top } 10 \text { magazines } \\
\text { identified by Citescore } \\
(10 \%) \\
\text { Weighted index of } \\
\text { citations of articles of } \\
\text { free economic zone } \\
(10 \%) \\
\text { Number of publications } \\
(7 \%)\end{array}$ & $\begin{array}{l}\text { Operational measures } \\
(26.7 \%) \\
\text { Ethical supply and food } \\
\text { supply policy }(4.8 \%) \\
\text { Policy on proper } \\
\text { disposal of hazardous } \\
\text { waste }(4.8 \%) \\
\text { Policy on measuring the } \\
\text { amount of waste sent to } \\
\text { landfill and the amount } \\
\text { of recycled ( } 4.8 \%) \\
\text { Plastic minimization policy } \\
(4.8 \%) \\
\text { Evidence that this policy } \\
\text { also applies to services } \\
\text { provided by contractors } \\
(1.35 \%) \\
\text { Evidence that this policy } \\
\text { also applies to suppliers } \\
\text { transferred by contractors } \\
(1.35 \%) \text { ( } \\
\text { Share of recycled waste } \\
(27 \%) \\
\text { Share of recyclable waste } \\
(13.5 \%) \text { a } \\
\text { Share of waste not sent to } \\
\text { landfill (13.5\%) }\end{array}$ & $\begin{array}{l}\text { Publication of the report on the } \\
\text { stability HEI for the last } 3 \text { years } \\
(19.3 \%) \\
\end{array}$ & \\
\hline $\begin{array}{l}\text { SDG } 16 \text { - peace, justice } \\
\text { and strong institutions }\end{array}$ & $\begin{array}{l}\text { Research }(27 \%) \\
\text { Share of articles in the } \\
\text { top } 10 \text { magazines } \\
\text { identified by Citescore } \\
(10 \%) \\
\text { Weighted citation index } \\
\text { of HEI articles }(10 \%) \\
\text { Number of publications } \\
(7 \%)\end{array}$ & 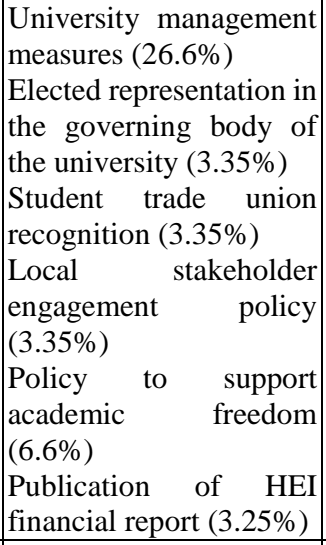 & $\begin{array}{l}\text { Cooperation with the government } \\
(23.2 \%) \\
\text { Providing expert advice to the } \\
\text { government }(6.4 \%) \\
\text { Ensuring coverage of national and } \\
\text { local self-government }(6.4 \%) \\
\text { Conducting a policy-oriented study } \\
\text { in cooperation with government } \\
\text { agencies }(6.4 \%) \\
\text { Providing a neutral platform for } \\
\text { political stakeholders to discuss } \\
\text { challenges (4\%) }\end{array}$ & $\begin{array}{l}\text { Share of graduates of legal } \\
\text { and civil services }(23.2 \%)\end{array}$ \\
\hline $\begin{array}{l}\text { SDG } 17 \text { is a } \\
\text { partnership to achieve } \\
\text { goals }\end{array}$ & $\begin{array}{l}\text { Research }(27.1 \%) \\
\text { Share of scientific } \\
\text { publications with co- } \\
\text { authors from } \\
\text { developing countries } \\
(13.55 \%) \\
\text { Number of publications } \\
\text { related to SDG } 17 \\
(13.55 \%)\end{array}$ & & \begin{tabular}{|l|} 
Relationships to support goals \\
$(18.5 \%)$ \\
SDG policy development with the \\
government $(3.7 \%)$ \\
Cross-sectoral dialogue on SDG \\
with government or NGOs (3.7\%) \\
Cooperation at the international \\
level for the collection of data \\
related to SDG (3.7\%) \\
Cooperation at the international \\
level to develop best practices for \\
solving SDG (3.7\%) \\
Collaboration with NGOs to \\
address SDG through student \\
volunteering programs, research \\
programs or educational resources \\
$(3.7 \%)$ \\
Publication of SDG reports $(27.2 \%)$
\end{tabular} & $\begin{array}{l}\text { SDG education }(27.2 \%) \\
\text { (how freelancers teach the } \\
\text { next generation to apply } \\
\text { stability in their lives) }\end{array}$ \\
\hline
\end{tabular}


Annex B

Table B.1

\section{Research of introduction of marketing innovations by domestic HEI on the basis of the analysis of Development}

Strategies

\begin{tabular}{|c|c|c|c|c|c|}
\hline $\begin{array}{l}\text { Kind of innovative } \\
\text { changes }\end{array}$ & I. Franko NU of Lviv & $\begin{array}{l}\text { T. Shevchenko NU of } \\
\text { Kiev }\end{array}$ & NTUU KPI & SSU & NTU "HPI" \\
\hline $\begin{array}{l}\text { the latest approaches } \\
\text { to career guidance }\end{array}$ & & $\begin{array}{l}\text { Expanding cooperation } \\
\text { with the Small Academy } \\
\text { of Sciences; } \\
\text { Organization and holding } \\
\text { of summer and winter } \\
\text { schools on the basis of } \\
\text { the University for } \\
\text { individual students, other } \\
\text { educational institutions } \\
\text { and research institutions }\end{array}$ & $\begin{array}{l}\text { Expansion of cooperation } \\
\text { with institutions of } \\
\text { secondary and secondary } \\
\text { special education, the } \\
\text { Small Academy of } \\
\text { Sciences; } \\
\text { implementation of the } \\
\text { program of the center of } \\
\text { professional orientation } \\
\text { of student youth "Future } \\
\text { of Ukraine" (including } \\
\text { the All-Ukrainian festival } \\
\text { engineering talents } \\
\text { "Future of Ukraine"); } \\
\text { faculty of pre-university } \\
\text { training }\end{array}$ & $\begin{array}{l}\text { pre-university education system; } \\
\text { University Center for Scientific and } \\
\text { Technical Creativity of School Youth, } \\
\text { fruitful cooperation with the Small } \\
\text { Academy of Sciences: scientific work, } \\
\text { sections of the University Center for } \\
\text { Scientific and Technical Creativity of } \\
\text { School Youth, branches of the Small } \\
\text { Academy of Sciences under the } \\
\text { direction of university staff and } \\
\text { graduate students, sports sections, } \\
\text { creation of specialized training, clubs, } \\
\text { preparatory courses, holding university } \\
\text { competitions; } \\
\text { - a regional network of centers for } \\
\text { preparation of youth for external } \\
\text { evaluation was created (full-time and } \\
\text { part-time preparatory courses, } \\
\text { preparation for external evaluation at } \\
\text { centers of technical creativity of } \\
\text { schoolchildren, training courses for } \\
\text { external evaluation by distance form, } \\
\text { etc.) } \\
\text { - Transformation of the University } \\
\text { Children's Health Center "Universe" } \\
\text { into a summer camp with the priority } \\
\text { of vocational guidance for high school } \\
\text { students and with summer schools, } \\
\text { thematic changes (teams, groups) of } \\
\text { various directions (IT, robotics, } \\
\text { language component, sports by type, } \\
\text { etc.); }\end{array}$ & $\begin{array}{l}\text { Pre-university } \\
\text { training, }\end{array}$ \\
\hline $\begin{array}{l}\text { Measures to promote } \\
\text { the results of } \\
\text { research }\end{array}$ & & $\begin{array}{l}\text { Promotion of scientific } \\
\text { achievements of the } \\
\text { University through } \\
\text { publications in the } \\
\text { media, participation in } \\
\text { regional, national and } \\
\text { international exhibitions, } \\
\text { etc. }\end{array}$ & & $\begin{array}{l}\text { annual holding of all-university } \\
\text { competitions of innovative startup } \\
\text { projects, competitions of NTSA, etc. } \\
\text { for search of new ideas for the } \\
\text { subsequent introduction of the } \\
\text { corresponding scientific and applied } \\
\text { results, development of material and }\end{array}$ & \\
\hline
\end{tabular}




\begin{tabular}{|c|c|c|c|c|c|}
\hline & & & & $\begin{array}{l}\text { technical base of researches and } \\
\text { developments; } \\
\text { participation in exhibitions of profile } \\
\text { orientation and thematic investment } \\
\text { forums with presentation of scientific } \\
\text { developments of the university; }\end{array}$ & \\
\hline $\begin{array}{l}\text { scientific } \\
\text { conferences as a } \\
\text { factor in forming a } \\
\text { positive image of the } \\
\text { university. }\end{array}$ & & $\begin{array}{l}\text { Presentation of scientific } \\
\text { achievements of the } \\
\text { University at national } \\
\text { and international } \\
\text { scientific, scientific- } \\
\text { practical and innovative } \\
\text { conferences and } \\
\text { exhibitions }\end{array}$ & $\begin{array}{l}\text { Supporting the image of } \\
\text { the university through the } \\
\text { organization and holding } \\
\text { of open events, } \\
\text { representation at } \\
\text { exhibitions, forums, } \\
\text { festivals, etc. }\end{array}$ & $\begin{array}{l}\text { organizer of about } 30 \text { scientific } \\
\text { conferences, some of which host } \\
\text { participants from about } 30 \text { countries, } \\
\text { the materials of three conferences are } \\
\text { indexed by Scopus and / or WoS } \\
\text { databases; }\end{array}$ & $\begin{array}{l}\text { Participation in } \\
\text { scientific and } \\
\text { practical conferences, } \\
\text { seminars, exhibitions }\end{array}$ \\
\hline $\begin{array}{l}\text { World recognition of } \\
\text { performance }\end{array}$ & $\begin{array}{l}\text { Entry of scientific } \\
\text { publications and } \\
\text { publications into world } \\
\text { rating systems and } \\
\text { databases. }\end{array}$ & $\begin{array}{l}\text { Continuous monitoring } \\
\text { of the publication of } \\
\text { articles in professional } \\
\text { journals included in } \\
\text { international databases } \\
\text { (Web of Science, } \\
\text { SCOPUS). }\end{array}$ & $\begin{array}{l}\text { Deepen international } \\
\text { recognition } \\
\text { teachers of the } \\
\text { university, namely } \\
\text { obtaining the status of } \\
\text { "European } \\
\text { lecturer at the University } \\
\text { of Engineering " } \\
\text { (ING.PAED.IGIP) }\end{array}$ & $\begin{array}{l}\text { Passing international accreditation not } \\
\text { less than } 10 \% \text { of educational programs, } \\
\text { thematic accreditation of programs by } \\
\text { relevant professional international } \\
\text { institutions (ACCA, international } \\
\text { passport of an engineer, international } \\
\text { e-leaning mark in the field of e- } \\
\text { learning, etc.) and international } \\
\text { accreditation of training programs for } \\
\text { doctors of philosophy } \\
\text { positioning in the group of leaders of } \\
\text { Ukrainian higher education according } \\
\text { to international ratings Webometrics } \\
\text { Ranking of World Universities and } \\
\text { uniRank University Ranking }\end{array}$ & \\
\hline $\begin{array}{l}\text { International } \\
\text { recognition through } \\
\text { participation in } \\
\text { organizations, } \\
\text { associations, ratings }\end{array}$ & $\begin{array}{l}\text { Promotion of the } \\
\text { University brand } \\
\text { through participation in } \\
\text { international scientific } \\
\text { and educational } \\
\text { organizations; } \\
\text { Increasing positions in } \\
\text { the leading world } \\
\text { rankings }\end{array}$ & $\begin{array}{l}\text { Intensification of the } \\
\text { University's participation } \\
\text { in international and } \\
\text { European associations of } \\
\text { research universities and } \\
\text { in the Grand Charter of } \\
\text { Universities }\end{array}$ & $\begin{array}{l}\text { KPI participation in } \\
\text { world university } \\
\text { ratings } \\
\text { Become one of the } 450 \\
\text { leading universities in the } \\
\text { world in the QS rating } \\
\text { system }\end{array}$ & & $\begin{array}{l}\text { Webometrics } \\
\text { Ranking of World } \\
\text { Universities - 8th } \\
\text { place in Ukraine; } \\
\text { QS World } \\
\text { Universities Ranking } \\
\text { - } 701-750 \text { place, 4th } \\
\text { place among } \\
\text { Ukrainian HEI; } \\
\text { Included in the } \\
\text { catalog of the best } \\
\text { universities in the } \\
\text { world from the } \\
\text { ratings of THE WUR } \\
\text { and U-multirank }\end{array}$ \\
\hline Advertising activities & & $\begin{array}{l}\text { programs of PR-events, } \\
\text { production of advertising }\end{array}$ & & $\begin{array}{l}\text { Information and advertising activities } \\
\text { of the university are implemented by } \\
\text { the Center for Media Communications }\end{array}$ & \\
\hline
\end{tabular}




\begin{tabular}{|l|l|l|l|}
\hline & & $\begin{array}{l}\text { products and attributes of } \\
\text { the University. }\end{array}$ & $\begin{array}{l}\text { and Advertising. Press Center, a group } \\
\text { for brand management and production } \\
\text { of media content, a group of computer } \\
\text { design technologies, the Center for } \\
\text { Media Broadcasts, the Student Media } \\
\text { Agency Studio16x9, the Department of } \\
\text { Journalism and Philology, the } \\
\text { university newspaper Resonance. The } \\
\text { "visibility" of the university in the } \\
\text { media space is growing, including } \\
\text { through the production of its own } \\
\text { media content. } \\
\text { creation of SSU Media Holding as a }\end{array}$ \\
structure that unites and coordinates \\
the activities of the Press Center, the \\
Center for Media Communications and \\
Advertising, the group for brand \\
management and production of media \\
content, the Center for Media \\
Broadcasts, the Student Media Agency \\
Studio16x9, relevant IT departments \\
line studios and TV-studios- \\
production, video broadcasting \\
systems, Internet television and radio \\
broadcasting, publishing houses, other \\
departments of the university, purely \\
student media. This includes the \\
implementation of projects "SSU \\
Television", "Campus - Radio SSU", \\
the reorganization of the university \\
newspaper.
\end{tabular}




\section{Continuation of Annex B}

Table B.2

\section{Research of introduction of product innovations by domestic HEI on the basis of the analysis of Development}

\section{Strategies}

\begin{tabular}{|c|c|c|c|c|c|}
\hline $\begin{array}{l}\text { Kind of innovative } \\
\text { changes }\end{array}$ & I. Franko NU of Lviv & $\begin{array}{l}\text { T. Shevchenko NU of } \\
\text { Kiev }\end{array}$ & NTUU KPI & SSU & NTU "HPI" \\
\hline $\begin{array}{l}\text { Formation of } \\
\text { specialists according to } \\
\text { the competence } \\
\text { approach }\end{array}$ & & $\begin{array}{l}\text { introduction of } \\
\text { interdisciplinary } \\
\text { educational programs } \\
\text { components. }\end{array}$ & & $\begin{array}{l}\text { directing the educational } \\
\text { program to the formation of } \\
\text { competencies relevant to the } \\
\text { labor market, by involving in } \\
\text { the formation of the content } \\
\text { of educational programs and } \\
\text { curricula of expert councils } \\
\text { of employers; }\end{array}$ & $\begin{array}{l}\text { Training of highly } \\
\text { qualified personnel }\end{array}$ \\
\hline $\begin{array}{l}\text { Carrying out of } \\
\text { scientific } \\
\text { developments which } \\
\text { have a product } \\
\text { (commodity) stage; }\end{array}$ & $\begin{array}{l}\text { Increasing the number of } \\
\text { patented inventions }\end{array}$ & & $\begin{array}{l}\text { Carrying out works in the } \\
\text { fields of nanotechnology, } \\
\text { energy, energy efficiency } \\
\text { of enterprises; }\end{array}$ & $\begin{array}{l}\text { About } 1000 \text { research and } \\
\text { development works are } \\
\text { performed annually and } \\
\text { scientific services are } \\
\text { provided to order by more } \\
\text { than } 400 \text { enterprises and } \\
\text { organizations of various } \\
\text { forms of ownership. }\end{array}$ & $\begin{array}{l}\text { Production and } \\
\text { implementation of } \\
\text { experimental samples of } \\
\text { new equipment, } \\
\text { technologies; high-tech } \\
\text { products }\end{array}$ \\
\hline $\begin{array}{l}\text { development of } \\
\text { centers, intellectual } \\
\text { property }\end{array}$ & $\begin{array}{l}\text { Scientific investment } \\
\text { projects involving domestic } \\
\text { and foreign business. }\end{array}$ & $\begin{array}{l}\text { Formation of joint } \\
\text { scientific programs, } \\
\text { consortia for integration of } \\
\text { scientific researches of the } \\
\text { University into the } \\
\text { European and world } \\
\text { research space; } \\
\text { Corporation "Taras } \\
\text { Shevchenko University of } \\
\text { Kyiv Science Park", } \\
\text { further development of } \\
\text { activities on its basis of the } \\
\text { student business incubator. }\end{array}$ & $\begin{array}{l}\text { Innovative } \\
\text { Sikorsky Challenge } \\
\text { ecosystem } \\
\text { Creation of joint } \\
\text { educational-scientific- } \\
\text { production complexes, } \\
\text { centers of common use, } \\
\text { laboratories with leading } \\
\text { scientific institutions and } \\
\text { companies } \\
\text { Innovative structures on } \\
\text { the basis of the university } \\
\text { (science park, technology } \\
\text { park, business incubator, } \\
\text { startup school); }\end{array}$ & $\begin{array}{l}\text { support of existing and } \\
\text { creation of new educational } \\
\text { and training centers in most } \\
\text { specialties, including with } \\
\text { educational and production } \\
\text { functions such as translation } \\
\text { center, training bank, PR } \\
\text { agency, advertising bureau, } \\
\text { web design studio, audit and } \\
\text { consulting center, legal } \\
\text { clinic, etc.; } \\
\text { The university has } \\
\text { developed scientific schools } \\
\text { that have received } \\
\text { recognition for } \\
\text { world level; in a number of } \\
\text { areas is provided }\end{array}$ & $\begin{array}{l}40 \text { scientific schools } \\
\text { were established; } \\
\text { Joint science parks and } \\
\text { centers with foreign } \\
\text { partners }\end{array}$ \\
\hline
\end{tabular}


The end of the table. B. 2

\begin{tabular}{|c|c|c|c|c|c|}
\hline $\begin{array}{l}\text { Kind of innovative } \\
\text { changes }\end{array}$ & I. Franko NU of Lviv & $\begin{array}{c}\text { T. Shevchenko NU of } \\
\text { Kiev }\end{array}$ & NTUU KPI & SSU & NTU "HPI" \\
\hline & & & $\begin{array}{l}\text { a laboratory that simulates } \\
\text { space conditions for testing } \\
\text { micro- and nanosatellites; }\end{array}$ & $\begin{array}{l}\text { full research and production } \\
\text { cycle: basic - applied } \\
\text { research - applied } \\
\text { development - } \\
\text { prototype - serial } \\
\text { production. -creation of } \\
\text { training and production } \\
\text { associations, basic } \\
\text { departments, laboratories }\end{array}$ & \\
\hline $\begin{array}{l}\text { ertification of acquired } \\
\text { knowledge and } \\
\text { scientific products } \\
\text { according to European } \\
\text { quality standards }\end{array}$ & & $\begin{array}{l}\text { Implementation of the } \\
\text { European Charter of } \\
\text { Researchers at the } \\
\text { University. }\end{array}$ & & & $\begin{array}{l}\text { Certification of the } \\
\text { quality of educational } \\
\text { services by the } \\
\text { European Organization } \\
\text { for the Evaluation of the } \\
\text { Quality of Higher } \\
\text { Education }\end{array}$ \\
\hline $\begin{array}{l}\text { Formation of } \\
\text { specialists according to } \\
\text { the competence } \\
\text { approach }\end{array}$ & & & & $\begin{array}{l}\text { - development of } \\
\text { educational programs based } \\
\text { on an integrated competency } \\
\text { approach }\end{array}$ & $\begin{array}{l}\text { development of } \\
\text { competency models of } \\
\text { educational programs }\end{array}$ \\
\hline $\begin{array}{l}\text { Carrying out of } \\
\text { scientific developments } \\
\text { which have a product } \\
\text { (commodity) stage; }\end{array}$ & & $\begin{array}{l}\text { Incubation of innovative } \\
\text { projects }\end{array}$ & $\begin{array}{l}\text { Implementation of the } \\
\text { results of scientific, } \\
\text { scientific and technical } \\
\text { work in the practice of } \\
\text { economic organizations } \\
\text { and institutions, } \\
\text { educational institutions }\end{array}$ & $\begin{array}{l}\text { creation and sale of } \\
\text { innovative technological } \\
\text { products; }\end{array}$ & \\
\hline $\begin{array}{l}\text { development of } \\
\text { intellectual property } \\
\text { centers }\end{array}$ & & & & $\begin{array}{l}\text { LLC Science Park } \\
\text { "Uzhgorod National } \\
\text { university"; } \\
34 \text { research institutes, } \\
\text { centers, laboratories, } \\
\text { educational and scientific } \\
\text { institute; } \\
\text { Technology transfer center }\end{array}$ & $\begin{array}{l}\text { building a network of } \\
\text { research centers, } \\
\text { institutes. } \\
\text { KNEU Science Park }\end{array}$ \\
\hline
\end{tabular}




\begin{tabular}{|c|c|c|c|c|c|}
\hline $\begin{array}{l}\text { Internationalization } \\
\text { of educational } \\
\text { activities }\end{array}$ & $\begin{array}{l}\text { Development of programs } \\
\text { with joint and double } \\
\text { diplomas. }\end{array}$ & $\begin{array}{l}\text { Increasing the number } \\
\text { of foreign partner } \\
\text { universities, "double } \\
\text { degree" programs }\end{array}$ & $\begin{array}{l}\text { Type programs } \\
\text { "Double diploma" with } \\
\text { foreign universities }\end{array}$ & $\begin{array}{l}\text { Double and joint diploma } \\
\text { programs }\end{array}$ & $\begin{array}{l}\text { Creation of joint educational } \\
\text { programs with foreign HEI; } \\
\text { compliance of educational } \\
\text { programs with international } \\
\text { qualifications }\end{array}$ \\
\hline $\begin{array}{l}\text { Independence in the } \\
\text { organization of the } \\
\text { educational process } \\
\text { taking into account } \\
\text { the needs of the } \\
\text { market and } \\
\text { stakeholders }\end{array}$ & $\begin{array}{l}\text { ompliance of curricula } \\
\text { with European and world } \\
\text { standards; } \\
\text { Establishment of the } \\
\text { sociological service of the } \\
\text { University for the } \\
\text { systematic study of public } \\
\text { opinion. }\end{array}$ & $\begin{array}{l}\text { Monitoring the needs } \\
\text { of the labor market; } \\
\text { Discovery of new } \\
\text { promising scientific } \\
\text { specialties; } \\
\text { taking into account } \\
\text { the needs of the labor } \\
\text { market in conducting } \\
\text { educational activities; }\end{array}$ & $\begin{array}{l}\text { Optimization of the list and } \\
\text { content of educational } \\
\text { programs in accordance with } \\
\text { the requirements of the labor } \\
\text { market; } \\
\text { Conduct foresight research } \\
\text { labor market development } \\
\text { and high-tech business in the } \\
\text { context of prospects and } \\
\text { demand for specialties and } \\
\text { educational programs of the } \\
\text { university }\end{array}$ & $\begin{array}{l}\text { Adult Education Center } \\
\text { Education for Life in which } \\
\text { new approaches to non- } \\
\text { formal adult education are } \\
\text { being implemented }\end{array}$ & $\begin{array}{l}\text { Discovery of new specialties in } \\
\text { modern fields of knowledge; } \\
\text { adaptation of educational } \\
\text { programs to professional } \\
\text { standards and requirements of } \\
\text { employers }\end{array}$ \\
\hline $\begin{array}{l}\text { Participation in the } \\
\text { development of } \\
\text { productive forces of } \\
\text { the industry, region, } \\
\text { country. }\end{array}$ & $\begin{array}{l}\text { Increasing innovation } \\
\text { potential, training of } \\
\text { highly qualified personnel } \\
\text { needed by society and the } \\
\text { state }\end{array}$ & $\begin{array}{l}\text { Ensuring the diverse } \\
\text { development of } \\
\text { students. }\end{array}$ & $\begin{array}{l}\text { Training of highly qualified } \\
\text { employees; interdisciplinary } \\
\text { training }\end{array}$ & $\begin{array}{l}\text { Training of highly qualified } \\
\text { employees; interdisciplinary } \\
\text { training }\end{array}$ & $\begin{array}{l}\text { Compliance of educational } \\
\text { programs with the needs of } \\
\text { society in accordance with the } \\
\text { National Qualifications } \\
\text { Framework }\end{array}$ \\
\hline $\begin{array}{l}\text { Foreign language } \\
\text { education }\end{array}$ & $\begin{array}{l}\text { Teaching Master's } \\
\text { Courses and Ph.D. in } \\
\text { English. }\end{array}$ & $\begin{array}{l}\text { Providing teaching of } \\
\text { educational } \\
\text { components and their } \\
\text { blocks in English and } \\
\text { other languages of the } \\
\text { European Union }\end{array}$ & $\begin{array}{l}\text { Provide an increase in the } \\
\text { number of educational } \\
\text { programs with teaching } \\
\text { subjects in English }\end{array}$ & $\begin{array}{l}\text { Opportunity to study in } \\
\text { foreign languages } \\
\text { disciplines of humanities, } \\
\text { general science and } \\
\text { professional orientation; } \\
\text { expanding cooperation with } \\
\text { the British Council, the } \\
\text { Goethe Institute and other } \\
\text { international institutions and } \\
\text { organizations to study and } \\
\text { use innovations in } \\
\text { in the field of foreign } \\
\text { language teaching; } \\
\text { development of existing and } \\
\text { creation of new linguistic } \\
\text { centers in English, German, } \\
\text { Polish, French and other } \\
\text { foreign languages. }\end{array}$ & \\
\hline $\begin{array}{l}\text { creation of new } \\
\text { forms of interaction }\end{array}$ & & & $\begin{array}{l}\text { The Sikorsky Challenge } \\
\text { ecosystem organizes the }\end{array}$ & $\begin{array}{l}\text { Creation of joint } \\
\text { educational-scientific- }\end{array}$ & $\begin{array}{l}\text { Joint research centers with } \\
\text { foreign partners }\end{array}$ \\
\hline
\end{tabular}




\begin{tabular}{|c|c|c|c|c|c|}
\hline $\begin{array}{l}\text { of the university with } \\
\text { business }\end{array}$ & & & $\begin{array}{l}\text { interaction of four groups of } \\
\text { participants: university } \\
\text { research schools, faculties } \\
\text { and departments, high-tech } \\
\text { companies, investment and } \\
\text { venture funds. } \\
\text { Innovative structures on the } \\
\text { basis of the university } \\
\text { (science park, technology } \\
\text { park, business incubator, } \\
\text { startup school) }\end{array}$ & $\begin{array}{l}\text { production complexes, } \\
\text { centers of common use, } \\
\text { laboratories with leading } \\
\text { scientific institutions and } \\
\text { companies }\end{array}$ & \\
\hline $\begin{array}{l}\text { involvement of } \\
\text { stakeholders in the } \\
\text { educational process }\end{array}$ & $\begin{array}{l}\text { Involvement of employers } \\
\text { in the educational process }\end{array}$ & $\begin{array}{l}\text { Involvement of } \\
\text { employers in the } \\
\text { design and evaluation } \\
\text { of learning outcomes; } \\
\text { Active activity of } \\
\text { public organizations, } \\
\text { foundations, patrons, } \\
\text { mass media in } \\
\text { development and } \\
\text { realization of } \\
\text { decisions of } \\
\text { educational and } \\
\text { scientific programs; }\end{array}$ & $\begin{array}{l}\text { Participation of employers in } \\
\text { the development and } \\
\text { implementation of curricula } \\
\text { and programs, } \\
\text { Involvement in the selection } \\
\text { procedure for master's } \\
\text { degree programs, to involve } \\
\text { partner companies in the } \\
\text { selection }\end{array}$ & $\begin{array}{l}\text { Directing the educational } \\
\text { program to the formation of } \\
\text { competencies relevant to the } \\
\text { labor market, by involving } \\
\text { in the formation of the } \\
\text { content of educational } \\
\text { programs and curricula of } \\
\text { expert councils of } \\
\text { employers; } \\
\text { IT training centers of } \\
\text { NetCracker, PortaOne, } \\
\text { MindK, AMS Bridge } \\
\text { successfully operate on the } \\
\text { basis of the university }\end{array}$ & $\begin{array}{l}\text { Involvement of IT industry } \\
\text { specialists in curriculum } \\
\text { development }\end{array}$ \\
\hline student government & $\begin{array}{l}\text { Strengthening the role of } \\
\text { the University in society } \\
\text { and the development of } \\
\text { student government and }\end{array}$ & $\begin{array}{l}\text { expanding the role of } \\
\text { student government in } \\
\text { the educational } \\
\text { process. }\end{array}$ & $\begin{array}{l}\text { Promoting the development } \\
\text { of student government }\end{array}$ & & $\begin{array}{l}\text { Promoting the development of } \\
\text { student government }\end{array}$ \\
\hline $\begin{array}{l}\text { internships and } \\
\text { academic mobility }\end{array}$ & $\begin{array}{l}\text { Academic mobility of } \\
\text { scientists, teachers and } \\
\text { students; } \\
\text { Outstanding scientists and } \\
\text { personalities are active } \\
\text { participants in the } \\
\text { educational process }\end{array}$ & $\begin{array}{l}\text { Increasing the share of } \\
\text { foreign teachers. }\end{array}$ & $\begin{array}{l}\text { Involvement in academic } \\
\text { programs } \\
\text { mobility. } \\
\text { Increasing the number of } \\
\text { University teachers who } \\
\text { teach, including abroad. } \\
\text { Invitation of foreign } \\
\text { specialists to teach individual } \\
\text { courses at the University }\end{array}$ & $\begin{array}{l}\text { organization of } \\
\text { international academic } \\
\text { mobility programs for } \\
\text { students, graduate students, } \\
\text { students and staff; } \\
\text { additional preparation of } \\
\text { students for participation in } \\
\text { academic mobility } \\
\text { programs (language } \\
\text { training, cross-cultural } \\
\text { adaptation trainings, } \\
\text { information support, etc.); }\end{array}$ & $\begin{array}{l}\text { Promoting academic mobility } \\
\text { and internships in leading } \\
\text { foreign HEIs }\end{array}$ \\
\hline
\end{tabular}




\begin{tabular}{|c|c|c|c|c|c|}
\hline International projects & $\begin{array}{l}\text { Development of } \\
\text { international agreements } \\
\text { with effective work } \\
\text { programs. }\end{array}$ & $\begin{array}{l}\text { More active } \\
\text { involvement of } \\
\text { scientific and } \\
\text { scientific-pedagogical } \\
\text { employees of the } \\
\text { University in } \\
\text { participation in } \\
\text { international } \\
\text { competitions under } \\
\text { the programs } \\
\text { HORIZON-2020, } \\
\text { CRDF }\end{array}$ & & $\begin{array}{l}\text { The University is actively } \\
\text { involved in TEMPUS, } \\
\text { Erasmus +, Horizon } 2020 \\
\text { grant projects, OOH, } \\
\text { USAID, DAAD, British } \\
\text { Council programs, } \\
\text { intergovernmental research } \\
\text { projects, grants from } \\
\text { private foundations and } \\
\text { organizations. }\end{array}$ & $\begin{array}{l}\text { Grant projects Horizon 2020, } \\
\text { STCU, NATO, CRDF, } \\
\text { ERASMUS +, DAAD }\end{array}$ \\
\hline $\begin{array}{l}\text { Opportunity to } \\
\text { cooperate with } \\
\text { business }\end{array}$ & & $\begin{array}{l}\text { an effective system of } \\
\text { cooperation with } \\
\text { business (Ukrainian } \\
\text { and international } \\
\text { companies) to attract } \\
\text { additional funds for } \\
\text { the development of } \\
\text { the University. }\end{array}$ & $\begin{array}{l}\text { effective connections with } \\
\text { high-tech enterprises and } \\
\text { scientific institutions; } \\
\text { Bringing up to } 80 \% \text { of the } \\
\text { number of graduates } \\
\text { employed in the specialty }\end{array}$ & $\begin{array}{l}\text { Interaction of scientific and } \\
\text { pedagogical workers with } \\
\text { science-intensive and high- } \\
\text { tech enterprises, } \\
\text { international institutions } \\
\text { and government } \\
\text { organizations } \\
\text { Most departments have } \\
\text { branches at enterprises } \\
\text { (organizations, institutions), } \\
\text { or located directly on } \\
\text { clinical bases where leading } \\
\text { practitioners are involved in } \\
\text { the educational process, } \\
\text { provide } \\
\text { management of students' } \\
\text { practice, course and } \\
\text { diploma projects, conduct } \\
\text { laboratory classes } \\
\text { Business hub that provides } \\
\text { consulting services for } \\
\text { small and medium } \\
\text { businesses. }\end{array}$ & $\begin{array}{l}\text { Creation of training, research } \\
\text { and production clusters to } \\
\text { deepen the connection with the } \\
\text { labor market; } \\
\text { Dual training with IT } \\
\text { companies }\end{array}$ \\
\hline Certification training & & & $\begin{array}{l}\text { pedagogical improvement } \\
\text { skills, including online } \\
\text { Professional platform } \\
\text { Development Endeavors }\end{array}$ & $\begin{array}{l}\text { short-term programs of } \\
\text { advanced training in } \\
\text { various directions,, } \\
\text { educational and methodical } \\
\text { seminars, seminars- } \\
\text { trainings, "round tables" }\end{array}$ & $\begin{array}{l}\text { "School of Young Scientists" to } \\
\text { improve the theoretical, } \\
\text { pedagogical and } \\
\text { methodological knowledge of } \\
\text { teachers; } \\
\text { methodical schools-seminars } \\
\text { "Modern pedagogical } \\
\text { technologies in education" }\end{array}$ \\
\hline
\end{tabular}




\begin{tabular}{|c|c|c|c|c|c|}
\hline $\begin{array}{l}\text { Commercialization } \\
\text { of research results }\end{array}$ & & & & $\begin{array}{l}\text { Improve the system of } \\
\text { commercialization of } \\
\text { intellectual property rights; } \\
\text { Introduce a system of } \\
\text { formation of innovative } \\
\text { structures for } \\
\text { commercialization of the } \\
\text { results of applied research } \\
\text { and development (science } \\
\text { and technology parks, small } \\
\text { enterprises such as spin- } \\
\text { offs, engineering centers, } \\
\text { etc.); } \\
\text { concluding dealer } \\
\text { agreements for the } \\
\text { introduction of scientific } \\
\text { and technical products of } \\
\text { the university, in particular } \\
\text { abroad; } \\
\text { sale of licenses for } \\
\text { scientific and technical } \\
\text { products; }\end{array}$ & $\begin{array}{l}\text { Establishment of companies for } \\
\text { the purpose of } \\
\text { commercialization of } \\
\text { intellectual property rights }\end{array}$ \\
\hline $\begin{array}{l}\text { Internationalization } \\
\text { of educational } \\
\text { activities }\end{array}$ & & & $\begin{array}{c}\text { joint international training } \\
\text { programs for bachelors, } \\
\text { masters and graduate } \\
\text { students } \\
\end{array}$ & 17 international agreements & \\
\hline $\begin{array}{l}\text { Independence in the } \\
\text { organization of the } \\
\text { educational process } \\
\text { taking into account } \\
\text { the needs of the } \\
\text { market and } \\
\text { stakeholders }\end{array}$ & & & $\begin{array}{l}\text { new areas of training, } \\
\text { specialty, specialization }\end{array}$ & $\begin{array}{l}\text { transition to a new list of } \\
\text { specialties of training }\end{array}$ & $\begin{array}{l}\text { intensification of university } \\
\text { activities in accordance with } \\
\text { the needs of stakeholders }\end{array}$ \\
\hline $\begin{array}{l}\text { involvement of } \\
\text { stakeholders in the } \\
\text { scientific process }\end{array}$ & & & & $\begin{array}{l}\text { carrying out of research } \\
\text { works which are carried out } \\
\text { within the limits of activity } \\
\text { on a self-supporting basis }\end{array}$ & $\begin{array}{l}\text { cooperation with business in } \\
\text { order to identify competitive } \\
\text { areas of research; } \\
\text { Annual business forum } \\
\text { "Science-business-education: } \\
\text { strategic partnership"; }\end{array}$ \\
\hline $\begin{array}{l}\text { creation of new } \\
\text { forms of interaction } \\
\text { of the university with } \\
\text { business }\end{array}$ & $\begin{array}{l}\text { Fablab International } \\
\text { Laboratory for Startups; } \\
\text { coworking centers; }\end{array}$ & Creating startups & Scientific schools & $\begin{array}{l}\text { creation of a business } \\
\text { incubator and business club } \\
\text { of Uzhhorod National } \\
\text { University for the }\end{array}$ & \\
\hline
\end{tabular}




\begin{tabular}{|c|c|c|c|c|c|}
\hline & $\begin{array}{l}\text { Establishment of Tech } \\
\text { Business School; } \\
\text { Creation of a science } \\
\text { park; Establishment of } \\
\text { training and research } \\
\text { centers and laboratories } \\
\text { with the assistance of } \\
\text { leading companies and } \\
\text { firms }\end{array}$ & & & $\begin{array}{l}\text { formation of student and } \\
\text { academic start-ups }\end{array}$ & \\
\hline $\begin{array}{l}\text { involvement of } \\
\text { stakeholders in the } \\
\text { educational process }\end{array}$ & $\begin{array}{l}\text { Annual organization of } \\
\text { lectures by leading } \\
\text { specialists of companies; } \\
\text { Concluding agreements } \\
\text { with enterprises (firms, } \\
\text { companies) on targeted } \\
\text { training }\end{array}$ & & $\begin{array}{l}\text { round tables, seminars with } \\
\text { employers, students, teachers } \\
\text { and scientists }\end{array}$ & & $\begin{array}{l}\text { development and } \\
\text { implementation of new } \\
\text { educational programs and } \\
\text { standards of educational } \\
\text { activities with the involvement } \\
\text { of stakeholders }\end{array}$ \\
\hline $\begin{array}{l}\text { Integration of } \\
\text { education, science } \\
\text { and production }\end{array}$ & $\begin{array}{l}\text { Carrying out energy } \\
\text { saving measures }\end{array}$ & $\begin{array}{l}\text { ncubation of } \\
\text { innovative projects }\end{array}$ & & & $\begin{array}{l}\text { student research programs and } \\
\text { summer research schools }\end{array}$ \\
\hline municipality & & & & & $\begin{array}{l}\text { support for the functioning of } \\
\text { student and public self- } \\
\text { government bodies; }\end{array}$ \\
\hline
\end{tabular}


Continuation of Annex B

The end of the table. B. 2

\begin{tabular}{|c|c|c|c|c|c|}
\hline $\begin{array}{l}\text { internships and } \\
\text { academic mobility }\end{array}$ & & $\begin{array}{l}\text { cademic mobility of students, } \\
\text { graduate students, doctoral } \\
\text { students, teachers, researchers } \\
\text { and staff }\end{array}$ & Academic mobility & Academic mobility & Academic mobility \\
\hline International projects & $\begin{array}{l}\text { Submission of } \\
\text { applications for } \\
\text { international grants: } \\
\text { collective (Horizon } \\
\text { 2020, Horizon Europe, } \\
\text { Erasmus Plus, } \\
\text { Volkswagen, NATO } \\
\text { program, joint } \\
\text { international projects } \\
\text { under the auspices of the } \\
\text { Ministry of Education } \\
\text { and Science, etc.) }\end{array}$ & & & $\begin{array}{l}\text { Submission of } \\
\text { applications for } \\
\text { international grants } \\
\text { under Horizon 2020, } \\
\text { Erasmus + }\end{array}$ & \\
\hline $\begin{array}{l}\text { Opportunity to } \\
\text { cooperate with } \\
\text { business }\end{array}$ & $\begin{array}{l}\text { Concluding economic } \\
\text { contract research by } \\
\text { each department }\end{array}$ & $\begin{array}{l}\text { Creating a system of } \\
\text { communication with leading } \\
\text { national and foreign } \\
\text { corporations interested in } \\
\text { university innovative } \\
\text { developments } \\
\end{array}$ & & $\begin{array}{l}\text { provision of consulting } \\
\text { services }\end{array}$ & \\
\hline $\begin{array}{l}\text { Commercialization of } \\
\text { research results }\end{array}$ & $\begin{array}{l}\text { Creation of a venture } \\
\text { fund to finance the } \\
\text { commercialization of } \\
\text { research, technology } \\
\text { transfer and } \\
\text { development of } \\
\text { startups; } \\
\text { Increasing the number } \\
\text { of commercialized } \\
\text { intellectual property } \\
\text { objects }\end{array}$ & $\begin{array}{l}\text { Increase in commercialized } \\
\text { scientific developments }\end{array}$ & & $\begin{array}{l}\text { Commercialization of } \\
\text { research and } \\
\text { development; }\end{array}$ & $\begin{array}{l}\text { Commercialization of intellectual } \\
\text { property }\end{array}$ \\
\hline
\end{tabular}


Continuation of Annex B

Table B. 3

Research of introduction of technological innovations by domestic HEI on the basis of the analysis of Development Strategies

\begin{tabular}{|c|c|c|c|c|c|}
\hline $\begin{array}{l}\text { Kind of innovative } \\
\text { changes }\end{array}$ & I. Franko NU of Lviv & T. Shevchenko NU of Kiev & NTUU KPI & SSU & NTU "HPI" \\
\hline $\begin{array}{l}\text { Organization of } \\
\text { educational space }\end{array}$ & $\begin{array}{l}\text { Development and } \\
\text { implementation of } \\
\text { training programs that } \\
\text { are flexible to market } \\
\text { requirements }\end{array}$ & $\begin{array}{l}\text { introduction of } \\
\text { interdisciplinary } \\
\text { educational programs } \\
\text { components. }\end{array}$ & $\begin{array}{l}\text { Interdisciplinary } \\
\text { educational programs based } \\
\text { on the introduction of } \\
\text { flexible training programs, } \\
\text { development of new } \\
\text { training courses based on } \\
\text { results research work }\end{array}$ & $\begin{array}{l}\text { Integration of educational and } \\
\text { scientific activities through } \\
\text { increasing the role of the } \\
\text { research component in master's } \\
\text { educational programs with the } \\
\text { mandatory allocation of } \\
\text { educational components that } \\
\text { provide both the development } \\
\text { of general research } \\
\text { competencies, skills and } \\
\text { abilities of interdisciplinary } \\
\text { teamwork; and research } \\
\text { competencies in the relevant } \\
\text { specialty }\end{array}$ & $\begin{array}{l}\text { Constant updating of } \\
\text { academic disciplines }\end{array}$ \\
\hline Information Technology & $\begin{array}{l}\text { Introduction of the } \\
\text { newest information } \\
\text { technologies in all } \\
\text { spheres of activity of } \\
\text { the University } \\
\text { (introduction of } \\
\text { electronic document } \\
\text { circulation, training, } \\
\text { information } \\
\text { management systems } \\
\text { of the University). }\end{array}$ & $\begin{array}{l}\text { Ensuring the } \\
\text { implementation of a } \\
\text { large-scale program of } \\
\text { informatization of the } \\
\text { University in order to } \\
\text { optimally and effectively } \\
\text { organize educational, } \\
\text { scientific, management } \\
\text { activities; } \\
\text {-use of elements of } \\
\text { artificial intelligence of } \\
\text { identification of the } \\
\text { person }\end{array}$ & $\begin{array}{l}\text { Create a digital learning } \\
\text { environment } \\
\text { Integration of information } \\
\text { and computing resources of } \\
\text { university departments on } \\
\text { the basis of KPI Data } \\
\text { Center. } \\
\text { System upgrade } \\
\text { of electronic document } \\
\text { management of the } \\
\text { university with a qualified } \\
\text { electronic signature and the } \\
\text { function of control of } \\
\text { executive discipline }\end{array}$ & $\begin{array}{l}\text { the only integrated information } \\
\text { system (IIS), which forms a } \\
\text { modern telecommunication and } \\
\text { information scientific and } \\
\text { educational environment - } \\
\text { "virtual university". } \\
\text { Electronic magazines; } \\
\text { Electronic document } \\
\text { management information } \\
\text { system }\end{array}$ & $\begin{array}{l}\text { E-learning projects: } \\
\text { "E-learning } \\
\text { resources", } \\
\text { "Multimedia } \\
\text { workshop", } \\
\text { "Ambulance", } \\
\text { "Educational e- } \\
\text { space", }\end{array}$ \\
\hline & & & $\begin{array}{l}\text { Development of the } \\
\text { standard "Electronic }\end{array}$ & & \\
\hline
\end{tabular}




\begin{tabular}{|c|c|c|c|c|}
\hline & & $\begin{array}{l}\text { archive of the university" - } \\
\text { Unification of processes of } \\
\text { archiving of electronic } \\
\text { copies of paper documents } \\
\text { of the university } \\
\text { Development of } \\
\text { information technology and } \\
\text { video surveillance system at } \\
\text { the university }\end{array}$ & & \\
\hline Forms of education & $\begin{array}{l}\text { Innovative } \\
\text { technologies in the } \\
\text { educational process }\end{array}$ & $\begin{array}{l}\text { Development of elements } \\
\text { of blended and distance } \\
\text { learning of students, } \\
\text { Reformatting of } 100 \% \text { of } \\
\text { academic disciplines in } \\
\text { accordance with the } \\
\text { requirements of blended } \\
\text { and distance learning. } \\
\text { Dual learning }\end{array}$ & $\begin{array}{l}\text { Electronic and distance } \\
\text { learning; definition of the } \\
\text { model of blended learning on a } \\
\text { full-time basis as basic, which } \\
\text { corresponds to the modern trend } \\
\text { of "blended education" (blended } \\
\text { education); } \\
\text { to integrate mass on-line } \\
\text { courses, distance courses, } \\
\text { separate modules and separate } \\
\text { components of educational } \\
\text { disciplines into the educational } \\
\text { process; }\end{array}$ & $\begin{array}{l}\text { Dissemination of } \\
\text { blended learning } \\
\text { practices; } \\
\text { Dual learning }\end{array}$ \\
\hline $\begin{array}{l}\text { Creating educational } \\
\text { platforms }\end{array}$ & $\begin{array}{l}\text { Formation of a unified } \\
\text { information } \\
\text { educational } \\
\text { environment at the } \\
\text { University and its } \\
\text { integration into the } \\
\text { world information } \\
\text { space, ensuring a high } \\
\text { level of organization } \\
\text { and openness of web } \\
\text { resources. }\end{array}$ & $\begin{array}{l}\text { "Electronic campus" } \\
\text { - electronic communication } \\
\text { of all participants of the } \\
\text { educational process, } \\
\text { information } \\
\text { support of the educational } \\
\text { process; } \\
\text { Providing 95\% of academic } \\
\text { disciplines with web } \\
\text { resources (distance courses) } \\
\text { for educational purposes }\end{array}$ & $\begin{array}{l}\text { Automated distance learning } \\
\text { system, consisting of a } \\
\text { subsystem for creating and } \\
\text { managing educational material, } \\
\text { a virtual learning environment } \\
\text { and a system for managing the } \\
\text { learning process through } \\
\text { electronic deaneries; }\end{array}$ & $\begin{array}{l}\text { Complete e-learning } \\
\text { system, including } \\
\text { technical, software, } \\
\text { methodological and } \\
\text { organizational } \\
\text { support }\end{array}$ \\
\hline $\begin{array}{l}\text { Creating educational } \\
\text { programs }\end{array}$ & & $\begin{array}{l}\text { system of choice of } \\
\text { disciplines; } \\
\text { individual learning } \\
\text { trajectories within the }\end{array}$ & $\begin{array}{l}\text { Students' choice of their own } \\
\text { individual learning trajectory; }\end{array}$ & $\begin{array}{l}25 \% \text { - disciplines of } \\
\text { free choice }\end{array}$ \\
\hline
\end{tabular}




\begin{tabular}{|c|c|c|c|c|c|}
\hline & & & $\begin{array}{l}\text { selected educational } \\
\text { program }\end{array}$ & $\begin{array}{l}\text { inclusion in the curriculum of a } \\
\text { wide range of disciplines of free } \\
\text { choice; }\end{array}$ & \\
\hline $\begin{array}{l}\text { Organization of quality } \\
\text { control of training }\end{array}$ & $\begin{array}{l}\text { The system of internal } \\
\text { and external evaluation } \\
\text { of the quality of the } \\
\text { educational process. }\end{array}$ & $\begin{array}{l}\text { Collection, analysis and } \\
\text { interpretation of } \\
\text { information on the } \\
\text { quality of education and } \\
\text { teaching, including } \\
\text { through surveys of } \\
\text { participants in the } \\
\text { educational process; } \\
\text { External, including } \\
\text { international, } \\
\text { accreditation of } \\
\text { educational programs }\end{array}$ & $\begin{array}{l}\text { Involvement of students in } \\
\text { the discussion of } \\
\text { educational programs, } \\
\text { conducting } \\
\text { surveys and taking into } \\
\text { account the opinion on the } \\
\text { quality of the educational } \\
\text { process, the system of } \\
\text { rating evaluation of the } \\
\text { activities of scientific and } \\
\text { pedagogical workers; } \\
\text { end-to-end monitoring } \\
\text { system and } \\
\text { improving the quality of the } \\
\text { fundamental } \\
\text { training: HEI - entrance } \\
\text { control - semester } \\
\text { certification - } \\
\text { rector's control }\end{array}$ & $\begin{array}{l}3 \text { levels of quality assurance: } \\
\text { Council for ensuring the quality } \\
\text { of educational activities and the } \\
\text { quality of higher education; } \\
\text { bureau for ensuring the quality } \\
\text { of educational activities and the } \\
\text { quality of higher education } \\
\text { (hereinafter - BZYAVO); } \\
\text { laboratory for monitoring the } \\
\text { quality of educational activities } \\
\text { survey of the entire contingent } \\
\text { of full-time students on the } \\
\text { quality of the organization of } \\
\text { educational activities in the } \\
\text { study of academic disciplines } \\
\text { ensuring the participation of } \\
\text { employers in the assessment of } \\
\text { general and professional } \\
\text { competencies of graduates }\end{array}$ & $\begin{array}{l}\text { System of internal } \\
\text { guarantee of quality } \\
\text { of education; } \\
\text { Monitoring for } \\
\text { compliance with } \\
\text { licensing and } \\
\text { accreditation } \\
\text { requirements of the } \\
\text { Ministry of } \\
\text { Education and } \\
\text { Science of Ukraine }\end{array}$ \\
\hline $\begin{array}{l}\text { Quality control of } \\
\text { scientific work }\end{array}$ & $\begin{array}{l}\text { Formation of a new } \\
\text { culture of attitude to } \\
\text { intellectual property, } \\
\text { introduction of a } \\
\text { system of plagiarism } \\
\text { prevention at all levels } \\
\text { of the University }\end{array}$ & $\begin{array}{l}\text { Improving the system of } \\
\text { monitoring academic } \\
\text { integrity with the use of } \\
\text { modern information } \\
\text { technologies for } \\
\text { technical verification } \\
\text { and text analysis; }\end{array}$ & & $\begin{array}{l}\text { formation and implementation } \\
\text { of the principles of academic } \\
\text { integrity, which is reflected in } \\
\text { the Code of Academic Integrity, } \\
\text { the Code of Corporate Culture } \\
\text { of the University, the } \\
\text { Regulations on Academic } \\
\text { Integrity and Ethics of } \\
\text { Academic Relations, the } \\
\text { creation of a group to promote } \\
\text { academic integrity, the } \\
\text { University Commission on } \\
\text { Ethics and Conflict } \\
\text { Management. }\end{array}$ & \\
\hline
\end{tabular}




\begin{tabular}{|c|c|c|c|c|c|}
\hline Activity financing & & $\begin{array}{l}\text { cooperation with } \\
\text { business in order to } \\
\text { attract additional funds } \\
\text { for the development of } \\
\text { the University }\end{array}$ & $\begin{array}{l}\text { Reach the level of } 20-25 \% \\
\text { from the total amount of } \\
\text { funds in the structure of the } \\
\text { university budget received } \\
\text { from foreign economic } \\
\text { activity from all possible } \\
\text { sources }\end{array}$ & $\begin{array}{l}\text { increase of competitive and } \\
\text { grant activity, development of } \\
\text { highly intelligent university } \\
\text { business; } \\
\text { strengthening international } \\
\text { grant activities and fundraising } \\
\text { as tools for innovative, } \\
\text { technological and financial } \\
\text { support of the university to } \\
\text { increase the share of financial } \\
\text { revenues from innovation to at } \\
\text { least } 20 \% \text { of the total funding of } \\
\text { the university; } \\
\text { - attraction of investment } \\
\text { sources in the implementation } \\
\text { of project activities of the } \\
\text { university; }\end{array}$ & $\begin{array}{l}\text { Execution of R\&D } \\
\text { at the expense of } \\
\text { international grants; } \\
\text { Provision of paid } \\
\text { services by scientific } \\
\text { and research } \\
\text { departments of the } \\
\text { university }\end{array}$ \\
\hline Energy efficiency & $\begin{array}{l}\text { Implementation of } \\
\text { energy saving projects }\end{array}$ & $\begin{array}{l}\text { Energy saving program, } \\
\text { costs not less than } 5 \% \text { of } \\
\text { the total budget of the } \\
\text { University for the } \\
\text { introduction of energy } \\
\text { saving technologies }\end{array}$ & $\begin{array}{l}\text { Implementation of the } \\
\text { University Energy } \\
\text { Efficiency Program; } \\
\text { Reduction of consumption } \\
\text { of energy resources and } \\
\text { water due to increase of } \\
\text { energy efficiency of } \\
\text { engineering networks and } \\
\text { their equipment, increase of } \\
\text { thermal protection of } \\
\text { enclosing designs }\end{array}$ & & \\
\hline Online library & $\begin{array}{l}\text { Electronic library } \\
\text { resource and } \\
\text { development of own } \\
\text { repository of } \\
\text { publications, its } \\
\text { integration into the } \\
\text { information space of } \\
\text { the city, country and } \\
\text { the world }\end{array}$ & $\begin{array}{l}\text { Full-scale digitization of } \\
\text { funds for use in the } \\
\text { Intranet environment of } \\
\text { the University and } \\
\text { further optimization of } \\
\text { useful areas of the } \\
\text { scientific library }\end{array}$ & $\begin{array}{l}\text { Electronic catalog and } \\
\text { image catalog of NTB } \\
\text { printed publications. } \\
\text { Development of electronic } \\
\text { archive of educational and } \\
\text { scientific materials }\end{array}$ & $\begin{array}{l}\text { OCW SSU and SSU Examiner } \\
\text { project as open electronic } \\
\text { resources of structured } \\
\text { collections of organizational, } \\
\text { educational and methodical } \\
\text { materials of disciplines, } \\
\text { organization of the Laboratory } \\
\text { of data analysis and digital } \\
\text { services to support quality }\end{array}$ & \\
\hline
\end{tabular}




\section{Continuation of Annex B}

Continuation of the table. B.3

\begin{tabular}{|c|c|c|c|c|c|}
\hline $\begin{array}{l}\text { Kind of innovative } \\
\text { changes }\end{array}$ & $\begin{array}{l}\text { Lviv Polytechnic } \\
\text { National University }\end{array}$ & V. Karazina KhNU & S. KUZNETS KhNUE & Uzhhorod National University» & $\begin{array}{l}\text { National Economic } \\
\text { University named } \\
\text { after Vadym Hetman }\end{array}$ \\
\hline & & & & $\begin{array}{l}\text { and quantitative digital } \\
\text { research, project management } \\
\text { consulting (RDM), } \\
\text { communication and publication } \\
\text { of research results; }\end{array}$ & \\
\hline $\begin{array}{l}\text { Organization of } \\
\text { educational space }\end{array}$ & $\begin{array}{l}\text { Optimizing the content } \\
\text { of educational } \\
\text { programs; } \\
\text { Introduction of } \\
\text { innovative educational } \\
\text { programs for training } \\
\text { specialists }\end{array}$ & & $\begin{array}{l}\text { Constant change and } \\
\text { optimization of educational } \\
\text { programs }\end{array}$ & $\begin{array}{l}\text { Changing the content of } \\
\text { academic disciplines and } \\
\text { strengthening interdisciplinary } \\
\text { interaction; } \\
\text { creation of a new generation of } \\
\text { interdisciplinary research } \\
\text { educational programs; }\end{array}$ & $\begin{array}{l}\text { formation of } \\
\text { competitive } \\
\text { educational programs } \\
\text { that correspond to the } \\
\text { best world practices }\end{array}$ \\
\hline Information Technology & & $\begin{array}{l}\text { Creation of an automated } \\
\text { system for issuing } \\
\text { documents to students } \\
\text { and staff on the principle } \\
\text { of "single window". }\end{array}$ & $\begin{array}{l}\text { Corporate development } \\
\text { university management } \\
\text { information system and its } \\
\text { subsystems; Use of an } \\
\text { electronic journal of } \\
\text { accounting for learning } \\
\text { outcomes }\end{array}$ & $\begin{array}{l}\text { E-learning technologies for all } \\
\text { forms of learning, }\end{array}$ & \\
\hline forms of education & $\begin{array}{l}\text { Distance education; } \\
\text { Introduction of game } \\
\text { and imitation forms of } \\
\text { training; Development } \\
\text { of a regulatory } \\
\text { framework for the } \\
\text { introduction of "dual } \\
\text { education" }\end{array}$ & $\begin{array}{l}\text { Development of dual } \\
\text { education }\end{array}$ & $\begin{array}{l}\text { modern organizational } \\
\text { forms of education: } \\
\text { trainings, business games; } \\
\text { video lectures, webinars, } \\
\text { video conferences }\end{array}$ & Distance learning technologies & $\begin{array}{l}\text { integration into } \\
\text { educational programs } \\
\text { of mass open online } \\
\text { courses }\end{array}$ \\
\hline $\begin{array}{l}\text { Creating educational } \\
\text { platforms }\end{array}$ & $\begin{array}{l}\text { Creating a platform for } \\
\text { placing online courses } \\
\text { on the information } \\
\text { resources of the } \\
\text { Institute of Distance } \\
\text { Learning }\end{array}$ & & $\begin{array}{l}\text { Provision of disciplines } \\
\text { with electronic interactive } \\
\text { educational publications, } \\
\text { such as: lecture courses, } \\
\text { video tutorials, simulated } \\
\text { laboratory workshops, } \\
\text { interactive collections of } \\
\text { exercises, etc.,\% }\end{array}$ & $\begin{array}{l}\text { Automated training courses; } \\
\text { information platform for } \\
\text { knowledge exchange "e- } \\
\text { university»» }\end{array}$ & \\
\hline $\begin{array}{l}\text { Creating educational } \\
\text { programs }\end{array}$ & & & & $\begin{array}{l}\text { improving the selective } \\
\text { component of curricula; }\end{array}$ & $\begin{array}{l}\text { individualization of the } \\
\text { approach to the } \\
\text { development of } \\
\text { creative educational } \\
\text { programs, }\end{array}$ \\
\hline
\end{tabular}




\begin{tabular}{|c|c|c|c|c|c|}
\hline $\begin{array}{l}\text { Organization of quality } \\
\text { control of training }\end{array}$ & $\begin{array}{l}\text { International } \\
\text { accreditation of } \\
\text { educational programs }\end{array}$ & $\begin{array}{l}\text { introduction of a system } \\
\text { of effective quality } \\
\text { control of } \\
\text { educationпроцесу за } \\
\text { участі студентського } \\
\text { самоврядування; } \\
\text { Акредитація освітніх } \\
\text { програм }\end{array}$ & & $\begin{array}{l}\text { training of specialists in the } \\
\text { field of innovation management }\end{array}$ & $\begin{array}{l}\text { development of the } \\
\text { internal system of } \\
\text { quality assurance of } \\
\text { education; } \\
\text { development of a } \\
\text { system for evaluating } \\
\text { educational outcomes } \\
\text { and processes with } \\
\text { the involvement of } \\
\text { stakeholders; } \\
\text { certification and } \\
\text { accreditation of } \\
\text { educational programs } \\
\text { in specialized national } \\
\text { and international } \\
\text { agencies }\end{array}$ \\
\hline $\begin{array}{l}\text { Quality control of } \\
\text { scientific work }\end{array}$ & - & & & $\begin{array}{l}\text { introduction of the "anti- } \\
\text { plagiarism" system for } \\
\text { qualification works }\end{array}$ & \\
\hline Activity financing & $\begin{array}{l}\text { Submission of requests } \\
\text { for international grants: } \\
\text { collective (Horizon } \\
2020 \text {, Horizon Europe, } \\
\text { Erasmus Plus, } \\
\text { Volkswagen, NATO } \\
\text { program, joint } \\
\text { international projects } \\
\text { under the auspices of the } \\
\text { Ministry of Education } \\
\text { and Science, etc.); } \\
\text { Growth of revenues to } \\
\text { the university budget for } \\
\text { research }\end{array}$ & $\begin{array}{l}\text { Reducing the share of } \\
\text { funding for science from } \\
\text { the state budget; } \\
\text { Increasing the share of } \\
\text { other sources: charitable } \\
\text { contributions, grants, } \\
\text { gifts. } \\
\text { Fundraising programs in } \\
\text { the areas of activity of } \\
\text { the University }\end{array}$ & $\begin{array}{l}\text { Increasing funding for } \\
\text { scientific, scientific and } \\
\text { technical work at the } \\
\text { expense of domestic and } \\
\text { foreign customers }\end{array}$ & $\begin{array}{l}\text { creation of a fund for financing } \\
\text { research at the expense of extra- } \\
\text { budgetary funds of the } \\
\text { university; } \\
\text { attraction of donor assistance at } \\
\text { the expense of funds received } \\
\text { from projects of international } \\
\text { funds and programs; } \\
\text { fundraising projects and } \\
\text { programs }\end{array}$ & $\begin{array}{l}\text { diversification of } \\
\text { sources of research } \\
\text { funding }\end{array}$ \\
\hline Energy efficiency & & & & & $\begin{array}{l}\text { introduction of the } \\
\text { energy efficiency } \\
\text { system of the } \\
\text { university functioning }\end{array}$ \\
\hline Online library & $\begin{array}{l}\text { Introduction of a new } \\
\text { automated library } \\
\text { information system }\end{array}$ & & & $\begin{array}{l}\text { system of electronic formation } \\
\text { of library funds, electronic } \\
\text { catalog of books and periodicals } \\
\text { of the library }\end{array}$ & \\
\hline
\end{tabular}




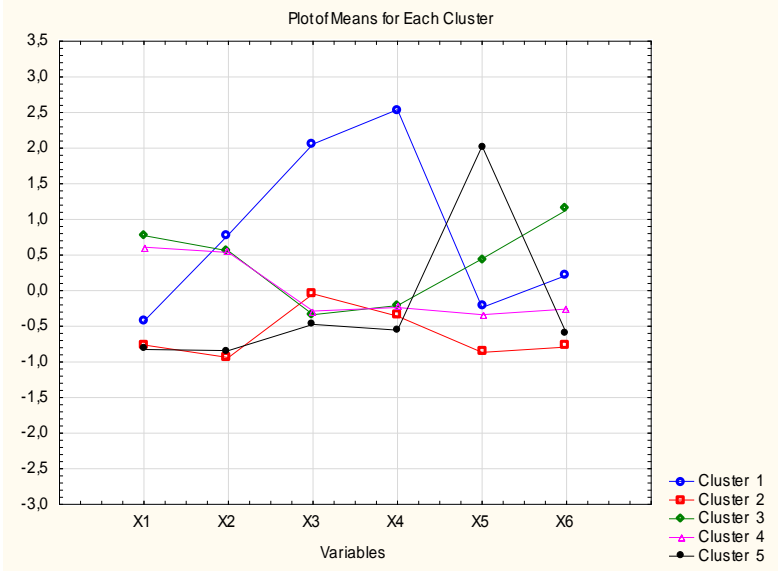

Fig. C.1. Graphic representation of average values of indicators by clusters for $\mathbf{2 0 1 3}$
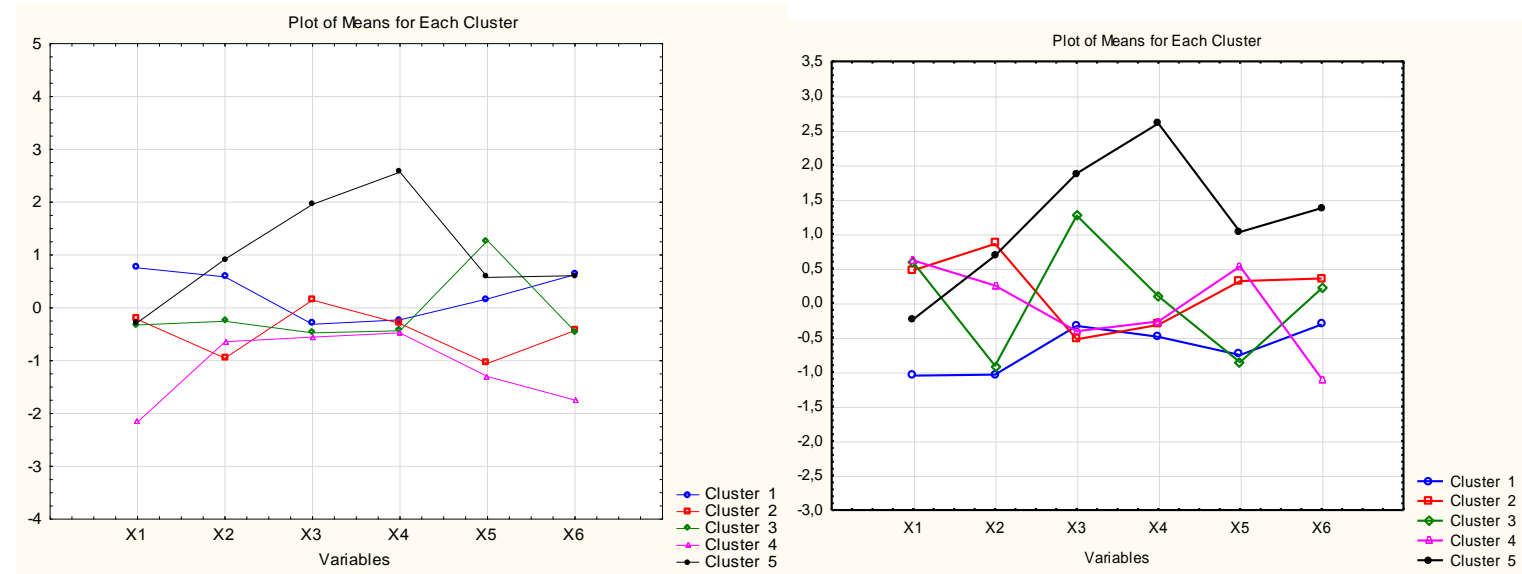

Fig. C.2. Graphic representation of average values of indicators by clusters for 2015 and 2017 
Annex D

Table D.1

\section{Dynamics of local integrated HEI}

\begin{tabular}{|c|c|c|c|c|}
\hline HEI & $\begin{array}{c}2012- \\
2013\end{array}$ & $\begin{array}{l}2014- \\
2015\end{array}$ & $\begin{array}{c}2018- \\
2019\end{array}$ & $\begin{array}{c}\text { The rate of } \\
\text { change in } 2019 \\
\text { compared to } \\
2012, \%\end{array}$ \\
\hline 1 & 2 & 3 & 4 & 5 \\
\hline Berdyansk State Pedagogical University & 0.218 & 0.225 & 0.265 & 1.214 \\
\hline Berdyansk University of Management and Business & 0.211 & 0.208 & 0.308 & 1.450 \\
\hline Bila Tserkva National Agrarian University & 0.276 & 0.273 & 0.225 & 0.817 \\
\hline Bukovynian State Medical University & 0.259 & 0.264 & 0.297 & 1.149 \\
\hline Bukovynian State University of Finance and Economics & 0.217 & 0.216 & 0.264 & 1.218 \\
\hline Ukraine Open International University of Human Development & 0.213 & 0.236 & 0.362 & 1.695 \\
\hline Mykhailo Kotsyubynsky Vinnytsia State Pedagogical University & 0.252 & 0.267 & 0.373 & 1.480 \\
\hline Vinnytsia National Agrarian University & 0.269 & 0.27 & 0.239 & 0.887 \\
\hline National Pirogov Memorial Medical University & 0.32839 & 0.324 & 0.238 & 0.726 \\
\hline & & & & \\
\hline Kyiv State Academy of Water Transport named after Hetman Petro Konashevych-Sahaydachniy & 0.2017 & 0.209 & 0.337 & 1.672 \\
\hline Kyiv Medical University UANM & 0.229 & 0.234 & 0.998 & 4.354 \\
\hline Kyiv International University & 0.3197 & 0.292 & 0.250 & 0.782 \\
\hline National Economic University named after Vadym Hetman & 0.516 & 0.477 & 0.230 & 0.445 \\
\hline Kyiv National Linguistic University & 0.2584 & 0.308 & 0.3404 & 1.317 \\
\hline Kyiv National University of Trade and Economics & 0.4651 & 0.4593 & 0.2823 & 0.616 \\
\hline Kyiv National University of Construction and Architecture & 0.333 & 0.330 & 0.224 & 0.674 \\
\hline Taras Shevchenko National University of Kyiv & 0.888 & 0.9426 & 0.221 & 0.248 \\
\hline Kyiv National University of Culture and Arts & 0.3270 & 0.348 & 0.213 & 0.652 \\
\hline Kyiv National I. K. Karpenko-Kary Theatre, Cinema and Television University & 0.281 & 0.270 & 0.340 & 1.214 \\
\hline Kyiv National University of Technology and Design & 0.339 & 0.368 & 0.256 & 0.754 \\
\hline Borys Hrinchenko University of Kyiv & 0.262 & 0.3026 & 0.347 & 1.303 \\
\hline Kyiv University of Law of the National Academy of Sciences of Ukraine & 0.2025 & 0.215 & 0.238 & 1.178 \\
\hline & & & & \\
\hline Simon Kuznets Kharkiv National University of Economics & 0.325 & 0.319 & 0.32 & 0.994 \\
\hline Kharkiv National Medical University & 0.288 & 0.318 & 0.281 & 0.974 \\
\hline H.S. Skovoroda Kharkiv National Pedagogical University & 0.3096 & 0.319 & 0.239 & 0.772 \\
\hline
\end{tabular}


Table D.2

Dynamics of local integrated indicators of assessment of scientific and technical activity of HEI

\begin{tabular}{|c|c|c|c|c|}
\hline HEI & $\begin{array}{c}2012- \\
2013\end{array}$ & $\begin{array}{c}2014- \\
2015\end{array}$ & $\begin{array}{c}2018- \\
2019\end{array}$ & $\begin{array}{c}\text { The rate of } \\
\text { change in } 2019 \\
\text { compared to } \\
2012, \%\end{array}$ \\
\hline Berdyansk State Pedagogical University & 0.142 & 0.247 & 0.2233 & 1.566 \\
\hline Berdyansk University of Management and Business & 0.347 & 0.231 & 0.221 & 0.639 \\
\hline Bila Tserkva National Agrarian University & 0.250 & 0.237 & 0.22 & 0.876 \\
\hline Ukraine Open International University of Human Development & 0.252 & 0.2399 & 0.217 & 0.850 \\
\hline Vinnytsia State Pedagogical University named after Mykhailo Kotsyubynskyj & 0.2478 & 0.239 & 0.209 & 0.843 \\
\hline Vinnytsia National Agrarian University & 0.1489 & 0.246 & 0.2185 & 1.467 \\
\hline National Pirogov Memorial Medical University & 0.2693 & 0.2560 & 0.2423 & 0.899 \\
\hline Kyiv Medical University UANM & 0.3668 & 0.252 & 0.211 & 0.577 \\
\hline Kyiv International University & 0.365 & 0.2367 & 0.209 & 0.573 \\
\hline Kyiv National University of Construction and Architecture & 0.267 & 0.2566 & 0.237 & 0.889 \\
\hline Taras Shevchenko National University of Kyiv & 0.487 & 0.971 & 0.978 & 2.051 \\
\hline Kyiv National University of Culture and Arts & 0.2695 & 0.2347 & 0.207 & 0.770 \\
\hline I.K. Karpenko-Kary Kyiv National University of Theater, Film and Televisionr & 0.266 & 0.2478 & 0.252 & 0.948 \\
\hline Kyiv National University of Technology and Design & 0.1653 & 0.24127 & 0.210 & 1.274 \\
\hline Borys Hrinchenko Kyiv University & 0.134 & 0.234 & 0.213 & $\mathbf{1 . 5 8 2}$ \\
\hline \multirow[t]{2}{*}{ Kyiv University of Law of the National Academy of Sciences of Ukraine } & 0,257 & 0.2147 & 0.237 & 0.922 \\
\hline & & & & \\
\hline Simon Kuznets Kharkiv National University of Economics & 0.2653 & 0.2425 & 0.227 & 0.855 \\
\hline Kharkiv National Medical University & 0.2663 & 0.272 & 0.260 & 0.979 \\
\hline H.S. Skovoroda Kharkiv National Pedagogical University & 0.1647 & 0.232 & 0.225 & 1.366 \\
\hline
\end{tabular}




\section{Dynamics of local integrated indicators of evaluation of innovation activity of HEI}

\begin{tabular}{|c|c|c|c|c|}
\hline HEI & $\begin{array}{l}2012- \\
2013\end{array}$ & $\begin{array}{c}2014- \\
2015\end{array}$ & $\begin{array}{l}2018- \\
2019\end{array}$ & $\begin{array}{c}\text { The rate of } \\
\text { change in } 2019 \\
\text { compared to } \\
2012, \%\end{array}$ \\
\hline Berdyansk State Pedagogical University & 0.5559 & 0.5559 & 0.879 & 1.588 \\
\hline Berdyansk University of Management and Business & 0.7824 & 0.7824 & 0.341 & 0.437 \\
\hline Bila Tserkva National Agrarian University & 0.973 & 0.973 & 0.527 & 0.541 \\
\hline Bukovynian State Medical University & 0.5400 & 0.540 & 0.517 & 0.957 \\
\hline Bukovynian State University of Finance and Economics & 0.9783 & 0.978 & 0.61 & 0.623 \\
\hline Ukraine Open International University of Human Development & 0.5825 & 0.58258 & 0.5515 & 0.946 \\
\hline Vinnytsia State Pedagogical University named after Mykhailo Kotsyubynsky & 0.557 & 0.5572 & 0.452 & 0.811 \\
\hline Vinnytsia National Agrarian University & 0.667 & 0.667 & 0.647 & 0.969 \\
\hline National Pirogov Memorial Medical University & 0.7848 & 0.784 & 0.425 & 0.541 \\
\hline Kyiv State Academy of Water Transport named after Hetman Petro Konashevych-Sahaydachniy & 0.634 & 0.5611 & 0.768 & 1.210 \\
\hline Kyiv Medical University UANM & 0.9417 & 0.7038 & 0.817 & 0.868 \\
\hline Kyiv International University & 0.9047 & 0.678 & 0.790 & 0.874 \\
\hline National Economic University named after Vadym Hetman & 0.803 & 0.6703 & 0.871 & 1.084 \\
\hline Kyiv National Linguistic University & 0.800 & 0.503 & 0.457 & 0.572 \\
\hline Kyiv National University of Trade and Economics & 0.686 & 0.429 & 0.38 & 0.564 \\
\hline Kyiv National University of Construction and Architecture & 0.71458 & 0.685 & 0.978 & 1.399 \\
\hline Taras Shevchenko National University of Kyiv & 0.856 & 0.699 & 0.893 & 1.042 \\
\hline Kyiv National University of Culture and Arts & 0.77658 & 0.710 & 0.9278 & 1.287 \\
\hline Kyiv National I. K. Karpenko-Kary Theatre, Cinema and Television University & 0.7914 & 0.665 & 0.8713 & 1.100 \\
\hline Kyiv National University of Technology and Design & 0.7891 & 0.614 & 0.746 & 0.946 \\
\hline Borys Hrinchenko Kyiv University & 0.7156 & 0.556 & 0.674 & 0.942 \\
\hline Kyiv University of Law of the National Academy of Sciences of Ukraine & 0.6781 & 0.576 & 0.762 & 1.124 \\
\hline & & & & \\
\hline Simon Kuznets Kharkiv National University of Economics & 0.599 & 0.434 & 0.486 & 0.810 \\
\hline Kharkiv National Medical University & 0.38 & 0.50 & 0.8731 & 2.255 \\
\hline H.S. Skovoroda Kharkiv National Pedagogical University & 0.4789 & 0.325 & 0.335 & 0.701 \\
\hline
\end{tabular}




\section{Continuation of Annex D}

Table D.4

Dynamics of local integrated indicators of assessment of international HEI activity

\begin{tabular}{|c|c|c|c|c|}
\hline HEI & $\begin{array}{c}2012- \\
2013\end{array}$ & $\begin{array}{l}2014- \\
2015\end{array}$ & $\begin{array}{l}2018- \\
2019\end{array}$ & $\begin{array}{c}\text { The rate of } \\
\text { change in } 2019 \\
\text { compared to } \\
2012, \%\end{array}$ \\
\hline 1 & 2 & 3 & 4 & 5 \\
\hline Berdyansk State Pedagogical University & 0.4619 & 0.2041 & 0.495 & 1.072 \\
\hline Berdyansk University of Management and Business & 0.4667 & 0.332 & 0.340 & 0.729 \\
\hline Bila Tserkva National Agrarian University & 0.857 & 0.452 & 0.451 & 0.526 \\
\hline Bukovynian State Medical University & 0.681 & 0.230 & 0.541 & 0.794 \\
\hline Bukovynian State University of Finance and Economics & 0.412 & 0.378 & 0.374 & 0.899 \\
\hline Ukraine Open International University of Human Development & 0.830 & 0.275 & 0.380 & 0.458 \\
\hline Vinnytsia State Pedagogical University named after Mykhailo Kotsyubynskyj & 0.825 & 0.304 & 0.268 & 0.324 \\
\hline Vinnytsia National Agrarian University & 0.690 & 0.235 & 0.555 & 0.803 \\
\hline National Pirogov Memorial Medical University & 0.468 & 0.309 & 0.728 & 1.550 \\
\hline Kyiv State Academy of Water Transport named after Hetman Petro Konashevych-Sahaydachniy & 0.5250 & 0.3914 & 0.658 & 1.254 \\
\hline Kyiv Medical University UANM & 0.7413 & 0.413 & 0.402 & 0.542 \\
\hline Kyiv International University & 0.6377 & 0.427 & 0.400 & 0.627 \\
\hline National Economic University named after Vadym Hetman & 0.611 & 0.300 & 0.778 & 1.272 \\
\hline Kyiv National Linguistic University & 0.3843 & 0.384 & 0.356 & 0.924 \\
\hline Kyiv National University of Trade and Economics & 0.660 & 0.292 & 0.294 & 0.446 \\
\hline Kyiv National University of Construction and Architecture & 0.4988 & 0.334 & 0.504 & 1.020 \\
\hline Taras Shevchenko National University of Kyiv & 0.5476 & 0.2983 & 0.463 & 0.846 \\
\hline Kyiv National University of Culture and Arts & 0.5524 & 0.202 & 0.7189 & 1.301 \\
\hline Kyiv National I. K. Karpenko-Kary Theatre, Cinema and Television University & 0.357 & 0.4230 & 0.399 & 1.116 \\
\hline Kyiv National University of Technology and Design & 0.694 & 0.292 & 0.335 & 0.483 \\
\hline Borys Hrinchenko Kyiv University & 0.695 & 0.2463 & 0.474 & 0.682 \\
\hline Kyiv University of Law of the National Academy of Sciences of Ukraine & 0.801 & 0.308 & 0.800 & 0.999 \\
\hline \multicolumn{5}{|l|}{ s } \\
\hline Simon Kuznets Kharkiv National University of Economics & 0.535 & 0.314 & 0.544 & 1.254 \\
\hline Kharkiv National Medical University & 0.4979 & 0.433 & 0.399 & 0.542 \\
\hline H.S. Skovoroda Kharkiv National Pedagogical University & 0.784 & 0.355 & $0, .628$ & 0.627 \\
\hline
\end{tabular}

